\title{
ESTRATEGIAS DE IMPLANTACION EN EL PAISAJE EN TRES OBRAS DE ENRIC MIRALLES
}

\author{
TESIS DOCTORAL. 2016
}

AUTOR: JOSE MANUEL MATEO VEGA. ARQUITECTO

DIRECTOR: FEDERICO SORIANO PELAEZ. DR. ARQUITECTO

UNIVERSIDAD POLITECNICA DE MADRID (UPM)

DEPARTAMENTO DE PROYECTOS ARQUITECTÓNICOS (DPA)

ESCUELA TECNICA SUPERIOR DE ARQUITECTURA DE MADRID (ETSAM). 
TRIBUNAL NOMBRADO POR EL MAGNIFICO Y EXCELENTISIMO

SR. RECTOR DE LA UNIVERSIDAD POLITÉCNICA DE MADRID

EL DÍA DE DE 2016

PRESIDENTE D.

VOCAL D.

VOCAL D.

VOCAL D.

SECRETARIO D.

REALIZADO EL ACTO DE DEFENSA Y LECTURA DE LA TESIS

EL DÍA DE DE 2016

EN

CALIFICACIÓN :

EL PRESIDENTE

LOS VOCALES

EL SECRETARIO 


\section{ESTRATEGIAS DE IMPLANTACION EN EL PAISAJE EN TRES OBRAS DE ENRIC MIRALLES}

ÍNDICE RESUMIDO

RESUMEN - ABSTRACT

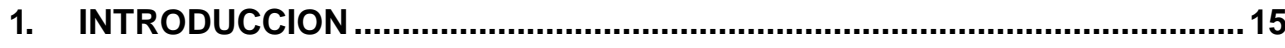

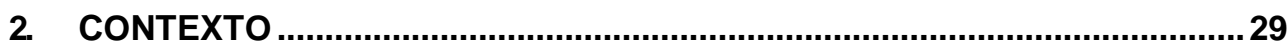

3. EL PARQUE CEMENTERIO EN IGUALADA (1985-1991)..........................113

4. EL COMPLEJO DE TIRO CON ARCO EN BARCELONA (1989-1992). ......183

5. EL PABELLON DE DEPORTES EN HUESCA (1988-1994)........................225

6. COMPARACION DE LAS ACCIONES ANALIZADAS.................................279

7. CONCLUSIONES. ........................................................................................... 347

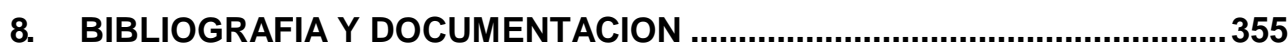

9. AGRADECIMIENTOS .............................................................................. 


\section{ESTRATEGIAS DE IMPLANTACION EN EL PAISAJE \\ EN TRES OBRAS DE ENRIC MIRALLES}

\section{ÍNDICE}

\section{RESUMEN - ABSTRACT}

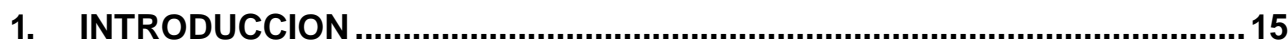

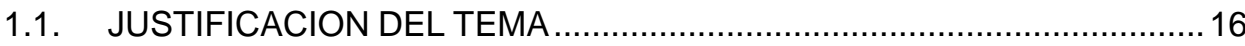

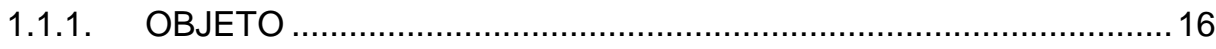

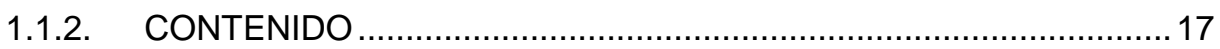

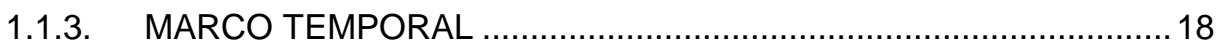

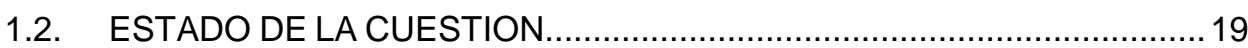

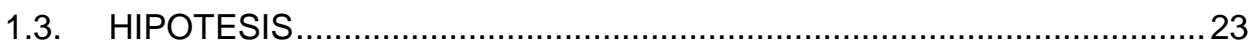

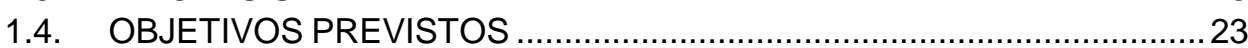

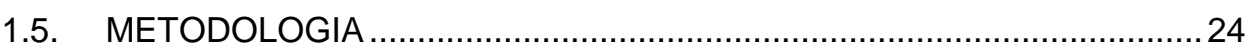

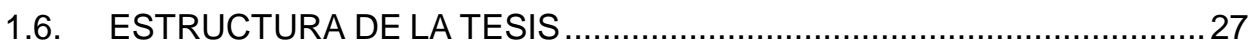

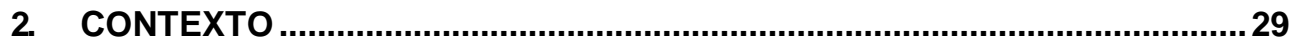

2.1. RELACION ENTRE ARQUITECTURA Y NATURALEZA ........................29

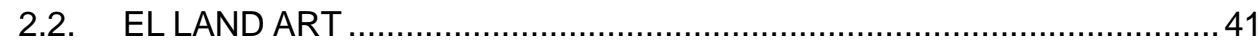

2.3. EL PAISAJE EN LA ARQUITECTURA DECONSTRUCTIVISTA ............61

2.4. EL PAISAJE EN LA CONTEMPORANEIDAD .....................................73

2.5. LA CONSTRUCCION DE LA MIRADA DE ENRIC MIRALLES .................89

2.6. EL AMBIENTE EN QUE SE GESTA SU ARQUITECTURA .....................105

3. EL PARQUE CEMENTERIO EN IGUALADA (1985-1991).........................113

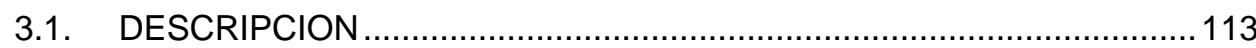

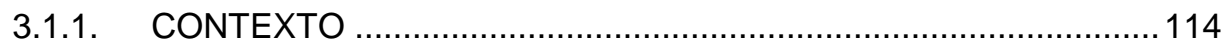

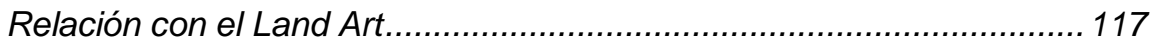

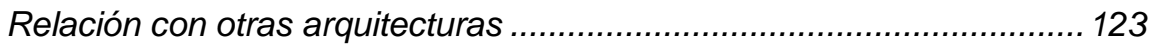

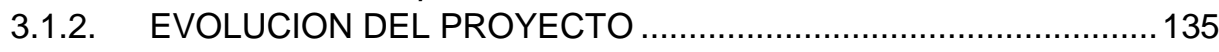

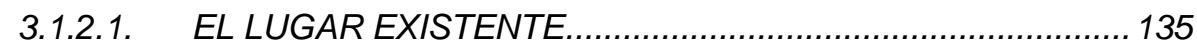

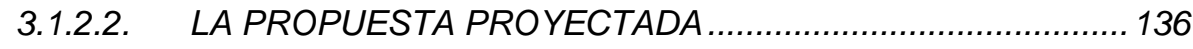

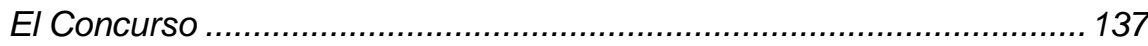

El Proyecto............................................................................... 140

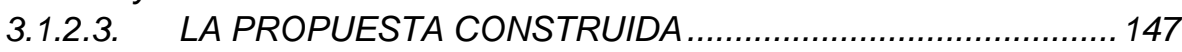

El Parque Cementerio en la actualidad ............................................. 150

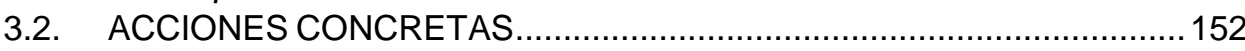

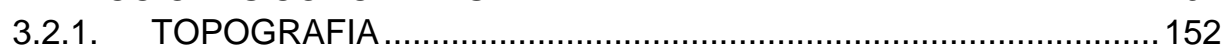

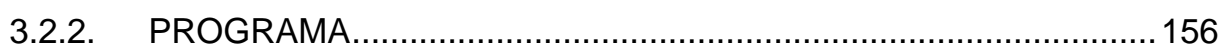

3.2.2.1. FRAGMENTACION SIN JERARQUIAS .................................. 156

3.2.3. RELACIONES INTERIOR - EXTERIOR .....................................160

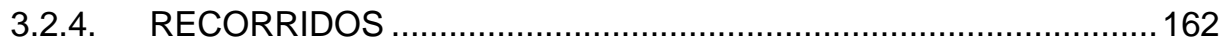

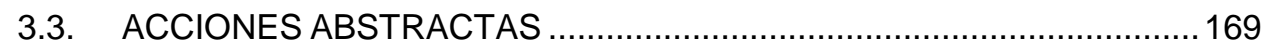

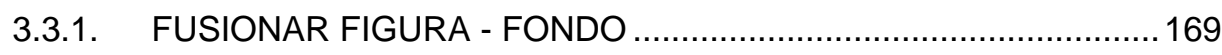

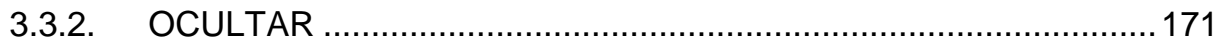

3.3.3. MANIFESTAR LA ACCION DEL TIEMPO ……..........................173 
4. EL COMPLEJO DE TIRO CON ARCO EN BARCELONA (1989-1992). .....183

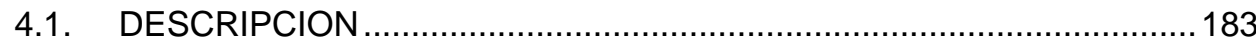

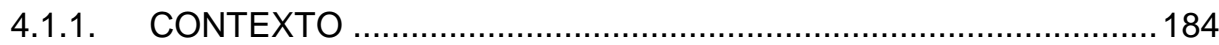

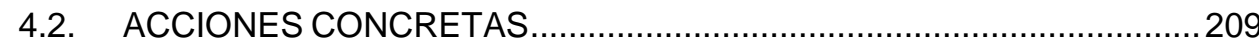

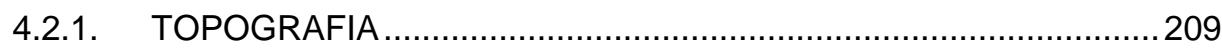

4.2.2. CUBIERTA

4.2.3. RELACIONES INTERIOR - EXTERIOR …................................... 214

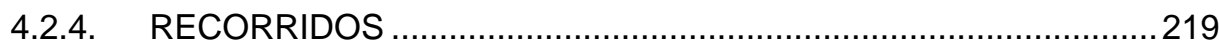

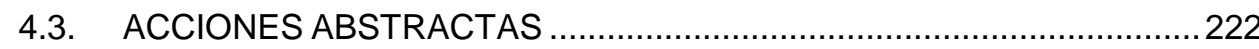

5. EL PABELLON DE DEPORTES EN HUESCA (1988-1994). .......................225

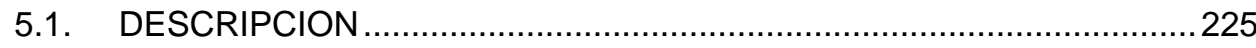

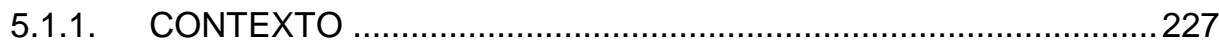

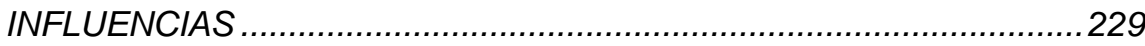

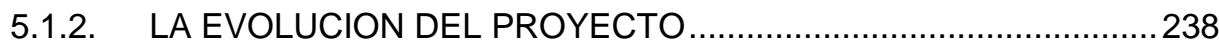

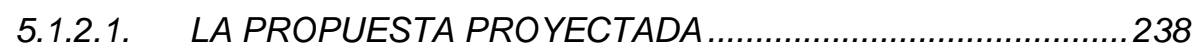

La construcción del edificio con la cubierta tensada .............................243

5.1.2.2. LA CUBIERTA APOYADA QUE SE CONSTRUYO...........................

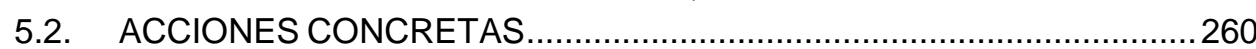

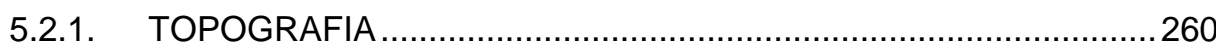

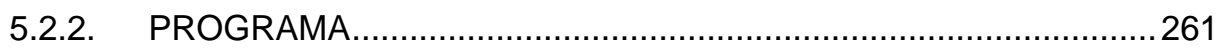

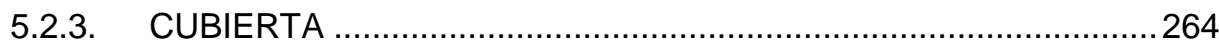

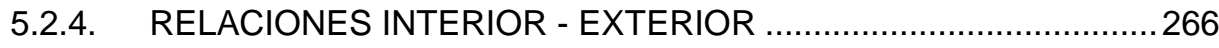

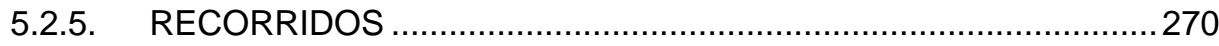

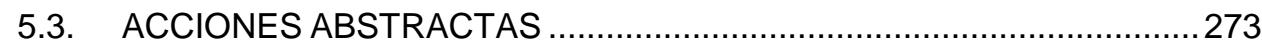

5.3.1. MANIFESTAR LA ACCION DEL TIEMPO ……..........................274

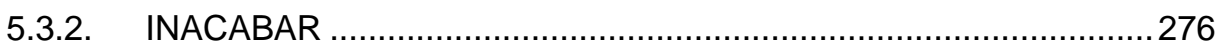

6. COMPARACION DE LAS ACCIONES ANALIZADAS................................279

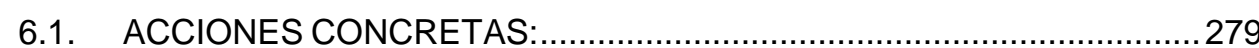

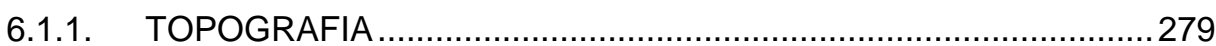

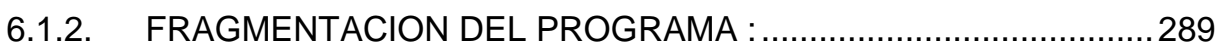

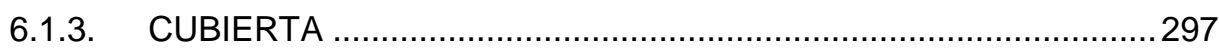

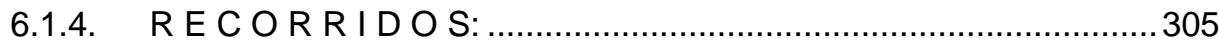

6.1.5. RELACIONES INTERIOR - EXTERIOR ……................................

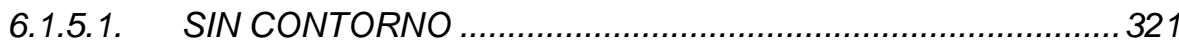

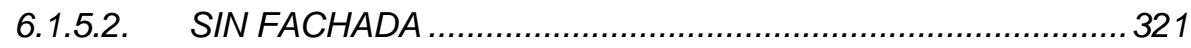

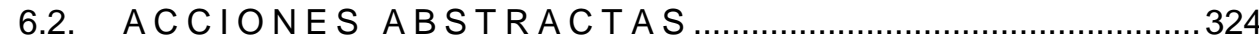

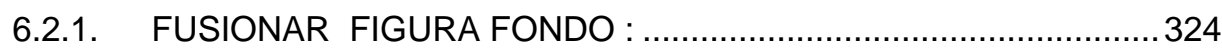

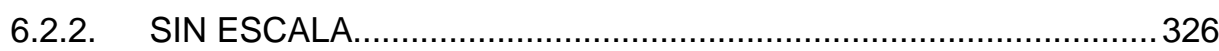

6.2.1. SIN FORMA, SIN VOLUMEN, SIN LIMITES :................................ 329

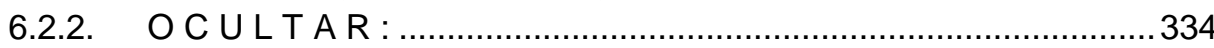

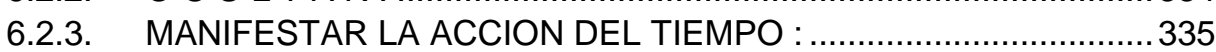

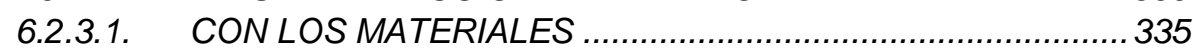

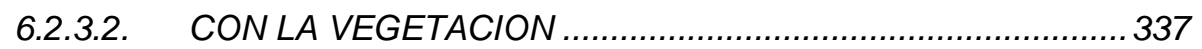

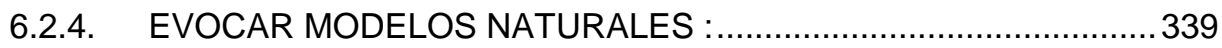

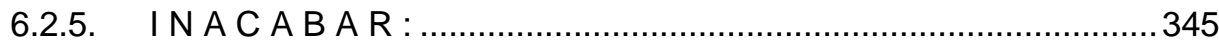

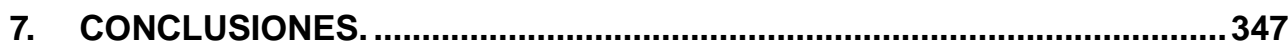

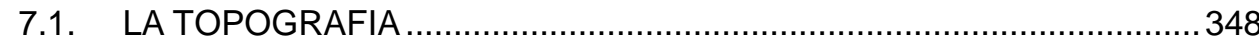

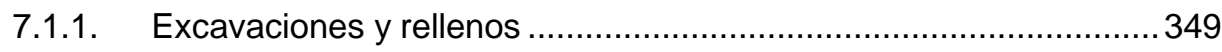

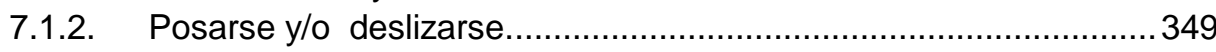

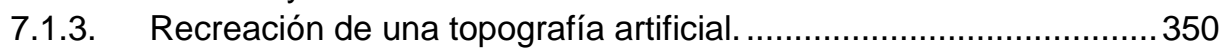

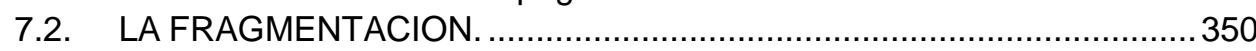




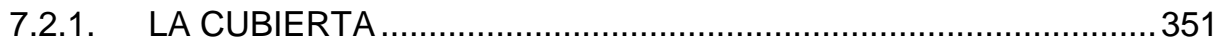

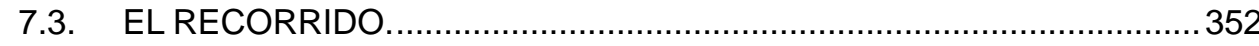

7.3.1. RELACIONES INTERIOR - EXTERIOR................................... 352

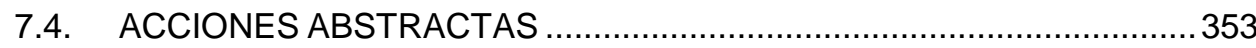

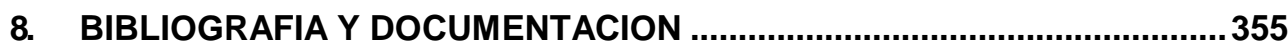

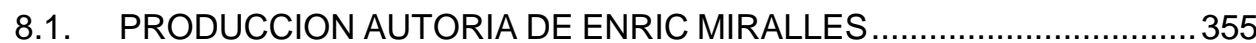

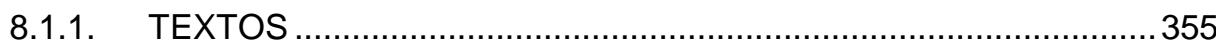

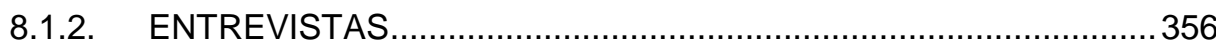

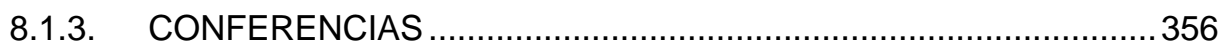

8.2. INTERPRETACIONES DE OTROS AUTORES SOBRE MIRALLES ......357

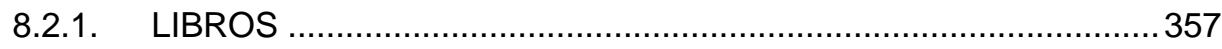

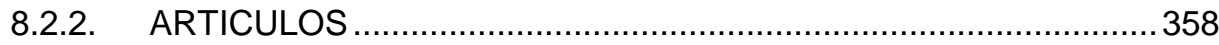

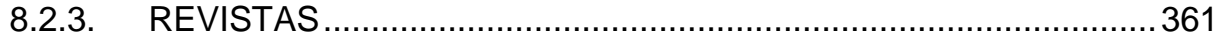

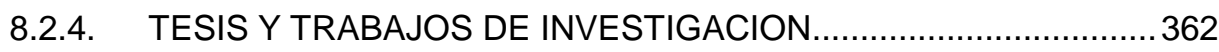

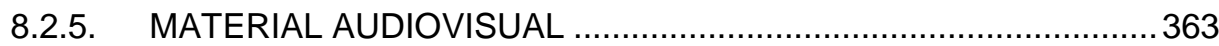

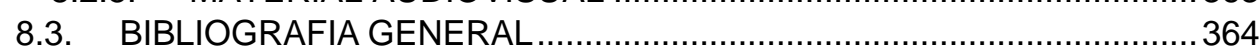

8.4. BIBLIOGRAFIA SOBRE EL PAISAJE ................................................. 370

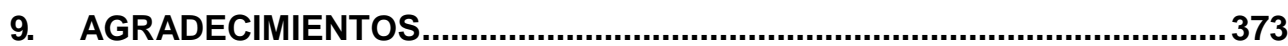


. El pensamiento y la obra del arquitecto español Enric Miralles (1955-2000) desde sus comienzos generó cambios significativos en la práctica de la Arquitectura, con un posicionamiento critico y el empleo de unas herramientas proyectuales que en opinión del autor de la presente Tesis Doctoral se adelantaron a su tiempo y todavía continúan hoy vigentes en la arquitectura contemporánea. Su arquitectura fue capaz de aceptar la complejidad de la existencia del mundo que le toco vivir, consciente de la llegada de la globalización, la perdida de los oficios artesanos y del control del arquitecto en el proceso de ejecución de la obra. Una estancia de investigación en la Universidad de Columbia en Nueva York en 1980-81, entre otras cosas, le puso en contacto con el Land Art norteamericano cuyas obras estudió a fondo "in situ". Ello, unido a la tradición catalana de buenas prácticas al operar en el paisaje, entre otras cosas, hicieron posible una obra como el Parque Cementerio de Igualada (1985-1991) realizada con Carmen Pinós.

La Tesis se centra en el objetivo de demostrar la hipotesis intuida en las visitas a las obras "in situ" por el doctorando, de que tenia que haber algo que explicase una fusion tan lograda entre arquitectura y paisaje, que debian existir ciertas acciones que Miralles creo para conseguir dicha fusion.

La Tesis como lo consigue? Analizando en detalle tres de las Obras construidas correspondientes a la etapa madura de Miralles, que no solo desarrollan los principios planteados en sus primeras obras sino que fundamentan su reputacion: el Parque Cementerio de Igualada (1985-1991), el Complejo deportivo de Tiro con Arco en Barcelona (1989-1992) y el Pabellón de Deportes en Huesca (1988 1994). Tras el analisis, la Tesis se centra en establecer una comparación de las acciones detectadas en estas obras, con el resto de la Obra de Miralles, demostrando que al final estas acciones se repiten en otras obras reforzando el entendimiento de la Obra de Miralles como si fuera un unico proyecto.

La Tesis demuestra como conclusión la existencia de esas acciones creadas por Mlralles desde el proyecto, unas mas concretas y otras mas abstractas, que desarrollan las estrategias proyectuales para implantar la obra en el paisaje natural materializando el objetivo perseguido por Miralles de disolver su Arquitectura en el medio. Acciones que comienzan en el Parque Cementerio de Igualada, pero que se emplearan en obras posteriores como en la Biblioteca de Palafolls, la propuesta de Concurso para la Remodelación del Puerto de Bremenhaven y el Parlamento de Edimburgo entre otros, y que consiguen que en el nuevo paisaje, transformado por las acciones de Miralles, lo construido sea un elemento mas, que al fragmentarse y desparramarse sin limites, se funde con todo lo circundante hasta llegar a confundirse siguiendo una especie de integracion infinita. Acciones que la Tesis expone y desarrolla para que puedan ser utilizadas en el futuro por la comunidad cientifica y aquellos arquitectos contemporaneos que como Miralles tengan vocacion de fundirse con el medio en el que intervienen.

Tras la investigación realizada en esta Tesis Doctoral se concluye que de las acciones que Miralles utilizaba para implantar su Arquitectura en el paisaje tales como: fusionar figura-fondo; velar la escala arquitectónica; ocultar; manifestar la acción del tiempo a través de la vegetación y los materiales; evocar modelos naturales; sin limites, inacabar, etc... destacan tres acciones por encima de las demás: la topografía, la fragmentación y el recorrido 
The thought and architectural practice of the Spanish architect Enric Miralles (19552000) from the beginning, generated significant changes in the Architectural practice with a critical attitude and the use of design tools of work, which in the author's opinion of this $\mathrm{PhD}$ thesis still have value today. The Architecture of Enric Miralles was able to accept the complexity of the contemporary existence, aware of the advent of Globalization, the loss of the craftmanship and control of the architect in the process of the Architecture construction. As visiting scholar at Columbia Unversity in New York in 1980-81, among other things, put him in contact with the North American Land Art earthworks whose study profoundly "in situ". This, and the design method used by landscape architects and Catalan tradition of good practice to operate in the landscape, among other things, made possible the lgualada Cemetery (1985-1991) designed with Carmen Pinós, in that they employ design strategies and tools usually used by land artist, expanding the architectural composition design method.

The thesis focuses on the objective of demonstrating the hypothesis intuited in visits to the "in situ" works by the doctoral student, that had to be something to explain a fusion so achieved between architecture and landscape, that there should be certain actions that Miralles I think to get it.

The thesis as it gets? Analyzing in detail three of the works constructed corresponding to the mature stage of Miralles, who not only develop the principles outlined in his earlier works but base their reputation: Igualada Cemetery Park (1985-1991), the Sports Complex Archery Arco in Barcelona (1989-1992) and the sports Pavilion in Huesca (1988-1994). After analysis, the thesis focuses on a comparison of the actions identified in these works with the rest of the work of Miralles, showing that in the end these actions are repeated in other works strengthening the understanding of the work of Miralles like an unique.

The thesis demonstrates the existence conclusion of those actions from the project, more concrete and more abstract, to develop design strategies to implement the work in the natural landscape materializing the objective pursued by Miralles to dissolve its architecture landscape. Actions beginning in Cemetery Park Igualada, but that will be used in later works such as the Library of Palafolls, the proposed Competition for the remodeling of the Port of Bremenhaven and Parliament Edinburgh among others, and getting the new landscape transformed by the actions of Miralles, built what is one more element that breaking and not put limits merges with all surrounding to be confused in a sort of infinite integration. Thesis actions that exposes and argues that they can be used in the future by the scientific community and those contemporary architects who have vocation as Miralles disovlerse in the environment in which they are involved.

After the research realized in this PhD thesis, concludes that within implantation strategies used by Enric Miralles in its architecture aimed to interact with the natural landscape: merge figure-ground; ensure the architectural scale; hide; manifest the action of time through the vegetation and materials employed; evoke natural patterns; no end works ... are three actions above the others: the topography, the fragmentation and route. 


\title{
1. INTRODUCCION
}

Enric Miralles advierte sobre la manera en la que el investigador debería analizar sus obras:

\begin{abstract}
“...buscar algunos puntos en común entre ellas. $Y$ estos puntos en común, sin embargo, no los buscaría en temas que aparentemente les pueden ser propios, como descripciones formales o a través de superficies, pliegues, deslizamientos, etc. que son para mí definiciones bastante lejanas y que acercan los proyectos a la caricatura...esta caricatura surge al fijarnos en lo que tenemos en las manos, cuanto probamos a describir las cosas... Y sin embargo, lo que hay fuera, lo que origina los proyectos, es de gran importancia"
\end{abstract}

Enric Miralles. ${ }^{1}$

Las dificultades que plantea para el investigador la complejidad de su trabajo, la diversidad de sus fuentes, y lo excesivo de su modo de hacer resultan abrumadoras. Cada obra de Miralles es una pieza más en un devenir de piezas que se llaman unas a las otras, hasta llegar a conformar una especie de diccionario sin fin. El mismo Miralles promociono su misterio, ocultando la relación entre las fuentes de inspiración y sus obras. La mayoría eran de artistas o escritores, con lo que si el investigador pretende establecer nexos de unión, puede terminar en una especie e tela de araña difícil de desenredar. La distancia critica que aportan los casi 16 años transcurridos desde su desaparición, y la proliferación de estudios críticos en los últimos años, ayuda a la investigación. La Tesis se centra en investigar un aspecto concreto de su Arquitectura, las estrategias proyectuales que utiliza Enric Miralles para implantarse en el paisaje natural o periurbano, en detalle en tres de sus obras construidas, abordando su complejidad a través de la recurrentes visitas a las obras, al Archivo Enric Miralles en Barcelona y toda la bibliografía estudiada. Dichas estrategias se llevan a cabo a través de unas acciones que se estudian en detalle en tres obras: el Parque Cementerio de Igualada (1985-1991), el Complejo deportivo de Tiro con Arco en Barcelona (1989-1992) y el Pabellón de deportes en Huesca (1988 - 1994). Como el mismo Miralles aclara la estrategia es lo importante: "Los Proyectos son lógicos...la estrategia es lo importante. El proyecto son relaciones, soluciones y variantes donde se van mezclando las diferentes cosas de la arquitectura. Es conversar sin imponer una idea." 2

En el proyecto del Parque Cementerio de Igualada, se sintetizan estrategias y acciones que se prolongaran en su obra posterior. Esta obra es singular en muchos aspectos: la impronta del lugar, el programa, la simbología, su temporalidad, etc. En dicha obra, se van a dar unas circunstancias que desencadenaran una metodología proyectual muy personal. Al abordar el análisis de estas tres obras, también se procede a investigar, sus referencias, sus influencias, el contexto en el que surgen, etc.

\footnotetext{
1 "1995/2000. Enric Miralles + Benedetta Tagliabue" El Croquis no 100-101. 2005, pp. 21
} 


\title{
1.1. JUSTIFICACION DEL TEMA
}

\subsubsection{OBJETO}

\begin{abstract}
"...Sin embargo, y a pesar del respeto que tengo hacia el concepto de lugar, hay que admitir que la sombra de una tierra de nadie -- porque es de todos -- se cierne sobre el mundo hoy. Vivimos rodeados de los mismos elementos, mecánicos y electrónicos. Usamos los mismos instrumentos y aparatos. Sería difícil desde el ámbito de una oficina $o$, si se quiere, desde cualquier lugar de trabajo, decir en qué país nos encontramos. Y lo mismo podría decir a propósito de un hospital, un aeropuerto o un supermercado. A esto hay que añadir el modo en que el transporte de masas ha alterado nuestra idea del espacio, el significado de la distancia. Todo parece estar en contra del lugar. Todo parece reclamar un mundo homogéneo, lleno de los mismos productos, inundado por las mismas imágenes. Parece como si tan sólo la ubicuidad del no-lugar existiese; como si la idea de lugar ya no tuviese valor; como si pudiésemos ignorar dónde nos encontramos, dónde estamos..."
\end{abstract}

Rafael Moneo. ${ }^{3}$

Este párrafo de Moneo extractado de su artículo "Inmovilidad substancial" retrata muy bien la situación del inmediato presente que vive la arquitectura.

Con el convencimiento de que efectivamente la vida se ha complejizado, pero aun siguen existiendo respuestas enriquecedoras para los "lugares" la Tesis Doctoral tratara de demostrar que no solo es posible el defender una Arquitectura ligada al lugar hoy, sino que en el futuro si el hombre quiere que el planeta siga siendo sostenible, no quedara más remedio que escuchar el murmullo del lugar, tener en cuenta su topografía, su clima, su ambiente, sus materiales, las costumbres de las gentes, su artesanía, etc. no solo para no deteriorar el paisaje, sino para intervenir en éste de manera sostenible.

La Tesis Doctoral trata de las estrategias de implantación que emplea Enric Miralles en el paisaje natural, analizando su manera de proceder en tres de sus obras, para en la comparación posterior entre estas y el resto de su obra, extraer datos inéditos y un poso de conocimiento que pueda emplear en el futuro la comunidad científica. Su actitud, sus estrategias proyectuales, sus herramientas tienen personalidad propia.

El paisaje hoy, no solo se percibe a través de la mirada contemplativa, es algo mucho más complejo que implica multitud de parámetros que entran en juego y que el hombre sensible es capaz de captar.

\footnotetext{
${ }^{2}$ Enric Mlralles. Conferencia en la Escuela de Arquitectura de La Coruña.1996.

3 “Inmovilidad substancial” CIRCO M.R.T. Editado por: Luis M. Mansilla, Luis Rojo y Emilio Tuñón.
} 


\subsubsection{CONTENIDO}

“...A diferencia de lo que es habitual en otros países donde se da una importancia desmedida al edificio mientras el entorno apenas recibe atención, los arquitectos españoles suelen articular el terreno de modo que refuerce los atributos expresivos de la forma, la sensibilidad topográfica puede considerarse el primer indicador de españolidad..."

Kenneth Frampton.

En lo que respecta al tema objeto de investigación, conviene destacar que la arquitectura española ha destacado especialmente por factores de identidad cultural, historia, costumbres, etc. Ello se demuestra a lo largo de la Historia mediante la excelente relación con el paisaje que siempre mantuvo la arquitectura popular. Además:

- La crítica especializada más respetada (Buchanan, Frampton, Curtis, Cohn, etc.) destacan la sensibilidad ante el paisaje de la arquitectura contemporánea española como uno de sus rasgos más característicos.

- De entre los arquitectos contemporáneos españoles; Miralles destaca por su maestría para implantar su arquitectura en el paisaje, mejorando en muchos casos con sus intervenciones el paisaje existente. Miralles exploran un ambiguo territorio intermedio entre los dominios del urbanismo, el paisajismo, la arquitectura y la escultura.

- A medida que se avanzaba en la investigación, se ha ido enfocando y reduciendo el foco de la investigación. El doctorando inicio una Tesis que llevaba por titulo. "Estrategias de implantacion en el paisaje en la arquitectura contemporanea española: Navarro Baldeweg versus Enric Miralles" tema aprobado por el DPA ETSAM en Marzo de 2011. En la fase de documentacion y visita a las Obras, en especial la del Pabellon de Huesca de Miralles, en un dia de Otoño, el doctorando intuyo unas Acciones que Miralles parecia hubiera puesto en practica y que fundian su arquitectura con el paisaje en aquel magico atarceder. Desde luego que las sensaciones y emociones que transmitio aquella visita al doctorando, hizo que centrase su investigacion en adelante en investigar que acciones habria creado Miralles para conseguir esa fusion con lo circundante. Dichas Acciones son las que estudia esta Tesis Doctoral.

- Los casos prácticos que se han analizado a fondo en esta investigación han sido: El Parque Cementerio de Igualada; el Complejo de Tiro con Arco en Barcelona y el Pabellón de Deportes de Huesca. Constituye un periodo muy intenso en la carrera profesional de Enric Miralles, pues al separarse de su pareja profesional Carmen Pinós, abordara en solitario la finalización y Dirección de Obra de estas tres obras. Por ello, el titulo de la Tesis hace referencia solo a Miralles, porque además es en el desarrollo, el proceso y la fase de construcción en obra donde un arquitecto como Mlralles sigue desarrollando los proyectos hasta el punto de no darlos por terminados nunca. 
- Enric Miralles siempre agrupo juntos estos tres proyectos respecto al resto de sus obras. En su intervención en el Seminario internacional Anymore ${ }^{4}$ volvió a incidir en la familaridad de estos tres proyectos e incluso avanzo su importancia en proyectos posteriores como la Biblioteca de Palafolls, el Parlamento de Edimburgo, según la siguiente frase: "First is to see one's own work as a kind of continuous field of research, where curiosity about architecture has produced a series of elements, where Igualada, Huesca and Archery Ranges have been transformed into Bremerhaven, Mollet, etc., and ultimately into the Edinburgh Parliament."

- El Parque Cementerio de Igualada, constituye un antes y un después en la producción del arquitecto. Es entonces cuando las resonancias del paisaje natural que se encuentra le hacen sacar todo lo que había aprendido de los Land Artist, cuyas obras visito "in situ" en su estancia de investigación en los EEUU en el curso 1980-1981. A partir de esta obra, las herramientas proyectuales empleadas y su modo de hacer se aplicaran al resto de sus obras, especialmente en Tiro con Arco ${ }^{5}$ y Huesca, donde lo aprendido en Igualada, será capaz de ampliarlo y reflejarlo en un espacio de gran escala que cuenta además con un gran volumen espacial cubierto.

\subsubsection{MARCO TEMPORAL}

La visión que el hombre mantiene sobre el paisaje está afectada por el espíritu de los tiempos en el que se perciba. Es importante destacar que la obra de Miralles, desde sus inicios estuvo imbuida del "zeitgeist", del espíritu de los tiempos, informado y al tanto de lo que sucedía en el Mundo, que tanto influye en la mirada que la sociedad y los arquitectos tienen sobre el paisaje, objeto de la investigación.

Además la tecnología ha avanzado mucho (imágenes por satélite, aparataje, etc.) desde que solo se contaba con planos topográficos detallados.

Pero la tesis, en lo que respecta a la elección de las tres obras a analizar como casos prácticos, concreta un periodo delimitado por dos fechas determinantes en la trayectoria de Enric Miralles:

- En el año 1985 Enric Miralles gana junto a Carmen Pinós el Concurso para el Parque Cementerio de Igualada. La coincidencia de múltiples factores hará que a partir de este momento se genere una manera de hacer y unos instrumentos que seguirán evolucionando a lo largo de la obra de Enric Miralles.

- En el año 1993, la cubierta del Pabellón de Deportes se desploma por un fallo de ejecución de uno de los tirantes que soportaban la cubierta, cometido por la constructora. A partir de este momento, las cosas no volverán a ser lo mismo. No solo los conocedores de la obra de Miralles reconocen este aspecto, sino que el mismo Miralles así lo admitió en muchas ocasiones. A partir de este momento, aunque se sigan aplicando

\footnotetext{
${ }^{4}$ Anymore Conference. Paris, junio de 1999

${ }^{5}$ Que por la urgencia a la que habia que realizarolo se desarrollo a la par del Parque Cementerio de Igualada.
} 
estrategias y acciones que evolucionan, otras muchas dejaran de aplicarse.

La tesis lógicamente también investiga el periodo temporal anterior al año 1985 y posterior al año 1993, pero las tres obras analizadas en detalles corresponden a este periodo de tiempo. Por ello se estudia como paso previo, el periodo de formación de Enric Miralles, el contexto del que surge su Arquitectura, las relaciones con el paisaje y el Land Art, etc. y también se estudia cómo evolucionan las acciones estudiadas en las tres obras en detalle demostrando como se siguen aplicando y evolucionando en obras posteriores como los proyectos para el Puerto de Bremenhaven, la Biblioteca en Palafolls y el Parlamento de Edimburgo.

\subsection{ESTADO DE LA CUESTION}

En el año 2011, cuando el autor de la Tesis se planteo este tema de investigación la obra de Enric Miralles no estaba estudiada en profundidad, pues a pesar de contar con una amplia bibliografía, los textos escritos sobre su obra, con alguna excepción, abarcaban material grafico pero de escasa voluntad interpretativa.

De entre los estudios críticos merecen destacarse los artículos escritos por Peter Buchanan, William Curtis, Dennis Dollens, Peter Blundell, Josep Quetglas, Rafael Moneo, Juan José Lahuerta, Ramón Faura, ...

La primera monografía sobre Enric Miralles, se edito en mayo de 1987, y constituyo el no 6 de la revista A 30, titulada "Enric Miralles y Carme Pinos, 1983-1987". Con aportaciones de Carme Ribas, Pere Joan Ravetllat y Joan Roig.

El artículo escrito por Peter Buchanan para el catalogo de la Exposición "The Architecture of Enric Miralles \& Carme Pinos". New York: Sites-Lumen, 1990. Celebrada en el Storefront for Art and Architecture de Nueva York en 1990. Con el título de "Dialogues and Distillation: The Architecture of Enric Miralles and Carme Pinos" ayudo al reconocimiento internacional de Miralles y Pinos. Buchanan trata en su artículo las referencias locales y universales de su obra; la metodología proyectual, la importancia del dialogo y especialmente la relación de su arquitectura con el paisaje.

En 1991, se publica otro artículo fundamental para desvelar la obra de Miralles, escrito por William Curtis en 1991, para la revista El Croquis 49+50, que llevaba por título "Mapas mentales y paisajes sociales". En dicho escrito, trata de las referencias, analiza críticamente lo proyectado y construido hasta el momento, sin poderlo encasillar en Arquitectura solo, sino como una mezcla de Paisajismo, Arquitectura y Escultura. También avisa sobre el futuro de Miralles, en el momento que la carga de trabajo rompa con el proceder artesanal con el que se trabajaba en ese momento. En el mismo número de la revista El Croquis 49+50, Josep Quetglas, con su artículo "No te hagas ilusiones", alumbra sobre el imaginario arquitectónico de Miralles en estado puro.

En 1991 Cino Zuchi organiza en el Politécnico de Milán un Seminario titulado "Bau Kunst Bau" reuniendo a Enric Miralles, Francisco Alonso de Santos, Jaques Herzog y Steven Holl entre otros. En dicho seminario Miralles defiende la práctica artesanal de la Arquitectura, mostrando sus obras realizadas hasta el momento, y destacando el Parque Cementerio de Igualada. 
En 1994, Marina Riglio publica "Architettura tra artificio e natura : progetti dal 1984 al 1990 " que tiene mucho que ver con la investigación desarrollada en esta Tesis Doctoral, estableciendo sugerentes conexiones entre la obra de Miralles y otros artistas y su conexión con la Naturaleza.

En 1995, la entrevista realizada por Alejandro Zaera, para el no 72 de la revista El Croquis titulada "Enric Miralles 1990-1994", destaca por la perspicacia de las preguntas planteadas a Miralles, que junto con sus respuestas aportan mucho al conocimiento de su obra.

También en 1995, se edita el libro "Enric Miralles CNAR Alicante" escrito por Peter Blundell Jones, con un articulo critico que analiza en profundidad la trayectoria de Miralles, sus referencia, destacando la calidad de las fotografías que documentan el proceso constructivo de este edificio, que es "hermano" del Pabellón de Deportes de Huesca.

De 1995 merece destacarse la edición del libro monográfico dedicado al Pabellón de Deportes de Huesca dentro de la colección Documentos de Arquitectura no 32 ., por cuanto que se aborda con datos técnicos y objetivos el proceso de génesis, evolución y construcción del edificio.

En 1996, Miralles, decide publicar sus trabajos contados por el mismo a través de la publicación de su monografía editada por Electa, "Enric Miralles: Obras y Proyectos". Al cuidado de Benedetta Tagliabue Miralles, el libro contiene un ensayo de Juan José Lahuerta que desgrana múltiples referencias del imaginario y los procesos metodológicos de Miralles. Además, en este libro, es Miralles quien presenta cada uno de los proyectos y obras que el libro documenta y constituye una valiosísima aportación para investigar en su obra.

En 1996, Anatxu Zabalbeascoa publica un libro monográfico dedicado al Parque Cementerio de Igualada titulado "Igualada Cemetery: Enric Miralles and Carme Pinós". Aparte de aportar relaciones importantes entre Miralles y sus maestros, la autora destaca los vínculos con el lugar y el paso del tiempo en esta obra y como determinadas herramientas empleadas en Igualada, seguirá empleándolas Miralles en obras posteriores.

En el año 2000, se edita un número monográfico de la revista El Croquis nำ100101, titulado "Miralles Tagliabue 1996-2000", en el que Miralles estuvo muy involucrado en su preparación, destacando una interesante entrevista de Emilio Tuñón y Luis Moreno Mansilla. Desgraciadamente Miralles, ya no pudo ver este número editado. También destaca en este número, el artículo de Rafael Moneo titulado "Enric Miralles. Una vida intensa, una obra plena".

En 2004, se edita el libro "Enric Miralles: Metamorfosi del Paesaggio" dentro de la colección Universale di Architettura, escrito por Fredy Massad y Alicia Guerrero Yeste, que ha sido importante para el tema abordado en esta Tesis Doctoral.

En 2009, el Departamento de Composición Arquitectónica de la Escuela de Arquitectura de Barcelona (ETSAB), edita una importante monografía de la revista DC no 17 - 18, dedicado íntegramente a analizar la obra de Miralles por diversos autores y recopilando gran parte de los escritos de Miralles y elaborando una completa bibliografía, del que merece extractar la siguiente cita: "En tiempos de escasas o perseguidas intensidades criticas, la microhistoria de alguna de sus arquitecturas, la reunión de sus textos, el esfuerzo por desvelar sus referentes, lecturas, imaginarios, viajes físicos y mentales, pueden hacer saltar por los aires 
años de papel impreso destinado a copiar secciones y detalles, o a vulgarizar los esfuerzos del mejor de los nuestros durante casi veinte años". ${ }^{6}$

También en el año 2009, se celebra en Barcelona los días 6, 7 y 8 de julio un Congreso monográfico sobre Miralles: "Alegoría del tiempo: la arquitectura y el universo de otro Enric Mlralles", con conferencias de Carme Pinós, Benedetta Tagliabue, Ramón Faura, Robert Bufrau, Enrique Granell, Josep María Rovira y otros. Destacando para la investigación en esta Tesis Doctoral entre otras las conferencias de Ricardo Lampreave, Ramón Faura sobre el Complejo de Tiro con Arco y el Pabellón de deportes de Huesca y la conferencia de Antonio Pizza sobre el Parque Cementerio de Igualada.

En 2010, el artista David Bestue publica "Enric Mlralles a izquierda y derecha (también sin gafas)", siendo un libro interesante porque supone la mirada fresca y critica de un artista plástico sobre la obra de Miralles, revisitando las obras para estudiar cómo les había afectado el discurrir del tiempo, y aportando perspicaces e ingeniosas lecturas de su obra.

En 2011, se publica un libro fundamental en el estudio de la obra de Enric Miralles, editado por Josep María Rovira que lleva por título "Enric Miralles 1972 -2000" que supone el estudio más profundo y critico hasta el momento sobre la obra de Miralles. Se ocupa de las principales obras construidas desde la óptica de diversos autores.

En lo que respecta al material audiovisual:

En al año 2000 conviene destacar el lanzamiento del DVD no 15 dedicado monográficamente a Miralles titulado " Enric Mlralles. Aprendizajes del arquitecto" junto con el libreto que acompaña al DVD.

Respecto a las Conferencias, aunque se han visionado muchas, destacan a los efectos de esta investigación, las conferencias dictadas por Miralles en la Architectural Association de Londres el día 28/02/1992. dentro del "Barcelona Symposium", sobre el Complejo de Tiro con Arco; y la dictada en la ETSAM el día el día 05/05/1993, a los pocos días del derrumbe de la cubierta del Pabellón de deportes de Huesca, en la que abordo la nueva solución de cubierta.

Recientemente, conviene destacar el Ciclo "Conversaciones con Enric Miralles". que la Fundación Enric Miralles, viene celebrando desde 2014, y por el que han pasado Rafael Moneo, Enrique Granell, Iñaki Abalos, Anatxu Zabalbeascoa, Elías Torres y Josep Quetglas entre otros.

También se han escuchado reiteradamente los podcast "Scalae" de entrevistas realizadas por Félix Arranz a Carmen Pinos, Benedetta Tagliabue, Marco Vidotto y otros, que han aportado también a la investigación.

En cuanto a los programas de televisión emitidos, destacan:

El documental emitido por "Canal 33 de Televisió de Catalunya", en 2001, titulado "Enric Miralles" en el que intervienen aportando sus visiones sobre la obra de Enric Miralles entre otros los siguientes arquitectos: Benedetta Tagliabue, Josep Lluís

6 "Enric Miralles, 1955 - 2000", Revista DC papers 17 - 18, Departamento de Composicion Arquitectonica, ETSAB, 2009, pp. 7. 
Mateo, Òscar Tusquets y Ricardo Bofill. Aparecen imágenes inéditas de Miralles trabajando en el estudio del Passatge de la Pau.

Recientemente, se ha emitido en Octubre de 2015 por TVE (Televisión Española) el programa titulado "La mitad invisible: el Zementeri de Igualada", en la que destacan las intervenciones de Carmen Pinos, Benedetta Tagliabue y Anatxu Zabalbeascoa. El periodista recorre la obra con Carmen Pinós y también se percibe desde el aire, en globo.

Respecto a Tesis Doctorales que han aportado mucho a la investigación, destacan las siguientes:

La Tesis de Javier FERNANDEZ CONTRERAS. Titulada "La planta Miralles: Representación y Pensamiento en la Arquitectura de Enric Miralles", leída en DPA ETSAM. UPM en 2013. Esta Tesis merece destacarse de entre las demas tesis consultadas de Miralles por el doctorando, pues es la que mas se ha consultado por el doctorando en el transcurso del desarrollo de la Tesis Doctoral, por sus importantes hallazgos y la cantidad de material grafico claramente ordenado que contiene de toda la Obra de Miralles.

La Tesis de Arturo BLANCO, titulada "Flujo laminar: El cementerio de Igualada y los procesos elásticos en la arquitectura de Enric Miralles y Carme Pinós" leída en DPA ETSAM. UPM en Noviembre de 2015, en la que se abordan 12 acciones que se emplean en el proyecto del Parque Cementerio de Igualada, demostrando que se inician desde este proyecto y seguirán empleándose en proyectos posteriores. Destaca el trabajo de catalogación de todos los croquis del proyecto facilitados por la Fundación Enric Miralles y su análisis minucioso. Esta Tesis tambien merece destacarse por su contenido, hallazgos y la cantidad de material inédito sobre el Parque Cementerio de Igualada.

La Tesis de Carlos ASENSIO titulada "Arquitectura abierta en el paisaje. Una metodología analítica desde la fenomenología". leída en DPA ETSAM. UPM en 2009 , en la que se aborda el paisaje desde la fenomenología y se trata como uno de los casos de análisis el Parque Cementerio de Igualada.

La Tesis de Montserrat BIGAS, titulada "Enric Mlralles. Procesos metodológicos en la construcción del proyecto arquitectónico". Leída en 2006 en Universidad de Barcelona. Departamento Dibujo y Grabado; en la que se aborda la metodología de Miralles y la importancia dada al dibujo, aplicándolo a la génesis del proyecto del Parlamento de Edimburgo.

La Tesis de Mayka GARCIA HIPOLA, titulada "La acción arquitectónica en el territorio a través de Peter Eisenman: transformación de las estrategias proyectuales durante la posmodernidad". Leída en DPA ETSAM UPM en 2008, en la que se aborda la obra de Peter Eisenman como tema principal, pero comparada con otras obras de diferentes arquitectos, entre los que se encuentra el Parque Cementerio de Igualada de Miralles y Pinós.

La Tesis de Darío GAZAPO DE AGUILERA, titulada "El Land Art y la Arquitectura. Una nueva definición de Land Art". Leída en DPA ETSAM UPM en 1991, en la que se aborda la relación entre Land Art y Arquitectura.

La Tesis de Salvador GILABERT, titulada " Enric Miralles. El dibujo de la Imaginación" leída en la UPV en 2015 en la que se aborda el dibujo en toda la obra de Enric Miralles, con material inédito de archivo dado que el autor es colaborador del estudio EMBT desde hace mucho tiempo. 
Existen otros trabajos menores de investigación que se han estudiado, que se encuentran referenciados en la bibliografía.

En conclusión, destacar que a pesar de la cantidad de documentación estudiada a lo largo de la investigación de esta Tesis Doctoral, ninguna aborda en profundidad las estrategias de implantación y sus acciones en el paisaje natural o periurbano como lo aborda esta Tesis Doctoral, centrada en tres obras "topográficas" que Enric Miralles abordo con acciones determinadas para fundirse con el paisaje circundante, y como se demostrara, algunas acciones dejaron de emplearse y otras sin embargo evolucionaron en su obra posterior. Es por ello que lo investigado en esta Tesis Doctoral a día de hoy, sigue siendo inédito.

\subsection{HIPOTESIS}

La hipotesis intuida en las visitas a las obras "in situ" por el doctorando, de que tenia que haber algo que explicase una fusion tan lograda entre arquitectura y paisaje, que debian existir ciertas acciones que Miralles creo para conseguir dicha fusion.

La investigación se centra en tres obras fundamentales de Enric Miralles: El Parque Cementerio de Igualada, el Complejo de Tiro con Arco y el Pabellón de Huesca, en un periodo en el que se emplean unas estrategias y acciones para implantarse en el paisaje inédito en el panorama de la arquitectura contemporánea.

Se plantea como hipótesis de trabajo que desde la primera de las tres obras analizadas en detalle en la investigación, el Parque Cementerio de Igualada, constituye un punto de inflexión en la carrera de Enric Miralles, pues a partir de esta obra la manera de proyectar cambiara y se demostrara como continua en las otras dos obras analizadas en detalle e incluso en obras posteriores. A partir de este proyecto

Las tres obras analizadas tienen en el trabajo con la topografía, una de las acciones determinantes para fundirse con el paisaje circundante. Pero aparte de esta acción se estudiaran otras muchas que Miralles emplea desde la fase de proyecto hasta el final.

\subsection{OBJETIVOS PREVISTOS}

La Tesis se centra en el objetivo de demostrar la hipotesis intuida en las visitas a las obras "in situ" por el doctorando, de que tenia que haber algo que explicase una fusion tan lograda entre arquitectura y paisaje, que debian existir ciertas acciones que Miralles creo para conseguir dicha fusion.

El objetivo de esta Tesis Doctoral es el estudio de las acciones empleadas por Miralles para desarrollar sus estrategias de implantación en el paisaje natural o periurbano, a través de tres obras concretas. Este objetivo no sería posible sin el conocimiento directo de las obras, las sensaciones que producen, el contacto con la escala, los recorridos, las relaciones interior - exterior, la relación con el paisaje, el contacto con los materiales, etc. Una arquitectura tan compleja, hay que visitarla para entenderla, ya que su esencia es difícil de captar en fotografías o a través de los planos. Por supuesto, que el análisis de la Documentación publicada en todos los formatos y el acceso al Archivo de la Fundación Enric Miralles, para conocer de primera mano la evolución de los croquis, las anotaciones al encontrarse con el lugar, el desarrollo de los proyectos, etc. Todo ello ha permitido al doctorando una reflexión más rica e intensa. La investigación de la relación de la arquitectura de 
Miralles con el paisaje natural o periurbano se lleva a cabo recurriendo a todo tipo de consideraciones, la formación del arquitecto, sus vínculos, sus viajes, sus escritos, sus dibujos...

El doctorando considera que el arquitecto contemporáneo debería conocer y saber manejar las herramientas y aquellas estrategias proyectuales que le ayuden a relacionarse mejor con el paisaje.

A lo largo de la investigación el termino paisaje se entiende como esa construcción artificial, producto cultural de la transformación arquitectónica sobre el territorio, de como ese territorio se convierte en paisaje a través de la implantación en él de la arquitectura. El paisaje hoy, no solo se percibe a través de la mirada contemplativa, es algo mucho más complejo que implica multitud de parámetros que entran en juego y que el hombre sensible es capaz de captar.

La Tesis Doctoral además demostrara con el ejemplo de la obra de Miralles, que no solo es posible defender una Arquitectura ligada al paisaje hoy, sino que en el futuro si el hombre quiere que el planeta siga siendo sostenible, no quedara más remedio que escuchar el murmullo del lugar, tener en cuenta su topografía, su clima, su ambiente, sus materiales, las costumbres de las gentes, su artesanía, etc. no solo para no deteriorar el paisaje, sino para intervenir en éste de manera sostenible, sin atacar su identidad, etc.

Los objetivos previstos, entre otros, que justifican la Tesis Doctoral son varios:

1.- Demostrar con esta Tesis Doctoral, que en contra de mucha de la arquitectura contemporánea que ha abusado de una actitud autista frente al lugar, todavía se puede confiar en determinadas prácticas de arquitectos contemporáneos como Enric Miralles que tiene en cuenta el lugar, respetando su identidad y estableciendo un dialogo para que la obra surja de este.

2.- Estudiar a fondo el cuerpo teórico existente sobre el paisaje en el "espíritu de los tiempos actuales" para proceder a aplicarlo al estudio de la obra de Enric Miralles.

3.- Analizar la documentación publicada en todos los medios (escrita, grafica, audiovisual, internet, etc.) y la documentación inédita obtenida en el archivo de la Fundación Enric Miralles de Barcelona, las visitas a las obras objeto de estudio, para encontrar las acciones que utiliza Miralles, para desarrollar su estrategia proyectual y fundir su Arquitectura con el paisaje.

4.- Generar una Tesis, que sirva a la comunidad científica para que pueda ser utilizada en un futuro para hacer más fácil y satisfactoria la relación de la arquitectura con el paisaje.

\subsection{METODOLOGIA}

La Tesis se centra en el objetivo de demostrar la hipotesis intuida en las visitas a las obras "in situ" por el doctorando, de que tenia que haber algo que explicase una fusion tan lograda entre arquitectura y paisaje, que debian existir ciertas acciones que Miralles creo para conseguir dicha fusion.. 
La Tesis como lo consigue? Analizando en detalle tres de las Obras construidas correspondientes a la etapa madura de Miralles, que no solo desarrollan los principios planteados en sus primeras obras sino que fundamentan su reputacion: el Parque Cementerio de Igualada (1985-1991), el Complejo deportivo de Tiro con Arco en Barcelona (1989-1992) y el Pabellón de Deportes en Huesca (1988 1994). Tras el analisis, la Tesis se centra en establecer una comparación de las acciones detectadas en estas obras, con el resto de la Obra de Miralles, demostrando que al final estas acciones se repiten en otras obras reforzando el entendimiento de la Obra de Miralles como si fuera un unico proyecto.

La metodología de investigación utilizada en esta Tesis Doctoral, gestiona las acciones que Miralles empleaba para implantarse en el paisaje que tan bien recibida fue por la crítica de la Arquitectura. Si bien la mayoría de estas acciones comienzan en el Parque Cementerio de Igualada, se aplicaran en obras futuras, como Tiro con Arco y Huesca, y también en otras más alejadas en el tiempo como la Biblioteca de Palafolls, Bremenhaven y el Parlamento de Edimburgo. Dicha metodología se ha centrado en el estudio de las obras analizándolas gráficamente, teóricamente e "in situ", en el paisaje en el que se ubican, realizando continuas visitas en las distintas estaciones climáticas.

El análisis grafico, se ha llevado a cabo, previa documentación y escaneo de planos, fotografías, etc. La mayoría de la documentación se ha obtenido de las publicaciones disponibles hasta la fecha, pero gran parte es inédita obtenida del Archivo de la "Fundación Enric Miralles" en Barcelona gracias a la colaboración de Benedetta Tagliabue. El análisis teórico se ha basado en el estudio de libros, artículos, conferencias, congresos, exposiciones, documentales, tesis doctorales, etc. Ha sido fundamental el abundante material disponible en las Bibliotecas en las que se ha llevado a cabo la labor de documentación destacando la biblioteca de la Escuela Técnica Superior de Arquitectura (ETSAM) y la Biblioteca Nacional, así como las Bases de datos de otras bibliotecas "on line". También destacar la cantidad de documentación, conferencias, podcasts, etc. accesibles a través de Internet.

El estudio del "corpus teórico", no solo se ha centrado en la obra de Miralles sino que también se ha ampliado a otros autores, arquitectos y artistas. El doctorando también ha obtenido un conocimiento profundo de la teoría existente sobre el Paisaje contemporáneo, fundamental para el arquitecto hoy. Se han estudiado obras fundamentales se ha ido ampliando la cantidad de obras a medida que avanzaba la investigación.

Para elaborar esta Tesis, ha sido necesario estudiar las referencias e influencias de Miralles, el contexto histórico y personal en el que Miralles se educo y trabajo: la Barcelona de de años '70; los años '80 y la estancia académica de Miralles en Estados Unidos; la influencia del Land Art y la arquitectura deconstructivista; los años '90 con la llegada de los grandes encargos y su reconocimiento internacional siendo profesor en la "Staedeschule de Frankfurt" y la "GSD de Harvard".La metodología a emplear ha consistido en ir cumpliendo las siguientes etapas en el desarrollo de la Tesis Doctoral:

1) Documentación.

2) Análisis.

3) Comparacion, razonamiento y reflexión.

4) Conclusiones. 


\section{Documentación:}

En una primera etapa de documentación se ha recopilado toda la información posible sobre el tema objeto de investigación, a través de consulta de libros, artículos, bases de datos, tesis doctorales, videos, conferencias, documentales, etc. no solo de la obra de Miralles sino también del paisaje contemporáneo, del Land Art, etc.

- Se ha llevado a cabo una prospección de todo tipo de documentación en las Bibliotecas de: la ETSAM, del COAM, y de la Biblioteca Nacional en Madrid. Fundamental ha sido la labor de investigación realizada en el Archivo de La Fundación Enric Miralles de Barcelona.

- Se han visitado las tres obras objeto de estudio y otras de Miralles, para ponerse en el lugar de Miralles e intuir en que se fijo cuando visito el paisaje donde tenía que proyectar su arquitectura, así como para sentir lo que ese paisaje comunica empleando todos los sentidos.

- Se ha indagado en el pensamiento de Miralles a través del estudio de libros, entrevistas realizadas, conferencias, interpretaciones de su obra, artículos críticos, tesis doctorales sobre su obra y el resto de conocimiento obtenido al que se tiene se tiene hoy acceso a través de Internet (you tube, webs de Centros y Escuelas de Arquitectura más avanzadas.

- Se han mantenido conversaciones con colaboradores, personas que conocieron a Miralles, en multitud de foros, para llegar a la conclusión de que cada uno hablaba de un Miralles distinto.

Con todo este material se ha generado un estado de la cuestión y se ha centrado la investigación.

\section{Análisis:}

Después de procesada y sintetizada la documentación se ha realizado un análisis en profundidad de las tres obras seleccionadas a través de las acciones que Miralles emplea para relacionarse con el paisaje natural o periurbano.

También se ha analizado como responden las obras seleccionadas a su lugar físico, intelectual, cultural y personal del autor. Que relaciones existen con lo que se ha hecho en la Historia de la Arquitectura y con lo que quizás se haga en el futuro, como han envejecido, como responden al paso del tiempo.

Por medio de aproximaciones paulatinas a las obras objeto de estudio se han captado las relaciones con el paisaje mediante el análisis de los documentos del proyecto y el material de campo recopilado en las visitas a las obras.

\section{Comparación, razonamiento y reflexión:}

Una vez procesada la documentación y con los resultados obtenidos se han sometido a comparación, estableciendo relaciones, visiones cruzadas, etc. estableciendo diferencias, semejanzas, conexiones, transformaciones y paradigmas en la manera de actuar respecto al paisaje.

\section{Conclusiones:}

La tesis no pretende ser un trabajo cerrado en sí mismo; su intención es dejar puertas abiertas para que otras personas puedan continuar desarrollando esta 
investigación, permitiendo que las ideas aportadas en esta tesis generen proyectos futuros.

Al termino de la Tesis Doctoral, el doctorando espera haber hecho avanzar algo el conocimiento disciplinar de la arquitectura, concretado en cómo los arquitectos pueden captar el "murmullo del lugar" y las estrategias proyectuales y herramientas con la que se cuenta hoy en día para dialogar e intervenir en el paisaje.

\subsection{ESTRUCTURA DE LA TESIS}

La Tesis se estructura en seis capítulos, el primero está dedicado al contexto, los tres siguientes al análisis de cada una de las tres obras seleccionadas, el ultimo capitulo establece la comparación entre las tres obras analizadas y otras anteriores o posteriores para llegar al ultimo capitulo dedicado a las conclusiones.

El primer capítulo, titulado contexto sirve para ir enfocando el tema de investigacion y aborda la construccion de la mirada de Miralles. De ahí que se estudien sus años de formación, el contexto socio cultural de aquella España, el ambiente arquitectónico en el que se gesta su arquitectura y las influencias diversas fundamentales para entender su obra: Como introduccion a la manera de relacionarse Miralles con la Naturaleza, que la Tesis desarrollara, este capítulo también estudia la relacion de la Naturaleza con la Arquitectura, a lo largo de la Historia; la importancia del Land Art que Miralles conoció de primera mano en su estancia de investigación en los EEUU, y los últimos estudios sobre el paisaje en la contemporaneidad en los escritos de Iñaki Abalos, Stan Allen o Philip Ursprung entre otros, intuyendo como Miralles se adelanta a los tiempos no solo con su Arquitectura sino tambien en la relacion con el paisaje.

Le siguen tres capítulos dedicados al análisis de cada una de las tres obras seleccionadas de acuerdo a unas acciones detectadas que utilizaba Miralles para implantar y fundir su Arquitectura con la Naturaleza. Mediante el análisis de los documentos del proyecto y el material de campo recopilado en las visitas a las obras, los textos escritos de y sobre Miralles, sus conferencias, congresos, etc. y por medio de aproximaciones paulatinas a las obras objeto de estudio se han captado las relaciones con el paisaje natural o periurbano, en base al análisis de una serie de acciones detectadas a lo largo de la investigación. La estructura de estos tres capítulos de análisis es similar: El primer subcapítulo aborda el contexto, la obra y su relación con otras arquitecturas, Land Art, Arte, etc., se aborda la evolución del proyecto desde los primeros croquis, pasando por su construcción y el estado de la obra en la actualidad. Le sigue un segundo subcapítulo dedicado a las Acciones Concretas que Miralles emplea para implantarse en el paisaje, que tienen que ver con Topografía, Programa, Cubierta y Recorridos. Le sigue un tercer y último subcapítulo de cada capítulo dedicado a Análisis dedicado a las Acciones Abstractas que tienen que ver con: escala, forma, volumen, figura - fondo, ocultar, manifestar la acción del tiempo, inacabar, etc.

El penúltimo capítulo, está dedicado a la comparación de los resultados obtenidos en cada uno de los tres capítulos de análisis, pero también abarcando la comparación a otras obras anteriores y posteriores, estableciendo relaciones, visiones cruzadas, diferencias, semejanzas, conexiones, transformaciones y paradigmas resultantes en la manera de actuar respecto al paisaje.

El ultimo capitulo se recapitulan las conclusiones parciales de todos los capítulos y a la vez se genera un discurso donde se definen los procesos abiertos de Miralles al intervenir en el paisaje natural o periurbano. 
INTRODUCCION 


\section{CONTEXTO}

\subsection{RELACION ENTRE ARQUITECTURA Y NATURALEZA}

Desde el periodo de la civilización griega hasta el siglo XVIII, la relación arquitectura - naturaleza se dio a través de la imitación. Según esta interpretación platónica del mundo, la imitación se extiende a todas las etapas de la época pre moderna y afecta a todas las disciplinas.

A lo largo de los siglos se da una estructura modelo-copia en arquitectura que desaparecerá al irrumpir el sujeto moderno en el siglo XVIII. La Naturaleza ya no será ese modelo perfecto a imitar, apareciendo un nuevo concepto, dinámico y en continua evolución: el paisaje, que dará comienzo a una nueva manera de pensar la relación entre Arquitectura y Naturaleza.

Aristóteles distinguía tres tipos de saber: el teórico de las cosas existentes o "espíteme"; el practico-moral sobre la conducta del hombre o "praxis" y el tecnicoartistico para la producción de cosas o "techne". A partir de esta distinción de saberes, surgen tres clases de imitación entrelazadas entre sí: de la naturaleza, de los antiguos y de las ideas. Para Aristóteles, la función de la mimesis es proporcionar un placer intelectual contemplativo o la adquisición de una técnica, e indirectamente tenía un efecto virtuoso y moral. Por tanto el tema principal que caracteriza el pensamiento occidental sobre el arte será la mimesis. La imitación de la naturaleza para Aristóteles era una manera de completar su imperfección. Todo arte representativo debía contener referencias a la realidad objetiva y con ello, todo arte era imitación de la naturaleza. La naturaleza era el modelo que la representación imitaba. El fundamento de la cultura pre moderna reside en el supuesto de que existe una realidad ya terminada, autónoma, eterna y que en ella se encuentra la perfección inmutable, el modelo con sus determinadas reglas a imitar.

Los arquetipos expresan en arquitectura la experiencia acumulada por generaciones a lo largo del tiempo. Constituyen un antídoto contra el libre arbitrio individual. La cabaña, la tumba, la sombra son algunos de los arquetipos arquitectónicos. En general, los arquetipos se han expresado por medio de símbolos. El término "símbolo" proviene del griego symballein que se traduce como poner juntos. Significa un plano de conciencia diferente al racional, transmite y hace entender algo por medio de elementos o figuras cuyo significado conoce el receptor del mensaje. La columna nace de la sugerencia del tronco del árbol, pero también de la forma erecta del cuerpo humano. Estos y otros elementos conviven en la columna como símbolos. ${ }^{8}$

\footnotetext{
7 QUESADA GARCIA, Santiago. Tesis Doctoral. "Imitatio naturae. El paisaje como referente en la arquitectura contemporánea”. DPA ETSAS. 2006.

${ }^{8}$ Ibidem
} 


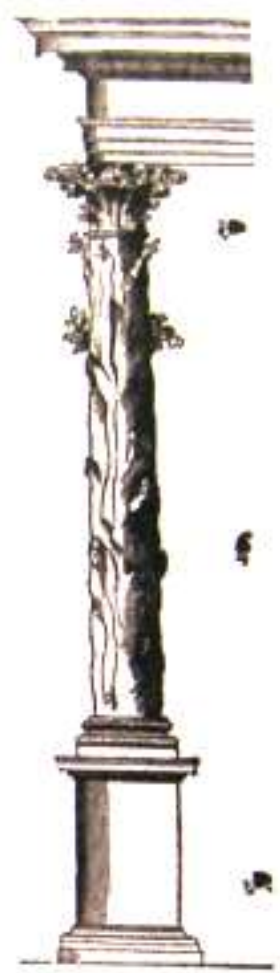

Ilustración 2-19

La imitación arquitectónica se ha entendido siempre de manera analógica, metafórica o simbólica, nunca en sentido estrictamente formal; ha tomado de los modelos aquello que los trasciende para utilizarlo. La analogía en arquitectura tiene una fuerza psicológica y emocional diferente a la lógica de la identidad, presente en todos los procesos de abstracción del pensamiento. La analogía no es lineal, se caracteriza por una carga emocional y por su organización temática inconsciente. La analogía, traerá a la arquitectura una repetición diferente.

El neoplatónico Plotino ${ }^{10}$ (205-270) defendía que para descubrir la armonía oculta de la Naturaleza era necesario utilizar la razón y la intuición (inteligencia y astucia). Según Josep María Rovira, Enric Miralles era un firme seguidor de las doctrinas neoplatónicas, desde que hiciera el curso de Doctorado en al ETSAB. Como neoplatónico era Miguel Angel, del que Miralles tenía la colección completa de la edición de Tolnay. ${ }^{11}$

\footnotetext{
${ }^{9}$ COLUMNA ARBOREA DEL LIBRO "LE PREMIER TORNE DE L'ARCHITECTURE" PHILIBERT DE L'ORME, PARIS 1567

${ }^{10}$ Plotino representa la renovación de la tradición platónica desarrollada en época imperial romana. E neoplatonismo de Plotino se basa en los diálogos tardios del maestro, el Parmenides y el Timeo, que le sirven como base y fundamento para desarrollar su propia filosofía de especulación cosmológica.

11 Josep Maria Rovira. Conferencia dada sobre el Mercado de Sta. Caterina. Congreso "Alegorias del tiempo" UIMP 2009
} 


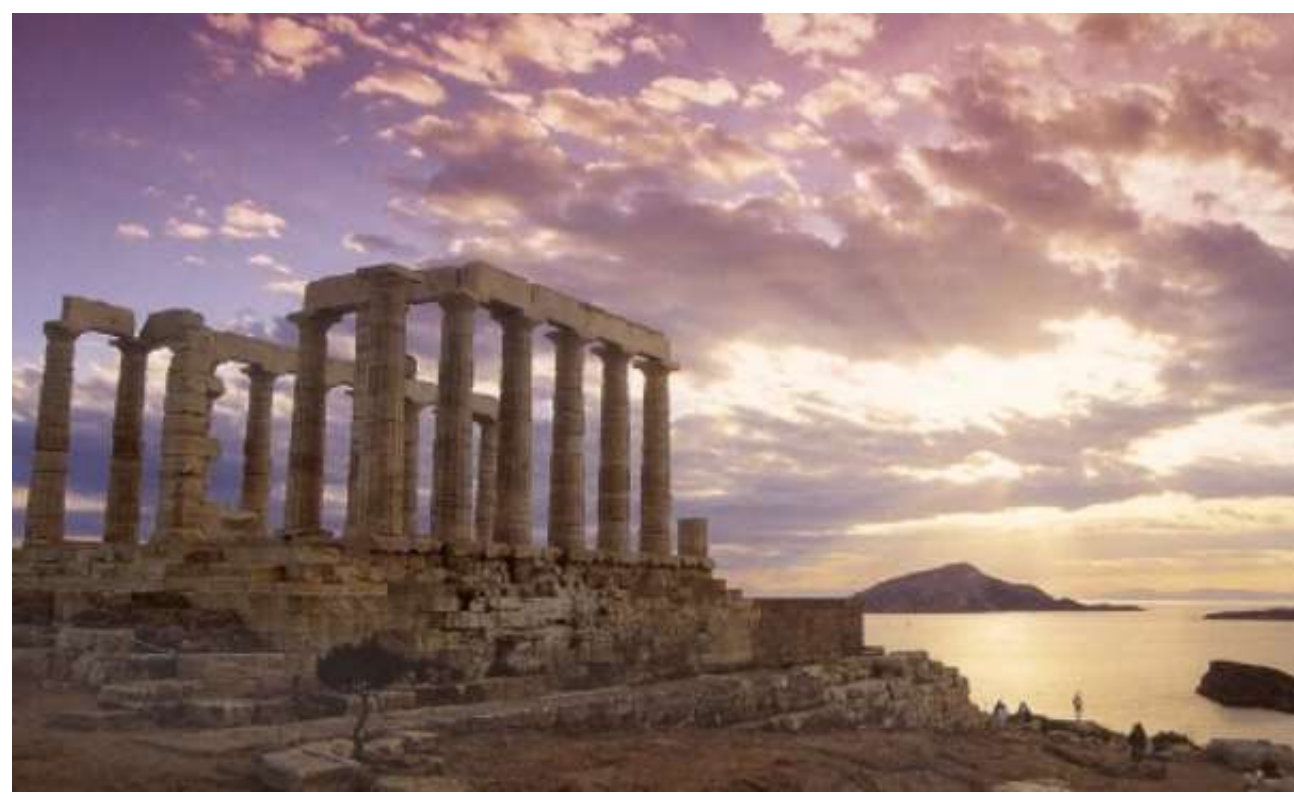

Ilustración 2-2 $\mathbf{2}^{12}$

La visión intimista de San Agustín retarda el reconocimiento del paisaje en la cultura occidental, generando una disociación entre sujeto y objeto, entre hombre y Naturaleza. Con Santo Tomas de Aquino, y su reintroducción de las teorías de Aristóteles, se provoca un nuevo interés por el paisaje. Cuando la arquitectura occidental sale al exterior de nuevo, el templo romano de Palestrina es el modelo. Bramante lo introduce en los jardines del Vaticano. La mirada del hombre renacentista cambiara la mirada medieval, estimulando de nuevo los sentidos. ${ }^{13}$

Sera la arquitectura de las villas renacentistas, con su implantación, orientación, recorridos, terrazas, logias, vistas, etc. la que más se acercará a percibir visualmente un determinado panorama desde la morada, lo que posteriormente se definiría como paisaje. Los jardines renacentistas llegan a tal grado de auto referencia y simbolismo que los aleja de cualquier relación con el paisaje circundante. Vasari, Varchi, Dolce, etc. comparten la idea de que el arte es imitación de la Naturaleza, pero al mismo tiempo afirman que la imitación como representación o copia de la realidad no basta, y que el artista debe tratar de complementar la Naturaleza. Leonardo Da Vinci, experimento con la racionalización de la topografía, al estudiar la relación entre un plano de trama geométrica y el curso natural de un rio. Así, demostró que era posible obtener un sistema proporcional ideal, un esquema racional de dimensiones y proporciones en el que se pusiera de relieve la relación entre el hombre y la Naturaleza.

En los tratados de Alberti se entiende la Naturaleza, no como apariencia o representación de la realidad sino como ley geométrica abstracta regida por la perspectiva y la proporción. Por tanto se puede imitar la Naturaleza sin copiar su

\footnotetext{
12 TEMPLO DE POSEIDON EN CABO SUNON, 440 A.C.

13 QUESADA GARCIA, Santiago. Tesis Doctoral. "Imitatio naturae. El paisaje como referente en la arquitectura contemporánea". DPA ETSAS. 2006.
} 
apariencia. Para Alberti, la interpretación matemática de la Naturaleza era un concepto artístico. La relación entre arquitectura - naturaleza es abordada por Alberti en su tratado De Re Aedificatoria (1485). Con el termino concinnitas o armonia, valorara la obra humana como equilibrio con el cosmos. Para el arquitecto renacentista, el principio que rige la formación de las cosas es la unión profunda entre mundo natural y artificial.

Palladio aboga por la voluntad de dialogo de la arquitectura con el entorno natural que la rodea, valorando el lugar y la posibilidad de contemplarlo con tranquilidad. En el libro segundo de los Quattro libri dellárchitettura, Andrea Palladio describe el entorno en el que se ubica la villa Rotonda (1569) : "El sitio es de los mas amenos y agradables que se pueden encontrar, porque está ahora sobre una loma de facilísima subida y bañado por una parte por el Bacchiglione, rio navegable, y por otra está rodeado de otras amenísimas colinas que dan el aspecto de un gran teatro...porque goza desde cada parte de bellísimas vistas, algunas de las cuales están terminadas, algunas más lejanas y otras terminan con el horizonte..." ${ }^{14}$

Si en su comienzos, la imitación fue la guía de la nueva cultura renacentista, al final fue objeto de contestación y crítica abierta. Se generaron disputas entre los defensores del ars-ingenium y los del ars-inventio, ya que el ingenio y la invención se consideraron opuestos a la imitación, estando la imitatio siempre del lado del ars.

El concepto de Paisaje nace en la primera mitad del siglo XVII, y el desarrollo de los conceptos de naturaleza y espacio se reflejaran en las teorías de los pensadores franceses René Descartes y Blaise Pascal, sentando las bases para las investigaciones posteriores de Isaac Newton en la segunda mitad del siglo XVII. Descartes en su obra Le dicours de la méthode (1637) expuso los principios de la geometría analítica, proponiendo un concepto de espacio completamente abstracto, y elaborando un sistema de coordenadas que hizo posible establecer la posición en el espacio. Pascal desarrollo la geometría proyectiva relativa a las cónicas, fundamental en el conocimiento posterior de la perspectiva.

Con la ayuda de las matemáticas, la representación de la Naturaleza adquirió carácter abstracto y universal. El conocimiento teórico de la perspectiva hizo posible su manipulación, alterando el horizonte y difuminando los límites entre realidad e imagen. El palacio del noble se localizara de manera simétrica entre la ciudad y el jardín, separándolos y relacionándolos a la vez. Se empleara la escala para trazar el jardín y para transferir las figuras geométricas a la superficie del terreno. Ese proceso lo denominaron poirtraitrure, un método para escalar y trasponer por puntos, como se hacía con los retratos de las esculturas. Este nuevo tipo de jardín surge por primera vez en Vaux-le-Vicomte obra de André Le notre, Louis le Vau y Charles Le Brun para el palacio de Nicolás Fouquet. ${ }^{15}$

A finales del siglo XVIII en Inglaterra surgió una polémica en torno a los principios estéticos de la arquitectura del nuevo jardín: frente a las reglas clásicas apareció el concepto de "pintoresco", teorizado en 1794 por Richard Payne Knight con su obra An Analytical Enquiry into the Principles of Taste y por Uvedale Price con su obra Essays on the Picturesque. En el nuevo jardín inglés, la percepción se individualizó

\footnotetext{
${ }^{14}$ Andrea Palladio. Quattro libri dellárchitettura.

15 QUESADA GARCIA, Santiago. Tesis Doctoral. "Imitatio naturae. El paisaje como referente en la arquitectura contemporánea". DPA ETSAS. 2006.
} 
y se hizo subjetiva. Cualquiera podía mirar con sus propios ojos y experimentar sus propias sensaciones, emociones, etc. El concepto de paisaje nacía por primera vez para la arquitectura como un elemento susceptible no solo de ser observado, sino también de ser proyectado y manipulado por el hombre.

En 1753 el abad jesuita Laugier en su famoso Essai sur l'architecture ${ }^{16}$ afirma que la mimesis constituye la ley de todas las artes y recomienda retornar al "primer modelo", el de la cabaña primitiva, en el que naturaleza y artificio se equilibran y donde se encuentran sus reglas. La "cabaña primitiva", marca la frontera entre lo natural y lo cultural.

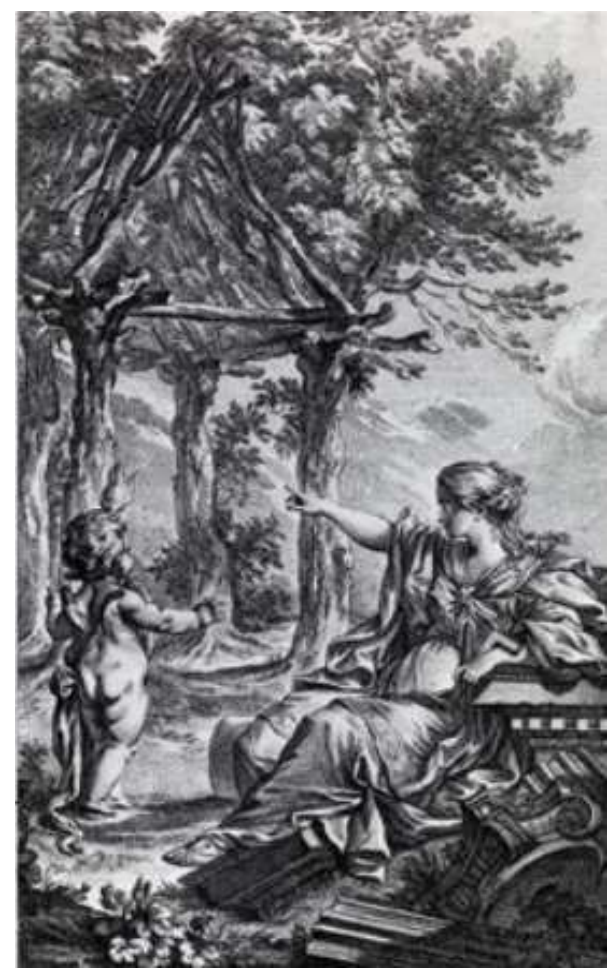

Ilustración 2-3 $3^{17}$

Entre 1785 y 1795 se da una transición entre el ideal de la Antigüedad clásica y la Modernidad. Dicho periodo lo caracteriza Fiedrich Schlegel, con el ensayo Sobre el estudio de la poesía griega, publicado en 1795, en la que defiende que la época moderna no es la continuación de la antigua sino algo diferente, proponiendo un nuevo arte moderno que recupere la objetividad de los griegos desde los presupuestos de la Modernidad, que sea síntesis entre lo bello y lo interesante, lo objetivo y lo subjetivo, la naturaleza finita y la libertad infinita. Para Schlegel lo antiguo, no debe imitarse ingenuamente.

El hombre en las culturas griega y romana era un ciudadano más de la polis, no un individuo. La mentalidad clásica anteponía el todo social a la parte (aunque esta parte fuese el hombre). El Cristianismo reconoció el carácter absoluto del hombre al creer en la inmortalidad del alma humana. Esa dignidad le venía dada al hombre

\footnotetext{
${ }^{16}$ M.A. Laugier, "Essai sur l' architecture, Paris 1755. "Ensayo sobre la arquitectura”. L. Maure, Akal, Madrid 1990.

${ }^{17}$ PORTADA DEL "ESSAI SUR L'ARCHITECTURE" DE MARC ANTOINE LAUGIER.
} 
por su destino trascendente y ultra terreno. En el Renacimiento, el hombre se descubre a sí mismo y a su espíritu al vivir una existencia singular en un mundo temporal. La individualidad humana se experimentara a sí misma como un absoluto y se enfrentara a todo lo que trate de anularla. Con dicha autoconciencia, el hombre no admitirá la prioridad de ninguna realidad sobre el yo. Surgirán las autobiografías, los retratos pictóricos, la novela moderna, los ensayos, etc. En el siglo XVII el idealismo de Descartes, Spinoza y Leibniz; y a comienzos del siglo XVIII el empirismo de Locke, Berkeley y Hume; hacen que el hombre rompa el espejo de la Naturaleza, aceptando solo la certeza de la experiencia del yo consciente o sujeto moderno, siendo la razón, la nueva base de la ética y la estética.

La imitación de la Naturaleza decaerá con la crisis del realismo. La estética clásica entendía que la belleza era universal y se podía medir y reproducir mediante reglas, era lógico por tanto que se aspirase a aprehenderla artísticamente mediante su reiteración imitativa. La estética moderna, sin embargo, no admite una instancia superior, autónoma, objetiva, natural; ya que se fundamenta en el sujeto, el artista que crea y el observador que disfruta contemplando. Desde la perspectiva del sujeto, la estética es la facultad intermedia entre la inteligencia y la razón; siendo la imaginación la facultad que armoniza las otras dos. Ya no se imita la Naturaleza, el nuevo ideario contiene dos conceptos fundamentales: la creación libre del genio por parte del artista, y el gusto del observador para experimentar el placer del creador genial. El artista no concebirá su arte como copia de un modelo dado sino que la esencia de su arte será la creación de su libertad y expresión del mundo interior de su yo; la revelación de su personalidad. El artista no imitara por tanto la Naturaleza sino que será el mismo una manifestación de la Naturaleza; no imitara las ideas eternas de Dios, sino el acto creador de Dios. El genio del artista, será una fuerza de la Naturaleza inconsciente que al estar dotado de una intuición interior, será capaz en estado de gracia e inspiración, de generar unas ideas que con la ayuda de la imaginación le permitirán crear una obra nueva y original. ${ }^{18}$

Entre el siglo XVII y comienzos del XVIII, desparece la estructura clásica existente desde los griegos, y es reemplazada por la idea de sujeto moderno. En la Modernidad, el sujeto moderno dicta sus leyes a la Naturaleza: su autonomía rechaza toda instancia exterior a la conciencia individual así como a la repetición o reiteración imitativa, incompatible con la intuición de un sujeto libre y creador.

\section{El origen de la modernidad.}

Dos interpretaciones del mundo se enfrentaran en la Querella de los Antiguos y los Modernos a finales del siglo XVII en Francia e Inglaterra. Los Antiguos, defendían que había que aceptar el magisterio de los modelos normativos inmutables que a lo largo de la Historia habían sido imitados y que debían seguir siéndolo para alcanzar la perfección; mientras que los Modernos defendían que cada etapa histórica debía superar a la anterior buscando un futuro de prosperidad y bienestar. Dicha Querella, la ganaron los Modernos, que elaboraron una doctrina completa sobre el progreso. La idea de progreso y la de la imitación eran incompatibles. La imitación de los Antiguos es sustituida por la doctrina del progreso histórico

\footnotetext{
18 QUESADA GARCIA, Santiago. Tesis Doctoral. "Imitatio naturae. El paisaje como referente en la arquitectura contemporánea". DPA ETSAS. 2006.
} 
Con la Querella de los Antiguos y los Modernos y el método de Descartes se impugno la tesis de la naturaleza todopoderosa. Con el triunfo del racionalismo y las ideas de los Modernos, el modelo del jardín francés entra en crisis.

A finales del siglo XVIII, comenzó una polémica sobre los principios estéticos del nuevo jardín: frente a las reglas clásicas surge el concepto de "pintoresco", teorizado en 1794 por Richard Payne Knight en su obra An Analytical Enquiry into the Principles of Taste y por Uvedale Price en su obra Essays on the Picturesque. La percepción del jardín ingles se hace subjetiva, se individualiza, y cualquiera podía experimentar sus propias emociones al contemplarlo. Por tanto el paisaje, a partir de este momento, no solo será observado por el hombre, sino que también podrá ser manipulado.

La belleza no es una propiedad de determinados entes que pueda imitarse, sino que depende de las facultades propias de cada individuo. El fundamento de la estética moderna se desplaza desde la metafísica a la psicología. El placer estético será suscitado tanto por la belleza de la naturaleza como por el arte, y a lo largo del siglo XVIII nacerá la estética moderna. La filosofía inglesa fue la vanguardia de esta estética en las reflexiones sobre lo sublime de Edmundo Burke en su $A$ Philosophical Enquiry into the Origin of our ideas of the Sublime and Beautiful ${ }^{19}(1757)$, en el que teoriza los principios estéticos del jardín clasicista ingles sobre lo sublime y lo bello. Burke afirma que cada experiencia emocional conlleva dos sensaciones diferentes: lo sublime que sería el miedo a algo y lo bello que sería la comodidad.

El Iluminismo hará de la analogía arquitectura - naturaleza su razón compositiva, defendiendo que el orden de las cosas está escrito en la naturaleza, y que es el proyecto de arquitectura el que lo tiene que hacer evidente. Ledoux y Boulle emplearan la naturaleza para legitimar su arquitectura. En esta investigación se irá viendo como la arquitectura de Enric Miralles también ayudan a entender el paisaje en el que se implanta. ${ }^{20}$

Las ideas filosóficas del siglo XVIII se recogerán en la Crítica del juicio (1790) de Kant, en el que se abordaran los principales temas de la estética subjetiva: el gusto, el genio, lo sublime, etc. El arte será bello si esta creado por un genio. El genio, "un favorecido de la naturaleza" a través de su talento natural innato y su originalidad creara nuevas ideas estéticas, sin reglas predeterminadas. Ello impedirá la imitación. EL filosofo Kant, se refería a la imitación en los siguientes términos: "todo el mundo está de acuerdo en que hay que oponer totalmente el genio al espíritu de imitación". ${ }^{21}$

El hombre vivía en un cosmos simbólico hasta la llegada de la Modernidad ilustrada. El hombre era parte del universo y su mundo humano (microcosmos) se encuadraba en el universo (macrocosmos). El mundo terrenal era la imagen de una realidad superior, el Universo. Esta mentalidad simbólica y cósmica apoyada en la teoría platónica de las ideas, se mantuvo hasta que la Modernidad la

\footnotetext{
${ }^{19}$ Burke Edmund " A Philosophical Enquiry into the Origin of our ideas of the Sublime and Beautiful". London 1757. "Indagacion filosofica sobre el origen de nuestras ideas acerca de lo sublime y de lo bello". M. Gras Balaguer, Tecnos, Madrid 1997.

${ }^{20}$ QUESADA GARCIA, Santiago. Tesis Doctoral. "Imitatio naturae. El paisaje como referente en la arquitectura contemporánea”. DPA ETSAS. 2006.

${ }^{21}$ Kant, I. Critica del juicio. Espasa Calpe, 2004, pag. 263
} 
sustituyo por el sujeto. La Modernidad, con su utopía de progreso histórico, su reivindicación del sujeto libre que experimenta individualmente, se enfrenta a ese modelo preexistente, defendiendo que es el hombre el que con su razón, impone pautas y modelos a la naturaleza, erigiéndose en creador genial de las producciones estéticas.

En la Modernidad, el hombre es considerado el centro del cosmos, y este hombre siente la necesidad de desechar una concepción de la naturaleza (la de la metafísica antigua) que asfixia su libertad y creatividad. Las nuevas categorías de Dios se aplicaran a la libertad del hombre haciendo residir lo humano en lo no realizado, lo posible o futuro. Para el sujeto moderno, el artista no debe reproducir lo ya dado, porque el mismo, es creador de lo nuevo, movido por la insatisfacción de lo existente. El carácter absoluto del hombre creador sustituye el anterior absolutismo de la naturaleza. Se piensa que hay que luchar contra la naturaleza para vencerla. El hombre no es ya naturaleza sino que la contempla como algo extraño a él. Durante la segunda mitad del siglo XIX, la doctrina del positivismo alcanzo su apogeo y en Europa se desarrollaron las ciencias experimentales coincidiendo con la segunda revolución industrial y el colonialismo. Se consideraba como real aquello que podía ser observado y verificado por los sentidos. Pero también había hechos psicológicos de la experiencia interior, por tanto solo se reconocían dos aéreas de conocimiento: las ciencias de la naturaleza para la experiencia exterior y la psicología descriptiva para la experiencia interior. El objetivo de ambas era enunciar leyes que explicasen las repeticiones de los hechos de la naturaleza, de modo que estos hechos fueran dominados en el presente y pudiesen ser predecibles en su comportamiento futuro. ${ }^{22}$

\section{La emancipacion del paisaje.}

Para el hombre moderno, la naturaleza pierde su ejemplaridad y en vez de imitarla se intentara dominarla y transformarla, dejando en ella su huella. Si en el pasado, la naturaleza encerraba todas las leyes de sabiduría y armonia que era preciso observar y respetar, ahora la naturaleza es percibida como una reserva de energías a disposición del hombre. La naturaleza se convertirá en el escenario de la voluntad del hombre que se auto-afirma con su actividad innovadora y original sobre ella. Con el espíritu de la llustración se genera por primera vez una conciencia histórica en virtud del cual, la Historia no viene determinada desde un principio, sino que está por hacer, dependiendo su desarrollo futuro de la libertad del hombre. La llustración rechaza todo pasado como norma de la historia y anuncia un tiempo nuevo, un tiempo moderno. ${ }^{23}$

De la critica a las teorías de la imitación y su estructura premoderna (modelo copia) emerge el sujeto moderno. Los antiguos, las ideas y la naturaleza, se deslegitiman por el nuevo sujeto moderno, que reclama su propia autonomía. Esta emancipación intelectual y moral es contemporánea a la liberación del absolutismo político y al reconocimiento de los derechos del individuo. En el periodo ilustrado, el súbdito se convierte en un ciudadano libre. Los cambios acontecidos en la religión, la moral, la política y lo intelectual, revelan el rechazo del sujeto a subordinarse a un orden exterior, a aceptar un modelo eterno, ideal, perfecto ya dado que era la sustancia de la imitación premoderna. El mundo clásico - medieval cederá ante el

\footnotetext{
${ }^{22}$ QUESADA GARCIA, Santiago. Tesis Doctoral. "Imitatio naturae. El paisaje como referente en la arquitectura contemporánea". DPA ETSAS. 2006.

${ }^{23}$ Ibidem.
} 
mundo nórdico, anglosajón, protestante y mercantil, en el que irrumpirán figuras del nuevo individualismo: el ciudadano, el artista genial, el filosofo ilustrado, el empresario emprendedor, el ingeniero transformador de la naturaleza, etc. cuyos valores de libertad, creatividad, progreso, productividad y dominio de la naturaleza son incompatibles con la doctrina premoderna de la repetición de un modelo ya dado perfecto.

Quatremere de Quincy defendía que la representación constituía una mimesis. En su obra De l'architecture égyptienne (1803) alumbra sobre la doble naturaleza de la mimesis. "hemos reconocido que hay en la arquitectura dos especies de imitaciones, la una sensible y la otra abstracta: la una apoya sobre los primeros modelos..., la otra tiene como base el conocimiento de las leyes de la naturaleza y de las impresiones que nuestra alma recibe de la vista y de las relaciones de los objetos". ${ }^{24}$ Como en Diderot años antes, Quatremere distingue dos imitaciones: la imitación sensible (la arquitectura imita la cabaña) y la imitación abstracta (las leyes de la naturaleza, las relaciones, etc.). ${ }^{25}$

En el Romanticismo, la naturaleza se concebía como un ser vivo, adoptando una racionalidad sintética, frente a la analítica disgregadora. Se prescindirá por tanto de la razón, en favor de facultades como: la imaginación, la intuición, el sentimiento, etc. exaltando lo que había dejado arrinconado la llustración. A lo largo del siglo XIX se detecta la subjetividad en el ámbito artístico. En el mundo espiritual del siglo XIX, deudor del positivismo decimonónico, la naturaleza ha perdido toda ejemplaridad y se ha quedado huérfana de significado simbólico. El nuevo estilo presenta como obra estética un mundo imperfecto.. El espíritu de los nuevos tiempos se manifiesta en la teoría de la imitación que contiene el ensayo de Oscar Wilde La decadencia de la mentira (1889) cuando al final del mismo afirma que "la Naturaleza externa imita al Arte". Para Wilde, el hombre en la naturaleza pierde su individualidad y se transforma en algo abstracto e impersonal. Para Wilde, el autentico arte huye de la verdad en favor de la belleza, que surge cuando el artista con indiferencia a los hechos, sueña, imagina e inventa. El arte por tanto como hijo de la creación y la invención, frente a la vida y la naturaleza que están animados por el ordinario principio de la imitación. Para Wilde el arte no imita la naturaleza sino que es la naturaleza la que imita al arte. Esta imitación inversa de la naturaleza hacia lo humano anuncia lo que será la moderna teoría de la imitación que surgirá a lo largo del siglo XX, desarrollada en el contexto de la crisis del pensamiento de la Modernidad.

Con el declive de la naturaleza, el paisaje alcanza su mayoría de edad. La noción moderna de paisaje se debe en parte a John Ruskin, que en su libro The Seven Lamps of Architecture (1880), analiza los problemas de la pintura del paisaje. Ruskin reflexiona sobre la analogía que detecta entre las formas naturales y la arquitectura viendo en la morfología natural una continuación de la creación. Pero no sugiere la imitación directa de las formas naturales, sino su interpretación abstracta. ${ }^{27}$ Defiende que el hombre no podrá crear belleza sin imitar las formas de

\footnotetext{
${ }^{24}$ De Quincy, Quatremere. De l'architecture égyptienne. 1803

${ }^{25}$ Mas adelante veremos como Enric Miralles se sirve de la imitacion abstracta para proyectar sus obras en el paisaje

${ }^{26}$ QUESADA GARCIA, Santiago. Tesis Doctoral. "Imitatio naturae. El paisaje como referente en la arquitectura contemporánea". DPA ETSAS. 2006.

${ }^{27}$ Ibidem.
} 
la naturaleza. Para apoyar esta idea, recurre a ejemplos: "el capitel dórico no era imitativo, sino que toda su belleza estaba subordinada a la precisión de su ovalo: una curva natural bastante común. El capitel jónico...no dependía menos...de la adopción de la línea espiral, quizás la más común de todas aquellas que caracterizan los ordenes inferiores de organismos animales..." 28

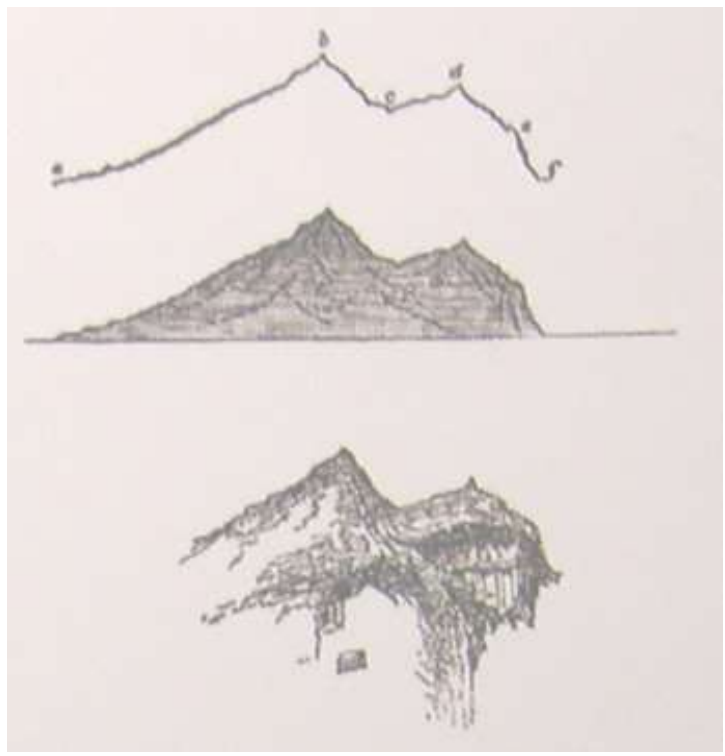

Ilustración 2-4

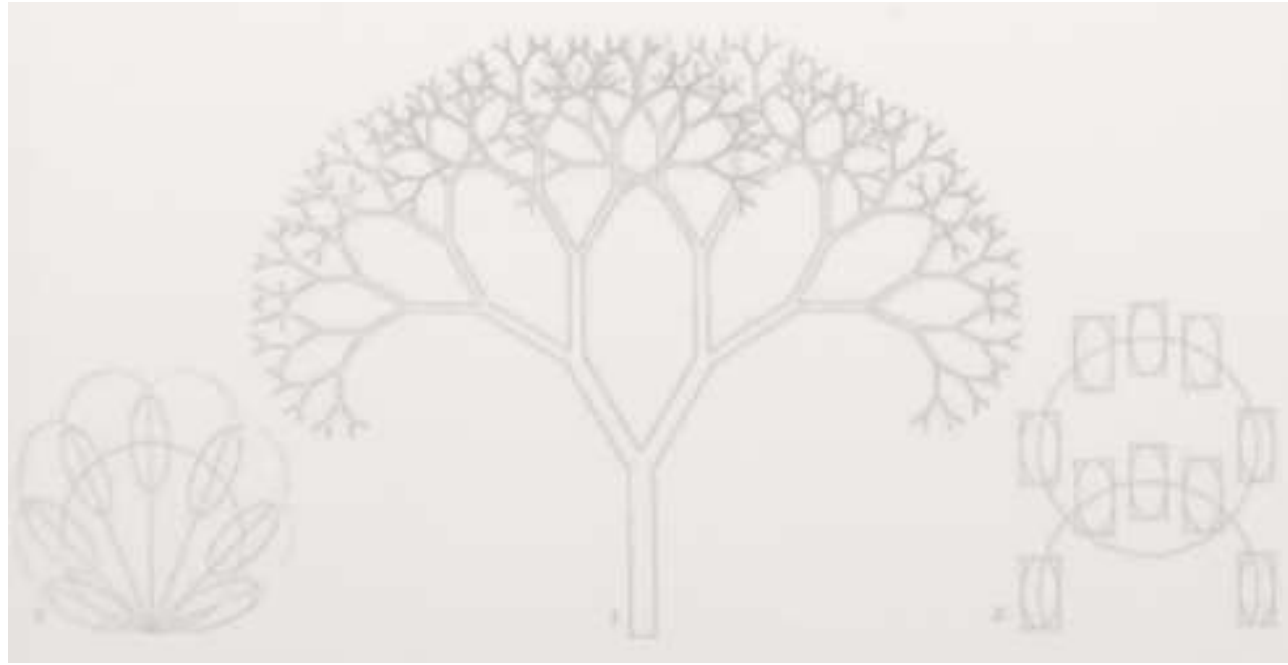

Ilustración 2-5

\footnotetext{
${ }^{28}$ Ruskin, John. Las siete lamparas de la arquitectura. 1880

${ }^{29}$ Analogia entre el perfil de una casa de campo francesa y el perfil lejano de los montes que se divisan desde la casa. Modern Painters (1843) John Ruskin. A lo largo de la investigacion se comprobara como Miralles utilizara esta analogia entre su arquitectura y el paisaje. Valgan los ejemplos de la Escuela Hogar en Morella, el Pabellon de Alicante, etc.

${ }^{30}$ Lamina 56 del quinto volumen de "Modern Painters" de Ruskin en el que ilustra la ley de ramificacion. Con un siglo de anticipación singulariza en la estructura de un árbol el carácter fractal de las estructuras naturales. Concepto que será definido matemáticamente por Benoit Mandelbrot y empleado por Herzog\&de Meuron en sus proyectos.
} 
Las ilustraciones de su libro Modern Painters (1843) ejemplifican el modo de ver la naturaleza que se establece desde la arquitectura y viceversa. En el mismo libro, Ruskin muestra una serie de dibujos dedicados a las reglas que rigen las estructuras naturales que podrían ser trasladadas a la arquitectura. En concreto, la lamina 56 del quinto volumen ilustra la ley de ramificación construyendo el perfil geométrico de un árbol sobre la base de un triangulo equilátero, prefigurando uno de los clásicos ejemplos de la matemática de los fractales ilustrado por Mandelbrot en su libro The Fractal Geometry of Nature (1977). A partir de Ruskin, el paisaje alcanza su mayoría de edad, aunque tendrá que pasar tiempo hasta que los arquitectos lo empleen como material de proyecto.

\section{Interpretaciones de la naturaleza en el siglo XX}

A comienzos del siglo XX, Benedetto Croce defiende que la Naturaleza hay que contemplarla con ojos de artista, y que el paisaje aportara al Arte, siempre que se lo mire de manera anómala, antinatural, "con la cabeza entre las piernas".

A finales de los años veinte del siglo XX, irrumpe el funcionalismo "organicista" como oposición al funcionalismo "maquinista" arquitectónico que estaba vigente. Dicho funcionalismo "organicista" se basaba en un funcionalismo biológico que explicaba que las formas eran la consecuencia natural de las estructuras de la naturaleza. Con ello surge un cambio en la percepción de la relación figura - fondo, definiéndose el vacio como figura, atribuyéndole un valor positivo en la configuración de la arquitectura. Así, aparecerán en las arquitecturas de Wright y Scharoun la centralidad de la experiencia del espacio cóncavo; en las manipulaciones perceptivas de Le Corbusier con su promenade architecturale como lugar de paso simbólico entre la imagen enmarcada del paisaje como fondo y su actualización como figura en la terraza - jardín. ${ }^{31}$

Para Kenneth Frampton, Le Corbusier y Mies van der Rohe son los responsables del acercamiento moderno al paisaje derivado de la arquitectura griega. Le Corbusier valorando el poder del paisaje, cuya relación con el hombre potenciara a través de su promenade architecturale. Mies, reclamando una arquitectura clásica y el uso de una estética desmaterializada en la que lo natural y lo artificial se fundan.

Para Ignasi de Solá-Morales el proyecto de la llustración participaba de la idea de que era posible encontrar un absoluto de la realidad según la cual el arte, la ciencia, la política se podía construir en base a una racionalidad global. Cuando este sistema entra en crisis, entra también en crisis el proyecto moderno en arquitectura. A partir de este momento, en el campo estético, ni la arquitectura, ni la pintura ni la literatura podrán generarse partiendo de un sistema., las propuestas artísticas y arquitectónicas contemporáneas deberan partir de la necesidad de justificar en cada paso dado, el objetivo y su fundamento. ${ }^{32}$

En la experiencia contemporánea, a través de lo estético se reconoce, según SolaMorales, el modelo de las experiencias más ricas, vivas y verdaderas del hombre

31 QUESADA GARCIA, Santiago. Tesis Doctoral. "Imitatio naturae. El paisaje como referente en la arquitectura contemporánea". DPA ETSAS. 2006.

32 Sola-Morales, Ignasi. Diferencias. Topografia de la arquitectura contemporanea. GG, Barcelona, 1995, pags. $66-70$ 
en relación a una realidad de confusos perfiles. En la obra de arte, se funden el sujeto que percibe la realidad y la realidad misma. Las experiencias estéticas constituyen el modelo más sólido, de la débil realidad contemporánea. Adquieren valor de paradigma en el sistema de referencias y valores de la cultura contemporánea. El universo artístico contemporáneo, es percibido desde experiencias puntuales, heterogéneas y con ello la aproximación a lo estético se produce débilmente. Sola-Morales mantiene que la noción de espacio como categoría propia de la arquitectura es una noción moderna, que emergió en la cultura centroeuropea en el mismo momento en que en la ciencia, entra en crisis la concepción euclidiana del espacio como una homogénea y estable determinación del universo tridimensional. ${ }^{33}$

La Teoría de la relatividad de Einstein modifico la noción de espacio que tenían los modernos, al considerarla inseparable del tiempo trayendo consigo el replanteamiento de las ciencias físicas, biológicas y psicológicas. Los filósofos y demás pensadores, defendieron un nuevo tipo de imitación diferente de la premoderna.

Para Sola-Morales, el concepto de espacio arquitectónico adoptado desde Picasso a Duchamp; desde Adolf Behne a Siegfred Giedion; desde Wright a Mies van der Rohe proponía novedades fundamentales para el nuevo arte nacido de la crisis del clasicismo. Para el arquitecto, el objetivo de su creación paso a ser las infinitas experiencias espacio-temporales que su arquitectura podía generar. La creatividad de las propuestas arquitectónicas surgirá ahora de mecanismos psicológicos y perceptivos del artista, a través de su mirada, tacto, movimiento, etc.

En este contexto, el paisaje también será visto como un modelo susceptible de ser manipulado por los arquitectos, ya que aunque el termino paisaje existía desde el siglo XVII, los arquitectos entendían que era algo especifico de la pintura y la literatura. Aunque los protagonistas de las vanguardias arquitectónicas mostraron cierto interés por el paisaje, tendrá que llegar la segunda mitad del siglo XX, para que los arquitectos consideren al paisaje como un material de proyecto mas.

La imitación de un modelo en la contemporaneidad supondrá no copiar sino que cada uno de los elementos que compone su estructura, conserve su autonomía y libertad. Sin investigar en profundidad el modelo a imitar, la imitación será irracional. Sirva como ejemplo de imitación acertada las Prairie Houses de Wright, que no imitan el paisaje en el que se ubican, sino que interpretan su condición de horizontalidad, como si un campo magnético las atase al terreno.

\footnotetext{
${ }^{33}$ Sola-Morales, Ignasi. Diferencias..., op. cit, pag. 111.
} 


\title{
2.2. EL LAND ART
}

\begin{abstract}
"El modo de entender la forma que nos interesa es el de artista como Richard Serra...intentamos seguir el pensamiento de personajes como Robert Smithson o Richard Long...sus libros siempre están por ahí. Buscamos su proximidad. Nos interesa la continuidad de su pensamiento."

Carmen Pinos. ${ }^{34}$

"En las Pérgolas de la Avenida Icaria, por supuesto que se traen a colación las maneras de hacer de un Richard Serra, Long, etc. pero no copiándolos tal cual, sino manteniendo una conversación...porque luego cada profesión es lo que es y así hay que responder."
\end{abstract}

Enric Mlralles. ${ }^{35}$

Miralles cuando estuvo en Columbia University en 1981 pudo visitar muchas obras de Land Art. El Miralles que regresa de Columbia, no es el mismo que se fue pues viene cargado de fotografías, dibujos, apuntes, reflexiones sobre el terreno de las obras de Land Art..

Land Art, es un término americano, de difícil traducción al castellano "el arte de la tierra", que empleo Walter de María para describir sus primeras intervenciones en el paisaje en los años 60s. Para el artista ingles Richard Long, este término se aleja de sus intenciones. Christo y Jean Claude, prefieren que se les considere "artistas ecológicos"; Michael Heizer denomina "esculturas" a sus intervenciones, etc. Existen por lo menos tres grupos dentro del Land Art: las obras que tienen que ver con el performance y la acción (como las de Oppenheim); las obras que precisan de un proyecto y un instrumental casi de ingeniero (como las de Smithson, Heizer, De María, Ross, Turrell, etc.); y obras más intimas, relacionadas con el arte primitivo, en las que el artista se las apaña con lo que tiene.

La consolidación del Land Art, se debió fundamentalmente a las exposiciones que se realizaron sobre sus obras: "Earthworks" en la Galería Dwan de Nueva York (1968); "Tierra, aire, fuego, agua" en el Museo de Bellas Artes de Boston (1969); la difusión realizada por la televisión alemana a través de películas y documentales sobre la practicas de estos artistas en 1969; y en la Galería de Arte Moderno de Turin, donde en 1970 se expuso Conceptual Art, Arte Povera, Land Art exponiéndose entre otras las trazas inglesas y americanas de Land Art -las modificaciones geográficas de Robert Smithson, los cráteres de James Turrell, los círculos de Richard Long - donde la operación artística la constituye el paisaje. ${ }^{36}$

\footnotetext{
${ }^{34}$ Entrevista en revista A30 № 6.1987

${ }^{35}$ Aprendizajes del arquitecto. Video. Arquia. Documental 15. 2000

${ }^{36}$ RAQUEJO, Tonia. Land Art.. Editorial Nerea. 1998
} 
Una obra de Land Art no lo es por estar realizada al aire libre, sino porque sus artistas en su realización tienen en cuenta reflexiones profundas acerca del espacio y el tiempo. Aunque antes de los años 60 s, ya se habían realizado intervenciones en la naturaleza por artistas, no se puede hablar de Land Art, hasta que artistas como Richard Long, Walter de María y Michael Heizer, entre otros, iniciaron sus primeros ensayos sobre el territorio. En el Land Art, el énfasis de la obra no recae en el objeto artístico que resulta de la acción, sino en el proceso del hacerse, así como en las relaciones que se establecen entre la obra y el paisaje, y la obra y el sujeto que la experimenta. El Land Art, no fue un fenómeno aislado sino que formo parte de las distintas tendencias artísticas que surgieron como respuesta al arte pop por considerarlo mercantilista al aceptar el capitalismo y ensalzar la sociedad de consumo. Valga como ejemplo de obra de reacción al arte pop, la obra Rancho Cadillac del grupo Ant Farm (1974) que, incrusta en el terreno diez automóviles de la marca Cadillac (símbolo de ostentación para la sociedad norteamericana de la época). ${ }^{37}$

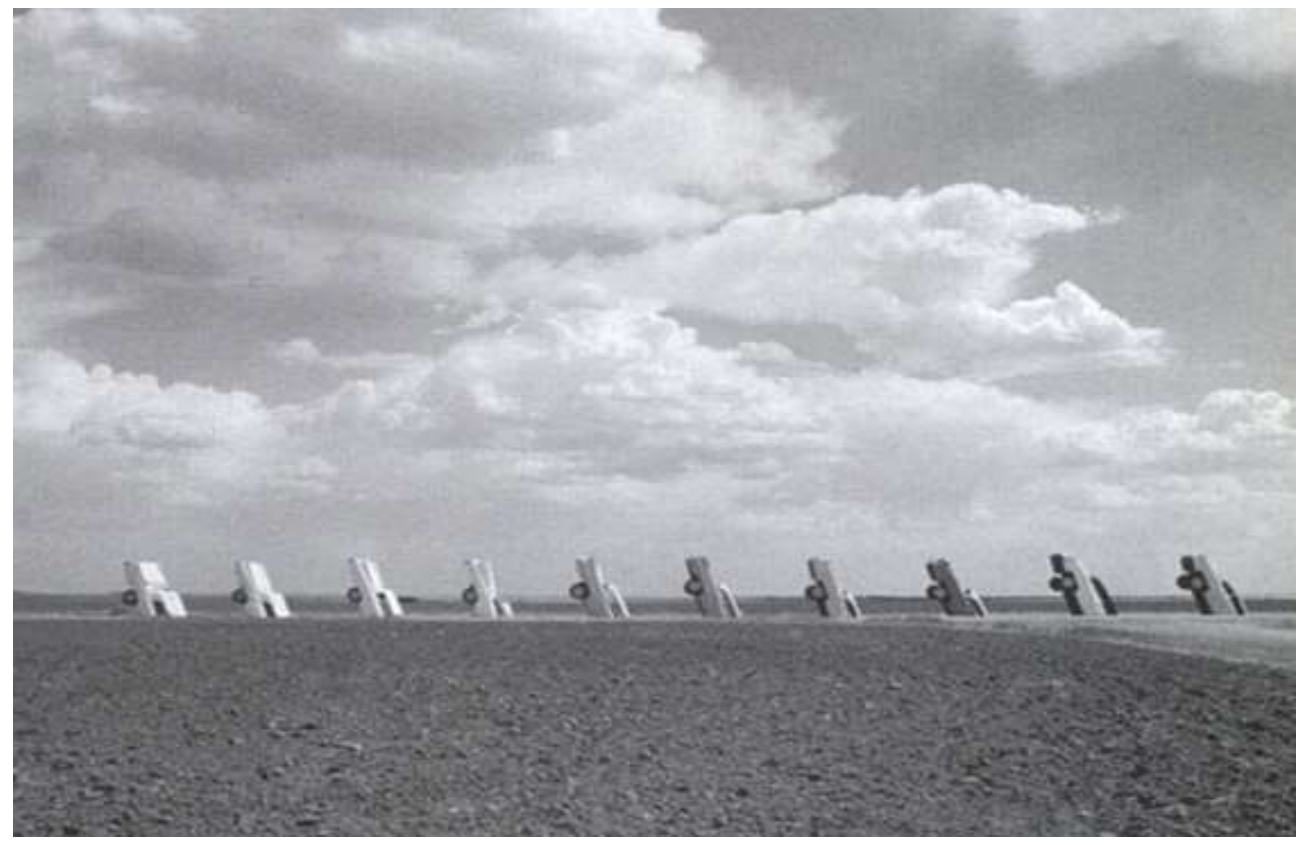

Ilustración 2-6

El Land Art es un término que remite al territorio como soporte del arte y lucho por terminar con el tráfico del arte, con los objetos artísticos cuyo precio fijaba el mercado artificialmente. Con la experiencia y las sensaciones que provocan sus obras no se puede comerciar. La actitud crítica del Land Art contra el valor mercantil de la obra, les llevo a los artistas a sacar sus obras de las galerías (localizándolas en parajes inhóspitos para el gran público) y a otorgarles un carácter efímero, cuyo proceso documentaban a través de dibujos, fotografías y películas. El predominio del carácter procesual de la obra y la exigencia de un espectador activo, cuya actitud no fuera contemplativa sino activa, obligaba a este

\footnotetext{
${ }^{37}$ Ibidem.

${ }^{38}$ Ant Farm / Cadillac Ranch 1974, just outside Amarillo, Texas
} 
a entrar en un estado mental desde el cual pudiera abordar la obra y apropiarse de esta, sin necesidad de poseerla como un objeto fetiche.

Según Javier Maderuelo: "...Mientras el termino land art europeo se refiere al campo, al territorio como soporte y tema del arte, la palabra earthwork americano supone una actitud de fuerza, indica un trabajo, y se refiere a un acto, a una transformación ejercida sobre la tierra.... Mientras que los europeos...pasean por el campo con el atavismo, más o menos consciente de aquella idea de pretender mejorar la naturaleza alterando su aspecto natural lo menos posible...los artistas americanos sienten la necesidad prepotente de mostrar su poder y su fuerza frente a la naturaleza intentando dominar aquellos parajes más indómitos..." 39

La despedida de la visión del paisajismo decimonónico es definitiva. El Land Art europeo y el Earthwork americano establecieron la diferencia entre la representación del paisaje y la intervención en el paisaje. En sus obras no hay representación de la naturaleza sino identificación entre arte y naturaleza. Arte y paisaje coinciden, por tanto el arte no tiene más valor que no sea él mismo: no representa el paisaje, es el paisaje. Son trabajos artísticos relacionados con el "conceptual art" o el "action art". Sus intervenciones en la naturaleza generan un detonante que acelera o hace visible las fuerzas que impulsan los procesos atmosféricos y geológicos. El valor de las obras de Richard Long, Donald Judd, Walter de Maria, Michel Heizer, Richard Serra entre otros, es la capacidad que tienen de enfrentarse de otra manera con lo infinito de la naturaleza, a través de intervenciones mínimas, esenciales, para conseguir el máximo efecto con el mínimo de recursos. Le confieren una escala, una medida al paisaje. Como refiere el filosofo Martin Heidegger : "El lugar no está presente antes del puente. Es cierto que antes de que este puesto el puente a lo largo de la corriente hay muchos sitios que pueden ser ocupados por algo. De entre ellos uno se da como un lugar, y esto ocurre por el puente". ${ }^{40}$

Para el "land artist", no es lo mismo pintar o representar un paisaje que estar en el paisaje, ser parte de él. Cuando pinta un paisaje conforme al recuerdo de la sensación y otra cosa bien distinta es experimentar "in situ" mientras se trabaja la obra en el paisaje. El énfasis se desplaza a las relaciones que se producen entre la obra y el sujeto que lo experimenta, por ello, el lugar ostenta el privilegio de la experiencia estética.

Para Richard Serra, los elementos escultóricos del Land Art actúan como barómetros para leer el paisaje. De esta manera la obra del land artist hace evidente los caracteres del lugar, su inmensidad, su topografía, su materialidad desvelándolo todo a través del hecho artístico. Richard Serra se interroga sobre los significados originales de la implantación sobre el territorio y estudia el tema evidente-escondido; realidad-apariencia. Los muros metálicos de Serra evidencian la topografía natural con un hecho artístico. La obra de Serra, mas allá de establecer una dialéctica entre hombre y naturaleza, define la modalidad de experimentación del hombre que se mueve en el espacio, condensando la percepción de lo local en el interior de lo global y al mismo tiempo, el carácter fenomenológico del conocimiento del ambiente que nos rodea. La relación entre

\footnotetext{
39 Javier Maderuelo. Nuevas Visiones de lo pintoresco. El paisaje como arte. Fundacion Cesar Manrique, 1996, p. 16

${ }^{40}$ Martin Heidegger : "construir, habitar, pensar" en Conferencias y artículos, Ediciones del Serbal, 2001, p. 114
} 
artificio y naturaleza se hace evidente. El cambio es pues esencial, el arte ya no consiste en contemplar un objeto, sino en experimentar nuestra naturaleza en él.

Para los artistas del Land Art, la obra tiene poco que ver con el resultado final que se percíbe. El arte no puede ya reducirse a su carácter objetual. El hecho artístico es un proceso interminable donde se combina todo: el lugar, la situación, el tiempo atmosférico, el artista y cada cosa de lo que en ese mismo momento sucede. ${ }^{41}$

Pero el paisaje también se puede estudiar a través de la fotografía. La fotografía contemporánea ocupa también un papel importante como instrumento de exploración y conocimiento del territorio y del paisaje. ${ }^{42}$

La obra fotográfica de Giacomelli, como ocurre en las obras de Land Art, elimina la complejidad de la realidad para reducirla a lo mínimo y hacerla inteligible. La creación de sentido no sucede por adicción, sino por sustracción, quitando a la realidad el exceso de complejidad y haciéndola inteligible. ${ }^{43}$

En la XVII Trienal de Milán, por vez primera, la fotografía tuvo un papel central y autónomo en una exposición de arquitectura. Las fotografías de Luigi Ghirri señalaron un giro en las relaciones entre fotografía y arquitectura, pasando de instrumento auxiliar a tener un discurso autónomo, de soporte documental a ser una mirada interpretativa. La fotografía será decisiva al describir las mutaciones del paisaje. En la región Emilia que Luigi Ghirri fotografía en 1986 el paisaje es explorado con sus trazados emergentes, acercando el pasado campesino a las formas de lo nuevo. El uso del blanco y negro, la serie, los ritmos, las geometrías hechas evidentes son lecturas que Ghirri hace emerger gracias a las experiencias de otras artes y disciplinas: desde la geometría de las imágenes cinematográficas a los signos en los territorios del Land Art. $^{44}$

A finales de los años sesenta el arte abandona la objetualidad y busca un lenguaje abstracto a favor de experimentaciones marcadas por el sentido de un arte ambiental y narrativo. El Land Art modifica la manera de mirar el paisaje, abstrayéndolo y viéndolo como el lugar en el que es posible una acción.

Por medio de la analogía el paisaje le transmite al proyecto de arquitectura una reverberación formal que proviene de su estructura profunda y no de las formas superficiales. El proyecto contemporáneo de arquitectura quiere ser paisaje y utiliza como recurso esta regla estructural del paisaje como prototipo, como analogía. Lo que caracteriza la analogía es el deseo de trascendencia. El deseo de imitación se basa en un sentimiento de intentar pertenecer a algo superior con lo que es posible compartir una cierta forma. Un sentimiento que brota de la admiración hacia algo que aun siendo irrepetible llama a la repetición. El "land artist" intenta emular al paisaje, hasta formar parte de éste, pero sin perder su propia personalidad, dado

\footnotetext{
${ }^{41}$ A lo largo de esta investigación se pondrá de manifiesto cuanto la obra de Miralles, al igual que las obras de Land Art, tiene poco que ver con el resultado final, sumidas en un proceso que no se termina.

${ }^{42}$ Conviene recordar que Luis Barragán proyecto los Jardines del Pedregal sobre una fotografía aérea y no sobre un plano

${ }^{43}$ Este aspecto de reducir la complejidad de la realidad, tiene mucho que ver con Miralles, quien sintetizaba en sus planos de emplazamiento en dos dimensiones las múltiples dimensiones de la realidad que encontraba en los lugares en los que intervenía.

${ }^{44}$ RAQUEJO, Tonia. Land Art.. Editorial Nerea. 1998
} 
que la imitación moderna conlleva una similitud pero básicamente una diferencia que mantiene separados al modelo y la copia. La facticidad provoca que el deseo imitativo no conlleve una pérdida de personalidad, ni una disolución del sujeto, porque la imitación entraña a la vez una diferencia entre modelo y copia que los mantiene separados y sin posibilidad de confusión.

Según Schiller hay dos clases de belleza en la figura humana: una natural, fija e innata, y otra espiritual, belleza en movimiento, que manifiesta la acción de la voluntad. Esta ultima belleza, que viene de la expresión en lo sensible y fenoménico de la libertad moral, designada como gracia, es exclusivamente humana, estadio intermedio entre la voluptuosidad sensible (inclinación) y la dignidad y respeto (deber). A la figura humana que posee gracia, la denomina Schiller alma bella, aquella que ha logrado la armonía entre el mundo sensible de las inclinaciones y el mundo racional del deber. El paisaje como prototipo se presenta lleno de autoridad y de prestigio por su completa totalidad, hacia la cual se dirige el deseo de imitación de los arquitectos. ${ }^{45}$ Estos presupuestos son validos teniendo un concepto revisado del sujeto. El sujeto conceptual de la llustración, fuera del espacio y del tiempo, autosuficiente en la plenitud de su entendimiento y voluntad, ha sido desbordado por la evidencia, proporcionada por diversas ciencias sobre la dependencia de la conciencia en relación a las conductas presubjetivas de naturaleza social y psicológica, es decir la presencia de la sociedad, la cultura, la historia...en suma "los otros". La influencia de los otros en la vida es un hecho y la influencia del modelo también. Hoy en día nadie puede cuestionar la heteronomia del sujeto y mucho menos la del arquitecto.

La acción imitativa será racional en la medida en que se sepa como reconocer el paisaje como prototipo, como conocer la esencia de éstos, como comunicar a los demás la ley del paisaje y qué tipo de experiencia cabe extraer de su imitación. En la elección del paisaje como prototipo el sujeto reconoce a este en un doble sentido. En primer lugar, reconoce en un paisaje a un prototipo autentico cuando percibe en este una ley generalizable excelente por reunir todos los valores estimables de una comunidad. Entre la pluralidad de modelos, reconoce en segundo lugar la ley enunciada por él, y presta reconocimiento al deber-ser realizado y a la evidencia de su idealidad concreta. Tras reconocer al modelo, se conoce el paisaje, dejándose influir por él. Quien elige un paisaje y lo intenta imitar, altera su horizonte de comprensión, dándole un nuevo sentido al mundo que percibe. La percepción de la ejemplaridad del paisaje suscita un deseo que desemboca en una acción imitativa, tras lo cual viene vivir y verificar el paisaje en la experiencia del proyecto de arquitectura. Es decir, aprovecharse por un lado de la ejemplaridad potencial del paisaje para el proyecto de arquitectura y por otro realizar una experiencia para comprobar el posible éxito o fracaso del ejemplo escogido. El artista neutraliza el azar al disponer de un modelo. ${ }^{46} \mathrm{~A}$ medida que el arquitecto asimila el ejemplo del prototipo-paisaje es capaz de repetirlo en situaciones nuevas, proyectándose hacia el futuro.

\footnotetext{
45 De la gracia y la dignidad, trad esp. J. Probst, R. Lida, Icaria, 1985, pag. 64 (Über Anmut und Würde, 1793)

${ }^{46}$ Miralles desde sus primeras obras siempre gusto mantener un dialogo con lo existente. Desde la eleccion de sus primeros Concursos a los que presentarse con Carmen Pinos desde 1984, que tenian que ver con Ampliaciones de Ayuntamientos (Algemesi, Lugo, etc.) hasta Igualada, Huesca, Edimburgo...sus proyectos surgen como reaccion ante algo que ya existe para establecer un dialogo y neutralizar el azar, el proyectar sobre un papel en blanco. Si el lugar en el que intervenir no le aporta nada como en su complejo para el Tiro con Arco en Barcelona, establecera un juego de contraste con
} 


\section{El contexto en el que se desarrolla el Land Art.}

Las obras de Land Art, se desarrollaron en paralelo a los grandes avances científicos de la época. En 1968, EEUU, se debate entre los reveses internacionales (Guerra del Vietnam) y nacionales (la ruptura de los valores sociales tradicionales del movimiento hippy). Rlchard Nixon se presenta como candidato a la presidencia comprometiéndose entre otras cosas, en estimular la vanguardia para desarrollar los talentos artísticos individuales con el objetivo de que las artes estuvieran a la altura que EEUU ostentaba en el ciencia y tecnología. Pero el gobierno de Nixon, cuando llego al poder y durante su mandato, termino por convertirse en un gobierno de extremo conservadurismo "restaurador de la ley y el orden". Desde el periódico New York Times, se lanzaron criticas durísimas a los Land Artists y a los artistas radicales, pues según estos críticos (en especial, Hilton Carme y Daniel Bell), la practicas de estos artistas, amenazaban la estabilidad social y rompían con la tradición y las creencias morales de la sociedad burguesa. Además, para los críticos de arte de este periódico, los land artists eran acusados de violar la madre Tierra con sus intervenciones, transformando su superficie agresivamente frente al buen hacer de los pintores paisajistas que hacían visibles el espíritu de los lugares con su pintura. Tal era la crispación del ambiente, que a James Turrell le encarcelaron por una declaraciones a propósito de la Guerra del Vietnam y Robert Smithson, se negó a colaborar en un proyecto artístico científico que le ofreció el Instituto Tecnológico de Massachusetts (MIT) por considerarlo militarista y colonialista. ${ }^{47}$

El Land Art, se desarrollo hasta los años 1980s como un movimiento de resistencia ante ese conservadurismo extremo. Con sus intervenciones, los land artists cuestionan el concepto de arte, cultura, y progreso que el hombre asume con normalidad. A través de relacionarse con la naturaleza, el artista retorna a sus orígenes primitivos, y no lo hace por nostalgia del pasado sino por su mirada crítica que detecta una realidad, la que le ha tocado vivir, que no le agrada. De manera que el land artist, camina de la mano del progreso y al amparo de las investigaciones científicas y antropológicas que empezaban a romper esquemas en aquellos años por su explicación de los orígenes del mundo y las civilizaciones bajo nuevos parámetros que todavía hoy día siguen sin ser asimilados.

En 1968, el director de cine Stanley Kubric realiza la película "2001. Odisea en el espacio", divulgando entre el público las consecuencias en la percepción del tiempo de la Teoría de la Relatividad de Einstein. El protagonista, es atraído por un monolito cósmico que representa la cuarta dimensión a donde viaja a la velocidad de la luz. Sometido a esta velocidad, regresa al planeta Tierra para auto contemplar su envejecimiento hasta su muerte, y la transformación de ese cadáver en un feto hasta volver a nacer de nuevo. Este sentido cíclico del tiempo y la idea de sujeto desdoblado (acorde a la difusión del psicoanálisis en aquellos años), interesara mucho a los artistas del Land Art. ${ }^{48}$

\footnotetext{
el edificio prismatico de Pabellon de Pelota situado encima del solar donde tenia que intervenir, y a la vez con los edificios de Competicion y el de Tiro con Arco

${ }^{47}$ RAQUEJO, Tonia. Land Art.. Editorial Nerea. 1998

${ }^{48}$ Ibidem.
} 


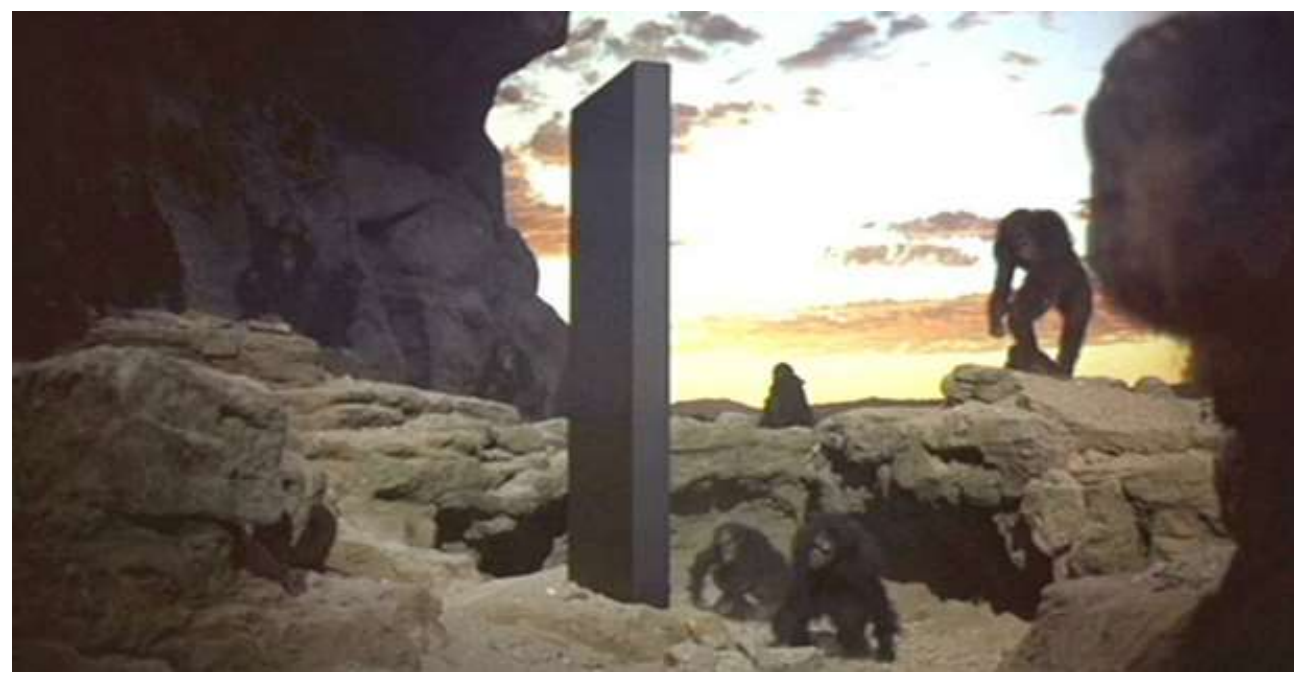

Ilustración 2-7
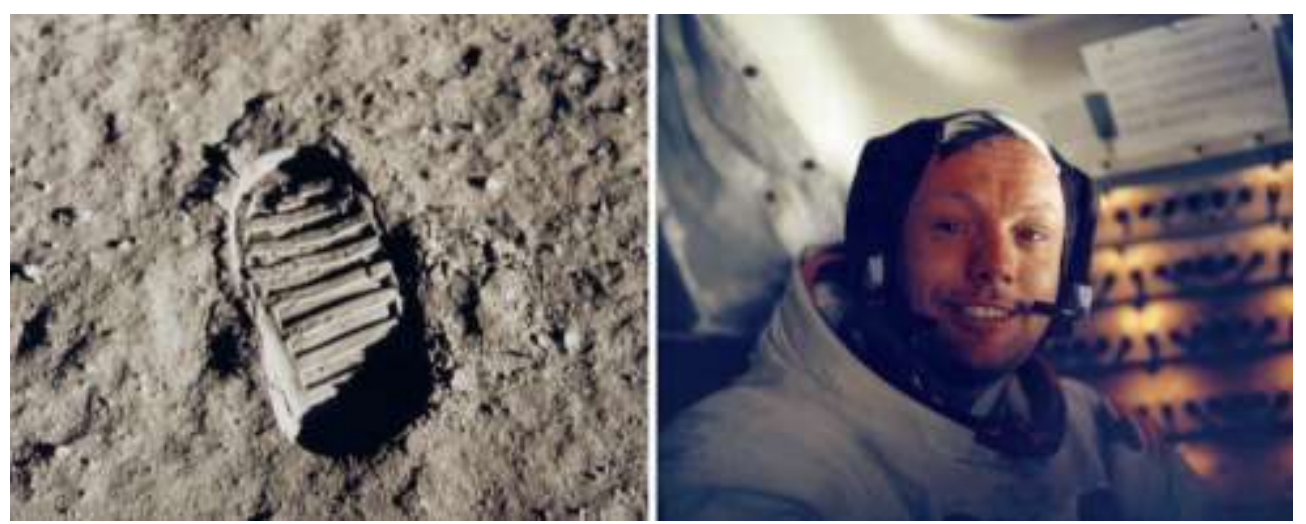

llustración 2-8

En 1969, la NASA (National Aircrat and Aero Space Administration) de los EEUU, pone a un hombre en la Luna. Por primera vez en la Historia de la Humanidad, el hombre imprime su huella en La Luna. Pisar es poseer; dejar huella es conquistar (llenar un espacio antes vacio convirtiendo un no-lugar (el galáctico) en lugar. La huella que dejo el astronauta norteamericano Neil Amstrong, ayuda a entender la relación del americano con el territorio. El interés de los Land Artists por los lugares de antiguas culturas como las neolíticas y las precolombinas (mayas y aztecas), coincidió con la publicación en aquel momento de textos pseudocientíficos que interpretaban los restos arqueológicos de dichas civilizaciones. Stonehenge, fue el blanco de las especulaciones mas excéntricas, al entenderlo unas teorías como un complejo megalítico sagrado de fuerzas telúricas y cósmicas (convocando en los solsticios solares a los hippies) y otras, como una obra realizada por extraterrestres (un sistema arcaico de computador dejado como huella por extraterrestres para permitirles conectar con la Tierra en el futuro). ${ }^{51}$

\footnotetext{
${ }^{49}$ Fotograma de la pelicula. El Monolito. "2001 Una odisea en el espacio" Stanley Kubrick. 1968.

${ }^{50}$ Neil Armstrong y su primera huella en la Luna. 21 de Julio de 1969, a las 3 horas, 56 minutos y 20 segundos

${ }^{51}$ RAQUEJO, Tonia. Land Art.. Editorial Nerea. 1998
} 


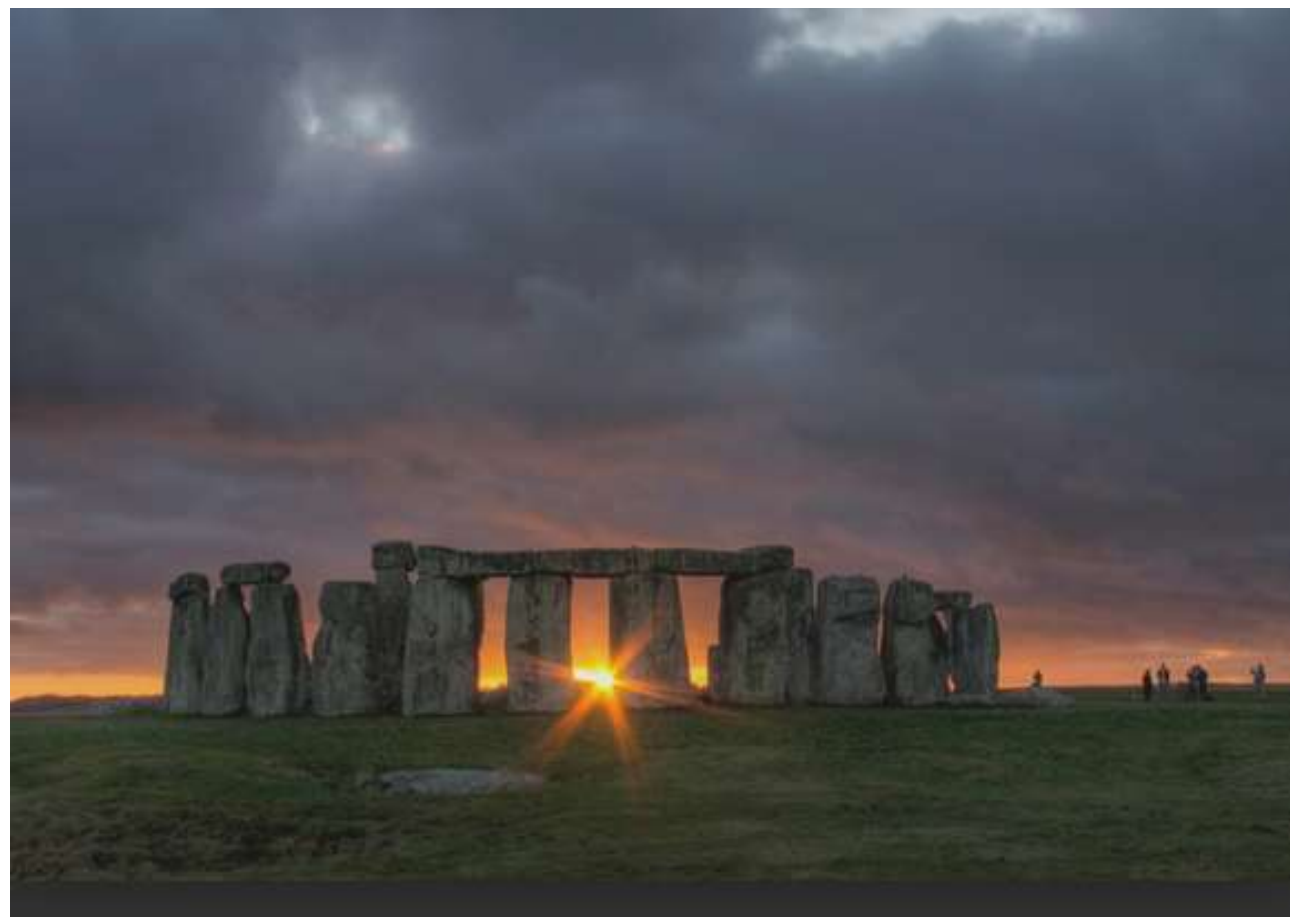

Ilustración $2-9^{52}$

\section{La experiencia de lo pintoresco.}

Para poder experimentar lo sublime, el artista tiene que haberlo previamente experimentado. Por ello, el viaje era tan importante para el artista romántico, quien viajaba en busca de lugares atractivos para la mirada aunque fuesen difícilmente accesibles y peligrosos para sentirlos "in situ", pues era en esos lugares, en los que podía sentir esa atracción - repulsión que definía lo sublime.

Hay muchos estudiosos que relacionan el Land Art con lo sublime romántico. Para Bearsdley en su libro Earthworks and Beyond, el Land Art tiene que ver con aquel espíritu experimental del viajero (relacionado con el paisaje romántico ingles) que en sus paseos distraídos encontraba sorpresas escondidas al primer vistazo. Robert Smithson continua la tradición del "objeto encontrado" que también fue utilizada por surrealistas y dadaístas cuando paseando distraídamente descubrían un elemento de la naturaleza que se parecía a otra cosa. Su mirada creativa era capaz de encontrarlo y sacarlo de ese contexto para situarlo en otro (el pedestal) y con ello llamar la atención sobre la importancia de la mirada creadora que descubre cosas donde otros no. Para los surrealistas, lo importante no era crear un objeto artístico, sino ser capaz de encontrarlo escondido entre la realidad cotidiana. $^{53}$

Para Javier Maderuelo, el Land Art, recoge la tradición de lo sublime, y lo detecta en cómo sus obras intentan superar los limites físicos de la propia obra a través

\footnotetext{
52 Stonehenge. monumento megalítico de finales del neolítico. 2600 a.c.

${ }^{53}$ Cuenta Elias Torres en una conferencia celebrada en la Fundacion Enric Miralles dentro del ciclo "Conversaciones con Enric Miralles", en 2015 que Enric solia realizar paseos similares a los realizados por los surrealistas con sus profesores de la Unidad docente y por este motivo le propuso colaborar con el en el montaje de la Exposicion sobre Los Situacionistas en el MACBA (Museo de Arte Contemporaneo de Barcelona).
} 
de la escala territorial y por el pulso de poder que establecen las obras de Land Art con las fuerzas de la naturaleza.

En el articulo Lo sublime y la vanguardia, Artforum, 1984, Francois Lyotard defiende que lo sublime en el romanticismo se encontraba en un mundo mas allá y diferente, pero que en el siglo XX, lo sublime se encuentra en el aquí y ahora. Por tanto, el instante producirá el acontecimiento. Lo sublime entendido así, queda materializado en la obra El campo de relámpagos de Walter de Maria (Quemado. Nuevo México, 1974-1977) en el que se crea un campo de atracción energética al descargar la electricidad los relámpagos de las nubes que por allí pasan. Para provocar esto, De Maria, coloca equidistantes 400 postes de acero inoxidable de 5 $\mathrm{cm}$ de diámetro y $6 \mathrm{~m}$ de longitud media ocupando una superficie de 1 milla por 1 $\mathrm{km}$ en medio del desierto. Para poder presenciar este acontecimiento los espectadores deberán permanecer en el lugar por lo menos durante 24 horas, para que puedan apreciar los cambios lumínicos que la luz natural provoca en los postes de acero inoxidable y para que la expectación prolongada hasta que aparezcan los relámpagos unido a la instantaneidad del suceso les haga captar el lugar en todo su esplendor. Por supuesto que ninguna imagen fotográfica puede reproducir la esencia de esta obra de Land Art, y por ello De Maria insistirá en que ninguna fotografía puede reproducir su obra, ya que esta necesita de la experiencia empírica en el mismo lugar. ${ }^{54}$

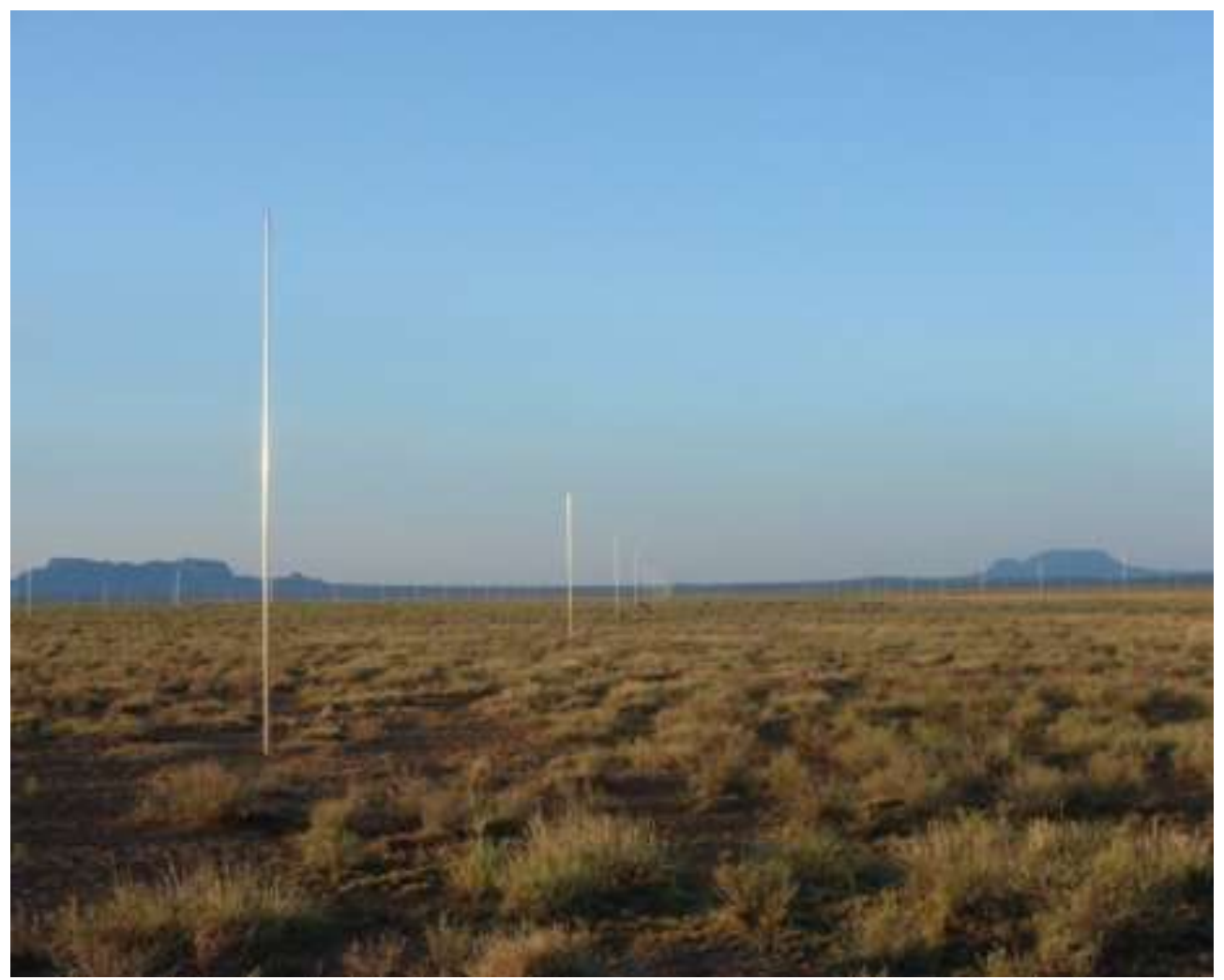

Ilustración 2-10

\footnotetext{
${ }^{54}$ RAQUEJO, Tonia. Land Art.. Editorial Nerea. 1998

${ }^{55}$ Walter De Maria, The Lightning Field, 1977
} 


\section{Tras las huellas de lo esencial}

Las obras de Land Art, en muchos casos, tienen un aspecto ancestral y remiten instintivamente a las que hicieron los hombres primitivos. Su parecido no es casual sino el resultado de la atracción que los land artist sintieron por la cultura primitiva.

La antropología de los años 60s revoluciono el concepto de progreso cultural y explico los signos abstractos del arte prehistórico. Dos obras clave del antropólogo Claude Levi-Strauss: El pensamiento salvaje (1961) y Mito y significado (1972), cambiaron el concepto de progreso cultural, al afirmar que el progreso nos acerca a la prehistoria en vez de alejarnos de ella, coincidiendo con el concepto de un tiempo cíclico desarrollado en muchas de la obras de Land Art. El tiempo cíclico interpreta el discurrir de la historia como una superposición de épocas lejanas, superponiendo la mas actual a la más antigua.

CLAUDE LEVI-STRAUSS

de thealinive froved

LA PENSÉE

SAUVAGE

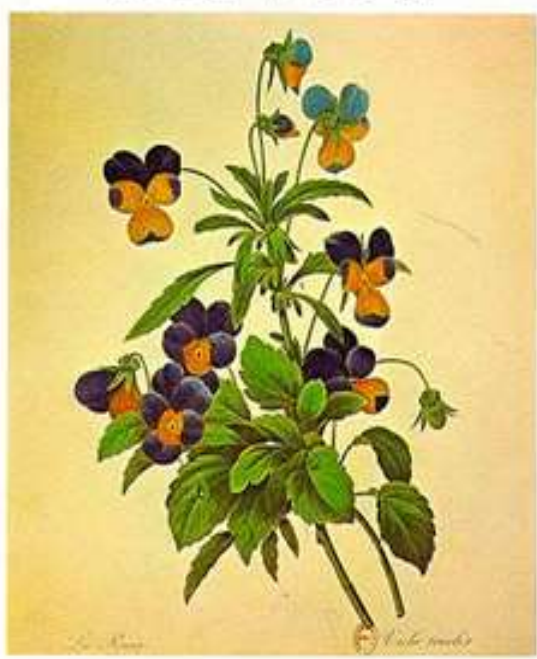

Ilustración 2-11 ${ }^{56}$

Respecto a la explicación del significado semántico de los símbolos, fue Sigfried Giedion quien encontró y difundió en sus libros, las similitudes entre el arte contemporáneo y el prehistórico. En su libro El presente eterno: los comienzos del arte ${ }^{57}$ defiende que tanto el hombre primitivo como el artista contemporáneo tienen la misma libertad de acción y ambos se expresan con un lenguaje abstracto que representa lo esencial. Las obras de Smithson, Pierce, etc. recuperan formas arcaicas para expresar mejor las relaciones entre hombre y naturaleza. El dialogo que las obras de los land artists establecen con el paisaje, recuerdan al dialogo que establecían las culturas primitivas. Este dialogo con la naturaleza en la que

\footnotetext{
${ }^{56}$ Claude Levi-Strauss: El pensamiento salvaje. 1961

${ }^{57}$ El presente eterno: los comienzos del arte. 1961
} 
actuaban, se establecía bien empleando materiales autóctonos, bien incorporando otros ajenos.

La primera manera de actuar la representa con claridad la obra El Muelle en espiral (Utah, 1970) de Robert Smithson estableciendo un dialogo con la naturaleza en la que emplea materiales autóctonos, usando las rocas de basalto que encontró alrededor del lago salado donde realizo su obra. Smithson, explica en sus escritos que cuando visito por primera vez el lugar donde tenía que intervenir no tenía una idea a priori de lo que iba a hacer, no quería imponer una imagen estética ajena al paisaje, sino todo lo contrario, quería trabajar desde el propio paisaje, haciéndolo visible, desentrañando sus formas ocultas. Y lo que su mirada descubrió mientras trabaja in situ fue una espiral emergiendo del fondo del lago cerca de la orilla. El efecto que provoca la visión de esa espiral, construida con rocas de basalto encontradas alrededor del lago, es mas telúrico que estético, más natural que artificial, resultado más de la acción de algún fenómeno natural que algo realizado por el hombre. La interdependencia entre lo creado por Smithson y la naturaleza es tan potente que difumina los límites entre arte y naturaleza. La metáfora construida en el paisaje se convierte en el mismo paisaje. Esta obra consta de tres umbrales perceptivos: desde el aire, a nivel del suelo y desde dentro del muelle. Desde el aire, se percibe la obra en su totalidad a gran escala, lo que permite apreciarla dentro del paisaje en el que se inserta. Al nivel del suelo, se percibe a escala humana. Dentro del muelle en forma de espiral, la obra envuelve al hombre y solo puede percibirla de manera fragmentada, con lo que no se puede percibir la espiral sino rocas, barro y agua. Esta misma manera de actuar, mediante la cual la metáfora se transforma en naturaleza, se observa también en las obras de Richard Long quien emplea los materiales encontrados en el lugar donde interviene, manipulándolos de tal manera que sus obras parecen ser construidas por la propia naturaleza, como si fueran huellas geológicas resultado de procesos climáticos, etc. ${ }^{58}$ La segunda manera de actuar, en la que el dialogo con la naturaleza en la que actúan los land artists, se establece incorporando materiales ajenos al lugar en el que intervienen, la representa bien la obra de Michael Heizer La Masa desplazada y reemplazada (Nevada 1969) en la que el artista realiza una excavación de un espacio rectangular para acoger una roca traída de otro lugar. Sigue la tradición neolítica de colocar grandes masas de piedra en lugares carentes de estas, como en Stonehenge donde sus dólmenes fueron realizados con un tipo de roca que no existe a kilómetros de distancia. Los Túneles solares. Desierto de Utah (1973-1976), de Nancy Holt, cuatro grandes cilindros de hormigón tumbados en posición horizontal con perforaciones circulares, fueron construidos con una masa, mezcla de arena y piedra existentes en el lugar. Holt, señala la dificultad de calcular las escalas en el desierto

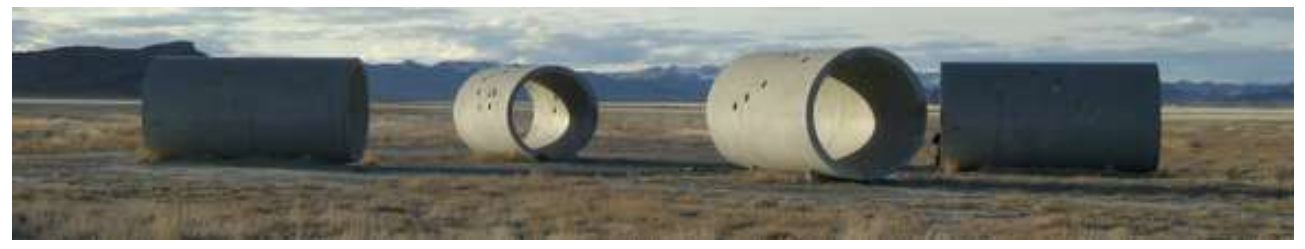

Ilustración 2-12

${ }^{58}$ RAQUEJO, Tonia. Land Art.. Editorial Nerea. 1998

${ }^{59}$ Nancy Holt, Sun Tunnels, Great Basin Desert, Utah, 1973-6. Cuando a lo largo de la investigacion se aborde el caso de estudio de Tiro con Arco en Barcelona, se detectaran semejanzas con esta obra en 
Sin embargo, la geometría de dichos túneles contrasta con la del lugar, y ese contraste buscado por la land artist conscientemente, es similar al efecto que se experimenta ante la contemplación de una pirámide egipcia de piedra en un desierto de arena. Como describe su autora: "...la vista panorámica del paisaje es demasiado grande para ser entendida sin puntos de referencia visuales, pues el panorama se desdibuja más que enfocarse. Por medio de los túneles, parte del paisaje se enmarca y se enfoca"

\section{Las formas abstractas y sus significados.}

El lenguaje del Land Art, en lo que respecta a sus formas, es de carácter abstracto: líneas, rectángulos, triángulos, círculos, espirales, etc. Es como si los land artists quisieran dejar huellas semejantes a las que dejo el hombre primitivo. En estos términos se refiere Tonia Raquejo: "los artistas (land artist) reescriben los mismos signos en lugares similares en los que escribieron nuestros antepasados, de la misma manera que los pintores del paleolítico pintaban una y otra vez los mismos motivos encima de los animales ya ejecutados para superponer el tiempo del antes y del ahora en el ritual que precedía a la caza." ${ }^{60}$

La obra de Richard Long, es un ejemplo expresivo de esta manera de hacer. Sus líneas, círculos y huellas se repiten una y otra vez en desiertos y montañas, con la intención de crear familias de formas similares a lo largo y ancho del planeta, para que puedan confundirse con las formas realizadas por los antepasados en el lugar. Sus intervenciones son obras superpuestas a otras para dejar constancia de su presencia, para que otros las encuentren tal y como Long se encuentra las huellas de otros. El lugar entendido así, se convierte en un superposición de capas que contienen la memoria ${ }^{61}$.

Para llegar al lenguaje de lo esencial en el momento presente, el artista contemporáneo tiene que rebuscar en su mente y traspasar los estratos culturales hasta llegar a lo esencial. Giedion en su libro El presente eterno: los comienzos del arte (1961), también estudio el significado de los símbolos abstractos que reiteradamente aparecen en el arte prehistórico, en especial el significado de líneas y círculos. Para Giedion, la línea recta remite a la representación del tiempo, mientras que el circulo remite a la representación del espacio. Línea y circulo, dos fuerzas contrarias, signos de lo masculino y lo femenino respectivamente que constituyen el origen de las cosas y se refiere en los siguientes términos: "....para el primitivo todas las líneas rectas significan el 'membrum virile', el falo; todo lo circular o en forma de hoz es el 'membrum muliere', la vagina,...es nuestra única vía de acceso al pensamiento primitivo; al significado de toda su cultura espiritual, de sus leyendas, canticos, cultos, artes y magias..." ${ }^{62}$

Los hombres primitivos "escribían" en la naturaleza con estos signos abstractos, para expresar su relación con el entorno. Los hombres primitivos entendían la

\footnotetext{
el tratamiento que reciben los modulos prefabricados de hormigon calados que configuran el edificio de Competición.

${ }^{60}$ RAQUEJO, Tonia. Land Art.. Editorial Nerea. 1998. pag. 24

61 Esto tiene mucho que ver con la obra de Miralles, en la que coloniza distintos lugares con las mismas formas, incluso defiende que un proyecto ya realizado en un enclave determinado se podia trasladar tal cual a otro lugar para definir mejor las caracteristicas de ese lugar.
}

${ }^{62}$ Sigfried Giedion. El presente eterno. Alianza Editorial, Madrid. 1985. pag. 272. 
naturaleza y por eso llamaron la atención de los land artists. La manera de ver la naturaleza por el hombre primitivo tiene influencia en el Land Art.

\section{El tiempo vectorial}

En su ensayo La configuración del tiempo (1962), George Kubler, un historiador especializado en civilizaciones antiguas, proponía una nueva manera de entender la historia del arte, al entenderla bajo un tiempo que denomino topológico, que diferencio del tiempo biológico y cronológico. Para Kubler, el tiempo biológico no debe aplicarse al arte, tal y como hicieran Vasari y después Winckelmann para explicar el discurrir de los estilos. Tampoco el tiempo cronológico (que marca el movimiento de las agujas del reloj) tiene que ver con el artístico, porque el tiempo artístico no estudia la sucesión de la aparición de las obras de arte sino las relaciones que se generan entre ellas. Según Kubler, los problemas del pasado pueden reactivase bajo unas nuevas condiciones y continuar su secuencia con formas nuevas. Los artistas del Land Art se adhirieron a este tiempo topológico de Kubler. "...hoy en día, la Antiguedad clásica ha sido desplazada por modelos aun más remotos, provenientes del arte prehistórico y primitivo...como si se quisieran completar ...posibilidades hace mucho tiempo sin realizar." 63

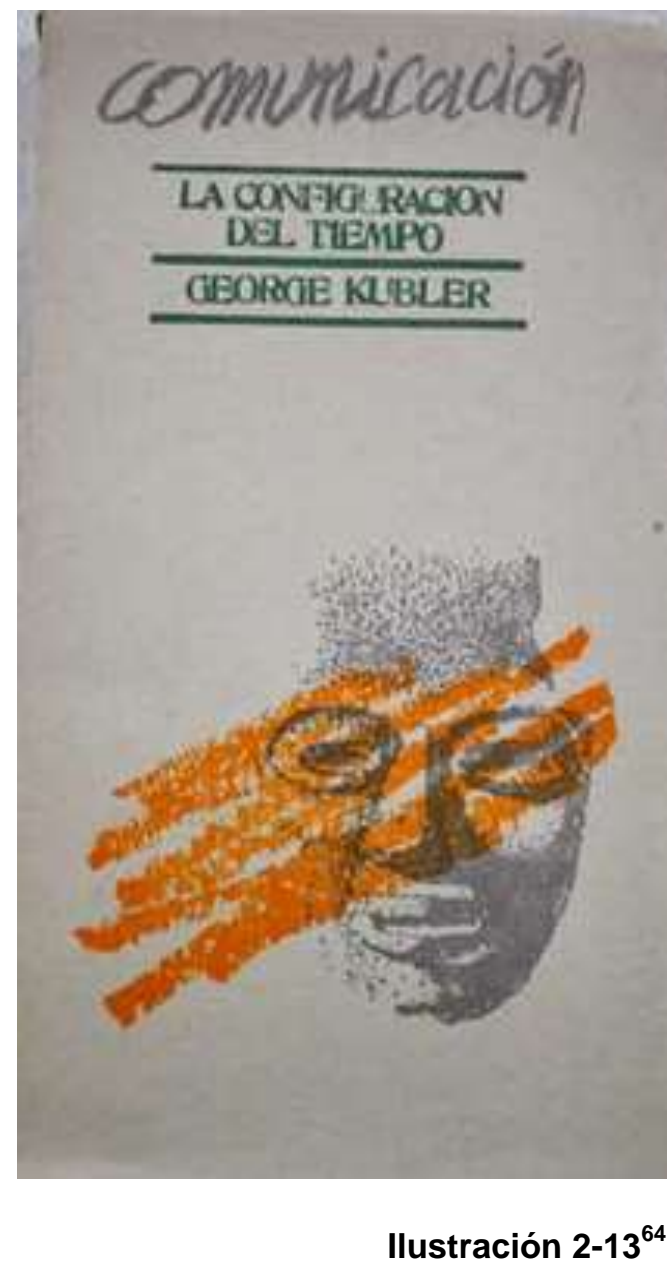

\footnotetext{
${ }^{63}$ George Kubler. La configuracion del tiempo. Nerea, Madrid. 1988. pag. 172.

64 Ibidem.
} 
Kubler, estaba por tanto en contra de la idea de progreso implícita en la filosofía hegeliana, para la que el devenir de la historia era vectorial como una flecha en el tiempo que ordenaba los sucesos cronológicamente interpretando el futuro como un estado superior según el cual lo venidero siempre mejoraba el pasado y el presente. Por tanto, Kubler y los land artists siguiéndole, revisaran el discurrir lineal del progreso del arte, la ciencia y la historia, apareciendo ya las primeras manifestaciones claras del pensamiento posmoderno. Como admite Michael Heizer: "...mas que innovar, deseo que mi obra vaya hacia atrás hasta fundirse con el pasado."

El Land Art es un arte fundamentalmente procesual. Muchas obras de Land Art, funcionan como detonantes que aceleran o hacen visibles las fuerzas que impulsan los procesos atmosféricos y geológicos. Una de los primeras obras de Robert Smithson, Leñera parcialmente enterrada (Ohio 1970), simula el proceso geológico de una duna de arena que en su avance va enterrando todo lo que se encuentra a su paso, hasta llegar a enterrar una construcción que albergaba leña. Para su realización, Smithson empleo una excavadora que vertía arena sobre esta construcción hasta colapsarla. Este simulacro geológico resulto ser una metáfora de la entropía, ese proceso que acaba por destruirlo todo. ${ }^{65}$ Para Morris, la obra de arte es un fenómeno que no puede definirse ni en términos casuales, ni objetuales, sino experimentales. De ahí que Morris y la mayoría de los land artists, insistan en que lo importante es el proceso y no el resultado.

El proceso exige un observador activo, ya que para entender la obra de land art, tiene que moverse, recorrerla, pues resulta imposible entenderla con su mirada de un solo golpe de vista ni desde una posición fija. El observador activo, al recorrer la obra, tiene que transformarse, verse a sí mismo y constatar que su sistema perceptivo es un instrumento que determina la realidad que ve y conoce. Tiene que ser consciente de su proceso de percepción y del proceso por el cual construye una realidad que se entiende en una dimensión más subjetiva y relativa, mas frágil. Con su obra, pretende desmontar la certeza del ego a través de espacios no jerárquicos ni secuencialmente ordenados, sino laberinticos y reiterativos para que la mirada pierda sus referencias habituales, de tal manera que no pueda imponer en el territorio un punto de vista dominante y una percepción mecánica del espacio. Perder el sentido de la izquierda y la derecha, el arriba y el abajo, en un movimiento circular que no conduce a un sitio en particular, sino que sirve para que el observador se redescubra construyendo una realidad, Se ve de una determinada manera porque se piensa según parámetros determinados. Desmontar dichos parámetros conllevaría desmontar la mirada fija que caracteriza la Historia y la cultura, pues desde el punto de vista espacial, el tiempo lineal identificado con el avance, genera una perspectiva euclidiana, una mirada unidireccional que exige la posición inmóvil del observador, tal y como representa Alberti en su "pirámide visual", proyección antropocéntrica del sujeto sobre el espacio, que genera un perspectiva lineal. Al recorrer "El Observatorio" de Morris, el observador es colocado en un espacio circular. En este espacio, el sujeto se descubre en el objeto. Con ello, Morris, transforma la mirada del observador convirtiéndola en reflexiva que se observa. El cambio es significativo, pues el arte ya no consistirá en contemplar un objeto sino en experimentar la naturaleza del hombre en el. ${ }^{66}$

\footnotetext{
${ }^{65}$ Esta obra de Land Art recuerda como Miralles entierra parte de la capilla del Cementerio de Igualada una vez construida
} 


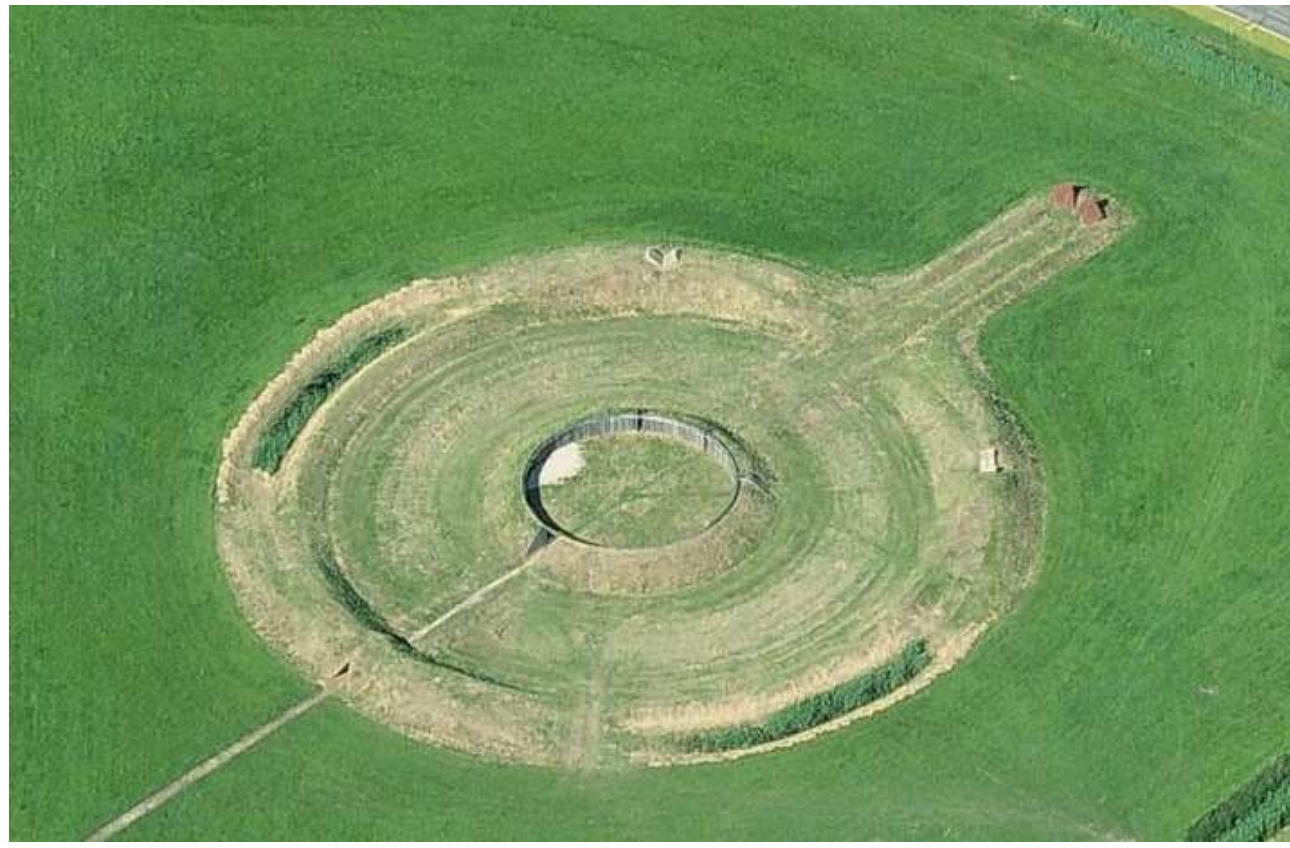

Ilustración 2-14

Morris entiende que la percepción esta determinada según la naturaleza del perceptor. Si es un "Yo imagen" vera una realidad, y si es un "yo existencial" vera otra. En la práctica es imposible separar ambas pues se encuentran interconectadas

Las obras de Land Art, no son para ser vistas, sino para ver el paisaje de otra manera a través de estas. La obra tiene poco que ver con el resultado que se persigue, sino que es un proceso interminable en la que se combina el lugar, el estado atmosférico, el artista, lo que sucede allí y en ese momento. El arte no puede limitarse ya a su carácter objetual al transgredirse la naturaleza como modelo mimético. El espacio ya no es representado sino experimentado. De ahí que el recorrido se convierta en parte esencial de la obra. ${ }^{68}$

\section{Diálogos con el lugar.}

El lugar es parte de la obra y juega un papel primordial en el proceso, imponiendo sus reglas de comportamiento. El land artist, cuando se desplaza al lugar donde intervendrá, se ve obligado a abandonar su vida confortable para trabajar en zonas muy alejadas, en las que falta agua, alimentos, gasolina, etc. exigiéndole cambiar sus costumbres.

La naturaleza deja de ser el modelo a imitar en su obra, para pasar a ser el escenario donde se registra el acontecer, el ser y estar en un presente continuo en el que todo cambia. El land artist, no actúa con ideas preconcebidas sino que

\footnotetext{
${ }^{67}$ Robert Morris. "Observatory". Oostelijk. Paises Bajos. 1971 - 77. Diametro $91 \mathrm{~m}$.

${ }^{68}$ Es fundamental visitar las obras de Enric Miralles.. Pero la visita es todavia mas obligada si se quieren entender sus obras insertas en el paisaje natural. La experiencia que me dejo la visita al Pabellon de Huesca en un atarceder otoñal, me animo a investigar sobre la relacion de la arquitectura con la naturaleza que establece la obra de Enric Miralles.
} 
descubre como un primitivo el lugar, escuchándolo y sacando a la luz lo que permanece oculto en el, mediante la paciente observación y estudio del lugar, detectando los elementos geológicos del paisaje que le ayuden a descubrirlo. Richard Long es el paradigma de este tipo de land artist, sus obras mantienen una relación intima con la naturaleza lo que le diferencia de los artistas del land art norteamericano.

Las intervenciones de Long, son casi presentimientos del lugar y mantienen un dialogo interno con el entorno. No transforman la naturaleza con excavaciones, perforaciones, etc. sino que sus obras se integran en la naturaleza de tal manera que la hacen visible que antes de la intervención de Long. Su obra "encarna al lugar" tal y como propone Heidegger en su ensayo El arte y el espacio en 1969: "...el juego mutuo de arte y espacio, tendría que ser pensado a partir de la experiencia del lugar y del paraje. Y así, el arte como escultura no sería conquista alguna del espacio...la escultura seria la encarnación de los lugares." 69

Para Richard Long, cada lugar requiere de su intervención única. La obra allí construida establece un dialogo con el lugar, siendo un complemento de este, interpreta lo que allí sucede. Las trazas y señales que se encuentran en el lugar, son rastros del acontecer, y el artista del land art tendrá que decidir cuales se haces visibles con su intervención. Long, abre el lugar a la mirada, para desocultarlo, estableciendo una relación intelectual con el lugar que entiende es parte de la obra y desempeña un papel primordial en el proceso. El lugar impone sus reglas de comportamiento, impone al artista una transformación de sus costumbres. Long descubre el lugar como un hombre primitivo y para ello tiene que ser capaz de escucharlo y sacar a la luz lo que permanece oculto en el. Mediante la observación y la intuición detecta elementos formales del paisaje que le ayudan a presentir el espacio en el territorio y descubrirlo mediante su intervención. ${ }^{70}$

Cada lugar requiere una intervención única, ex profeso, de tal manera que la escultura allí erigida no podría estar en otro sitio, ya que es un complemento del lugar y de lo que allí sucede. los materiales de sus acciones en el territorio, no son solo las acciones realizadas y erigidas, sino también los documentos de sus viajes por los lugares del mundo que ha visitado, algo que recuerda la importancia que le dan a los dibujos arquitectos contemporáneos como Siza, o Miralles.

Las obras de Christo y Jeanne-Claude recubren sitios. La palabra sitio, presupone un espacio donde se ha establecido un orden previo (poner las cosas en su sitio). El lugar se constituye, mientras que el sitio se ocupa, se cubre, se envuelve. La ocultación a la que someten parte de la naturaleza en sus intervenciones, transforman el lugar. Del juego de ocultar, resulta paradójicamente una mejor lectura de las formas naturales recubiertas bajo el envoltorio, que se dejan ver mejor, abstraídas. Al envolver el sitio y darle forma, lo están convirtiendo en lugar.

\footnotetext{
${ }^{69}$ Martin Heidegger. El arte y el espacio. 1969.

${ }^{70}$ RAQUEJO, Tonia. Land Art.. Editorial Nerea. 1998
} 


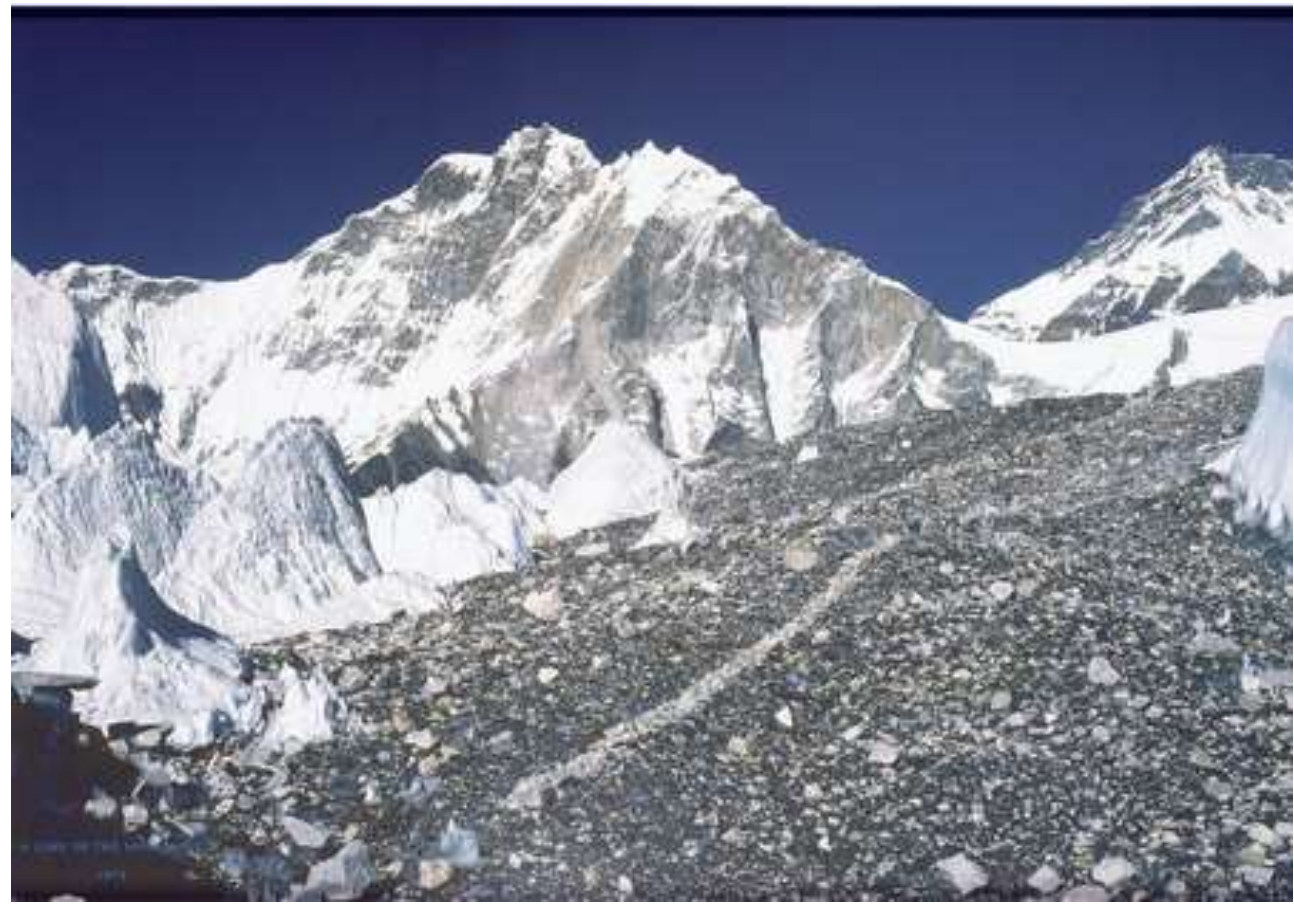

Ilustración 2-15

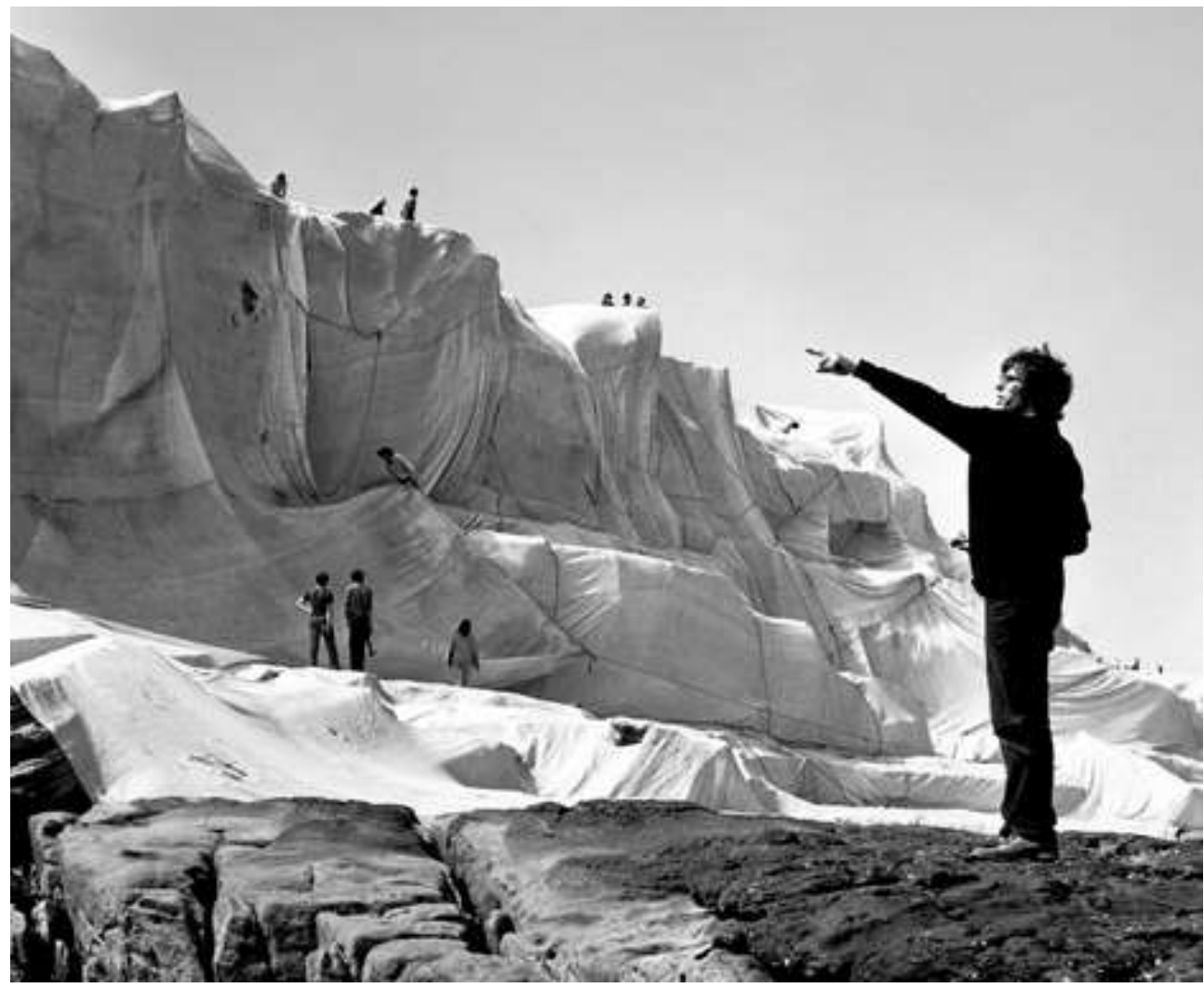

Ilustración 2-16 ${ }^{72}$

${ }^{71}$ Richard Long A Line in the Himalayas 1975 
El valor de las obras de Richard Long, Donald Judd, Walter de María, Michel Heizer, Richard Serra entre otros, es la capacidad que tienen de enfrentarse con la naturaleza, a través de intervenciones mínimas, esenciales, para conseguir el máximo efecto con el mínimo de recursos. Le confieren una escala, una medida al paisaje. Para el land artist, no es lo mismo pintar o representar un paisaje que estar en el paisaje, ser parte de él. Cuando pinta un paisaje conforme al recuerdo de la sensación y otra cosa bien distinta es experimentar in situ mientras se trabaja la obra en el paisaje. Destaca entre los land artists, por la relación que Miralles mantendrá con su obra, Robert Smithson, artista estadounidense, fallecido en 1973 mientras supervisaba la construcción de unos de sus Earthworks, que comenzó dedicándose a la pintura abstracta para dedicarse a partir de 1965 a la escultura sobre el paisaje en lugares remotos naturales. Iñaki Abalos destaca la importancia de este artista en los siguientes términos: "...testamento artístico de Robert Smithson 'Frederick Law Olmsted y el paisaje dialectico'... hace en él una reivindicación totalizadora de Olmsted como artista contemporáneo capaz de entender el paisaje como algo dialectico, nunca concluso, capaz de hacer visible en su obra tiempos geológicos y dar nuevas direcciones al espacio público". ${ }^{73}$

Smithson, pertenece a esa generación norteamericana de después de la $2^{\mathrm{a}} \mathrm{GM}$, que de niño disfrutaba en el Museum of Natural History de Nueva york viendo los dioramas con las recreaciones de los paisajes distintos y sus animales disecados. De niño pensó en estudiar biología, pero el contacto con amigos artistas pop art, le hicieron valorar la capacidad del artista de intervenir en el Mundo. Cambio la visión del paisaje contemporáneo al descubrir el valor de los paisajes industriales abandonados, y trajo la visión de lo pintoresco a la contemporaneidad, al valorar los no lugares, lo obsoleto. Defendió el valor de estos paisajes obsoletos, abandonados, degradados, como polos de oportunidad, para lo cual había que cambiar la mirada y erradicar los prejuicios que se tenían sobre estos paisajes. Robert Smithson se sentía atraído por las teorías científicas que estudiaban el tiempo y el espacio, para él la obra de arte debía liberarse del tiempo cronológico rompiendo los límites del espacio newtoniano, donde la materia pudiera viajar por el túnel del tiempo visitando simultáneamente el presente, el pasado y el futuro. La dialéctica entre dentro y fuera será muy importante para Robert Smithson. El binomio interior-exterior cobra un significado estético que lo resume en otro formado por lo abstracto y lo natural. Esta es la base de su compleja teoría sobre el site y el non-site representada en varias de sus obras en las que utiliza el espejo. Para Smithson el espejo es a la vez un contenedor (una superficie o non-site) y sus reflejos (site). Según el artista americano, el espejo es en sí mismo una abstracción atemporal y los reflejos son ejemplos efímeros que eluden conformarse. Los no-lugares de Smithson constituyen una crítica al arte tradicional que baso su existencia solo en la mirada, en la contemplación. Su no-lugar es no al arte visual. Uno de los sentidos del no-lugar es un material que no puede divisarse, uno de los sentidos del no-lugar es el proceso de desmaterialización que se lleva a cabo con respecto a la naturalidad del lugar, que desaparece por abstracción.

\footnotetext{
${ }^{72}$ Christo and Jeanne-Claude Wrapped Coast, One Million Square Feet, Little Bay, Sydney, Australia, 1968-69

73 Iñaki Abalos. Naturaleza y artificio. El ideal pintoresco en la arquitectura y el paisajismo contemporaneos. GG. 2009, pag. 12.
} 

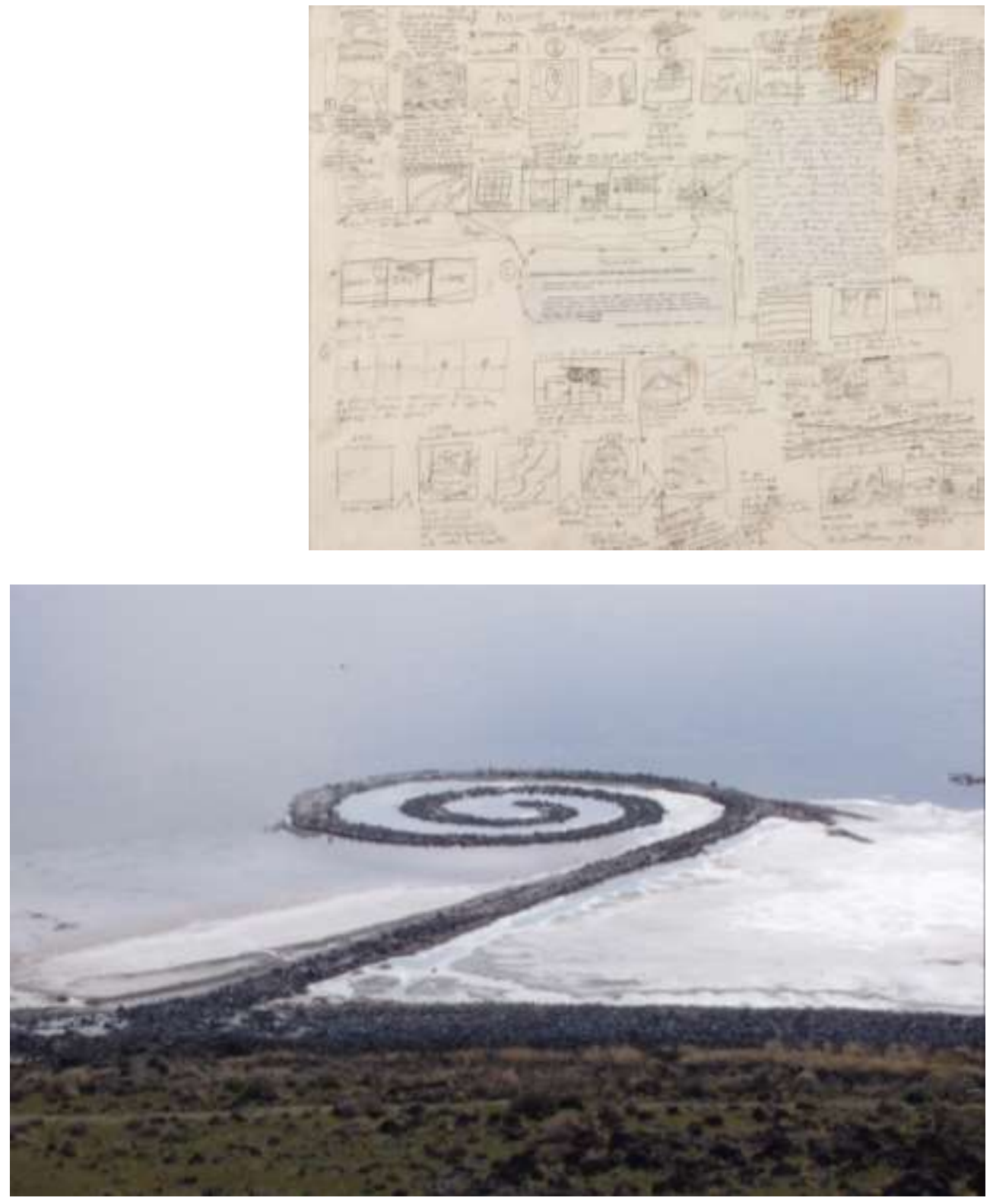

Ilustración 2-17 ${ }^{74}$

${ }^{74}$ Robert Smithson. "Spiral Jetty", Rozel Point, Great Salt Lake, Utah, EE.UU. 1970 y manuscrito para su tratamiento filmico. $48 \times 61 \mathrm{~cm}$ lapiz y collage sobre papel. 
CONTEXTO 


\subsection{EL PAISAJE EN LA ARQUITECTURA DECONSTRUCTIVISTA}

"...me acuerdo un paseo que hicimos con Enric por Central Park y le pregunte que pensaba sobre la obra de Libeskind, Zaha Hadid... y me respondió que no los entendía, que para él, eran demasiado modernos."

Benedetta Tagliabue ${ }^{75}$

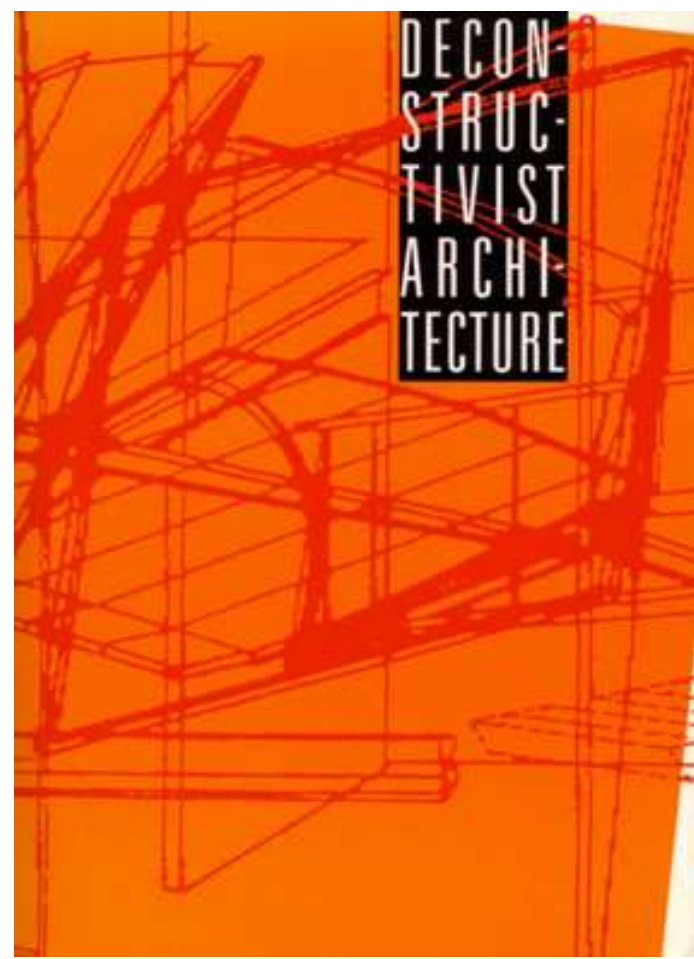

Ilustración 2-18

Rafael Moneo, encuentra ecos de la arquitectura deconstructivista en la arquitectura que Miralles hacia cuando colaborara en el estudio de Viaplana -Piñón y en su obra posterior. Encuentra similitudes entre las propuestas que se presentaron en el Concurso del Parque de la Villete en Francia ( las propuestas de Bernard Tschumi, Peter Eisenman, Zaha Hadid, etc. especialmente la primera etapa de Zaha) y las propuestas de Enric Miralles, en las que los planos son algo cerrado en sí mismo, un mundo complejo que lleva hasta la entropía. ${ }^{77}$

\footnotetext{
${ }^{75}$ Debate en Curso de verano de la UIMP, "alegoria del tiempo: la arquitectura y el universo de Enric Miralles" Barcelona, 2009. De cualquier manera no se debe hacer mucho caso a la contestacion de Enric a Benedetta, puesto a lo largo de esta investigación se ha ido comprobando como a Enric Miralles no le gustaba enseñar sus referencias.

76. La Exposición "Deconstructivist Architecture" celebrada en el MOMA de Nueva York en 1988, comisariada por Philip Jhonson, Mark Wigley y Peter Eisenman tiene como objetivo acabar con el Posmodernismo y el daño que estaba haciendo a la Arquitectura. Se expusieron obras de Frank Ghery, Peter Eisenman, Coop Himmelblau, Zaha Hadid y Bernard Tschumi.
}

${ }^{77}$ Rafael Moneo. Conversaciones con Enric Miralles. Fundacion Enric Miralles. 2015 


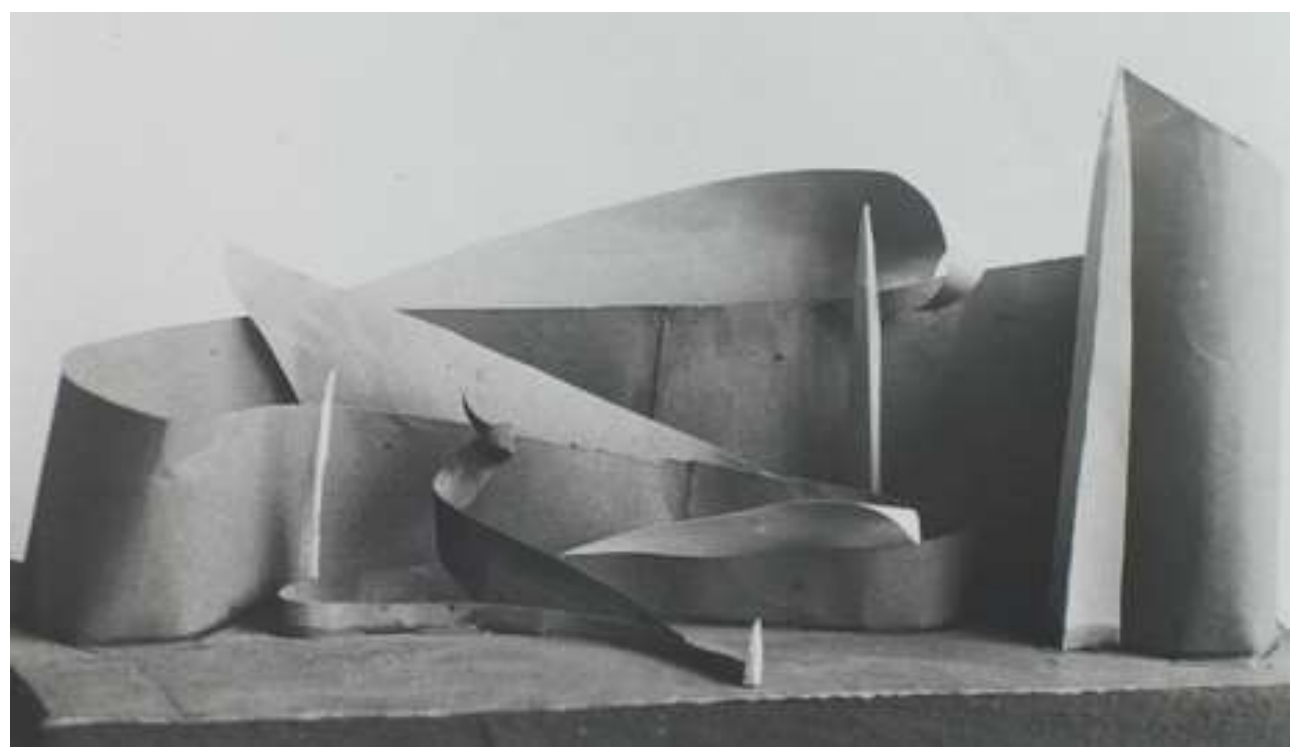

Ilustración 2-19

“...La arquitectura como la expresión exacerbada de las tensiones inherentes a un lugar o a un programa."

Coop Himmelblau. ${ }^{79}$

El Deconstructivismo debe su denominación a la referencia al constructivismo y a la filosofía de la deconstrucción que es su inspiradora. La Exposición "Deconstructivist Architecture" celebrada en el MOMA de Nueva York en 1988, comisariada por Philip Jhonson, Mark Wigley y Peter Eisenman tiene como objetivo acabar con el Posmodernismo y el daño que estaba haciendo a la Arquitectura. Se expusieron obras de Frank Ghery, Peter Eisenman, Coop Himmelblau, Zaha Hadid y Bernard Tschumi. Se legitima el nuevo movimiento arquitectónico a través de la filosofía derivada de los libros del filosofo Derrida; se incita a seguir los proyectos de la vanguardia rusa como los de Alexander Rodchenko, Vesnin... admirando el carácter inestable de sus obras y abogando por la creación de espacios laberinticos (que es lo que tienen en común la obra de los arquitectos seleccionados para la exposición).

Miralles siempre estuvo muy informado del acontecer de la evolución de Arquitectura, y conocio este movimiento de la Deconstrucción cuando estuvo de Profesor en Columbia University en el curso 1989 -1990. Quizás la analogía formal de su Arquitectura con la Deconstructivista, le favoreció en su salto internacional, pero su arquitectura supo ir mas allá, como muchos críticos han defendido.

Las obras de los arquitectos deconstructivistas asumen la complejidad, la densidad, la congestión, la velocidad y el caos. Tienen en cuenta el contexto: social, político, cultural y edilicio dando mucha importancia al emplazamiento, a los datos que aporta el lugar, a esa historia del lugar que aportara datos al proyecto. $\mathrm{Se}$ intenta por tanto conocer el "genius loci" del lugar. Para ello desarrollaran nuevas herramientas de trabajo para poder descifrar la esencia del lugar.

\footnotetext{
${ }^{78}$ Vanguardia rusa. Escuela Vkhutemas, “Model Construction”,1925.

${ }^{79}$ Citado en "Enciclopedia Akal de Arquitectura S. XX". 2004, pag. 212
} 
Daniel Libeskind indaga en los lugares generando matrices de datos como punto de partida para realizar el proyecto. Son matrices abiertas, flexibles que representan un histograma de realidades invisibles y las relaciones que se establecen entre ellas, para llegar a captar la esencia del lugar.

Tschumi, Libeskind y Eisenman son tres arquitectos deconstructivistas que han mostrado su interés particular por el tema del lugar como generador del proyecto arquitectónico. Para captar la esencia del lugar en el que proyectar su obra, utilizan herramientas como: la excavación arqueológica, la huella y el palimpsesto.

Peter Eisenman rechazara la obra de los contextualistas a lo Leon Krier, Robert Venturi o Colin Rowe, porque su contextualismo representaba un estado presente sin tener en cuenta gran parte de la historia del lugar. La obra de Eisenman no se preocupo por el lugar hasta el año 1978 cuando abordo el proyecto para el Cannaregio en Venecia. El método de "Excavación arqueológica o Arqueología ficticia" es un método que suele emplear Eisenman para obtener la información contenida en el lugar. Eisenman empleo este método entre 1978 y 1988, lo comenzó en el proyecto para el Cannaregio y lo termino en su propuesta para el Parque de la Villete, como versión actualizada del "genius loci", en el que las trazas históricas se mezclan con las presentes. Pero en la periferia, los suburbios, los limites, etc. no hay memoria que sirva de punto de partida, y es en esos casos en los que Eisenman recreara el lugar mediante una historia invertida. En estos casos, Eisenman sostiene que en esos lugares, surge una sensación de inseguridad, desconocimiento, extrañeza. Para extraer en estos lugares lo escondido, lo reprimido, Eisenman propone actuar con fuerza, agitación, movimiento. Una vez que Eisenman ha superado esa situación de extrañamiento en estos lugares y tiene información de los datos inherentes "a priori" ocultos, realiza diagramas y esquemas de partida que sintetizan las condiciones del lugar y los hace interactuar con los de función y tipo. ${ }^{80}$

El concepto de huella en Eisenman, es reinterpretado del concepto del filosofo Jaques Derrida para quien la huella no es tan solo un resto sino un origen. La huella, engendra un edificio no figurativo, abstracto, no explicativo pero capaz de extraer las huellas del pasado del lugar. Derrida sostiene que ningún elemento puede funcionar como signo sin remitir a otro que a su vez haya estado presente con anterioridad. Dicho encadenamiento hace que cada componente se constituya a partir de la huella que hace referencia a los otros componentes de la cadena o sistema. Dicha sucesión configurara por tanto el contexto en el que la nueva obra de arquitectura proyectada entrara a formar parte. Derrida se acerca con ello al pensamiento del eterno retorno, vinculándolo con la repetición. Para Eisenman, mientras que la planta de la arquitectura es una escritura finita, la huella sugiere plantas diferentes, la huella sugiere potenciales relaciones que podrían emerger de figuras previamente reprimidas y generarlas de nuevo. ${ }^{81}$ Es decir que las huellas podrían generar figuras arquitectónicas alternativas que a su vez contuviesen otras huellas. La huella derrideana por tanto aporta datos sobre el lugar en el que se interviene.

\footnotetext{
${ }^{80}$ Es evidente que Miralles actua de la misma manera ante esos lugares sin identidad, perifericos, con una arquitectura dinamica, una vez que ha detectado las trazas parcialmente ocultas que se enconden en cada lugar.

${ }^{81}$ Vicente Esteban Medina. Tesis Doctoral "Forma y composicion en la arquitectura deconstructivista" ETSAM. UPM. 2003
} 
Según Kenneth Frampton, Eisenman entiende el lugar: "como una tabla geológica sobre la que una serie teóricamente eterna de jeroglíficos han sido inscritos por la naturaleza arbitraria y por la igualmente caprichosa mano del hombre" ${ }^{82}$

Cada lugar tiene significados invisibles que pueden ser sacados a la luz. La técnica del palimpsesto ${ }^{83}$ revela que el significado es anterior a la obra de arquitectura y continua mas allá de su construcción. La arquitectura contemporánea en muchas ocasiones tiene que intervenir en localizaciones en la periferia, en los límites de las ciudades. El concepto de limite, tiene dos acepciones para los arquitectos deconstructivistas: por un lado seria lo que encierra lo preestablecido y por otro sería algo que además de separar, tiene presencia física y dimensión propia, constituyendo un espacio intersticial. Los intersticios ${ }^{84}$ se captan mejor mediante la percepción inconsciente, las sensaciones y las intuiciones. Para Tschumi, los intersticios los denomina espacios "in-between" y son para el espacios dinámicos que deberían ser tratados como lo mas importante en un proyecto. Para Eisenman, el intersticio es un sólido articulado entre un espacio interior y otro exterior o entre dos espacios interiores. Posee por tanto una condición doble. No se trata solo de una presencia continente como podría ser un muro sino también una presencia figurada o articulada que se materializa como si fuese un contenedor que encierra y refugia a la vez.

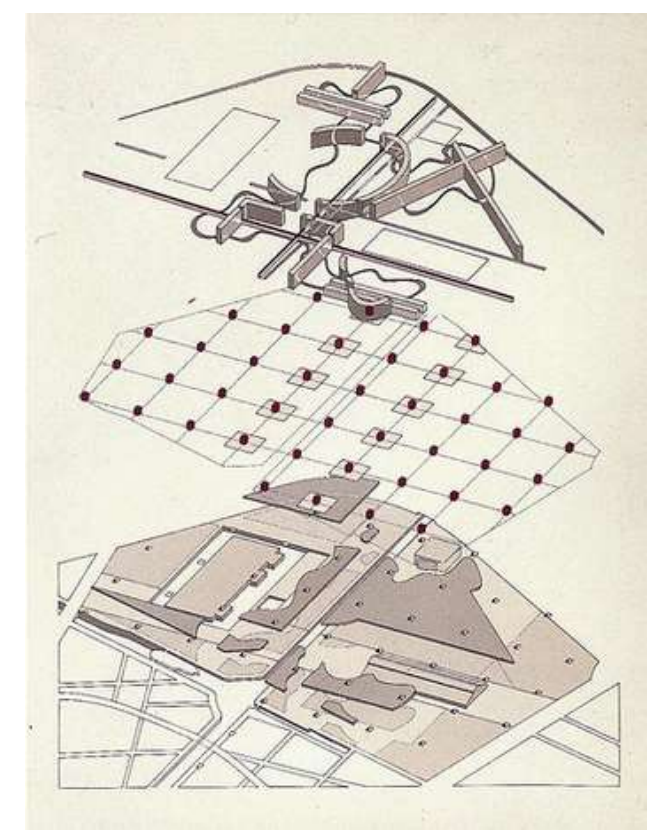

Ilustración 2-20 ${ }^{85}$

82 Kenneth Frampton. "Eisenman por segunda vez: Interferencia corriente" $A+U$ Architecture and Urbanism, 1988. pag. 64.

${ }^{83}$ Según el Diccionario de la Real Academia de la Lengua española, "palimpsesto" es un manuscrito antiguo que conserva huellas de una escritura anterior borrada artificialmente.

84 Cuanta importancia tiene en la arquitectura de Miralles, estos espacios intermedios, esos intersticios, especialmente en sus primeras obras: Tiro con arco, Huesca, Alicante, etc. pero a partir de la obra de esos dos estadios, se tomara muy en cuenta la resolucion constructiva de estos espacios intermedios, pues le trajo problemas de falta de estanqueidad del edificio entre exterior e interior, fallos de seguridad en la envolvente, etc...

${ }^{85}$ Bernard Tschumi. Lines/Points/Surfaces, Parc de la Villette, Paris. 1982 
Robert Venturi en su libro Complejidad y Contradicción en la Arquitectura, ya admitía la existencia de los espacios intermedios, a través de ejemplos construidos a lo largo de la historia. Por ejemplo, en las plantas de la iglesia de St. Basel, se puede observar como si dentro de la misma iglesia existieran otras iglesias dejando espacios intersticiales entre ellos, resultado de la proximidad de las capillas entre si y el muro de cerramiento exterior. A estos espacios intersticiales los denominaba "residuales". Lo intersticial deja de ser el contorno de la figura, es más bien la figura, asumiendo un forma tridimensional, alcanzando forma, estructura y función propias, no residuales.

Aldo Van Eyck, muy admirado por Miralles, también reconocía la existencia de estos espacios intermedios: "la arquitectura debería concebirse como una configuración de lugares intermedios claramente definidos. Esto implica un rompimiento con el concepto contemporáneo de la continuidad espacial y la tendencia a borrar todas las articulaciones entre espacios, es decir, entre el exterior y el interior, entre un espacio y otro, entre una realidad y otra ... la transición debería articularse por medio de lugares intermedios definidos que permitan el conocimiento simultaneo de lo que es significativo al otro lado. Un espacio intermedio en este sentido proporciona el terreno común donde las polaridades conflictivas pueden ser fenómenos gemelos". ${ }^{86}$

Heinrich Wolfflin en su libro "Renacimiento y Barroco", sostenía que la diferencia entre ambos periodos residía en el perfil. En el Renacimiento el perfil tenía bordes definidos, en el Barroco tenia bordes difusos. En las obras del periodo Barroco, todo el sistema, los elementos, la geometría y el detalle son el resultado de un proceso de mutación. Aunque se emplean los mismos elementos y herramientas proyectuales del Renacimiento, el Barroco los expresa de otra manera. Un recurso barroco es solapar los espacios para que todos los elementos que componen el espacio superen sus límites. Ello unido a la particular manera de tratar la forma y la luz genera unos espacios que a diferencia de sus equivalentes renacentistas, casi nunca están definidos y delimitados con claridad. Esta indefinición permite múltiples lecturas de la obra.

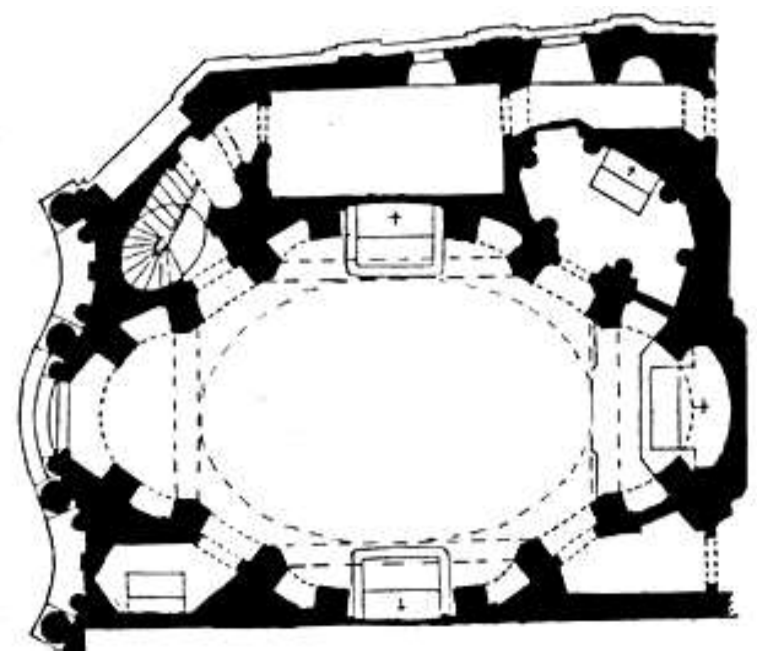

Ilustración 2-21

${ }^{86}$ Aldo Van Eyck. Architectural Design 12, 1962, pag. 602.

${ }^{87}$ Franceso Borrimini San Carlos de las Cuatro Fuentes en Roma (1634 - 1667) 
La indeterminación se relaciona con lo que no tiene unos límites definidos, con la dislocación de la estructura y la fragmentación de las partes, generando un objeto cuya imagen no es sintética que provoca una ambigüedad en la percepción entre el espacio público y el privado, entre el exterior y el interior Peter Eisenman defiende que el limite, al materializarse se percibe por un lado como un contorno al igual que en la pintura, pero por otro lado se percibe como un perfil como sucede en la escultura o la arquitectura. Y esto le permite defender el binomio contorno / perfil. Eisenman propone el desdibujamiento del perfil, dejándolo indeterminado, para profundizar en lo intersticial, en el límite. Propone utilizar una nueva herramienta: el Spacing o trabajo espacial del límite opuesto al tradicional Forming o trabajo formal del límite. En el proceso tradicional del Forming, los espacios habitables se generan como consecuencia de los planos delimitadores: suelos, paredes y techos. El Spacing, como oposición al Forming, plantea la nueva posibilidad de que lo instersticial se haga habitable convirtiéndose lo intersticial en el objetivo del proceso de diseño, no su residuo. El intersticio en el proceso de Spacing, supera su condición de solido, con significado prefijado, para producir espacios dentro de espacios, superposiciones de espacios que conllevarían una densidad espacial inalcanzable con el método tradicional del Forming. La diferencia entre los dos procedimientos se podría sintetizar según la secuencia Espacio-Muro-Espacio frente a Espacio-Espacio Mural-Espacio. ${ }^{88}$ La investigación llevada a cabo por los arquitectos deconstructivistas sobre los conceptos de limite, perfil y contorno, conllevo por un lado el establecimiento de paralelismos entre las obras del Barroco y las indagaciones deconstructivistas y por otro lado, la posibilidad de configurar una arquitectura indefinida o indeterminada ligada a los espacios borrosos y difusos que contienen los intersticios. ${ }^{89}$ Aunque es evidente que Miralles le gustaba estar informado de la escena internacional y formar parte de esta, encasillarle como arquitecto deconstructivista, seria realizar una lectura superficial de su obra. En realidad, la fragmentación, las curvas, las diagonales y la angulosidad de su arquitectura, tienen que ver más con referencias anteriores al movimiento de la Deconstrucción. Habría que irse a consultar la obra de Miguel Angel, de Gaudí, de Aalto, de Scharoun, de Hugo Haring para explicarlos mejor. Los maestros de la arquitectura moderna, ya experimentaron en los años 1920 con geometrías curvas y ángulos distintos de $90^{\circ}$ articulando las partes que componían sus edificios de manera poco convencional. Tildados por la tendencia dominante del Movimiento Moderno de extravagantes y de realizar una arquitectura demasiado personal por ello y no la que necesitaba la sociedad; sin embargo Haring y Scharoun siempre defendieron que sus edificios eran la representación de una nueva conciencia para una nueva sociedad.

En Miralles como en Scharoun, los edificios se ligan al lugar en profundidad, pero no en términos de estilo o a través de las fachadas, sino controlando las relaciones entre los espacios de alrededor, con transiciones orquestadas entre exterior e interior, interactuando con los elementos que conforman el paisaje natural y construido entorno a sus edificios, generando una especie de "ciudad - paisaje" como lo denominaría Scharoun. Las formas del exterior también tienen resonancias en las formas del interior, configurando un paisaje interior. La importancia dada a los recorridos del publico por sus edificios también coincide en Mlralles y Scharoun.

\footnotetext{
${ }^{88}$ Vicente Esteban Medina. Tesis Doctoral "Forma y composicion en la arquitectura deconstructivista" ETSAM. UPM. 2003

${ }^{89}$ Ibidem.
} 


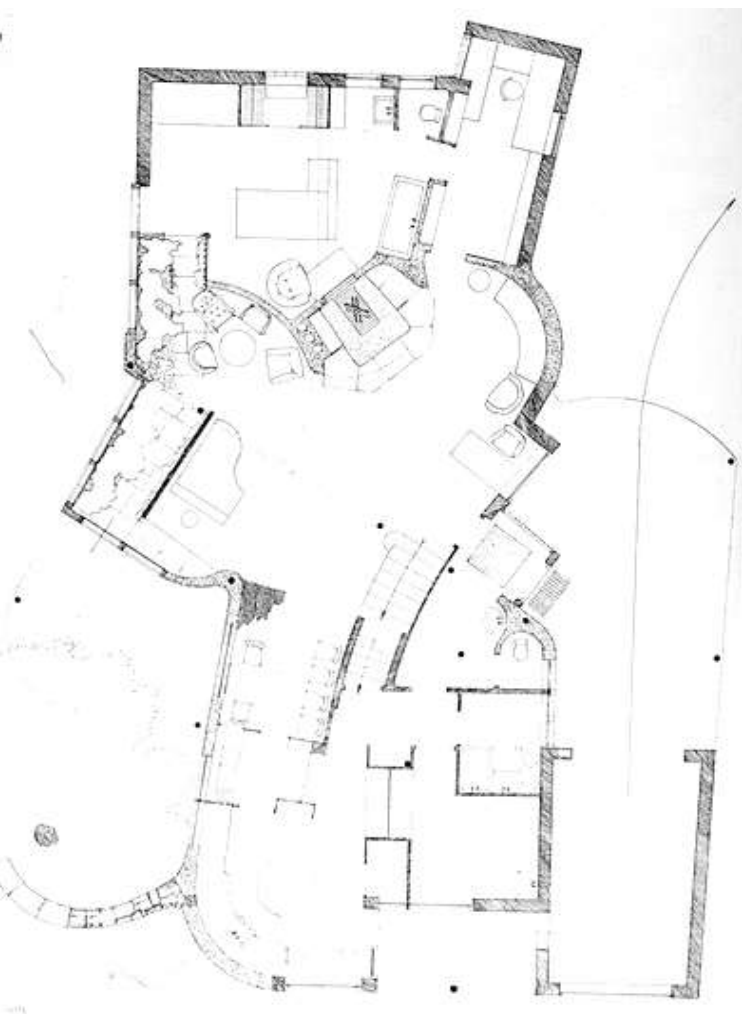

Ilustración 2-22 ${ }^{90}$
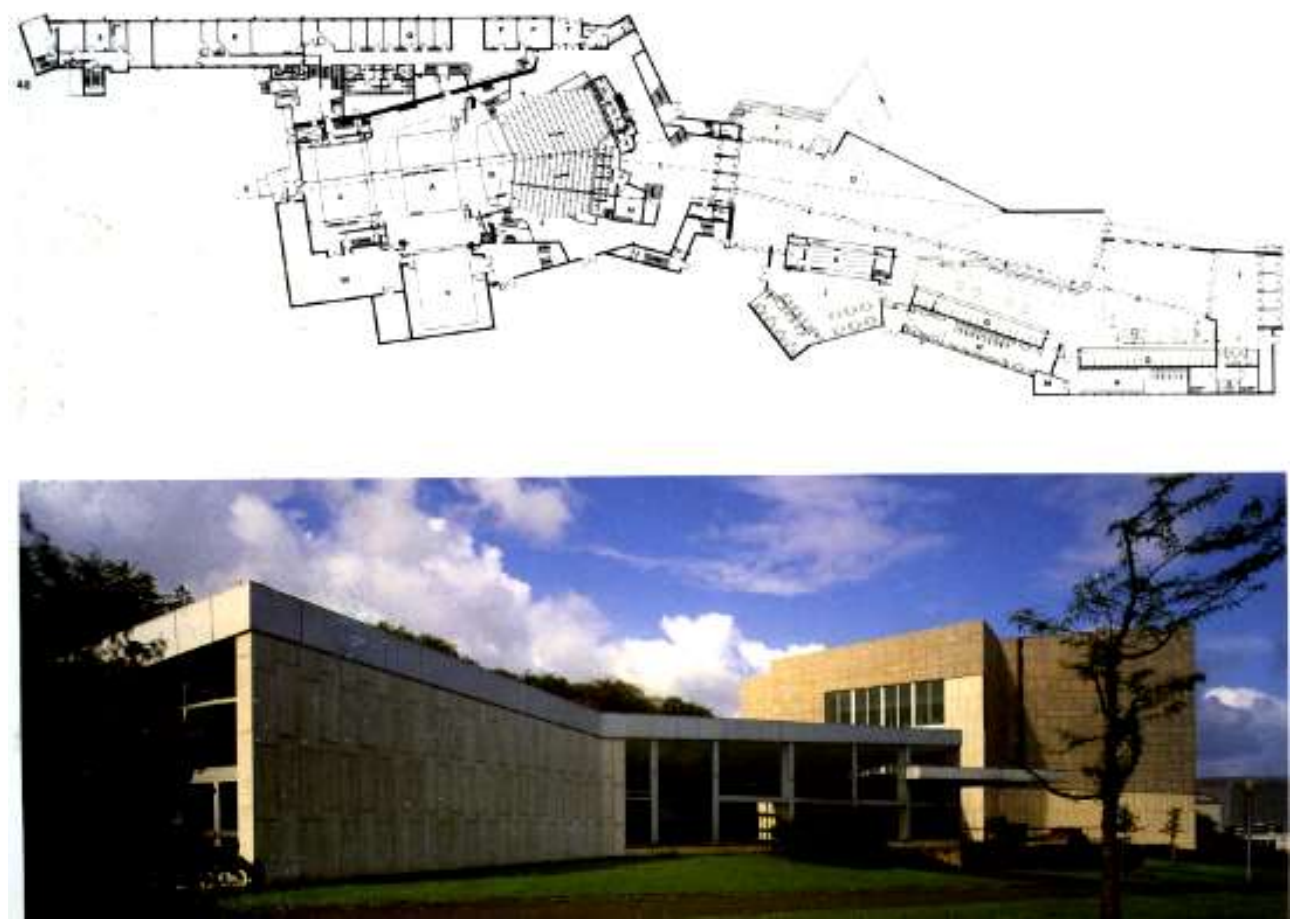

Ilustración 2-23 ${ }^{91}$

\footnotetext{
${ }^{90}$ Hugo Häring: House projects, 1941-46

${ }^{91}$ Hans Scharoun. Teatro en Wolfsburg.1969
} 
El Movimiento Moderno, rechazo el organicismo, la arquitectura de los Aalto, Scharoun y Haring principalmente porque era contraria a la arquitectura tipo que se realizaba con la técnicas de producción de la epoca, generando una arquitectura que producida "en masa" pudiera colonizar todo el planeta ${ }^{92}$. Pero las consecuencias nefastas de este proceder se comenzaron a detectar en los años 1970s, pues el rechazo general al Estilo Internacional trajo consigo el Posmodernismo que defendía volver al orden y retornar al Clasicismo, siguiendo ignorando con ello el Organicismo. Hasta que llegaron los años 1980s, en los que muchos se mostraron contrarios a los dictados del Posmodernismo y el Organicismo fue redescubierto por una joven generación de arquitectos, que no buscaban solo un estilo organicista sino que descubrieron que sus principios que dictaminaban que la arquitectura no solo debía ser una respuesta conducida por la técnica, sino sobre todo por su especificidad ligada al genius loci del lugar. Miralles no fue el único, sino que coincidió con un grupo de jóvenes arquitectos como Bolles Wilson, la New Graz Architecture, etc. que continuaron el organicismo, demostrando con sus edificios la importancia dada al lugar, a su especificad impensable en otros lugares, al entendimiento de la historia pero captando la esencia y no quedando atrapada por ella estilísticamente y el empleo de los avances de la tecnología pero subordinados a materializar la idea arquitectónica.

En 1978 Peter Eisenman realiza la propuesta para el Cannaregio en Venecia, siendo la primera en la que el paisaje aparece como un elemento significativo en el proceso de diseño de sus proyectos. En su ensayo "The end of the classical, the end of the beginning, the end of the end" pone de manifiesto la búsqueda de una nueva arquitectura que no tenga origen ni final, eludiendo el mito de la historia; que no tenga significado, escapando del mito de la representación; y que sea arbitraria, esquivando el mito de la razón.

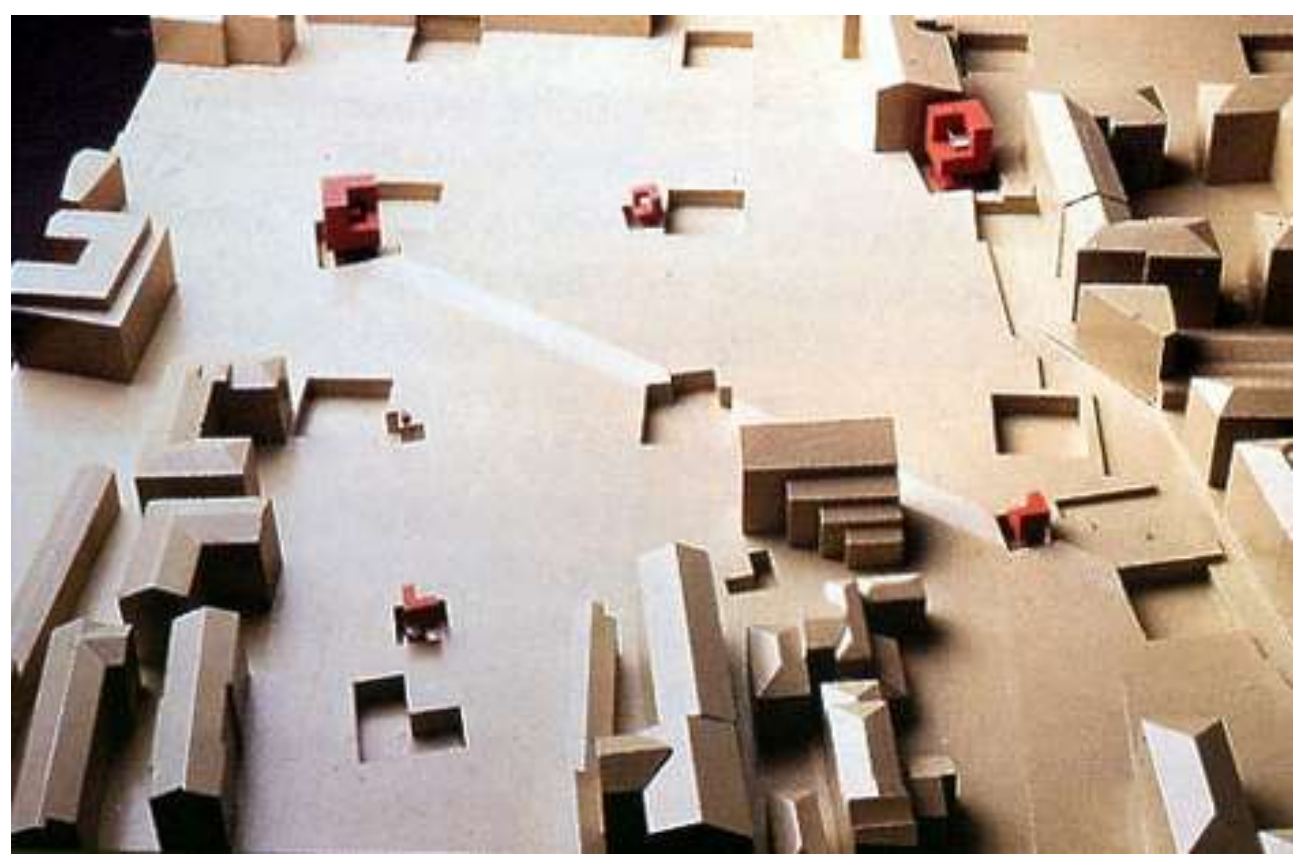

Ilustración 2-24 ${ }^{93}$

\footnotetext{
${ }^{92}$ Lo que perseguia el denominado Estilo Internacional.

${ }^{93}$ Peter Eisenman. Propuesta para el Cannaregio en Venecia. 1978
} 
Enmarcados dentro del grupo Ciudades de la Arqueología Ficticia (1978-1988) aparecen proyectos como el Cannaregio o las viviendas de la Koch/Friedrichstrasse en Berlín. En estos proyectos se trata la ciudad como un palimpsesto y se entiende la arquitectura como una manifestación de las múltiples inscripciones históricas del lugar. Las nuevas fuentes de inspiración de Eisenman serán los textos de pensadores como: Foucault, Lacan, Deleuze y Derrida. Eisenman expone estrategias para crear una arquitectura no clásica, una arquitectura artificial, y como metáfora para explicarlo se sirve del concepto de injerto. En las Ciudades de la Arqueología Ficticia el elemento generador de la obra ya no es la forma genérica sino el injerto; un elemento ficticio de origen artificial, impuesto o traído de la historia del lugar.

Peter Eisenman califica su proyecto de la Koch-Friedrichstrasse como el lugar de la anti-memoria. El proceso de generación del proyecto se basa en el registro, acumulación y manipulación de los datos del lugar, lo que Eisenman denomina "rastrear índices". Adoptando el término que Rosalind Kauss acuñó para definir el arte americano de los 70s, un índice será entendido como una marca física, traza, huella $o$ indicio. Las relaciones que se obtienen entre los diferentes índices generan resultados artificiales e inesperados y a través de su reinterpretación se acomete el proceso de proyecto. Esta estrategia se convierte en crucial en las propuestas que, desde Venecia, se sucederán durante los siguientes once años.... En Cannaregio, Eisenman adopta la retícula del hospital de Venecia de Le Corbusier, proyectado pero no construido, y la manipula con distorsiones. El resultado se caracteriza por una serie de vacíos en los nodos de la retícula, con la intención de mostrar la potencialidad que tiene lo ausente. ${ }^{94}$

Pero es el proyecto de las viviendas de la Koch-Friedrichstrasse, en Berlín, escenario perfecto para entrelazar historia y realidad. Eisenman genera una retícula ficticia, el Mercator grid, de tres por tres metros, la misma altura que el muro de Berlín. Se recuperan las trazas ausentes de la antigua fortificación del siglo XVIII, las de la muralla del siglo XIX, las cimentaciones de tres edificios existentes en el solar, que a su vez representan la presencia del siglo XX. El último vestigio histórico será la propia traza del muro de Berlín. Se genera una nueva retícula artificial que se extiende en el lugar. Para representar este proceso, Eisenman abandona la representación axonométrica y recurre a la representación bidimensional en planta donde se registran todos los documentos seleccionados, históricos o artificiales, y se generan un conjunto de capas superpuestas o índices que serán el motor del proceso de diseño. La obra no será entendida como un volumen a manipular sino como un compendio de capas desde las que operar. La tercera dimensión se obtendrá como una extrusión de ellas. El contexto se estudia para operar con él formalizando una condición inicial ficticia a manipular. La condición histórica del lugar se convierte en el generador de la obra de arquitectura actuando como archivo arqueológico.

Tras el paso por cuestiones de sintaxis en los 1970s, el uso de retículas, superposiciones y cambios de escala en los 1980s, la arquitectura de Peter Eisenman se distingue por el uso de superficies plegadas durante los $90 \mathrm{~s}$.

En 1999, la propuesta para la Ciudad de la Cultura de Santiago el paisaje se convierte en generador. Con la intención de superar el entendimiento del espacio como relación geométrica entre figura y fondo, la Ciudad de la Cultura se genera como una gran topografía artificial. En este proyecto se recuperan operaciones formales experimentadas en las ciudades de la arqueología ficticia, a través de la superposición y manipulación de una retícula impuesta a la topografía del lugar y a la trama medieval de la ciudad. De esta operación resultan una serie de índices

\footnotetext{
${ }^{94}$ Vicente Esteban Medina. Tesis Doctoral "Forma y composicion en la arquitectura deconstructivista" ETSAM. UPM. 2003
} 
que definirán el proyecto en planta. La posterior deformación tridimensional de estas capas, mediante técnicas digitales, hará que estos índices sugieran una nueva lectura del lugar. En la Ciudad de la Cultura, trazas y retículas serán combinadas para producir un índice codificado. Este código rompe la relación entre signo y significante dando lugar a una nueva interpretación que, a través de movimientos estratégicos del terreno, reinterpretando el paisaje original, enfatizando su condición táctil y disolviendo la figura con su fondo.

El interés en esos años por el estudio del paisaje como ente físico a manipular se manifiesta en este proyecto. La propuesta es tratada como una gran topografía generadora de espacios interconectados que dan cabida a un programa extenso y diverso. Cada parte del programa se origina como contenedor claramente diferenciado del resto, una biblioteca, un teatro, un archivo, un centro administrativo, un museo y un centro de nuevas tecnologías. Sin embargo, los seis edificios son entendidos como parejas programáticas de manera que la experiencia del visitante en cualquier edificio se vea afectada por las relaciones que se generan con su par.

Es en este proyecto donde el paisaje se convierte en generador de la obra. En ella, se "busca crear una matriz que interconecte un tejido de objetos y espacios con un proceso dinámico de eventos" a través de la materialización de una topografía táctil, que reinterpreta su condición original consiguiendo que paisaje y cultura se reúnan.

Aclara mucho la aportación de Rafael Moneo respecto a lo que Eisenman entiende por contexto: "Contexto para Eisenman no significa reconciliación ... significa el aceptar la presencia del marco físico existente que se convierte en un punto de partida del proceso que da origen a la creación de una obra de arquitectura. El contexto se convierte así en campo magnético que orienta el trabajo, en razón última desde la que se explica una intervención capaz tanto de hacerlo desaparecer como de crear uno nuevo si fuera preciso. Contexto no es, por tanto, un escenario estático y fijo en el que se actúa. El contexto esta en el origen pero nadie garantiza su permanencia. De ahí que Peter Eisenman no preste atención a los aspectos visuales que, para muchos, son los más característicos del contexto. Lo visual, lo ambiental, implicaría un entendimiento del contexto como realidad bien establecida que impediría la interpretación, que eliminaría cualquier posible intervención definitiva sobre el mismo. Para Peter Eisenman contexto es origen y no termino" 95

95 Rafael Moneo. " Inesperadas coincidencias". El Croquis 41, 1989, pag. 56. 

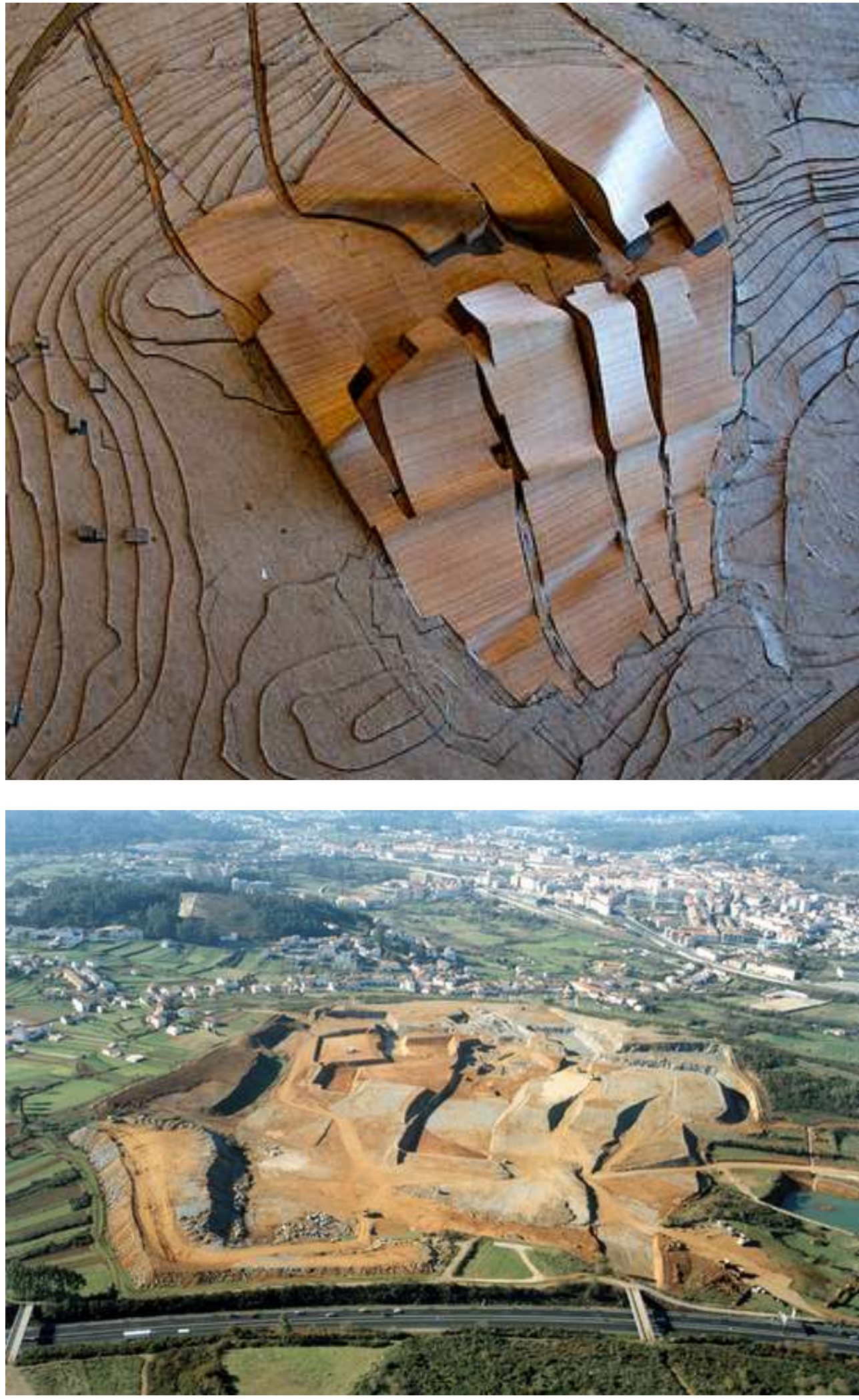

Ilustración 2-25 ${ }^{96}$

${ }^{96}$ Peter Eisenman propuesta para la Ciudad de la Cultura de Santiago de Compostela. 1999 
CONTEXTO 


\title{
2.4. EL PAISAJE EN LA CONTEMPORANEIDAD
}

\begin{abstract}
“...ya no queda nada útil de la madura y estable relación entre arquitectura y paisaje, tan apreciada por Gregotti, construida en el siglo XVIII ... Las nuevas relaciones que se están estableciendo parecen acogerse a un modelo único ... Sera pues, necesario establecer nuevos pactos entre lo natural y lo artificial, que presumo difícilmente generalizables, y que dependerán de cada lugar y situación determinadas. Si, el 'Genius Loci' quizás nos podrá ayudar. Pero ante nuestros prepotentes medios ... los genios del lugar son irreconocibles o demasiado pequeños o no se encuentran ya entre nosotros ... pronto, no habrá más genios en el lugar que los que nosotros acordemos inventar."
\end{abstract}

Eduard Bru. ${ }^{97}$

Eduard Bru, sostiene que hay tres maneras en las que la arquitectura se relaciona con el lugar: ${ }^{98}$

1. A la manera como lo hacen los arquitectos contextualistas que se contagian de lo que les rodea; siguiendo la línea ortodoxa, las preexistencias ambientales.

2. Haciendo "estallar" su arquitectura en el lugar, al asumir sus autores que la tensión entre incertidumbre y cambio hace imposible cualquier estabilidad. Es una arquitectura que celebra esa tensión e inestabilidad. Para los arquitectos que practican esta manera de hacer, lo construido es algo en formación o en disolución, que intenta relacionarse con el lugar según la aproximación abstracta al acometer el proyecto. ${ }^{99}$

3. Los que se enrocan frente al lugar. Para estos arquitectos, el objetivo del proyecto es mostrar la extrañeza que existe entre la objetualidad de lo construido y el carácter del lugar, generando objetos elementales que se deforman por la influencia del lugar. ${ }^{100}$

Xavier Costa, sostiene que el término "periferia" es muy importante en el discurso arquitectónico de los últimos años, y remite tanto al topos de la ciudad marginal como al reconocimiento de la ciudad plural y cambiante. El ámbito de la periferia es el límite donde la ciudad comienza a dejar de serlo para convertirse en territorio, paisaje. Pero en ese lugar periférico también se encuentra el "genius loci", el carácter mercurial y fundacional, y por tanto el arquitecto puede abordar todavía el proyecto con las herramientas tradicionales del arquitecto, ya que el significado del lugar permanece intacto en el sentido antropológico e histórico. Pero el arquitecto contemporáneo ya no podrá actuar así, al intervenir en los "no lugares".

\footnotetext{
97 "Los genios del lugar no se encuentran ya entre nosotros". Quaderns 186, pag. 51.

${ }^{98}$ Ibidem

99 La arquitectura de Miralles, se encuadraría dentro de este grupo.

${ }^{100}$ La arquitectura de Viaplana y Piñón,y tambien la de Miralles participan de esta tendencia.
} 


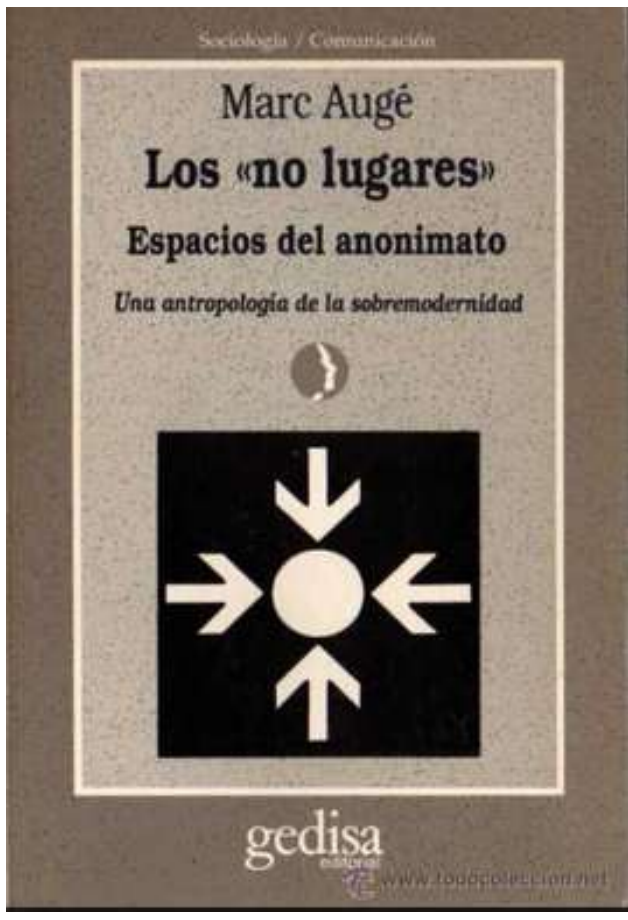

Ilustración 2-26 ${ }^{101}$

El antropólogo francés Marc Augé define el "no lugar" como el producto espacial de la condición contemporánea en la que el exceso de acontecimientos, de información, de espacio, genera un exceso de relaciones espaciales determinadas por los nuevos medios de transporte rápido, los cambios de escala, la multiplicación de imágenes referenciales, etc. El "no lugar", carece de memoria y no se relaciona con los otros lugares existentes. Según Augé, la relación con los "no lugares" tiende a ser inocente, primaria, alejada de las cualidades de la memoria y el ritual que impregnan los lugares per se.

Las cualidades de estos espacios, no pueden desvincularse del exceso de información ni del nuevo sujeto, al que hay que saber entender e interpretar desde las pulsiones del inconsciente que gobierna su relación visual y corporal con los "no lugares" más que desde modelos de dinámica y orden social propios del lugar público o ágora. Josep Lluis Mateo, relaciona los "no lugares" con las "fuerzas inmateriales" y los elementos intangibles que se resisten a ser intervenidos con las herramientas del proyecto moderno y la tectónica. A los arquitectos les costó mucho entender que no podían intervenir con los mismos instrumentos proyectuales con los que lo hacían en los lugares "per se", y aplicarlos en los "no lugares", donde no existen cualidades como la identidad, la historia y la relación. El reto de los "no lugares" que anónimamente se multiplican invadiendo el entorno, es el de exigir una aproximación arquitectónica diferente, una refundación topológica, en la que el objeto arquitectónico autónomo está amenazado por unas condiciones y fuerzas ambientales cada vez mas inmateriales y efímeras.

Con la aparición del sujeto moderno en el siglo XVIII desaparece la Naturaleza como modelo perfecto a imitar por la Arquitectura ( algo que había pervivido hasta

\footnotetext{
${ }^{101}$ MARC AUGÉ - LOS NO LUGARES - GEDISA EDITORIAL - 1996
} 
entonces a lo largo de los siglos) y aparece un concepto nuevo, dinámico, en continua evolución que es el paisaje. Noción que cambiara la manera de pensar la relación entre Arquitectura y Naturaleza.

Benedetto Croce, a comienzos del siglo XX, mantenía que la Naturaleza es bella para quien la contempla con ojos de artista. Para quien reflexiona sobre la naturaleza de lo construido, los elementos que el hombre dispone en la Naturaleza y la manera de hacerlo, hay dos formas de observación privilegiadas, el refugio y el camino, es decir quién habitando un lugar desde el interior de la morada observa el horizonte lejano, los fenómenos de la Naturaleza y quien en el exterior observa ese paisaje natural o construido. A finales de los años 20 del siglo $\mathrm{XX}$, al funcionalismo "maquinista" arquitectónico se le opuso otro denominado "organicista", basado en un funcionalismo biológico que explicaba las formas como consecuencia natural de las estructuras de la Naturaleza. Surge un cambio visual y perceptivo de la figurafondo, definiéndose el vacio como figura, atribuyéndole un valor positivo, concreto y fáctico en la configuración de la arquitectura.

En las arquitecturas de Frank Lloyd Wright y de Hans Scharoun aparecerá la centralidad de la experiencia del espacio cóncavo como lugar vital para el sujeto, mientras que en las de Le Corbusier utilizara su promenade architecturale como lugar de paso físico-simbolico entre la imagen enmarcada del paisaje como fondo y su actualización como figura en la terraza-jardin. Las Prairie Houses de Wright no imitan el escenario de la pradera sino que interpretan la condición de su horizontalidad, obedecen a un proceso de aplastamiento pero no para reducir su presencia sino para exaltar un haz de líneas paralelas, cercanas a la tierra y orientadas de una determinada manera.

Javier Maderuelo sostiene que la modernidad abandonó el paisaje, porque este carecía de limites concretos, al ser una de las tareas de la modernidad el representar objetos abarcables. Kenneth Frampton llega a detectar en la obra de los pioneros del Movimiento Moderno distintos acercamientos indirectos al tema del paisaje. En su ensayo In Search of the Modern Landscape (1991) Frampton recorre algunos textos de la modernidad arquitectónica analizando las modalidades de transformación de la Naturaleza, entendida ya como paisaje, redescubriendo con ello, la raíz moderna del tema del paisaje como material de proyecto. Frampton señala a Le Corbusier y Mies van der Rohe como los artífices de un acercamiento moderno al paisaje. Le Corbusier demostrando su atención al evocador poder del paisaje y a la manipulación de su relación con el hombre mediante la promenade architecturale. Mies, reclamando la arquitectura clásica y el uso de una estética desmaterializada en la cual lo natural y artificial se fundan. Uno de estos acercamientos está ligado a la reelaboración de la arquitectura griega, concebida en relación a la inmensidad y lo absoluto del espacio y el tiempo.

La teoría de la relatividad de Einstein modifico la noción moderna de espacio, asociándola inseparablemente al tiempo y estableciendo una permanente mutabilidad del mundo físico entre los parámetros espacio temporales. Ello trajo consigo un replanteamiento de las ciencias físicas, biológicas y psicológicas que fue paralela a los escritos tanto filosóficos como de otras disciplinas en los que se plantea la idea de un nuevo tipo de imitación diferente a la premoderna. En este contexto, el paisaje aparece como un espacio susceptible de ser manipulado y en determinados casos es tomado como modelo.

El termino paisaje aparece en el siglo XVII, pero era algo especifico de la pintura o la literatura. Serán los maestros del movimiento moderno los que a través de su manera de mirar el paisaje abrirán el camino para que los arquitectos incorporen el 
paisaje como material de proyecto a mediados del siglo XX. En el siglo XX el objeto y el sujeto se encuentran inmersos en un mundo caracterizado por la complejidad, la interacción, la interferencia, etc. El espacio paso de ser absoluto a relativo; los lugares pasaron de ser neutros a cualificados, lo singular participa de lo universal y viceversa. Cualquier sistema no puede estar fundado sin la referencia a otro exterior a éste, es decir que cualquier sistema es relativo. El termino paisaje en su complejo, ambivalente y creciente significado mantiene una estrecha ligazón entre el mundo real y su representación. En el paisaje de hoy, se pueden reconocer los límites entre el mundo físico y el fenomenológico que la visión moderna había separado. La separación entre objeto y sujeto se ha superado, entendiéndose mejor la unidad de la realidad.

Con el objetivo de superar la crisis del pensamiento de la Modernidad, pensadores como Jung, Bergson, Schiller, Adorno, etc. plantearan nuevas formas de pensar fuera del paradigma lingüístico y cuyo pensamiento servirá de base para una posterior teorización de una nueva clase de imitación. Tras la crisis de la Modernidad cambia la acción misma de imitar. La imitación de un modelo en la contemporaneidad no supondrá ceder a deseos irreflexivos sino que abre al sujeto la posibilidad de acceder a la forma de racionalidad y universalidad que el modelo presenta, siguiendo la inclinación del deseo. En la nueva clase de imitación, cada uno de los elementos de su estructura conserva su autonomía, individualidad y libertad. Lo que ahora se ofrece para la imitación es el ser del prototipo, que se elige en función de una decisión racional. El proceso de armonización ArquitecturaNaturaleza es ahora racional, interpretativo y analítico de la realidad y se produce en una doble dirección. Sin investigar para entender el modelo, la conducta del imitador se convierte en irracional, premoderna, en el "ars simia naturae" que lanzo Alberti como reproche en el Renacimiento.

La imagen del territorio como palimpsesto remite a una visión fragmentaria, discontinua, incompleta, a un proceso en continua reescritura y por tanto a la construcción continua de ese paisaje por el hombre. El territorio contemporáneo se presenta como una pluralidad fragmentada, que aparece sin proyecto, caótico, caracterizado por una multiplicación de signos, lenguajes, códigos. Sin embargo, a través de la mirada al paisaje se puede aprehender la novedad de los procesos recientes, sin traicionar los nexos entre cultura y ambiente; espacio y sociedad. El paisaje se indaga también a través de la geografía, la pintura, la escultura, el cine, la fotografía, etc. La acumulación de conocimientos, lecturas, la construcción de aparatos interpretativos complejos y las hipótesis desplegadas en distintas investigaciones, caracterizan la fortuna del tema del paisaje en Europa. Este encuentro con la dispersión es el difícil trabajo de comprensión que los nuevos paisajes imponen, con sus heterogéneos y múltiples significados.

Por primera vez, la respuesta de una nueva generación de arquitectos de la arquitectura contemporánea, como Enric Miralles, Steven Holl, Peter Zumthor, Herzog \& de Meuron, Zaha Hadid, demuestran una disponibilidad a utilizar figuras de la tradición, el paisaje, la naturaleza artificial, los iconos de vanguardia, para construir una identidad propia en un mundo globalizado.

Uno de los pensadores que ha considerado el paisaje de singular importancia en la arquitectura contemporánea es el arquitecto Iñaki Abalos quien afirma en la Introducción su libro Naturaleza y artificio. El ideal pintoresco en la arquitectura y el paisajismo contemporáneos (2009) que el ideal pintoresco sigue vigente hoy día y destaca como la estética de los primeros autores pintorescos ha revivido gracias a los nuevos valores culturales e instrumentos de diseño en el mundo contemporáneo, y lo describe en los siguientes términos: "...desde el punto de vista 
teórico se han esbozado posiciones arquitectónicas a partir de postulados ecológicos, bioclimáticos o paisajísticos...muestran hasta qué punto la imitación de la naturaleza y de las actuales visiones científicas de la misma sirven como inspiración a un modelo estético y técnico hibrido que busca la disolución de la dicotomía naturaleza/artificio, amparado en las tecnologías digitales para la construcción de sistemas análogos a los de la vida orgánica...Leyendo simultáneamente escritos que desarrollaban alguna de estas teorías contemporáneas y el bellísimo texto escrito entre 1790 y 1810 por Uvedale Price 'Three essays on the picturesque' fue como visualicé este retorno del paradigma pintoresco a la escena cultural arquitectónica y paisajística...De hecho, al documentar y escribir los dos volúmenes del 'Atlas Pintoresco' fui descubriendo que esta idea, la de la ligazón entre la estética pintoresca y la contemporánea, había dado lugar a textos memorables de autores cuyo prestigio no solo reforzaba, sino que ampliaba y contextualizaba esta primera intuición". ${ }^{102}$

Según Iñaki Abalos, la crisis energética de 1973, marca el declive de la metas de la modernidad y el auge de una nueva sensibilidad medioambiental que afectando a la vida cotidiana, la política, la economía y la cultura ha modificado la percepción del entorno. El año 1973, es señalado por muchos autores como el del advenimiento de una condición "contemporánea", en la que uno de los asuntos clave de las practicas artísticas y arquitectónicas, será el cuestionamiento de la relación dialéctica heredada de la modernidad entre naturaleza y artificio. Tan es así, que los intereses de muchas creaciones contemporáneas se explican mejor en los textos de aquellos autores pintorescos del siglo XVIII que en la tratadística moderna (defendido por primera vez por Robert Smithson en 1970).

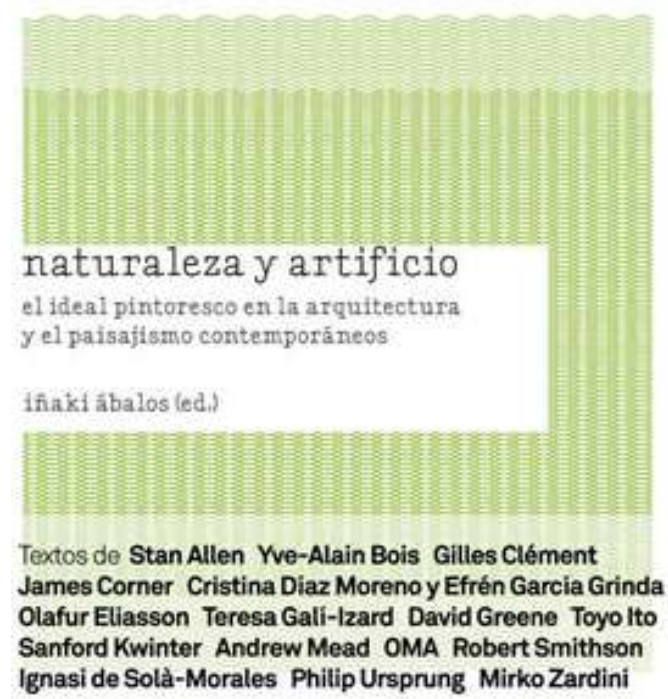

GG'

Ilustración 2-27 ${ }^{103}$

\footnotetext{
102 Iñaki Abalos. "Naturaleza y artificio. El ideal pintoresco en la arquitectura y el paisajismo contemporaneos". GG. 2009, pag. 9.

103 Iñaki Abalos. "Naturaleza y artificio. El ideal pintoresco en la arquitectura y el paisajismo contemporaneos". GG. 2009
} 
El prestigio creciente del paisajismo como disciplina creativa es un hecho medible en la difusión que tiene esta disciplina en los medios profesionales de los arquitectos. Los artistas y arquitectos se inspiran cada vez más en la nueva materialidad natural (materiales constructivos naturales, cubiertas ecológicas, fachadas verdes...) y en los fenómenos atmosféricos: viento, nubes, agua, moléculas, flujos .. Como ejemplo valga en la obra del artista Olafur Eliasson. La escasez de la energía y el considerable aumento de su coste económico, ha generado una preocupación por la reducción de su consumo y con ello la reducción de los nocivos gases de efecto invernadero. Por tanto la energía se ha convertido en un nuevo material que el arquitecto cada vez mas estima en sus proyectos, y ha provocado un cambio en sus técnicas proyectuales y cuestionando los parámetros materiales y técnicos del confort moderno. Todo ello según Iñaki Abalos ha generado un "paradigma termodinámico" frente al "paradigma mecánico" característico de la modernidad. Iñaki Abalos afirmo en la Conferencia dada en 2014 en la Fundació Enric Miralles de Barcelona que admiraba de Enric Miralles la importancia que desde sus inicios daba al clima, las sombras y las técnicas naturales de acondicionamiento: "Santa Maria del Mar, el Umbráculo... que se que a Enric le encantaban... la posibilidad de utilizar forma y materia, naturaleza y abstracción...donde todos los ingredientes están al servicio de las especies vegetales a conservar, al hombre...estas arquitecturas que están en el límite entre lo natural y lo artificial...los umbráculos o invernaderos en los que acondicionar especies vegetales que no podrían sobrevivir fuera del invernadero..."104 Enric Miralles en cierto sentido se adelanto al pensamiento de Stan Allen sobre la arquitectura como campo.

Ramón Faura lo expresa en los siguientes términos: "...sigamos con la ciencia ficción: septiembre de 1991, la revista El Croquis publica un monográfico sobre la obra de Enric Miralles y Carme Pinós. Proponíamos ojearlo como si nada supiéramos de la posterior carrera ascendente de Enric Mlralles;... sin saber nada del efecto Guggenheim en Bilbao; sin haber leído ningún texto de Stan Allen sobre la arquitectura como campo... la proliferación de geometrías extrañas tanteadas desde el ordenador..." 105
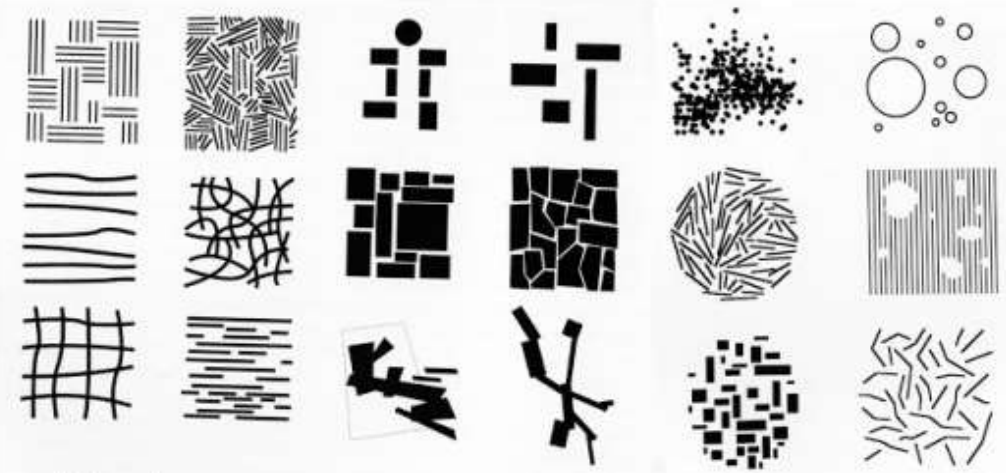

llustración 2-28 ${ }^{106}$

\footnotetext{
104 Iñaki Abalos. "Conversaciones con Enric Miralles". Conferencia en Fundación Enric Miralles. 28 /11/2014. Barcelona

${ }^{105}$ Ramon Faura. Enric Miralles 1972-2000 arquia/temas 33, 2011

${ }^{106}$ Allen, Stan, From object to field: field conditions in architecture and urbanism, publicado en AD Vol. 67, Mayo-Junio 1997
} 
Stan Allen nos habla de las "condiciones de campo" en "From object to field: Field conditions in architecture and urbanism" ${ }^{107}$ Las condiciones de campo ${ }^{108}$, aceptan el desorden y la incertidumbre de la realidad. Los arquitectos que trabajan con el lugar registran su complejidad e improvisan en el emplazamiento, produciendo algo nuevo. La repercusión de las condiciones de campo en arquitectura implica asumir los comportamientos complejos y dinámicos de los usuarios de la arquitectura. Las configuraciones de campo son conjuntos unidos de manera flexible caracterizados por su conectividad interna. La forma tiene menos importancia que la relación interna entre las partes.

Las condiciones de campo son relacionales y se basan en el intervalo y la medida, haciendo visibles las fuerzas abstractas. Por ejemplo, una lamina de limaduras de hierro expuesta a un campo magnético registrara los patrones de dicho campo magnético, pero las limaduras de hierro son solo el registro grafico de las fuerzas invisibles del campo. Según Stan Allen: "...una atención a las condiciones de campo puede implicar tácticas más flexibles para acomodar topografías existentes en el lugar...las logísticas de campo...trabajan a favor del lugar registrando y aceptando la complejidad de los datos existentes." 109

En la arquitectura clásica, sus elementos se organizaban en conjuntos coherentes mediante sistemas geométricos de proporción, buscando sobretodo relaciones geométricas. Las partes formaban conjuntos, pero cada elemento individual mantenía su orden jerárquico por medio de relaciones geométricas cuyo fin era preservar la unidad global. La geometría era el andamiaje que controlaba la distribución de las partes. La mezquita de Córdoba, fundada en el siglo VIII, es un espacio no direccional, un orden seriado en el que una cosa viene después de la otra. A pesar de que fue ampliada en cuatro fases cada ampliación mantuvo la estructura original intacta permaneciendo fijas las relaciones internas. En la mezquita se combinan de manera aditiva elementos independientes hasta formar un conjunto indeterminado. Las relaciones entre las partes son idénticas tanto en la primera versión construida como en la última. En la mezquita existen dos principios de combinación. uno algebraico, que funciona con unidades numéricas combinadas y otro geométrico, que funciona con líneas, planos y sólidos organizadas en el espacio conformando conjuntos mayores. ${ }^{110}$

En la mezquita de Córdoba, sus proyectistas no prestaron demasiada importancia a la forma exterior pues sabían que vendría determinada por el tamaño y las restricciones del lugar, pero si prestaron mucha atención a la dimensión y el intervalo de sus elementos individuales constituyentes. Frente a la arquitectura clásica occidental, en la mezquita es posible hacer añadidos a la estructura sin que se transforme su morfología. Cada ampliación replica y conserva la anterior. Es en

\footnotetext{
107 Practice: Architecture, tecnique + representation, Routledge, Nueva York, 2009, pags 216-243,

${ }^{108}$ Campo, como 'cruce de fuerzas', referida al lugar sugiere una condicion abierta y abstracta flexible y reactiva del proyecto contemporaneo en relacion con el medio. Manuel Gausa. Diccionario METAPOLIS de Arquitectura Avanzada. pag. 96

${ }^{109}$ Stan Allen. "Distribuciones, combinaciones, campos". BAU 014. 1996.

${ }^{110}$ el termino 'algebra' procede del arabe al-jebr "la reunion de las partes fragmentadas". Es la rama de las matematicas que utiliza numeros positivos y negativos, letras y otros simbolos para expresar y analizar la relacion entre conceptos de cantidad segun formulas, ecuaciones, etc.
}

el termino 'geometria' procede del griego. Es la rama de las matematicas que trata con puntos, lineas, planos y solidos, examinando sus propiedades, dimensiones y relaciones mutuas en el espacio. 
las relaciones matemáticas entre las partes donde está prevista esa posibilidad de crecimiento. Incluso cuando la mezquita se consagro como iglesia cristiana insertándose la catedral gótica en esa estructura continua e indiferenciada, el orden espacial resistió el recentramiento. La integridad de la mezquita a pesar de tantas modificaciones, se debe al ajustado entrelazamiento de una parte con otra, a la precisión de los propios elementos: columna, arco, lucernario, y al intervalo que estructura las relaciones entre estos elementos. Algo muy distinto ocurre por ejemplo en San Pedro del Vaticano en Roma, donde sus ampliaciones generan transformaciones morfológicas que amplían un esquema geométrico básico.

El Hospital de Venecia de Le Corbusier tiene una sintaxis en planta con piezas repetidas que establecen múltiples vínculos con el tejido urbano próximo. La pieza básica del programa, la "unidad de cuidados" de 28 camas se repite continuamente. Su desarrollo horizontal se realiza siguiendo una lógica de acumulación. No existe un centro único, ni un esquema geométrico unificador. La forma global responde a las condiciones que se establecen localmente. En referencia al edificio-alfombra Alison Smithson se refiere en los siguientes términos: "Puede decirse que el edificio-alfombra epistomiza lo colectivo anónimo; donde las funciones vienen a enriquecer el tejido y lo individual gana nuevas libertades de acción a través de un orden nuevo y reorganizado basado en la interconexión, en patrones de asociación fuertemente tejidos y las posibilidades de crecimiento, disminución y cambio" ${ }^{111}$

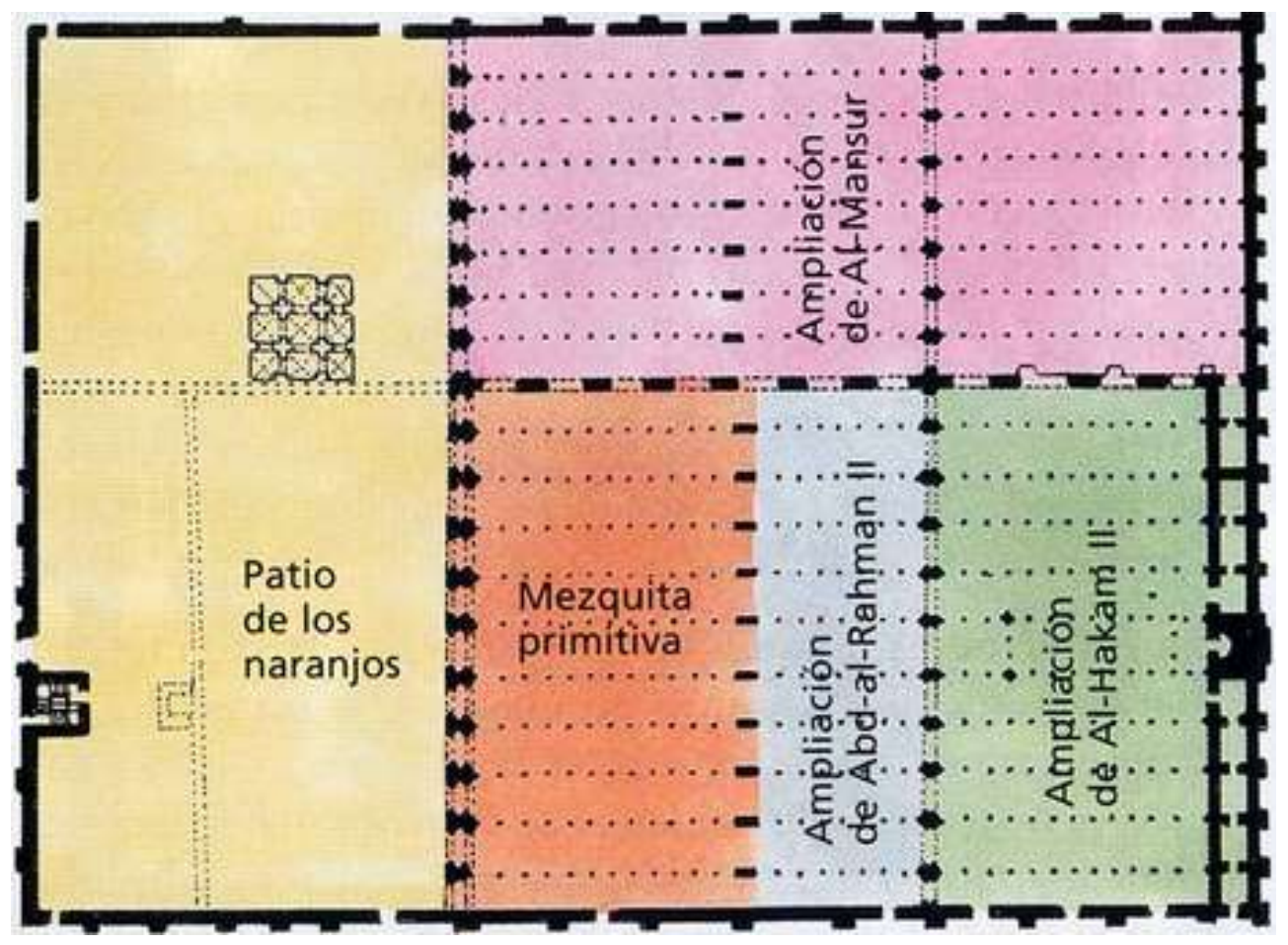

Ilustración 2-29112

\footnotetext{
${ }^{111}$ Alison Smithson. "How to recognise and read mat-building". Architectural Design, XLIV, 9, 1974 pags. $573-590$

${ }^{112}$ Planta de la Mezquita de Cordoba con sus respectivas ampliaciones a lo largo de la Historia.
} 


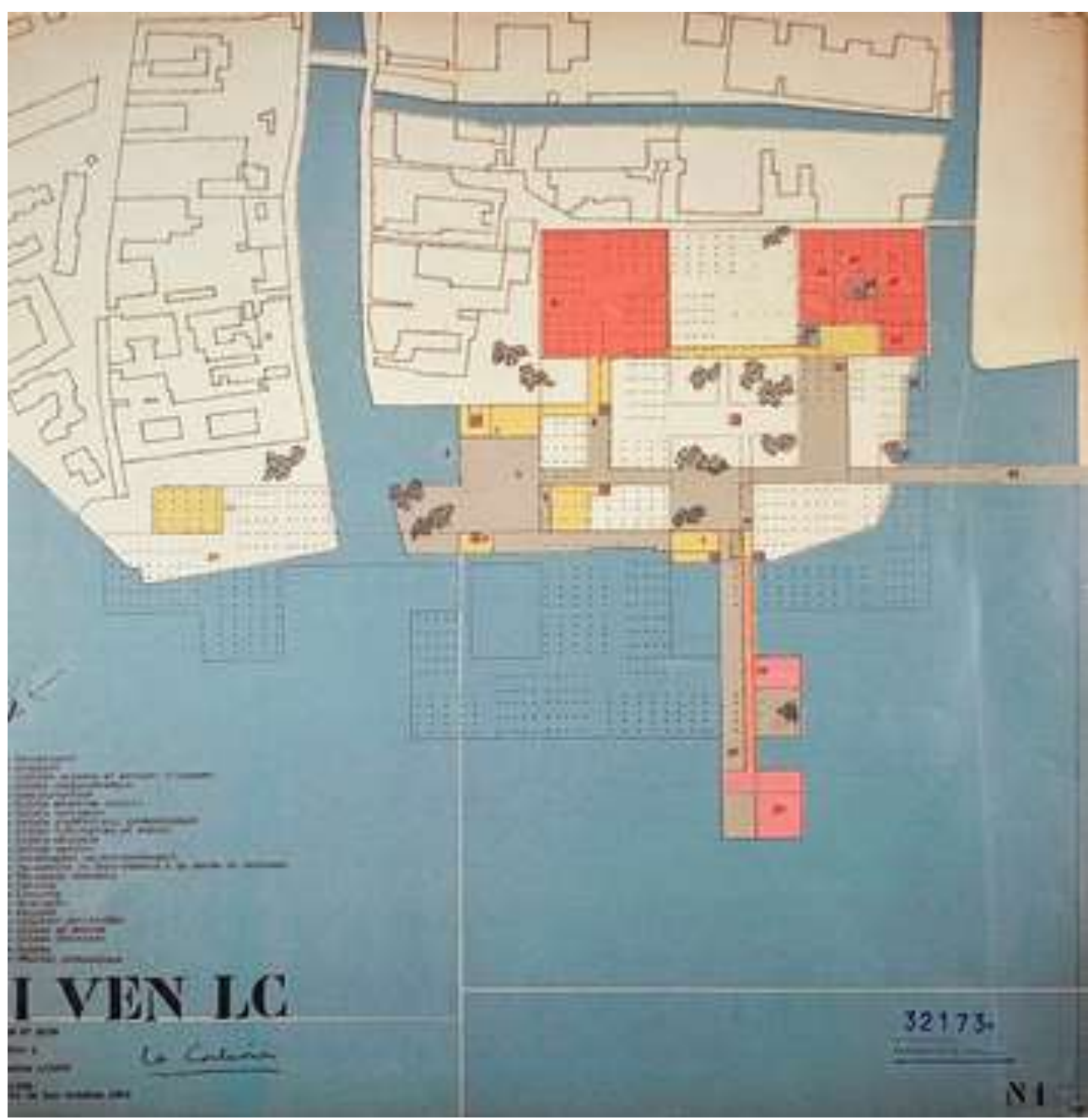

Ilustración 2-30 ${ }^{113}$

La pintura y escultura estadounidense de posguerra intento ir mas allá de los límites de la sintaxis compositiva cubista, desconfiando de la composición y encontrando nuevas estrategias de trabajo basadas en el proceso, lo que dio lugar a la aparición del minimalismo a mediados de la década de 1960. La obra minimalista de las décadas de 1960 y 1970 ensalzo la condición arquitectónica de la obra de arte, frente al carácter figurativo.

Tras el minimalismo llego el posminimalismo que se caracterizo por la vacilación y la duda ontológica allí donde los minimalistas eran definitivos, por lo pictórico e informal, por su compromiso con las cosas tangibles, Desde las construcciones con alambre de Alan Saret, hasta los non-sites de Robert Smithson introducen el azar en la obra de arte. Las relaciones locales son más importantes que la forma global. El tiempo y el proceso se erigen como variables fundamentales en la factura de la obra. Se pasa del control a unas reglas internas de combinación. Al trabajar con materiales como telas metálicas (Alan Saret) o harina esparcida (Barry Le Va) el artista no puede ya controlar formalmente el material, tan solo marca las condiciones en las que se desplegara el material y luego ordenara sus flujos. 
La bandada de pajaros, es un fenómeno de campo definido por condiciones internas simples y es indiferente a la forma global. Al definirse las reglas internamente, las obstrucciones del entorno no suponen problema para el conjunto que se adapta a este fluidamente. Las condiciones de campo ofrecen a la arquitectura un terreno de pruebas donde poder tratar las dinámicas de uso, las pautas de comportamiento de las multitudes y la compleja geometría de las masas en movimiento. Las condiciones de campo combaten los métodos compositivos del movimiento moderno, de la misma manera que el movimiento moderno combatía las reglas clásicas de la composición.

En un artículo reciente escrito por Stan Allen ${ }^{114}$ se afirma que en las dos últimas décadas la metáfora biológica ha sido la dominante en el debate arquitectónico, persiguiendo hacer una arquitectura más natural, fluida y sensible a los cambios. En la década de 1990, los arquitectos miraban la arquitectura del paisaje considerándola como un modelo de síntesis productiva entre continuidad formal y flexibilidad programática. Ello coincidió con el potencial de los ordenadores para modelar superficies complejas comunes al paisaje y la arquitectura, que generaron una nueva estética de la fluidez. La arquitectura se disolvía en un campo horizontal de superficies interconectadas. Actualmente ha surgido una tendencia que se inspira en el comportamiento colectivo de los sistemas ecológicos. Los paisajes cambian y evolucionan a lo largo del tiempo. La arquitectura se sitúa entre lo geológico y lo biológico. Los arquitectos crean un nuevo lugar basado en los usos, movimientos, espacios públicos, etc. trabajando con superficies alabeadas y plegadas; pero no utilizando la paleta clásica de la arquitectura del paisaje (la ecología del lugar, el acondicionamiento del suelo, el diseño de espacios públicos y ajardinados...), sino trabajando con las técnicas operativas que proporciona el diseño parametrito y las superficies topográficas continuas. Como ejemplo sirva "La terminal portuaria de Yokohama" de FOA, una obra basada en técnicas paisajísticas, un paisaje construido más que un edificio en el sentido convencional. El límite entre interior y exterior es fluido y permeable; la forma viene dada por los movimientos de los pasajeros, creando un espacio cívico frente al mar.

Iñaki Abalos destaca la aportación de Stan Allen : "Stan Allen con 'Del objeto al campo: condiciones de campo en la arquitectura y el urbanismo' (1999-2008) habla de una condición nueva y convergente...identifica en las condiciones de campo referido tanto al campo físico, al emplazamiento, como a la teoría de campos matemáticos-un nuevo referente estético y creativo de la arquitectura, ejemplar para aproximaciones de carácter procesual al diseño que explotan las posibilidades de los medios informáticos en la consolidación de composiciones hibridas, a medio camino entre un 'mat building' y un paisaje natural" ${ }^{115}$

Philip Ursprung es otro pensador contemporáneo sobre el paisaje con grandes aportaciones en este campo. En su artículo "Double helix and blue planet: the visualization of nature in twentieth century" (en el catalogo de la exposición homónima "Nature design: From inspiration to innovation", Lars Müller Publishers, Baden, 2007) admite que el significado del término "naturaleza" ha cambiado a lo largo del siglo XX al ser consciente el hombre que su actividad en el planeta tierra puede llegar a aniquilarlo. La naturaleza por tanto ya no será algo dado e

\footnotetext{
${ }^{113}$ Proyecto de Le Corbusier para el Hospital de Venecia, de 1964-65

114 "De lo biologico a lo geologico" Arquitectura Viva 166. 2014. pags. 11 a 17,

115 Iñaki Abalos. "Naturaleza y artificio. El ideal pintoresco en la arquitectura y el paisajismo contemporaneos". GG. 2009, pag. 13.
} 
inagotable, sino una proyección de la humanidad, y por tanto puede proyectarse. Existían dos tendencias diferenciadas de relacionar naturaleza y diseño en el periodo que va de 1920 a 1970 . Una de estas dos tendencias defendía que naturaleza y diseño se encontraban inseparablemente entrelazados. Este modo de entender el diseño natural en la década de 1930 se agoto, ya que la naturaleza entendida como imagen o forma, tal como aparece en la figura de motivos florales o en la evocación de las leyes naturales, no podía ya representarse adecuadamente. Además la Gran Depresión económica de $1929{ }^{116}$, afecto a la percepción que se tenía hasta entonces de la naturaleza y el diseño natural. La otra tendencia se basaba en la premisa de que naturaleza y diseño eran complementarios entre si y el diseño podía imitar la naturaleza. Como continuación del diseño de finales del siglo XIX, su postura era comparable a la de Antoni Gaudí o Héctor Guimard quienes se inspiraban y buscaban referencias en las formas organicas que la industrialización había desplazado, y sacaban provecho en sus proyectos de las fuerzas de la naturaleza, imitando o transformando formas especificas de la naturaleza.

En el siglo XX, las figuras más relevantes de esta tendencia, fueron Alvar Aalto, Eero Saarinen y Henry Moore. Estos autores no solo utilizaban formas orgánicas en sus proyectos sino que la manera de emplear los materiales que materializaban sus obras reflejaba la acción de las fuerzas naturales - como la erosión, la gravedad, etc. - sobre estos. Su postura era anti moderna y comparable a la de Antoni Gaudí o Héctor Guimard. Los proyectos de Aalto, tuvieron tanto éxito internacional porque, abarcaban todas las escalas -su obra abarcaba desde proyectar un mueble, hasta un Palacio de Congresos - integrando la escala humana. Las curvas generosas de las esculturas de Henry Moore, insinuaban protección maternal y por ello fueron tan efectivas como adorno de los edificios públicos en la Europa de las décadas de 1960 y 1970, reflejando la visión del estado del bienestar de la posguerra.La arquitectura de Eero Saarinen ${ }^{117}$ evocaba modelos naturales para proyectar una arquitectura monumental con identidad. La terminal de la TWA en el aeropuerto John F. Kennedy (un pájaro a punto de echar a volar), la pista cubierta de hockey Ingalls en la Universidad de Yale (conocida por los alumnos como la ballena de Yale)

En la terminal de la TWA en el aeropuerto Kenedy de Nueva York, de Eero Saarinen todos los espacios, las curvaturas, elementos, barandillas, señaletica y mobiliario tienen el mismo caracter consistente, generando un ambiente en el que cada parte es consecuencia de la otra y todo pertenece al mismo universo formal surgido el empleo de una familia de formas. Lo mismo que hicieron los arquitectos barrocos enfrentados al mismo problema de crear un espacio dinamico.Eero Saarinen veia la arquitectura no solo como un edificio, sino como el edificio en relacion con sus alrededores, ya fuera la naturaleza o el entorno construido por el hombre. Segun Benedetta Tagliabue: "Miralles sentia gran admiracion por la obra de Saarinen" 118

\footnotetext{
${ }^{116}$ Provocada por el crack bursátil que se produjo al perderse el control sobre las fuerzas del mercado.

${ }^{117}$ Cuya obra admiraba Miralles segun un comentario de Benedetta Tagliabue.

${ }^{118}$ EI Croquis EMBT 2009.
} 


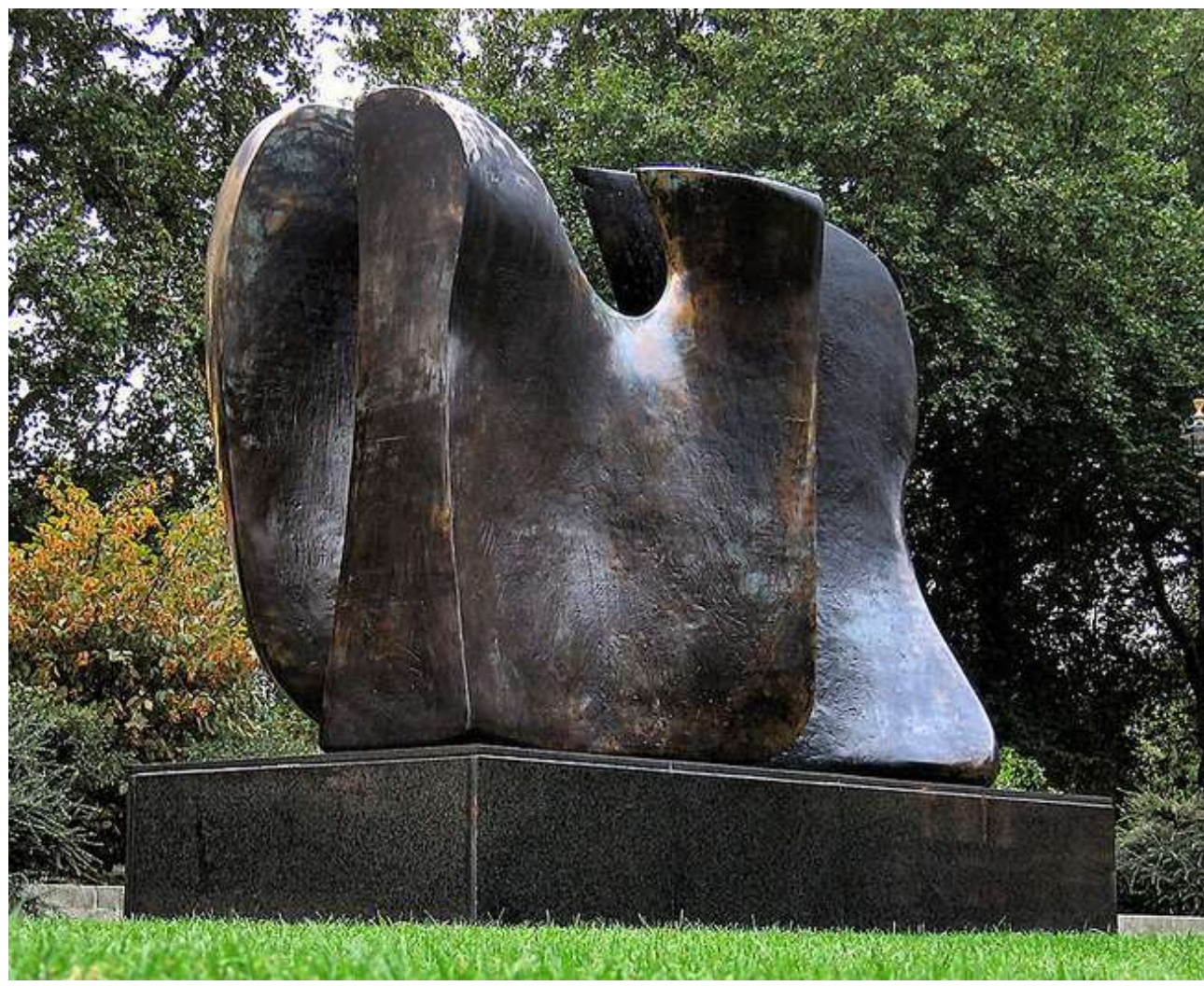

llustración 2-31 ${ }^{119}$

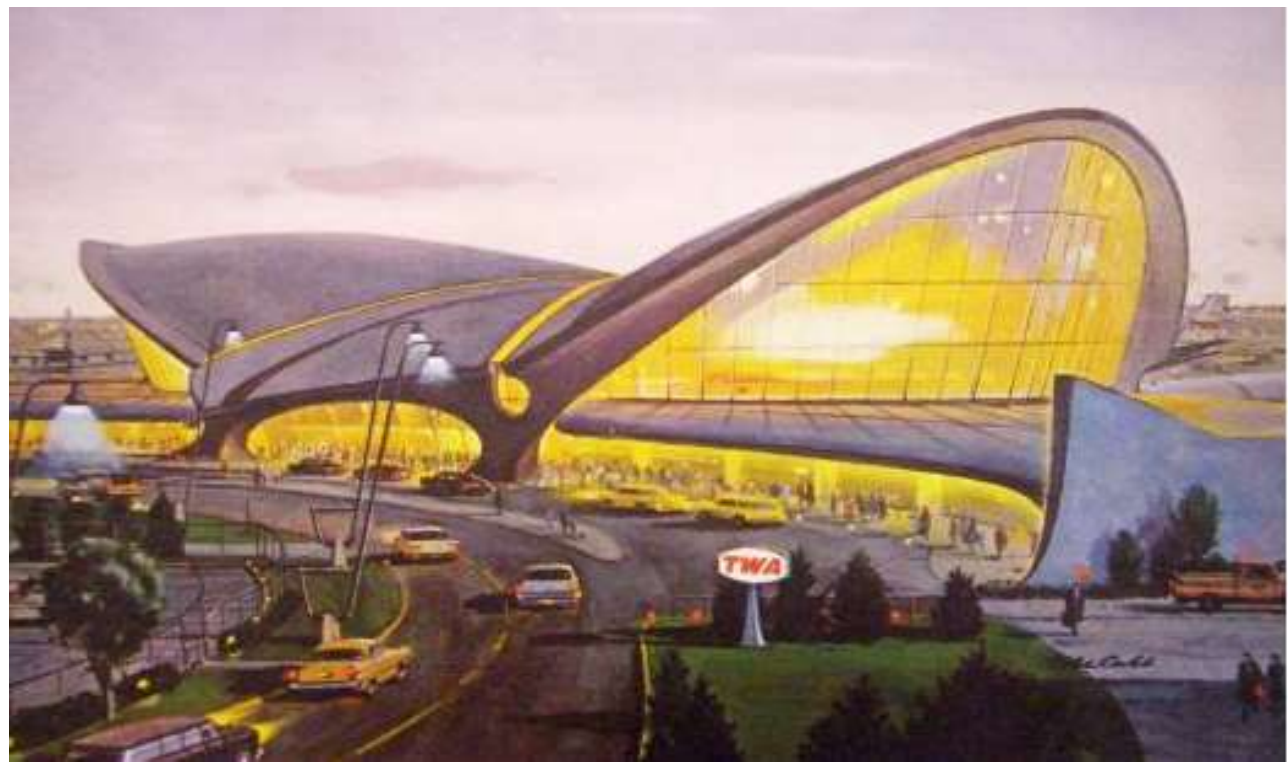

Ilustración 2-32

${ }^{119}$ Hnery Moore. Knife Edge - Two Piece (1962), escultura de bronce, a lado de la Cámara de los Lores. la manera de emplear los materiales que materializaban sus obras reflejaba la accion de las fuerzas naturales.

${ }^{120}$ Terminal de la TWA en el aeropuerto John F. Kennedy. Nueva York. 1962. La arquitectura de Eero Saarinen (a quien Enric admiraba) evocaba modelos naturales para proyectar una arquitectura monumental con identidad. 
Desde la perspectiva de estos autores, la naturaleza está diseñada en la medida en que el diseño es natural. El plan es algo vivo. El proyecto no será un objeto, sino que tendrá en cuenta múltiples factores: planificación, relación con el entorno, etc.

En 1953 se produce un hallazgo científico en Cambridge que avanzara en la relación entre naturaleza y diseño: la descripción de la estructura del material genético realizada por el biólogo James $\mathrm{D}$. Watson y el físico Francis $\mathrm{H}$. Crick que representaron la estructura del ADN en forma de doble hélice. Esta doble hélice no solo hacia entendible los mecanismos de la transmisión hereditaria sino también su manipulación. Es decir que la naturaleza no era ya el misterioso otro a cuya merced nos encontrábamos sino que era algo que se podía dominar.

Tendría que llegar 1968 para que la "doble hélice" llegase a la gente gracias al best seller escrito por James D. Watson La doble hélice. Además en este mismo año de 1968, la nave de la NASA Apolo 8 logra orbitar alrededor de la Luna y captar unas imágenes del planeta Tierra visto por primera vez desde La Luna, que mostraban un planeta de color azul rodeado por un Universo de color negro. El hombre por primera vez visualizo la naturaleza tanto a escala del Universo y como a escala molecular con la doble hélice. El término 'naturaleza' se sustituyo por la idea de sistemas holísticos y equilibrios de fuerzas de los que el hombre formaba parte, y que también podía llegar a conformar. Así, el producto se hizo menos importante que el proceso y la forma menos importante que la función.

El Whole Earth Catalog producido a principios de la década de 1970, consistía en una enciclopedia de objetos y herramientas para proteger los recursos limitados del planeta y desarrollar alternativas a la sociedad industrial. El Whole Earth Catalog junto con los movimientos de protección ambiental y la ONG Greenpeace creada en 1971 abogaron por un nuevo estilo de vida para el hombre con el objetivo de proteger el frágil "Sistema Tierra".
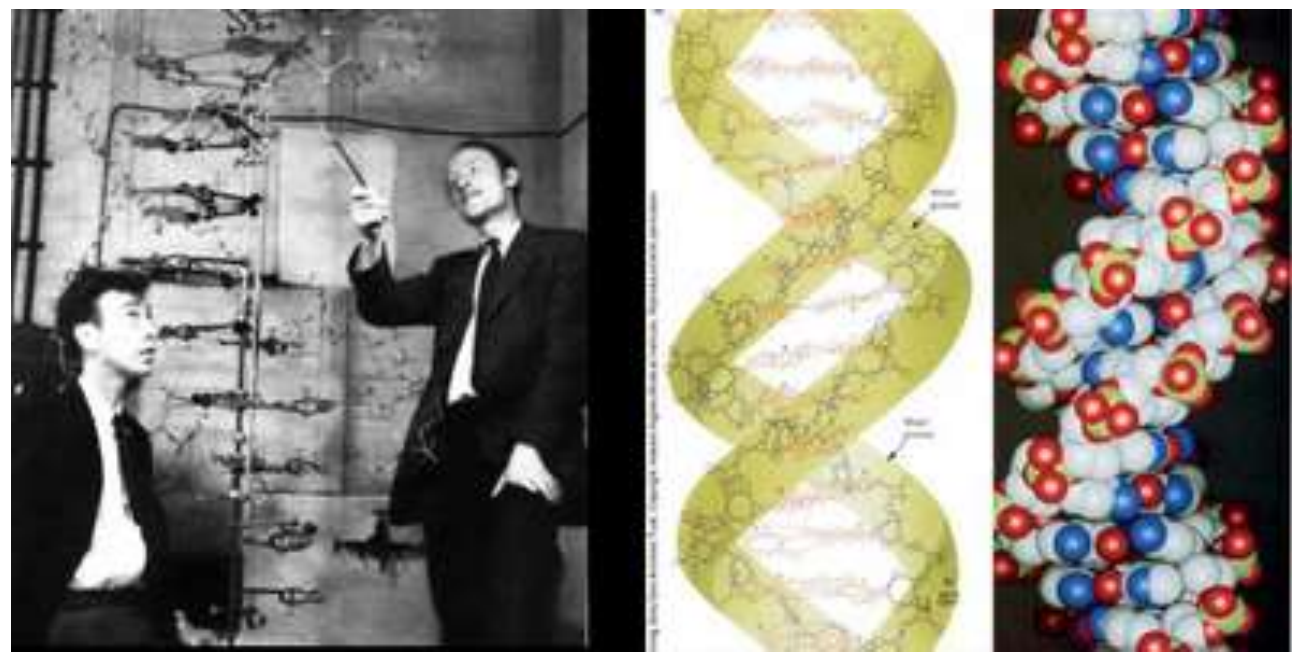

Ilustración 2-33 ${ }^{121}$

\footnotetext{
${ }^{121}$ En 1953 se produce un hallazgo cientifico en Cambridge que avanzara en la relacion entre naturaleza y diseño: la descripcion de la estructura del material genetico realizada por el biologo James D. Watson y el fisico Francis H. Crick
} 
Pero en la década de 1970 también aconteció un hecho que provoco el nacimiento de lo que desde la década de 1990 se conoce como globalización, y es que las compañías petroleras y la Organización de países exportadores de petróleo (OPEP) incrementaron en exceso el precio del barril de petróleo sumiendo al mundo en la denominada "crisis del petróleo" que provoco una recesión económica. ${ }^{122}$ Dicha crisis hizo que surgieran compañías globales como "Ikea" que no solo vendían muebles a precio razonable al alcance de la mayoría sino que proponía una identidad enfocada en la "naturalidad".

La frase de Buckminster Fuller "piensa globalmente actúa localmente" se convirtió en una consigna a seguir por todos aquellos que eran conscientes de su responsabilidad hacia el "Sistema Tierra". Fuller, junto con Frei Otto y Friedrich Kiesler, fue una figura clave en el diseño natural dada la naturaleza polifacética de su ejercicio profesional que abarcaba: arquitectura, ingeniería, arte y diseño. Todos sus diseños tratan con contextos sistemáticos, el equilibrio de fuerzas y la conexión del hombre con su entorno.

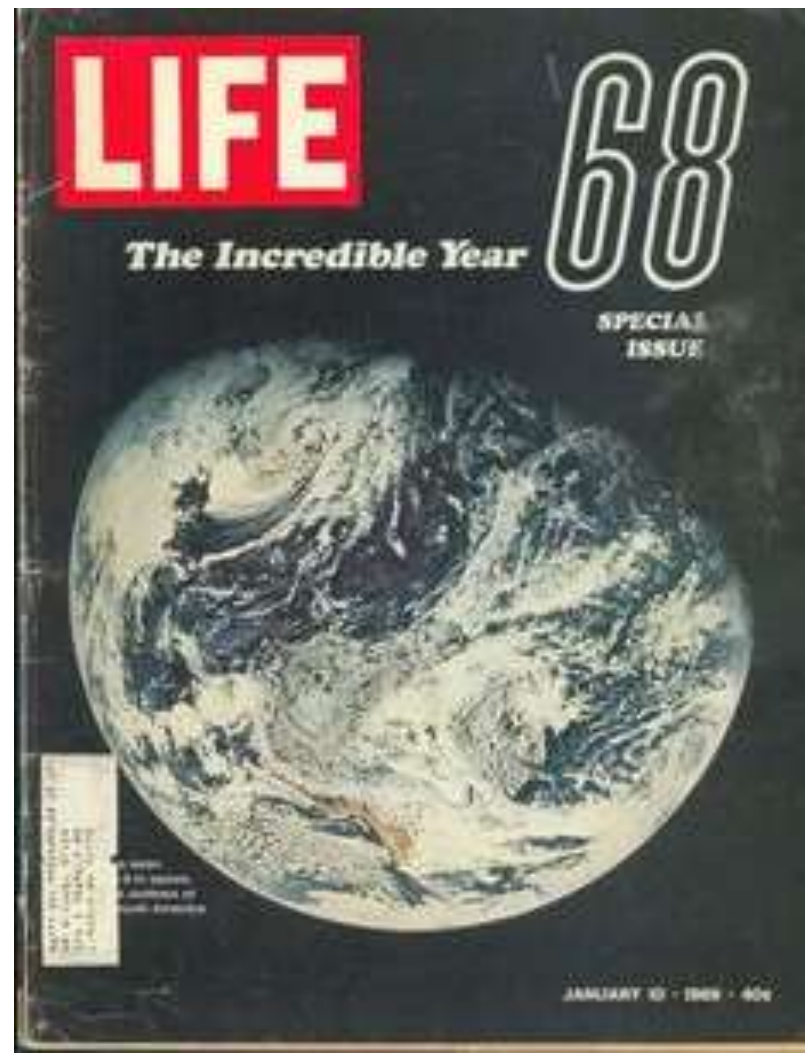

Ilustración 2-34 ${ }^{123}$

\footnotetext{
122 El hombre sensibilizado con no agotar los recursos naturales del planeta Tierra, no interpreto la subida de precios como lo que en realidad era, una explotación despiadada de las empresas petroleras.

${ }^{123}$ 1968, la nave de la NASA Apolo 8 logra orbitar alrededor de la Luna y captar unas imagenes por primera vez del planeta Tierra visto desde La Luna, que mostraban un planeta de color azul rodeado por un Universo de color negro.
} 


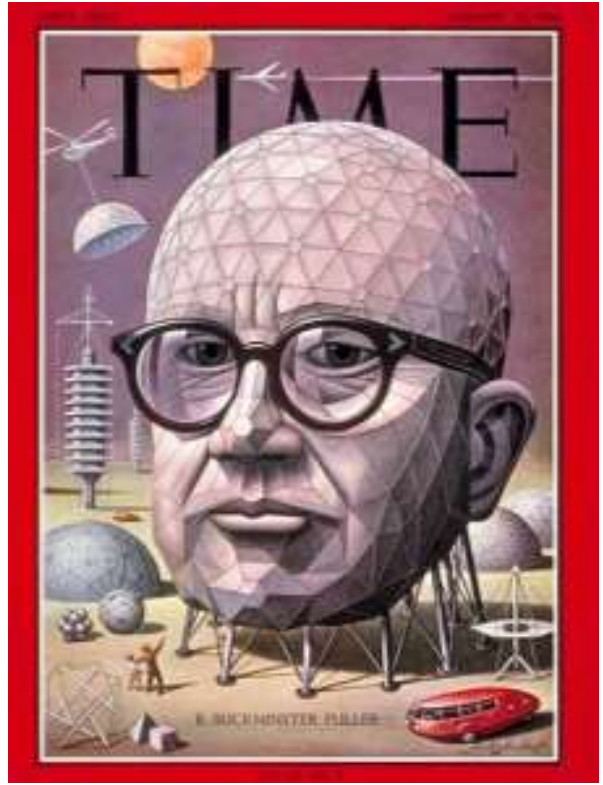

Ilustración 2-35

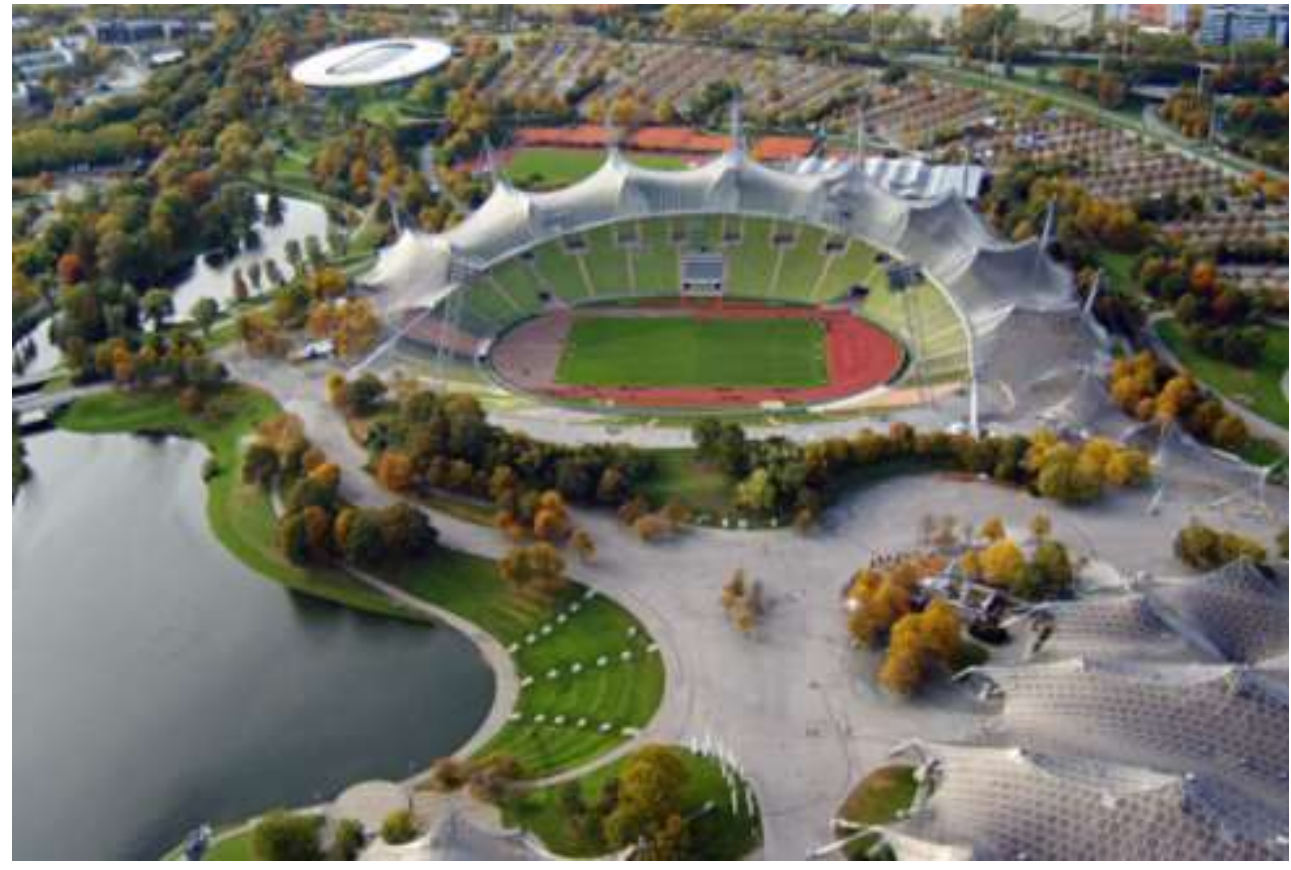

Ilustración 2-36 ${ }^{125}$

124 Time Magazine. portada del 10 de Enero de 1964. La frase de Buckminster Fuller "piensa globalmente actua localmente" se convirtio en una consigna a seguir por todos aquellos que eran conscientes de su responsabilidad hacia el "Sistema Tierra". Fuller, junto con Frei Otto y Friedrich Kiesler, fue una figura clave en el diseño natural dada la naturaleza polifacetica de su ejercicio profesional que abarcaba: arquitectura, ingenieria, arte y diseño. Todos sus diseños tratan con contextos sistematicos, el equilibrio de fuerzas y la conexion del hombre con su entorno.

${ }^{125}$ Frei Otto y Besnich. Estadio olimpico de Munich para las Olimpiadas. 1972. Estadio que aprovecha el crater de un impacto de una bomba de la Segunda Guerra Mundial para acomodar las gradas que se cubren con una cubierta ligera tensada apoyada en mastiles exteriores. Algo que tambien se vera en el Pabellon de Huesca de Miralles que se estudiara mas adelante. 
CONTEXTO 


\title{
2.5. LA CONSTRUCCION DE LA MIRADA DE ENRIC MIRALLES
}

\begin{abstract}
"no se puede estudiar a Miralles encuadrándolo dentro del movimiento deconstructivista, sino que hay que indagar en su momento histórico, su contexto y su formación; que es lo que de verdad genera su arquitectura".
\end{abstract}

$$
\text { Francisco Jarauta. }{ }^{126}
$$

Miralles es una figura escurridiza, ${ }^{127}$ y algunos de sus textos y declaraciones mas que aclarar, confunden. De ahí que estudiar sus circunstancias y su formación ayuden a indagar en su pensamiento y arquitectura. Defiende Josep Quetglas que la mirada de Miralles era como la de Picasso pues se había construido del tal manera que lo que representaba en su Arte era lo que su mirada veía; frente a la mirada de Viaplana que asimilaba a la de Juan Gris, quien para representar su Arte interponía un velo entre sus ojos y lo observado para que ayudase a deformar la realidad y poder pintar parecido a las pinturas de Picasso. Para Quetglas, Mlralles cuando dibuja ya está construyendo, sus dibujos son Arquitectura, frente a Viaplana que como Dalí, lo que tiene es ocurrencias, ideas felices que luego construye. ${ }^{128}$

\section{La etapa de estudiante}

Enric Miralles Moya, comienza sus estudios de Arquitectura ${ }^{129}$ en la Escuela Técnica Superior de Arquitectura de Barcelona (ETSAB) en el curso 1972-1973, y los termina el 4 de Diciembre de 1978 con un Proyecto Final de Carrera (PFC) calificado de Aprobado. Destacan excelentes notas en Historia del Arte, Matemáticas, Física y Proyectos. ${ }^{130}$

Miralles tuvo como profesor a Rafael Moneo ${ }^{131}$ y fue su "Ayudante" en clase. Moneo recomendaba la lectura de diez libros cada curso, y uno de ellos "Teoría de la proporción en Arquitectura" de P.H. Scholfield, intereso especialmente a Miralles y le ayudo a entender la faceta matemática de la arquitectura y el cómo están hechas las cosas. Miralles abandonara el sistema matemático cartesiano cuando descubra el libro escrito por Benoit Mandelbrot "Los Objetos fractales" que

\footnotetext{
${ }^{126}$ Conferencia dictada en Curso de verano de la UIMP, "alegoria del tiempo: la arquitectura y el universo de Enric Miralles"., Barcelona, 2009. ( 06/07/09)

127 Tal y como explico Moises Gallego en la lectura de Tesis Doctoral de Fernandez Contreras en la ETSAM en Diciembre de 2013, Enric Miralles era muy simpatico y accesible, hasta que intentabas superar su limite, porque era en ese momento cuando Miralles empleaba la estrategia del calamar segun la cual, arrojaba una mancha de tinta para hacerte imposible acceder a lo que de verdad pensaba.

128 QUETGLAS, José. “No te hagas ilusiones”. El Croquis MIRALLES / PINÓS 1983-1990, no 30, 49+50, pp. 24-29.

${ }^{129}$ Segun Anachu Zabalbeascoa, tuvo que decidir entre la Carrera Universitaria de Arquitectura o el baloncesto de competicion al que se dedicaba en aquellos años.

${ }^{130}$ Enric Mlralles: 1972-2000 Editorial Fundación Caja de Arquitectos 2011.

${ }^{131}$ Moneo se incorpora a la ETSAB en 1971 tras ganar la Catedra de Elementos de Composición.
} 
solía llevar en el bolsillo. ${ }^{132}$ Por tanto, se alejo de la geometria convencional euclidiana, para emplear la geometria fractal y poder con ello desarrollar mejor su Arquitectura. Es decir necesitaba la geometria fractal para dar rienda suelta a su creatividad, pero ayudada de un soporte geometrico. El profesor Juan Antonio Cortés, en su articulo "la geometria ha muerto. jviva la geometria!" ${ }^{133}$ tambien relaciona la obra de Miralles con la geometria fractal, en concreto destaca su proyecto para un Aulario en la Universidad de Valencia basado en la repeticion de los pupitres de los alumnos, siguiendo un esquema fractal, que configuran las aulas que repetidas igualmente configuran la forma global del edificio.

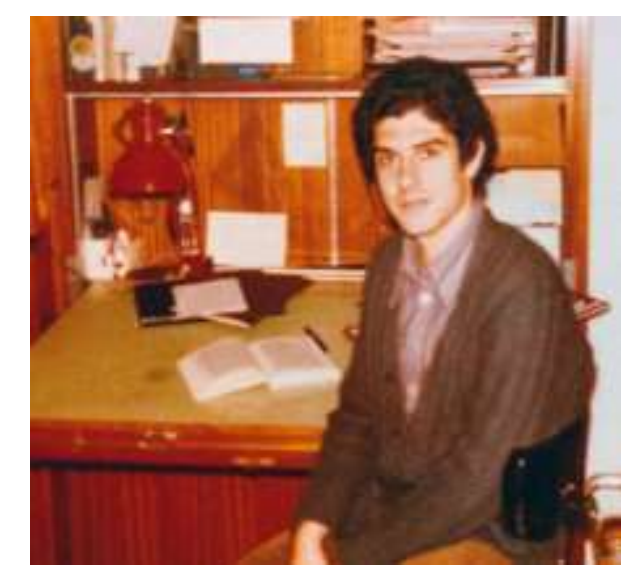

Ilustración 2-37 ${ }^{134}$

FORMALISMO Y VANGUARDIA rextoe do yos yoverizisis subes vol. 1 TYNIANOV EIKHENBAUM
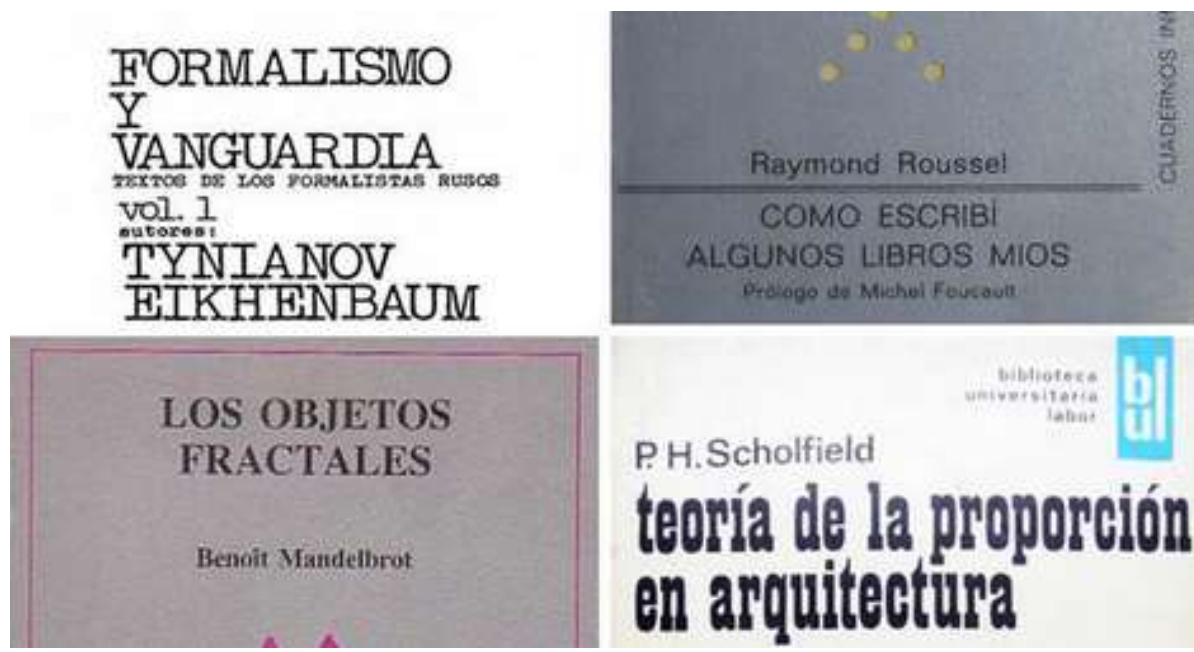

LOS OBJETOS

FRACTALES

Ilustración 2-38 ${ }^{135}$

\footnotetext{
132 Enrique Granell. "Una maleta Ilena de arquitectura" en Enric Mlralles: 1972-2000 Editorial Fundación Caja de Arquitectos 2011.

133 Juan Antonio Cortes. Lecciones de equilibrio. Fundacion Arquia. 2006

${ }^{134}$ Enric Miralles cuando era estudiante de $2^{\circ}$ curso de la ETSAB. 1974. Observese la reducida dimension de la mesa de trabajo. Quizas por esto se aficiono a croquizar en tamaño DIN A5 como se vera mas adelante.

${ }^{135}$ Libros recomendados por Moneo en sus clases que interesaron a Miralles.
} 
El estudiante Mlralles aprendio la obra de Le Corbusier a traves su coleccion de la Obra Completa, pues era el libro que el profesor Moneo utilizaba como libro de texto El Proyecto Final de Carrera (PFC) lo realizo Miralles, junto con su compañero de estudios Marcia Codinachs ${ }^{136}$, documentando el proyecto en plantas y secciones a la escala inusual de $1 / 20^{137}$ y dado el enorme tamaño de dichos planos hizo que Mlralles pidiese prestada la casa de un familiar en el barrio barcelonés de La Clota donde poderlos dibujar. ${ }^{138}$ Josep Maria Rovira nos precisa al respecto: "Los planos de la propuesta de Codinachs y Miralles se conservan en el archivo gráfico de la ETSAB bajo el nombre, atribuido por la catalogadora, de "La Gran Casa" y están realizados a escala 1/20. Contienen cinco dibujos en planta y tres secciones. Se trata de ocho* láminas dibujadas a lápiz de grafito de mina muy dura y lápiz azul sobre papel de grandes dimensiones y medidas variables: desde los 119,5 x 239,8 cm de las plantas hasta los 113,5 x 119,5 cm de las secciones. Los alzados no existen dado que el proyecto termina en el límite del papel, algo que al tribunal debió de costarle aceptar ". ${ }^{139}$ Tan es asi, que a Elias Torres que fue miembro de aquel Tribunal, le pareció que les estaban tomando el pelo, y lo expresa en los siguientes términos: "Conoci personalmente a Enric el dia de la presentacion de su PFC ante el tribunal, del que yo era el miembro mas joven. Hablar de Enric en ese final... ya su nombre tenia un runrun... sus planos se esparcieron, estos planos enormes y enigmaticos... no sabiamos si nos estaban tomando el pelo o provocando una situacion de dejarnos en estado de shock..." 140

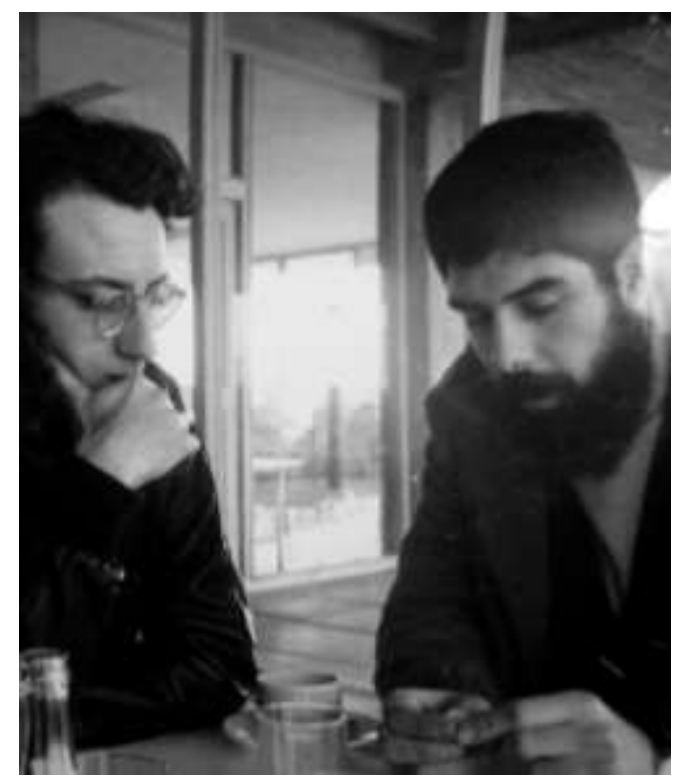

Ilustración 2-39 ${ }^{141}$

\footnotetext{
${ }^{136}$ Marcia Codinachs era el "alter ego" de Miralles segun los comentarios de personas que coincidieron en su etapa de estudiantes.

${ }^{137}$ Una escala que se suele emplear para dibujar planos de detalles constructivos

${ }^{138}$ Dicha casa fue restaurada posteriormente por Miralles, la famosa "Casa en La Clota".

${ }^{139}$ Josep M. Rovira, Enric Miralles 1972-2000 arquia/temas 33, 2011 pág. 31.

140 Elias Torres. "Conversaciones con Enric Miralles". Conferencia en Fundación Enric Miralles. 03/04/2014. Barcelona

${ }^{141}$ Enric Miralles con su "alter ego" Marcia Codinachs en los tiempos de estudiantes de la ETSAB.
} 


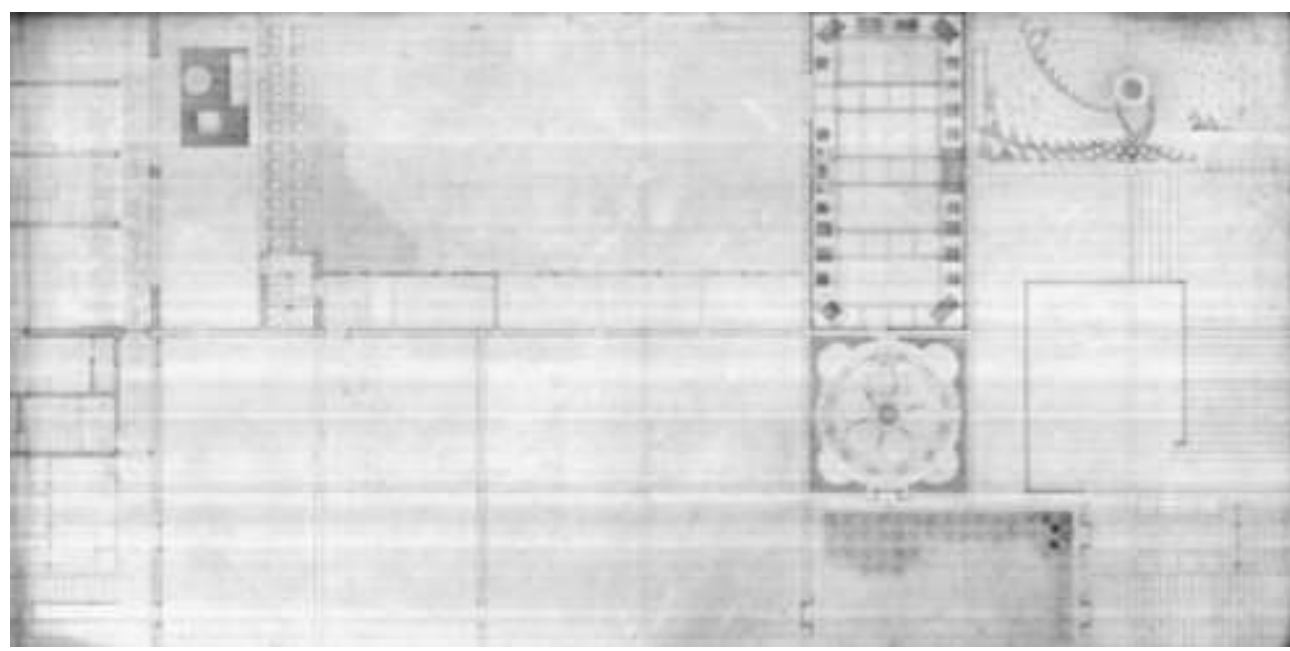

Ilustración 2-40

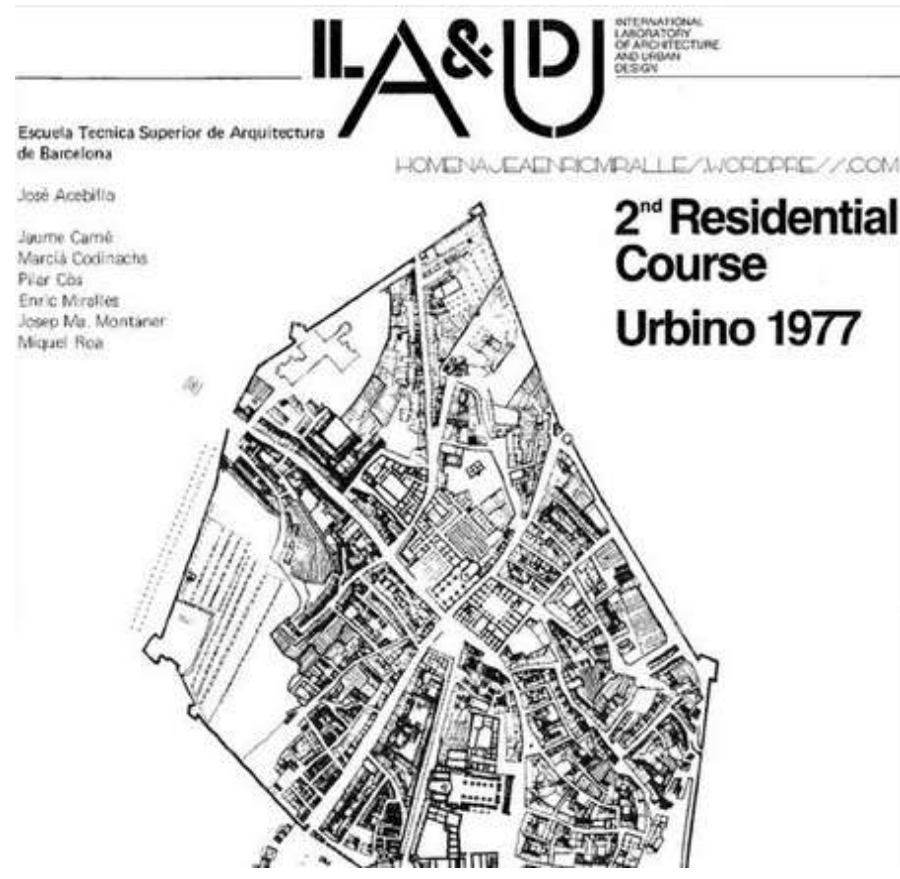

Ilustración 2-41 ${ }^{143}$

${ }^{142}$ Enric Miralles y Marcia Codinachs. La Gran Casa. PFC ETSAB. 1978. Planos dibujados a escala 1/20 dibujados con lapiz mina dura de $7 \mathrm{~h}$ sobre papel canson. Tamaño del formato: $237.6 \times 118.8 \mathrm{~cm}$. Para dibujar estos planos de gran tamaño Miralles le pidio una casa en La Clota a un familiar.

${ }^{143}$ Enric Miralles, asistio a aquellos Congresos, y entablo amistades con arquitectos de todo el mundo, especialmente con Gian Carlo de Carlo, que era un tipo que lo sabia todo sobre Arquitectura y tenian muchisimo prestigio en la disciplina de la Arquitectura en aquella epoca...Allii Miralles conocio a los Smithson de quienes se hicieron muy amigos. 


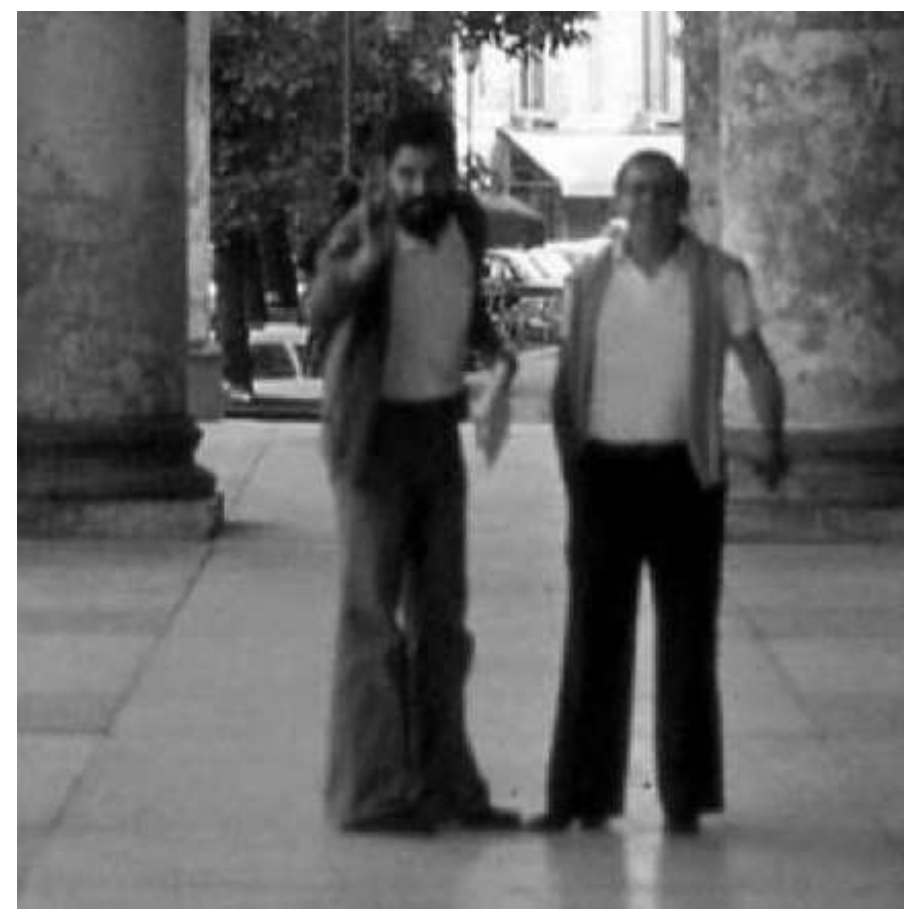

Ilustración 2-42

Miralles asistió en 1974 al Curso que cada año organizaba el "Centro Internacional de Estudios Andrea Palladio" y aprovecho para visitar las villas del arquitecto en el Veneto. En otoño de 1976 paso dos semanas en Vicenza con Vicente Maestre, quien había sido su profesor de Historia de la Arquitectura en la ETSAB. En 1977 participa en el curso "Participation \& Re-use" del ILAUD ${ }^{145}$ becado por la ETSAB impartido en la Universidad de Urbino, donde coincidirá con: Jacob Bakema, Franco Mancuso, Ludovico Quaroni y Peter Smithson.

Miralles tambien asistió a los cursos organizados en Siena por Gian Carlo di Carlo, en los que se invitaban a diversas Facultades de Arquitectura entre las que destacaban las de Estados Unidos y las escandinavas. ${ }^{146}$ lo que le ayudo a contactar con arquitectos de todo el mundo. Marco Vidotto, asistente a aquellos cursos, entablo una estrecha amistad con Miralles y Pinos, quienes le invitaban reiteradamente a su casa de Barcelona, y que relata en lo siguientes términos: " desde el principio vi que eran diferentes, la primera Navidad me invitaron a su casa y ya veía que (Miralles y Pinos) desarrollaban proyectos fresquísimos, muy interesantes... cuando en Italia estábamos cargados de cosas pesadísimas.... hicimos un viaje muy interesante viendo la arquitectura de Aldo Van Eyck en Holanda." 147

\footnotetext{
${ }^{144}$ Enric Miralles y su profesor de Historia de la Arquitectura Vicente Mestre, en el Palacio Chiericati. Vicenza 1976

145 ILAUD. The International Laboratory of Architecture and Urban Design.

${ }^{146}$ Donde en opinión de Marco Vidotto, los catalanes eran muy respetados por sus dotes creativas. Vease conversacion de Marco Vidotto con Felix Arranz y Benedetta Tagliabue. Scalae o 65

${ }^{147}$ Marco Vidotto. Ibidem.
} 
En el año 1979 siendo ya Profesor Ayudante en la ETSAB, Miralles se matricula de dos cursos de Doctorado: un curso dedicado a "Frank Lloyd Wright" que impartió Josep María Sostres y el curso titulado "Texto y Discurso de las Vanguardias", que impartia Helio Piñón. Posteriormente se matriculó de otros cursos de Doctorado: "Historia de la arquitectura catalana desde el Renacimiento hasta la actualidad "y "Los primeros modernos"; y en 1983 del curso "La prensa de las vanguardias".

Además, según cuenta su compañero de estudios en los primeros años de la ETSAB, Enrique Granell ${ }^{148}$, Miralles tuvo una formación muy rica "por libre", en paralelo a sus estudios oficiales. Granell, destaca la admiración de Miralles por los dibujos de los arquitectos ${ }^{149}$, en especial los de: Leon Krier aparecidos en la monografía de Stirling aparecida en 1975; de los de Saul Steinberg; los dibujos de Alejandro de la Sota que se publicaron en los dos números monográficos que las revistas Nueva Forma y Hogar y Arquitectura dedicaron a De la Sota; de los dibujos de Paul Klee ${ }^{150}$; del compositor musical John Cage; y de los de Federico García Lorca entre otros. Un libro que apasionaba a Miralles desde su etapa de estudiante era "Krisis. Saggio sulla crisi del pensiero negativo a Nietzsche a Wittgenstein", de critica del pensamiento negativo.

Los procesos imaginativos de Miralles, según Granell, proceden no solo de la arquitectura, sino de ciertos aspectos de la historia literatura moderna:

1. La obra de James Joyce y su idea del texto no como novela convencional sino como experimento verbal, en el que destaca ante todo un proceso de elaboración, un "work in progress".

2. La escritura automática de los surrealistas estaba implícita en la manera de aproximarse de Miralles a las cosas, como parte integrante de su manera de dibujar, donde la mano en determinadas ocasiones no obedecía al pensamiento consciente sino que fluía por sí misma.

3. El formalismo de los Situacionistas.

4. La nueva ciencia patafisica, contraria a la ciencia científica, según la cual el mundo es un conjunto de casos particulares y tiene que haber una solución imaginativa para cada uno de estos.

5. Los libros de Raymond Queneau, en especial "Exercises de style" y de sus "Cent mille milliards de poémes" y los de Georges Perec en especial "Espéces d'Espaces" y "la Vie, mode d'emploi "le ayudaron a entender puntos de vista simultáneos y diversos en su proceso creativo.

6. La obra de David Hockney y Gordon Mata Clark, de los que Miralles encontró un método que incorporado a su proceso creativo, le daba la oportunidad de obtener la suma de las intenciones que deseaba en cada caso. Así utilizó el mecanismo del collage de formas diferentes y con todas las combinaciones posibles para proyectar su arquitectura

\footnotetext{
148 Enrique Granell "Una maleta Ilena de arquitectura” en Enric Mlralles: 1972-2000 Editorial Fundación Caja de Arquitectos 2011.

${ }^{149}$ De hecho dicha coleccion de dibujos recopilados de los viajeros del S. XVIII en su etapa de estudiante formaron parte de su Tesis Doctoral.

${ }^{150}$ Según Enrique Granell, Mlralles pudo contemplar al natural los dibujos de Klee, en la exposición celebrada en la Fundación Joan Miró de Barcelona en 1981.
} 
7. La revista "Poesia" ${ }^{151}$ en especial el tercer número que estaba dedicado al caligrama y a la relación de la poesía con el dibujo. Según Granell, gracias a la esta revista, también conoció a Henri Michaux y a Francis Ponge que para Miralles representaban la tentativa al igual que los Exercises de style de Georges Perec de agotar el acoso a un objeto o a una situación desde múltiples ángulos, intentando su definitiva definición.

Miralles tambien aprendió de los artistas plásticos: Del cubismo de Picasso, y la representación de la realidad en múltiples facetas a través de la fragmentación; de Marcel Duchamp descubrió la idea del movimiento capturado en un plano; de Paul Klee aprendio la línea sintética, la abstracción y la utilización de los colores; de Max Bill la matemática de la geometría en las cosas; de Joseph Beuys aprendio que las disciplinas artísticas se pueden combinar para crear algo totalmente nuevo; de Giacometti, su manera de trabajar con la repetición donde el resultado no está planificado sino que es el proceso el que le lleva hasta él. Tambien aprendió de Matisse, de Joan Miró, etc.

Miralles acostumbraba a decir que habia que aprender de las Obras Maestras de la Arquitectura, tanto estudiandolas teoricamente como visitandolas "in situ". Su obra tiene una relación con la Historia de la Arquitectura de todos los tiempos, que se nota en el primitivismo de su obra y en especial en la Arquitectura en la que primó la idea por encima de todo: Egipto, Grecia, el Renacimiento, etc.

También se capta en la obra de Miralles, la influencia de Miguel Angel, Alberti, Giulio Romano, Palladio, Piranesi, Borromini, Gaudi, Jujol, Melnikov, Asplund, Bruno Taut, los Maestros de la Arquitectura Moderna (en especial Le Corbusier, Wright y Aalto), Scharoun, Utzon, Eero Saarinen, Louis I. Khan, Aldo Van Eyck, Gardella, Albini, Terragni, Los Smithson, Coderch,...pero son influencias que hace suyas y hace pasar por su filtro.

Miralles defendia que los inicios del arquitecto contemporáneo se encontraban en el siglo XVI. De Miguel Angel aprende Miralles "el contraposto" representado en el giro con el que contorsiona la escultura de sus esculturas como "el Moises", que llevara a su edificio de Hostalets; lo inacabado en la "Pieta Rondanini" del castillo Sforzesco de Milan, etc.

Del Manierismo de Andrea Palladio descubrió un lenguaje personal y la utilización del cambio de escala con el orden gigante. Esta idea de gigantismo, junto a los los colosos de Goya, la trasladó a proyectos como el Palacio de deportes de Huesca en 1988 o a las Pérgolas de la Avenida Icaria en 1992

Del Barroco de Piranessi extrajo la retórica de la construcción escenográfica en la arquitectura. De Gaudi, aprendió el Panteismo, la capacidad plástica, el mundo del inconsciente de Freud, la morfología naturalista de su arquitectura, tener a la Naturaleza como su principal referente y el entendimiento del tiempo no como algo lineal sino como algo ciclico a la manera de un Kubler, la recuperación del sentimiento en la arquitectura, etc.

Todas estas influencias cruzadas ayudaron a Miralles a tener una actitud diferente a la de sus contemporáneos a la hora de proyectar : "Tentativas parecidas a las del arquitecto que quiere capturar lo intangible y que cree que ese comenzar desde

\footnotetext{
${ }^{151}$ La revista Poesia era una revista ilustrada de información poética, que se edito desde finales de 1978
} 
posiciones diferentes y a veces contrarias conseguirá rendir a la postre el esquivo objeto arquitectónico buscado" 152

Por tanto, recorrer el laberinto intelectual de las obras de Miralles enredadas en multiples referencias no es tarea fácil, maxime cuando sus proyectos además se van anudando unos a otros, conteniéndose, colisionando,dialogando, etc. De entre la amplia formación de Miralles, merece destacarse, por la influencia que tiene en el tema investigado en esta Tesis Doctoral, la estancia de investigación en la Universidad de Columbia en Nueva York en 1980-81, como Fullbright Visiting Scholar pues, entre otras cosas, puso a Miralles y Pinos $^{153}$ en contacto con el Land Art norteamericano cuyas obras estudiaron a fondo "in situ". Ello, unido al método utilizado por los arquitectos paisajistas catalanes y a la larga tradición catalana de buenas prácticas al operar en el paisaje, entre otras cosas, hicieron posible una obra como el Cementerio de Igualada (1985-1996) realizada con Carmen Pinós, en el que se emplearan estrategias proyectuales y herramientas más ligadas a las utilizadas por los land artists, y al método paisajístico, ampliando el método compositivo específicamente disciplinar de la arquitectura.

Respecto al posicionamiento de Miralles respecto a la naturaleza, conviene destacar la afirmacion de Moneo: "Enric Miralles era bien consciente de la voluntad panteista que animaba a su arquitectura." ${ }^{154}$

La naturaleza es sinonimo de Dios en el Panteismo. Esta corriente de pensamiento ha estado muy presente en la reciente historia catalana. Ello justificaria que en la obra de Mlralles, se de esa omnipotente creatividad. Su obra es un continuo testimonio de su capacidad creadora y por otro lado, esa actitud panteista se da en el obsesivo interes por crear naturalezas artificiales en tantos proyectos en los que lo construido se confunde con lo natural. El Panteismo es una doctrina filosofica segun la cual el Universo, la naturaleza y Dios son equivalentes. Panteismo proviene del griego "pan" que significa "todo" y "theos" que significa Dios : "todo es Dios y Dios es todo". Conviene destacar tambien a Frank Lloyd Wright como panteista cientifico, al igual que Albert Einstein.

Uno de los panteístas más destacados fue el sacerdote jesuita francés Pierre Teilhard de Chardin (1881-1955). En 1916 publica La vida cósmica y en 1919 El potencial de la materia. En ellos ya se detecta lo que será el núcleo de su pensamiento. Su pensamiento se estructura en cuatro puntos: el cambio pasara a ser lo esencial y lo estático es lo inexistente; la vida, la materia y el pensamiento están también involucrados en el proceso de la evolución; el sentido de la evolución se encuentra dentro de un principio mas general: la tendencia hacia el logro de mayores niveles de complejidad y simultáneamente, al logro de mayores niveles de conciencia; y la meta de la evolución. según la cual la evolución requiere una unificación de sentido y ningún futuro evolutivo aguarda a la persona si no es en asociación con los demás.

\footnotetext{
152 Enrique Granell “Una maleta Ilena de arquitectura” en Enric Mlralles: 1972-2000 Editorial Fundación Caja de Arquitectos 2011.

${ }^{153}$ Miralles y PInos viajaron juntos a Nueva York recien casados. Carmen Pinos hizo un curso en la Universidad de Columbia con Leonardo Benevolo, y quienes alli coincidieron con ellos como Beatriz Colomina, o Ignasi de Sola Morales comentan que se lo leian todo, viajaban, etc. Aprovecharon muy intensamente aquella estancia.

${ }^{154}$ Rafael Moneo "Una vida intensa, una obra plena" El Croquis no100-101, Julio 2000. pag. 306
} 


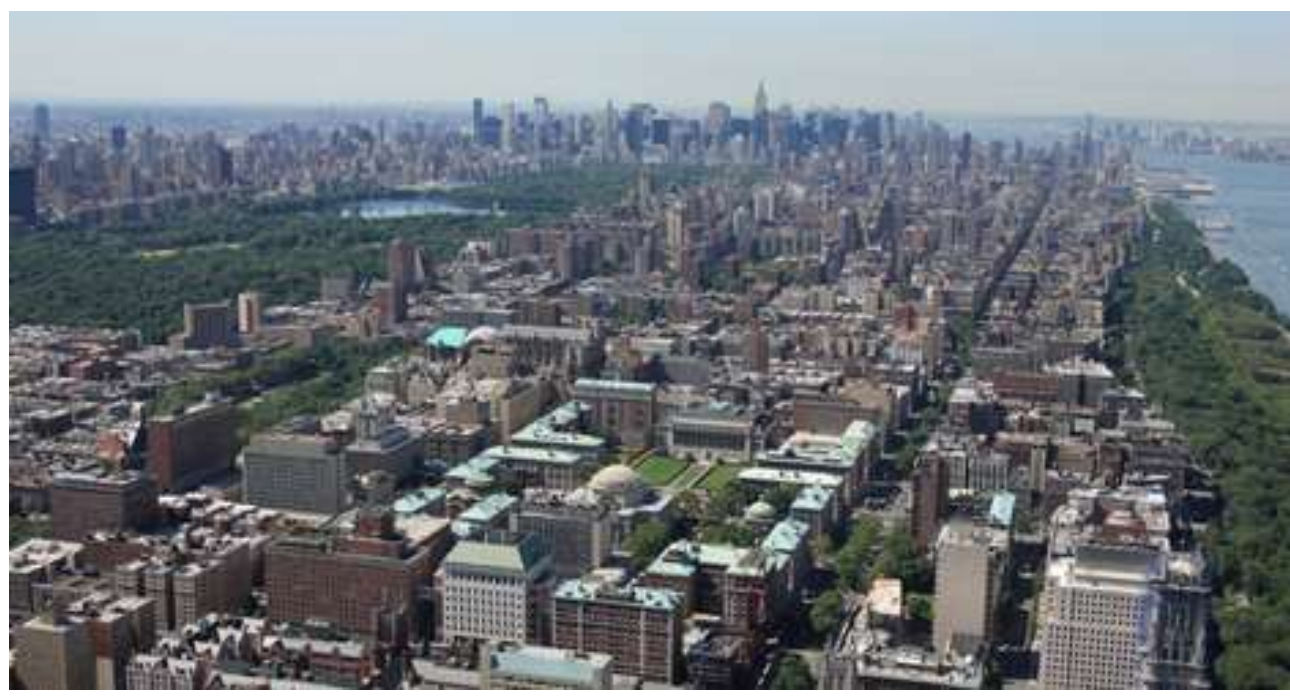

Ilustración 2-43 ${ }^{155}$

Como relato Carmen Pinos en la entrevista realizada por la revista DC : "Gracias a una beca de investigación obtenida por Miralles para la Universidad de Columbia, al año siguiente y tras casarse, Miralles y Pinos tendrán la posibilidad de vivir en New York. Se dedicarán con resolución a estudiar, leer, recopilar información y viajar principalmente por la Costa Este: Boston, New Haven y otras para conocer las obras de Louis Kahn, Kevin Roche, Mies y Saarinen. Descubrirán el Land Art y las expresiones artísticas de Richard Long, Robert Smithson y James Turrell lo que marcará decididamente su mirada hacia la arquitectura. Coinciden en este período, en la Universidad de Columbia, con Beatriz Colomina e Ignasi Solá Morales con quien tendrán la oportunidad de conocer la Casa en la Cascada, de Frank Lloyd Wright gracias a una invitación hecha por el propio Edgar Kaufmann a un círculo muy reducido de personas." 156

\section{La Tesis Doctoral. (1979-1988)}

Enric Miralles comienza sus estudios de Doctorado en octubre de 1979 y en febrero de 1985, presenta su tema de Tesis doctoral con el título "Cuando las catedrales eran blancas" teniendo como Director de Tesis hasta el mes de Mayo de 1987 a Albert Viaplana ${ }^{157}$ con quien venia colaborando en su Estudio profesional desde que comenzó la carrera univesitaria de Arquitectura. La tesis doctoral de Miralles, verso sobre los dibujos que los viajeros ingleses, alemanes, etc. de antes de la Revolucion francesa, realizaban cuando hacian el Grand Tour visitando las Ruinas de la Antiguedad. Se componia de dibujos e imagenes que Miralles habia ido recopilando desde que era estudiante, junto con los comentarios que le sugerian.

\footnotetext{
155 Gracias a una beca de investigación obtenida por Miralles para la Universidad de Columbia en 1980-1981, tras casarse, Miralles y Pinos tendrán la posibilidad de vivir en New York. Se dedicarán con resolución a estudiar, leer, recopilar información y viajar principalmente por la Costa Este: Boston, New Haven y otras para conocer las obras de Louis Kahn, Kevin Roche, Mies y Saarinen.

156 'Mirada Retrospectiva' Entrevista a, DC 17-18 / Enric Miralles 1955-2000

157 Mlralles solicito el cambio de Director de tesis, seguramente debido al empeoramiento de la relacion de amistad con su entonces Director Albert Viaplana tras abandonar su Estudio de Arquitectura molesto por no reconocerle publicamente su autoria en los ultimos proyectos elaborados conjuntamente en el estudio siendo ya arquitecto.
} 


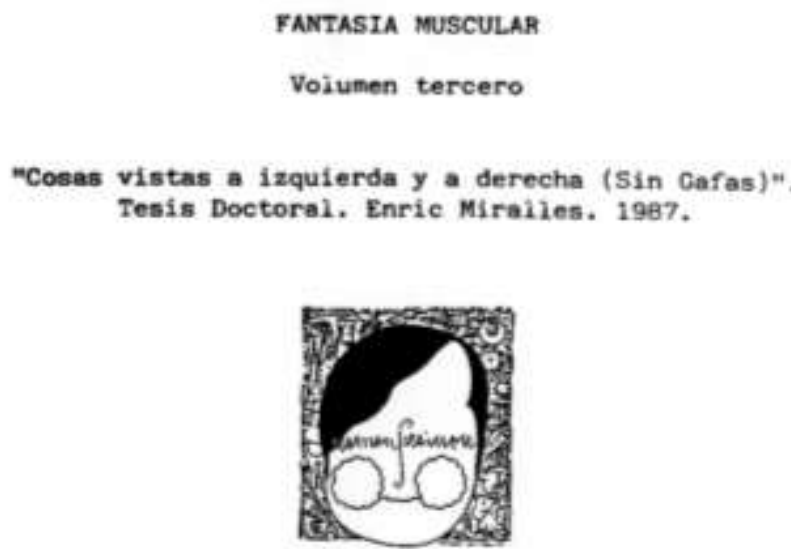

Ilustración 2-44 ${ }^{158}$

Conviene tener en cuenta que Miralles tenía urgencia en cumplir el trámite académico de obtener el grado de Doctor ${ }^{159}$ al que obligaba la Universidad en aquella época para poder seguir siendo profesor universitario. Como demostración de la determinación de Miralles para defender su Tesis doctoral, hizo llegar el borrador de la Tesis a Rafael Moneo acompañado de una carta en la que se expresaba en los siguientes términos: "...con algunas páginas más (las dos o tres primeras), este texto es el que pensaba leer....lo he enviado a los otros miembros del tribunal...esperaré los comentarios de los más cercanos: Pep, Azúa, Muntañola..., ya te diré su opinión sobre el cómo llevar adelante esto...Dale un vistazo si puedes. He colocado aparte texto e imágenes y funciona algo así como diapositivas que merecerían un más largo comentario. De veras gracias por tu interés en todo esto... Hasta pronto, Enric." 160

Miralles tituló su tesis doctoral haciendo alusion a la pieza de música para violín y piano del compositor Erik Satie. Dicha pieza era una Suite en tres movimientos "Choses vues à droite et à gauche (sans lunettes)" (I Choral hypocrite, II Fugue á tatons y III Fantasie musculaire), La tesis la tituló: Cosas vistas de derecha a izquierda, sin gafas. Enric invirtió el orden: de izquierda a derecha.

La tesis doctoral se presento a su lectura en Noviembre de 1987 ante un tribunal compuesto por Félix de Azua, Josep Muntañola, Juan Navarro Baldeweg, Josep

\footnotetext{
${ }^{158}$ La música de Erik Satie y John Cage se metió entre los espacios de Enric y éste tituló su tesis doctoral en clara referencia a la música del título original de la obra para violín y piano de Satie es una Suite en tres movimientos "Choses vues à droite et à gauche (sans lunettes)" (I Choral hypocrite, II Fugue á tatons y III Fantasie musculaire), La tesis la tituló: Cosas vistas de derecha a izquierda, sin gafas. Enric invirtió el orden: de izquierda a derecha, además introdujo varios retratos de Satie en la propia tesis.

${ }^{159}$ En Noviembre de 1987, Miralles esta construyendo el Cementerio de Igualada, el Centro Civico de Hostalets de Balenyá y la Escuela Hogar de Morella entre otros asuntos. En Octubre de ese mismo año la revista El Croquis no 30 editaba la primera monografia dedicada a Miralles y Pinos.

${ }^{160}$ Enric Miralles. "Cosas vistas a izquierda y a derecha (sin gafas) Tesis Doctoral de Enric Miralles Moya, 1987" en Enric Mlralles: 1972-2000 Editorial Fundación Caja de Arquitectos 2011. P. 61
} 
Quetglas y Rafael Moneo. El documento, presentado estaba compuesto por dos pequeños cuadernos: El primero titulado "Resumen (texto)" consistía en un texto mecanografiado a dos espacios de 31 páginas y un apéndice de una página. El segundo de los cuadernos titulado "Resumen (ilustraciones)" constaba de 68 ilustraciones para hacer más explícito lo que se decía en el texto.

El tribunal considero "no apta" la Tesis presentada y solicito se completase. En palabras de Rafael Moneo: "el documento presentado por Enric Miralles era un texto intimo y personal, sin el debido contenido académico y le pidió que lo redactase de nuevo ampliándolo y completándolo, para proceder a una nueva lectura...solicitando a Enric Miralles...que procediese como tantos otros presuntos doctorandos, presentando un escrito que contribuyese a extender el conocimiento disciplinar de la arquitectura, dando prueba así ser acreedor al título de Doctor." ${ }^{161}$ La segunda lectura de la Tesis doctoral tuvo lugar en la ETSAB el día 25 de febrero de 1988. Esta Tesis revisada y completada por Miralles, se componía de tres volúmenes: El primero titulado "Coral Hipócrita" constaba de 94 páginas en las que se alternaban texto e imágenes; el segundo, titulado "Fuga a Tientas" contaba 262 páginas y el tercer volumen titulado "Fantasía Muscular" de 52 páginas consistía en una colección de los propios dibujos de Miralles

Para Moneo, la Tesis de Miralles es una declaración de principios y refleja lo que significaba la arquitectura para él en aquellos años. La tesis contiene dibujos que los artistas ingleses y alemanes realizaban en sus viajes a la Italia de finales del siglo XVIII, de entre los que destacan los de Juvarra, Sangallo, Carracci, Piranesi, Blake, Ingres, Cozens, Schinkel, Soane, etc. La Tesis tambien trata de: la lección de la Historia; el impacto de lo sublime; el registro del paisaje, etc. Miralles manifiesta en su investigación, preferencia por los artistas que se expresaban con la línea, sin sombras, que reflejaban los contornos de las cosas en sus dibujos. Miralles defiende en su Tesis que se puede hacer Arquitectura con los instrumentos del dibujante, desde el dibujo espontaneo y directo que rastrea el origen de las cosas, hasta el que encuentra solución a los problemas arquitectónicos. Para Miralles, los dibujos denotan una visión simultánea y múltiple de la realidad atesorando las claves para construir.

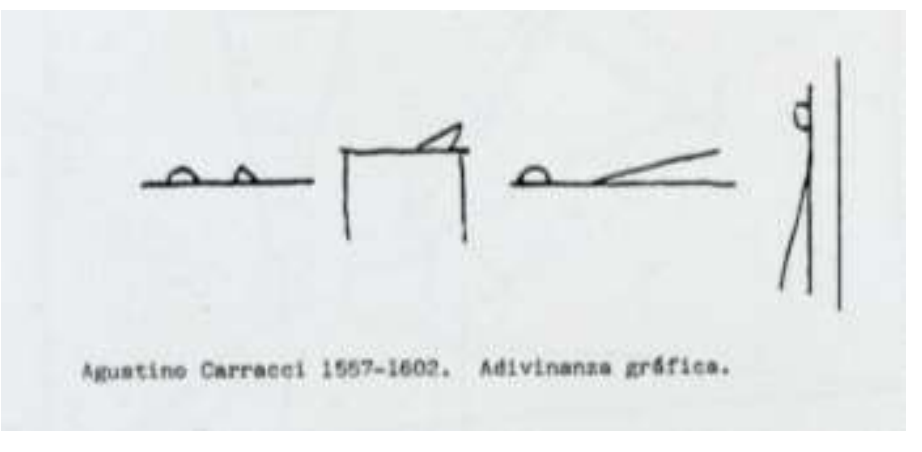

Ilustración 2-45 ${ }^{162}$

161 Rafael Moneo. "Cosas vistas a izquierda y a derecha (sin gafas) Tesis Doctoral de Enric Miralles Moya, 1987" en Enric MIralles: 1972-2000 Editorial Fundación Caja de Arquitectos 2011. P. 61

162 Uno de los dibujos contenidos en la Tesis de Miralles, realizado por Agustino Carracci 


\section{La colaboración con Viaplana y Piñón (1973-1985).}

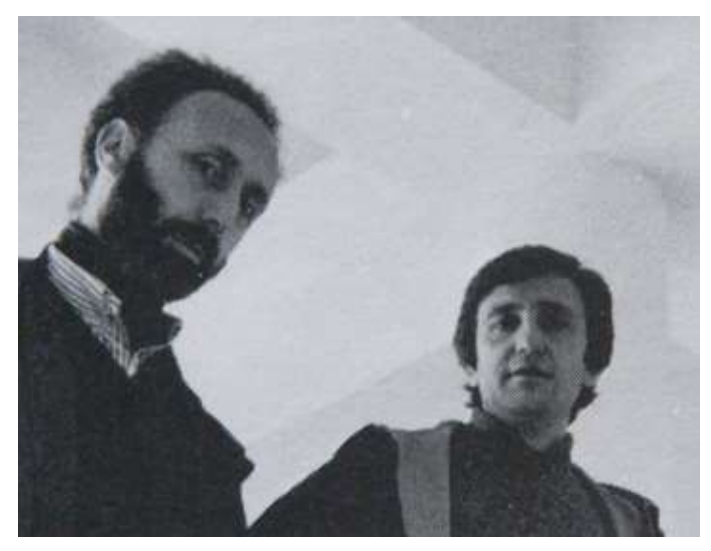

$2-46^{163}$

"...interesado por todo y por todos, entusiasta, brillante estudiante...Helio Piñón y Alberto Viaplana pronto pusieron sus ojos en él y lo incorporaron a su despacho cuando todavía estaba en la escuela. Terminada la carrera en 1978, Enric Miralles paso a ser un colaborador destacado del estudio de Viaplana y Piñon,y sin duda su presencia en dicho estudio se hizo notar cuando, al comenzar los años ochenta, el trabajo de los arquitectos barceloneses se presentaba en el panorama de la arquitectura catalana como una iluminada alternativa a los excesos del posmodernismo...en 1984 Enric creía que su carrera profesional debía desarrollarse con independencia de quienes habían sido sus mentores. Y que había llegado el momento de encontrar un modo de acercarse a la arquitectura desde posiciones a las que cabia calificar como propias y personales."

Rafael Moneo. ${ }^{164}$

Para Rafael Moneo, Miralles se forjo como arquitecto en el Estudio de Arquitectura de Viaplana y Piñón ${ }^{165}$ durante 10 años, desde el año 1974. En 1984, Miralles abandona el Estudio al no reconocerle en los créditos como coautor del Concurso de la Plaza Berenguer. El Estudio formado por Viaplana - Piñón, teniendo como colaborador al joven Miralles realizo una arquitectura enraizada con el acontecer de la arquitectura contemporánea, con lo que estaban haciendo los Koolhaas,

\footnotetext{
${ }^{163}$ Albert Viaplana y Helio Piñon, en la epoca en la que Miralles comoestudiante colaborara en su Estudio de Arquitectura.

164 "Cosas vistas a izquierda y a derecha (sin gafas) Tesis Doctoral de Enric Miralles Moya, 1987" en Enric Mlralles: 1972-2000 Editorial Fundación Caja de Arquitectos 2011. P. 63

165 Segun comento Rafael Moneo en el ciclo "Conversaciones con Enric Miralles" en la Fundacion Enric Miralles.
} 
Tschumi, Eisenman, Ghery, Zaha Hadid, etc. compartiendo con ellos: su grafismo; su manera de operar por piezas; y su postura alternativa al Posmodernismo ${ }^{166}$.

El primer paso cuando abordaban un proyecto Albert Viaplana y Helio Piñón, consistía en generar las condiciones necesarias para que su arquitectura pueda implantarse. Cada obra de arquitectura solo podia estar en ese lugar y no en otro, negando con ello el carácter objetual de la arquitectura. Es el lugar el que dicta la propuesta arquitectónica, y por eso se estudia en profundidad, hasta que se aprende donde se esta interviniendo. En ese momento mediante la geometría, se formalizara la propuesta. Viaplana lo relacionaba con el humor, que solo puede salir cuando hay confianza entre las personas y ya se conocen bien.

La arquitectura de Viaplana y Piñón, se enfrento a la denominada Escola de Barcelona, pues no compartía con dicha escuela, la defensa de la artesanía ni su huida del intelectualismo entre otras cosas. Por eso mismo cabe calificarla de moderna, por su oposición a los valores defendidos en el ideario de la Escola de Barcelona y porque aceptaba la novedad y la complejidad del mundo contemporáneo. Como comenta Juan José Lahuerta: "Constructivismo, Dadá, la vanguardia clásica...la obra de Viaplana-Piñón tiene en común con esa vanguardia clásica la abstracción...la arquitectura de Viaplana-Piñón es moderna porque acepta la novedad... y porque con la abstracción nos informa de la desolación del mundo contemporáneo." 167

La arquitectura que se hacía en el Estudio, era conceptual, los dibujos de Viaplana eran como conceptos, el primer registro grafico de la idea con la que resolver el proyecto. Acostumbraban a ponerlos a la vista, colgados en una pared para ir a consultarlos y no perderse al desarrollar el proyecto. La manera de dibujar en el Estudio era a línea fina, con rotring 0.1, para dibujar lo estrictamente necesario, solo aquellas líneas mínimas necesarias para transmitir el proyecto. ${ }^{168}$ Con cada paso que daban al proyectar ponian a prueba el proyecto, de manera que si no estaban convenidos no daban el siguiente paso. Tenian que estar convencidos de que: "el proyecto ya ha nacido y tiene nombres y apellidos", para pasar después con confianza a ponerle el ropaje y los elementos secuandarios. El mismo Viaplana nos lo define en los siguientes términos: "Nosotros pensamos que la arquitectura ya está en el lugar, no inventamos nada, le proponemos al lugar interrogantes... $y$ de todas esas preguntas $y$ respuestas sale al final el proyecto...imaginamos que ya existía la arquitectura que proponemos en el lugar...proyectar no sobre el plano del tablero, ni a uno setenta del suelo, desde el cielo, dice muchas más cosas..." 169

Helio Piñón acostumbraba a recalcar que el banco con forma rara que tanto criticaba la gente en la plaza de la Estación de Sants, en Barcelona, no era solo un banco; que era una pieza proyectada ex - profeso para ese lugar concreto y que no se la debia reducir solo a su función de asiento, porque segun el, tenia otras

\footnotetext{
${ }^{166}$ Movimiento arquitectónico que dominaba la arquitectura de aquellos años.

${ }^{167}$ Lahuerta, Juan José . Reportaje televisado sobre la obra de Viaplana - Piñón". TVE. Diciembre de 1990. [fueron una serie de reportajes televisados sobre la obra de arquitectos como Oiza, Calatrava, etc.]

${ }^{168}$ Era una manera de dibujar que tenia relacion con los dibujos de Sota y de Stirling entre otros, muy sinteticos. Miralles tambien dibujara asi.

${ }^{169}$ Albert Viaplana. "Reportaje televisado sobre la obra de Viaplana - Piñón". TVE. Diciembre de 1990. [fueron una serie de reportajes televisados sobre la obra de arquitectos como Oiza, Calatrava, etc.]
} 
funciones más complejas y abstractas que lo relacionaban con el discurso del resto de elementos proyectados para la propuesta, siguiendo un sistema de relaciones. Ignasi de Sola Morales se refiere a la arquitectura de Viaplana - Piñón en los siguientes términos: "...la de Viaplana-Piñón es una arquitectura que no intenta mostrar un orden coherente entre las piezas y el lugar donde se coloca, sino que por el contrario actúa caóticamente, opaca, hermética, difícil de ser entendida globalmente, es una arquitectura que con elementos convencionales organiza cierta parte del paisaje...con vocación efímera, remitiendo a la idea que hay detrás..." 170

En la propuesta de Concurso para la Plaza de San Esteban en Murcia, generan un mundo con sus propias leyes: sus soles; sus lluvias; sus centros de gravedad diferentes; una gran ola solidificada como arquería al final del solar; la vertical que ya no era la del lugar sino la perpendicular al plano inclinado creado en el proyecto; los soles eran cuadrados y se iluminaban cuando se ponía el Sol físico; había montañas geométricas que escondían un garaje; un surtidor gigante que mojaba las gradas y marcaba cuando estas se podían utilizar. En esta intervención, lo más importante es el espacio exterior, siendo el edificio el negativo de ese espacio exterior. Esta manera de hacer, continuara en su obra hasta el Museo de la Ciencia de Barcelona, en el que su arquitectura surge de las relaciones del edificio con el espacio exterior. El mismo Helio Piñón se refiere a su arquitectura de la siguiente manera: "Nuestra arquitectura es un sistema de relaciones...los elementos no están unidos geométricamente sino por una historia...esas relaciones dependen de cómo les da el Sol, sus texturas, su relación con el lugar...es un situarse como se sitúa la personalidad de cada persona o el rol de cada cargo al disponerse en una sala, etc...este concepto ayuda a superar el parales, la escuadra, la geometría que solo son instrumentos que hay que ponerlos en su justo lugar..." 171

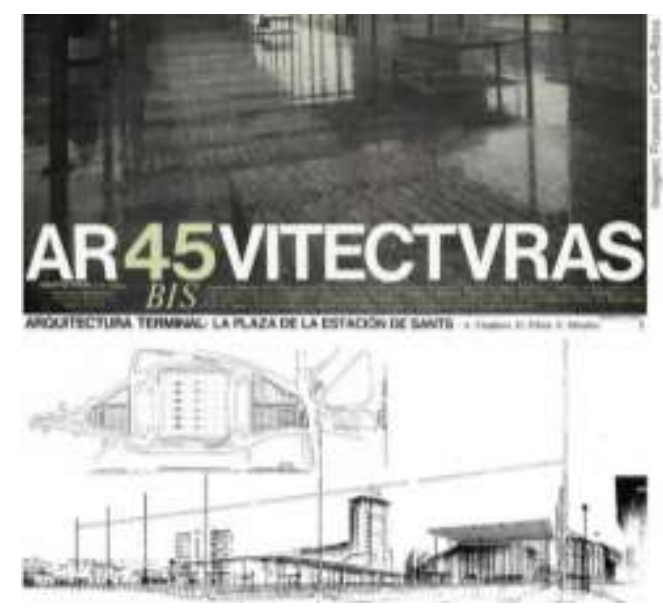

$2-47^{172}$

\footnotetext{
${ }^{170}$ Ignasi Solá-Morales "Reportaje televisado sobre la obra de Viaplana - Piñón". TVE. Diciembre de 1990. [fueron una serie de reportajes televisados sobre la obra de arquitectos como Oiza, Calatrava, etc.]

${ }^{171}$ Helio Piñon. Ibidem.

172 Plaza de la Estacion de Sants. 1981-1983.
} 

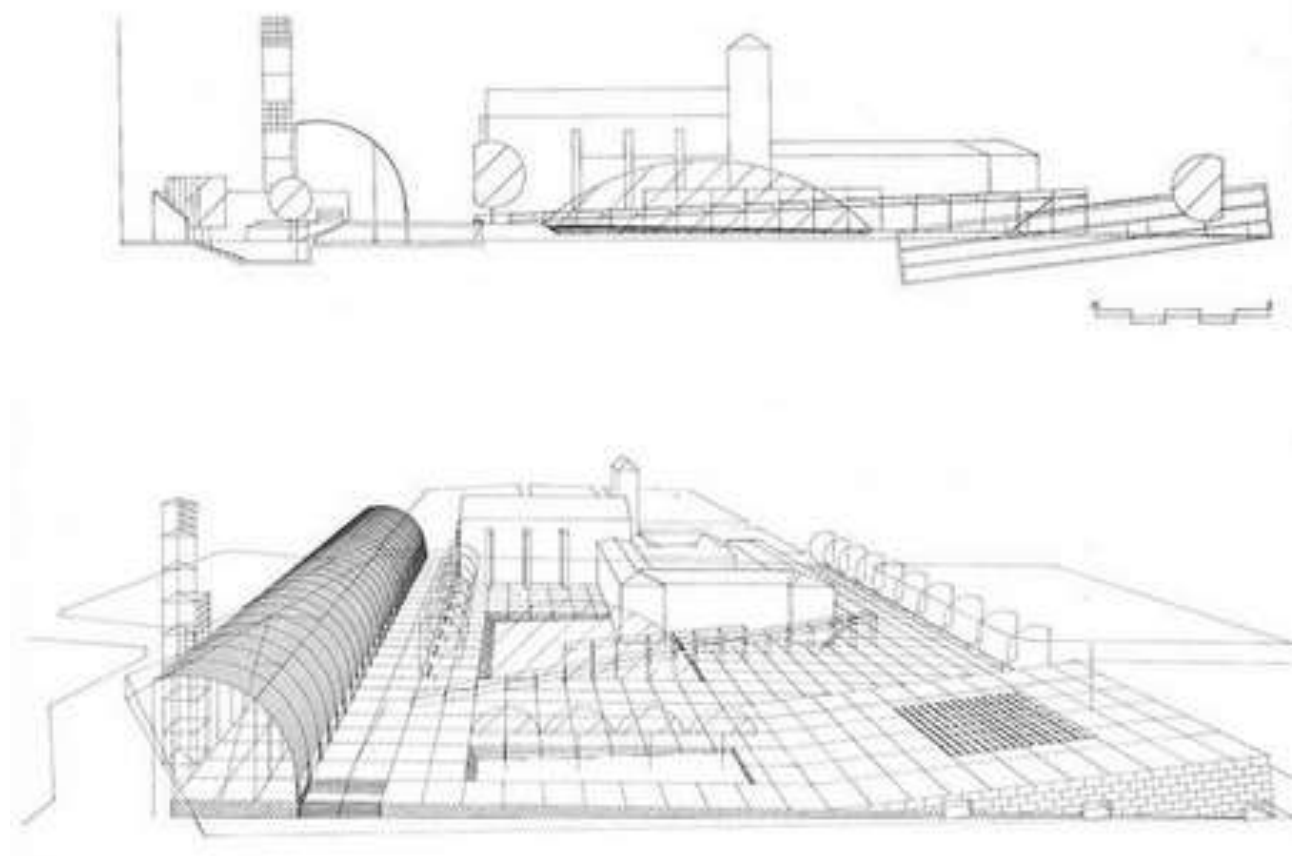

Por tanto son evidentes las enseñanzas que recibio el joven colaborador Mlralles durante 10 años en el estudio de Viaplana y Piñon, que formaran parte de su ADN de arquitecto, y que ya en solitario las hara pasar por su tamiz y llevara a limites que sus mentores ni imaginaban.

La profesora Marta Llorente, conocedora de la ETSAB de aquellos años en los que Miralles era estudiante, defiende lo importante que fue Albert Viaplana para Miralles, puesto que desde que siendo estudiante comenzó a trabajar en el Estudio de Viaplana, estuvo sentado en la mesa contigua, aprendiendo mucho de sus conocimientos. Fueron años de una relación muy intensa, y Viaplana le consideraba un discípulo. Por eso cuando el discípulo decidió volar solo, el Maestro no se lo perdono. Además, Miralles dejo una carta escrita de despedida a Viaplana metida en un sobre que Viaplana se negó a abrir como se ha podido saber después del fallecimiento de Viaplana. ${ }^{174}$

Como muestra de la intensidad en la relacion personal mantenida entre Viaplana y Miralles, que iba mas alla de lo profesional, valga el relato de Carmen Pinos recordando aquellos años: "A Viaplana le conozco al final de la carrera, le conozco por Enric, iba a recogerle y les ayudaba con alguna entrega... bajábamos a la salida por la calle Aribau con Enric y Viaplana todas las noches hablando de Arquitectura, de lo que hacían..." ${ }^{175}$

\footnotetext{
${ }^{173}$ Plaza de San Esteban en Murcia. 1977. A partir de este proyecto de Concurso se inicio un nuevo camino en la arquitectura del Estudio Viaplana PIñon.

174 Trasladado por Marta Llorente al autor de esta tesis.

${ }^{175}$ Podcast Scalae 2006. Conversaciones con Felix Arranz
} 
Uno de los colaboradores de Miralles, Josep Mias ${ }^{176}$ subraya la importancia que fue Viaplana para Miralles, pues según el, le puso en el "grado cero de la arquitectura", al mostrarle la importancia de lo realizado en la Historia de la Arquitectura: "Albert Viaplana permitió a Enric volver a los orígenes de la arquitectura. No tuvo que asumir la evolución crítica que ha creado tantos problemas a los arquitectos europeos" ${ }^{177}$ Miralles, gracias a Viaplana, se ahorro la pérdida de tiempo y el callejón sin salida al que sus contemporáneos se vieron abocados al seguir las tendencias a la moda del momento. Miralles, prefirió por tanto inspirarse en el Renacimiento y en el Modernismo catalán de Gaudí y Jujol cuyas obras además se encontraban en Barcelona y constituían parte de su identidad cultural. Corre el año 1984, cuando Miralles decide abandonar el Estudio Viaplana - Piñón, por desavenencias al no considerarle autor en los créditos de los proyectos en los que colaboro, y decide montar su propio estudio junto con su mujer y arquitecta Carmen Pinós, continuando la lección aprendida con Viaplana Piñon: La capacidad de abstracción; la síntesis del lenguaje arquitectónico con el que expresarse; el entendimiento que la arquitectura es un oficio con responsabilidad; el respeto por la Historia y los lugares en los que se interviene; la estética constructivista, etc.

Rafael Moneo, relata el momento de la separación en los siguientes términos: "En 1984 Enric creía que su carrera profesional debía desarrollarse con independencia de quienes habían sido sus mentores. Y que había llegado el momento de encontrar un modo de acercarse a la arquitectura desde posiciones a las que cavia calificar como propias y personales." ${ }^{178}$ Dicha separación la relata bien el critico Peter Buchanan en un articulo de la revista "The Architecture Review" .
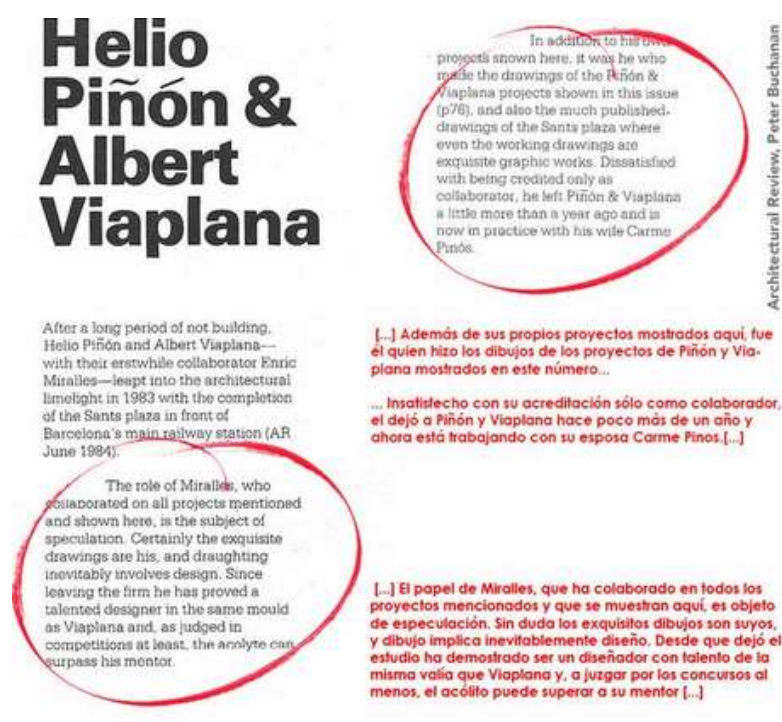
-1. Además de sus propios proyectos mostrodos aqui fue
el quien hizo los dibujos de los proyectos de piñon y Via. plana mostrados en este número.

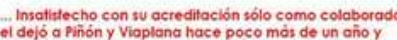
ahora está trabajando con sv esposa Carme Pinos. [.]

1.] E g popel de Mirolles, que ha colaborado en todos los de especulación. Sin duda los exquisitos dibujos son suyos arbujo implica inevitablemente clieño. Descle que dejo

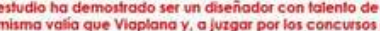

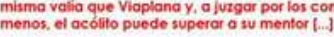

\footnotetext{
176 'Enric Miralles, para evitar equívocos' por Josep Mìas, revista DPA № 17 dedicada a Max Bill, 2001

177 Josep Mias. Ibidem.

178 "Cosas vistas a izquierda y a derecha (sin gafas) Tesis Doctoral de Enric Miralles Moya, 1987" en Enric Mlralles: 1972-2000 Editorial Fundación Caja de Arquitectos 2011. P. 63

${ }^{179}$ En 1986 Peter Buchanan relata en un articulo de la revista "The Architecture Review" la separación de Miralles del Estudio Viaplana - Piñon.
} 


\subsection{EL AMBIENTE EN QUE SE GESTA SU ARQUITECTURA}

\section{El clima arquitectónico mundial}

Fallecidos los Maestros del Movimiento moderno (Frank Lloyd Wright en 1959, Le Corbusier en 1965, Mies Van der Rohe en 1969, Louis Khan en 1974, Alvar Aalto en 1976.) el clima arquitectónico en el que comenzara a gestarse la arquitectura de Enric Miralles se encuadra dentro de la tendencia dominante en aquellos tiempo del Postmodernismo, siendo los Neomodernos y las Neovanguardistas episodios del mismo movimiento.

a) En Europa Occidental, se crea una escuela en torno a los escritos de Ernesto Nathan Rogers en Milán que derivara en la Tendenza. Personajes como Aldo Rossi, Manfredo Tafuri, Carlo Aymonino, Gian Carlo de Carlo, Vittorio Gregotti, Giorgo Grassi, etc. comienzan a valorar la Historia que el movimiento moderno había desechado. Destaca dentro de las aportaciones teóricas el libro escrito por Aldo Rossi en 1966 "La Arquitectura de la ciudad", en el que se defiende la relación de la arquitectura con el lugar, al defender que la arquitectura depende y está condicionada por el lugar; se critica la incoherencia del funcionalismo y se determina que los lugares son más fuertes que las personas, el escenario es más importante que el acontecimiento.

b) En los Estados Unidos de América, irrumpe la figura de Louis Khan, quien rompe con la máxima de Louis Sullivan según la cual "la forma debía seguir a la función". Para Khan, la función no generaba la forma, inspirando a uno de sus discípulos, Robert Venturi, que en 1966 escribe: "Complejidad y contradicción en la arquitectura", escrito el mismo año que el libro de Rossi. En este libro de Venturi, destaca el interés de la Historia de la Arquitectura; se presta especial atención al Barroco y al Manierismo (Miguel Angel, Giulio Romano...); se determina que las obras encierran complejidades y contradicciones en sí mismas, que son impuras pero a la vez llenas de riqueza y sabiduría; se desecha "la caja" o espacio único multifuncional y se apuesta porque cada elemento arquitectónico cumpla su cometido independientemente del resto de elementos.

c) Surge el movimiento anglosajón "New Brutalism" difundido por Reyner Banjam en su libro "Theorie and design in the first machine age".

d) En 1975 Charles Jencks publica "The Language of Post-Modern Architecture" como un intento de acabar con la tradición moderna de la arquitectura, al considerar la continuidad del proyecto moderno uno más, entre las diversas actitudes que existían en la producción arquitectónica internacional.

Todo este "zeitgeist" o espíritu de los tiempos, tendrá influencia en Enric Miralles. 


\section{El contexto socio cultural}

"si lo ubicamos en el tiempo, es el Madrid de la movida y la Barcelona del diseño...en ese contexto, la arquitectura era todavía seria, muy deudora de lo que se enseñaba en las Escuela y Mlralles era una 'rara avis'".

Anatzu Zabalbeascoa. ${ }^{180}$

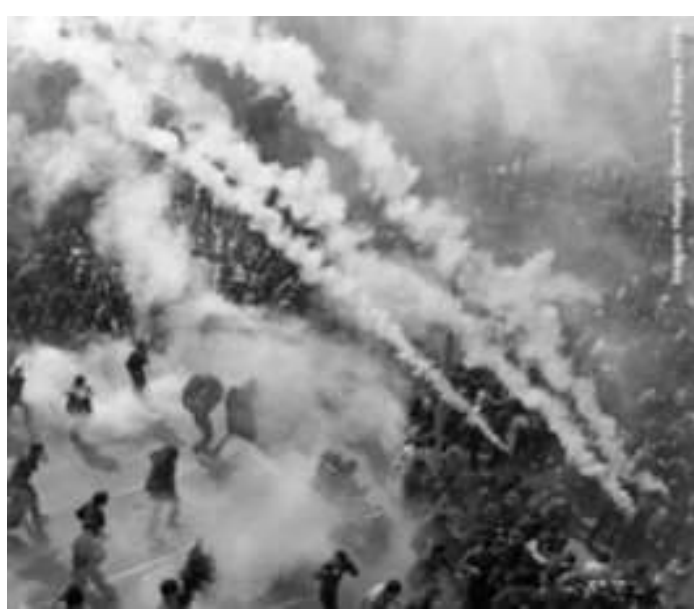

Ilustración 2-50 ${ }^{181}$

Los años de estudiante de Miralles en los años 1970s fueron tensos por las continuas manifestaciones y huelgas acaecidas en los últimos años de la Dictadura. De hecho el primer curso de Miralles como estudiante de Arquitectura, la ETSAB permaneció cerrada mucho tiempo por la crispación del ambiente en la calle. ${ }^{182}$

En la segunda mitad de los años 1970s, la transformación del régimen político español lleno de optimismo los trabajos cívicos y culturales de la arquitectura. La Administración confió en muchos casos en arquitectos jóvenes, sin experiencia profesional, para apoyar la nueva imagen figurativa que entendía debían tener los nuevos programas arquitectónicos de arquitectura pública. Todo ello genero la atención internacional sobre la arquitectura que se estaba haciendo en Cataluña en aquellos años.

La llegada al poder de los socialistas en 1982, fue un cambio significativo, en especial para la Arquitectura como manifestación del nuevo poder, ya que las

\footnotetext{
${ }^{180}$ Extracto del Programa televisado en TVE "La mitad invisible: el Zementeri de Igualada". Con la intervencion de Carmen Pinos, Benedetta Tagliabue y Anatzu Zabalbeascoa, proyectado en television el dia 29 de Septiembre de 2015

181 La etapa de estudiante de Miralles fue muy convulsa debido a las continuas huelgas y manifestaciones muestra de la crispacion social con la politica dominante.

182 Este tiempo lo aprovecho Miralles días para asistir a Academias de Arquitectura y visitar librerías para comprar libros, según cuenta su compañero de estudios en aquellos primeros años Enrique Granell.
} 
instituciones públicas apostaron por regenerar las ciudades, movidas para dar respuesta a unos ciudadanos que llevaban tiempo reclamando mejoras en sus barrios, dotaciones públicas: colegios, bibliotecas, centros de salud, etc. Carmen Pinos relata lo que significaron aquellos años de oportunidades para los jóvenes arquitectos: "...la llegada de los sociatas al poder nos vino muy bien porque confiaron mucho en los arquitectos jóvenes para ayudar a cambiar lo existente, tan es así que había muchos concursos e incluso recibías encargos directamente de la Administración solo por ser jóvenes..." ${ }^{183}$

Oriol Bohigas (por entonces Director de la ETSAB), fue nombrado máximo responsable del área de Urbanismo del Ayto. de Barcelona y Pascual Maragall consiguió la Alcaldia de Barcelona continuando la cruzada comenzada por el anterior alcalde Narcis Serra, de "amueblar la ciudad y regenerarla" con obras de arte y arquitectura de artistas consagrados. Según el crítico de arte Richard Hughes, la ciudad de Barcelona era en aquellos tiempos, la ciudad con mas inversión económica en Arte y Arquitectura de todo el Mundo. Esta situación se reforzó considerablemente cuando Barcelona fue designada para organizar las Olimpiadas de 1992. En el reparto de obras orquestada por Bohigas desde la Gerencia de Urbanismo, para la Villa Olímpica, Miralles, recibió un encargo menor, las pérgolas en la Avenida Icaria, que Miralles, proyecto como protesta ante el tabula rasa de las edificaciones que fueron demolidas para la construcción de la Villa Olímpica. Sin embargo, el segundo de abordo en la Gerencia de Urbanismo del Ayto., Josep Antonio Acebillo, amigo de Mlralles, le encargaría el Complejo de Tiro con Arco en el Valle de Hebrón. ${ }^{184}$

\section{La arquitectura catalana de los ochenta (1980s)}

"...la arquitectura catalana defendió la 'Escola de Barcelona' en los años sesenta, pero en los setenta hay caminos que se alejan de esa ortodoxia...Ricardo Bofill...el estudio PER...la arquitectura de Viaplana-Piñón que irrumpe con toda su contundencia...mas basada en la forma, que defiende el trabajo del arquitecto como algo intelectual con vocación de innovación..."

Josep María Montaner. ${ }^{185}$

Tras la publicación en 1975 del libro de Charles Jencks The Language of PostModern Architecture el posmodernismo fue el movimiento que domino la Arquitectura mundial.

La arquitectura catalana sufrió los avatares de la crisis posmoderna, y los problemas de fondo que el debate posmoderno planteaba tuvieron en Barcelona una particular asimilación y respuesta, debido a las nuevas circunstancias políticas y culturales marcadas por la transición desde la dictadura hasta la democracia.

\footnotetext{
${ }^{183}$ Carmen Pinos. Conferencia dictada en Curso de verano de la UIMP, "alegoria del tiempo: la arquitectura y el universo de Enric Miralles"., Barcelona, 2009.

${ }^{184}$ Latzer Moix . "La ciudad de los arquitectos"

185 "Reportaje televisado sobre la obra de Viaplana - Piñón". TVE. Diciembre de 1990. [fueron una serie de reportajes televisados sobre la obra de arquitectos como Oiza, Calatrava, etc.
} 
Frente a la arquitectura objetual que se estaba realizando en los EEUU, ó la arquitectura de Italia (reconsideración de modelos ideales); la arquitectura catalana de los años ochenta tendrá como elemento diferenciador la relación que establece su arquitectura con el lugar urbano. El objetivo de estas arquitecturas es completar una ciudad llena de lugares residuales, aéreas degradadas, periferias..., mejorándola, siendo el lugar, el elemento generador de la arquitectura. Los instrumentos se encontraran en la tradición académica de la ciudad decimonónica reflejada en los escritos de: Sitte, Stüben, Jaussely... para los cuales la arquitectura es un arte cívico, una contribución a la vida civil. De esta manera se enlazaba con el legado cultural del Noucentisme haciendo que el clima catalán de los ochenta sea de recuperación noucentista: primacía de la ciudad; equilibrio entre lo público y lo privado; relación con los elementos de identidad de la tradición del siglo XX, etc. ${ }^{186}$

En la arquitectura mas celebrada de esos años se distorsiona el lenguaje clásico, enlazando con la arquitectura de los años veinte situada al margen de las vanguardias y con el clima de la crisis finisecular de la Viena postwagneriana (Un revival vienés que afectara a un amplio sector de la arquitectura catalana de los ochenta). Sera una arquitectura de la continuidad, del equilibrio entre las distintas partes, donde la imaginación y el ingenio serán los generadores del universo creativo.

Sin embargo a finales de los años ochenta, la situación cambiara al llegar a término el renacimiento neo-noucentista. Finalizada la transición política, la entrada de España en la Comunidad Económica Europea (CEE) y el desencanto catalanista, generarán una arquitectura estimulada por la cultura urbana, ante la perspectiva del crecimiento económico y de la internacionalización de la cultura. Las intervenciones de "cirugía y sutura" en la ciudad, dejaran paso a la llegada de los grandes proyectos: edificios en altura, contenedores para la actividad terciaria, parques para disfrute del ocio, infraestructuras, autopistas, hoteles, hipermercados, etc. haciendo crecer aceleradamente una periferia demandara nuevas arquitecturas. La confianza en los instrumentos proyectuales de los arquitectos disminuirá al cerciorarse los clientes (tanto públicos como privados) que dichos instrumentos no eran ya capaces de dar respuesta adecuada a los nuevos retos planteados. Una ideología neotecnológica comenzara a tomar posiciones y así lo plasmaran las paginas de la revista Quaderns d'Arquitectura $i$ Urbanisme, ${ }^{187}$ que destaco por detectar los cambios que se estaban produciendo en aquellos años.

Los arquitectos más inquietos se sumaran a la exaltación de la tecnología en sus proyectos, para escapar de la tradición y el localismo, buscando una nueva objetividad conscientes de no poder resolver ya, con sus obsoletos instrumentos proyectuales, los grandes problemas colectivos que ahora esperaban respuesta rápida encima de sus tableros.

Ignasi de Solá-Morales detectara un cambio de tendencia en la arquitectura catalana, analizando la obra de: Garces y Soria, Miralles y Pinós, Viaplana y Piñon, Llinas, Clotet y Elias Torres, que demostraran con su obra la apertura de nuevas vías las que transitar. Estas arquitecturas renuncian a la obsesión dominante por la referencia contextual urbana y afrontaran una arquitectura relacionada con la cultura internacional, abandonando su pertenencia al equipo local de de la

\footnotetext{
${ }^{186}$ Ignasi de Sola Morales "Arquitectura catalana 1990" Quaderns 187

${ }^{187}$ Dirigida por Josep Lluis Mateo desde 1981 hasta 1990.
} 
"Escuela de Barcelona" y sintonizando con el conceptualismo artístico de la artes plásticas que había ido ganando terreno en esos años. ${ }^{188}$

Estos arquitectos generaran unas arquitecturas que serán la materialización sensible de sus ideas, en las que el proceso de proyecto, será el que genere las nuevas formas de Arquitectura. Ello conllevara una autorreferencialidad que les mantendrá alejados del contextualismo. Conscientes de la fragilidad de la arquitectura como mensaje, se permitirán la ironía y el juego empleando su talento en demostrar la débil condición que todo producto cultural tiene en una sociedad que devora cualquier producto creativo. ${ }^{189}$

Desde mediados de los ochenta, la Escuela de Barcelona daba signos de esterilidad pero a pesar de ello seguía manteniendo su poder para imponer la arquitectura de la Barcelona preolímpica. Oriol Bohigas como responsable máximo del urbanismo de la ciudad. La dura pugna en lo académico de Bohigas con Rafael Moneo, hizo que una serie de profesores se decantaran por el navarro y sus enseñanzas, intentando actualizar y cambiar el discurso de la arquitectura catalana adaptándose a los nuevos tiempos. ${ }^{190}$

En la necesidad de renovación de aquellos años tuvo mucho que ver el papel desempeñado por la revista Quaderns d'Arquitectura i Urbanisme ${ }^{191}$ dirigida por Josep Lluis Mateo desde 1981 hasta 1990, marcando un cambio de rumbo de la tradición marcada aun por las directrices obsoletas de la Escuela de Barcelona, para con ello reformular los objetivos de la profesión. Y según Ignasi de SoláMorales, como alternativa a esta alternativa, para renovar lo local de otra manera es donde entra en juego el trabajo de Miralles y Pinós, cuyas obras no son fáciles de encajar en aquellos tiempos por su radical novedad. En su obra, existía una preocupación por la referencia y por una idea de lugar generada desde el proyecto; pero lo que les separaba de la lista de alternativos a la alternativa de la Escuela de Barcelona era precisamente el valor que lo constructivo tenía en su obra, reformulando lo constructivo al margen de todo moralismo.

De manera que Miralles y Pinós no solo no renunciaran a los dos grandes temas de la tradición local: lugar y construcción, sino que pondrán uno al servicio del otro entendiendo que la idea de lugar y de construcción son muy otras. Si los intereses intelectuales de los arquitectos catalanes mas punteros, se centraban en asimilar las ultimas tendencias arquitectónicas que venían de fuera a través de Aldo Rossi, Robert Venturi, Alexander, Miralles y Pinos se interesaran por arquitecturas producidas mucho antes: "El problema con los arquitectos vivos es que estas demasiado apegado a ellos, compartes demasiadas cosas. Siempre me han atraído aquellos que son mas remotos donde tienes que efectuar un esfuerzo de interpretación". ${ }^{192}$

La pareja de arquitectos, prefirieron no hacer lo que hacían los arquitectos punteros de su tiempo sino construirse a si mismos. Viajes y lecturas, con tiempo y sin prisas. En sus primeros proyectos la torpeza en algunos detalles tambien

\footnotetext{
188 Ibidem

189 Ibidem

${ }^{190}$ Ibidem

${ }^{191}$ Revista oficial del Colegio Oficial de Arquitectos de Barcelona. COAB.

192 Enric Miralles. “Technology, place and architecture”.1998.
} 
sacuden por su contundencia. Los Smithson y algo del New Brutalism están detrás de ello. Recuperan el expresionismo y un uso audaz de los materiales, el espíritu de la arquitectura catalana de finales del siglo XIX y principios del XX, las raíces de Gaudí, Jujol y Coderch y de las obras maestras de la Arquitectura de todos los tiempos, en especial la realizada por los arquitectos rompedores como: Miguel Angel, Giulio Romano, Alberti, Borromini, Palladio, etc Según cuenta Ricardo Flores colaborador en el estudio de Miralles: "Otra de las cosas que nos llevamos del paso por ese estudio fue una biblioteca compartida... lo más importante fue aprender de él los autores que él miraba y cómo los miraba." 193

Cuenta Ramón Faura ${ }^{194}$ que la idea de una arquitectura local amenazada por lo global solo es enunciable si se entiende que la identidad de lo local se sustenta en el control de la obra. La Escuela de Barcelona se basaba en el esfuerzo, la modestia y la desconfianza ante cualquier práctica multidisciplinar que atentase contra la integridad del oficio. Existía un miedo local a la globalización que de imponerse traería consigo una pérdida del estatus al que pertenecía entonces la profesión. Un miedo a que la llegada de nuevos modos de producción conllevase la pérdida de poder frente al operario artesanal de la obra que se reconvertiría en industrial. Pero lo cierto es que la desaparición de los artesanos, la masificación de la universidad con excedente de titulados y los flujos de capital al margen de identidades que traería la globalización; convirtieron en simulacro aquello que se presentaba como depositario de lo local.

Al termino de las Olimpiadas quedara patente como la oda al oficio entonada por Coderch años atrás tan repetida después por la Escuela de Barcelona no podrá seguir siendo la consigna al quedar determinado con claridad un panorama arquitectónico dominado por las practicas globales y por poderes económicos que llegaran a situarse por encima de los poderes locales. A partir de este momento el arquitecto entiende que para ser respetado y poder ejercer la profesión con suficiente autonomía, tendrá que tener un elevado reconocimiento mediático.

Kenneth Frampton destaca la inagotable capacidad catalana para la poesía topográfica, y su resistencia a la uniformidad universal de la globalización. La tectónica y la topografía son dos atributos con los que cuenta la arquitectura catalana desde la Edad Media y siguen muy arraigados. Como paradigma contemporáneo de la aplicación de ambos atributos valgan las instalaciones de tiro con arco realizados por Miralles y Pinós en el Valle de Hebrón para las Olimpiadas de Barcelona 1992.

En 1991, la tradición local a la que pertenecen Miralles y Pinós, todavía vive anclada en una arquitectura que exhibe la humildad conceptual y la modestia formal como sus grandes valores. Una tradición local que se presenta como un gremio. En el mes de septiembre de 1991 cuando la revista El Croquis publica un numero monográfico sobre la obra de Miralles y Pinós, nada se sabe todavía del efecto Guggenheim de Bilbao; de la ciudad de la cultura en Santiago de Compostela de Peter Eisenman; de los escritos de Stan Allen sobre la arquitectura como campo; ni siquiera se está habituado a proyectar con programas de diseño

\footnotetext{
${ }^{193}$ Ricardo Flores. "Las tardes de dibujo en el estudio Miralles \& Pinós"

194 Ramón Faura. "Palacio de deportes Huesca 1988-1994. Club de tiro con arco Barcelona 19891991" EM 1972-2000. Barcelona. Fundación Caja de Arquitectos. 2011. pag. 173-199

${ }^{195}$ Kenneth Frampton. "Sobre la tradición tectónica en la forma catalana contemporanea" Quaderns 206.
} 
asistido por ordenador y la proliferación de sus complejas geometrías. En 1991 todavía no se ha celebrado la Olimpiada de Barcelona que convirtió el espacio público en espacio de consumo. En 1991 las instalaciones de Tiro con Arco están terminadas y el Cementerio de Igualada se encuentra casi terminado. La critica recurrente sobre estas primeras obras de Miralles y Pinos, será la falta de rigor constructivo, cuando es precisamente el valor de la construcción, la condición materia de estas arquitecturas lo que podría vincular esas primeras obras con la tradición local empeñada en presentarse como gremio. En estas obras, no hace falta analizar el detalle constructivo para saber de que están hechas.

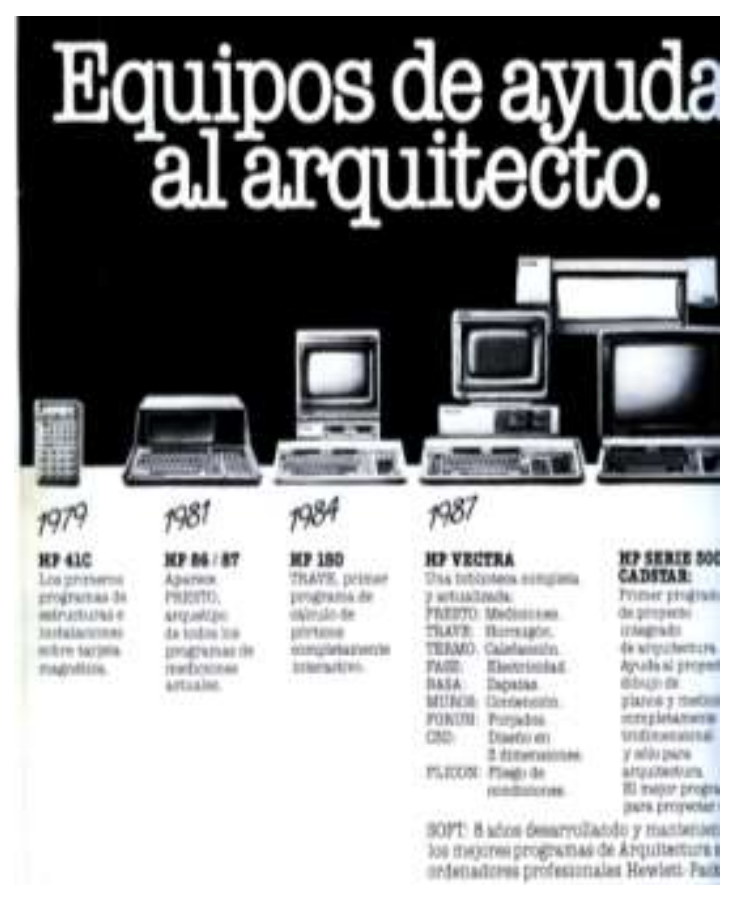

Ilustración 2-51 ${ }^{196}$

\footnotetext{
${ }^{196}$ Reseña comercial de los años 1980s extraida de la revista de Arquitectura QUADERNS . Miralles pronto comenzo a utilizar el ordenador, destacando las perspectivas generadas con este medio de su propuesta para el Centro Civico de Hostalets.
} 
EL PARQUE CEMENTERIO EN IGUALADA (1985-1991) 


\title{
3. EL PARQUE CEMENTERIO EN IGUALADA (1985-1991).
}

\begin{abstract}
“...un cementerio no es una tumba. Es más bien una relación con el paisaje y con el olvido: huellas como signos abstractos, una abstracción que se origina en el caminar y en el trazar con los pasos el mejor camino Ese caminar produce un surco que constituye un recorrido de ida $y$ vuelta...donde se inicia el descenso hacia las tumbas, comenzando a olvidar el brutal entorno industrial para concentrarse sobre la topografía natural de ese lugar..Siempre me ha parecido que operaba sobre un lugar donde ese proyecto ya existía, pareciéndome acabado desde el primer movimiento de tierra que se hizo ."
\end{abstract}

Enric MIralles. ${ }^{197}$

\subsection{DESCRIPCION}

Parque Cementerio de Igualada. (1985 - 1994).

Dirección: Països Baixos, 23, Igualada. Barcelona.

Encargo: Concurso 1ำ premio, 1985. Ayto. de Igualada.

Arquitectos: Enric Mlralles y Carmen Pinós.

Dirección de Obra: Enric Miralles (1986 - 1991)

Colaboradores: Se Duch, V. Giró, Josep Mías. Joan Callis, Eva Prats, Albert Ferré. Agusti Obiol y Robert Bufrau (BOMA) en Estructuras

Superficie: $2150 \mathrm{~m} 2$

Presupuesto: 2.707 .000 euros

El Parque Cementerio se apoya en la topografía existente, que modela en terrazas para acoger los enterramientos y los panteones familiares. Dejando a la izquierda la capilla y la zona de servicios, el terreno desciende suavemente en el acceso y el recorrido discurre entre las paredes de los nichos, ligeramente inclinadas, de hormigón prefabricado visto, para desembocar en el espacio elíptico que contiene los panteones. El regreso se realiza por una escalera que atraviesa los bloques de nichos. El cuidado uso de los materiales, la ausencia de revestimientos y el detallado diseño dotan al conjunto de austeridad y solemnidad.

\footnotetext{
197 "Enric Miralles. Obra completa" Juan José Lahuerta. Electa. 1996, pag. 52.
} 


\subsubsection{CONTEXTO}

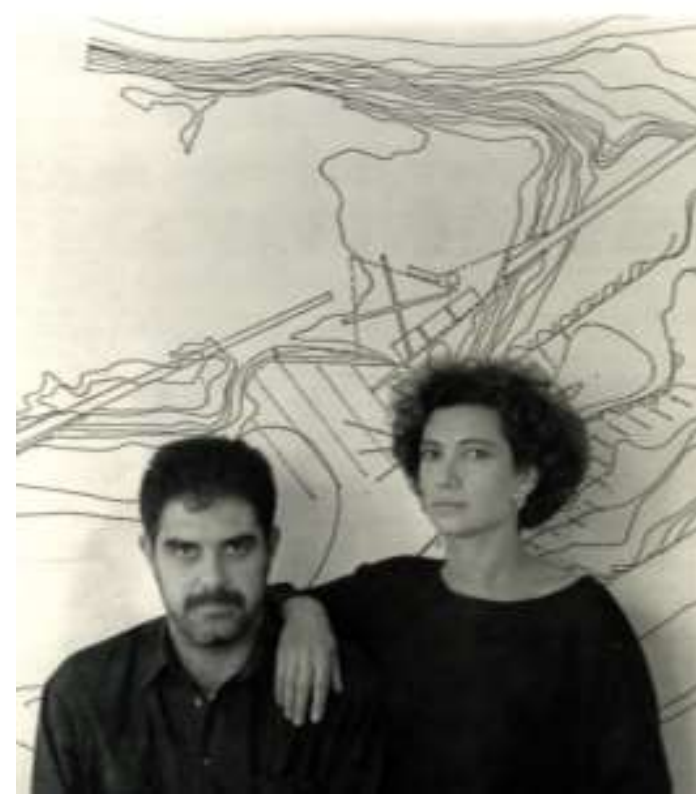

llustración 3-1 ${ }^{198}$

"Nos entendíamos, podíamos decir lo que quisiéramos, sabíamos que el otro iba a da la medida, no teníamos miedo a equivocarnos, la confianza mutua de compartir intenciones era enorme ..."

\section{Carmen Pinós. ${ }^{199}$}

En 1985, el año en que Miralles y Pinós proyectan el Parque Cementerio de Igualada (1985-1991) todavía están terminando las pérgolas de Parets del Vallés, y el Instituto La LLauna. Desconocen que al año siguiente, les encargaran el Centro Cívico de Hostalets de Balenyá y la Escuela Hogar en Morella. En Febrero de este mismo año, Miralles presenta su tema de Tesis Doctoral titulado "Cuando las Catedrales eran blancas". ${ }^{200}$ Miralles es desde el curso 1985-86 profesor titular en la Cátedra de Proyectos V, en la ETSAB. Y Profesor encargado del Taller de Proyectos junto con Alison Smithson, en el primer semestre de dicho curso en la ETSAB.

Las arquitecturas contemporáneas que Miralles miraba del contexto internacional en aquella época eran las de Frank Ghery, Coop Himmelblau y Zaha Hadid. La iraní, había publicado a finales de 1983 su Planetary Architecture Two con su proyecto para Hong Kong. Miralles estaba en sintonía con esas obras de fulgurante

\footnotetext{
${ }^{198}$ Enric Miralles y Carmen Pinos en la mesa de su estudio en Avda. Diagonal de Barcelona, con las imágenes superpuestas aparecidas en la revista El Croquis de 1987 y 1991 respectivamente.

199 "Presencia estructural y otras cosas relevantes 1983- 1986". Enric MIralles, 1972-2000. Fundación Caja de Arquitectos, colección arquia / temas n 33, Barcelona, 2011, pág. 145

${ }^{200}$ La Tesis Doctoral, tras una primera lectura el día 4 de Noviembre de 1987 que no consiguió el Apto, se volvió a realizar el día 25 de Febrero de 1988 con la calificación de Sobresaliente "Cum Laude", doctorándose con 33 años.
} 
aparición. ${ }^{201}$ En 1985, Norman Foster proyecta el Hong Kong and Shangai Bank; Juan Navarro Baldeweg proyecta el Palacio de Congresos y Exposiciones de Salamanca ${ }^{202}$.

En lo relativo a acontecimientos importantes a nivel mundial, Mljail Gorbachov es elegido nuevo líder de la URSS e inicia su perestroika. En lo cultural triunfa la pintura de José María Sicilia. En lo que respecta a España,en el periodo en el que se esta construyendo el Parque Cementerio de Igualada, se produce el ingreso en la OTAN y la CEE animando la economia; Camilo Jose Cela recibe en 1989 el Premio Nobel de Literatura y culminan los preparativos para la Expo de Sevilla y los Juegos Olimpicos de Barcelona.

En 1991, año en que se termina la obra del Parque Cementerio de Igualada; Miralles y Pinos, solo tienen dos proyectos terminados: La Escuela La LLauna en Badalona y las Pérgolas en la Plaza Mayor de Parets del Valles, ambas obras proyectadas cinco años antes. Mientras que el Centro Cívico de Hostalets de Balenya y el Complejo de Tiro con Arco en Barcelona, ambos proyectados en 1989, todavía se encuentran en construcción. Los encargos de mayor escala como el Pabellón de Deportes de Huesca y el Centro de Gimnasia Rítmica de Alicante están completamente dibujados. ${ }^{203}$ Miralles es desde 1990 Director y profesor de la Master Class Städelschule de Frankfurt y en 1992 se incorporara como profesor en la Harvard University con la Kenzo Tange Chair. En lo que respecta al panorama internacional, en 1991: Frank Ghery proyecta el Museo Guggenheim de Bilbao; Robert Venturi obtiene el Premio Pritzker. Como acontecimientos destacables a nivel mundial, estalla la Guerra del Golfo Pérsico; y se asiste a la abolición del Apartheid en Sudáfrica.

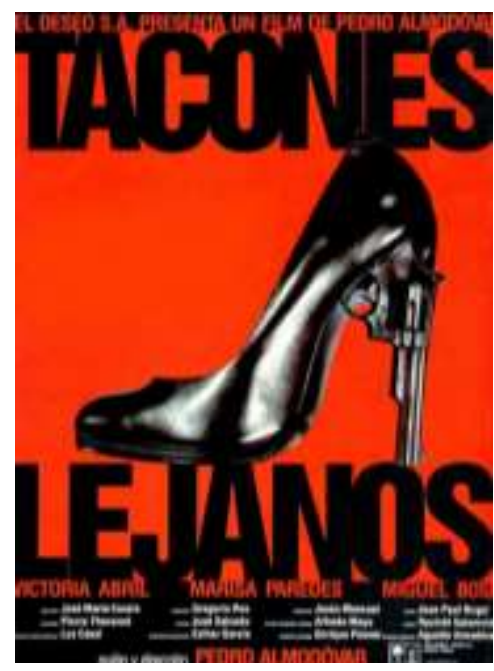

Ilustración 3-2 ${ }^{204}$

\footnotetext{
201 Enrique Granell. Enric MIralles: 1972-2000, Editorial Fundación Caja de Arquitectos, Barcelona 2011, pag. 52

${ }^{202}$ A este Concurso también se presentaron Miralles y Pinós, pero su propuesta no resulto premiada.

${ }^{203}$ William Curtis. "Mapas mentales y paisajes sociales". El Croquis MIRALLES / PINÓS 1983-1990, nº 30, 49+50, pág. 6-21.

${ }^{204}$ La pelicula de cine "Tacones Lejanos" de Pedro Almodovar de 1991 triunfaba en los cines en este periodo.
} 


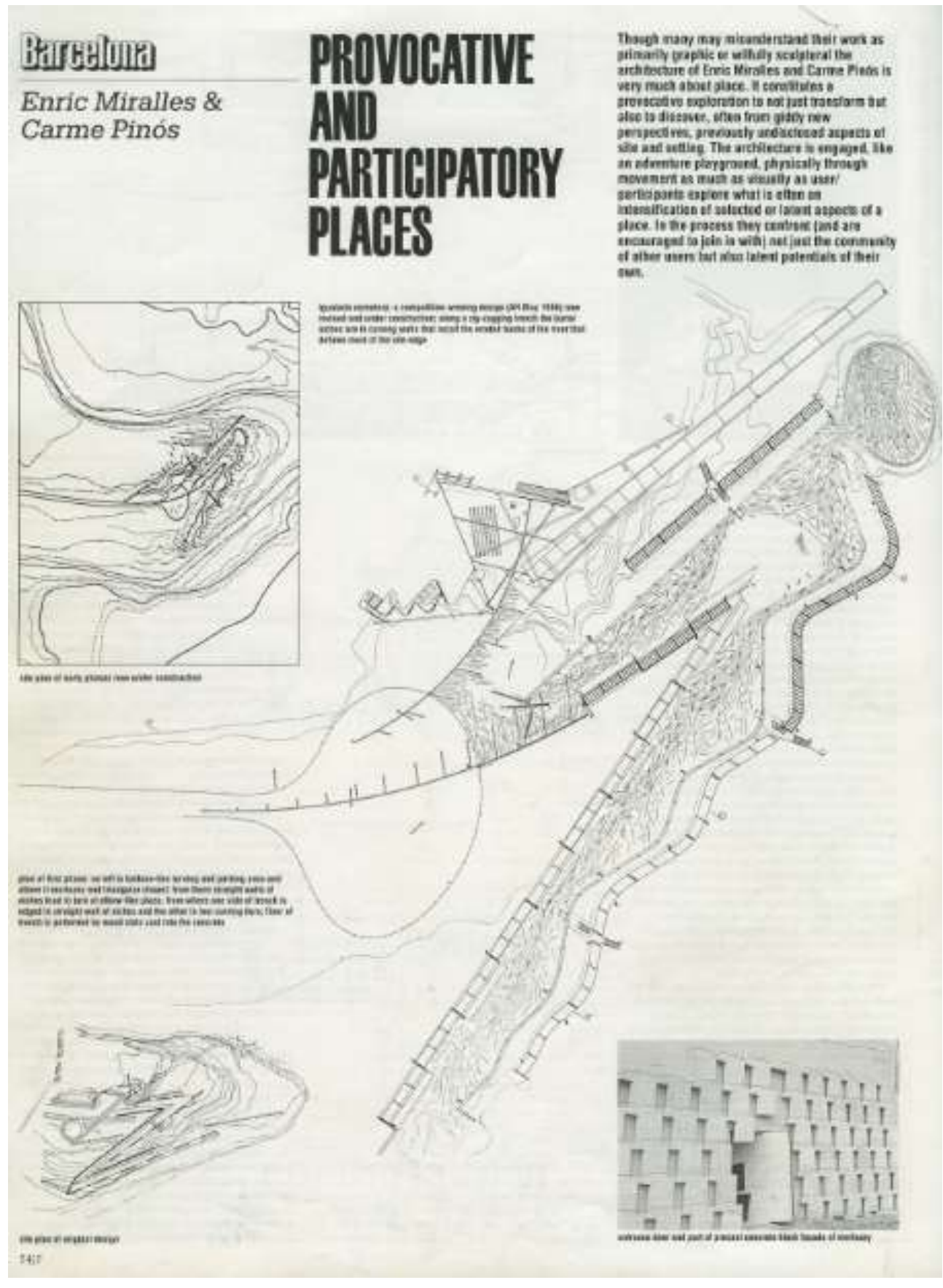

Ilustración 3-3205

205 El articulo de Peter Buchanan "Provocative and participatory places" editado en la revista Architectural Review dio conocer a Miralles y Pinos internacionalmente. 


\section{Relación con el Land Art}

\begin{abstract}
"releyendo el lugar con ojos completamente distintos...En Nueva York descubrimos el Land Art, del que aquí no se hablaba...y alucinamos. De golpe descubrimos a Robert Smithson, Richard Long...con esta gente descubrimos por primera vez, lo que son arquitecturas que reinterpretan el lugar".
\end{abstract}

Carme Pinós. ${ }^{206}$

Hay un guiño en este proyecto a los movimientos culturales y artísticos del momento. Miralles mientras vive un año en Columbia University de Nueva York, conocerá la obra de los Land Artist: Richard Serra, Michael Heizer, Richard Long...así los gaviones de piedra, las traviesas de madera, los desechos industriales (acero en redondos)...deben a estos artistas y al Art Povera su potencial. De esta manera, se consigue una obra que habla más de los propios materiales que de la autoría creativa del proyecto. Muchos de estos materiales provienen del proceso de construcción del propio lugar: los gaviones de piedra, la malla de redondos de acero. Respecto a la relación con la naturaleza, el posicionamiento no es de protección sino de transformación de ésta. La misma actitud que la experimentada por los artistas del Land Art como Michael Heizer o Alberto Burri.

La relación del Parque Cementerio de Igualada con el Land Art, se tiene nada más rebasar su umbral de entrada, en la colina artificial de círculos concéntricos que remite a la obra de Robert Smithson Muelle en espiral (Utah, 1970) generada con las tierras obtenidas de la excavación. La manera en la que la gran grieta practicada en el terreno, conformada por los muros de contención que contienen los nichos de enterramiento en columbario, también recuerda las intervenciones de Richard Serra en el paisaje, que ayudan a realizar su lectura.

Es evidente la analogía que se establece al observar la maqueta de la propuesta de Concurso de Miralles y Pinos, con una vista aérea de la obra de Richard Serra. "Shift" realizada en Ontario, Canada en1970. Para Richard Serra, los elementos escultóricos del Land Art actúan como barómetros para leer el paisaje. De esta manera la obra del land artist hace evidente los caracteres del lugar, su inmensidad, su topografía, su materialidad desvelándolo todo a través del hecho artístico. Richard Serra se interroga sobre los significados originales de la implantación sobre el territorio y estudia el tema evidente-escondido; realidadapariencia. Los muros metálicos de Serra evidencian la topografía natural con un hecho artístico. La obra de Serra, mas allá de establecer una dialéctica entre hombre y naturaleza, define la modalidad de experimentación del hombre que se mueve en el espacio, condensando la percepción de lo local en el interior de lo global y al mismo tiempo, el carácter fenomenológico del conocimiento del ambiente que nos rodea. La relación entre artificio y naturaleza se hace evidente.

${ }^{206}$ Trasladado por Carme Pinós en la entrevista realizada por Arturo Blanco el día 9 de diciembre de 2012 en Madrid. 

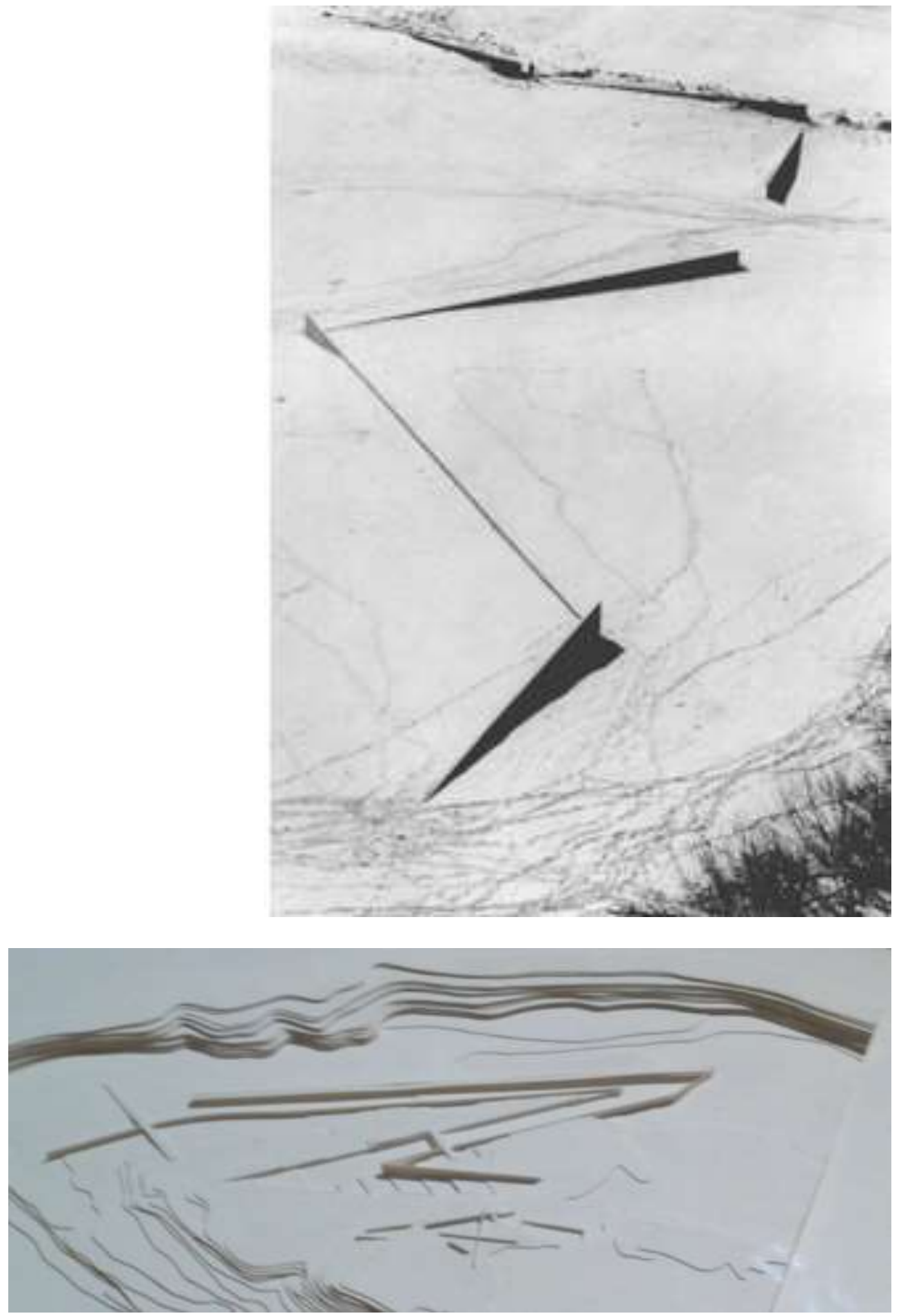

Ilustración 3-4 ${ }^{207}$

207 Richard Serra. "Shift". Ontario, Canada. (1970) versus Enric Miralles. Parque Cementerio de igualada (1985 - 1996). Observese la similitud en la manera de emplear los muros y la tension que se establece entre lo natural y lo artificial 
"En la etapa de Igualada, estudiábamos mucho el Land Art...ahí tienes una buena clave..."

Carme Pinos. ${ }^{208}$

En Diciembre de 1969, Michael Heizer da a conocer la obra "Double Negative". en la meseta Mormon de Overton, Nevada. La obra es el resultado de una gran excavación, extrayendo 250000 toneladas de piedra arenisca y generando dos enormes brechas en el terreno de 9 metros de anchura y 15 metros de profundidad, teniendo una longitud de 230 y 100 metros respectivamente. Dicha intervención, se realizara para dar testimonio de la erosión de los agentes naturales a través del tiempo. Para Antonio Pizza, la relación de esta Obra de Miralles y Pinós con la Obra de Robert Smithson, no solo se debe a sus formas, sino el entendimiento del site y del non - site. Es decir, en la relación que se establece entre dos entes geométricos, en el que uno puede considerarse la imagen especular del otro. Pero la obra también está en la relación que se establece entre los documentos expuestos en la galería de Arte y el Lugar; en la relación abstracta que se da entre los dos extremos. ${ }^{209}$

Es evidente la similitud entre la geometria en zig - zag de la escultura urbana "serpiente de luz" proyectada en la propuesta de la Plaza Barenge de Granollers de Viaplana- Piñon -Mlralles (1982), con la obra de Land Art titulada Rift (1968) de Michael Heizer. Una de los primeras obras de Robert Smithson, Leñera parcialmente enterrada (Ohio 1970) simula el proceso geológico de una duna de arena que mientras va avanzando va enterrando todo lo que se encuentra a su paso, hasta llegar a enterrar y colapsar una leñera. Para su realización, Smithson empleo una excavadora que vertió arena sobre la leñera hasta que colapso. Este simulacro geológico resulto ser una metáfora de la entropía, ese proceso que acaba por destruirlo todo. ${ }^{210}$

Robert Smithson cambio la vision del paisaje contemporaneo al descubrir el valor de los paisajes industriales abandonados, y trajo la vision de lo pintoresco a la contemporaneidad, al valorar los no lugares, lo obsoleto. Defendio el valor de estos paisajes obsoletos, abandonados, degradados, como polos de oportunidad, para lo cual habia que cambiar la mirada y erradicar los prejuicios que se tenian sobre estos paisajes. Segun Javier Maderuelo la aportación de Robert Smithson al abandonar la idea de un arte objetual fue fijarse en el valor del lugar, del sitio, en la capacidad de sugerencia que tienen ciertos emplazamientos concretos del espacio.

Respecto a la relación con la naturaleza, el posicionamiento no es de protección sino de transformación de ésta. La misma actitud que la experimentada por los artistas del Land Art como Michael Heizer o Alberto Burri. Como ellos, en Igualada Miralles y Pinos consiguen con un reducido catalogo de materiales generar una experiencia espacial muy rica, una intensidad notable

\footnotetext{
${ }^{208}$ Trasladado al autor de la Tesis por Carme Pinos en persona el día 23 de Octubre de 2014

209 Antonio Pizza. "Cementerio de Igualada" Conferencia dictada en el Curso de la UIMP 2009. "Alegorías del tiempo: la arquitectura y el universo de Enric Miralles". http://upcommons.upc.edu/video/handle/2099.2/1226

210 Esta obra de Land Art recuerda como Miralles entierra parte de la capilla del Cementerio de Igualada una vez construida
} 

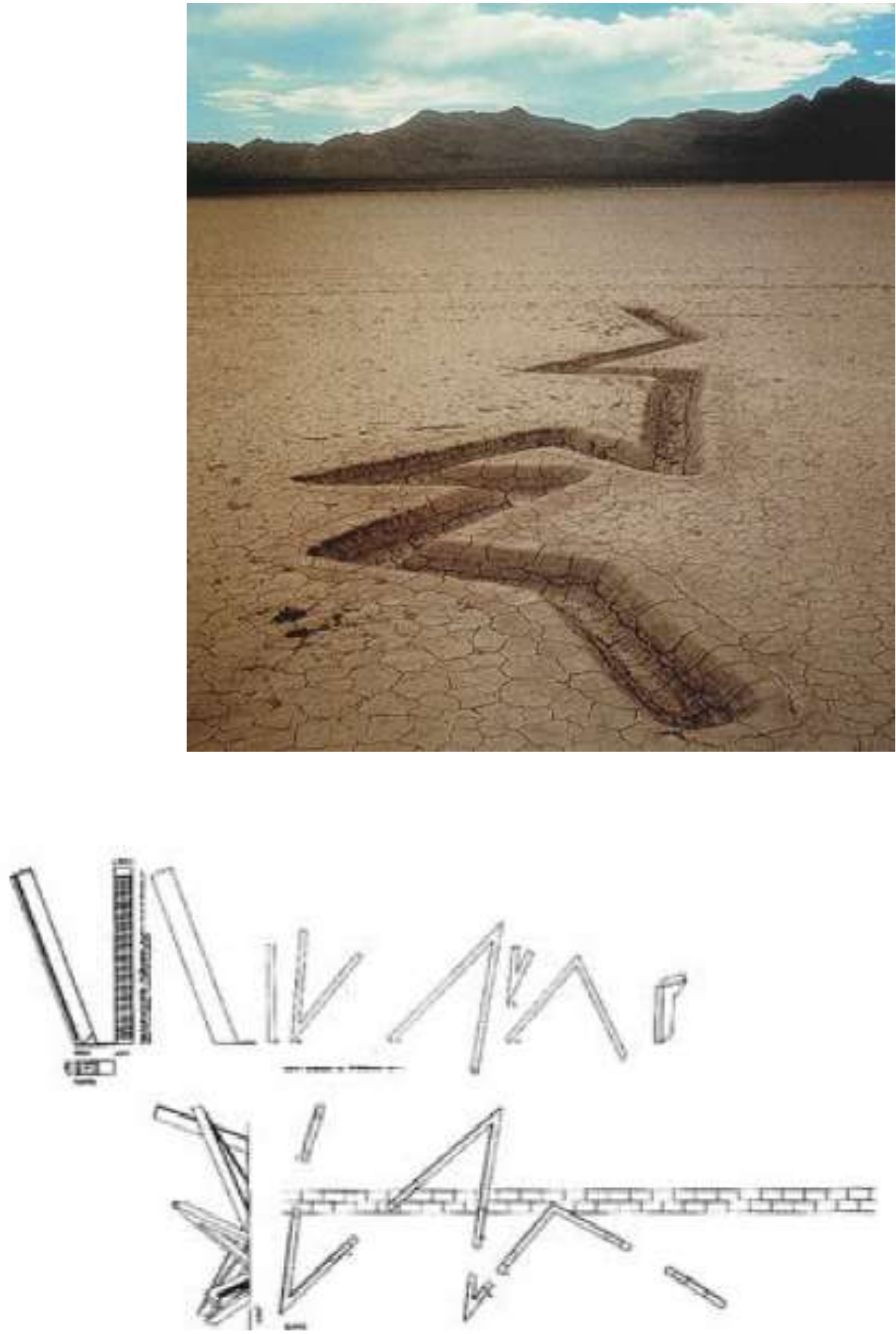

Ilustración 3-5 $5^{211}$

211 Michael Heizer. Rift (1968) versus Enric Miralles-Viaplana-Piñon en Plaza Barenge Granollers (1982) 

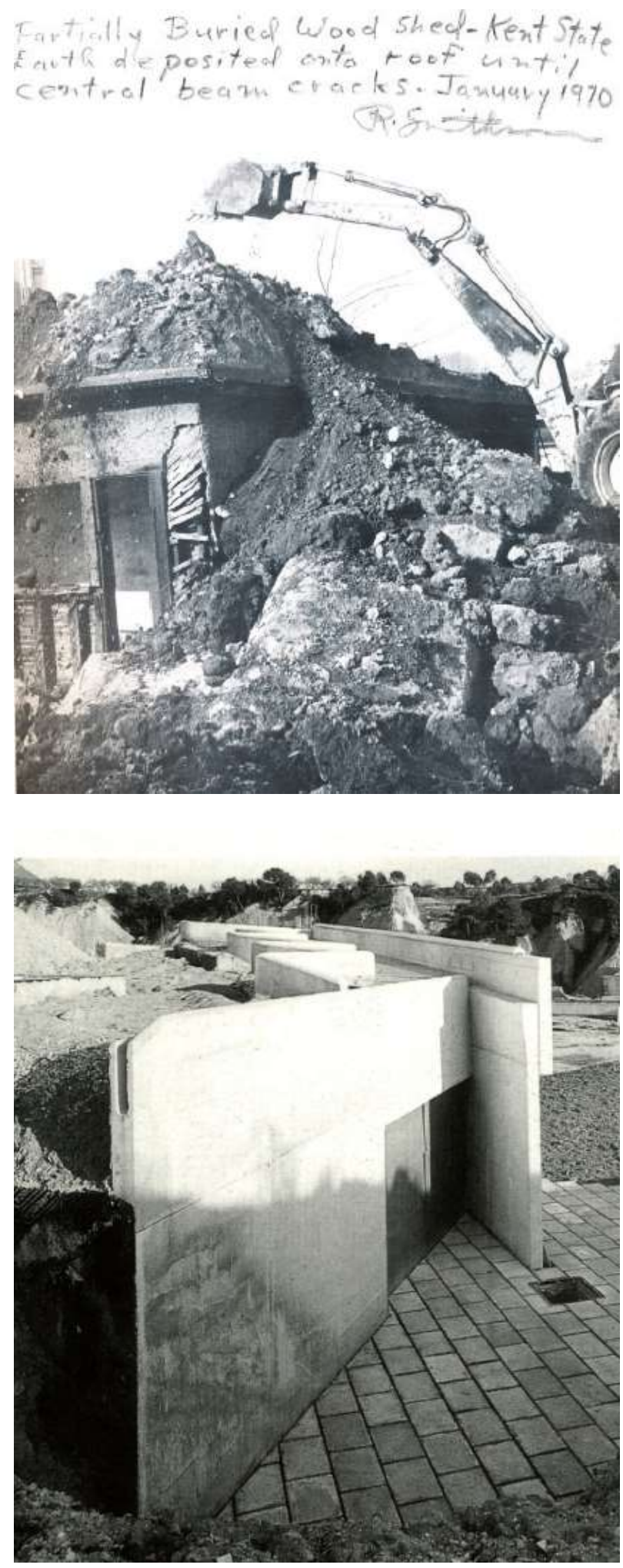

Ilustración 3-6 $6^{212}$

212 Robert Smithson, Leñera parcialmente enterrada, Ohio. 1970 versus Enric Miralles. Parque Cementerio de igualada (1985 - 1996) 

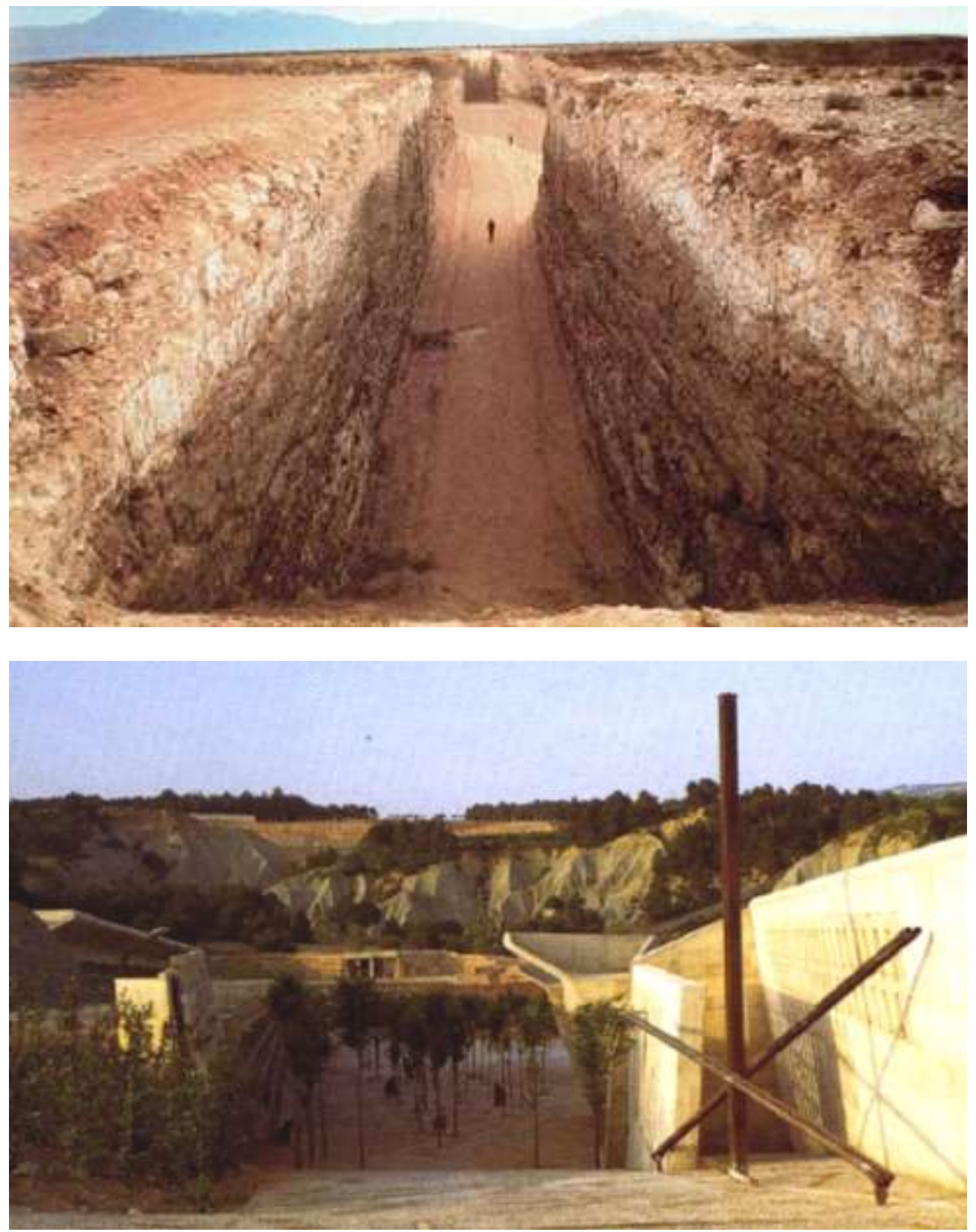

Ilustración 3-7

${ }^{213}$ Michael Heizer, "Double Negative“. Mormon Mesa. Nevada 1969 - 70. Excavación de 250000 toneladas de arenisca. $450 \times 15 \times 9$ m versus Enric Miralles. Parque Cementerio de igualada (1985 1996) 


\section{Relación con otras arquitecturas}

"...Cuando Enric Miralles y Carme Pinós ganaron a mediados de los años ochenta el concurso la crítica internacional reaccionó reconociendo en estos jóvenes arquitectos la producción de un lenguaje donde se conjugaban la obra de Gaudí, Aalto, Jujol, Sostres, Asplund, Le Corbusier... La idea de que el cementerio es una metáfora construida, fruto de la conjunción y del estudio, no sólo de la obra sino del pensamiento arquitectónico de todos ellos. $Y$ en este punto radica su gran valor. No es una construcción de la metáfora, como un ejercicio posmoderno, sino que es la metáfora hecha de piedra, acero y hormigón. La arquitectura escarbada en la tierra."

\section{Fredy Massad y Alicia Garcia Yeste. ${ }^{214}$}
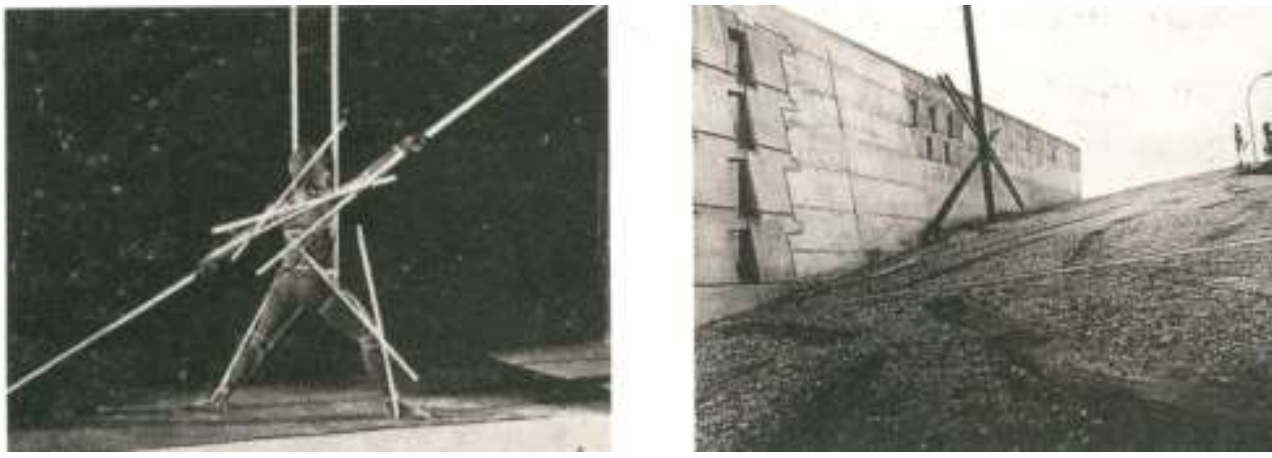

$3-8^{215}$

El Parque Cementerio de Igualada es una intervención que deriva en un culto al lugar, y constituye un homenaje a la arquitectura en la que Miralles y Pinós creyeron. Su obra es un lenguaje que es síntesis apasionada de rasgos de los maestros, de otras arquitecturas, y de un conocimiento emocional del paisaje de Cataluña. Como obra arquitectónica contemporánea, el Parque Cementerio de Igualada es un desafío sobre una forma de plantear las relaciones y diálogos entre hombre- naturaleza- arquitectura, expresando la complejidad de las dimensiones inherentes a cada uno de ellos, como individuales y como tríada indisoluble unida para el espacio y el tiempo. Miralles y Pinós, en Igualada, tienen en cuenta experiencias medioambientales para dignificar el lugar ya realizadas en el pasado: las paredes inclinadas que contienen los nichos recuerdan las realizadas por Le Corbusier en Ronchamp y Chandighar. El desvelamiento de capas en su obra, con el empleado por Carlo Scarpa en el cementerio Brion. El primitivismo que se aprecia en la zona de panteones tiene que ver con los monumentos funerarios de la antigua Micenas.

\footnotetext{
${ }^{214}$ http://vitruvius.es/revistas/read/arquitextos/04.048/581

${ }^{215}$ Oscar Schlemmer. Danza, 1927. versus Cruces de Igualada.
} 

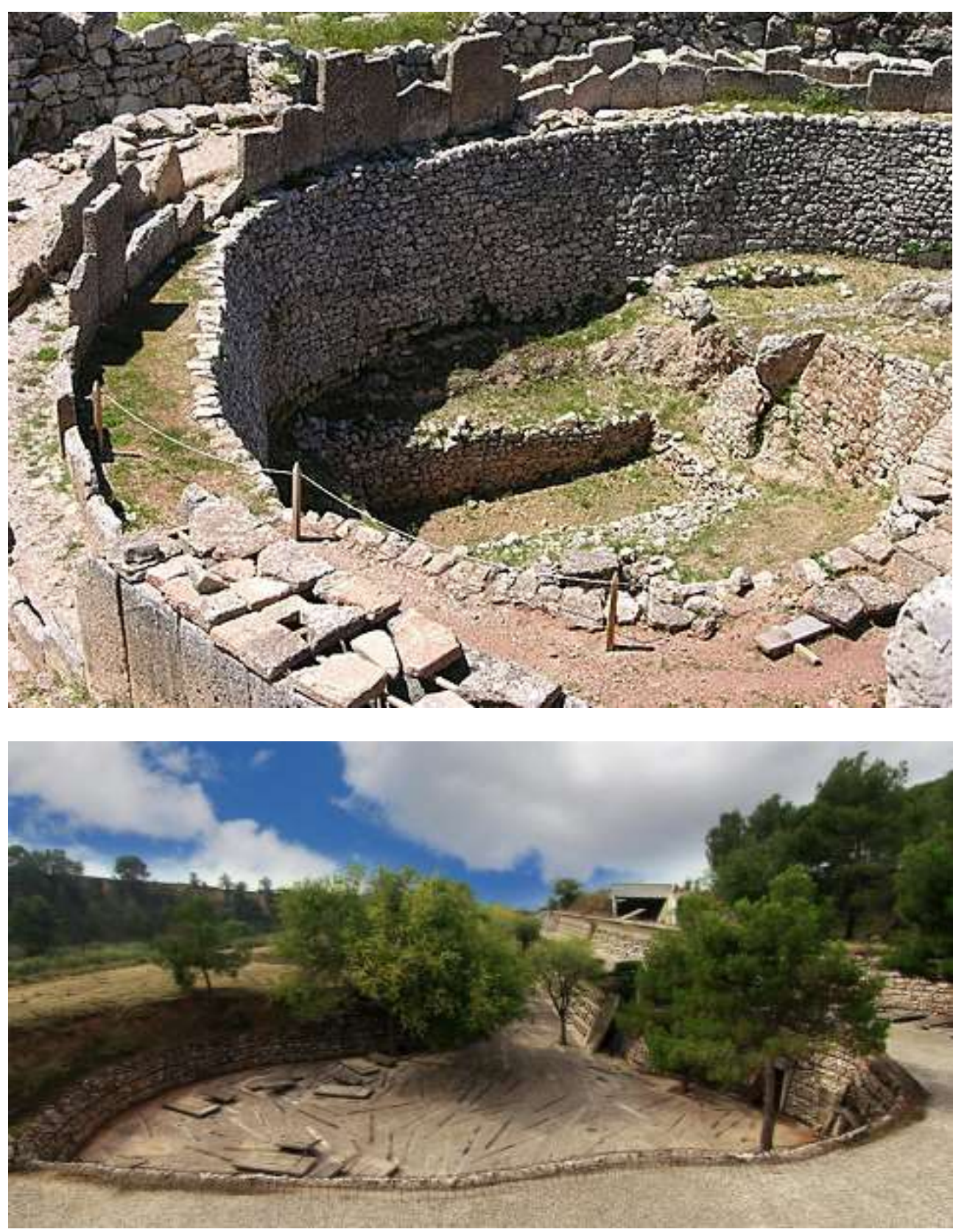

Ilustración 3-9216

${ }^{216}$ Tumba de Vafio en Mlcenas, Grecia (1600 a 1100 a.C.) versus zona de Panteones Cementerio de Igualada (1985 - 2000) 
Enric tenía una enorme capacidad para transformar la realidad. Una transformación, no literaria, que le permitía traducir el Park Güell, y aderezarlo con la obra de Richard Long en el cementerio de Igualada, en el que hoy reposa; que le permitía integrar los gigantes de la mitología catalana con su apuesta formal más novedosa; la visión fragmentaria de Hockney, manteniendo una unidad y coherencia absolutas o reinterpretar el Arlequín no acabado de Picasso con tantos de sus dibujos que insinúan, cuando quieren insinuar, y afirman, cuando así lo pretenden. ${ }^{217}$

En el Parque Cementerio de Igualada, como en el Park Güell de Antoni Gaudí, la arquitectura crea formas naturales, se vuelve orgánica, no copia a la Naturaleza sino que la vuelve a definir. Surge algo sublime como un santuario antiguo. También como hacia Gaudi en el Park Güell, en esta obra, la tierra se percibe "transparente" permitiendo al observador echar un vistazo a su mundo interno. Una abertura practicada en el suelo en forma de escalera permite comunicar los diferentes niveles del proyecto. Al tomar la escalera desde el nivel superior del terreno, donde se ubica la capilla, se entiende bien la idea de levantar el suelo y hacerlo transparente. Miralles lo comenta en estos términos: "...la idea de una tierra completamente permeable, de un suelo cuasi transparente. Esto es lo que me gusta del Parque Güell de Gaudí. Gaudí sabe aprovecharse de las líneas invisibles como las del agua, de las sombras, del movimiento...." 218

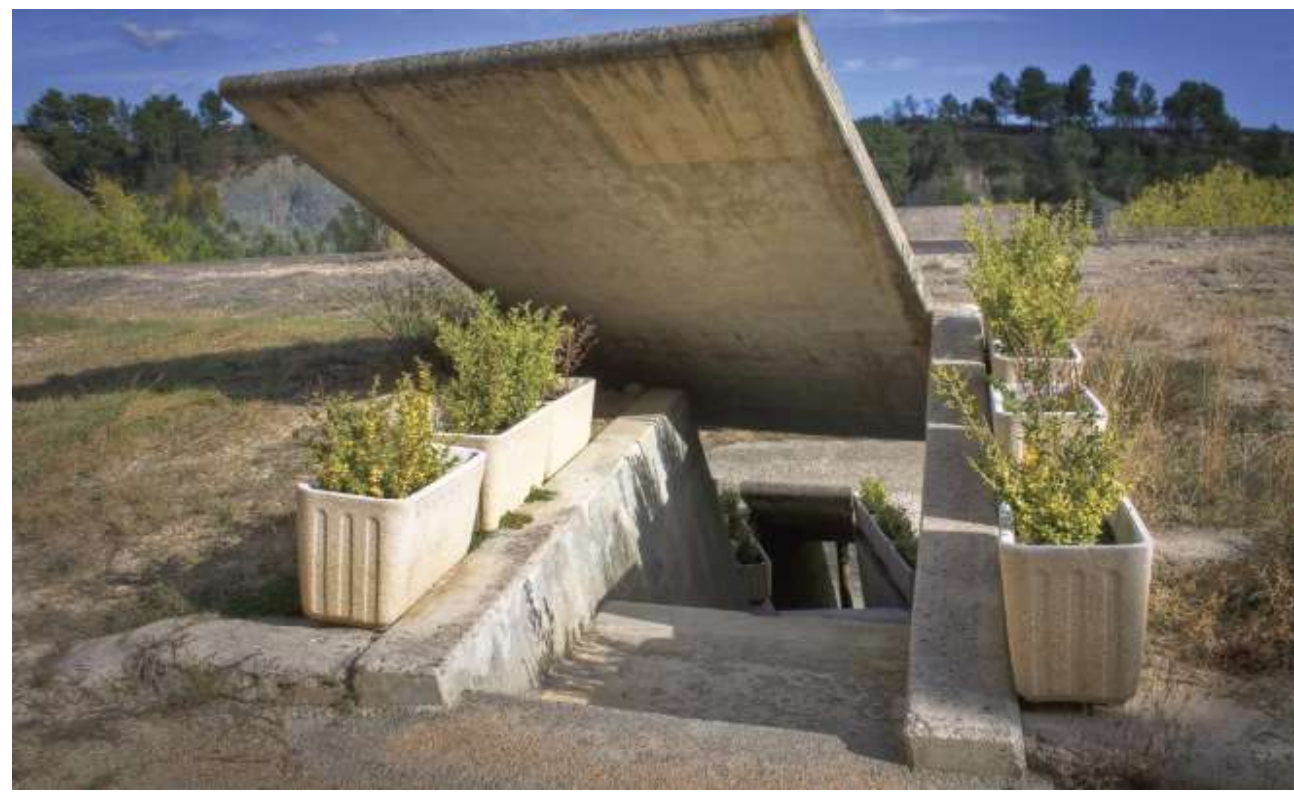

Ilustración 3-10

\footnotetext{
${ }^{217}$ Octavio Mestre. Homenaje a Enric Miralles. Septiembre del 2013. Obtenido en Internet.

218" Enric Miralles. Miralles Tagliabue, arquitecturas del tiempo". Gustavo Gili/Gingko Press, Barcelona 1999.

${ }^{219}$ la idea de una tierra completamente permeable, de un suelo cuasi transparente que defiende Miralles y que aprendio del Parque Guell de Gaudi.
} 

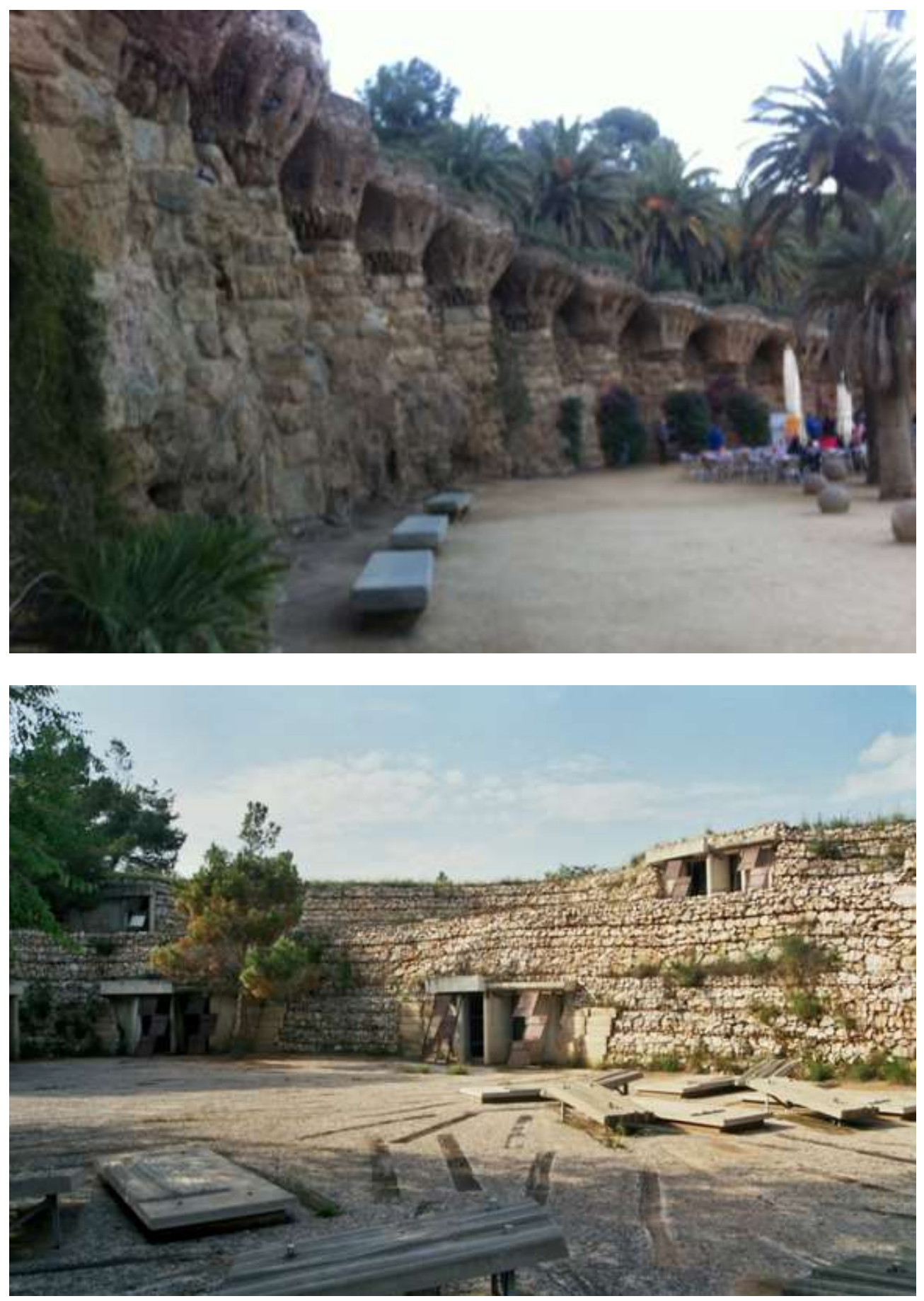

Ilustración 3-11 220

${ }^{220}$ Park Güell de Gaudí versus Parque Cementerio de Igualada 
La influencia de Antoni Gaudi en Enric Miralles se encuentra en toda su obra, Antoni Gaudi tiene en la Naturaleza su principal referente y entiende el tiempo no como algo lineal sino como algo ciclico a la manera de un Kubler (algo en lo que coincidiran tambien los land artists, artistas que tambien influyeron mucho en Miralles). Cuenta Antonio Fernandez Alba, que Gaudi, refleja la sintesis de la integración de la Artes, el arquitecto como sembrador de formas, imágenes y espacios. ${ }^{221} \mathrm{Si}$ Gaudi emplea formas curvas, naturalizadas, inspiradas en la naturaleza: las rocas, las plantas, los animales, es para huir del racionalismo maquinista imperante en su epoca. La Arquitectura de Gaudi, no se concibe como una maquina, sino como un organismo natural, fabricado por artesanos, como trabajan las abejas, las hormigas, etc. En las formas dinamicas de sus trabajos en madera, forja, ceramica, etc. es un canto a la artesanía de la creacion, a imagen y semejanza de la creacion divina. La sintesis de las distintas artes, con una policromia maravillosa...para que al final la materia sea una integracion de distintos materiales y no se sepa si prima la piedra, la porcelana, etc. Para Gaudi, la materia es el residuo del espiritu.

Si Dios creo al Mundo, Gaudi se ve como un servidor de Dios y la creacion en el, esta influida por un sentimiento mistico religioso. Este Panteismo presente en Gaudi, tambien lo estara en Miralles, como en otros creadores como Frank Lloyd Wright. Gaudi, escindido entre la razon y el sentimiento, fue un constructor de espacios, con vinculos surrealistas. Su talento y capacidad plastica de su apasionada personalidad, no tuvo parangon., entre lo racional y lo sensible. Acerto en lograr llevar a la arquitectura mas alla de su momento y de las circusntancias historicas de la epoca que le toco vivir. La visión del espacio desde los presupuestos de un pensamiento generalizador a lo Bergson, la descripcion del tiempo a la manera de un Proust, su Arquitectura se siente acorralada por una escatologia de formas, imágenes de carácter magico, que evocan el acontecer del mito. Lo nuevo siempre viejo, lo viejo siempre nuevo. El mundo del inconsciente, el mundo del sueño de Freud...se refleja en su Arquitectura. Morfologia naturalista de su Arquitectura, la ordenacion del espacio interior como una gruta protectora para que el hombre viva. Frente a la trasparencia del movimiento moderno Gaudi prefiere la opacidad, la gravedad de la materia, como sembrador de formas, imágenes y espacios, nos revela como el arquitecto se enfrenta a la construccion del espacio mediante el lenguaje de la forma, Anticipa el conflicto del arquitecto moderno, entre el final de la individualidad concebida bajo la tradición del humanismo renacentista que tiene que enfrentarse hoy día a una objetividad neutra y abastracta que lo destruye. Gaudi ejercio mucha influencia pero no fue posible que creara escuela siendo una obra tan personal, solo continuada por Josep Maria Jujol, su mas directo colaborador. Algo que tambien ocurre con Mlralles, cuya obra, tan peculiar y personal, es muy dificil que genere discipulos

Luis M. Mansilla nos relata el posicionamiento de Gaudi respecto a la naturaleza: "El Gozar de un arquitecto como Gaudi... es un vinculo entre la obra y la naturaleza... Gaudi acerca la arquitectura a la naturaleza..." 222

\footnotetext{
${ }^{221}$ Notas del autor de la Tesis, tomadas en la Conferencia dada por Antonio Fernandez Alba en Fundacion Juan March. Madrid. 2001

222 "Apuntes de viaje al interior del tiempo". Tesis Doctoral de Luis Moreno Mansilla leida en la ETSAM en 1998 ante un Tribunal de Tesis en el que se encontraba Miralles.
} 

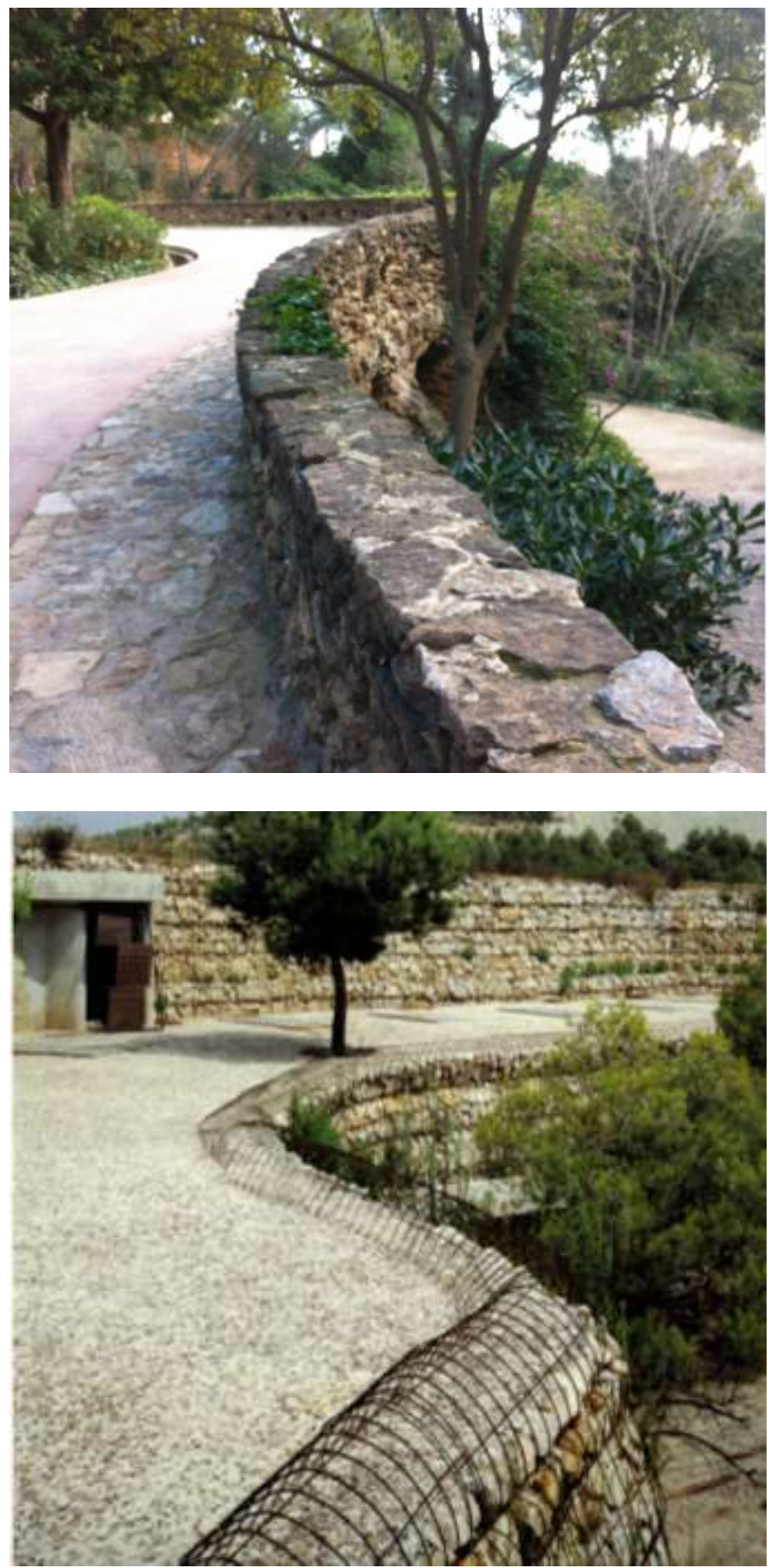

Ilustración 3-12

${ }^{223}$ Park Güell de Gaudí versus Parque Cementerio de Igualada 1 

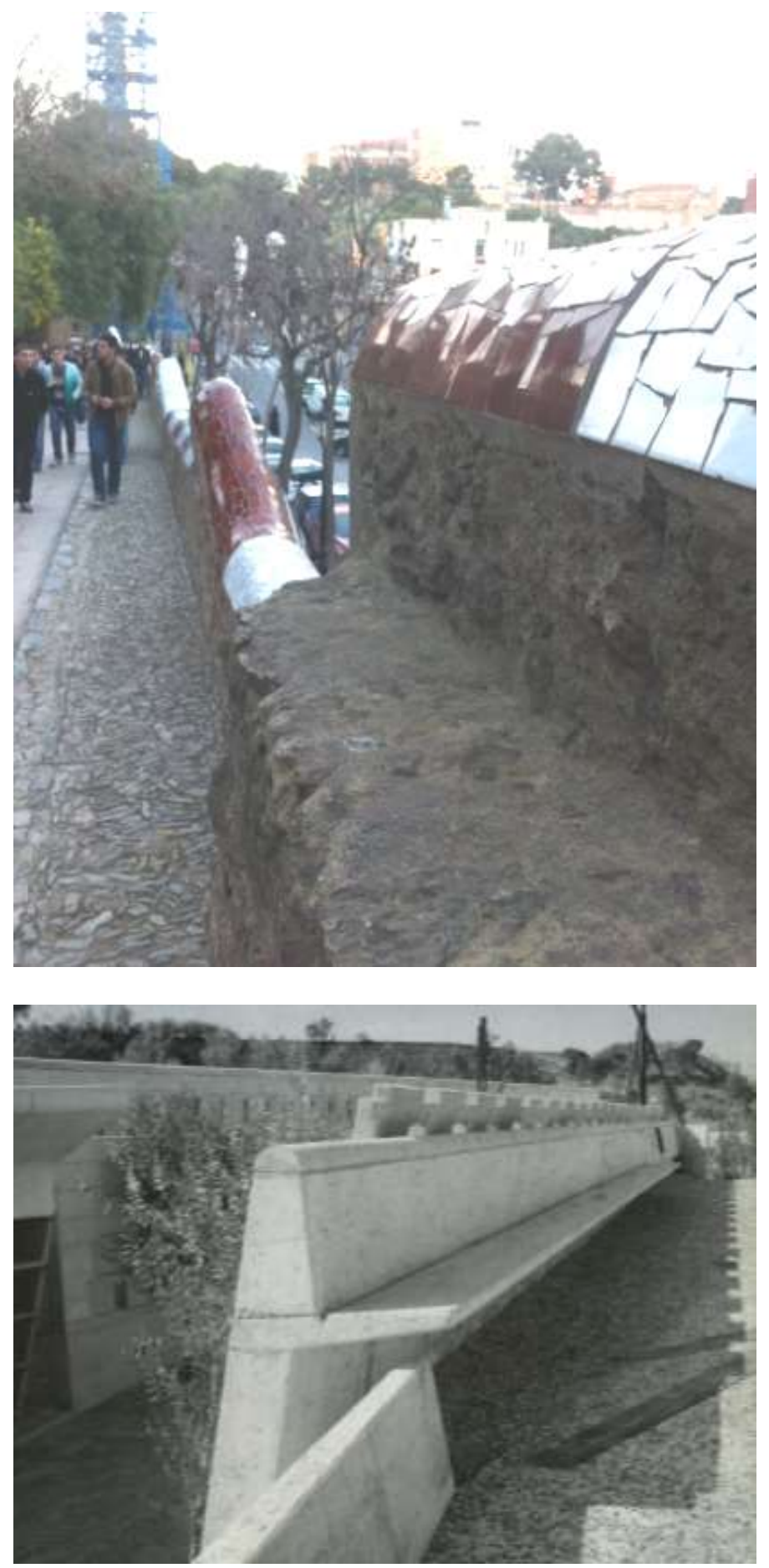

llustración 3-13

${ }^{224}$ Park Güell de Gaudí versus Parque Cementerio de Igualada 2 
En la Antigüedad greco-romana se prohibían los enterramientos en el espacio sagrado alrededor de las murallas, ubicándose las tumbas a lo largo de las vías de salida de las ciudades como por ejemplo en la Vía Apia de Roma, etc. En la Edad Media, se enterraba en emplazamientos lo más próximos posibles a los restos de los Santos, en los recintos próximos a las iglesias. En estos recintos, el Cementerium (lugar donde se duerme) ocupaba un ámbito especifico. A partir del siglo XVIII, se comienza a enterrar en las afueras de las ciudades e incluso se procedió a la exhumación de cadáveres para ubicarlos en las nuevas necrópolis creadas a las afueras. ${ }^{225}$ También, se proyectaron cementerios alejados de las ciudades, como enclaves mono funcionales y exclusivos. Respondiendo a diversas tipologías, destaca el Parque Cementerio por la relación que establece con la Naturaleza, donde lo construido y el paisaje se fusionan. Estos cementerios se caracterizaban por una disposición según una planimetría abierta, los limites estaban constituidos por los accidentes paisajísticos, y el recorrido según itinerarios lineales que se subdividían en otros secundarios que llevaban hasta las zonas de enterramiento y panteones. Dentro de esta tipología de Parque Cementerio se incluyen el Cementerio Woodland (Del Bosque) de Asplund y Lewerentz ${ }^{226}$ y el Parque Cementerio de Igualada. El Cementerio Woodland de 1920, continua la tradición escandinava de cementerios construidos en intima relación con el paisaje. La Colina de la Meditación remite al arquetípico túmulo nórdico, y también el gran vientre de la tierra. Este doble simbolismo representa las ideas de la muerte y de la resurrección. La capilla mayor, la tumba y el vientre materno. Tanto el pórtico como el bosque de la colina de la meditación provocan una tensión entre cielo y tierra, una especie de comunicación simbólica. Los arboles de la colina se levantan hacia el cielo mientras que el pórtico, con su techo invertido y abierto como un impluvium, recibe el agua y la envía al suelo. El crematorio representa una organización lineal, con cabeza conformada por la capilla principal de carácter estático y la cola conformada por las capillas pequeñas, organizadas a lo largo del muro bajo que sigue el camino de acceso. Tema recurrente éste, pues el camino de la cruz era una serpenteante cola que conducía a la capilla mayor en cabeza. Tambien esta en cabeza la capilla de Miralles y Pinos en Igualada. Luis Moreno Mansilla nos resume el acierto de Asplund en Woodland en los siguientes terminos: "Asplund tiene el talento de hacer desaparecer el espacio que media entre la arquitectura y la naturaleza; la acerca hasta que se confunde. La suave pendiente de la capilla grande, la colina de la meditacion, la capilla del bosque tan natural, tan primitiva...La arquitectura de Asplund es emocionante porque establece una relacion con la naturaleza en 'si misma'. ${ }^{227}$ En Igualada, el movimiento es mas lineal, pero no de ida y vuelta, ya que el último destino es la tumba; y no funciona según un pintoresquismo a la inglesa por adición de elementos sino que se valora más la percepción pictórica del paisaje. En Igualada no aparece el símbolo de la cruz porque es el propio lugar, en concreto el suelo, el que hace significante y sagrado el proyecto, sin necesidad de mostrar un símbolo adicional; sigue respetando la convención del cementerio.

\footnotetext{
${ }^{225}$ Como en Paris que se exhumaron veinte mil cadáveres para trasladarlos a las nuevas necrópolis de Montparnasse, etc.

226 Cuenta Miralles en una entrevista que cuando el y Carmen Pinos, ganaron el Concurso del Parque Cementerio de Igualada, se gastaron todo el dinero del premio en un viaje por Escandinavia para visitar in situ en profundidad las obras de Asplund, Lewerentz, Aalto, etc. Aunque Miralles diga que no tenga una relación directa con el Cementerio de Asplund, lo cierto es que en muchos aspectos si que la tiene.

227 "Apuntes de viaje al interior del tiempo". Tesis Doctoral de Luis Moreno Mansilla leida en la ETSAM en 1998 ante un Tribunal de Tesis en el que se encontraba Miralles.
} 

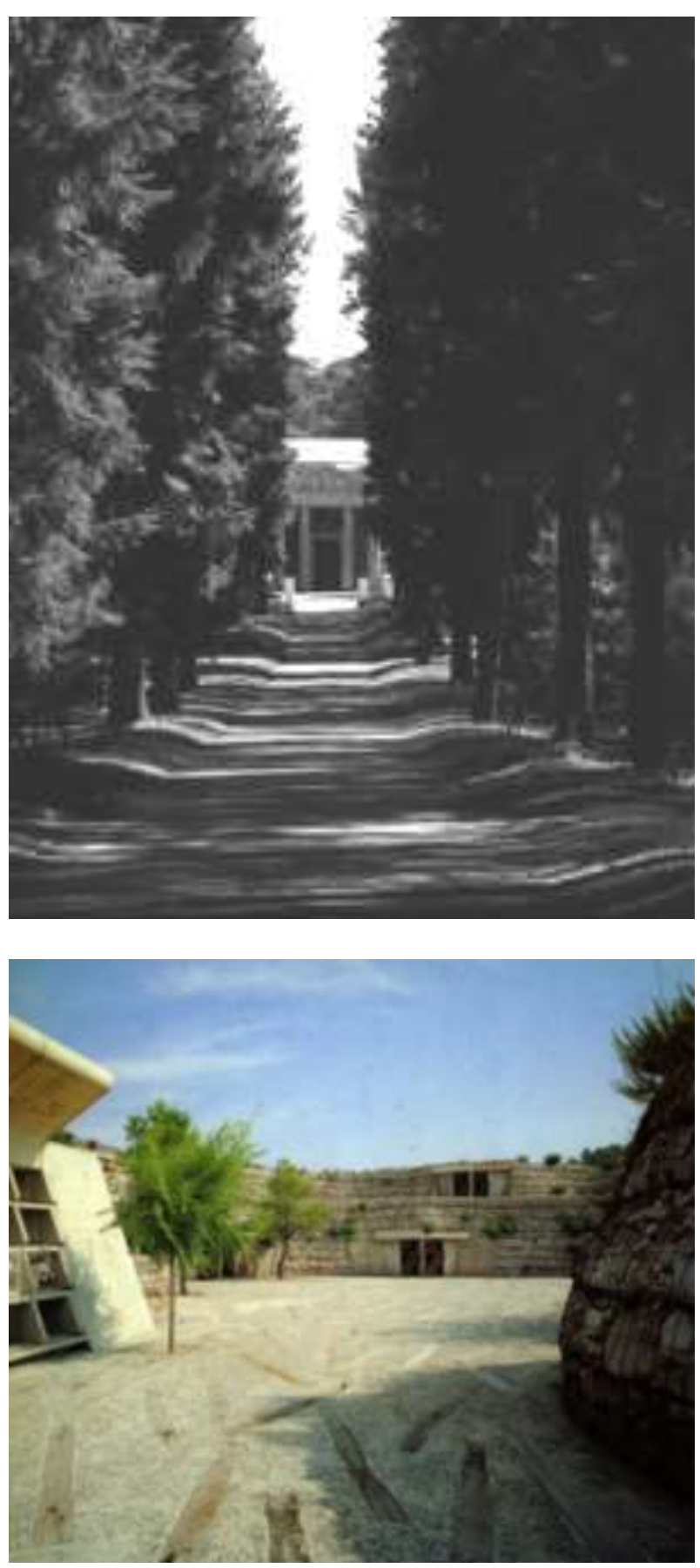

Ilustración 3-14

${ }^{228} \mathrm{Y}$ al final del camino aparece el claro en el bosque. Cementerio del bosque de Asplund y Lewerentz versus Cementerio de Igualada. 
El primer contacto con Le Corbusier lo tuvo Miralles en las clases que Moneo daba en la ETSAB. Miralles tenia la costosisima edicion del archivo de Le Corbusier y a juzgar por los comentarios de Tuñon y Mansilla, pudieron comprobar como se lo sabia casi de memoria, por la rapidez con la que localizaba algun boceto concreto al que se referia en la conversacion mantenida, dentro de los tomos que componen la edicion. En 1992 realiza junto con Elias Torres un viaje a la India para estudiar in situ la obra de Le Corbusier y Louis I. Khan, dos de sus reconocidos maestros.

Como afirman Miralles y Pinos en una entrevista: "Quien nos da confianza es Le Corbusier. Nuestro primer curso de proyectos fue dedicado integramente por Rafael Moneo a este arquitecto. Como en un juego, todo debia encontrarse ahi... Le Corbusier es el personaje que te da confianza. Nos admira la rotundidad de sus dibujos...su constante voluntad de volver a pensar...no son imagenes, son lugares del pensamiento." 229

Le Corbusier en los años 50 s del siglo XX, tras la $2^{\text {a }}$ Guerra Mundial, cambia su manera de ver la vida y lo traducira en su Arquitectura. A Miralles le interesaba esa arquitectura del Le Corbusier posterior a los años 50s. Obras como Ronchamp, el Centro de Artes Visuales en MIT con esa rampa curva que lo atraviesa, las cubiertas de las unites de habitation. los acabados brutalistas, etc. Ronchamp surge de la historia, el ambiente, la naturaleza y la memoria del lugar, del sol, el viento y la lluvia; de los recorridos de los peregrinos; de lo popular; de lo sagrado al encontrarse cerca un antiguo camino romano y un templo solar; del paisaje conformado por una colina que acoge el primitivo culto medieval a la Virgen. Fue este un territorio bombardeado que tras la liberación francesa al termino de la guerra se convierte en un simbolo. Todos estos ingredientes son los que generan la capilla de Ronchamp.

Se encuentran muchas semejanzas en la obra de Miralles con Ronchamp: los muros abandonan la geometria ortogonal y mediante contracurvas se relacionan mejor con el paisaje circundante; existe una ambiguedad entre interior y exterior; hay una presencia de lo primitivo que contrasta con lo moderno, yuxtaposicion de de formas distintas, entre las que se da un juego de diferencias y semejanzas, pasando a importar la relacion entre las piezas.

El adentrarse en una lectura en profundidad de la capilla de Ronchamp de Le Corbusier, de su espacio indicible, de las conexiones con Gadamer, Bataille, Walter Benjamin, etc. se reconocen coincidencias claras en la obra de Mlralles, pero no solo en sus aspectos formales sino en la aplicacion de la esencia del pensamiento que lo ha llevado a cabo lo que esta en Mlralles y que se plasmara en proyectos como Igualada, Huesca, etc

Pero tambien tiene relacion la capilla de Igualada con el proyecto de Le Corbusier para una capilla subterranea, "la baute mode", y con la gruta donde se encontro la talla de la Virgen de Montserrat y la cripta de la Colonia Guell de Gaudi. La apariencia una vez terminada la capilla de Igualada, es que Miralles la hubiera excavado en el terreno para alojar el espacio sagrado sin embargo es un artificio, pues se levanto desde la rasante del terreno y luego se relleno de tierra

\footnotetext{
${ }^{229}$ Miralles y Pinos. Entrevista en revista A30 № 6 .
} 
EL PARQUE CEMENTERIO EN IGUALADA (1985-1991)
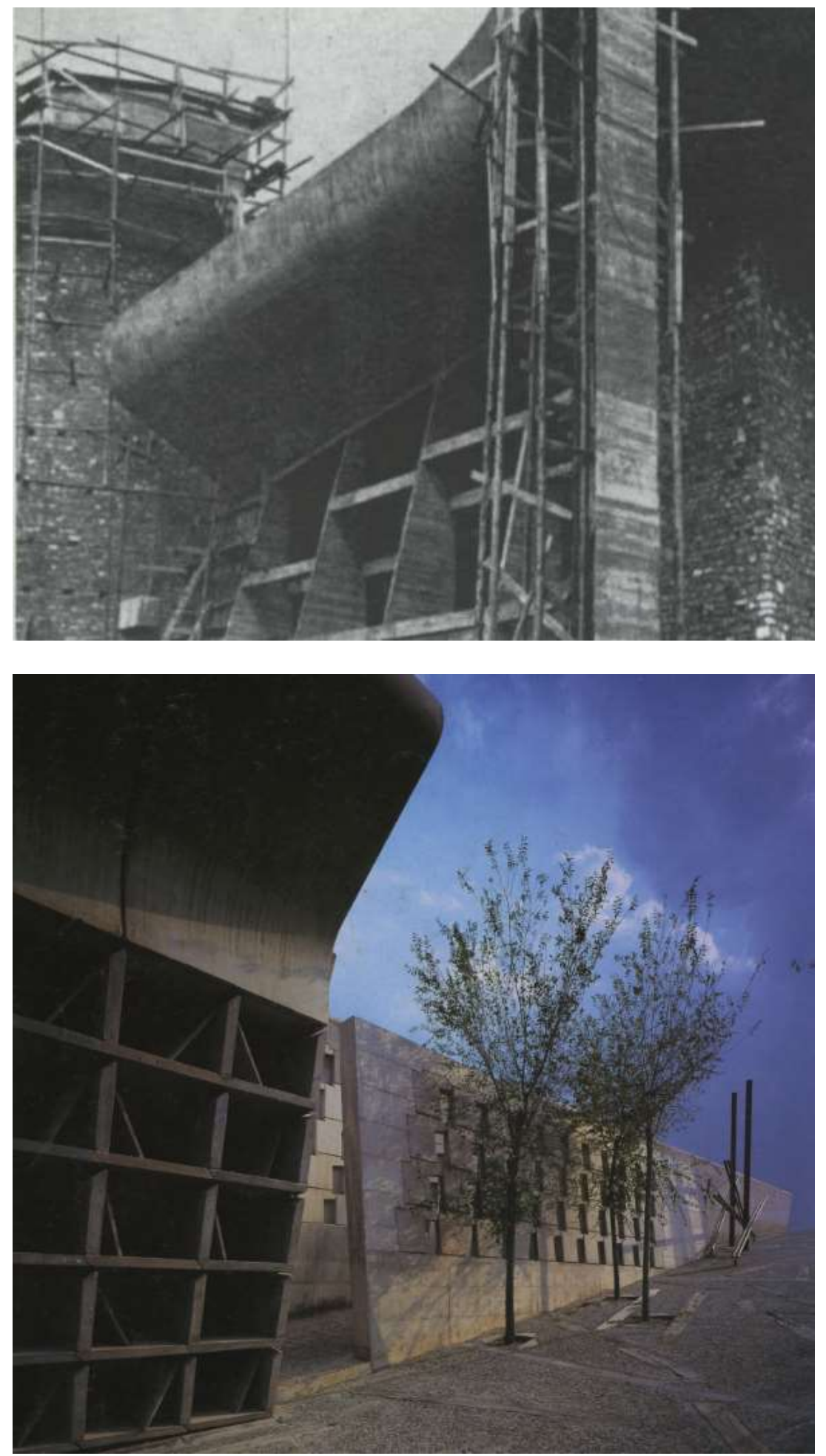
Ilustración 3-15
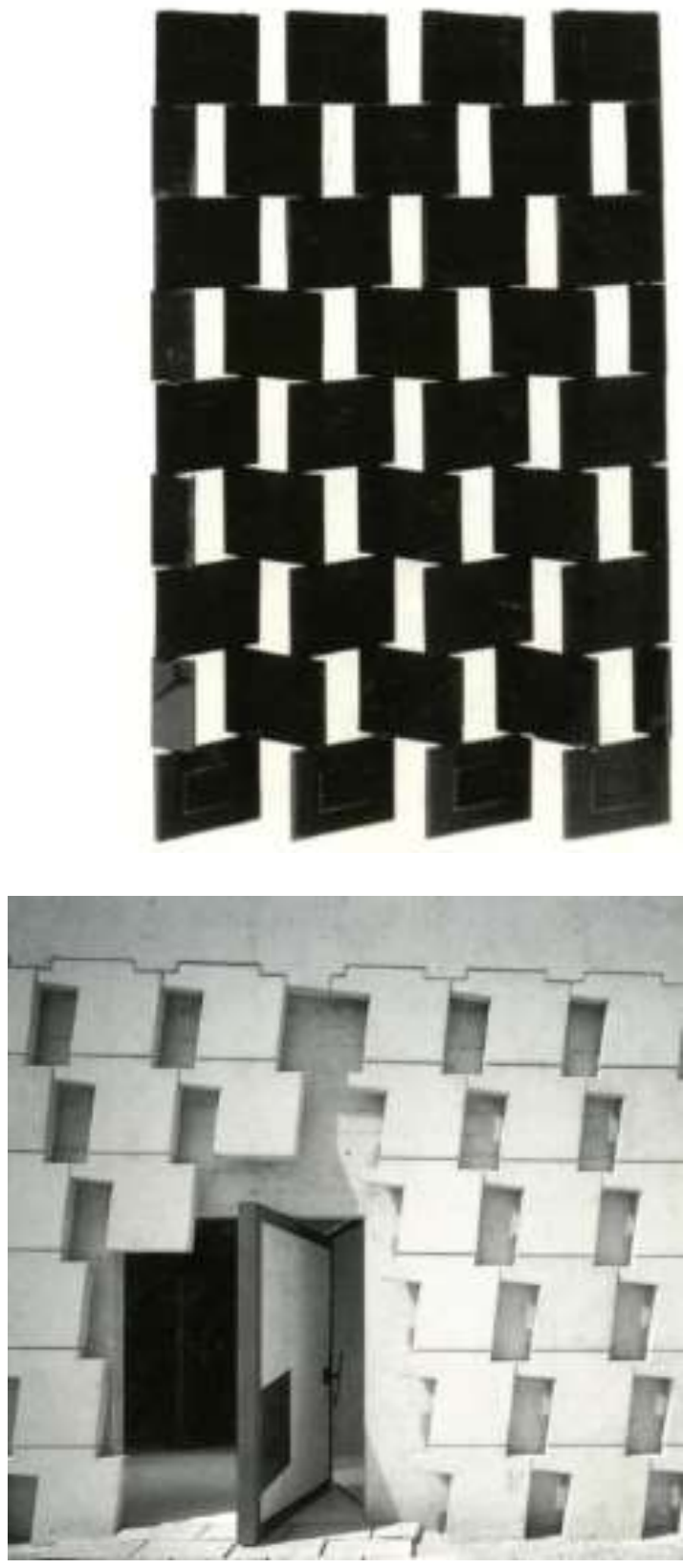

Ilustración 3-16 ${ }^{231}$

${ }^{230}$ Fachada Sur en construcción de la Iglesia en Ronchamp de Le Corbusier versus Muros de nichos en columbario del Cementerio de Igualada.

231 "Block Screens" de Elieen Gray versus muro que forra edificio de servicios del Cementerio de Igualada. 


\subsubsection{EVOLUCION DEL PROYECTO}

\subsubsection{EL LUGAR EXISTENTE}

"El lugar no existía antes de la construcción del puente...se origina a partir del puente"

Martin Heidegger. ${ }^{232}$

Lo que queda en un lugar conforma su espesor y su memoria: cultura, biología, geología, clima, antropología, arqueología, etc. dotando al lugar de su especificidad. Las condiciones básicas del lugar son: carga simbólica, delimitación, capacidad para generar relaciones. ${ }^{233}$

El Parque Cementerio de Miralles y Pinós, se sitúa $a^{234}$ en Igualada, una ciudad periférica industrial, a $80 \mathrm{Km}$ de Barcelona, en España. Próxima a la autovía A2, en la zona del Pla de les Gabarreres, Igualada es una localidad con más de 1000 años de antigüedad y una población de aprox. 35000 habitantes.

El paisaje pertenece al ámbito de la Cuenca del Barberá, pero esta zona concreta esta bañada por el rio Francolí y sus afluentes. La potencia erosiva del rio Francolí, provoca por erosión remontante un vaciamiento de los sedimentos eocenos y oligocenos que rellenan la cuenca horizontalmente. Las litologías dominantes presentan un relieve escalonado con terrazas salpicadas de cerros y colinas.

Esta zona fue hace cuarenta millones de años el fondo del mar, en el que se depositaron una margas grises azules, denominadas por los geólogos "margas de Igualada". El lugar donde se ubica el Parque Cementerio es el meandro de una riera, la riera Dodena, que deja al descubierto las margas de Igualada. ${ }^{235}$

El solar donde se ubica el Parque Cementerio se encuentra a las afueras de la ciudad, es un lugar periférico, peri urbano, si nos atenemos a la clasificación de la Convención Europea del Paisaje del año 2000. Próximo a un polígono industrial, en los terrenos de una antigua cantera de piedra, el paisaje se caracteriza por cerros de vegetación dispersa; cárcavas formadas por escorrentías de rio y lomas cultivadas. No tiene unos límites precisos, estando rodeado por un paisaje envolvente de laderas verdes, grises y ocres. Incluso existe un arroyo discurriendo entre una pequeña hoz, que limita de manera natural la zona de intervención.

232 "Construir, habitar, pensar". Capitulo VI. Ediciones Del Serbal, Barcelona, 1994.

${ }^{233}$ Carlos Asensio.Tesis Doctoral. "Arquitectura abierta en el paisaje. Una metodología analítica desde la fenomenología". DPA ETSAM. UMP. 2009.

${ }^{234}$ Sitio viene del latín "situs", es el lugar donde se encuentra algo.

${ }^{235}$ Extracto del Programa televisado en TVE "La mitad invisible: el Zementeri de Igualada". Con la intervencion de Carmen Pinos, Benedetta Tagliabue y Anatzu Zabalbeascoa, proyectado en television el dia 29 de Septiembre de 2015 

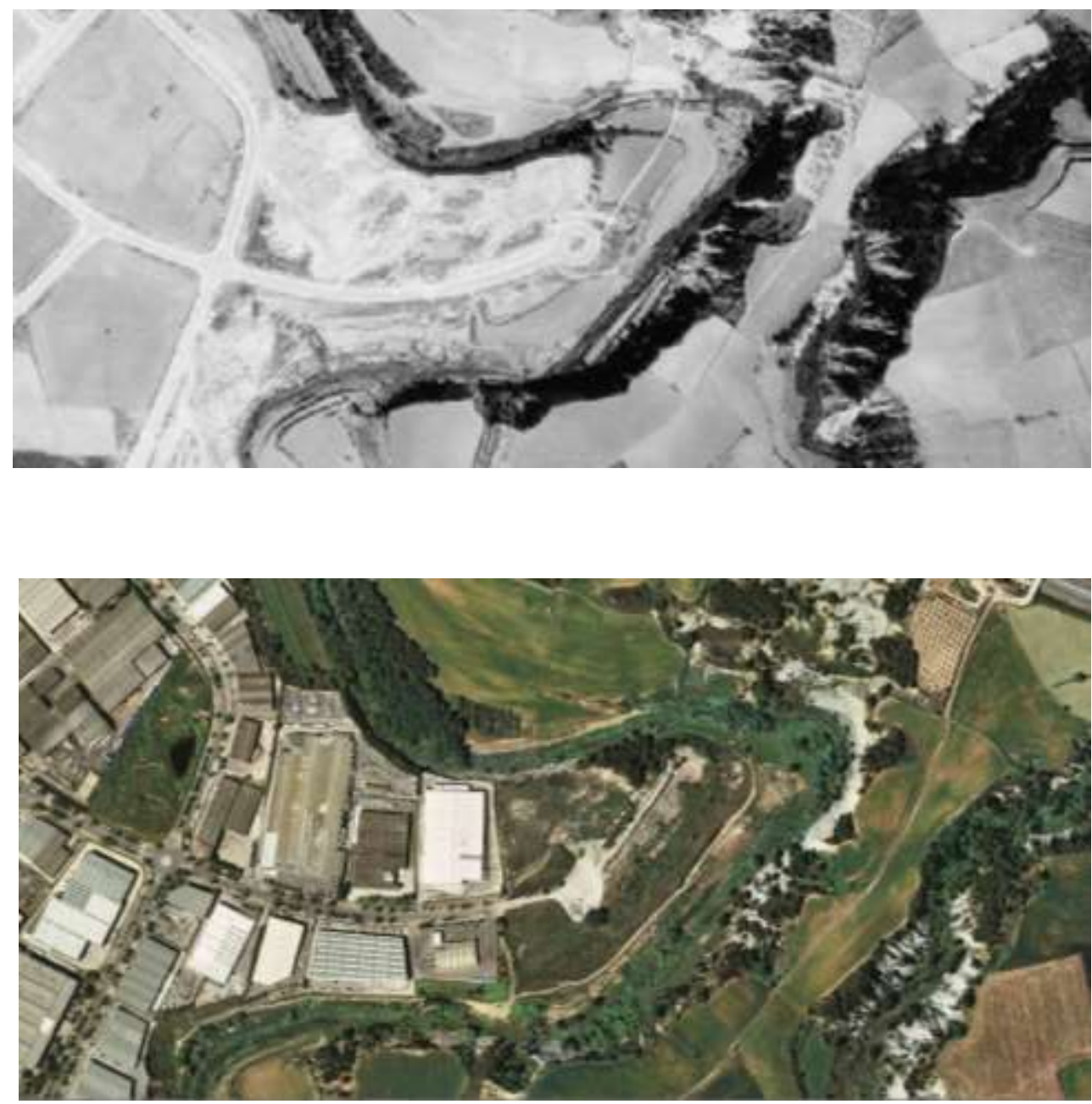

Ilustración 3-17

\subsubsection{LA PROPUESTA PROYECTADA}

“...lo dibujamos contándonos mil historias...una de ellas, teniendo el sentimiento del lugar en el pensamiento nos remitía a la idea de en polvo eres $y$ en polvo te convertirás...queríamos ser naturaleza, queríamos que el cementerio fuera el lugar donde los visitantes volvieran a encontrarse con lo que realmente son: naturaleza con la capacidad de sentir poemas ."

Carme Pinós. ${ }^{237}$

${ }^{236}$ Fotografías aéreas que reflejan el estado anterior y posterior a la intervención de Miralles y Pinos en el lugar

237 "Arquitectura española 1975-2000. 35+ Construyendo en democracia". Electa. 1996, pag. 52. 


\section{El Concurso}

La localidad de Igualada, debido a su proximidad a Barcelona y su actividad industrial, incremento su población considerablemente en la década de los años 1970. El Cementerio existente en Igualada estaba llegando a su saturación y este hecho obligo a las autoridades municipales a convocar un concurso de ideas para la construcción de un nuevo cementerio que diera respuesta a las necesidades de la población.

El programa requerido en las bases del Concurso, demandaba la construcción de un nuevo Parque Cementerio que se pudiera realizar en cinco fases realizables a lo largo de diez años. El presupuesto de ejecución material asignado para la primera fase se establecía en 125 millones de pesetas para la construcción de 2500 nichos. Entre los criterios de valoración de las propuestas presentadas, se daba mucha importancia a la integración de lo proyectado con el entorno paisajístico existente y a la optima relación entre calidad arquitectónica y coste. Se presentaron un total de 25 equipos al concurso.

Enric Miralles y Carme Pinós visitaron el lugar en el otoño de 1984 y quedaron prendados de la belleza del paisaje. Aunque la pareja ya había proyectado anteriormente otros cementerios como el de Aranda de Duero en Burgos, y estaban familiarizados con este tipo de programas; no será hasta que proyecten el de Igualada, donde gracias al paisaje que se encontraron pudieron aplicar todo lo aprendido in situ de las obras de Land Art tras su estancia de investigación en Columbia University de Nueva York en el curso 1980-1981. ${ }^{238}$

Los primeros tanteos del proyecto como se puede comprobar en los croquis iniciales, persiguen materializar la idea de un gran signo sobre el territorio, que enlazase descendiendo el nivel de llegada situado a la entrada, con el nivel del rio situado a una cota inferior. Dada la elevada demanda de nichos de enterramiento y lo estrecho del solar, se vieron obligados a disponerlos en columbario; por lo que ese camino que desciende iría acompañado a ambos lados de muros conteniendo nichos de enterramiento. Arturo Blanco en su tesis doctoral se refiere a la capacidad de observación de la pareja de arquitectos, en los siguientes términos: "Miralles y Pinos buscan en el valle lo que siempre ha existido, sus trazas ocultas bajo la tierra, las capas de los huertos que existieron, las capas de la erosión que durante siglos sufrió la tierra." ${ }^{239}$

Su proyecto dibujaba, guiado por las formas de la tierra de un áspero terreno situado entre un área industrial y el paisaje natural, un recorrido que narraba el descenso de un cuerpo a las entrañas de la tierra para reposar. El cometido principal era la recreación del paisaje. Se propusieron hacer del paisaje arquitectura y, mediante su arquitectura, crear un nuevo paisaje. La reelaboración constante de los dibujos y la apropiación de metáforas fueron herramientas de estos arquitectos para "dialogar con lo que existe" y "lo que existe" implica lo sensorial y lo suprasensorial. En otras palabras: hallar y trabajar el absoluto potencial del lugar. En la memoria de los arquitectos está grabado el paisaje: una tierra áspera de formas sinuosas. No podemos extraer el cementerio ni su concepción de este contexto.

\footnotetext{
${ }^{238}$ Arturo Blanco. Tesis Doctoral "Flujo laminar: El cementerio de Igualada y los procesos elásticos en la arquitectura de Enric Miralles y Carme Pinós" defendida el día 18 de Noviembre de 2015 en la ETSAM. UPM,

${ }^{239}$ Ibidem, pag. 259
} 


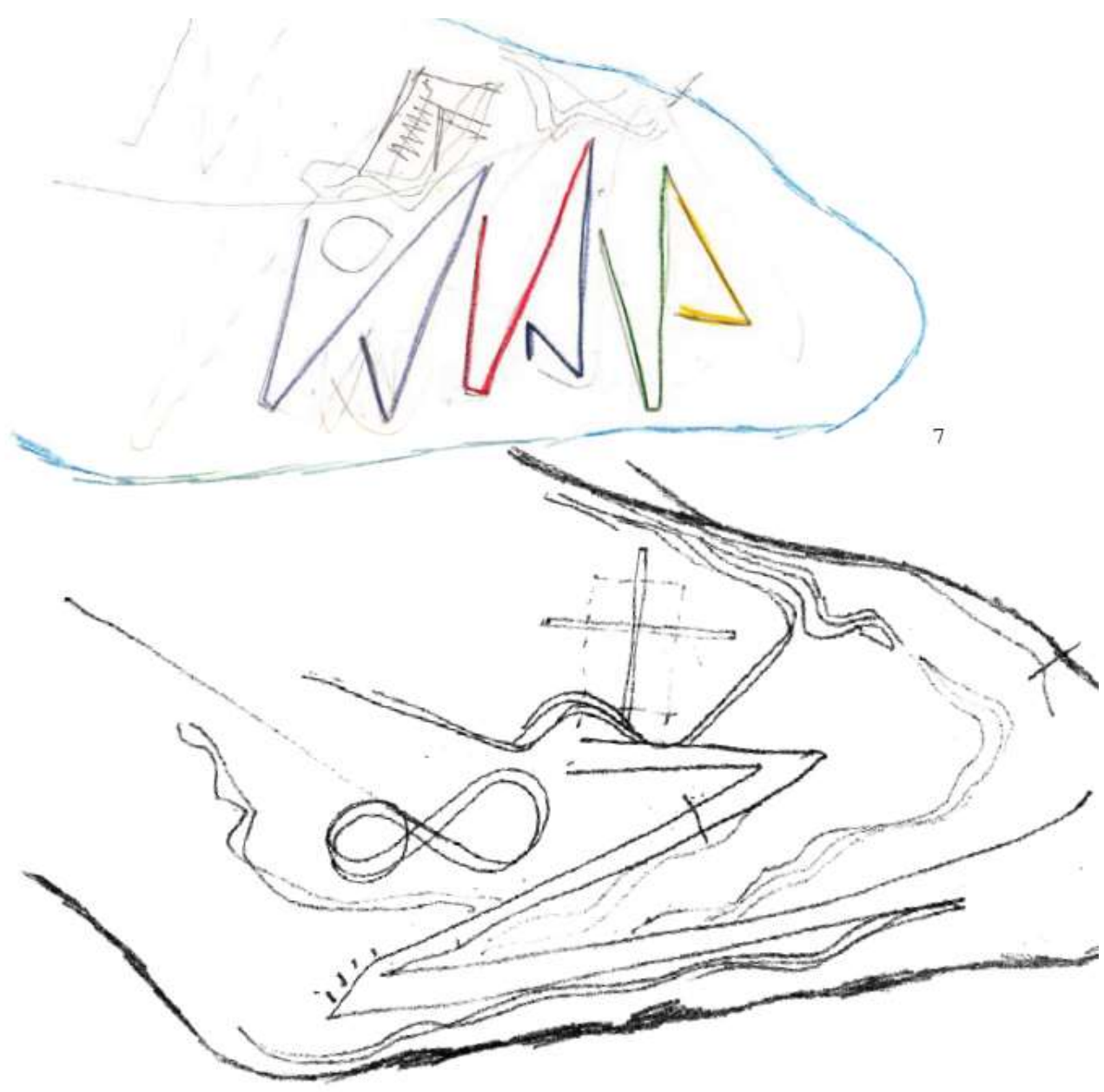

Ilustración 3-18

240 Primeros croquis de tanteo al abordar el proyecto. Se observa como en el inferior, aparece claramente definido la ubicacion de la capilla marcada con la cruz, asi como el recorrido en zig zag formando una Z. (OFundació Enric Miralles. 

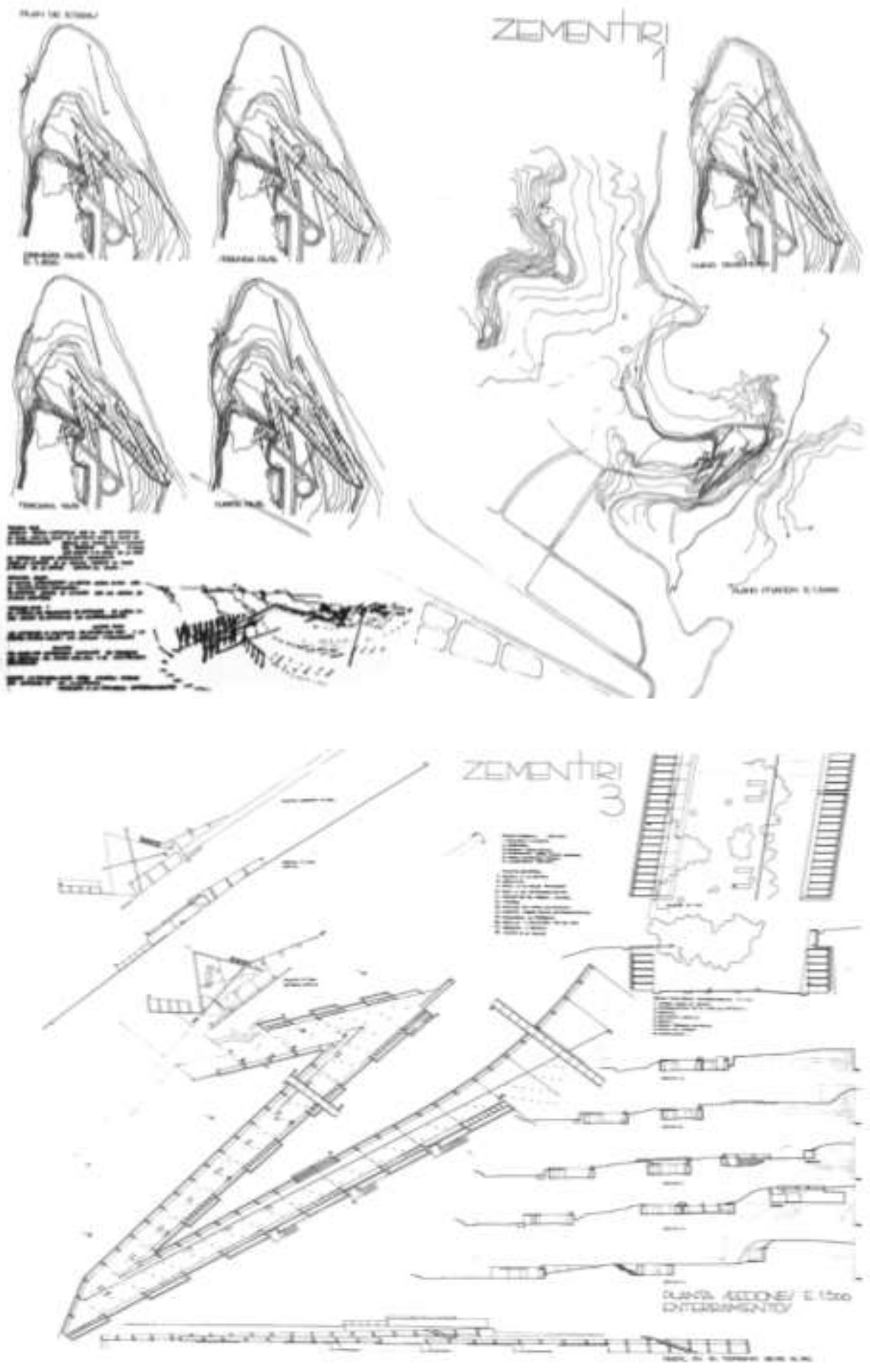

Ilustración 3-19241

${ }^{241}$ Dos de los tres paneles presentados a Concurso. En la parte superior, destacan las distintas fases con las que Miralles y Pinos ejecutarían el proyecto. En la parte inferior, se determina el trazado en zig - zag conformando una $Z$ que desciende acompañado a ambos lados por los muros conformados por nichos de enterramiento. 
El Primer Premio se otorgo el día 3 de Mayo de 1985, al proyecto presentado bajo el lema "Zementiri" cuyos autores eran Enric Miralles, Carme Pinós, Alberto Noguerol y Victoria Giró. ${ }^{242}$ El Acta de los miembros del Jurado valoro de la propuesta su adaptación al paisaje existente sin menoscabar su identidad y también la capacidad de síntesis al ordenar toda la intervención con un solo gesto. Los comentarios del Acta del Jurado justificando las razones para otorgar el Primer Premio a la propuesta presentada por Miralles y Pinos quedan claros en el fragmento del Acta : "El Anteproyecto del primer premio, bajo el lema: Zementiri, resuelve la ordenación con un solo gesto: una incisión en el terreno que toma la forma de un camino en "zig-zag" que desciende hacia el nivel de la riera. Se ha valorado, especialmente, la capacidad de recrear la forma del Cementerio tradicional adaptándola a un lugar con marcadas características geográficas. El cementerio y el lugar se intersecan manteniendo cada uno su propia forma e identidad. Se valora también el cuidadoso tratamiento dado al espacio para ceremonias religiosas y la atención dispensada a los aspectos constructivos." ${ }^{243}$

Siguiendo las indicaciones recogidas en las bases del concurso, la propuesta presentada, por Miralles y Pinos recogía un Plan de etapas para su desarrollo, con la previsión de cinco fases realizables en el término diez años. Se enuncian a continuación los trabajos a los que correspondería a cada fase.

En la Primera Fase, se construirían los accesos, la Capilla y el edificio de servicios bajo el perfil existente. El paso hacia el Valle se construiría como el lugar de los enterramientos. Los árboles darían sombra bajo la rasante del terreno y a un paseo que se iría construyendo a lo largo de las sucesivas fases. En la Segunda Fase, un camino atravesando la Capilla llegaría al río y conformaría el futuro paseo perimetral. En la Tercera Fase, el sistema de relaciones se completaría llegando al nivel del río descendiendo desde el camino de los enterramientos. En la Cuarta Fase, se comenzaría a construir el paseo del río, y los muros que acogerían los panteones.

En la Primera Fase, se construirían los accesos, la Capilla y el edificio de servicios bajo la topografía existente. En la Segunda Fase, el camino que atravesando la Capilla, llegaría al río y conformaría el futuro paseo perimetral. En la Tercera Fase, se construiría hasta el nivel del río siguiendo el camino conformado por los enterramientos en columbario. En la Cuarta Fase, se comenzaría a construir el paseo del rio, mientras que en la última Fase, se construiría la zona de panteones.

\section{El Proyecto}

El proyecto narra el recorrido, guiado por la topografía existente, desde la entrada situada próxima a un polígono industrial y el paisaje natural, un recorrido que simboliza el descenso de un cuerpo sin vida conducido a las entrañas de la tierra para su reposo eterno. En la maqueta de Concurso se aprecia muy bien la intervención que se quería practicar en el paisaje.

Con el signo abstracto del recorrido en $Z$ de la fase de Concurso, se obtenía la mayor longitud de trazado posible en el estrecho espacio del Valle, un camino

\footnotetext{
${ }^{242}$ En el jurado que delibero el proyecto ganador se encontraba el arquitecto Carles Martí, como traslado Carmen Espegel Alonso, miembro del Tribunal de Tesis Doctoral de Arturo Blanco "Los procesos elásticos... Igualada" defendida el día 18 de Noviembre de 2015, en la ETSAM. UPM.

${ }^{243}$ Comentarios del Acta del Jurado justificando las razones para otorgar el Primer Premio a la propuesta presentada por Miralles y PInos.
} 
para ser recorrido, donde lo importante no eran los extremos sino el recorrido mismo. Miralles y Pinos proyectan una metáfora construida sobre el tránsito de la vida a la muerte y todas las decisiones de proyecto se piensan en función de la manera de recorrer ese tránsito y las reacciones psicológicas que provoca al paseante. El proyecto es la materialización de una idea en relación con los ritos cristianos del final de la vida. Es una metáfora construida en piedra, hormigón y acero excavada en la tierra, generando un camino que desciende hacia las sepulturas de enterramiento.

El proyecto, realza el paisaje existente con su intervención. Se comienza el proyecto quedándose con unas trazas existentes en el paisaje, dejando lo esencial y realzándolo. De las muchas posibilidades que tiene el paisaje, Miralles y Pinos, renuncian a muchas de ellas, para quedarse tan solo con las que hacer el proyecto. Como decía Francisco Javier Sáenz de Oiza. : "El proyecto es una suma de renuncias"

El paisaje y la memoria, fueron fundamentales como datos de partida para Miralles y Pinos al comenzar a proyectar, estableciendo un diálogo con el genius loci, y captando la esencia del lugar. La reelaboración constante de los dibujos, redibujando en primer lugar la topografía existente, unido a la apropiación de metáforas fueron herramientas de Miralles y Pinós para "dialogar con lo que existe" y "lo que existe" para Miralles y Pinos, implica lo sensorial y lo suprasensorial.

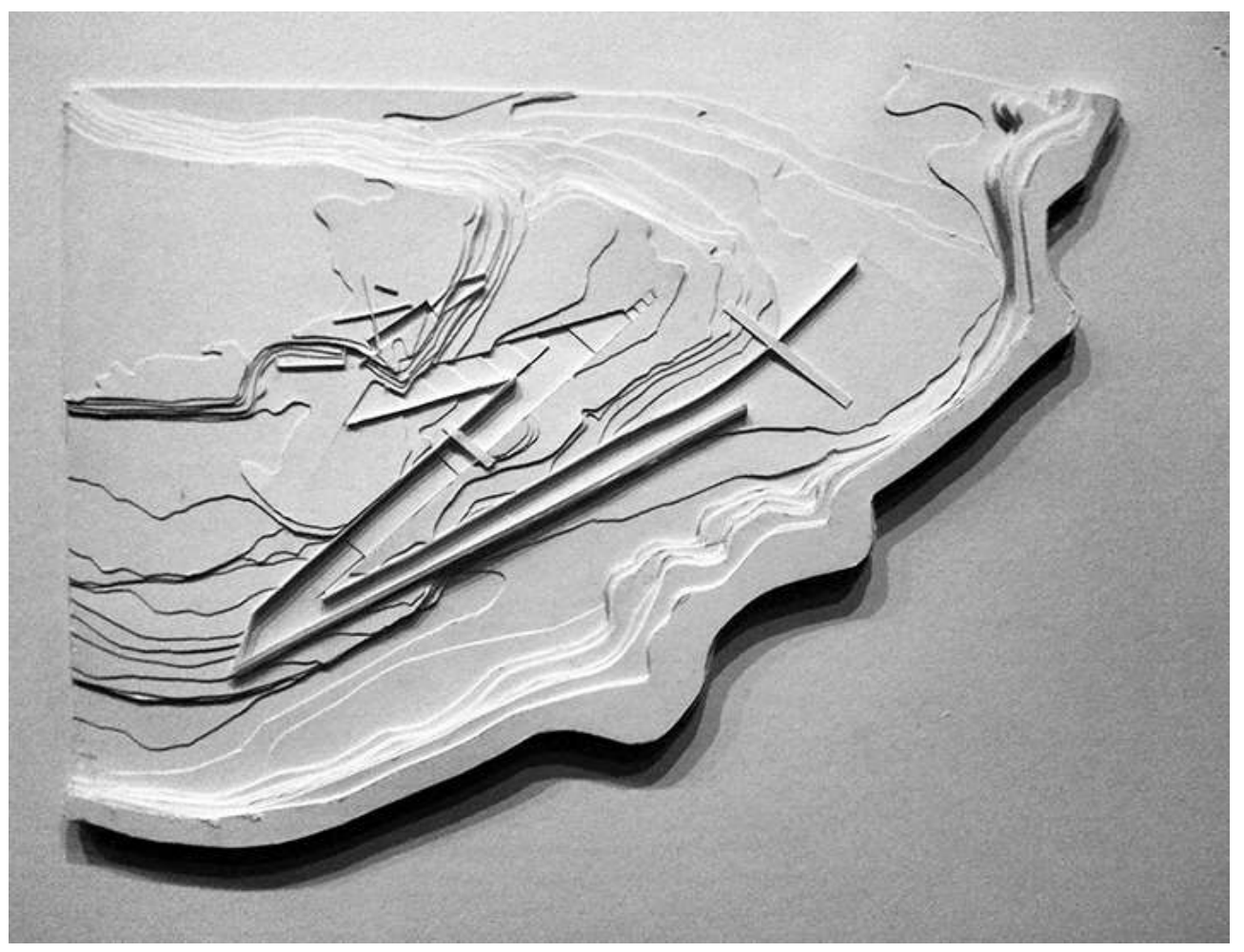

Ilustración 3-20 244

\footnotetext{
${ }^{244}$ Maqueta del proyecto con el camino en forma de Z. 1985. @Fundació Enric Miralles.
} 


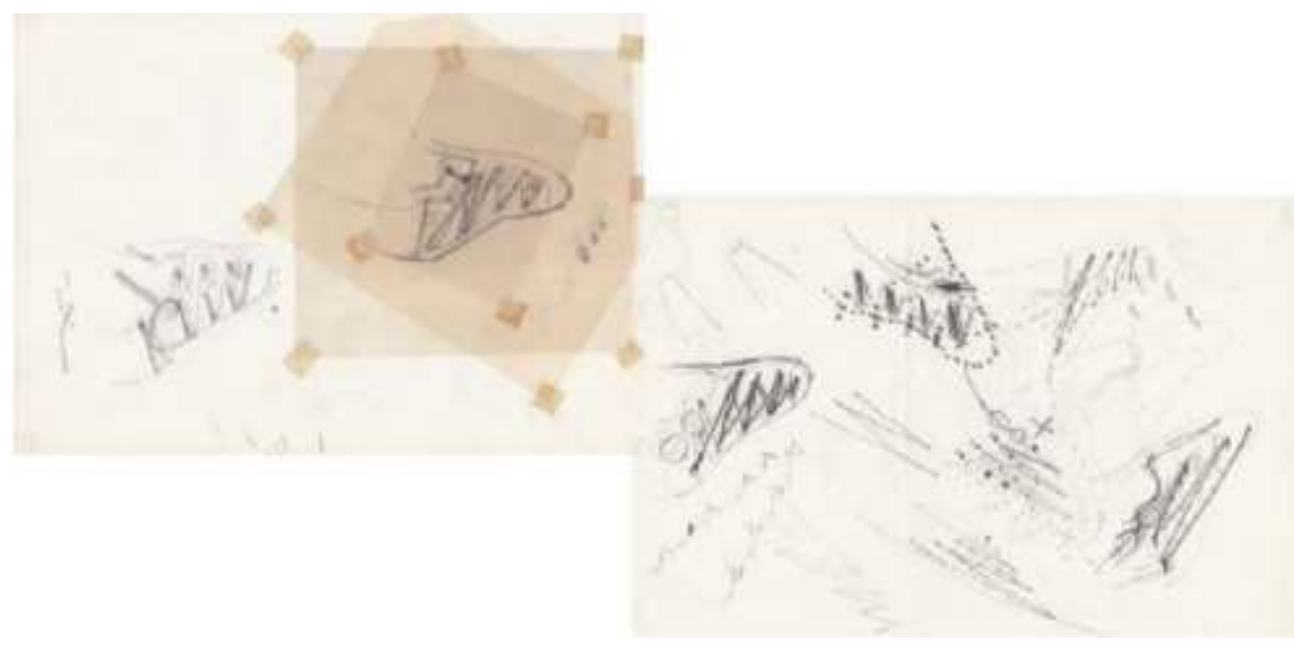

Ilustración 3-21245

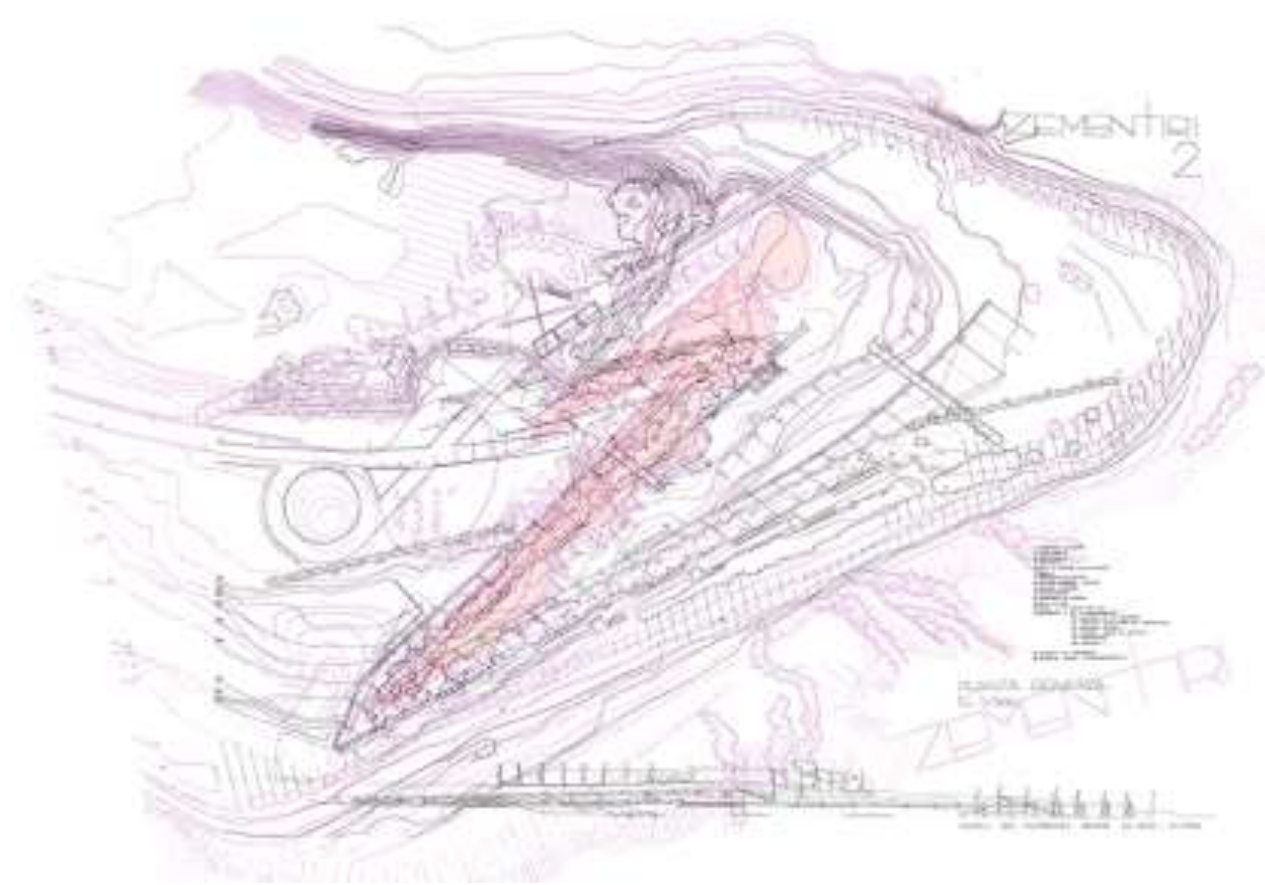

Ilustración 3-22 246

${ }^{245}$ Croquis manuscritos en los que se se aprecia la repetición de los dibujos superponiendo croquis. CFundació Enric Miralles.

246 Superposición de las plantas de Concurso (1985) y Proyecto de Ejecución (1987). 
En el momento de abordar la redacción del Proyecto de Ejecución, el Ayuntamiento les solicitó mayor capacidad de enterramiento y Miralles y Pinós presentaron el Proyecto de Ejecución en el mes de Marzo de 1987 con ciertas variaciones respecto a la propuesta presentada a Concurso. ${ }^{247}$

En el intervalo de tiempo que media entre la propuesta de concurso de abril de 1985 y el proyecto de ejecución de abril de 1987, el proyecto se fue modificando considerablemente, en especial al cambiar el recorrido de la propuesta inicial en forma de Z, a un recorrido en forma de V, formalizando el vértice de dicho recorrido con un geometría elíptica. Si en la propuesta de Concurso habían determinado que el recorrido en forma de $Z$ se podría ejecutar en cuatro tramos, al encargarles solos dos tramos, el recorrido cambio de forma, desde la $Z$ inicial hasta un recorrido en forma de $\mathrm{V}$ de brazos asimétricos, uno de ellos recto y el otro sinusoidal ${ }^{248}$. El vértice de dicha $\mathrm{V}$ lo conformaría un lugar estancial dedicado a albergar panteones de forma elíptica.

El empleo de la geometría curva en el área de panteones, se extendió también a otras zonas del proyecto, como el montículo de tierra artificial de la entrada; la reja curva que encinta la entrada principal, y la geometría sinusoidal de los nichos de enterramiento en columbario del lado Sur. Según Fernández Contreras, a partir de este proyecto, Miralles y Pinos comenzaran a experimentar con geometrías curvas, añadiéndose el compas y la plantilla de elipses, a la escuadra y el cartabón que ya utilizaban como herramientas de dibujo. ${ }^{249}$

Pero los cambios en el trazado de la planta también conllevaron cambios en las secciones. La importancia de la topografía del paisaje existente, llevaron a Miralles y Pinos a tratar la topografía como un material de proyecto mas, y ello les llevo a comenzar a proyectar en sección. En las secciones que documentaban la propuesta de Concurso el ángulo recto se empleaba de manera recurrente, mientras que en el proyecto de ejecución posterior, el ángulo recto se reserva a las secciones que documentan la capilla, siendo ángulos agudos y obtusos, los que aparecen en las secciones del resto de zonas, estableciendo una relación más natural y telúrica entre lo proyectado y el paisaje existente. Y ello afecto a la conformación de los nichos de enterramiento en columbario, que pasaron de un apilamiento vertical en ángulo recto, a una disposición inclinada de ángulos no ortogonales, generando un ritmo diferenciado respecto al camino que limitan a ambos lados, pues en unos casos los nichos empujan el terreno y en otros son empujados por este. Si la sección de Concurso, evocaba la sección de una calle, la sección del proyecto de ejecución transforma esa calle en un espacio interior al proyectar un capitel (que remite a secciones del Park Güell de Gaudí) como remate superior de los nichos de enterramiento que tapan las vistas del entorno inmediato e incitan al paseante a sentir que se encuentran en un espacio interior con una abertura central que deja pasar la luz cenitalmente.

\footnotetext{
${ }^{247}$ Arturo Blanco. Tesis Doctoral "Flujo laminar: El cementerio de Igualada y los procesos elásticos en la arquitectura de Enric Miralles y Carme Pinós" defendida el dia 18 de Noviembre de 2015 en la ETSAM. UPM.

${ }^{248}$ Este tramo sinusoidal, a día de hoy se encuentra todavía sin construir. La inspiración de la forma sinusoidal la tomo Miralles de una publicación sobre la obra de Thomas Jefferson editada en 1984.

249 Javier Fernández Contreras "La planta Miralles: Representación y Pensamiento en la Arquitectura de Enric Miralles", Tesis Doctoral leída en la ETSAM. UPM en el año 2013, pág. 38
} 


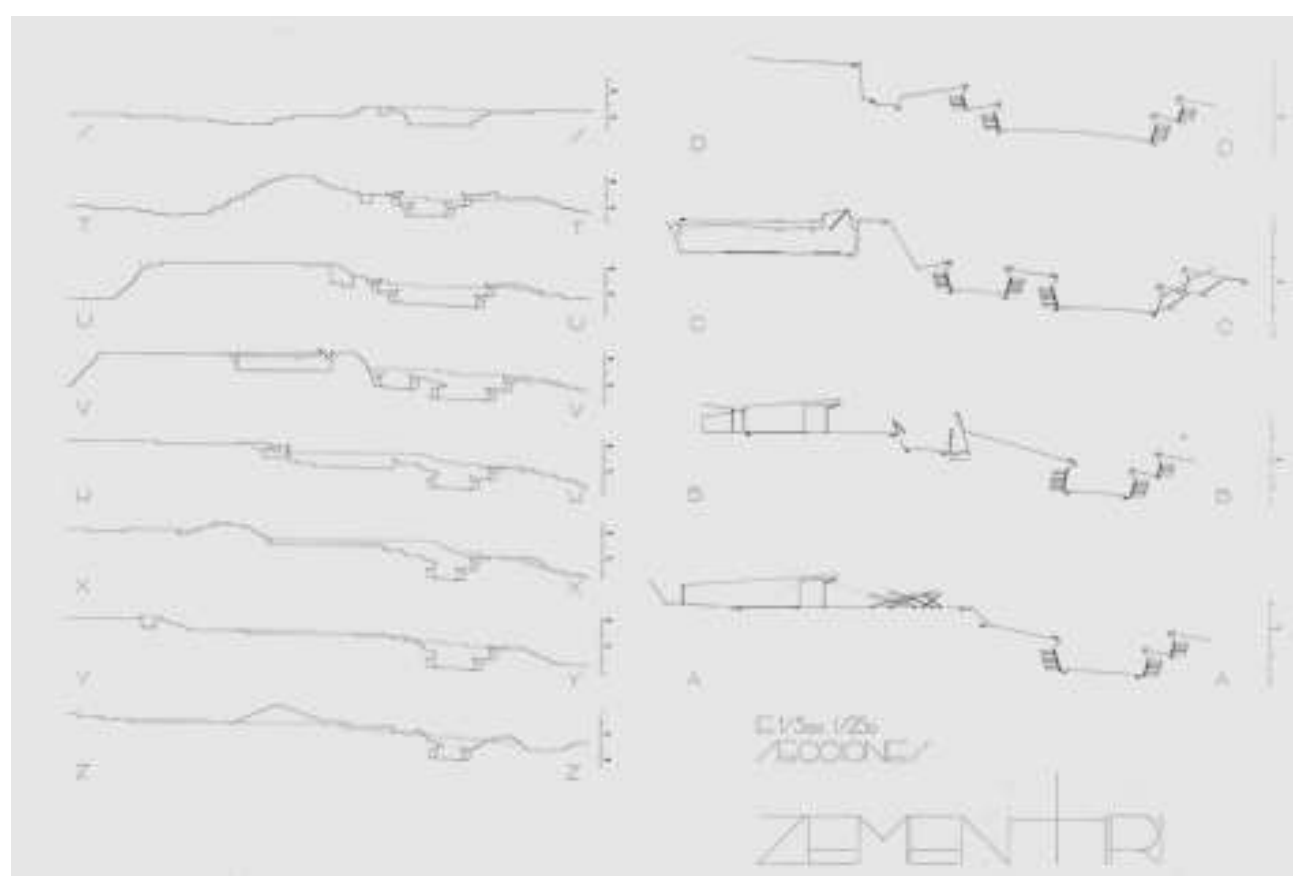

Ilustración 3-23 250
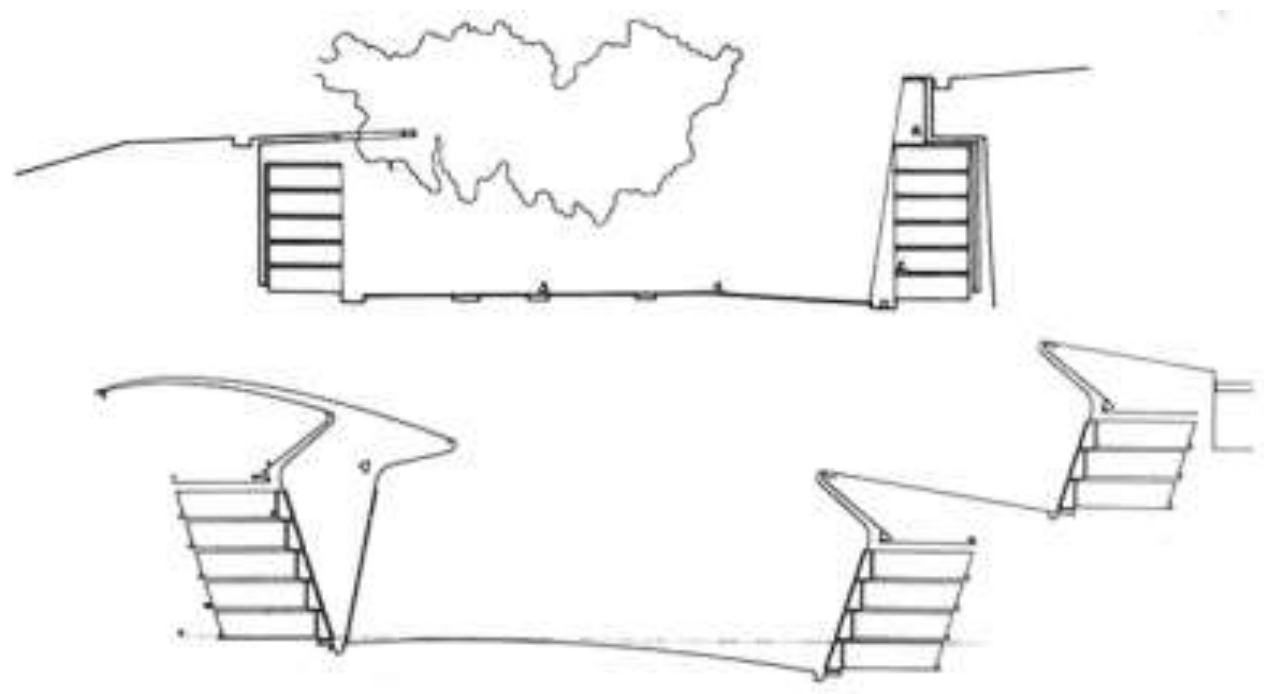

llustración 3-24 ${ }^{251}$

${ }^{250}$ A la izquierda secciones versión Concurso (1985) versus versión definitiva (1987).

${ }^{251}$ En imagen superior sección versión Concurso (1985) versus versión definitiva (1987). 


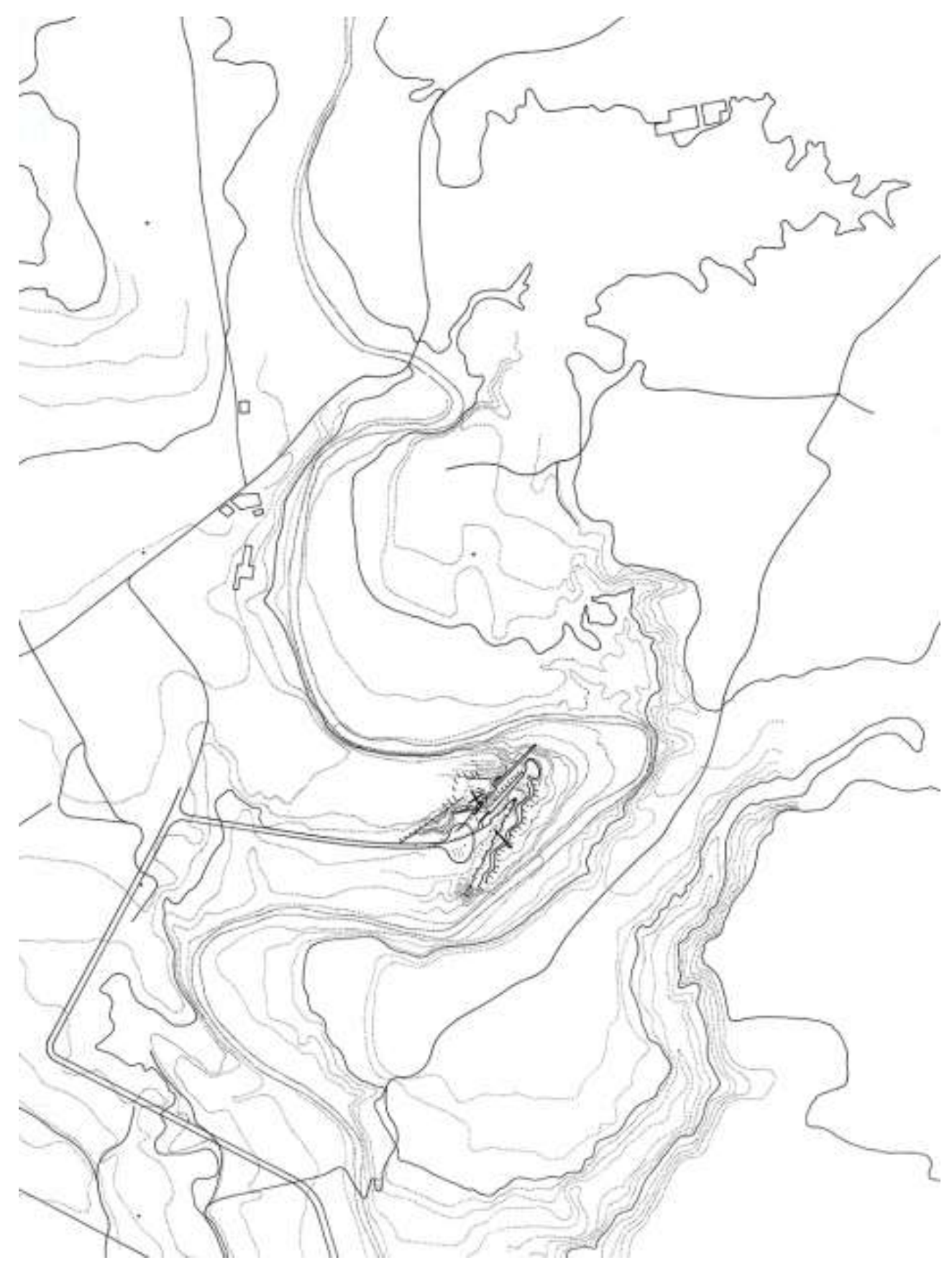

Ilustración 3-25 $5^{252}$

${ }^{252}$ Plano de localización versión definitiva (1987). 

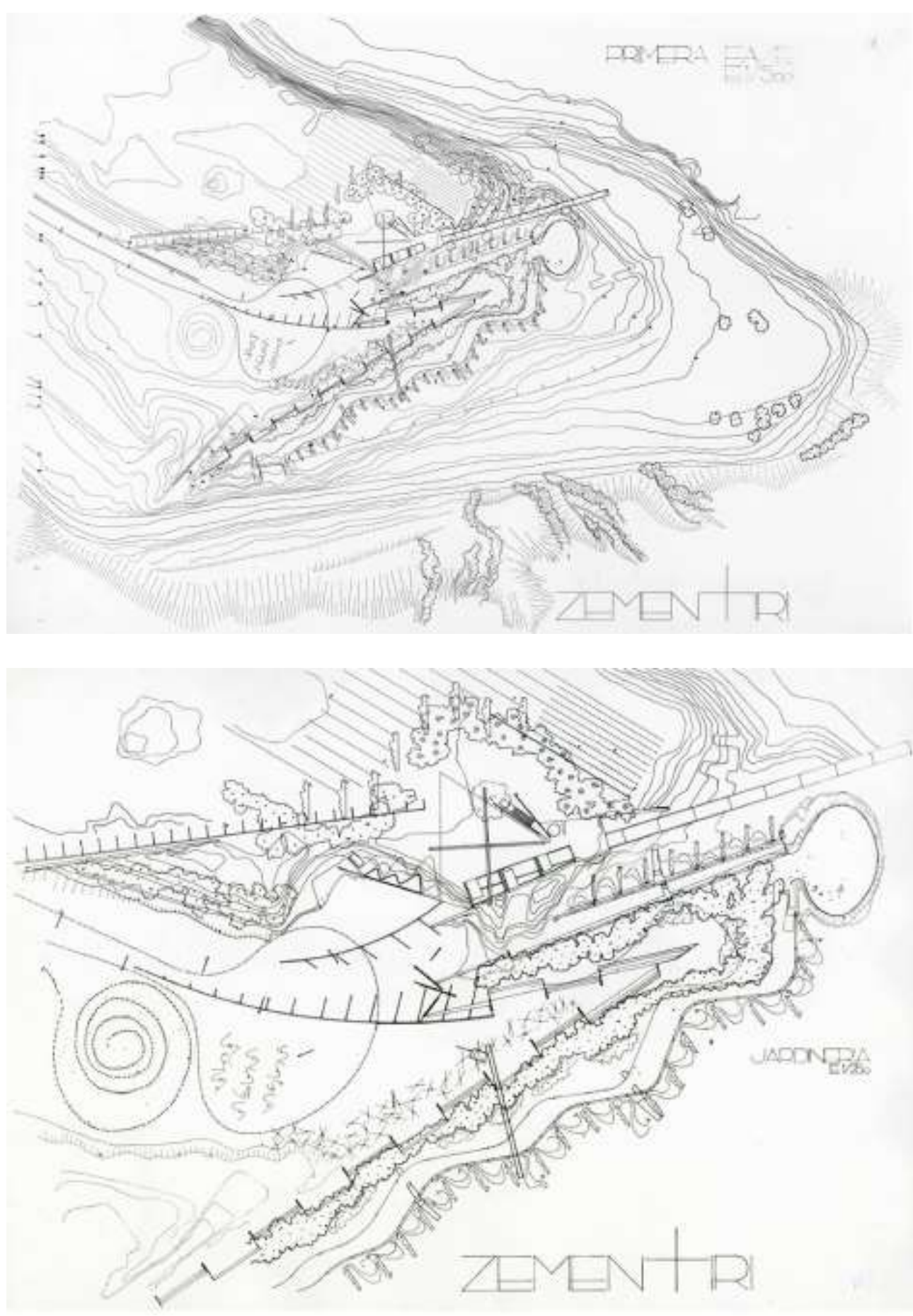

Ilustración 3-26 $6^{253}$

${ }^{253}$ En imagen superior Plano de situación, en la inferior planta. Versión definitiva (1987). 


\title{
3.1.2.3. LA PROPUESTA CONSTRUIDA
}

\begin{abstract}
"porque (Igualada)era un trabajo con la tierra y hecho casi directamente, trabajando con los obreros, con el día a día y le gustaba mucho (a Miralles) porque se acercaba mucho a la manera de trabajar de Gaudi.., el hacerse sobre la marcha, poco a poco...que da el tiempo de sedimentarse".
\end{abstract}

Benedetta Tagliabue. ${ }^{254}$

El proyecto de ejecución se entrego en Abril de 1987, pero las obras de la Primera Fase no comenzaron hasta el año 1988. A pesar de que el Parque Cementerio de Igualada, se inauguro oficialmente en Abril de 1991, las obras siguieron entrando en fases sucesivas hasta el día en el que Enric Miralles falleció. ${ }^{255}$

Si en el desarrollo del proyecto de ejecución siguió evolucionando la propuesta de Concurso, el proceso de ejecución en obra, continuara ese proceso. Tan es así, que entre otros, la disposición de los tablones de madera procedentes de traviesas de vías de tren embebidos en el suelo que documentaba el proyecto, transmitían menor fluidez que los que se ejecutaron finalmente en obra. ${ }^{256}$

La orquestación en la sucesión de compresiones y dilataciones espaciales, de luces y sombras, realzan la experiencia dinámica de descender por el recorrido. Los materiales con sus texturas apropiadas están calibrados para acrecentar la idea de dicha transición, y también en el suelo se incrustan traviesas de madera procedentes de vías de tren, que dan la impresión de ser troncos flotando en una corriente de movimiento detenido. El mundo del mas alla es aludido a través de ranuras en las jambas y sepulturas. El color del bloque de hormigón se asemeja al color de las rocas en la lejanía y el color mas ocre del hormigón usado en los muros de las tumbas también evoca los estratos del fondo. El recorrido junto al juego de sombras, permiten aportar al proyecto la cuarta dimensión, la del tiempo, a través del movimiento. En Igualada elementos intangibles como las sombras de los arboles contrastan con la materialidad y estabilidad de otros elementos como las traviesas de madera del suelo, que expresan un movimiento congelado generando una sensación "no-estática".

Como comenta Rafael Moneo: "...la metáfora de la vida, como un rio que nos lleva, hace acto de presencia en el cementerio tan pronto como advertimos que el pavimento transforma aquel ámbito en corriente inmóvil: los taludes de piedra cautiva definen el cauce de una corriente que ha cesado. Los tablones embebidos, incrustados en el pavimento, son mudos testigos del colapso del tiempo que la muerte, las muertes traen consigo. Los tablones de lgualada convierten en sagrado aquel espacio, al hacernos sentir la presencia de quienes fueron...".

\footnotetext{
${ }^{254}$ Extracto del Programa televisado en TVE "La mitad invisible: el Zementeri de Igualada". Con la intervencion de Carmen Pinos, Benedetta Tagliabue y Anatzu Zabalbeascoa, proyectado en television el dia 29 de Septiembre de 2015

${ }^{255}$ Arturo Blanco. Tesis Doctoral "Flujo laminar: El cementerio de Igualada y los procesos elásticos en la arquitectura de Enric Miralles y Carme Pinós" defendida el dia 18 de Noviembre de 2015 en la ETSAM. UPM

256 Ibidem
} 

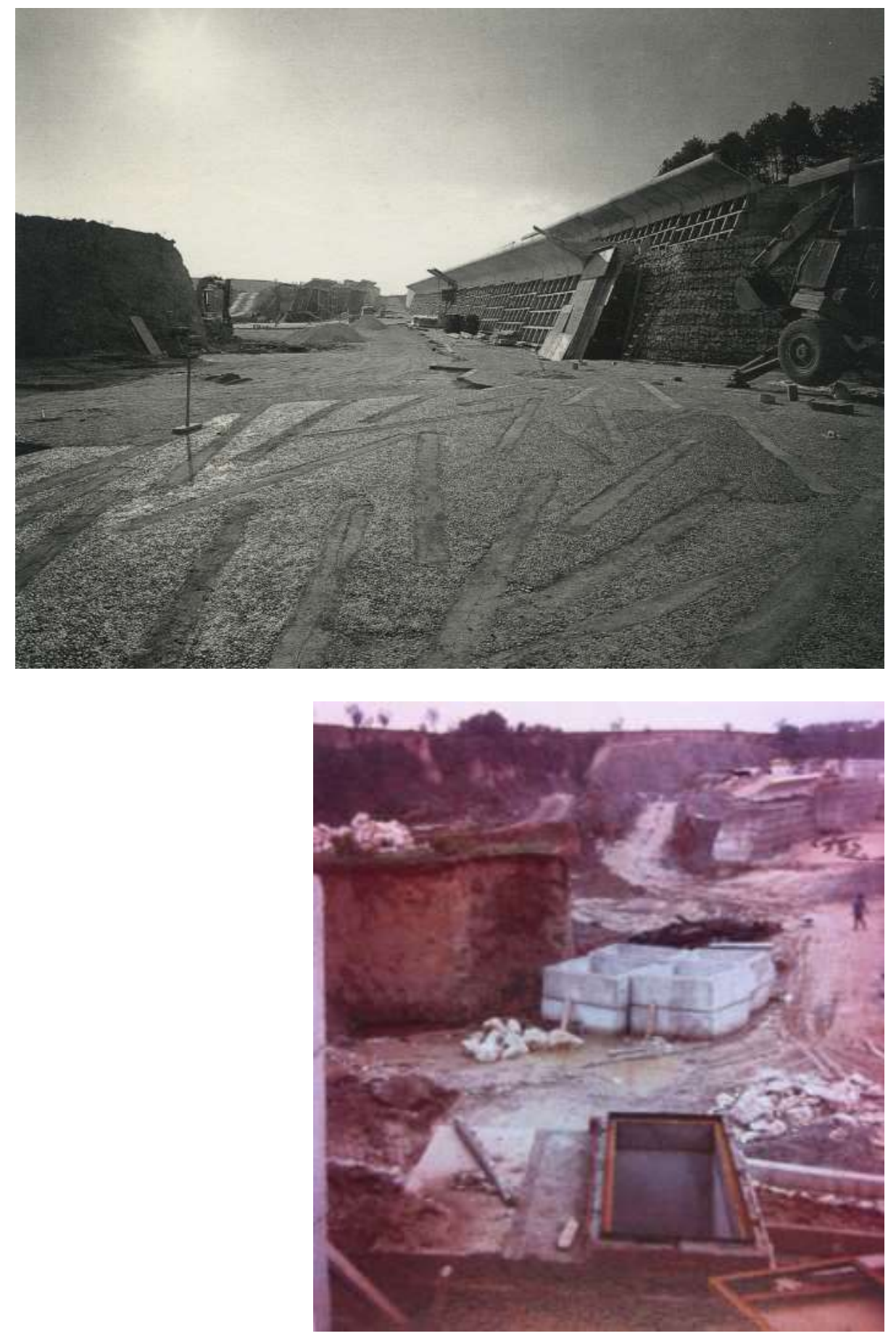

Ilustración 3-27 257

${ }^{257}$ Fotografías durante el proceso constructivo. 1988.. @Fundació Enric Miralles. 


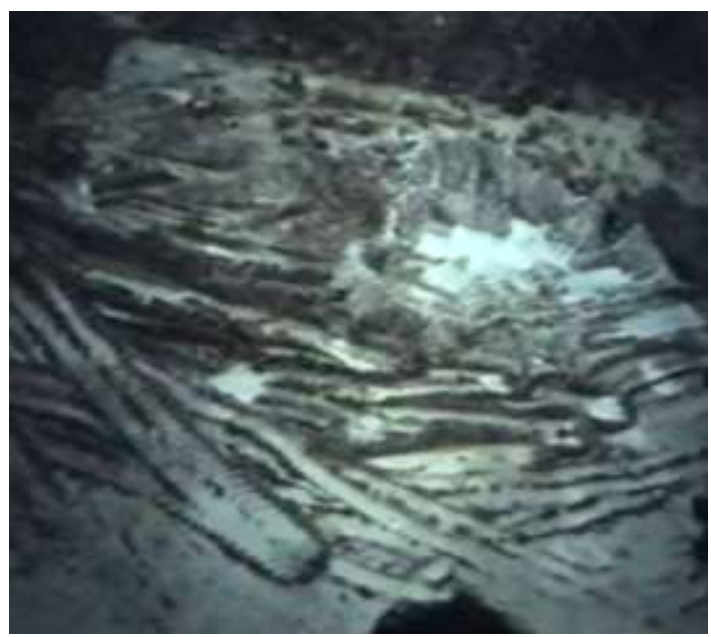

Ilustración 3-28 ${ }^{258}$

"Cuando trabajas estas intentado aprovechar cosas como estas que te encuentras en la obra...por ello las cosas que te encuentras en obra, que luego haces vaciados de hormigón con esta textura superficial..."

Enric Miralles. ${ }^{259}$

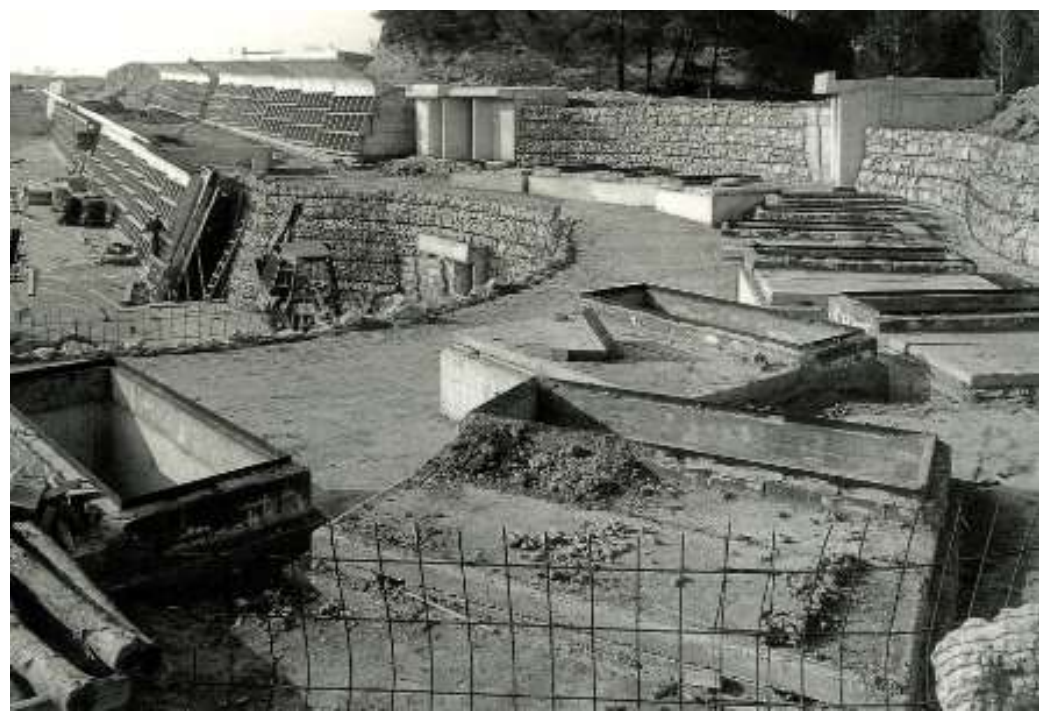

Ilustración 3-29260

258 Diapositiva mostrada por Enric Miralles durante la Conferencia dictada en la Escuela Técnica Superior de Arquitectura (ETSAM) el día 05/05/1993, a los pocos días del derrumbe de la cubierta del Pabellón de Deportes de Huesca.

${ }^{259}$ Conferencia dictada en la Escuela Técnica Superior de Arquitectura (ETSAM) el día 05/05/1993.

${ }^{260}$ Fotografías durante el proceso constructivo de la zona de Panteones. 1991. 


\section{EI Parque Cementerio en la actualidad}

El resultado es una obra en la que se aprecia como se ha dialogado con el paisaje existente respetando en la medida de lo posible su morfología y en la unión con el artificio construido por Miralles, como diría Goethe, es una unión que también puede producirse en un sentido superior, cuando lo dividido primero se intensifica, y con la unión de sus partes intensificadas produce un tercero nuevo, superior e inesperado.

Como comenta Anatxu Zabalbeascoa las relaciones entre hombre y arquitectura, arquitectura y sitio, sitio y paisaje y por tanto hombre y paisaje se redefinen en este Parque Cementerio que emula el camino de la vida tanto espacial como temporalmente. Lo cita en su libro "Igualada Cemetery" en los siguientes terminos: "Relationships such as man - architecture, architecture - site, site - landscape and thus, man - landscape, are forced to redefine themselves within this valley of the dead, in which the cemetery emulates the path of life, both spatially and temporally" 261

En este proyecto se demuestra la capacidad de Miralles y Pinos para transformar la realidad, mezclando el Parque Guell de Gaudi, con la obra de los Land Artists. La evolución del edificio en el tiempo sometida al paso de las estaciones, el crecimiento de la vegetación, la oxidación del acero en puertas y redondos calibrados, y el uso al que ha sido sometido por parte de los usuarios tuneando los nichos, no le ha quitado una apice de solemnidad y modernidad. . El deseo de los arquitectos era erigir sus obras pero, también, verlas envejecer, añejarse: que los árboles crezcan, que las piedras se recubran de musgo, que la obra de arquitectura desarrolle una vida propia. Hacer arquitectura capaz de tener y manifestar recuerdos, de envejecer. Como defiende Mayka Garcia Hipola en su Tesis Doctoral: "...el lugar que se crea no estaba allí antes ya que se produce un nuevo ambiente y una nueva atmosfera que trata tierra y suelo como elementos constructivos a la par que representativos. Se reinventa el sitio...este proyecto ${ }_{262}$ puede definirse como eterno habiendo detenido el tiempo y situándose fuera de el"

En el programa de televisión dedicado al Parque Cementerio de Igualada retransmitido el día 29 de Septiembre de 2015 en la cadena TVE con el titulo de: "La mitad invisible: el Zementeri de Igualada", en el que intervieron Carmen Pinos, Benedetta Tagliabue y Anatxu Zabalbeascoa, entre otras cosas se relato que las siguientes fases de ampliación contempladas en el proyecto inicial, ya ni se plantean, porque han aumentado en los últimos años las solicitudes de cremación frente a las de enterramiento. También que el uso del cementerio ha ido languideciendo, pues actualmente se encuentran cerrados los servicios de autopsias y la capilla sigue sin terminarse. ${ }^{263}$

\footnotetext{
${ }^{261}$ Anatxu Zabalbeascoa. "Igualada Cemetery" Anatxu Zabalbeascoa, Phaidon Press Limited, Londres 1996.

262 Mayka Garcia Hípola.Tesis Doctoral DPA ETSAM. 'La acción de Peter Eisenman en el territorio', pag. 274
}

\footnotetext{
${ }^{263}$ Extracto del Programa televisado en TVE "La mitad invisible: el Zementeri de Igualada". Con la intervención de Carmen Pinos, Benedetta Tagliabue y Anatxu Zabalbeascoa, proyectado en televisión el día 29 de Septiembre de 2015
} 

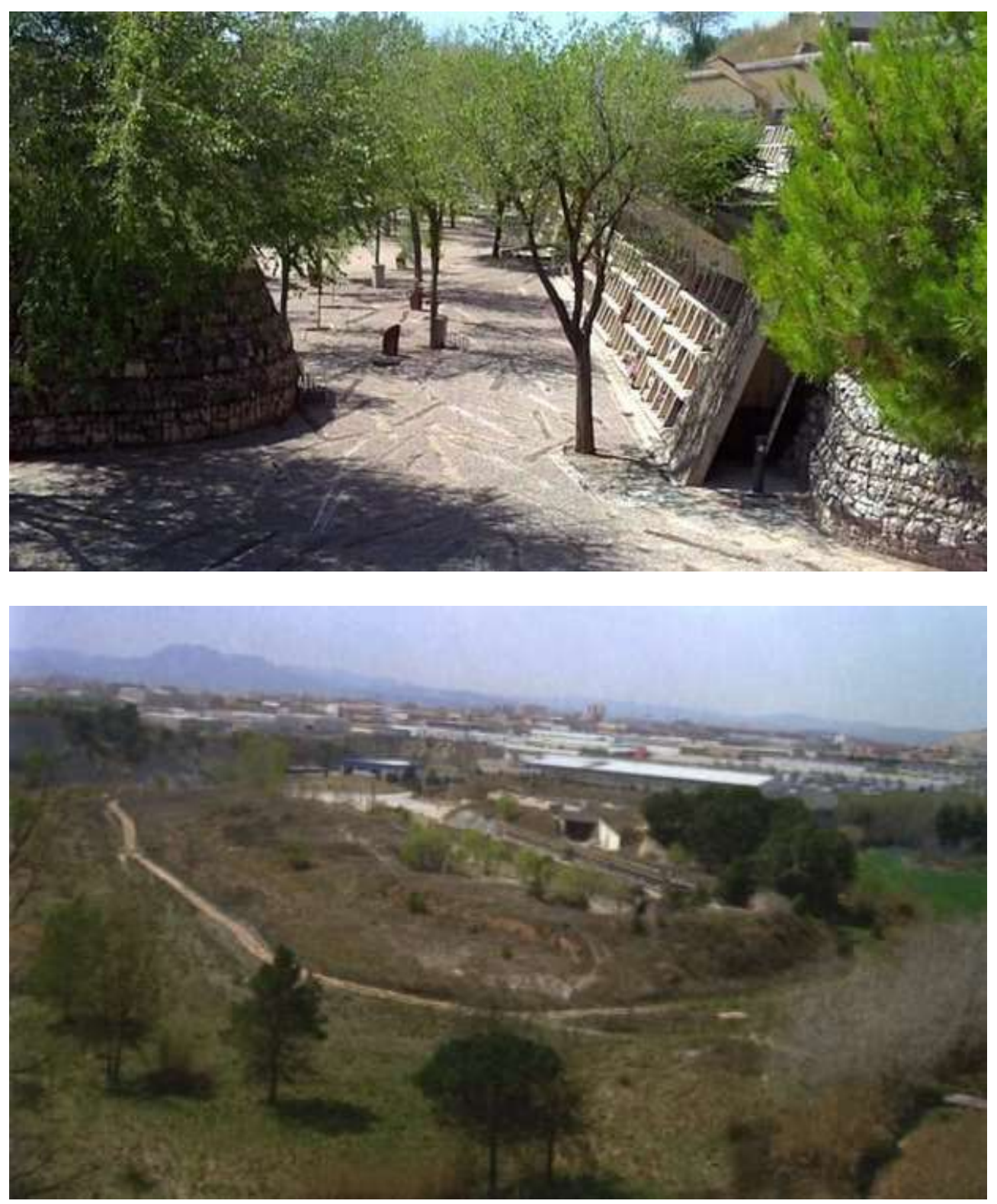

Ilustración 3-30264

${ }^{264}$ Fotografías que muestran el estado actual del Parque Cementerio. 


\subsection{ACCIONES CONCRETAS}

\subsubsection{TOPOGRAFIA}

“...El proyecto parecía acabado desde la primera rotura (cirugía) que hicimos en el terreno. Las memorias se depositan en las fisuras de las tumbas, la vegetación llena los espacios vacios del terraplén y las sombras empiezan a actuar como un reloj"

Enric Miralles.

"...la obra de Miralles y Pinos ha sido mejor cuando han anclado los edificios profundamente en el suelo como en el edificio de tiro o en el cementerio del Igualada..."

Kenneth Frampton. ${ }^{265}$

Según Arturo Blanco, en los primeros croquis del proyecto, están dibujadas y redibujadas insistentemente las curvas de nivel del plano topográfico que determinaba el estado existente del terreno. ${ }^{266}$ En los mismos términos se expresa Carmen Pinos en una entrevista: "siempre lo mismo, siempre se empezaba a dibujar la topografía...mil veces, dibujar las curvas de nivel y buscar una geometría" 267

Miralles y Pinós obtienen las trazas a las que agarrarse para comenzar su proyecto de la topografía natural del paisaje en el que van a actuar. Generaran una topografía artificial empática con esta, que les permitiese alojar el programa funcional demandado por el Ayuntamiento de la localidad. La pareja de arquitectos tenía una idea clara desde el principio de lo que debía ser este Cementerio, según un sistema sistema de enterramientos subterráneos, para que la Naturaleza cubriese los cuerpos sin vida. ${ }^{268}$

En el Parque Cementerio de Igualada, el orden topográfico existente es realzado por la intervención de Miralles y Pinos mediante la generación de una nueva topografía a través de la generación de una falla artificial de formas angulosas, abierta por la excavación que enlaza el nivel de entrada con el nivel inferior del rio. Es decir que se modifica la topografía desde la geometría sin renunciar al contexto geográfico para conseguir una relación más intensa con el lugar. Arturo Blanco se refiere en los siguientes términos: "en la trama del territorio se eligen una serie de elementos que parecen importantes. Se dibuja sobre ellos, toman grosor...las primeras líneas sobre el plano topográfico redibujan lo inmediato, los diferentes

\footnotetext{
265 "Sobre la tradición tectónica en la forma catalana contemporánea" Quaderns 206.

${ }^{266}$ Arturo Blanco. Tesis Doctoral "Flujo laminar: El cementerio de Igualada y los procesos elásticos en la arquitectura de Enric Miralles y Carme Pinós" defendida el dia 18 de Noviembre de 2015 en la ETSAM. UPM, pag. 23

267 Trasladado por Carme Pinós en la entrevista realizada por Arturo Blanco el dia 9 de diciembre de 2012 en Madrid.

${ }^{268}$ Arturo Blanco. Tesis Doctoral "Flujo laminar: El cementerio de Igualada y los procesos elásticos en la arquitectura de Enric Miralles y Carme Pinós" defendida el dia 18 de Noviembre de 2015 en la ETSAM. UPM, pag. 90
} 
niveles, el terreno existente. Las siguientes líneas que aparecen son diferentes, rehacen los niveles anteriores, pero como si fuera la primera vez que se trazan. El rehacer supone un volver a dibujar dese el principio, sin prejuicios, pero con mas información. Las líneas se rehacen constantemente" 269

La gran excavación practicada en el paisaje, genera un umbral entre el paisaje existente y el paisaje creado por la pareja de arquitectos. Las formas de las incisiones practicadas en el paisaje por Miralles y Pinós, aunque potentes y severas, responden a la topografía existente y se producen en sintonía con el paisaje existente, dando la sensación de que siempre hubieran estado allí.

Miralles y Pinós, re-utilizaran esta antigua cantera mediante un trabajo topográfico que cose las heridas del lugar y también creando incisiones nuevas, creando una nueva naturaleza artificial. Se aprovechan de las curvas de nivel y los taludes para albergar los nichos de enterramiento y los panteones familiares, a la manera de muros de contención.

En este proyecto Miralles y Pinós, trasladan su interés por la semántica del lugar y el plano del suelo, relacionando la Arquitectura con la Geología, la Geografía y la Historia del lugar. La acción topográfica conforma la intervención arquitectónica, que parece hubiera sido realizada por un agente geológico erosivo dejando al descubierto los diferentes niveles, confundiéndose los taludes naturales ya existentes en la cantera con los taludes proyectados (los que albergan los nichos y los de gaviones de piedra). Se practica un corte en el terreno generando una hoz artificial conformada por los nichos.

Se detectan tres niveles en la intervención de Miralles y Pinos. El nivel inferior está conformado por el camino que desciende acompañado a ambos lados por los muros que albergan nichos de enterramiento dispuestos en columbario que desemboca en un espacio de forma elíptica donde se encuentran los panteones. El nivel intermedio comprende una sola banda de nichos de enterramiento en columbario excavados en el terreno a un lado, dejando ver por el otro lado todo el paisaje del Valle. En el nivel superior se disponen semienterrados tanto el edificio de servicios como la Capilla. Como comenta Arturo Blanco en su tesis doctoral: "los primeros pasos son dibujar sobre las líneas topográficas. la repetición de las trazas incluidas que construyen el plano topográfico será un primer tanteo...las líneas que se repiten se ponen unas sobre otras generando tramas, como urdimbres que van construyendo una interpretación del paisaje existente. Desde lo topográfico surge lo geométrico...la topografía sigue siendo sustrato fundamental en las repeticiones." 270

\footnotetext{
${ }^{269}$ Ibidem, pag. 337

${ }^{270}$ Arturo Blanco. Tesis Doctoral "Flujo laminar: El cementerio de Igualada y los procesos elásticos en la arquitectura de Enric Miralles y Carme Pinós" defendida el día 18 de Noviembre de 2015 en la ETSAM. UPM, pág. 379
} 


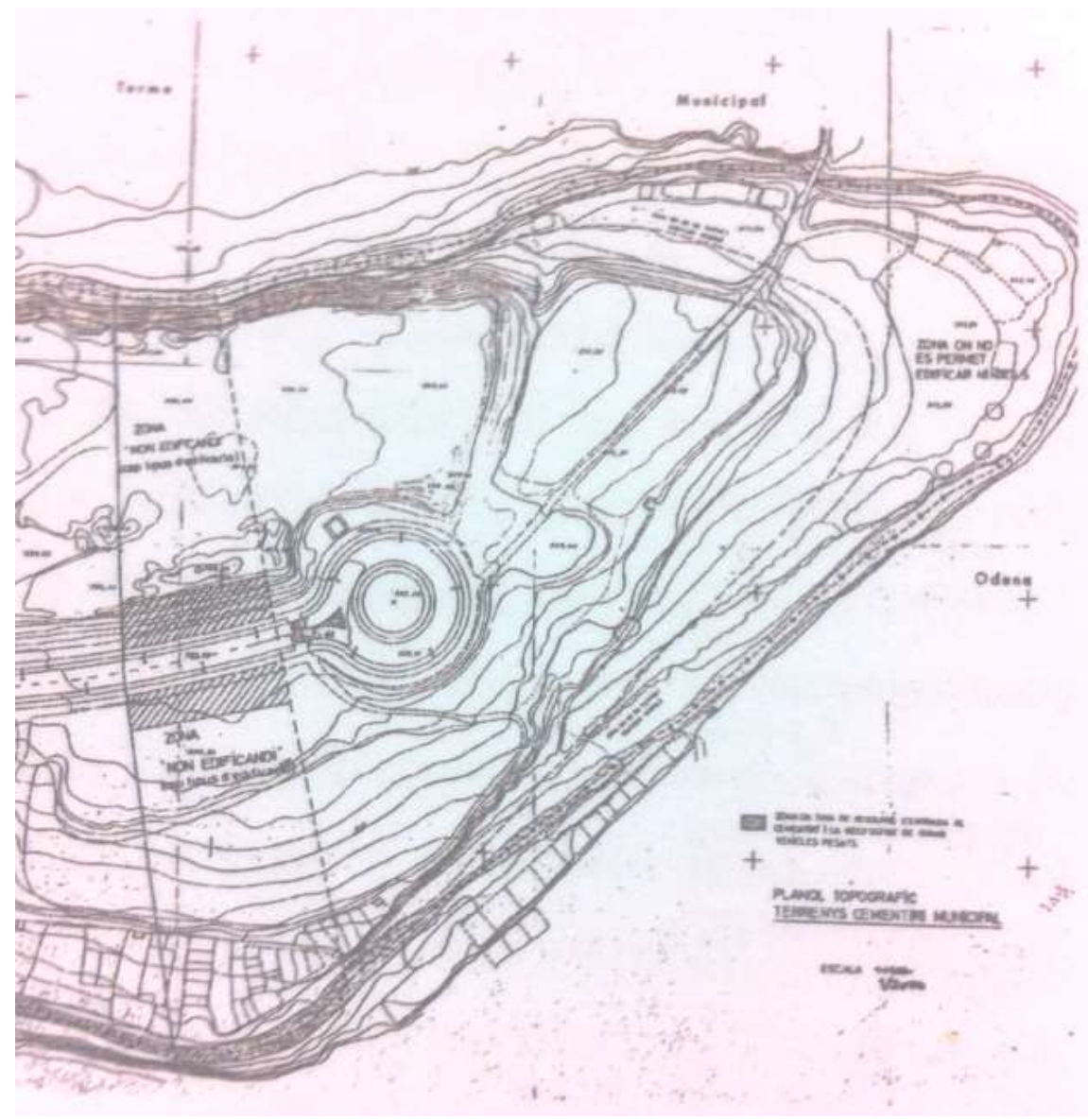

Ilustración 3-31271

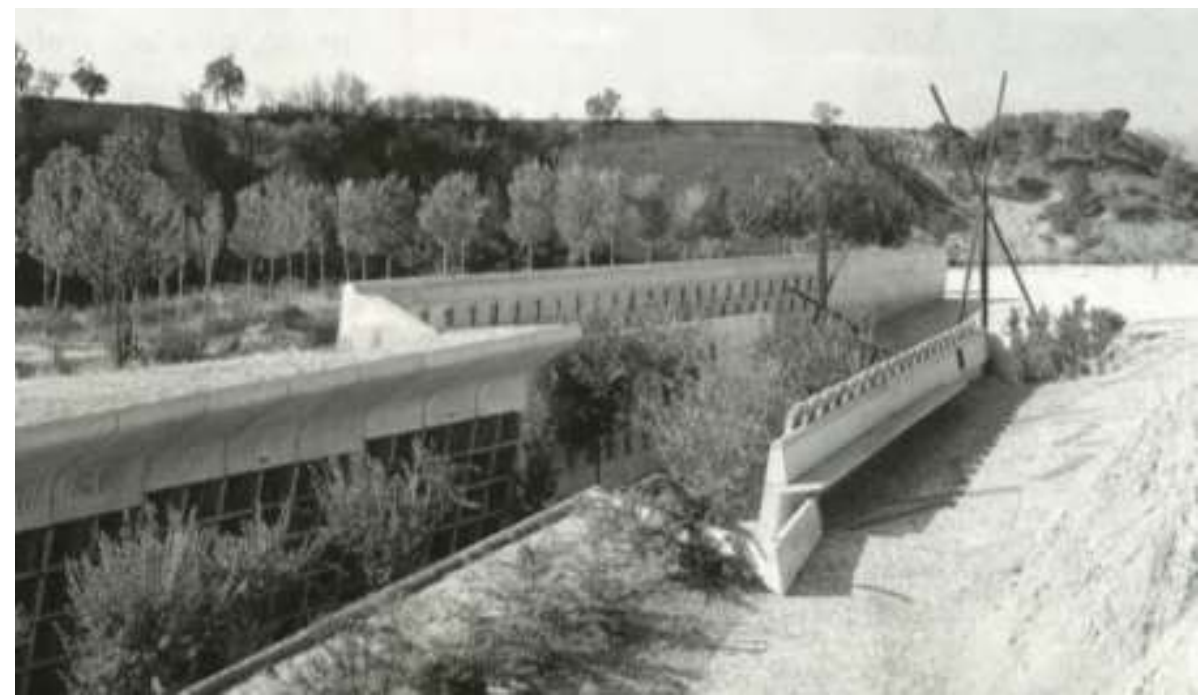

Ilustración 3-32 272

${ }^{271}$ Planimetría de la parcela objeto del Concurso utilizada por Miralles y Pinos.

${ }^{272}$ Fotografía que demuestra la brecha abierta en el terreno artificialmente. 
Los arquitectos para soportar el terreno, proyectaron en la zona de panteones unos muros de contención realizados con gaviones de piedra envueltos en malla metálica (recordando los muros bajos que se pueden ver en la arquitectura vernácula catalana). Las secciones revelan los estratos geológicos del territorio, representando en sus planos la sección cinética para narrar la variabilidad topográfica del proyecto. Esta obra supone la incorporación del carácter estereotómico en la arquitectura de Miralles y Pinos, al incorporar el terreno como un material de proyecto mas. Tal como relata el mismo Miralles: "...parte de las tierras de la excavación inician el ajardinamiento del borde sinuoso...este trabajo del trabajo de la primera fase..., ha sido el definir el interior de las trazas que habiamos encontrado en ese lugar." 273

Los muros de hormigón que contienen los nichos y acompañan el recorrido son el resultado de una sustracción, de un desmonte y excavación previas. Estos nichos se encajan en los muros siguiendo un ritmo cambiante, en el que empujan el terreno o son empujados por este. La Capilla, es el resultado de una adición, de un relleno de tierra posterior a su construcción ${ }^{274}$, un truco ayudado por la vegetación para disimular, cuyo artificio se revela en los extremos del testero de hormigón. La capilla, por tanto, no es una gruta, sino un artificio, pues se erigió exenta partiendo del plano del suelo y luego se relleno de tierra. La apariencia una vez terminada es que Miralles la hubiera excavado en el terreno para alojar el espacio sagrado de la capilla, la cueva, la gruta como algo sagrado en la cultura, especialmente en la catalana, haciendo referencia a la gruta donde se encontró la talla de la Virgen de Montserrat, o la cripta de la Colonia Güell. El organismo construido es un zócalo desparramado que alberga el programa funcional y distribuye el recorrido.

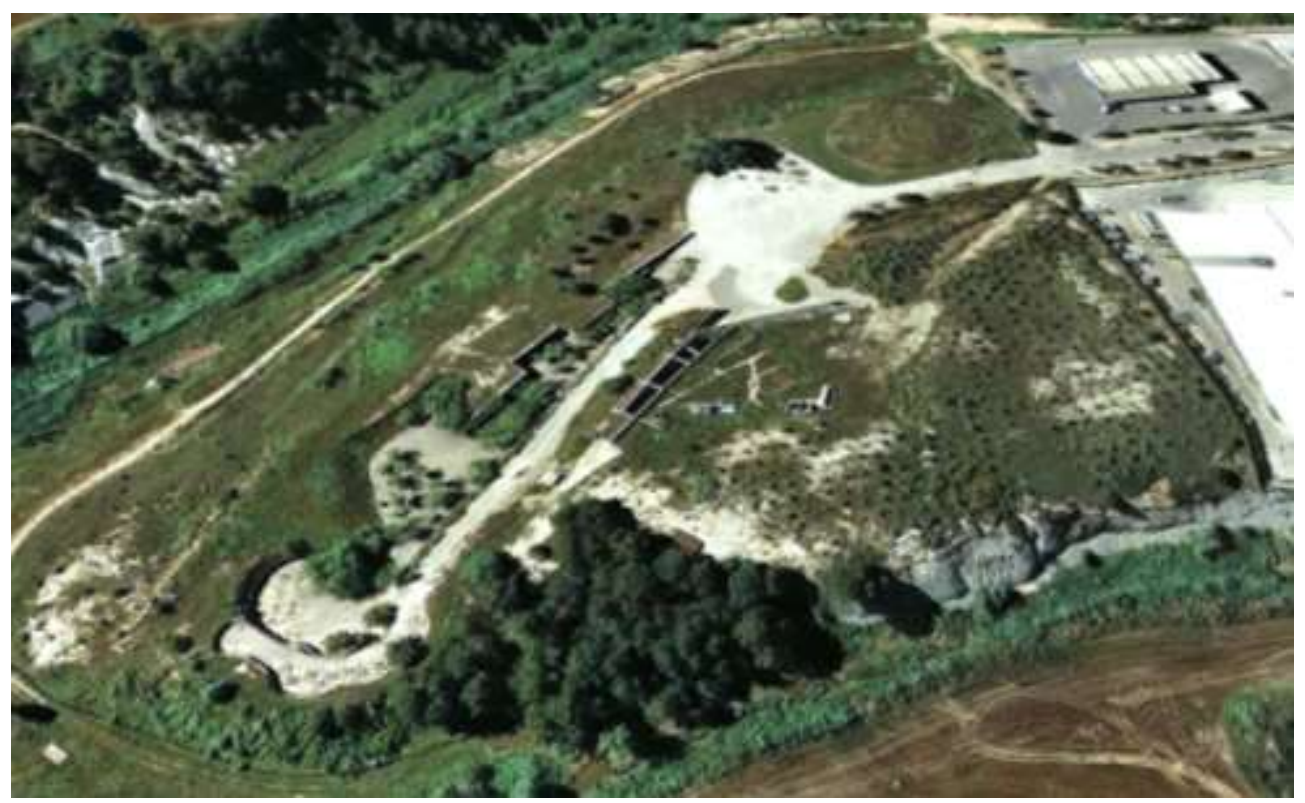

Ilustración 3-33 ${ }^{275}$

\footnotetext{
273 "Zementiri" Obradoiro № 13, 1987, p. 70-78.

${ }^{274}$ La obra de Land Art de Robert Smithson "Leñera parcialmente enterrada" tiene mucho que ver con esta acción de Miralles y Pinos con el enterramiento parcial de la Capilla en este proyecto.

${ }^{275}$ Vista aérea en la que se entiende la intervención general en el paisaje.
} 


\subsubsection{PROGRAMA}

El programa cuantifica el Proyecto, su misión es hacer coherente la relación entre el espacio, el uso y los medios materiales. Todo el programa funcional se encuentra albergado en el terreno, modificando previamente la topografía para acogerlo. El programa consta de: Pabellón de servicios, Capilla, nichos de enterramiento en columbario ${ }^{276}$, Panteones, y una serie de sepulturas dispuestas en el subsuelo de la plaza ovoidal.

En el nivel superior se sitúa el Pabellón de servicios y la Capilla, y en los niveles inferiores se encuentran los nichos de enterramiento y los panteones. Pero en el Parque Cementerio de Igualada, los cuerpos ya no son todos devueltos a la tierra como en la Antigüedad, sino que en su mayoría se almacenan en ataúdes dispuestos en altura, que se encierran en nichos, en columbario, debido a la elevada de enterramientos solicitada por el Ayto.

\subsubsection{FRAGMENTACION SIN JERARQUIAS}

La formalización de la intervención se lleva a cabo con formas indeterminadas e imprecisas; destacando la componente horizontal para vincularse con la extensión del paisaje.

Esta obra constituye el primer proyecto de Miralles y Pinos en el que se compone con piezas morfológicamente diferenciadas, fragmentándose el sistema de representación en planta matriz y planos parciales. Una planta matriz documenta la planta de la totalidad de la propuesta, mientras que unos planos parciales desarrollan en detalle fragmentos de la planta matriz. La capilla, una sala semienterrada de forma triangular; y la zona de panteones, una plaza al aire libre de forma elíptica resultado de una operación topográfica, son piezas dotadas de rasgos diferenciales y con lógica propia dentro del conjunto, que se proyectan autónomamente en planos separados. ${ }^{277}$

Compositivamente, la planta presentada a concurso es la yuxtaposición de la forma en $Z$ (que corresponde con el recorrido entre nichos) con la forma triangular que tiene la capilla. El triangulo aquí representado es una figura inestable al estar roto en dos de sus tres vértices para poder caminar a través de ellos. Ello confiere a la capilla una condición de lugar de paso, alejada del estatismo de cuadrados y rectángulos. En la documentación aportada en el Proyecto de Ejecución, la planta del proyecto se transformo desde una forma inicial en $Z$ a una forma en $V$ de brazos asimétricos incorporando en su vértice una forma elíptica para alojar los panteones. Desde el punto de vista espacial, capilla; nichos y panteones, son diferentes: la capilla es una sala semienterrada; los nichos son unos muros de contención huecos y la zona de panteones es una plaza elíptica de dos niveles. ${ }^{278}$

\footnotetext{
${ }^{276}$ Cuando los ataúdes se almacenan dispuestos en vertical y cerrados en nichos.

277 Para mas información puede consultarse la Tesis de Javier Fernandez Contreras "La planta Mlralles: Representación y Pensamiento en la Arquitectura de Enric Miralles", leída en la ETSAM. UPM en el año 2013, pág. 94

278 ibidem
} 
La zona de entrada, se conforma con una plaza de forma oblonga y a su derecha, por un montículo de tierra de 5 metros de altura realizado con la tierra aprovechada de la excavación. Dicho montículo hace alusión a la obra de Land Art Spiral Getty de Robert Smithson. El edificio de servicios, contiene distintas dependencias: sacristía, depósito de cadáveres, sala de disección, vestidor, aseo, entrada, y sala de espera. Un muro de pavés siguiendo el perfil del lucernario cierra las dependencias de la zona de espera. La sacristía está separada por una puerta corredera de marco tubular metálico. Una puerta giratoria circular de chapa metálica separa la sacristía de la capilla. El muro exterior de cerramiento es de hormigón blanco, forrado al exterior con un aplacado de hormigón calado formando una celosía. ${ }^{279}$ La capilla se sitúa a la izquierda. De forma triangular, la capilla es atravesada por el camino por el que discurre el coche fúnebre que llega desde la entrada al Cementerio. Deja en dos de sus lados una gran abertura para su tránsito. Estaba prevista en proyecto un cierre de vidrio con grandes puertas correderas que darían acceso al interior de la capilla desde el camino, pero que a día de hoy sigue sin ejecutarse.

Los acompañantes que han asistido a la ceremonia religiosa, al salir de la capilla, divisaran el paisaje y podrán descender hacia la zona de los nichos a través de una escalera en diagonal que atraviesa los muros que albergan los nichos en columbario.

Los enterramientos son de distintos tipos: muros de nichos dispuestos en columbario y panteones encajados contra el talud y el suelo. Estos nichos en columbario se desplazan según un movimiento sucesivo bien empujando el terreno o siendo empujados por este, convirtiendo el camino practicado en el terreno en una concatenación de lugares a cielo abierto. Estos muros de nichos, están coronados por viseras de hormigón que remiten a Le Corbusier y Gaudí, además de generar sombras, cierran el espacio para que desde el camino solo se puedan contemplar el cielo y las montañas próximas, para redundar en la sensación de aislamiento a que remite el haber dejado el mundo terrenal arriba.

Por último se llega a la plaza de forma elíptica que alberga la zona de panteones, y con ello al punto final del recorrido. Esta plaza se divide en dos niveles: el inferior de planta elíptica rodeado por muros que ayudan a entender este espacio como un interior al aire libre y el nivel superior de contorno más irregular se abre al paisaje. Existen dos tipos de panteones: encajados contra el talud o en el suelo, estando los primeros cerrados con unas puertas de geometría esviada y los otros con tapas. ${ }^{280}$

No se puede hablar de cubierta propiamente dicha en esta obra, puesto que todo el programa funcional se encuentra enterrado o semienterrado, siendo el propio terreno el que hace de cubierta.Mención especial merecen las viseras de hormigón que rematan los nichos de enterramiento que no solo generan sombra en sus respectivos muros sino que también ayudan a aislar del entorno superior la obra.

\footnotetext{
${ }^{279}$ Celosía que remite a "Block Screens" de Elieen Gray.

280 Para mas información puede consultarse la Tesis de Javier Fernandez Contreras "La planta Mlralles: Representación y Pensamiento en la Arquitectura de Enric Miralles", leída en la ETSAM. UPM en el año 2013, pág. 96
} 


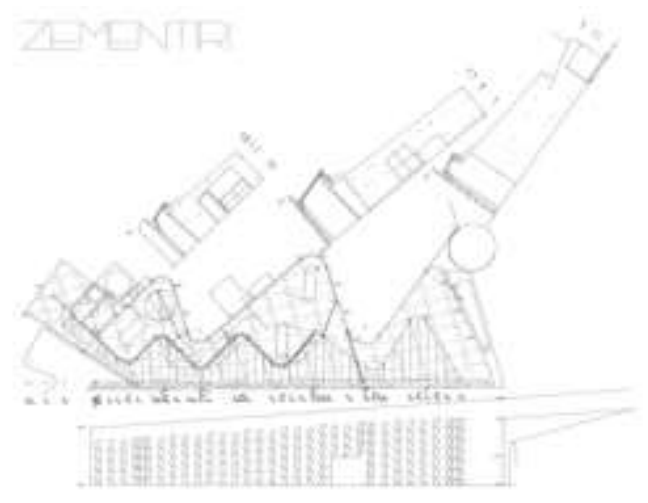

Ilustración 3-34 ${ }^{281}$

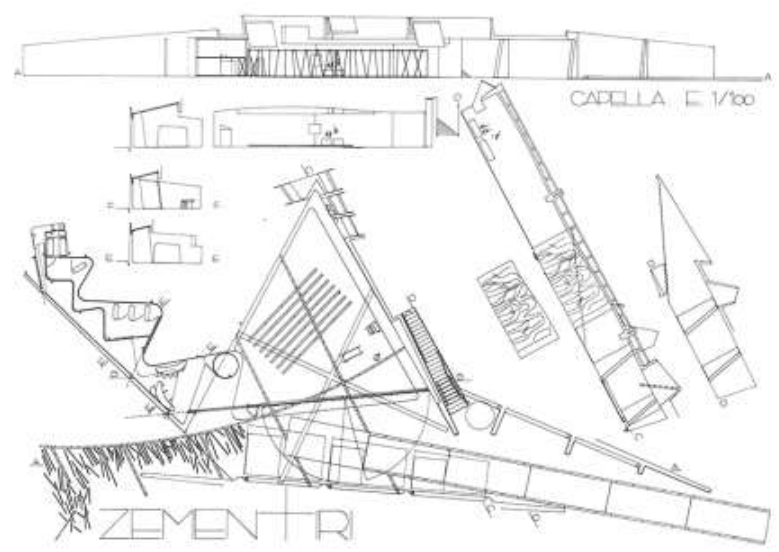

llustración 3-35 282

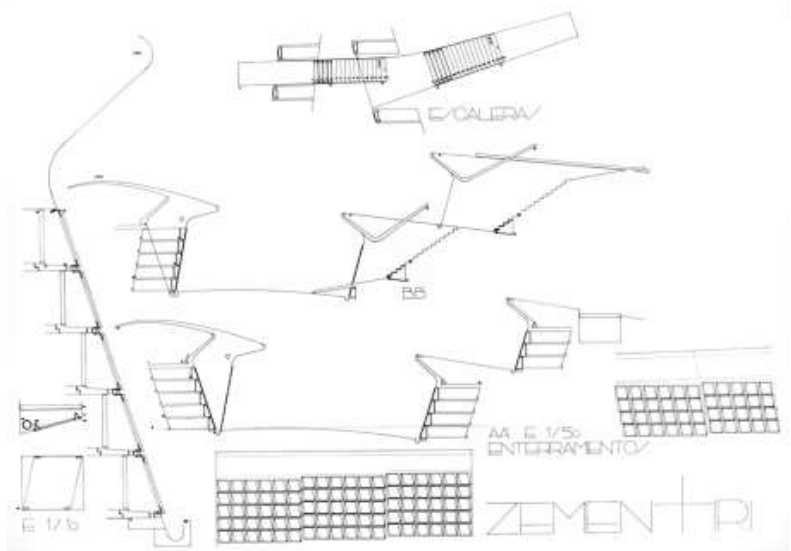

llustración 3-36 ${ }^{283}$

${ }^{281}$ Edificio de servicios semienterrado que se ilumina cenitalmente.

${ }^{282}$ Planta y secciones de la Capilla y edificio de servicios. 


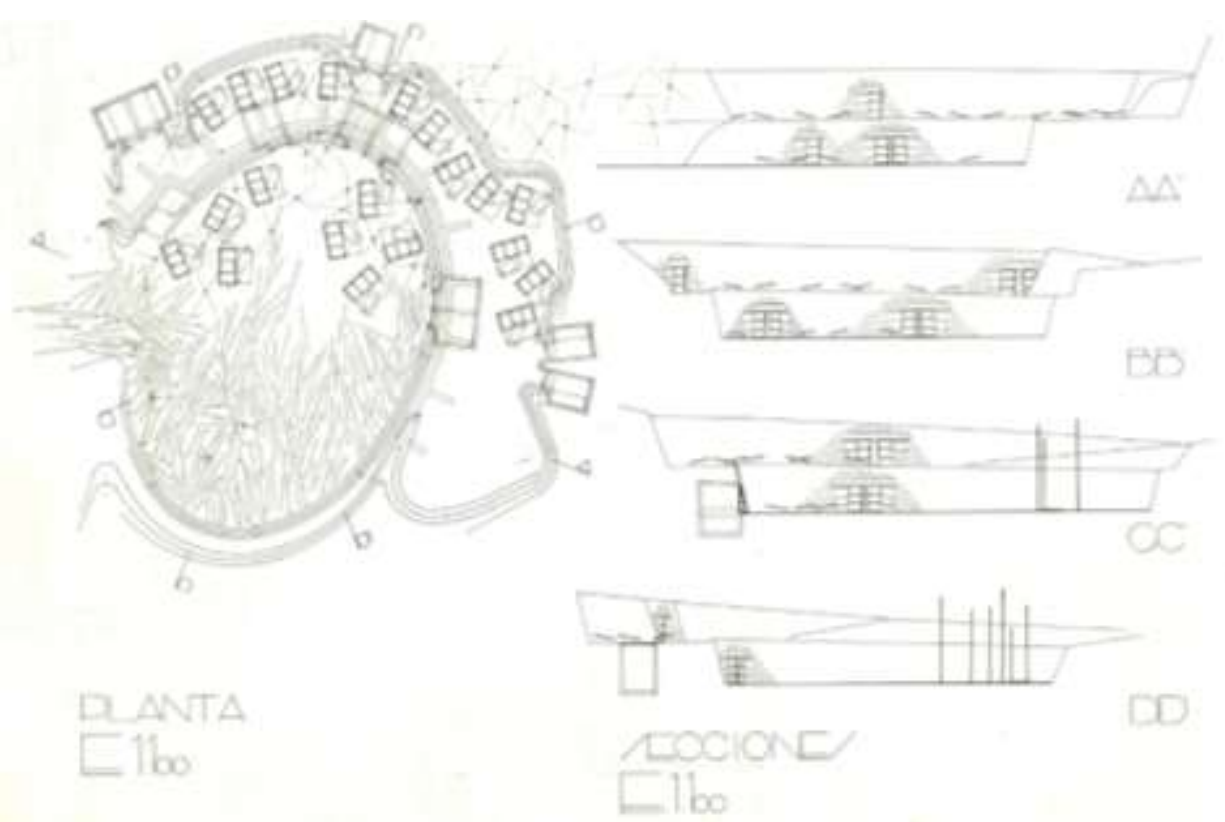

llustración 3-37 ${ }^{284}$

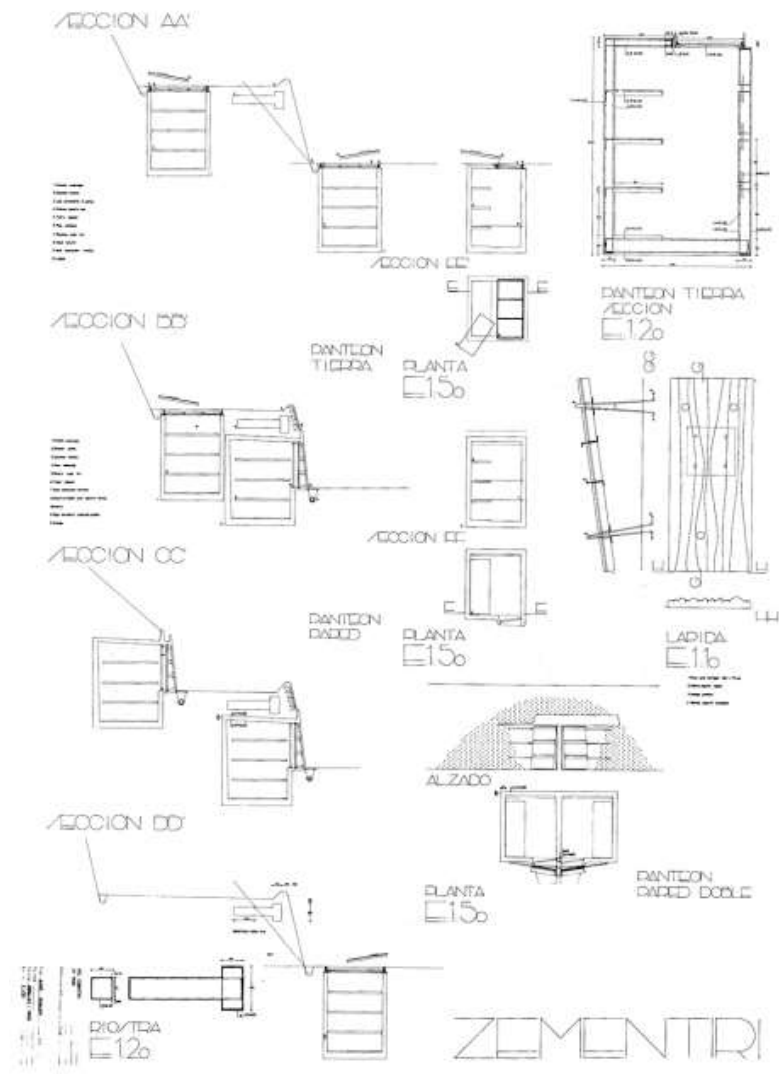

Ilustración 3-38 285

${ }^{283}$ Sección por los nichos de enterramiento en columbario en zona de camino que desciende.

${ }^{284}$ Planta y secciones de zona de Panteones. 1987.

${ }^{285}$ Secciones por Panteones empotrados en muros de gaviones y en suelo. 


\title{
3.2.3. RELACIONES INTERIOR - EXTERIOR
}

\begin{abstract}
"las piezas se disponen unas junto a otras. En algunos casos están separadas, en otros se generan intersecciones...los intersticios son espacios nuevos...los espacios intersticiales son estas fisuras que forman el límite de la materia."
\end{abstract}

Arturo Blanco ${ }^{286}$

En esta obra, se rompe con la dualidad interior - exterior. Se relaciona el mundo exterior del paisaje con el mundo interior del más allá. Las puertas entreabiertas de los panteones crean un espacio transitorio entre interior y exterior, un lugar de aislamiento, que deja de estar fuera sin estar dentro, anunciando el misterio e incitando al visitante a que se asome "al otro lado".

La intervención asume la climatología del lugar que permite espacios sin climatizar. El asoleo excesivo se combate con la creación de umbrales de sombra, no solo con la vegetación proyectada sino con los elementos construidos, pues existen umbrales en los que es difícil diferenciar si uno se encuentra en un interior o en un exterior. De esta manera también se rompe con las dualidades natural - artificial y Naturaleza - Arquitectura.No existe un contorno, un perfil de lo edificado que se destaque respecto al paisaje, siendo el contorno en esta obra, el contorno del propio paisaje.

No existe una fachada convencional, al uso, con sus habituales elementos: ventanas, puertas, etc. La única fachada propiamente dicha cierra el área de servicios y se encuentra semienterrada, camuflando su existencia al confundirse su muro de cerramiento como si fuera un muro de contención. Incluso la puerta de acceso, recibida en este muro, se camufla, confundida entre el despiece de la celosía de hormigón. Dicho artificio es posible porque la iluminación de este espacio habitable se realiza cenitalmente. En lo que respecta a la Capilla, la otra pieza que junto con el área de servicios puede habitarse, se construye semienterrada y por tanto sin fachadas a exterior. Lo único que se aprecia por el visitante es un gran hueco que la atraviesa, pero de escala paisajística, pareciendo más bien un túnel perteneciente a una infraestructura de las que se encuentran en las carreteras y no un edificio propiamente dicho. La iluminación de este espacio habitable se realiza cenitalmente. No existe una barrera climática que tenga que compartimentarse, tan solo en el edificio de servicios que requiere de un control ambiental y la privacidad necesarias para poder realizar las autopsias. Todas estas acciones, orquestadas por Miralles y Pinos, ayudan a integrar lo construido con el paisaje.

\footnotetext{
${ }^{286}$ Arturo Blanco. Tesis Doctoral "Flujo laminar: El cementerio de Igualada y los procesos elásticos en la arquitectura de Enric Miralles y Carme Pinós" defendida el dia 18 de Noviembre de 2015 en la ETSAM. UPM, pag. 365
} 


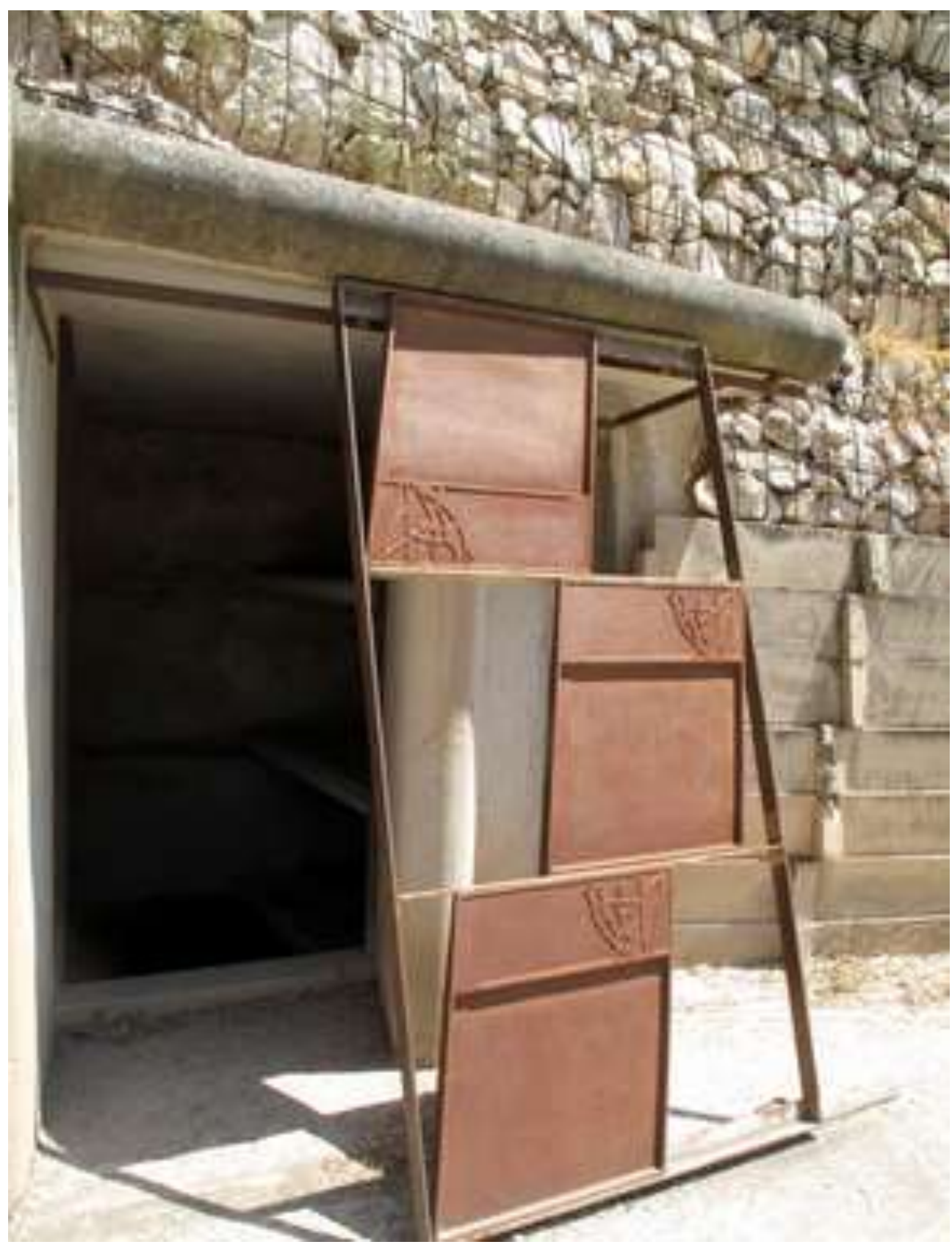

Ilustración 3-39287

287 Las puertas entreabiertas de los panteones crean un espacio transitorio entre interior y exterior, un lugar de aislamiento, que deja de estar fuera sin estar dentro, anunciando el misterio e incitando al visitante a que se asome "al otro lado". 


\title{
3.2.4. RECORRIDOS
}

\begin{abstract}
"Un cementerio no es una tumba. Es más bien una relación con el paisaje y con el olvido: huellas como signos abstractos, una abstracción que se origina en el caminar y en el trazar con los pasos el mejor camino...Siempre me ha parecido que operaba sobre un lugar donde ese proyecto ya existía, pareciéndome acabado desde el primer movimiento de tierra que se hizo..."

Enric Miralles. ${ }^{288}$
\end{abstract}

Los cementerios modernos como Igualada, son herederos del tema del recorrido que se ha planteado a lo largo de la Historia desde la Acrópolis de Atenas hasta la ciudad de Pompeya. Su diseño puede variar desde la tipología de "ciudad jardín" hasta aproximaciones mas "urbanas" representadas por cementerios como el de Woodland de Asplund y Lewerentz en Estocolmo, de 1920. Woodland continua la tradición escandinava de cementerios construidos en intima relación con el paisaje en la que los elementos construidos son "depositados sobre" los paisajes y no "construidos en ellos" como hace el de Igualada de Miralles y Pinos.

El Parque Cementerio de Igualada, obliga a ser recorrido y experimentado para poderlo entender. La promenade architecturale de Le Corbusier está aquí muy presente, existiendo distintos puntos de vista orquestados por Miralles y Pinos para poder comprender su intervención y realzar el paisaje existente. El recorrido afianza las tensiones entre lo construido y el paisaje. Se enmarcan las vistas hacia el paisaje existente, y de ahí que el recorrido sea muy importante al respecto. La arquitectura adopta la forma de una calle, un recorrido lineal, donde caminos y senderos siguen un recorrido procesional que desciende hasta la zona de enterramientos, relacionando en el recorrido el mundo exterior del paisaje con el mundo interior del más allá. La ruta creada por Mlralles y Pinós, recrea el camino serpenteante que existía en la cantera abandonada y que desde lo alto del emplazamiento descendía hasta el rio. Todas las decisiones de proyecto, se toman en relación a la manera de recorrer ese camino y a las operaciones psicológicas que se generan recorriéndolo. La obra, es una metáfora sobre el tránsito hacia la muerte. Como comenta Arturo Blanco: "las líneas se despliegan por la topografía. Las líneas establecen cruces, conexiones, encuentros y desencuentros. aparecen espacios entre líneas, lugares aun por colonizar." ${ }^{289}$ Este recorrido es representado en las perspectivas dibujadas por Miralles, presentadas a Concurso. Cuando se camina por una hoz, se tiene la sensación de protección pero también de cierta presión, cuando el camino se estrecha pues al comprimirse el espacio, el hombre se siente hostigado, las escalas del hombre y del paisaje se llevan al límite, y las miradas buscan el cielo. La sensación de protección, de refugio que se ofrece al visitante al recorrer el camino descendente entre muros, se aprecia especialmente en los meses cálidos de verano y en los fríos de invierno, a resguardo de las inclemencias y disfrutando del silencio, dando la sensación de que el tiempo se para.

\footnotetext{
${ }^{288}$ Texto de la memoria del cementerio de Igualada

${ }^{289}$ Arturo Blanco. Tesis Doctoral "Flujo laminar: El cementerio de Igualada y los procesos elásticos en la arquitectura de Enric Miralles y Carme Pinós" defendida el dia 18 de Noviembre de 2015 en la ETSAM. UPM, pag. 365
} 

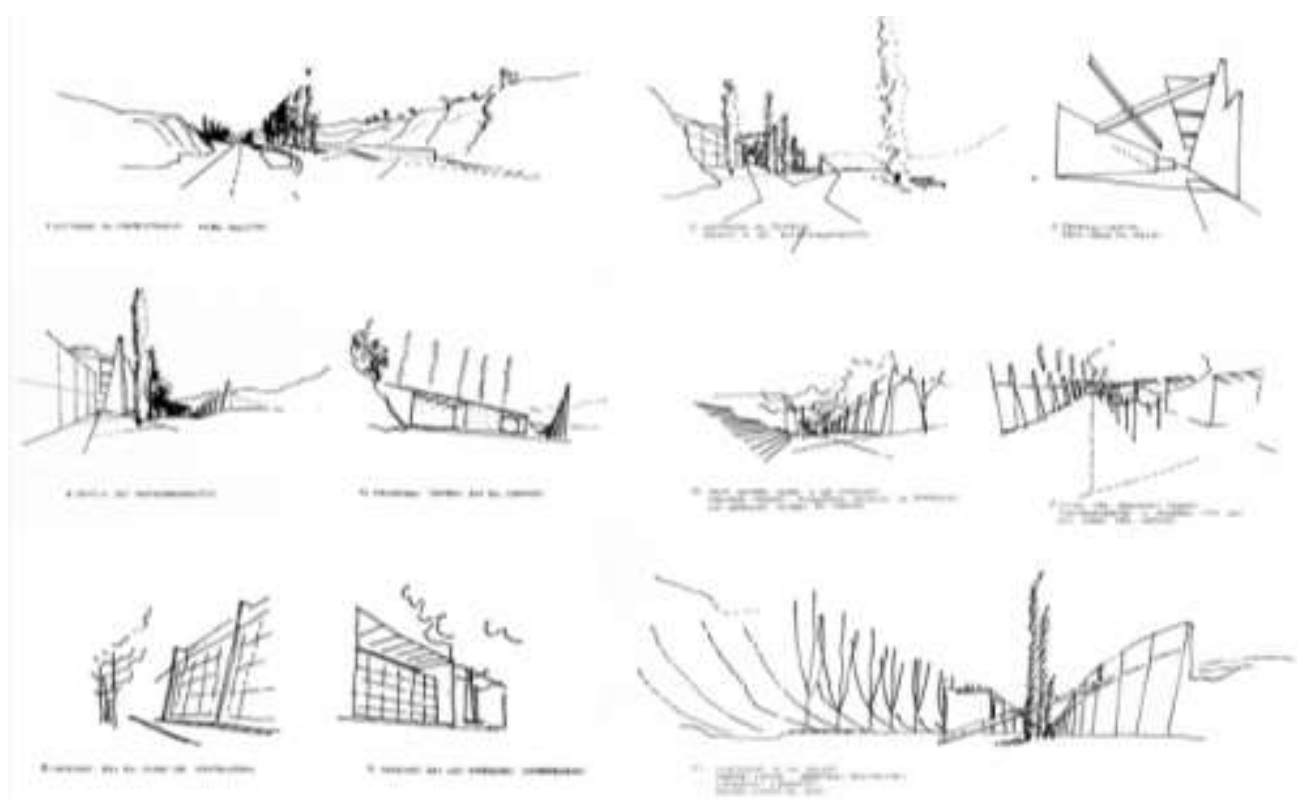

Ilustración 3-40 290

En la hoz artificial construida por Miralles y Pinos, la separación entre los lados construidos de nichos que franquean el descenso, y los capiteles que rematan dichos muros, tienen una escala humana; nada que ver con la desmesurada escala de una hoz natural. El valor de esta hoz artificial generada por la pareja de arquitectos, radica en la conformación de un espacio acogedor tanto para el visitante que lo recorre linealmente como para el familiar que se detiene a rendir su recuerdo ante uno de los nichos en columbario alojados en los muros dispuestos a uno y otro lado del camino. Como comenta Wlliam Curtis: "Miralles y Pinós exploran un ambiguo territorio intermedio entre los dominios de la escultura, la arquitectura, el urbanismo y el diseño paisajístico. La imagen subyacente es una suerte de 'campo de fuerzas', una trama de relaciones sociales trazada como una multitud de nodos, puntos focales y recorridos". ${ }^{291}$ Pero unido al recorrido lineal, también existe un recorrido transversal que se inicia cuando al regresar desde la zona de panteones, un peldaño en voladizo que no llega a tocar el suelo y sale en perpendicular del muro de nichos, invita a tomar la escalera diagonal que comunica los niveles inferior y superior del Parque Cementerio. Mientras que en el recorrido lineal, la visión del paseante se encuentra jalonada por distintos elementos, apreciando un mismo espacio desde diferentes perspectivas, en este recorrido transversal, la visión que se tiene, es concentrada.

\footnotetext{
290 Perspectivas dibujadas por Enric Mlralles que relatan el recorrido secuencial por el Parque Cementerio desde la entrada. Fue uno de los tres planos presentados a Concurso. 1985.

291 William Curtis "Mapas mentales y paisajes sociales". El Croquis MIRALLES / PINÓs 1983-1990, № $30,49+50$, pag. $6-21$.
} 


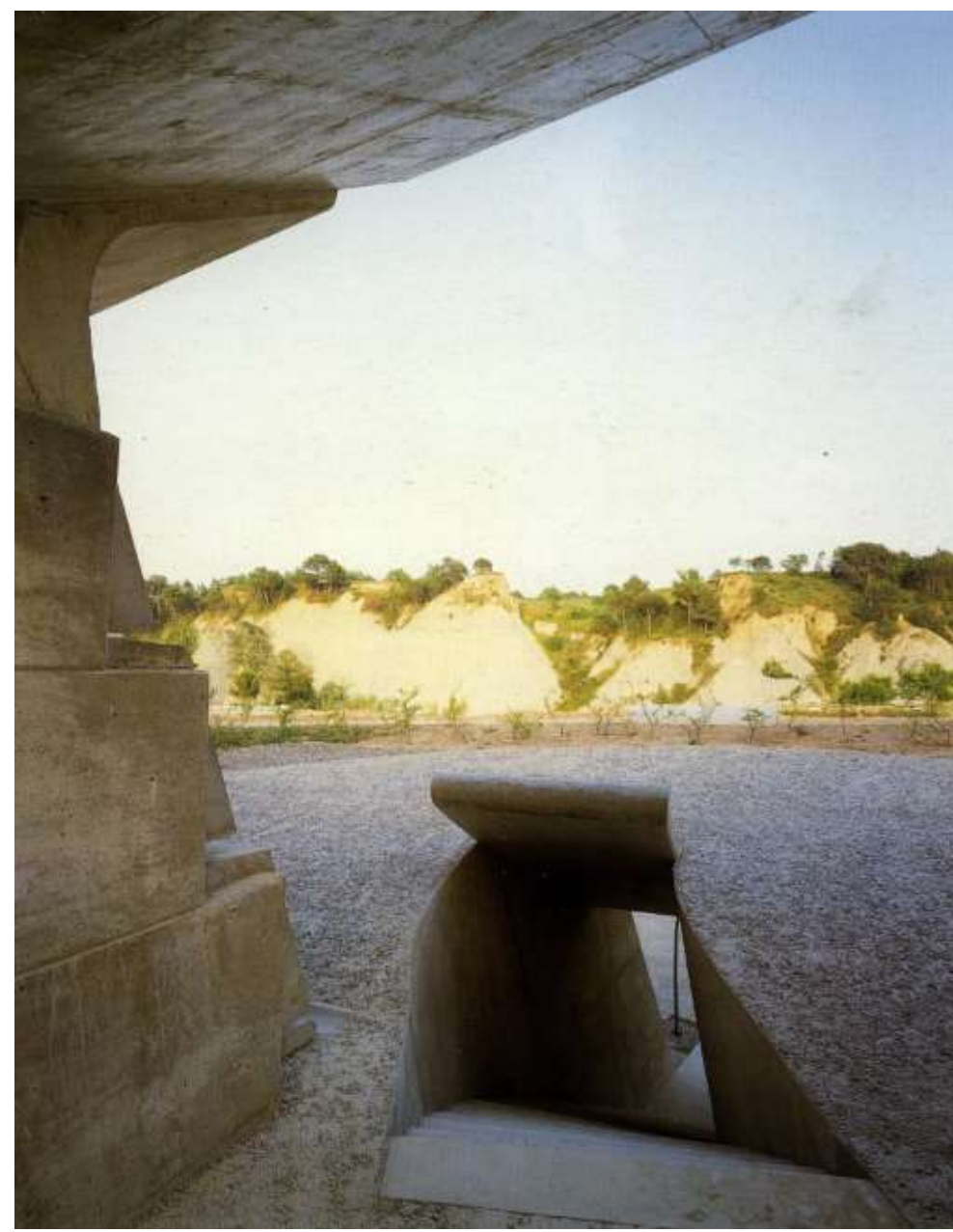

Ilustración 3-41292

Según Antonio Pizza, el recorrido tiene una geometría en zig- zag para eludir la ciudad análoga, la de los vivos, y también para sembrar la desorientación en el visitante, generándole una sensación poco familiar que le arrastre a una dimensión atemporal entre el tiempo prosaico y el sin tiempo del final del hombre. ${ }^{293}$ Para William Curtis, el recorrido en zig - zag puede entenderse como la culminación del sistema de carreteras que rodean el Parque Cementerio puesto que debe responder al acceso procesional en coche. ${ }^{294}$ Como defiende Oscar RodriguezMora en su tesis doctoral, Miralles se apoya en líneas geométricas directrices: "la reducción dimensional y la presencia de la geometría no euclidiana alcanzan una sostenida interacción en la obra de Miralles. Los instrumentos inherentes a estas geometrías se materializan en arquitectura ayudándose de la presencia literal de

\footnotetext{
292 Escalera que enlazando los distintos niveles cruza en diagonal los nichos de enterramiento en columbario.

293 Antonio Pizza. "Cementerio de Igualada" Conferencia dictada en el Curso de la UIMP 2009. "Alegorías del tiempo: la arquitectura y el universo de Enric Miralles". http://upcommons.upc.edu/video/handle/2099.2/1226

294 "Mapas mentales y paisajes sociales". El Croquis MIRALLES / PINÓs 1983-1990, no 30, 49+50, pag. 6-21.
} 
las líneas geométricas directrices. La reducción unidimensional coadyuva a la aprehensión formal y espacial implícita en este orden geométrico" 295

En la propuesta inicial presentada al Concurso, el recorrido tenia forma de Z mientras que el proyecto final se ejecuto en forma de $S$. Ambas letras, son simétricas y hablan de un recorrido lineal. Si bien la $Z$ presenta una discontinuidad en el recorrido, propiciando una serie de pliegues angulares, la $S$ ofrece un recorrido más amable y continuo, proporcionando al visitante lecturas distintas ${ }^{296}$. El ritmo de la experiencia lo marca el discurrir del coche fúnebre y la procesión que le sigue a pie. El punto de llegada de la comitiva lo constituye una puerta conformada por unos postes inclinados que remiten subliminalmente a las cruces del Calvario ${ }^{297}$.

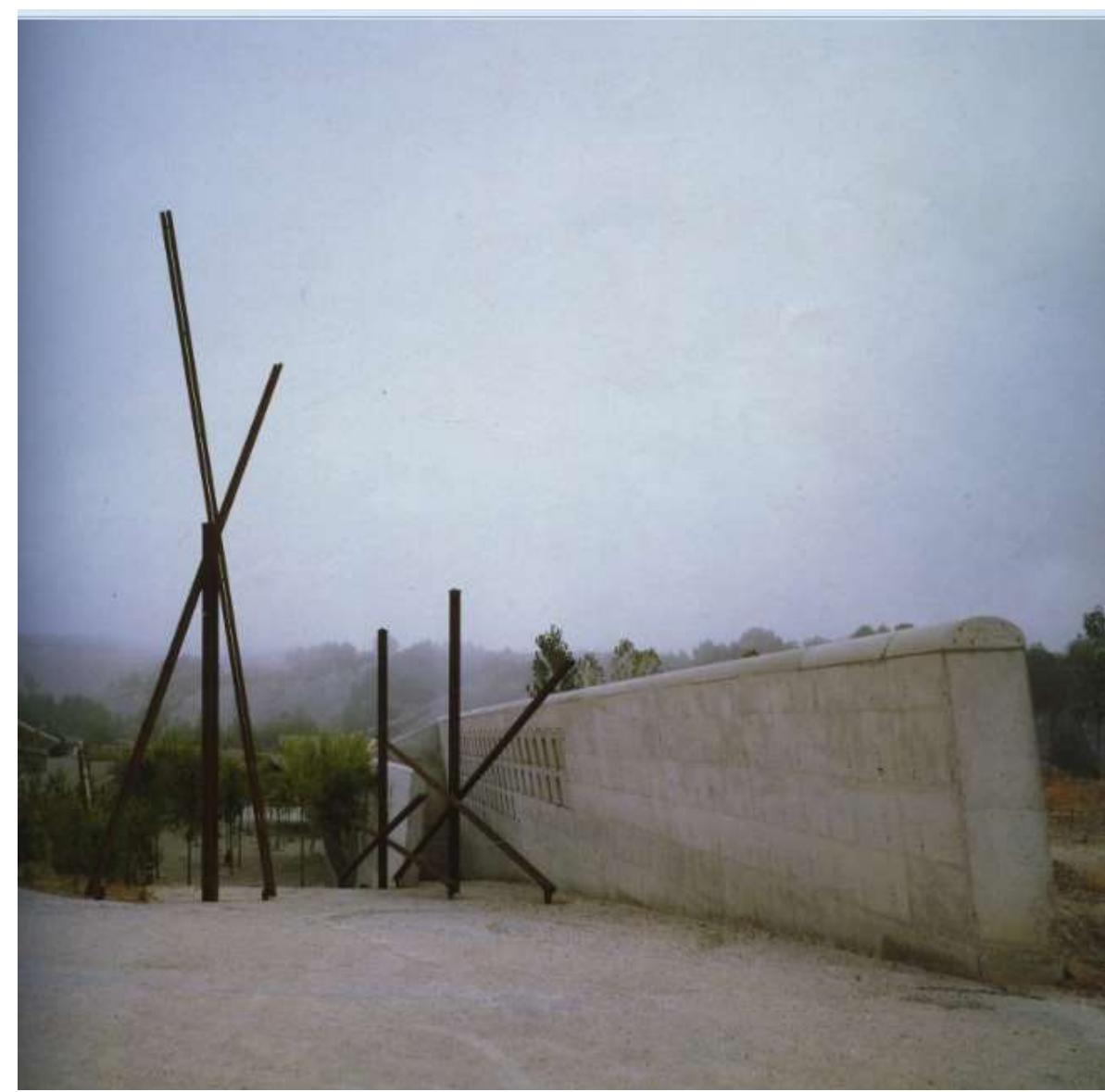

Ilustración 3-42 ${ }^{298}$

\footnotetext{
295 Oscar Rodríguez - Mora Tesis Doctoral titulada " Nuevos invariantes espacio - formales en la arquitectura contemporánea. Espacio- tiempo, hiperespacio y nuevas geometrías en el siglo XX" defendida en DPA ETSAM en Diciembre de 2004.

${ }^{296}$ Como pretendía Barthes con su obra literaria y también como lo hace Cervantes en El Quijote.

297 Según le traslado Carmen Pinós a Arturo Blanco, esta puerta que se había proyectado para una vivienda unifamiliar que finalmente no se construyo, se trajo a esta obra. Trasladado en la defensa de su Tesis Doctoral titulada "Los procesos elásticos...lgualada" defendida el día 18 de Noviembre de 2015, en la ETSAM. UPM.

${ }^{298}$ La puerta metálica que anuncia el descenso a los enterramientos simboliza las cruces del calvario.
} 


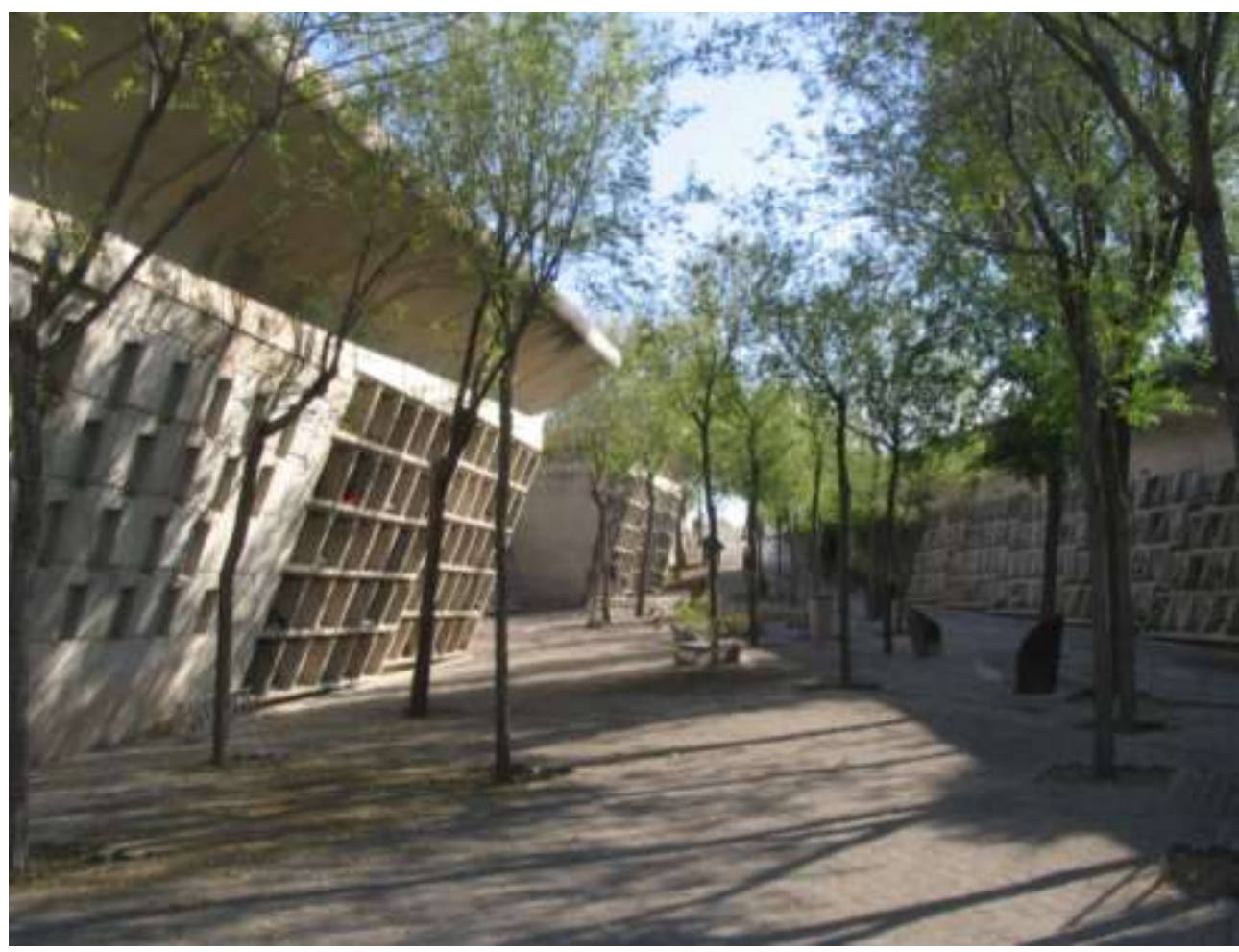

Ilustración 3-43 299

Desde este punto, los asistentes que en la cota superior asistan al acto religioso, se dirigirán a la Capilla ${ }^{300}$ tomando el camino a la izquierda, mientras que los que decidan esperar en el punto de enterramiento, descenderán hacia la cota inferior con pendiente suave discurriendo entre taludes de hormigón prefabricado que albergan los nichos, para desembocar en un espacio elíptico donde se encuentran los panteones familiares, enfatizando la idea de un fluir de la vida, a través de un lugar que lleva a un final. Dichos panteones se excavan en los taludes ondulados de la topografía existente ayudados en su contención por mallas metálicas.

El ritual del descenso convierte el recorrido en la génesis de la intervención. Al descender e ir perdiéndose la línea del horizonte, se evoca la distancia con el mundo de los vivos que se ha quedado arriba. El camino descendente, se comprime por los muros laterales que albergan los nichos y provoca miradas verticales donde solo se percibe el cielo y las montañas circundantes; pero al mismo tiempo el camino seguido aleja del mundanal ruido que ha quedado arriba. La sucesión de compresiones y dilataciones espaciales orquestadas por la pareja de arquitectos, realzan la experiencia dinámica al descender por el camino. El juego de luces y sombras que acompaña el recorrido aporta al proyecto la cuarta dimensión, la del tiempo, a través del movimiento.

\footnotetext{
299 Tramo intermedio del camino que desciende con los enterramientos en columbario a ambos lados y el juego de luces y sombras como el que se produce en un bosque. En este camino solo se percibe el cielo arriba y el paseante busca el escape hacia el claro en el bosque que se percibe al final del descenso que conforma la plaza de panteones.

${ }^{300}$ La Capilla, se sitúa tras un muro perforado que define el límite entre lo sagrado y lo profano, al tiempo que anuncia el tema de las capas que más adelante se irán eliminando progresivamente a medida que se va recorriendo el Parque Cementerio.
} 
Al fondo, como en el claro de un bosque, una necrópolis de formas curvas conformada por muros de gaviones aloja panteones y sepulturas en el suelo. Las puertas entre abiertas de dichos panteones con los umbrales de oscuridad que se perciben entre sus jambas, remiten subliminalmente al mundo del más allá. Félix Ruiz de la Puerta, nos relata la experiencia de llegar al claro de un bosque en los siguientes términos : "el proceso de pasar de la luz oscura, a la luz blanca; el proceso de pasar de los espacios comprimidos, dispersos y cambiantes, al espacio descomprimido, único y abierto, es el proceso que hace que el hombre quiera atravesar el Bosque...al final...es aquí cuando sabemos que el viaje ha llegado a su fin. Aquí finaliza el recorrido por el Bosque." 301

El recorrido orquestado se ve jalonado de elementos que guían al paseante. Al regresar de la zona de Panteones, un peldaño de grandes dimensiones que no toca el suelo, sobresale perpendicularmente del plano de los muros que contienen los nichos, indicando el camino de regreso a través de un vía transversal de escape conformada por una escalera en diagonal que atraviesa los dos niveles de enterramientos, comunicando el nivel inferior perteneciente al mundo de los muertos con el nivel superior donde se encuentra el mundo de los vivos, próximo a la Capilla y al Pabellón de servicios.

En esta Obra, a medida que se va recorriendo el camino que desde el acceso lleva a la zona de panteones, se comprueba cómo se van eliminando capas de información y de materia, para al final solo quedar la esencia. En este sentido, es significativo como el muro con el patrón geométrico inspirado en Elieen Gray que forra los muros de contención en la capilla y zona de servicios, va progresivamente desapareciendo. William Curtis encuentra similitudes con Carlo Scarpa: "Esta idea de ir eliminando capas y aproximarse a una realidad sagrada, sin llegar nunca a ella, nos hace pensar por el tema, aunque no por la forma, en el Cementerio de Brion de Carlo Scarpa". ${ }^{302}$

\footnotetext{
${ }^{301}$ Félix Ruiz de la Puerta. "Principios de Arquitectura. El bosque, el desierto, la cueva". Ediciones asimétricas, 2014, pág. 32

302 William Curtis. "Mapas mentales y paisajes sociales". El Croquis MIRALLES / PINÓS 1983-1990, no 30, 49+50, pag. 6-21.
} 

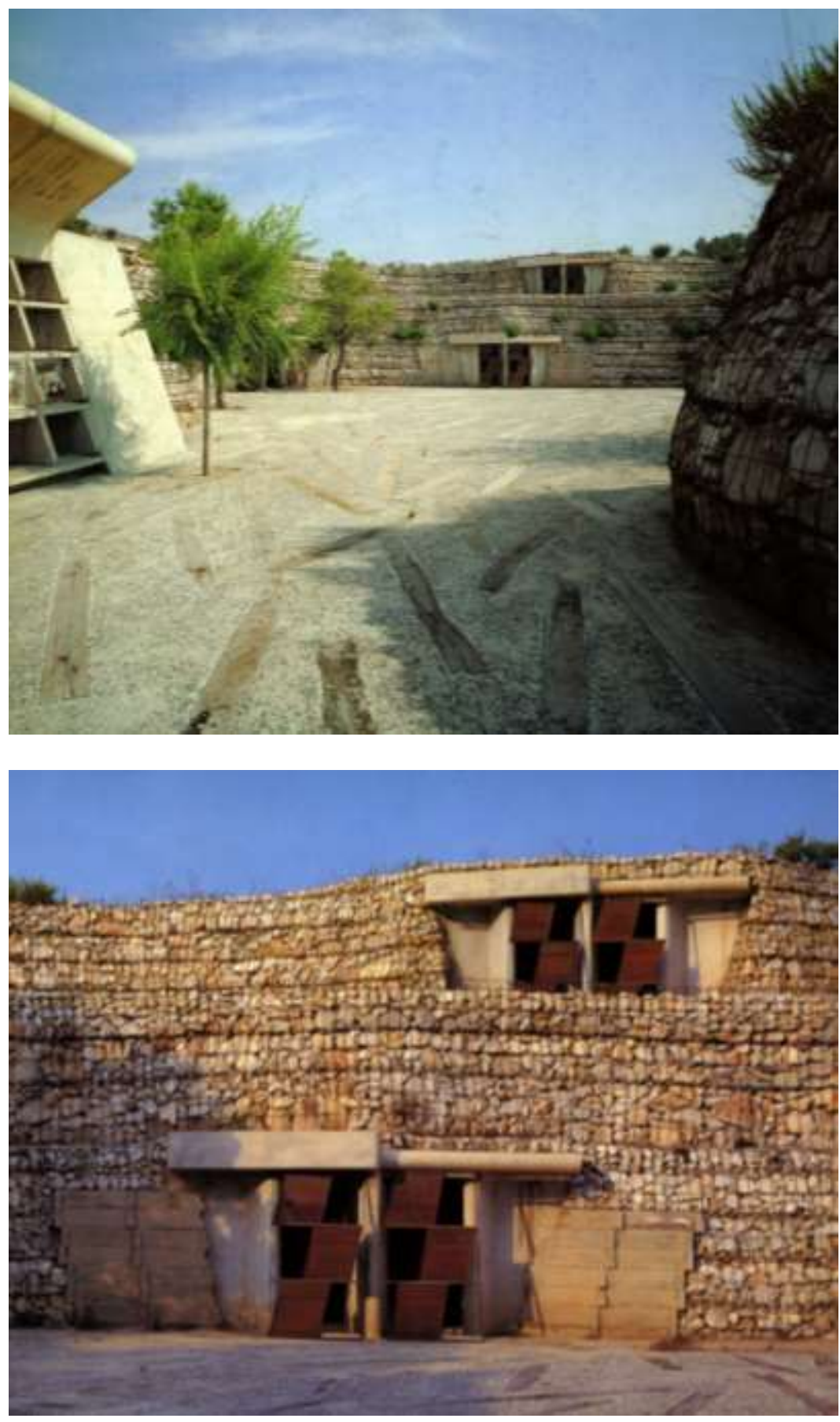

Ilustración 3-44

${ }^{303}$ La llegada a la plaza elíptica conformada por la zona de panteones se asemeja a la sensación de llegar a un claro en un bosque. 


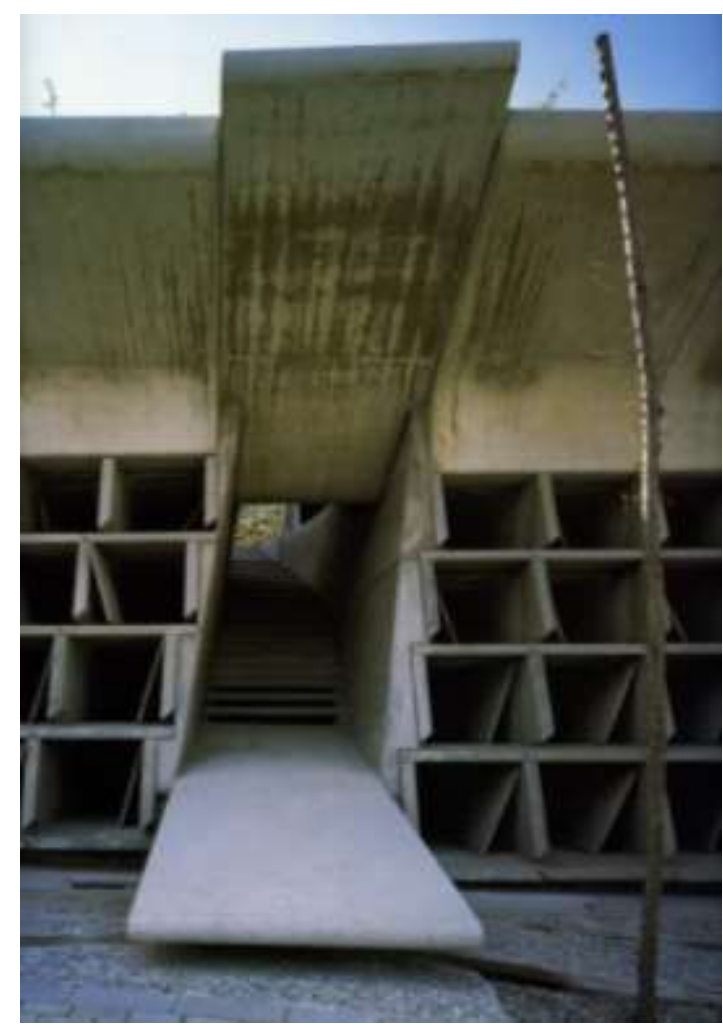

Ilustración 3-45

\title{
3.3. ACCIONES ABSTRACTAS
}

\subsubsection{FUSIONAR FIGURA - FONDO}

\begin{abstract}
"Estando en relación con la naturaleza, la propia naturaleza es la que te fuerza hacia la abstracción, te empuja a ser equivalente o paralelo... intentar mantener el territorio lo más intacto posible."
\end{abstract}

Enric Miralles.

En esta obra, se rompe la jerarquía figura-fondo. Se logra una ambigua relación entre figura y fondo, mediante el uso de: incisiones en diagonal; planos inclinados superpuestos; estructuras dinámicas, etc. La fusión del organismo construido, (la figura) con el paisaje natural existente (el fondo) es tal, que no se sabría separar la figura del fondo, que pertenece a lo proyectado y que existía ya allí antes de la intervención. En esta Obras, se consigue un tercer término que va mas allá de los tradicionales binomios antagónicos: natural - artificial; paisaje - arquitectura; fondo figura.

Lo construido no establece límites arquitectónicos. Tan solo el edificio de servicios y la capilla en el nivel superior de acceso al Parque Cementerio, tienen un borde construido; ya que en el resto de la intervención, tan solo existe un límite cognitivo

\footnotetext{
${ }^{304}$ En el camino de regreso un peldaño que sobresale del muro de nichos indica una salida transversal hacia el nivel superior del Parque Cementerio a través de una escalera diagonal que atraviesa los nichos de enterramiento.
} 
que se basa en umbrales. La apropiación del entorno inmediato y del borde mediante las cubiertas ajardinadas, unen visualmente la vegetación proyectada con la vegetación existente del paisaje. Se observa claramente como el tiempo ha ayudado a fusionar lo artificial y lo natural. Se funde la patina del hormigón con los estratos geológicos de las montañas al fondo y la vegetación plantada con la existente.

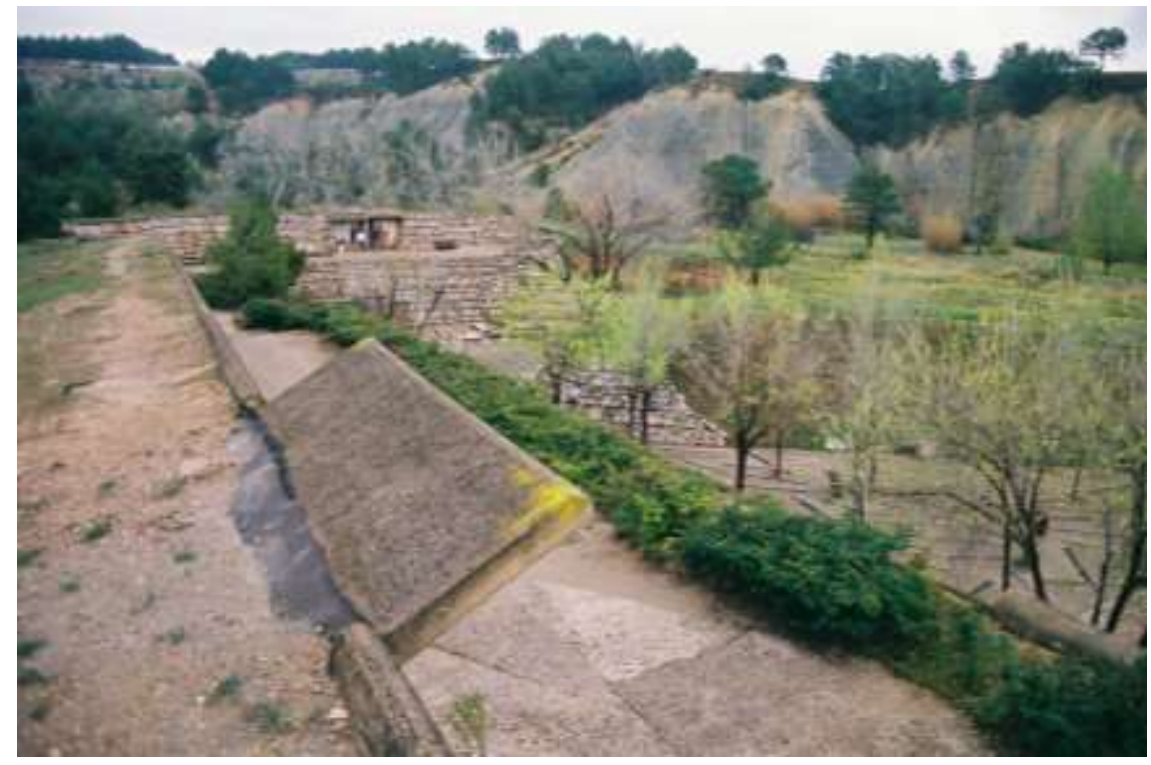

Ilustración 3-46

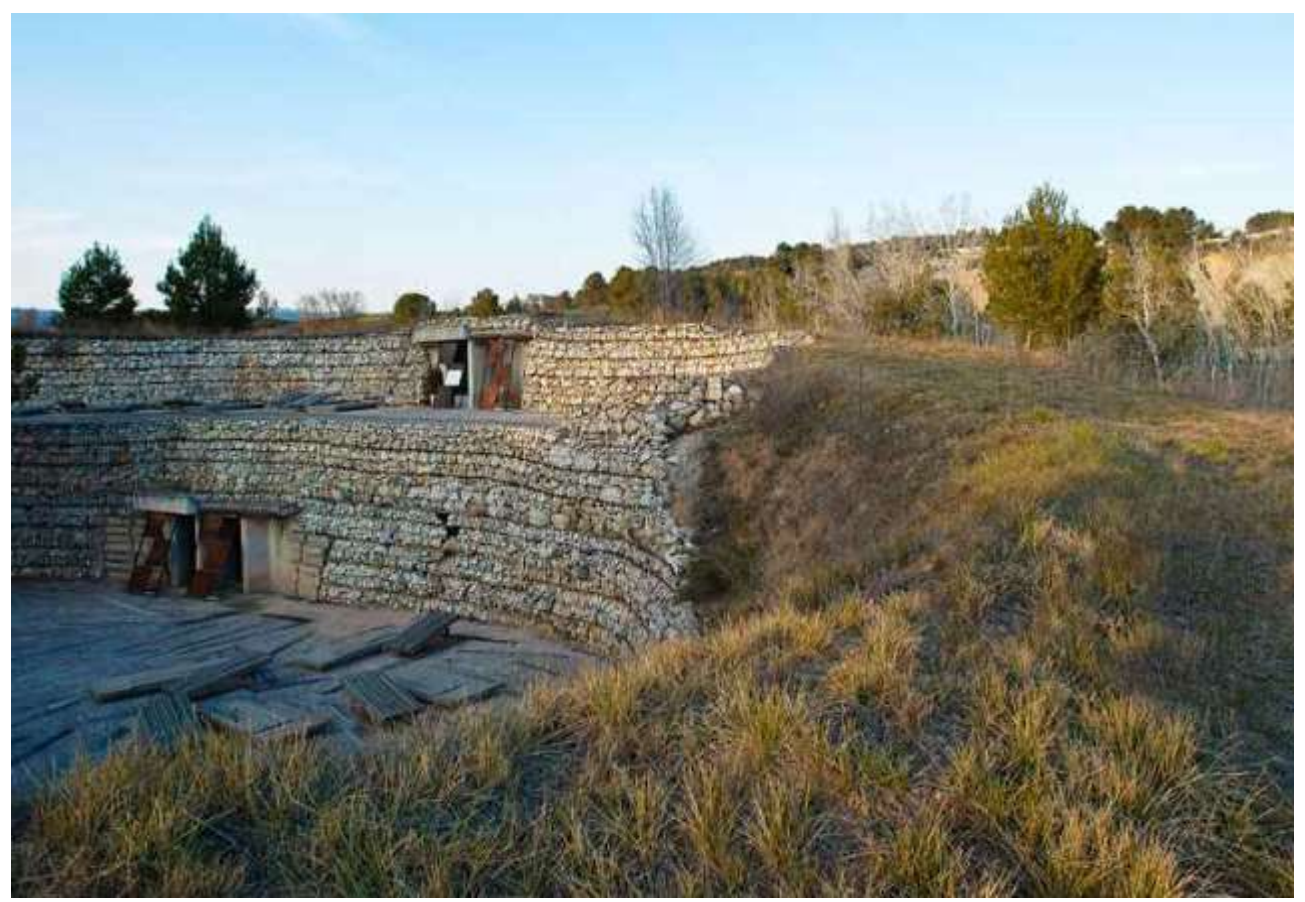

Ilustración 3-47

\footnotetext{
${ }^{305}$ Vista del paisaje desde el nivel superior del Parque Cementerio cerca de la Capilla.
} 
En esta obra, se calibra la escala de lo construido para relacionarse mejor con el paisaje, con sus accidentes geográficos, el perfil del paisaje, su vegetación, etc. No se aprecian elementos escalares que permitan asignar una escala arquitectónica a la intervención de los arquitectos. Incluso en las únicas construcciones que albergan espacios habitados como la Capilla y el Pabellón de servicios, estas se disponen semienterrados, materializando sus cerramientos al exterior con el mismo acabado que el muro de contención de tierras empleado en todo el Parque Cementerio. La iluminación se proyecta cenital para no tener que abrir ventanas en el único muro que se percibe desde el exterior. Además las puertas se camuflan, para que no existan elementos escalares que remitan a un edificio.

La intervención, no tiene una forma reconocible, pues asume la morfología del propio paisaje en el que implanta y esto se consigue desdibujando la acción material de la arquitectura en el paisaje. Tampoco existe un volumen rotundo que emerja del terreno y que se pueda interpretar como un edificio, lo que ayuda a su fusión con el paisaje. En esta obra tienen prevalencia las superficies frente a los volúmenes, como en muchas de las obras de Miralles.

\subsubsection{OCULTAR}

En esta obra, existe ambigüedad respecto al uso al que se destina lo construido, y ello deja la obra abierta a sugerir nuevos significados.

La primera impresión que se tiene al rebasar el primer umbral de la puerta conformada por redondos de acero, es la visión de una arquitectura semienterrada de formas libres que penetran en el terreno sin remitir a la imagen convencional que se tiene de un cementerio. Frente al Campo Santo tradicional, que se extiende en superficie; aquí los nichos de enterramiento son el resultado de una excavación. ${ }^{307}$ Nada indica al visitante que se encuentre en uno de los muchos cementerios que pueblan la geografía española. No hay lapidas que emerjan del suelo coronadas con cruces, tampoco los panteones remiten a una imagen convencional.

La simbología se encuentra abstraída en elementos tales como la puerta por la que se accede al camino descendente que remite a las cruces del calvario o en las traviesas de ferrocarril embebidas en el pavimento que remiten a las personas allí enterradas. Rafael Moneo expresa bien el significado oculto de esta obra: "...la metáfora de la vida, como un rio que nos lleva, hace acto de presencia en el cementerio tan pronto como advertimos que el pavimento transforma aquel ámbito en corriente inmóvil: los taludes de piedra cautiva definen el cauce de una corriente que ha cesado. Los tablones embebidos, incrustados en el pavimento, son mudos testigos del colapso del tiempo que la muerte, las muertes traen consigo. Los tablones de Igualada convierten en sagrado aquel espacio, al hacernos sentir la presencia de quienes fueron..."

\footnotetext{
${ }^{306}$ Vista de la zona de panteones en escorzo en la que se funde la forma de lo construido con la topografía cubierta de vegetación. No existe volumen construido, tan solo una contención superficial del terreno con muros de gaviones de piedra.

307 Tesis Doctoral. "Arquitectura abierta en el paisaje. Una metodología analítica desde la fenomenología". DPA ETSAM. UMP. 2009, pag. 334
} 
La obra además se encuentra repleta de símbolos figurativos, en muchos casos realizados por las manos de Enric Miralles en su Dirección de Obra, como por ejemplo los grabados realizados con soplete sobre las puertas metálicas de los Panteones. Y esto recuerda la manera de hacer de Jujol, que gustaba de realizar grabados en sus obras con símbolos, como por ejemplo la inscripción de la palabra M A R I A, en el banco corrido del Parque Güell de Barcelona.

Respecto a la zona de enterramientos en columbario, se retranquean los nichos, para que se perciban en sombra. Esta estrategia además, permite que aunque cada nicho se personalice según el gusto de cada usuario, no afecte a la imagen unitaria de conjunto proyectada.

En la Capilla, no se encuentra la típica torre campanario de un cementerio convencional, tampoco cruz alguna que simbolice su uso. Además, al encontrarse semienterrada no se ve emerger su volumen. La cruz existe, pero solo se percibe en los planos de planta o en el interior de la capilla pues las vigas que soportan el techo de dicha Capilla se cruzan formando una cruz. Tampoco existe un volumen construido que emerja del suelo con sus ventanas y puertas a la manera de un espacio habitado convencional. En el caso del edificio de servicios y la Capilla, también se encuentran semienterrados y comparten por uno de sus lados un cerramiento que simula ser un muro de contención de tierras de los que se encuentran en el Parque Cementerio.

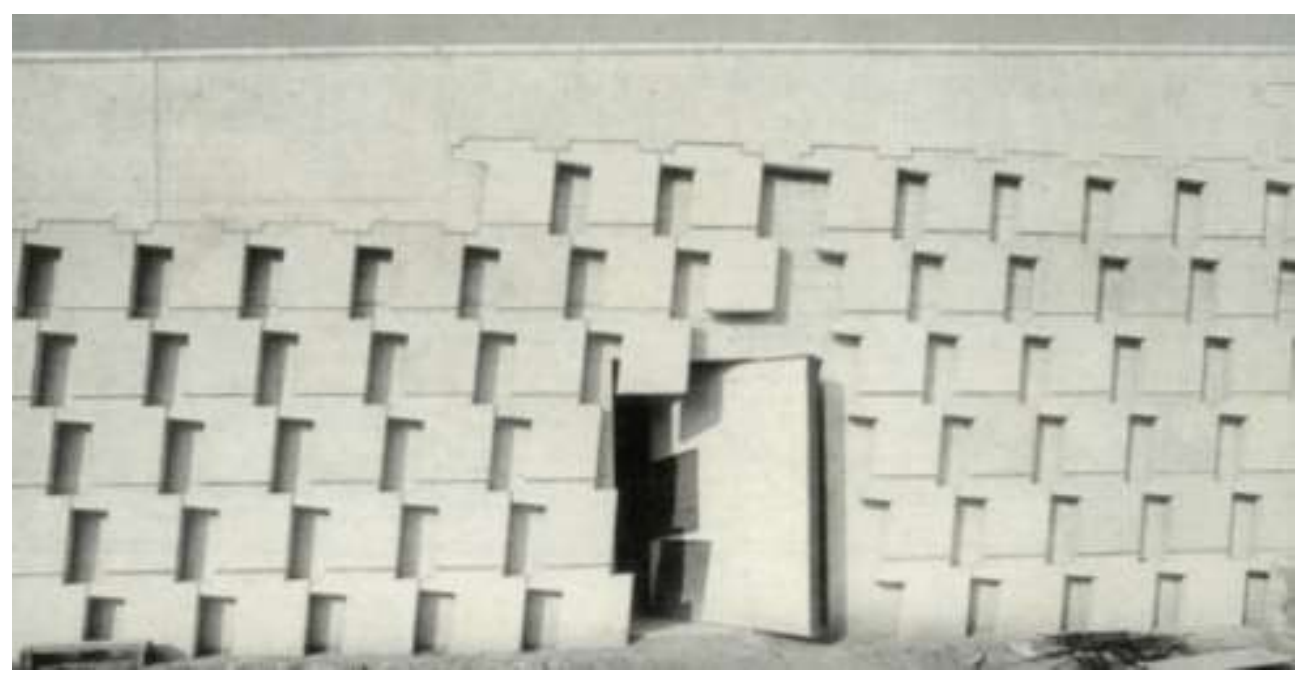

Ilustración 3-48

\footnotetext{
308 Hasta la puerta de acceso a este pabellón de servicios se ha proyectado camuflada en dicho muro, solo se percibe cuando esta entre abierta, para que no se perciba este elemento escalar que remite a la escala humana
} 


\title{
3.3.3. MANIFESTAR LA ACCION DEL TIEMPO
}

\begin{abstract}
"...la incisión representa el tiempo absoluto, mientras sus diferentes detalles materializan el mensurable flujo del tiempo: los pequeños almendros entre los coches en la entrada, los arbustos de laurel a lo largo de la rampa de acceso, la tierra desnuda frente a los diferentes edificios, los pequeños arbustos y los diferentes tipos de chopos que sellan la incisión del terreno con sus hojas pequeñas y plateadas"
\end{abstract}

Enric Miralles. ${ }^{309}$

En esta obra es muy importante la acción del tiempo, pues se toma como un material de proyecto mas ya desde la fase de Proyecto. Miralles entiende el tiempo a la manera de George Kubler en su libro "La configuración del tiempo" ${ }^{310}$. Este tiempo topológico, que nada tiene que ver con el tiempo lineal que determina el movimiento de las agujas del reloj, también lo tuvieron en cuenta los Land Artists, pues fueron ellos los que siguieron a finales de los años 1960s las enseñanzas de Kubler, en su libro aparecido en aquellos años. Para los Land Artists, el tiempo pasado y el tiempo presente coexisten porque todo está marcado por un proceso de expansión y recesión que permite relacionar pasado, presente y futuro.

Por tanto, Miralles y Pinos como los Land Artists tenían otra manera de mirar, entender y manipular el paisaje, y también otra manera de trabajar con el tiempo, al que consideraban como una herramienta más a la hora de proyectar.

En el Parque Cementerio de Igualada, el tiempo está presente desde la propuesta de Concurso que se ejecutaría en fases sucesivas. Miralles considera el Parque Cementerio de Igualada como un espacio intemporal. ${ }^{311}$ Pero no solo es intemporal por la acción del tiempo sobre materiales y vegetación, sino por la geometría que construye el proyecto que hace que el tiempo discurra de otra manera diferente a como acontece por ejemplo en la ciudad.

Para Miralles, el tiempo es un material de proyecto mas y en esta Obra tiene la ocasión de demostrarlo. La utilización de metáforas para dar forma a la hoz artificial, como si esta hubiera sido creada en el pasado por fuerzas geológicas; del rio que en un pasado remoto fluía en este lugar y que al secarse dejo en su fondo los restos que en su momento arrastro; las puertas de acceso a los panteones oxidadas y medio abiertas, etc. muestran un tiempo pasado, un movimiento que en determinado momento hubiera quedado congelado mostrando las consecuencias en el paisaje que se percibe. La idea del paso del tiempo y el retorno a los orígenes fueron factores fundamentales para proyectar el Parque Cementerio. La intención de Miralles y Pinos, era ver cambiar la apariencia de esta Obra a lo largo del tiempo.

\footnotetext{
${ }^{309}$ Miralles, Enric. "de que tiempo es este lugar ? ". TOPOS 8 European Landscape Magazine, 1994, pp. $102-108$

310 "La configuración del tiempo" George Kubler. Editorial Nerea, Madrid, 1988

${ }^{311}$ Miralles, Enric. "de que tiempo es este lugar ? ". TOPOS 8 European Landscape Magazine, 1994, pp. $102-108$
} 
Si la vegetación al cambiar con el transcurso de las estaciones climáticas hace patente en su aspecto el paso del tiempo, es en realidad la variación del aspecto de los materiales con el paso del tiempo lo que evidencia la lenta marcha de lo construido hacia la ruina, en la que la fusión de arquitectura y paisaje se realiza lentamente, a medida que transcurre el tiempo, y queda grabado en la memoria de aquellos que visitan el Cementerio en sus visitas espaciadas en el tiempo. ${ }^{312}$

Tal y como comenta Mayka Garcia Hipola en su tesis doctoral, este proyecto detiene el tiempo situándose fuera de este, en los siguientes términos:“...pero esta tesis defiende que el lugar que se crea no estaba allí antes ya que se produce un nuevo ambiente y una nueva atmosfera que trata tierra y suelo como elementos constructivos a la par que representativos. Se reinventa el sitio...este proyecto $\underset{313}{p u e d e}$ definirse como eterno habiendo detenido el tiempo y situándose fuera de él"

\section{CON LOS MATERIALES}

El Parque Cementerio de Igualada es una obra que escarba y se enraíza en las entrañas del suelo, uniéndose al paisaje con sus materiales y formas. La fusión de la piedra, el acero y el hormigón con la dureza de la tierra natural del paisaje existente, transforma las esencias de lo natural y de lo artificial en este lugar. La obra construida transmite solemnidad y austeridad, ayudada por el detallado diseño y el cuidadoso uso de los materiales sin revestir. El empleo de pocos materiales, hormigón y piedra en su mayoría, se muestran con su identidad propia haciendo que la Obra se integre mejor con el paisaje.

El muro de gaviones de piedra con el que se construye la zona dedicada a los panteones, se construye ex profeso con una aparente dejadez alejándose de la manera de construir del resto de arquitectos contemporáneos, obsesionados por la precisión y el empleo de la tecnología más puntera ${ }^{314}$ olvidando con ello que mostrar el material en bruto, con su textura e identidad sin revestir, es un valor añadido al proceso constructivo. El primitivismo que rezuma al construir así, genera la sensación de que los materiales siempre hubieran estado en dicho paisaje. La comunión de los materiales con el paisaje identifica al paisaje con la sustancia, lo que subyace, y al material con la materia, que permanece aunque cambie de forma. El gavión de piedra, el suelo de cantos rodados, etc. son cambios de forma de una materia que ya estaba en el lugar. Sin embargo, estos materiales que parecen pertenecer al lugar se relacionan con las traviesas de madera y los elementos metálicos proyectados, traídos de otro lugar.

Como defiende Carlos Asensio, en esta Obra, el gavión de piedra quiere construir un muro de gran espesor, estable por gravedad y permeable; de la misma manera

\footnotetext{
${ }^{312}$ Valgan como ejemplo de esto, los grabados que Piranesi realizo sobre los monumentos romanos con el paso del tiempo convertidos en ruina.

313 'La acción de Peter Eisenman en el territorio' Mayka Garcia Hípola. Tesis Doctoral DPA ETSAM, 2008. pag. 274

${ }^{314}$ Para como defendía Eero Saarinen "anclar la Obra de Arquitectura a su tiempo" con el empleo de la tecnología mas avanzada.
} 
que el hormigón prefabricado quiere adquirir formas maleables y repetibles. ${ }^{315} \mathrm{El}$ tiempo se encargara de hacer surgir patinas en el hormigón, desbastara el solado dejando al descubierto el árido, oxidara la malla de acero que ata el muro de gaviones, etc. y la arquitectura lentamente se irá fundiendo con el paisaje, al ir cambiando las propiedades de los materiales con los que está hecha.

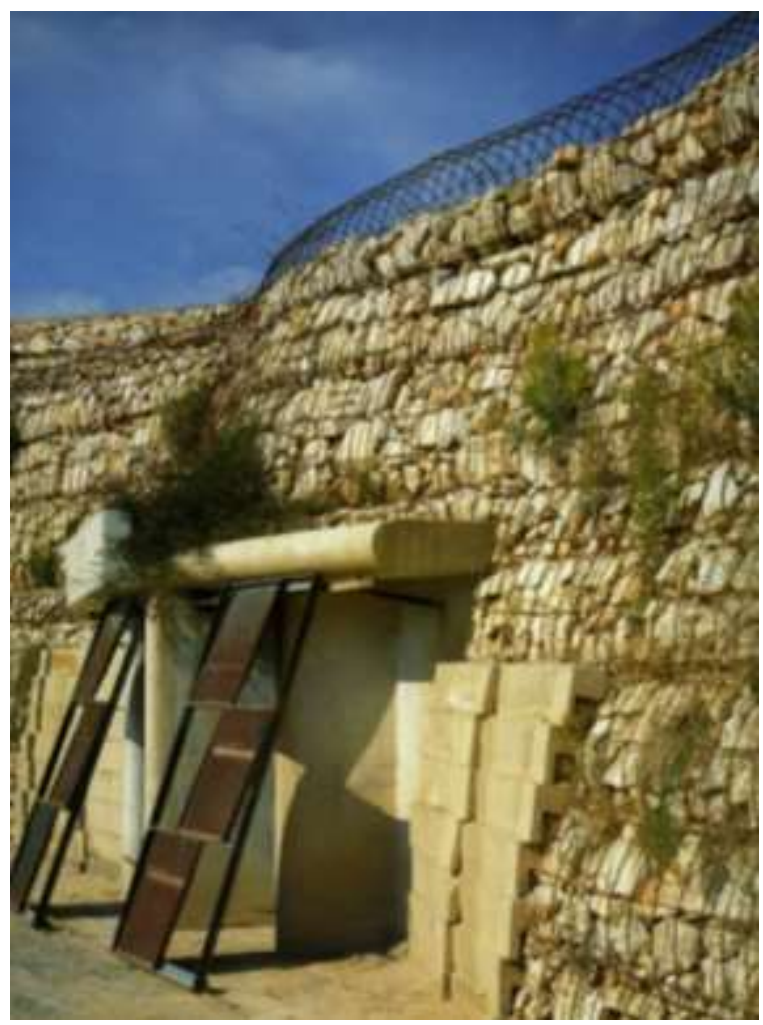

Ilustración 3-49316

"Las texturas y los materiales están calibrados para acrecentar la idea de transición a través de velos creados por paños de sombra, onduladas cortinas de vidrio o muros de mampostería con agujeros".

William Curtis. ${ }^{317}$

El plano de suelo es fundamental en esta obra, pues dota de continuidad narrativa al recorrido, siendo soporte y nexo de toda la operación. Pavimentado con un hormigón rugoso y traviesas de ferrocarril embebidas, dichas traviesas de madera vistas en su conjunto parecen troncos flotando en la corriente de un rio que hubiera quedado detenida y remiten subliminalmente a las vidas que han quedado detenidas. Como nos cuenta Carmen Pinos al respecto: "El modo de pensar el pavimento estaba ligado al hecho de que existían árboles. Pensar un pavimento donde puedan depositarse las hojas de los árboles... Una pavimentación de hojas

\footnotetext{
${ }^{315}$ ASENSIO, Carlos. Tesis Doctoral. "Arquitectura abierta en el paisaje. Una metodología analítica desde la fenomenología". DPA ETSAM. UPM. 2009.

${ }^{316}$ Vista de uno de los umbrales de acceso a los panteones empotrados en los muros de gaviones.

317 "Mapas mentales y paisajes sociales". El Croquis MIRALLES / PINÓs 1983-1990, no 30, 49+50 pág. 6-21.
} 
caídas de los árboles frutales que llenan la fractura...El rumor provocado por los pasos de los visitantes sobre esta alfombra que no se quitará nunca, ni se rastrillará, sino que se dejará sedimentar" ${ }^{318}$

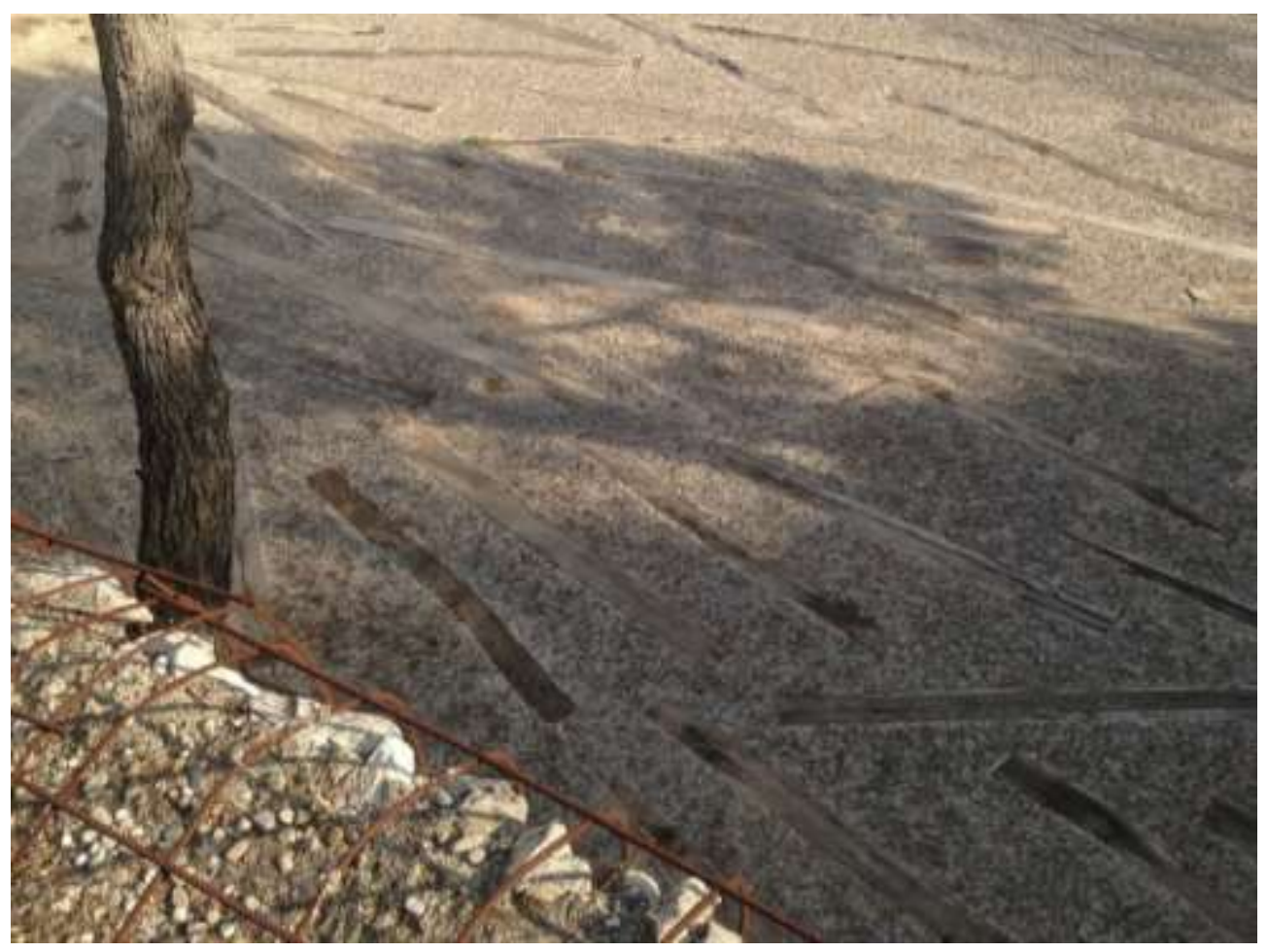

Ilustración 3-50 319

El repertorio de materiales utilizado es reducido: piedra y hormigón, metal y madera. El vidrio tan solo se emplea en el pabellón de servicios por requerir iluminación natural, control climático y privacidad. Miralles y Pinos, al igual que los Land Artist, consiguen con un reducido catalogo de materiales generar una experiencia espacial rica e intensa. Todos los materiales se emplean sin revestir, mostrando su identidad (el gavión quiere ser muro de gran espesor estable por gravedad y permeable), como si fuera una intervención de Arte Povera, lo que hace que la tectónica y el material contribuyan a ligar la obra con el paisaje. Esta aparente dejadez, y la sensación de que no se ha proyectado por el hombre sino por la naturaleza, es parte del éxito con el que la obra se liga en lo material con el paisaje. El gavión de piedras, un elemento utilizado para la contención de tierras se convierte aquí en el protagonista de la intervención, puesto que construye la plaza elíptica dedicada a la zona de panteones, al final del recorrido. La disposición de estos taludes de gaviones de piedra, unido a su aspecto descuidado hace que sintonicen mejor con el paisaje, como si estuvieran hechos de la misma materia

\footnotetext{
${ }^{318}$ Carme Pinós. Tagliabue, Benedetta." No es serio este cementerio". En L’Architettura Cronache e Storia núm. 409- año XXXV-no11. 1 ed. Milán. Gruppo editoriale Fabbri, Bompiani, Sonzogno, ETAS, noviembre 1989. pag. $844-845$

${ }^{319}$ Elementos intangibles como las sombras de los arboles contrastan con la materialidad austera con la que se construye la obra.
} 
del lugar ${ }^{320}$, pero transformada la forma de su materia por el arquitecto. Otros guiños a la expresividad del material en bruto y al material traído de otro lugar, se perciben en los tablones de madera encastrados en el pavimento, que antes fueron traviesas de vía férrea.

La acción del tiempo se aprecia en los materiales empleados: en la patina que va cogiendo el hormigón en su superficie; la suciedad acumulada en el calado patrón decorativo ${ }^{321}$ que se repite en los elementos de hormigón prefabricado que forran algunos muros de contención; la oxidación del acero corten y los redondos de acero, etc. Las manchas de oxido crean chorretones inesperados, etc. y lentamente arquitectura y paisaje se van fundiendo, acompañando a la memoria del hombre que visita periódicamente el Parque Cementerio. Todos estos episodios dan muestras de la entropía del proceso y la lenta e inexorable marcha hacia la ruina. Conviene destacar como elementos intangibles, como las sombras de los arboles, contrastan con la materialidad austera con la que se construye la Obra en su conjunto.

\title{
CON LA VEGETACION
}

\begin{abstract}
"No será hasta que los troncos (de los nuevos árboles) hayan crecido y sus copas se hayan desarrollado plenamente, que estos sellaran visualmente la incisión y ... reconstruirán el nivel original del terreno. El cementerio entero parecerá entonces desaparecer bajo la tierra formando una especie de fosa común, cubierta por una verde lapida."
\end{abstract}

Enric MIralles. ${ }^{322}$

Al considerar el tiempo como material de proyecto, el crecimiento de los arboles llegara a cicatrizar la falla abierta por Miralles y Pinos, y finalmente el cementerio será subterráneo, con una cubierta vegetal conformada por las copas de los arboles. La vegetación se proyecta por los arquitectos, teniendo en cuenta que a medida que pasa el tiempo, ésta invadirá el muro de gaviones, surgirán arbustos de la tierra arenosa y sobretodo crecerá el follaje de los chopos plantados en la herida abierta en el terreno hasta llegar a la cota de coronación de los muros de nichos que delimitan dicho surco, generando una cubierta vegetal que cubrirá todos los nichos como si de una fosa común se tratase. Merece destacarse en esta Obra como se apropia del entorno inmediato y la configuración de los bordes mediante cubiertas ajardinadas que unen visualmente la vegetación proyectada con la vegetación existente del paisaje.

\footnotetext{
${ }^{320}$ En realidad la piedra que constituye estos gaviones aunque sintonice cromáticamente con el paisaje, no pertenece al lugar, sino que se trajo de una cantera de Manresa.

${ }^{321}$ Patrón decorativo tomado de un proyecto de Elieen Gray.

322 "For what time is this place?" TOPOS 8. European Landscape Magazine, 1994, p. 102-108.
} 


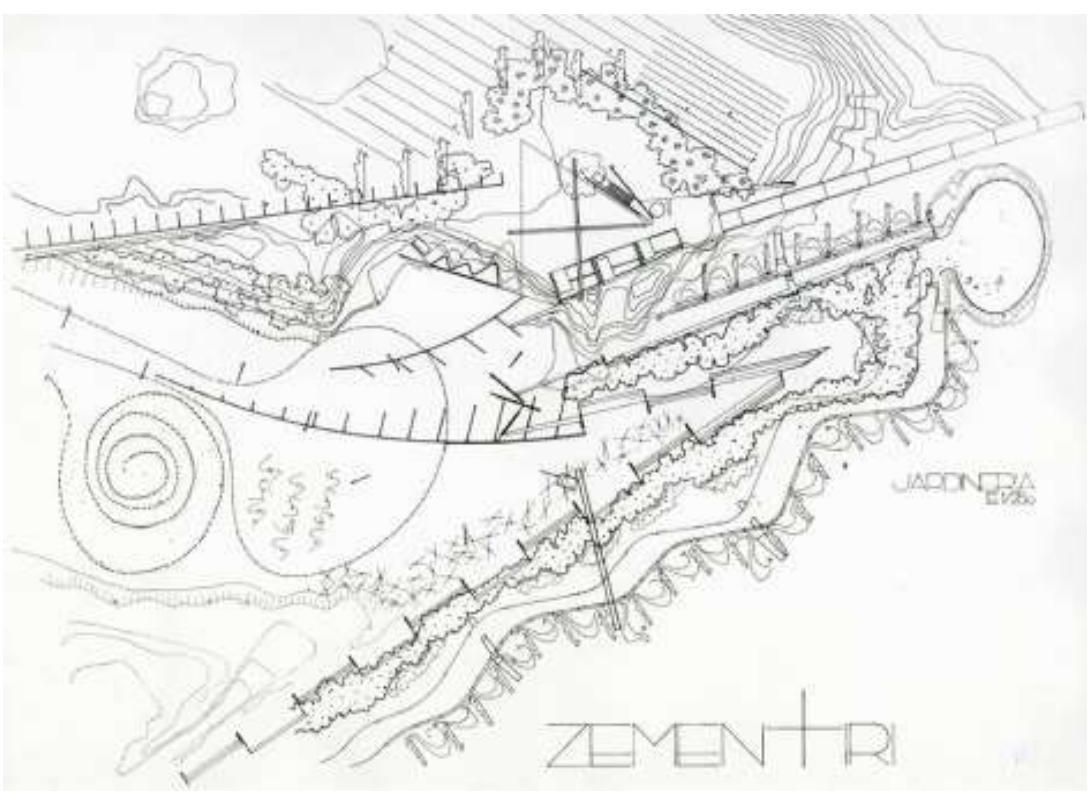

Ilustración 3-51 323

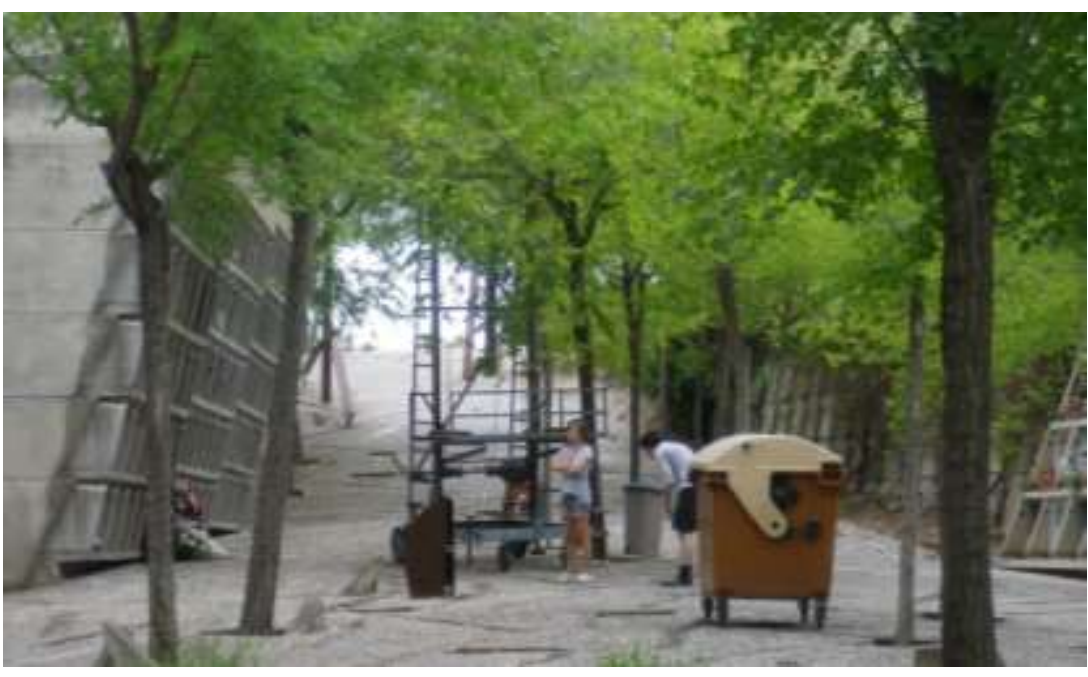

Ilustración $3-52^{324}$

En el proyecto se estudia pormenorizadamente el ajardinamiento del Parque Cementerio para enfatizar la acción del tiempo en la obra construida. Existe un plano dedicado a Jardinería con muchas plantaciones de hoja caduca para que reforzasen la lectura cíclica de la Obra. Se proyectan plantaciones de helechos y retamas formando pantallas vegetales; parterres de "diente de león" que cerrarían el perímetro de la excavación, flores en la cubierta de la capilla; el camino generado por la grieta excavada iría plantado de tilos y chopos. A pesar de la variedad vegetal documentada en los planos del proyecto, al final solo se

\footnotetext{
${ }^{323}$ Plano de jardinería del Proyecto de Ejecución, que demuestra la importancia otorgada a la vegetación proyectada para fusionarse con la vegetación existente con el paso del tiempo.

${ }^{324}$ En esta imagen se entiende muy bien aquello que decía Miralles que cuando hubiera pasado el tiempo el follaje de los arboles llegaría a cubrir el tajo abierto artificialmente constituyendo la nueva cubierta, y haciendo una fosa común.
} 
ejecutaron en obra las especies más representativas del curso cíclico de la naturaleza, como los almendros de la entrada y los tilos del interior. ${ }^{325}$

En la zona de entrada, se proyectan unos almendros, tras pasar el montículo artificial de tierra en el lado derecho del camino, para manifestar la acción del tiempo. En el interior del camino que desciende, también se proyecto la plantación de árboles de hoja caduca.

La percepción del Parque Cementerio varia considerablemente dependiendo de la estación del tiempo en la que se visite, y ello se debe a que Arquitectura y Paisaje se condicionan mutuamente. En esto tiene mucho que ver el hecho de que se ha proyectado la plantación de la vegetación para que se imbrique con la existente a media que el tiempo discurra, hasta que llegado el momento, no se pueda diferenciar cuales son la especies vegetales que hizo plantar el arquitecto y las que allí estaban antes de su intervención. El empleo de especies caducas como los almendros plantados en la zona de entrada y los chopos plantados en la hoz conformada por nichos de hormigón, se emplean para que al cambiar su aspecto con las estaciones climáticas, también lo haga el organismo construido.

Al comparar dos fotografías que registren momentos diferentes se percibe como la vegetación proyectada, ya crecida, ayuda a relacionar lo proyectado con el paisaje. Actualmente, no se puede diferenciar la vegetación proyectada por los arquitectos de la que ya existía en el paisaje. Se han fundido ambas, y con ello han ayudado a fundir el organismo construido con el paisaje.

En esta obra Miralles evoca el proceso natural de una hoz artificial generada por la excavación del Parque Cementerio se asemeja al resultado de un proceso geológico ocurrido en el pasado que hubiera quedado congelado. Esta imagen de tiempo detenido, tiene mucha relación con un cementerio, pues ¿qué es un cementerio sino la máxima expresión del tiempo detenido? Miralles nos los relata: "...mediante la excavación fui capaz de ahuecar el paisaje mucho más rápido que el propio proceso natural. Esta erosión artificial acelero el curso del tiempo.” 326

El Parque Cementerio de Igualada, es una obra inacabada, que se deja intencionadamente sin terminar por Miralles y Pinos, para que siga siendo interactivo, abierto, dialogante, permeable y propositivo. Para Martin Heidegger, lo inacabado es "lo que permanece abierto."

Se aspira a una integración total persiguiendo una continuidad perceptiva entre las partes de lo construido, y los perfiles montañosos y vegetales del paisaje. Es una Obra atemporal, porque Miralles y Pinos lo han proyectado para la eternidad, como una utopía, como si siempre fuese a disfrutar de un eterno presente. Como nos dice Miralles: "la arquitectura es presente continuo."

En los primeros croquis del Concurso está presente lo inacabado, no solo en los caminos, pasarelas, líneas, etc. sino en que no se sabe cómo puede ser el final. No documentan un final. Incluso el recorrido que desemboca en la riera, sigue, se reabre y deja los recorridos con diferentes posibilidades.

\footnotetext{
${ }^{325}$ Arturo Blanco. Tesis Doctoral "Flujo laminar: El cementerio de Igualada y los procesos elásticos en la arquitectura de Enric Miralles y Carme Pinós" defendida el día 18 de Noviembre de 2015 en la ETSAM. UPM, pp. 401

${ }^{326}$ Enric Mlralles. "For what time is this place?" TOPOS 8. European Landscape Magazine, 1994, p. 102-108."
} 

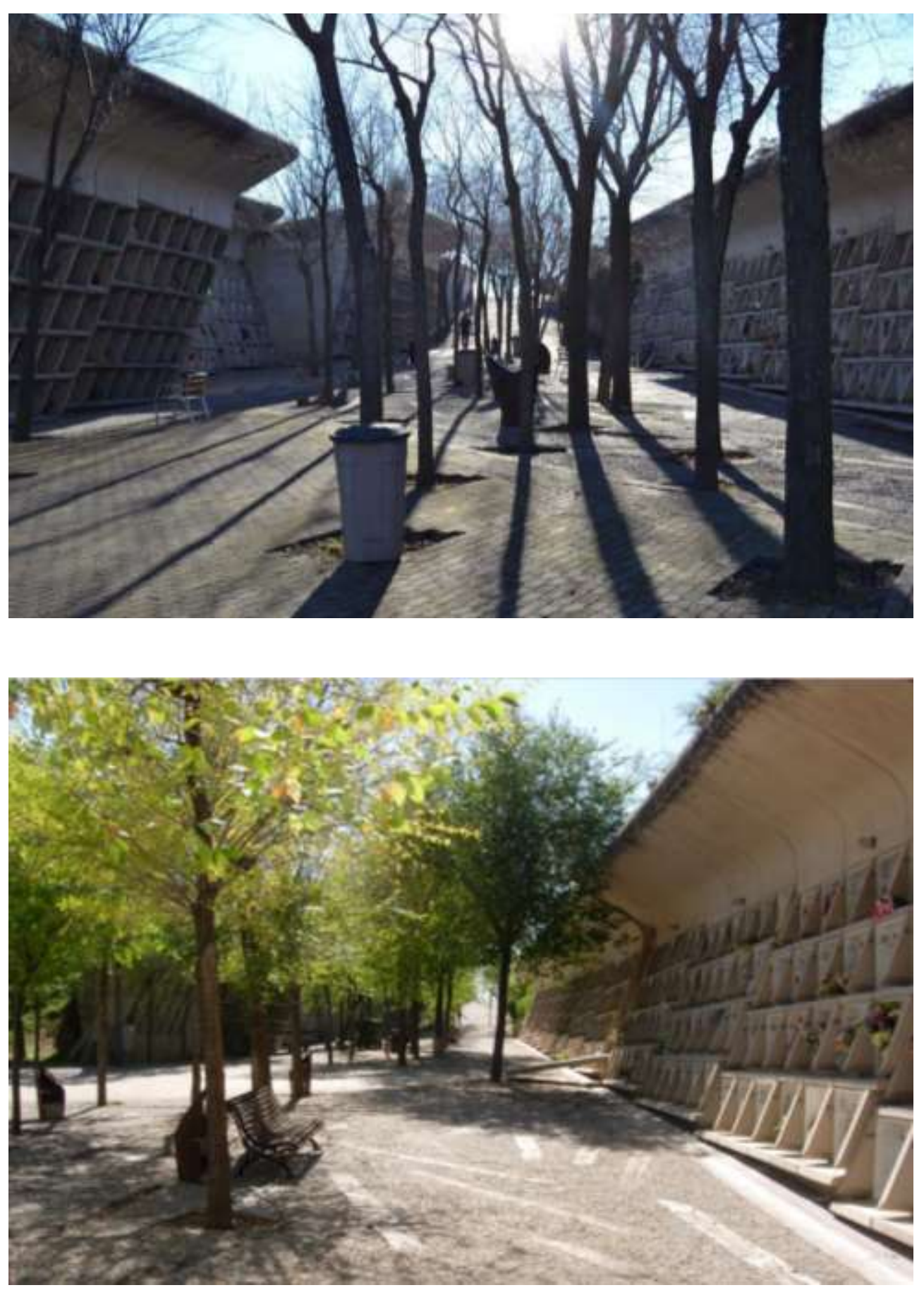

llustración 3-53 327

${ }^{327}$ Distinta percepción de la Obra en función de las estaciones del año. 
Desde el acceso principal se anuncia lo inacabado mediante una puerta a sin terminar construida en redondos de acero oxidados que incide en la idea de que el edificio todavía no está terminado. Algo que está todavía en construcción inacabado se asemeja mucho a una ruina. Como comenta Ramón Faura la ruina es un momento simétrico entre la construcción y la destrucción. ${ }^{328}$

La capilla, todavía hoy en construcción, es otro acento mas dentro de la intervención general, para transmitir que la Obra todavía se encuentra inacabada.

A día de hoy, todavía no se ha construido el otro ramal de la $V$ de nichos recogida en proyecto, que parte desde la plaza elíptica de los panteones, pero la obra permitirá su ampliación cuando las necesidades lo requieran y haya presupuesto para ello sin perder su esencia.

En el solar se encuentra todavia una de las piezas del encofrado metálico que se emplearon para hormigonar el remate de los muros que contienen los nichos, como si fuera una reliquia, una ruina arqueológica que recuerda la intencionalidad de Miralles en mantener los mástiles tumbados en el suelo en la zona al aire libre del Pabellón de Huesca que un día tensaron los cables de la cubierta tensada que se derrumbo.

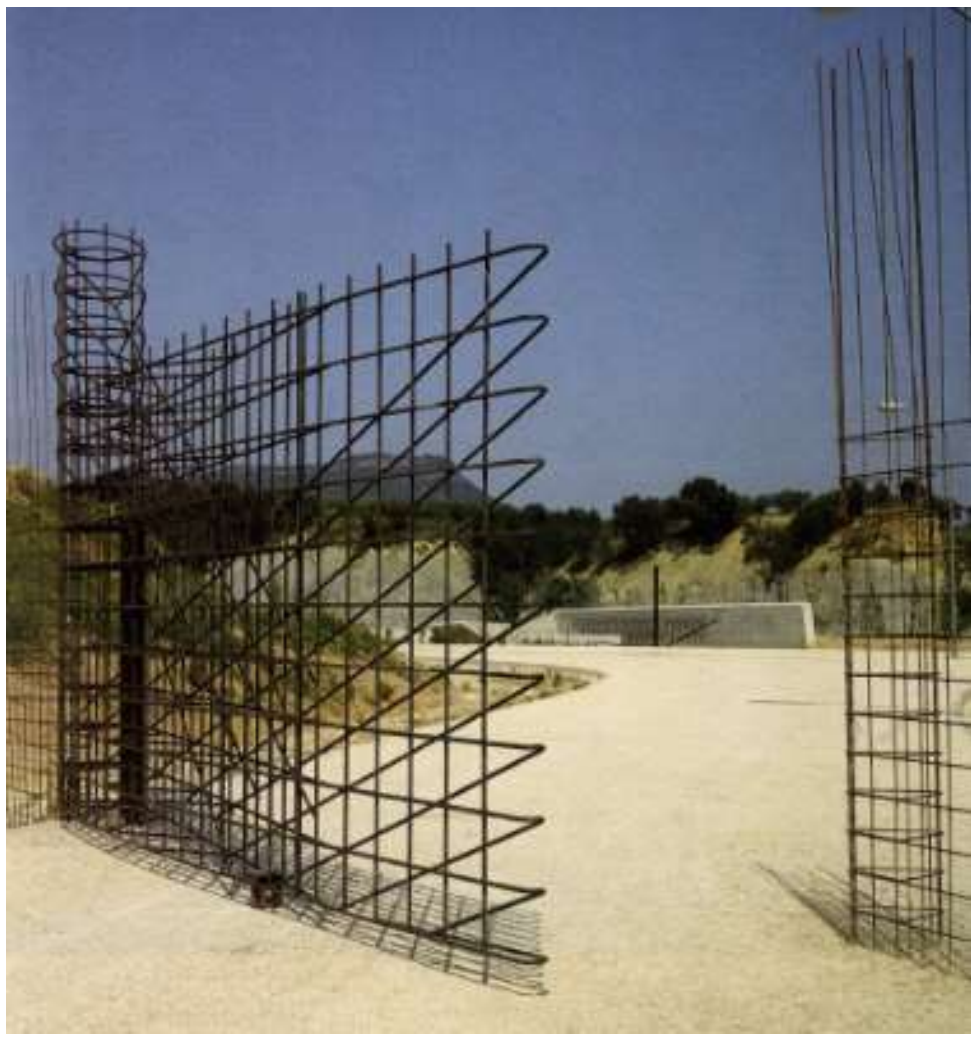

Ilustración 3-54

${ }^{328}$ Enric Miralles 1972-2000. Colección Arquia/temas oㅜ 33. Caja de Arquitectos, 2011. Edición de Josep M. Rovira

${ }^{329}$ La puerta de acceso al Parque Cementerio conformada por redondos de acero oxidados traslada al visitante la idea, desde la entrada, de que la Obra es todavía provisional y se encuentra sin terminar. 


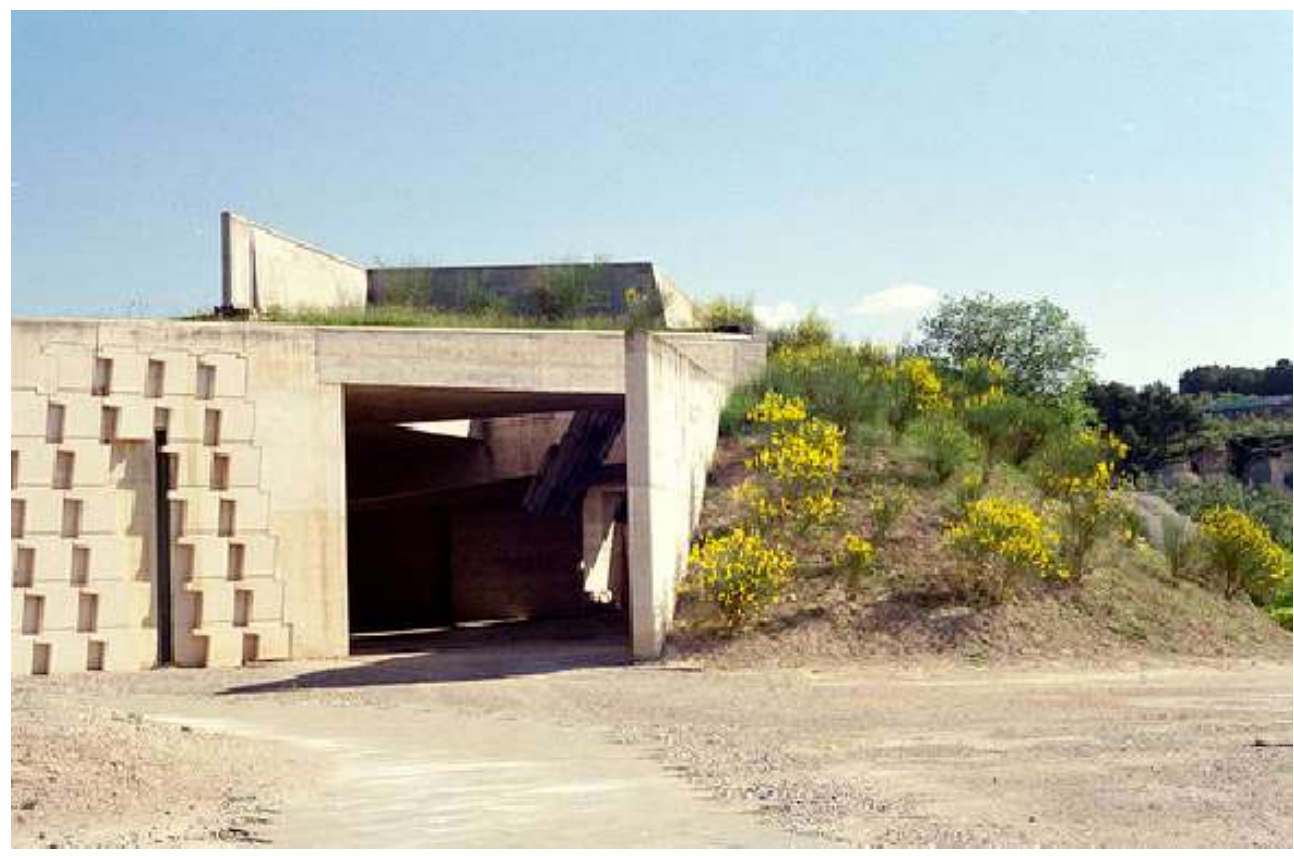

Ilustración 3-55

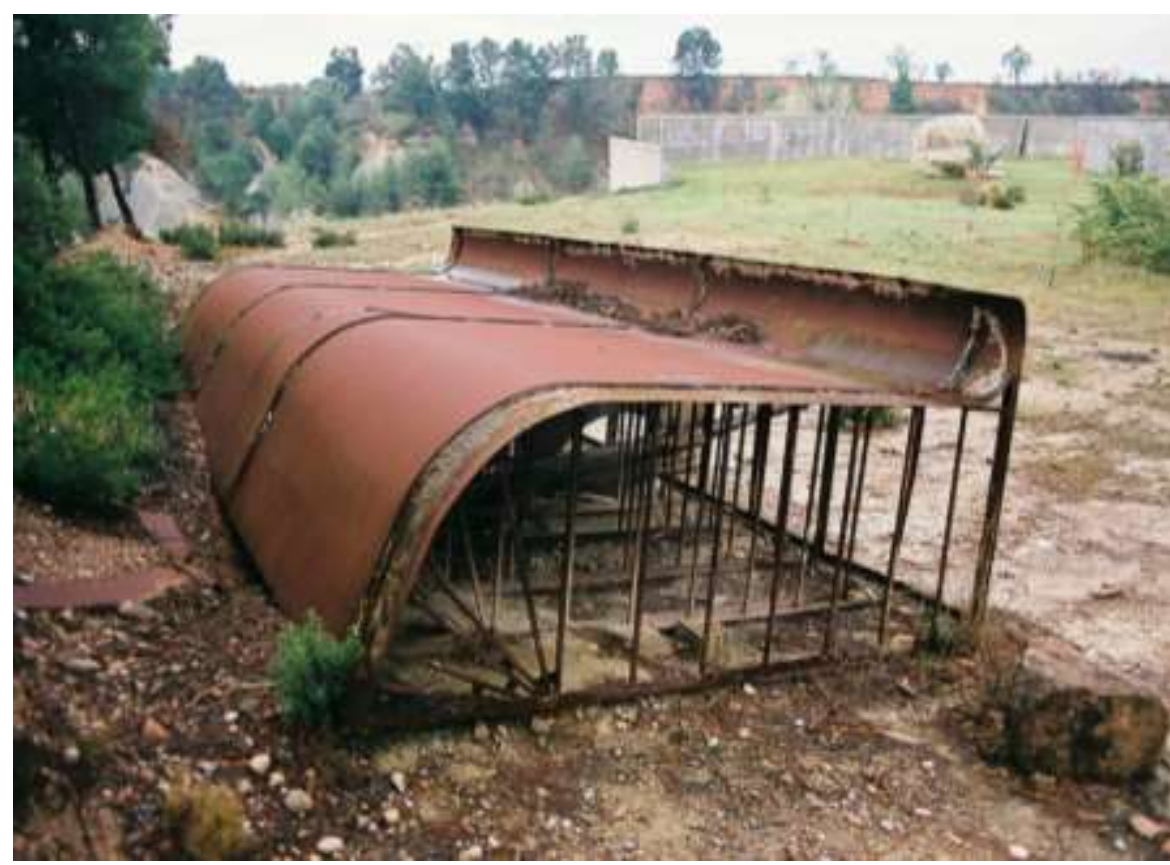

Ilustración 3-56 331

330

Imagen del umbral de acceso a la capilla en la actualidad.

${ }^{331}$ Resto de una de las piezas metálicas que sirvieron como encofrado de los capiteles de hormigón que rematan los nichos de enterramiento en columbario desperdigados por el paisaje, como un resto arqueológico de lo que ocurrió en el lugar en el pasado. 


\title{
4. EL COMPLEJO DE TIRO CON ARCO EN BARCELONA (1989- 1992).
}

\begin{abstract}
"Los dos edificios, uno para entrenamiento y otro para competiciones, delimitan la amplia superficie que se extiende al frente, situándose junto a los muros de contención que aterrazan la fuerte pendiente del parque...el área operativa está constituida por dos larguísimas superficies, orientadas exactamente hacia el este, que reciben el sol de la mañana...recogiendo sobre sus fachadas retranqueadas los últimos rayos...el edificio para los entrenamientos se transforma en un pórtico y el pórtico en una serie de ambientes que sobresalen de un muro revestido de ladrillos y de un cerramiento de metal. El edificio para las competiciones consiste en un muro de contención que, al duplicarse, inventa un espacio interno iluminado desde arriba, que organiza el movimiento del publico en la zona superior."

Enric Mlralles. ${ }^{332}$
\end{abstract}

\subsection{DESCRIPCION}

Complejo de Tiro con Arco. (1989 - 1992). Demolido edificio Competición 2008.

Dirección: Passeig de la Vall d'Hebron, 166-176, Barcelona.

Encargo: Directo. Ayto. de Barcelona, Josep Antonio Acebillo.

Arquitectos: Enric Mlralles y Carmen Pinós.

Dirección de Obra: Enric Miralles (1991 - 1992)

Colaboradores: Silvia Martínez, Albert Ferré, Eva Prats, Rodrigo Prats,Soraya Smithson, Hugo Wilson, Jordi Altés. Agusti Obiol y Robert Bufrau (BOMA) en Estructuras.

El proyecto surge para dar acomodo a los servicios necesarios para la celebración de las competiciones de Tiro con Arco en las Olimpiadas de Barcelona 1992. Se emplaza en un desnivel orientado a Este, entre dos plataformas sucesivas. El programa se subdivide en dos edificios separados 400 metros por una calle de tráfico rodado. Los dos edificios, uno para Entrenamiento y otro para Competiciones, delimitan una amplia superficie que tienen enfrente, situándose junto a los muros de contención que aterrazan la pendiente. El edificio de Entrenamiento se transforma en un pórtico y en una serie de estancias que sobresalen de un muro de cerramiento de ladrillo. El edificio de Competición es un muro de contención que al duplicarse genera un espacio interno iluminado cenitalmente. 


\subsubsection{CONTEXTO}

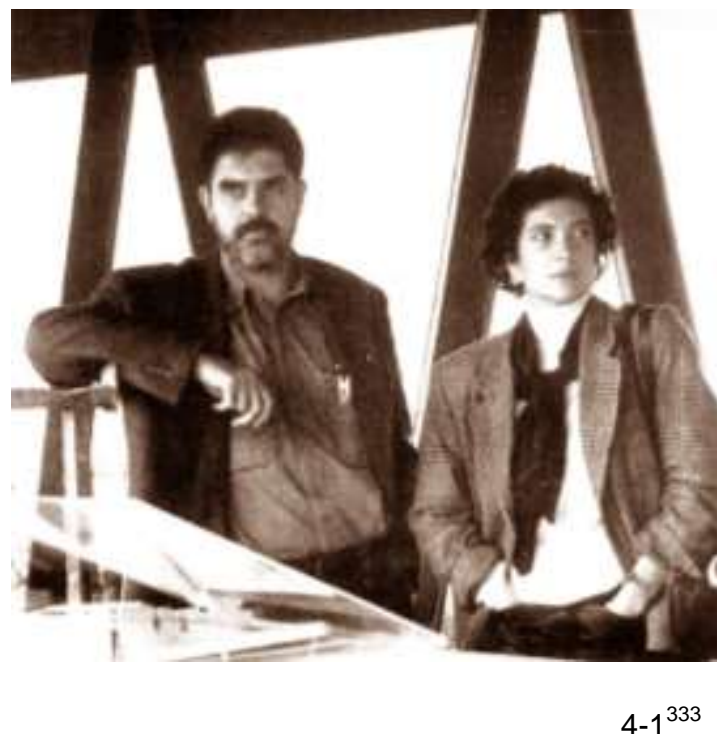

"...la llegada de los sociatas al poder nos vino muy bien porque confiaron mucho en los arquitectos jóvenes para ayudar a cambiar lo existente, tan es así que había muchos concursos e incluso recibías encargos directamente de la Administración solo por ser jóvenes..."

\section{Carmen Pinos. ${ }^{334}$}

En 1989, el año en que Enric Miralles y Carmen Pinós proyectan el Complejo de Tiro con Arco: Peter Eisenman termina el Centro Wexner de Artes Visuales en Ohio; Frank Gehry obtiene el Premio Pritzker; Oiza termina las viviendas cerca de la M-30 en Madrid; y Tuñón - Mansilla proyectan el Museo de Zamora. En lo cultural, Camilo José Cela obtiene el Premio Nobel de Literatura. En el panorama internacional, cae el muro de Berlín y se produce la revuelta estudiantil en Tianamén, China.

El 1992, año en que se termina la construcción del Complejo de Tiro con Arco, Alvaro Siza obtiene el premio Pritzker; Sevilla acoge la Exposición Universal y Barcelona las Olimpiadas. Como acontecimientos destacables a nivel mundial, se produce la desintegración de Yugoslavia.

Miralles y Pinós, abordan el proyecto tras el encargo directo de Josep Antonio Acebillo ${ }^{335}$, en un momento en el que ya han demostrado lo bien que se manejan

\footnotetext{
${ }^{333}$ Enric Miralles y Carmen Pinos en una foto de la época en la que abordaron el Proyecto de Tiro con Arco.

${ }^{334}$ Conferencia dictada en Curso de verano de la UIMP, "Alegoría del tiempo: la arquitectura y el universo de Enric Miralles", Barcelona, 2009.

335 Josep Antonio Acebillo que había entrado a trabajar de delineante en el Estudio de Oriol Bohigas, se hizo arquitecto y era una persona de máxima confianza para Bohigas, quien le asigno un cargo muy importante en la Gerencia de Urbanismo del Ayto. de Barcelona.
} 
con su arquitectura en el paisaje natural ${ }^{336}$. Miralles en 1989, ya es $\mathrm{Dr}$. arquitecto $^{337}$, y profesor titular en la ETSAB ${ }^{338}$ y en este curso 1988-1989 también es profesor visitante en la Universidad de Columbia en Nueva York. Como relata Eva Prats, colaboradora del Estudio en aquellos tiempos: "En ese momento Carme y Enric no viajaban tanto y estaban todas las tardes ahí, con la música clásica de la radio, te pasabas la tarde dibujando, era un tiempo detenido, como en una biblioteca. Tardes muy concentradas, llegabas a las 4 y te ibas no sabías exactamente cuándo, ya de noche". ${ }^{339}$

En el momento de recibir el encargo, la pareja de arquitectos, solo han terminado las pérgolas de Parets del Vallés y el Instituto de bachillerato La Llauna; y tienen en marcha los siguientes proyectos: el Parque Cementerio de Igualada comenzado en 1985; el Centro cívico de Hostalets de Balenyá; la Escuela hogar en Morella y el Palacio de Deportes de Huesca. ${ }^{340}$ Fue muy importante para la proyección internacional de su obra la exposición que Exposición: "Enric Miralles \& Carme Pinós. Projects 1985-90" celebrada en Diciembre de 1989 en el Storefront for Art and Architecture de Nueva York. En el texto escrito en el folleto de la Exposición, el Comisario Dennis L. Dollens se refería a la obra de la pareja de arquitectos en los siguientes términos: "Enric Miralles and Carme Pinós are such architects. They design; they do not write. They are pragmatic workers who use architecture as their voice and drawings as manifestos. Theirs is not an architecture of theory; it is an architecture of communication. In drawn lines and constructed forms this team speaks of materiality, site and place...These exhibition presents a series of these drawings, as well as models and photographs, in order to broaden debate and dialogue, as well as to make more widely known the architectural experiments Miralles and Pinós are creating from their Barcelona studio...one of the most active and dynamic teams currently emerging in Europe..." ${ }^{341}$ Dennis Dollens, comenta que hay arquitectos que toman fuerzas de lo mejor de la arquitectura del Movimiento Moderno esquivando las irrelevancias del Posmodernismo haciendo uso de materiales tradicionales y contemporaneos para proyectar con criterios locales utilizando la tecnologia universal. Ademas defiende que Miralles y Pinós, no escriben sino que dibujan; que son pragmaticos; emplean su arquitectura como su voz y sus dibujos como sus manifiestos. En los trazos de sus dibujos y en sus formas construidas, nos hablan de materialidad, sitio y lugar. Dennis Dollens, uno de los equipos emergentes mas importantes de Europa. finaliza la introduccion admitiendo que Miralles y Pinós es en el momento de la Exposicion uno de los equipos emergentes mas importantes de Europa.

\footnotetext{
${ }^{336}$ El éxito obtenido en el Concurso y lo ejecutado del Parque Cementerio de Igualada les catapultan al reconocimiento internacional.

${ }^{337}$ Enric Miralles obtuvo el titulo de Doctor el dia 25 de Febrero de 1988 con Sobresaliente "cum laudae"

${ }^{338}$ Enric Mlralles obtuvo el cargo de Profesor Titular en la ETSAB en 1985, con 30 años de edad.

339 Eva Prats. "Las tardes de dibujo en el estudio Miralles \& Pinós". Extractado de la web: wikispaces.org

340 Hasta 1990, los proyectos realizados por Enric Miralles y Carmen Pinós, se realizan en una pequeña habitación casi artesanalmente y con pocos colaboradores, en el piso del padre de ella, en el cruce de las calles Diagonal con Balmes de Barcelona.

341 Dennis L. Dollens. Introducción en el folleto de la Exposición: "Enric Miralles \& Carme Pinós. Projects 1985-90" Diciembre de 1989. Nueva York
} 


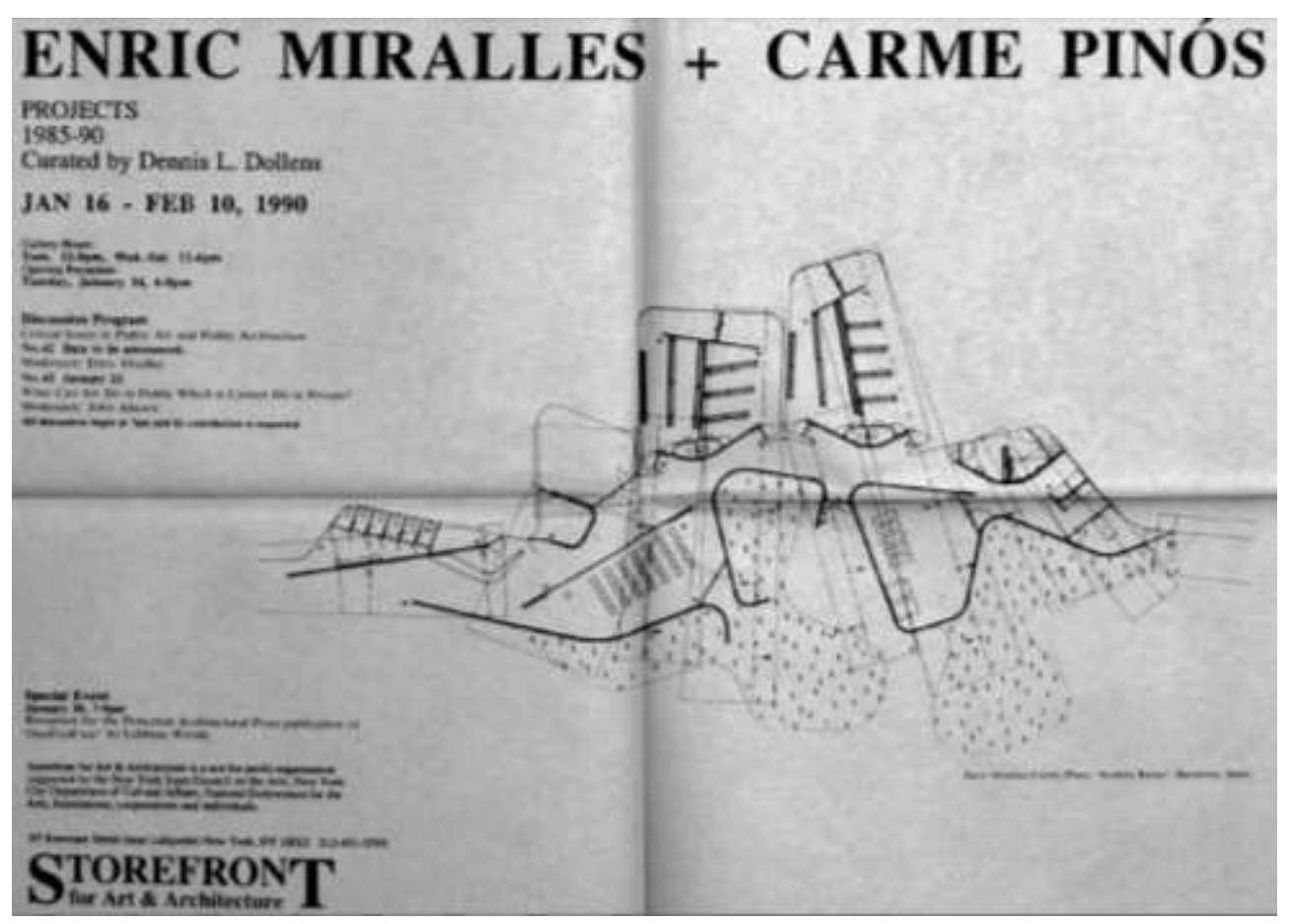

$4-2^{342}$

\section{Relación con el land Art y otras arquitecturas.}

Existe parecido entre las piezas de hormigón prefabricado empleadas por Mlralles para el edificio de Competición y las piezas de hormigón, también caladas con pequeñas perforaciones de los Túneles Solares de la Land Artist Nancy Holt en el Desierto de Utah (1973-1976). Allí cuatro grandes cilindros de hormigón de $2.80 \mathrm{~m}$ de diámetro exterior por $5.5 \mathrm{~m}$. de longitud se disponen tumbados en posición horizontal con perforaciones circulares, fueron construidos con una masa, mezcla de arena y piedra existentes en el lugar. Holt, señala la dificultad de calcular las escalas en el desierto. La geometría de dichos túneles contrasta con la del lugar, y ese contraste buscado por la land artist conscientemente

La gran escala de la intervención del movimiento de tierras llevado a cabo en el Complejo de Tiro con Arco, remite a actuaciones del Land Art norteamericano como el realizado por Michael Heizer en Buffalo Rocks, Illinois entre 1983 y 1985, en el que en una antigua explotación de carbón de la década de 1930, es transformada en un parque público mediante la regeneración y la remodelación artística del terreno. Heizer se inspiro en los montículos funerarios indios a los que otorgo formas de animales endémicos de Buffalo Rock.

\footnotetext{
342 Folleto de la exposición: "Enric Miralles \& Carme Pinós. Projects 1985-90" Diciembre de 1989. Nueva York. Dennis Dollens, finaliza la introducción al folleto de la exposición, admitiendo que Miralles y Pinós es en el momento de la Exposición uno de los equipos emergentes mas importantes de Europa. Esta exposición fue muy importante para Miralles y Pinós, pues les dio a conocer internacionalmente.
} 

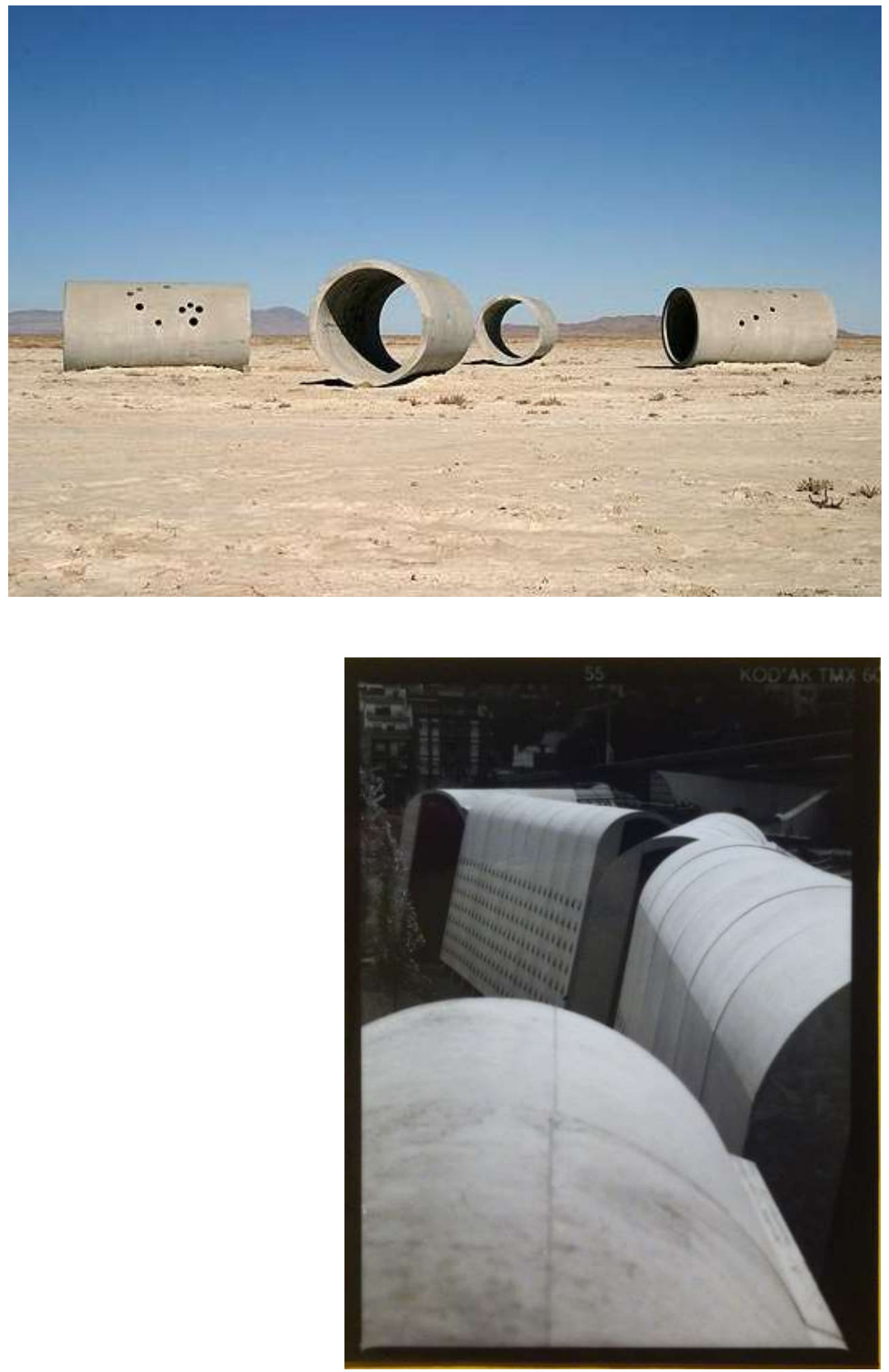

$4-3^{343}$

343 Túneles solares de Nancy Holt versus piezas de hormigón del edificio de Competición. @Fundació Enric Miralles. 

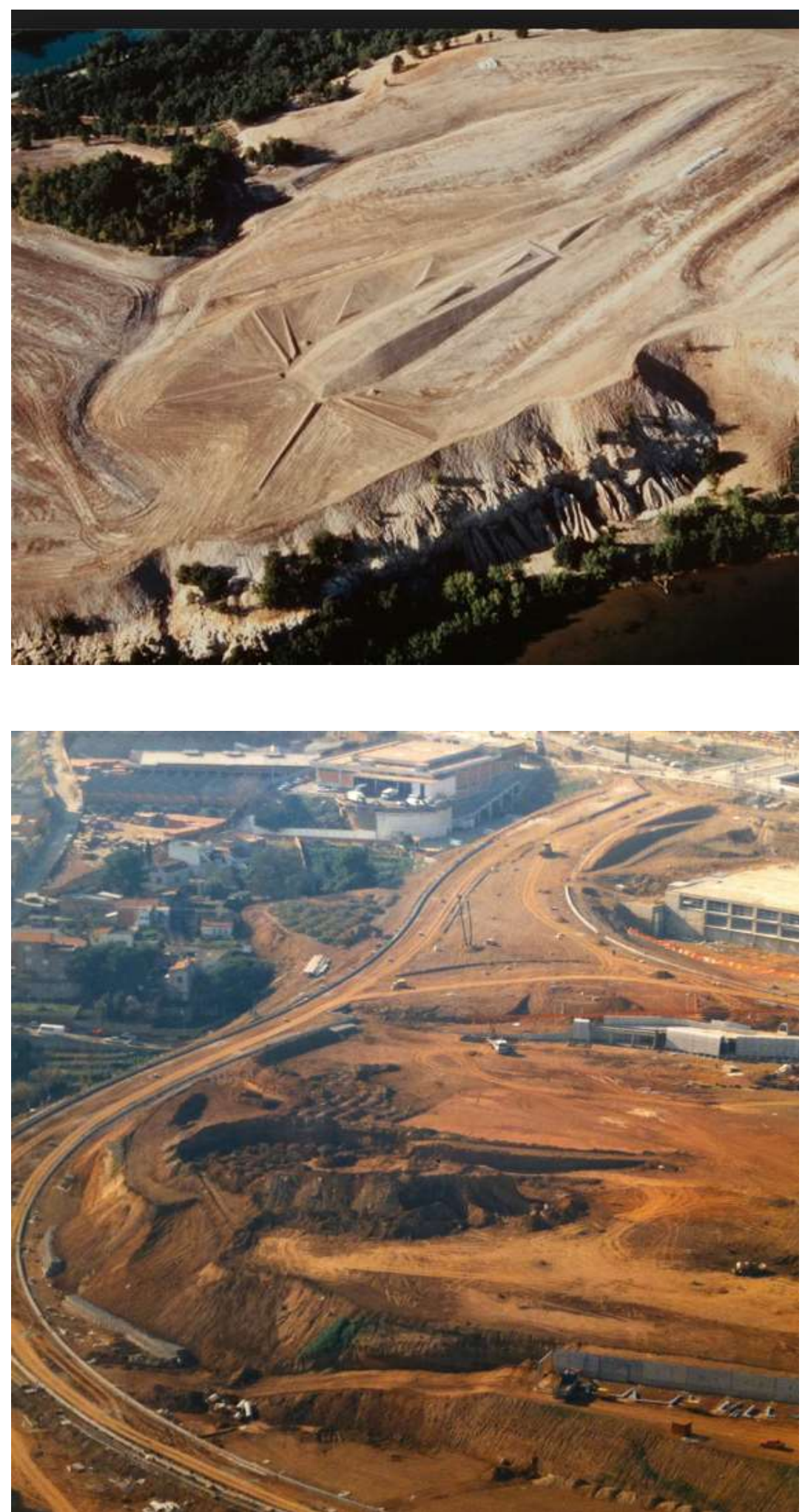

$4-4^{344}$

${ }^{344}$ Effigy tumuli de Michael Heizer, Buffalo Rock, Illinois 1985, versus gran excavación Complejo Tiro Arco. OFundació Enric Miralles. 
Enric Miralles hizo un curso de Doctorado en la ETSAB sobre Wright. Cuando se observan las viseras de hormigón sobrevolando el muro de gaviones de piedra en Tiro con Arco, o en los pabellones de Huesca, Alicante, etc. dejando ese umbral en sombra que hace que se borre el encuentro entre muro y cubierta, recuerda la manera en la que flota la cubierta en la Casa Willis del maestro norteamericano Frank Lloyd Wright. Parecen decir que la arquitectura es lo que queda entremedias del suelo y una cubierta que flota. En la Williis House (1902) tres de las cuatro alas de su planta terminan en espacios ambiguos -un pórtico, la entradade coches y una terraza- elementos que desarrollan la casa en un entorno tenso, buscando la transición entre exterior e interior con una secuencia espacial revelada por los característicos recorridos de las obras de Wright.

Segun C. de Sessa: "Wright concibe la existencia humana como un complejo de eventos insertados en un flujo transformador; por lo que ninguna forma puede ser definitiva...la forma para Wright es un testimonio de precedentes transiciones...el fotograma que sintetizando las condiciones de cierta situación en un determinado momento de un proceso morfo genético en permanente evolución." ${ }^{345}$ Cuanto tiene que ver este comentario de $\mathrm{C}$. de Sessa sobre la obra de Wright, con la manera de entender la complejidad de la vida que tiene Enric Miralles y el reflejo en su Arquitectura.

Wright junto con Alvar Aalto es una de las figuras más representativas de la simbiosis (en el significado griego de "vida en conjunto, de convivencia" entre Naturaleza y Arquitectura. La arquitectura de Wright se puede interpretar como una metáfora del paisaje, entendido en su concepción fenomenológica. Una de las metáforas preferidas de Wright al definir su proceso proyectual remite al trabajo del tejedor, quien conoce la trama y la medida, el peso y el modelo, los detalles y el conjunto. El pensamiento de Wright tambien es deudor del pensamiento del filosofo francés de finales del siglo XIX Henri Bergson, precursor del antipositivismo. En sus teorias, defiende la intuición, considerandola una combinación de inteligencia e instinto y admite que cada individuo es un ejemplar único, que participa de la generalidad de la especie pero a la vez de la exclusividad del individuo. El principio de la evolución interior, expresado por Bergson en su libro Evolucion creadora (1907), también es el fundamento y raíz de lo exterior, en forma de vida y evolución. La arquitectura orgánica acepta la dimensión del tiempo en todas sus manifestaciones. Wright proyecta Taliesin, para que la acción del tiempo altere sus superficies con patinas que contribuyan a adaptar la obra en el paisaje, hasta adoptar sus características visuales y perceptivas, transfiguradas en un continuum ambiental y atmosférico que como una veladura equilibra arquitectura y Naturaleza, exaltando su relación. ${ }^{346}$ Para Wright, el paisaje es considerado una metáfora estética que representa la Naturaleza y la manera de relacionarse el hombre con el ambiente. Dichos principios orgánicos explican la adaptacion de la arquitectura en el ambiente natural, la inspiración en los colores del entorno, la expresión auténtica de los materiales sin revestir, la singularidad de cada obra, etc

\footnotetext{
${ }^{345}$ Capire lo spazio architettonico. Studi di ermeneutica spaziale. Roma 1990, p 125-126

${ }^{346}$ En el Cementerio de Igualada, tratado anteriormente, se ha comprobado como se ha proyectado teniendo en cuenta el tiempo como ingrediente del proyecto. Los elementos de acero corten se oxidaran y mutaran su aspecto, los relieves con oquedades que revisten los muros de contencion acumularan polvo, los tablones de madera que conforman el suelo se pudriran a la intemperie, los almendros floreceran en primavera y los chopos plantados generaran una cubierta a ese tajo en la tierra conformando una gran tumba que engloba todo el cementerio.
} 

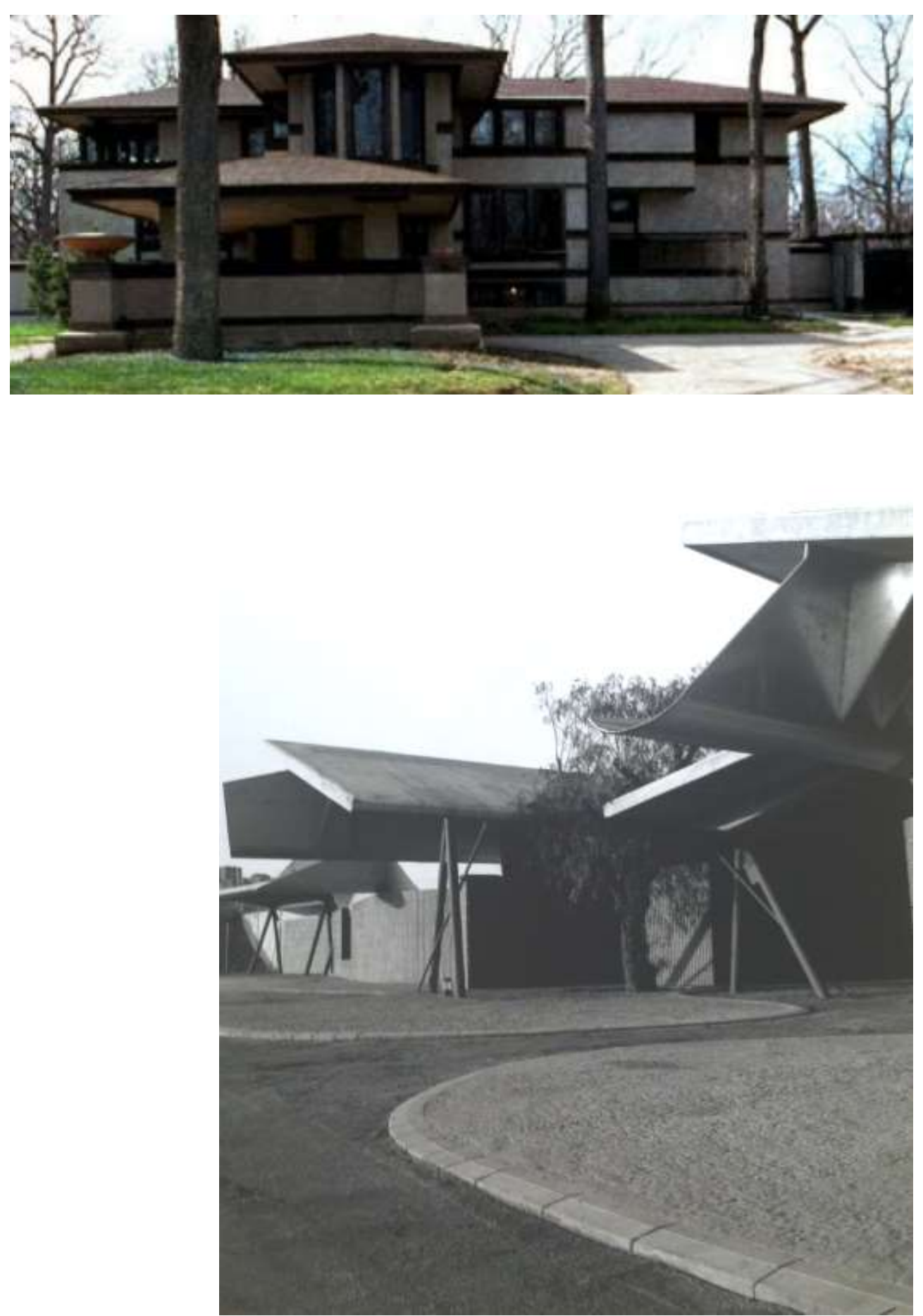

$4-5^{347}$

${ }^{347}$ Casa W. Willitts, en Illinois (1902) de Frank Lloyd Wright versus Edificio de Entrenamiento de Tiro con Arco. (OFundació Enric Miralles. 

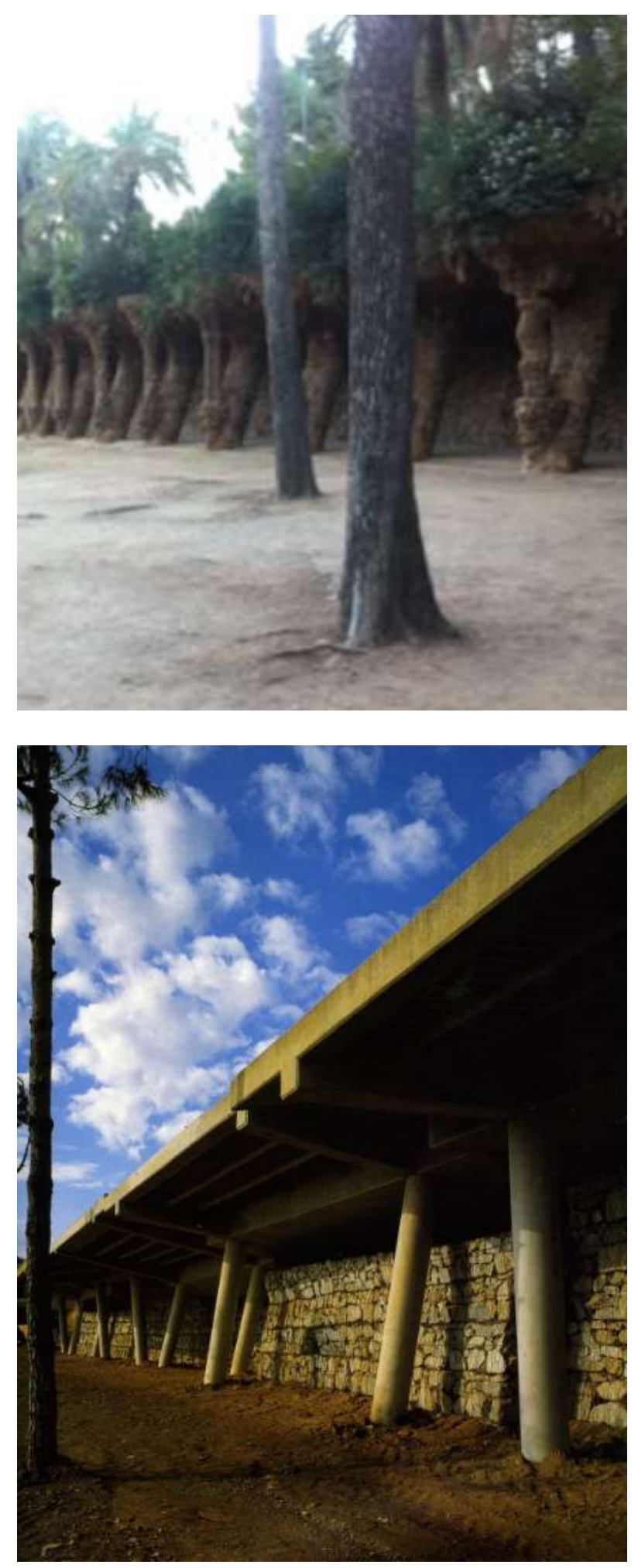

Ilustración $4-6^{348}$

${ }^{348}$ Parque Guell de Gaudi versus Edificio de Entrenamiento de Miralles. 
EL COMPLEJO DE TIRO CON ARCO EN BARCELONA (1989-1992)
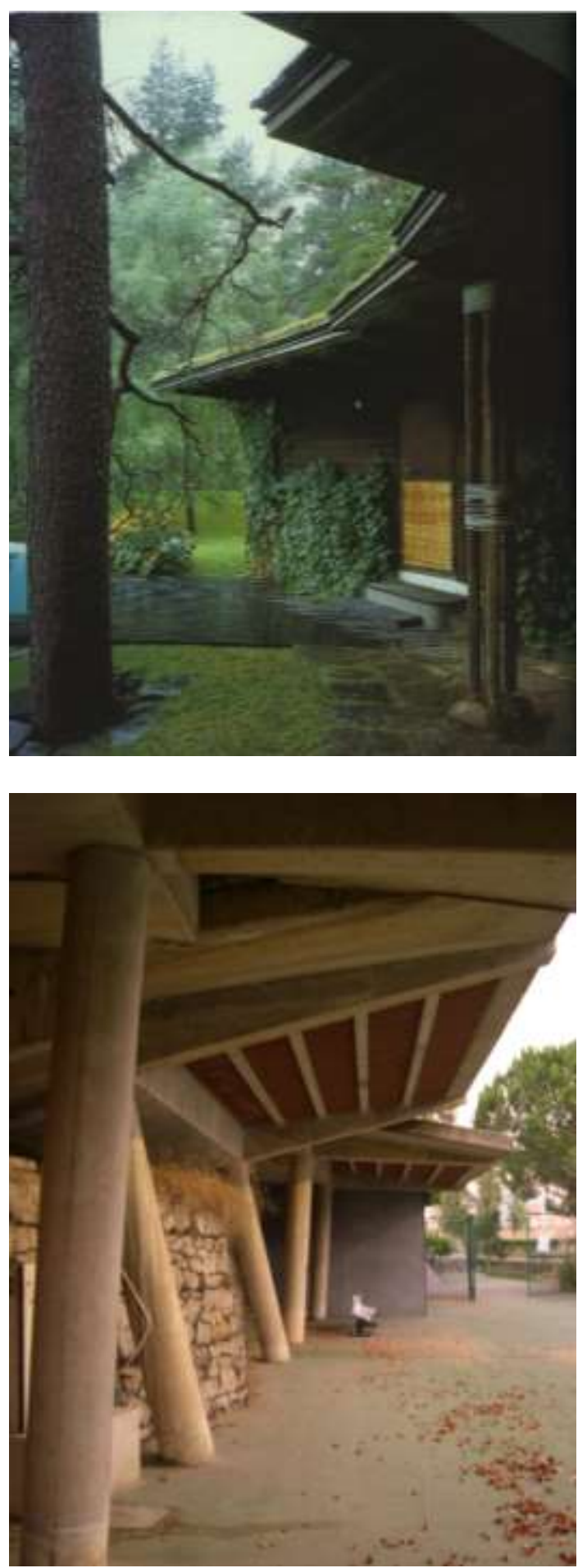

llustración 4-7

${ }^{349}$ Villa Mairea de Alvar Aalto versus Edificio de Entrenamiento de Enric Mlralles. 


\section{EVOLUCION DEL PROYECTO}

El lugar en el que se realiza el proyecto de Miralles y Pinós se encuentra en el Valle de Hebrón, a las afueras de Barcelona, en el encuentro entre la ciudad y las estribaciones de la Sierra de Collserola. ${ }^{350}$

El uso asignado por el Ayto. de Barcelona a ese sector de terreno era de parque y equipamiento deportivo (campo de hockey sobre hierba, piscina cubierta, pabellón para la final olímpica de voleibol, complejo de frontones, campo de rugby, club de tenis y la zona para la competición olímpica de Tiro con Arco). Una de las prioridades del Plan Director del Plan Urbanístico para el Valle de Hebrón, redactado por un equipo liderado por el arquitecto Eduard Brú, era establecer acuerdos entre el final de la montaña y el frente de la ciudad, según relaciones propuestas entre topografía y trazado urbano, entre lo natural y lo artificial. Diversas piezas menores como rampas, escaleras, miradores, etc. se formalizaran según geometrías curvas y sinuosas como si hubieran sido moldeadas por las tensiones generadas entre naturaleza y artificio. ${ }^{351}$
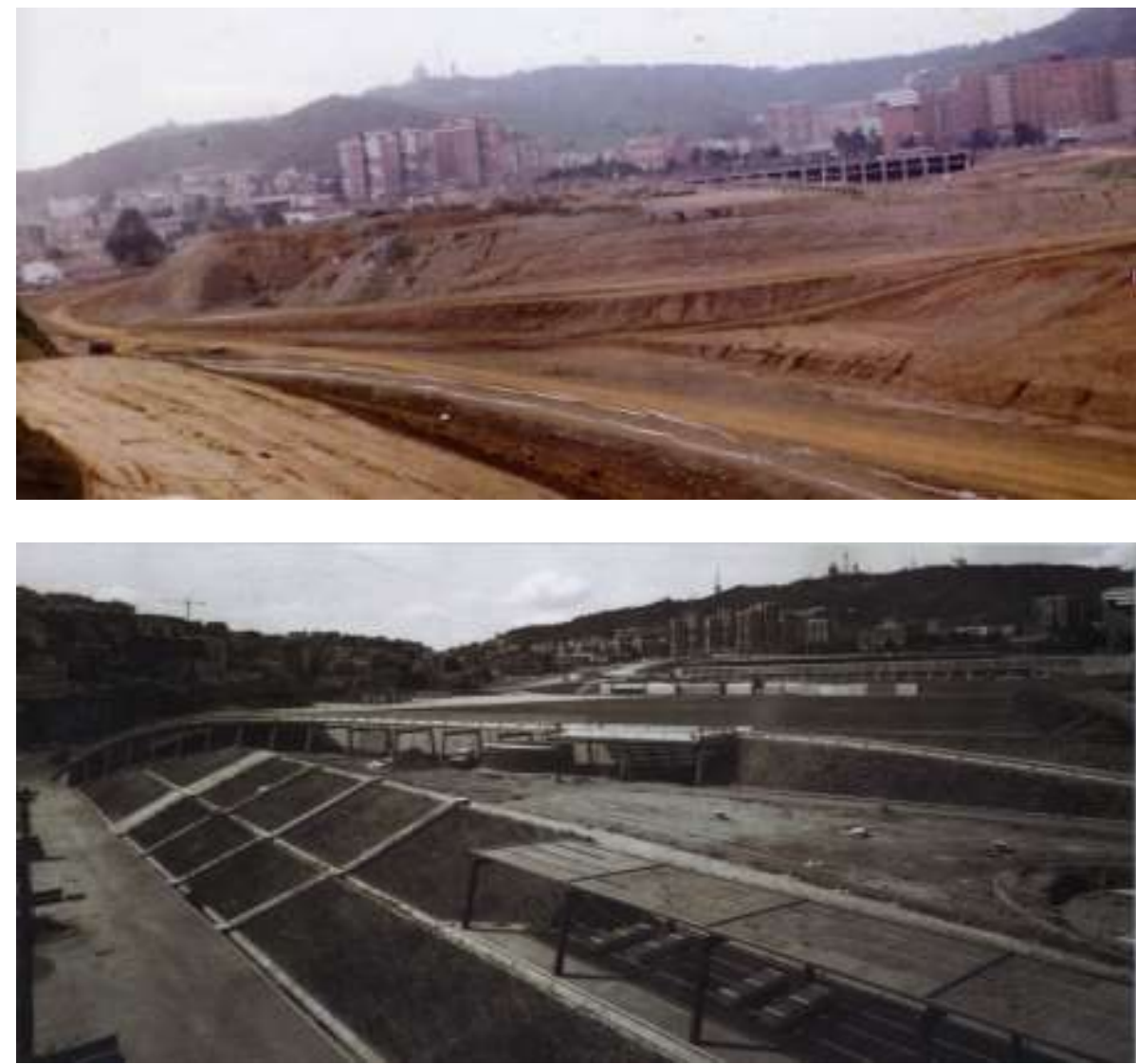

Ilustración $4-8^{352}$

\footnotetext{
350 Se trataba de una zona desordenada urbanísticamente con distintos focos de atracción pero sin conexión entre ellos fracturados por el tránsito de la Ronda de Dalt.

${ }^{351}$ Extracto de QUADERNS ํㅜ183, pág. 55

${ }^{352}$ El vacio que se encontró Miralles en el Valle de Hebrón, en la foto en fase de movimiento de tierras y recién terminado el edificio de Competición.
} 

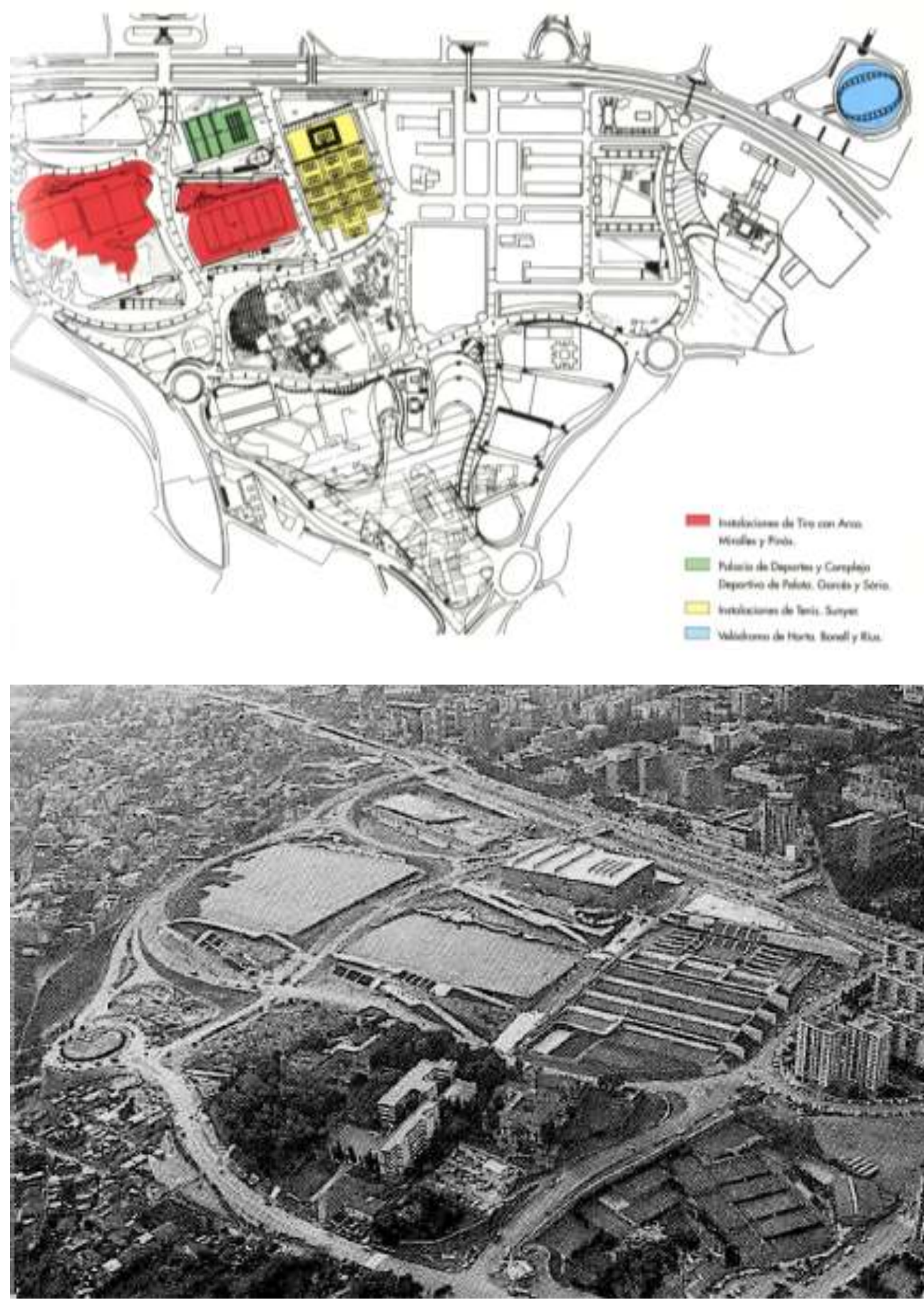

Ilustración 4-935

${ }^{353}$ El área del Valle de Hebrón donde tuvo lugar la intervención. En color rojo destacan los edificios de Competición y Tiro con Arco proyectados por Miralles y Pinós. En la fotografía se observan las dos grandes superficies planas que conforman la pistas de Tiro con Arco, a las que tenían que servir los edificios. 
Los edificios para las competiciones de Tiro con Arco fueron proyectados y construidos en un tiempo record, entre 1989 y 1992, como equipamientos para los Juegos Olímpicos de 1992 celebrados en Barcelona. Cuando Miralles y Pinós reciben el encargo, los vecinos más próximos aun no han llegado y nadie sabe qué cara tienen. Por ello la estrategia de implantación será tratar de fundirse con un entorno que todavía no existe, acomodar un vacio, generar un lugar. Ambos edificios debían servir de apoyo a las pistas exteriores, donde se da la acción y desarrollan las posibilidades constructivas de contener tierras aunque se pliegan a ritmos distintos, el de Competición en horizontal y el de Entrenamiento en vertical.

El emplazamiento se caracteriza por dos grandes superficies orientadas hacia el Este, que reciben el sol de la mañana. El proyecto estuvo condicionado por la exigencia del promotor de situar ambos edificios contra el desnivel existente en el solar que les facilitaron y sirviendo a los campos de juego. Los dos edificios, uno para Entrenamiento y otro para Competición, delimitan la amplia superficie que se extiende al frente, situándose junto a los muros de contención que aterrazan la pendiente del parque y orientados con precisión respecto a la trayectoria del sol. En el plano de emplazamiento lo proyectado apenas se identifica. No se realza con una trama, no existe voluntad de destacar lo proyectado sobre su entorno. Del entorno tampoco se dibuja. No hay indicación sobre llenos, vacios o sombras. Es un plano que simplifica la realidad deliberadamente para garantizar que se su arquitectura se funda con el entorno.

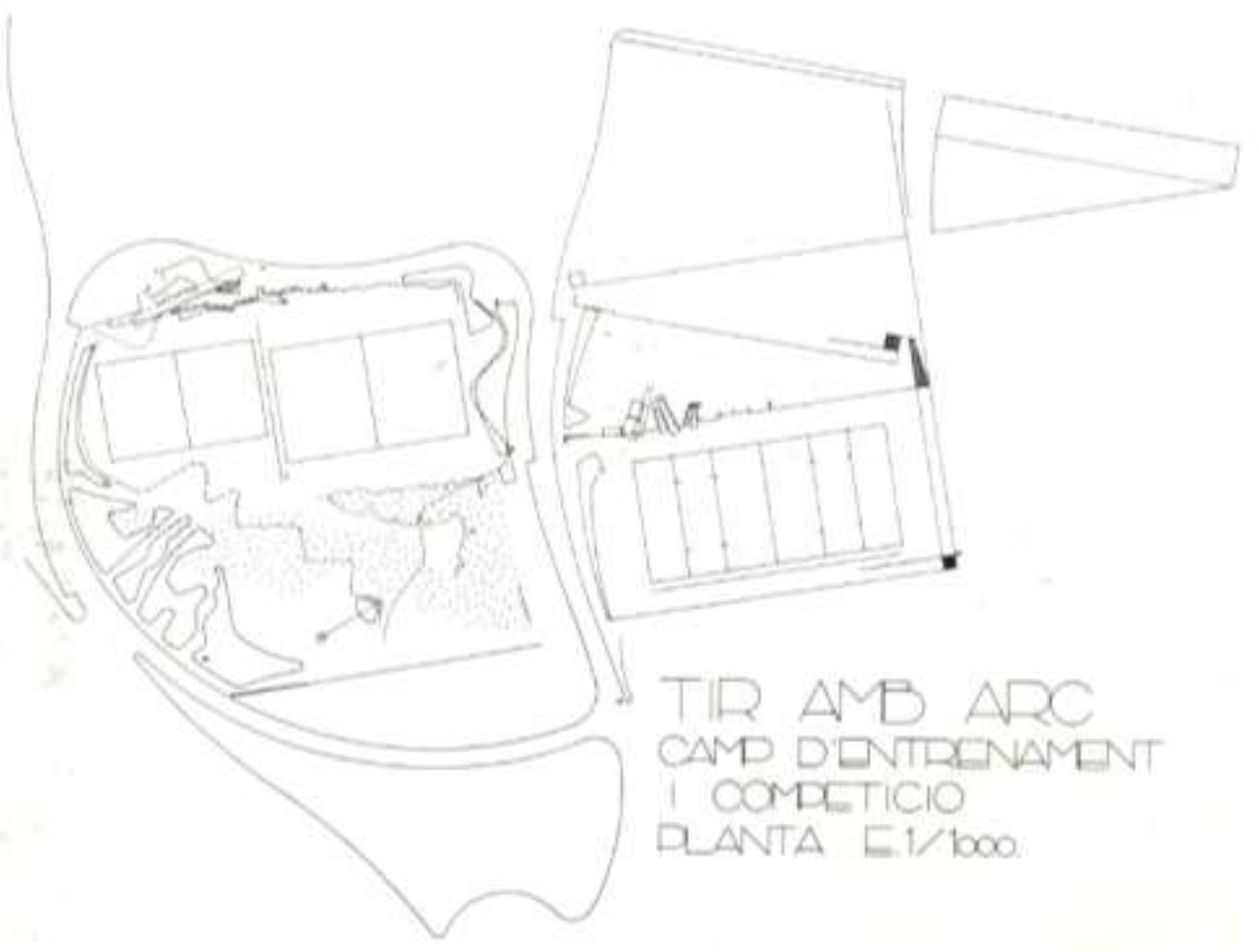

Ilustración 4-10 354

\footnotetext{
${ }^{354}$ El plano de Emplazamiento del proyecto.
} 


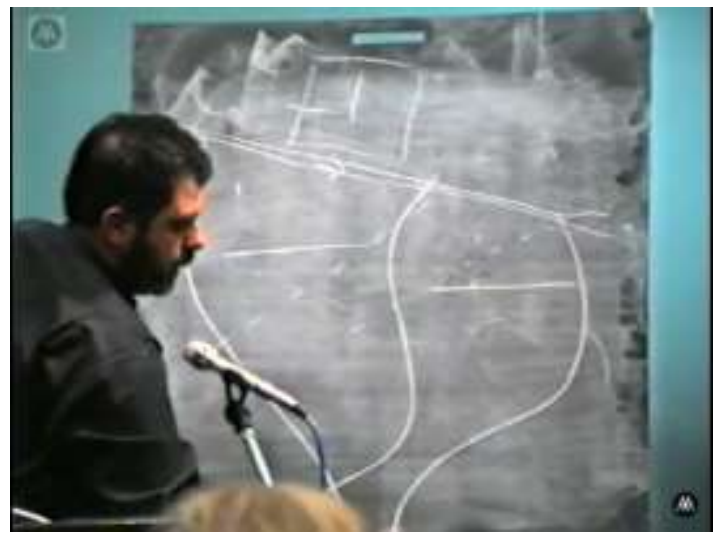

4-11 $11^{355}$

"Si en un edificio la actuación es trabajar con la horizontalidad, en el otro lo es con la verticalidad."

Enric Mlralles y Carmen Pinos. ${ }^{356}$

Miralles en la Conferencia dada en la en Architectural Association de Londres en febrero de 1992, reconoce lo difícil que es entender su arquitectura en los planos y por ello explica a los asistentes su proyecto del Complejo de Tiro con Arco, dibujando en una pizarra la génesis del proyecto. Dedica tiempo a hablar del lugar en el que se debía intervenir y dada la falta de ideas con las que comenzar por la falta de identidad del lugar, comienza el proyecto estableciendo un dialogo entre ambos edificios y conteniendo las tierras a las que debían responder por la diferencia de nivel entre el plano superior de los espectadores y el inferior de las pistas de juego. La contención de tierras, le recuerda a lo que había realizado en el Parque Cementerio de Igualada y se trae a este proyecto el muro de contención de tierras pero ahora habitándolo para alojar las estancias solicitadas en el programa funcional demandado. ${ }^{357}$ También señala que la calle que los separaba se cerraría al tráfico durante la celebración de las Olimpiadas.

Aunque entre ambos edificios exista una separación de casi 400 metros, Miralles y Pinos emplean el dialogo entre contrarios para generar su proyecto. En un entorno sin alicientes con los que dialogar, el dialogo lo realizaran los arquitectos entre su propia arquitectura. Si en el edificio de Competición se trabaja con la horizontalidad, en el de Entrenamiento se trabaja con la verticalidad; si en uno se emplean módulos de hormigón prefabricado dispuestos en horizontal, en el otro se emplea ladrillo con despiece vertical; si en Competición la cubierta se conforma plegando el panel de hormigón prefabricado que hace de cerramiento, en el de

\footnotetext{
${ }^{355}$ Enric Miralles explicando el proyecto de Tiro con Arco en Architectural Association de Londres el dia 28/02/1992. https://www.youtube.com/watch?v=fb5OlzObpGQ\#t=1366

356 "+35 Construyendo en democracia 1975-2010" Antonio Ruiz Barbarín, 2010, pág. 79.

357 Mlralles y Pinós se encontraban construyendo el Parque Cementerio de Igualada cuando recibieron este encargo, que tenía unos plazos de entrega reducidos, con lo que se trajeron el muro de contención proyectado previamente en Igualada, haciéndolo habitable para poder albergar el programa funcional demandado.
} 
Entrenamiento las cubiertas son independientes del cerramiento y su envolvente no coincide con el cerramiento, etc.

El edificio de Competición, se configura mediante la repetición de varios módulos de hormigón prefabricado que albergan el programa dispuestos en zigzag, que son cerramiento y cubierta a la vez, con unos huecos pequeños de forma triangular con el vidrio dispuesto retranqueado para que no se percibiese al estar en sombra. ${ }^{358}$ Miralles comenta al respecto: "Y este muro de Igualada se lleva directamente a Tiro con Arco...algo que ya no tiene direcciones... Se solaparon en el tiempo..." 359

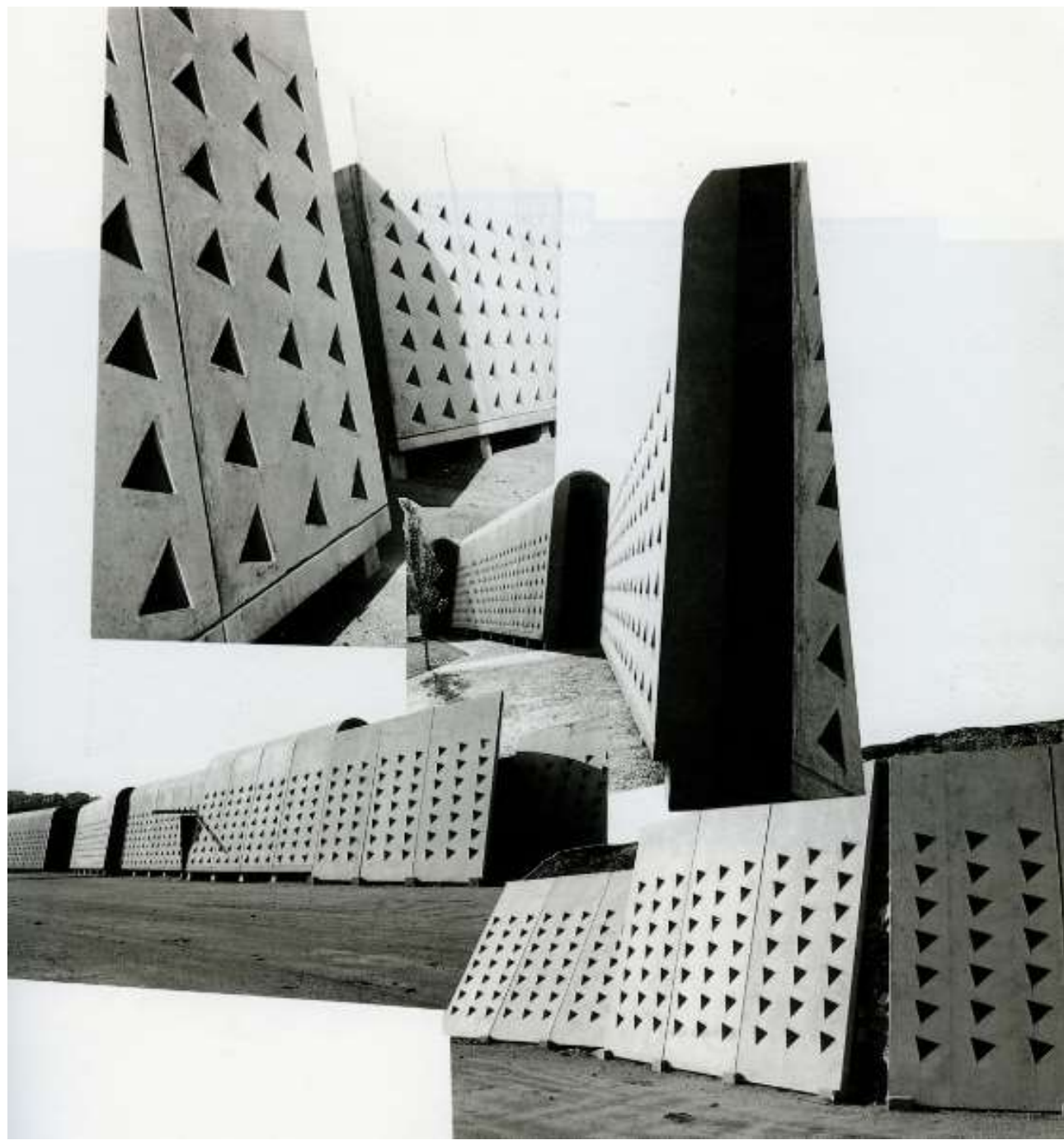

Ilustración 4-12

\footnotetext{
358 Para mas información puede consultarse la Tesis de Javier Fernandez Contreras "La planta Mlralles: Representación y Pensamiento en la Arquitectura de Enric Miralles", leída en la ETSAM. UPM en el año 2013, pág. 148

${ }^{359}$ Enric Miralles. De la Conferencia dictada en la Escuela Técnica Superior de Arquitectura (ETSAM) el 05/05/1993.

${ }^{360}$ Collage en el que Miralles expresa la génesis del edificio de Competición, a partir del muro de contención de tierras empleado en el Parque Cementerio de Igualada. CFundació Enric Miralles.
} 

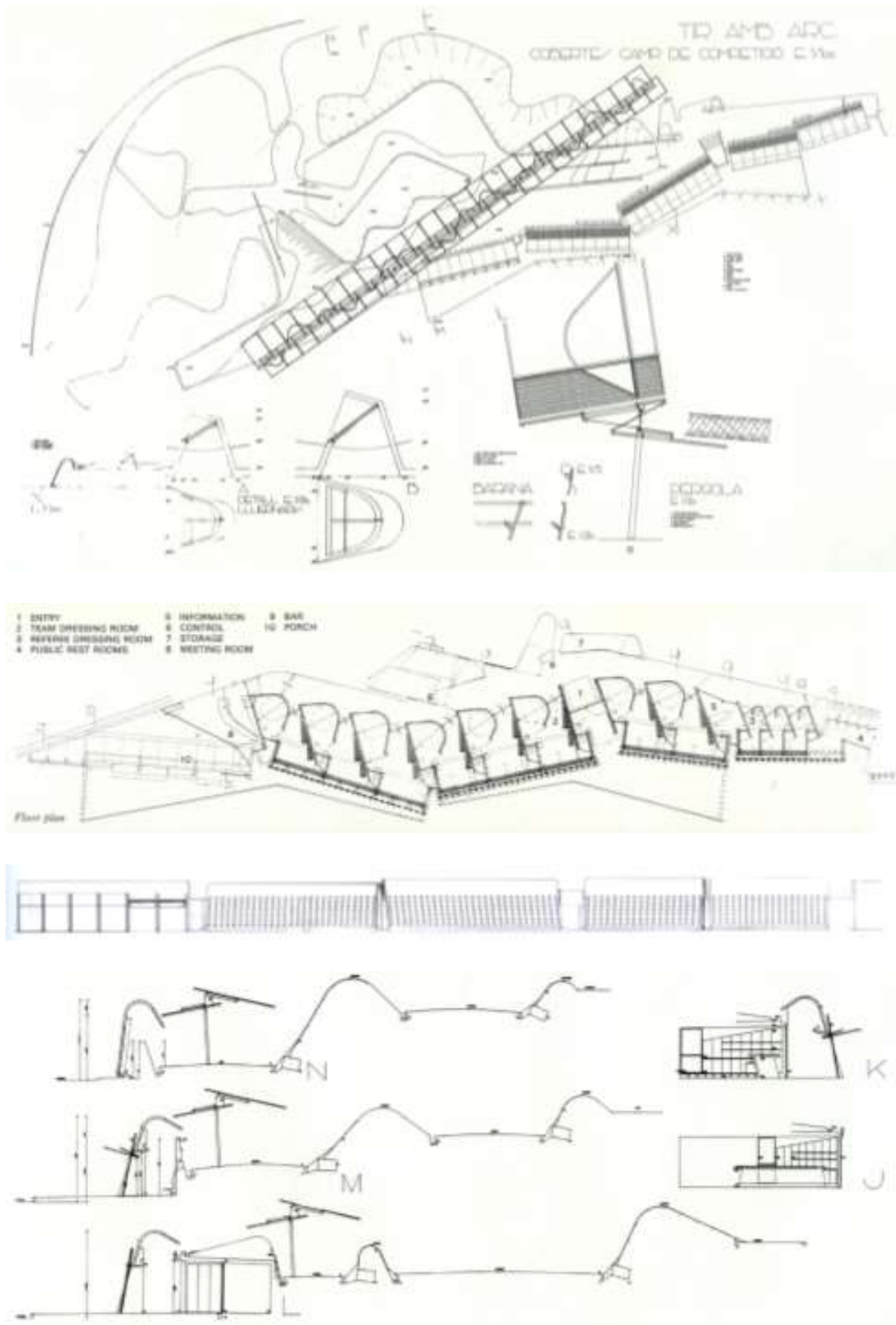

Ilustración 4-13

${ }^{361}$ Planos de proyecto del Edificio de Competición. 
“...nuestra intervención consiste en incrustar unas grandes losas de hormigón en el terreno, el espacio lo encontramos bajo ellas pero no condicionado por ellas. La visión desde la cota superior no tiene porque explicar el espacio generado en la cota inferior, que queda delimitado por unos muros curvos a semejanza de cortinas."

Enric Miralles. ${ }^{362}$

El edificio de Entrenamiento se configura por un muro de cerramiento de directriz lineal que se pliega para albergar las estancias demandadas en el programa funcional y por una cubierta en voladizo facetada en varios tramos que deja pasar la luz cenital a los interiores.

La manera en la que estas cubiertas en voladizo dejan la fachada en sombra, recuerdan a como lo hacen en algunas obras de Frank Lloyd Wright. En este edificio, al igual que ocurrirá en los Pabellones de Huesca y Alicante, la fachada es tan solo el resultado de lo que ocurre entre el suelo y la cubierta, y eso se percibe en el interior, donde los tabiques y las puertas, no llegan a tocar la cubierta.
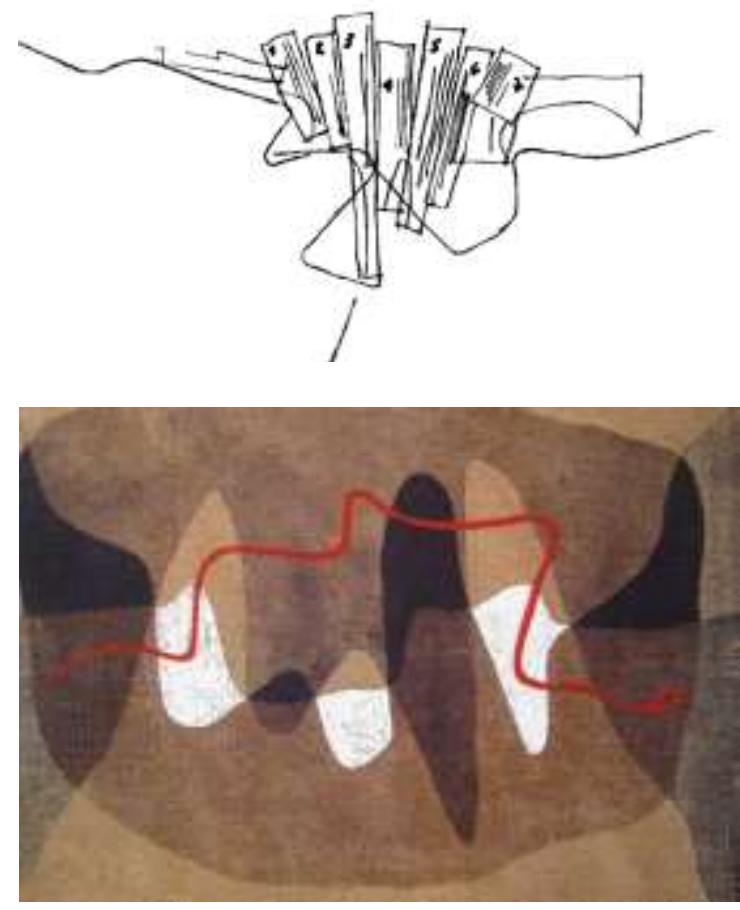

Ilustración 4-14

\footnotetext{
362 "+35 Construyendo en democracia 1975-2010" Antonio Ruiz Barbarin, 2010,

${ }^{363}$ Enric MIRALLES. Bocetos del edificio de Entrenamiento versus pintura de Paul KLEE. Snake Paths 1934. Según muestra la Tesis de Salvador GILABERT: " Enric Miralles. El dibujo de la Imaginación" UPV, 2015.
} 

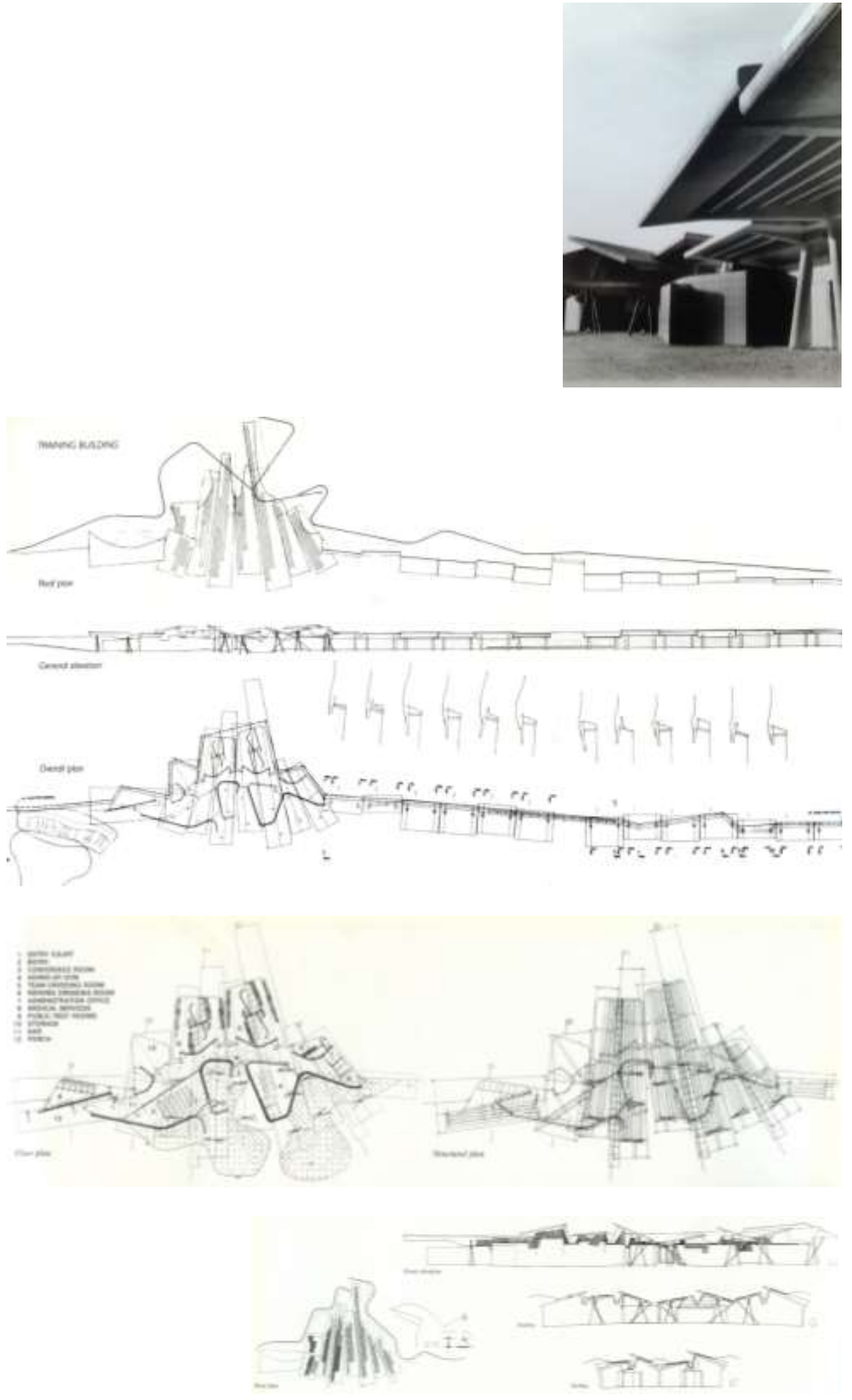

Ilustración 4-15

${ }^{364}$ Fotografía del Archivo Enric Miralles y Planos de proyecto del Edificio de Entrenamiento. CFundació Enric Miralles. 


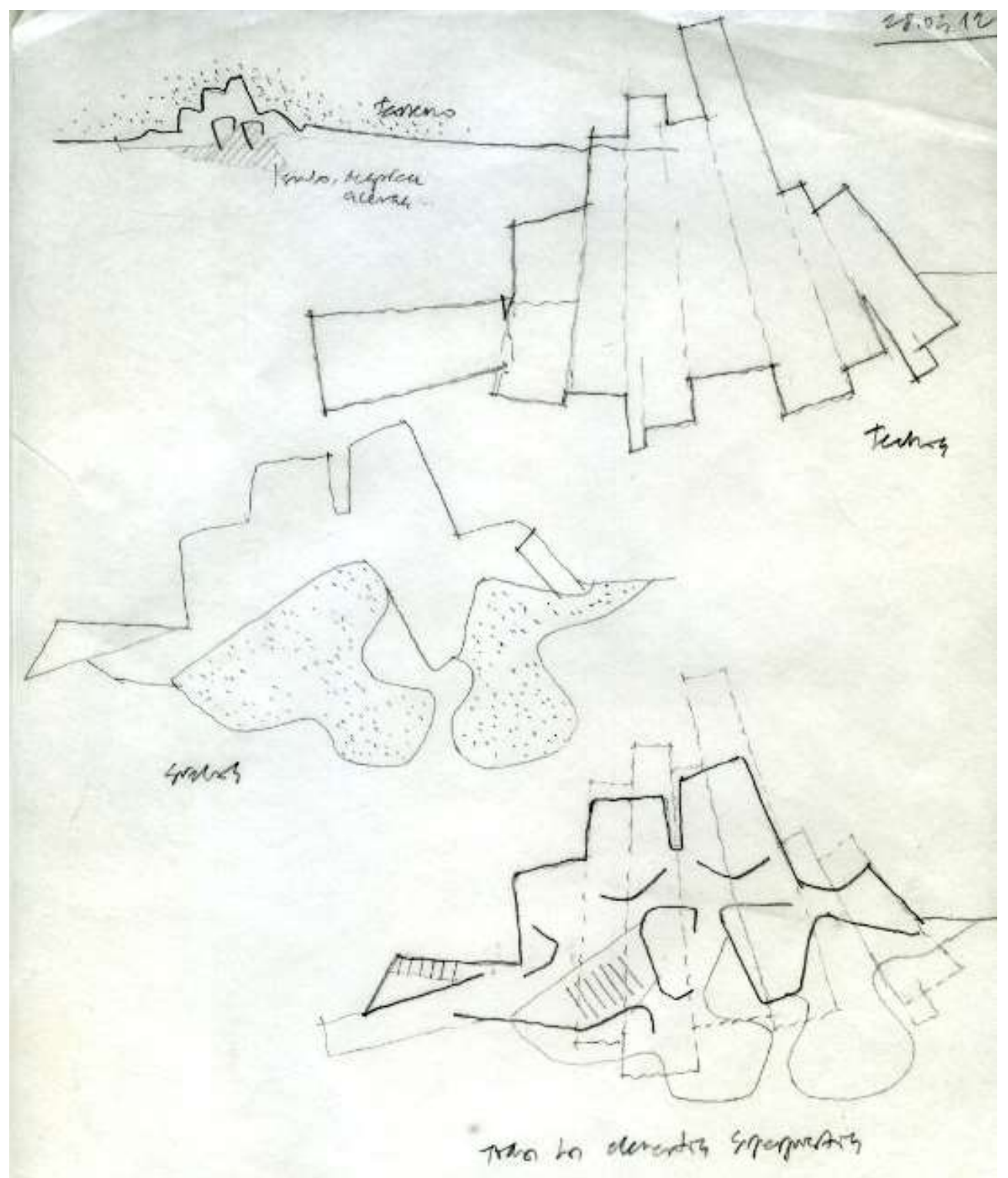

Ilustración 4-16

${ }^{365}$ Croquis del autor de la Tesis, interpretando la implantación del proyecto de Entrenamiento de Miralles y Pinos. Destaca la excavación en uno de los extremos del largo muro de contención para albergar el programa funcional demandado y la no coincidencia entre los perímetros de la planta y la cubierta. 

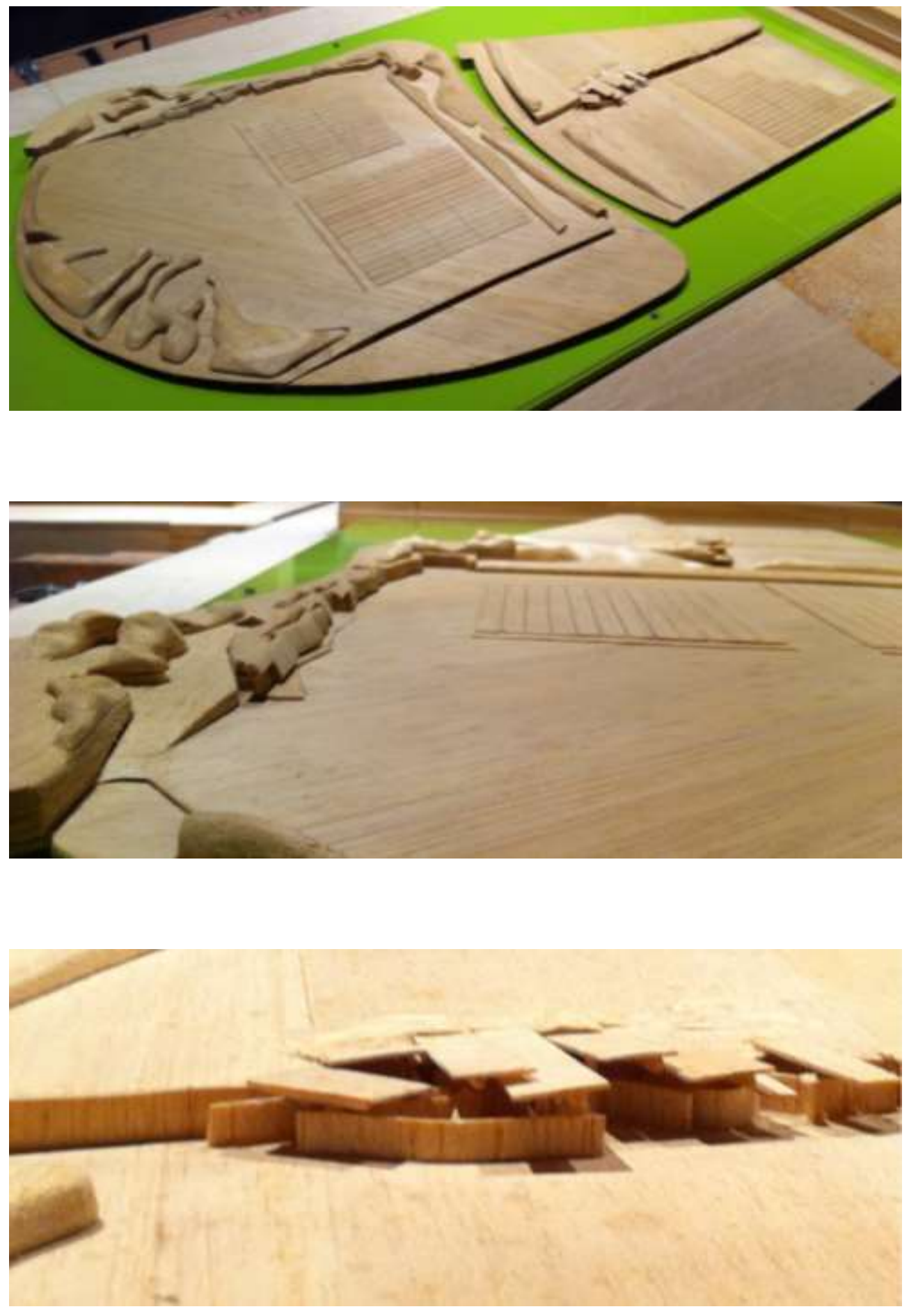

Ilustración 4-17

${ }^{366}$ Imágenes tomadas por el autor de la tesis de la maqueta del proyecto realizada por el estudio de Miralles y Pinos durante la celebración de Exposición "+35 Construyendo en Democracia" en la Arquería del Ministerio de Fomento en Madrid. 
Del proceso de construcción, dieron buena muestra las fotografías aparecidas en la revista El Croquis de septiembre de 1991. En ellas, nada permite identificar lo construido como un edificio. No existe un volumen nítido que permita comprender donde empieza y dónde termina el edificio. Miralles reconoce como en el proceso constructivo empleo las técnicas para retener tierras ya utilizadas en el Parque Cementerio de Igualada: "I usually take projects from the conditions they give to me. The main condition here was the physical necessity of a retaining wall...l reused some of the techniques of the Igualada cemetery but I had to work very fast. More than a project, this is a dialogue between two constructions, which are like two brothers. " ${ }^{367}$

Varios cambios se introdujeron en el proyecto para anclar la intervención al sitio. En el edificio de Entrenamiento, las cubiertas tratan de buscar una relación con la vegetación emergente del complejo Martí Codolar localizado en los niveles inferiores; mientras que en el edificio de Competición, los elementos prefabricados de cerramiento - cubierta, se aproximaron al desorden agrietado de las áreas que existen en los bordes del parque. ${ }^{368}$

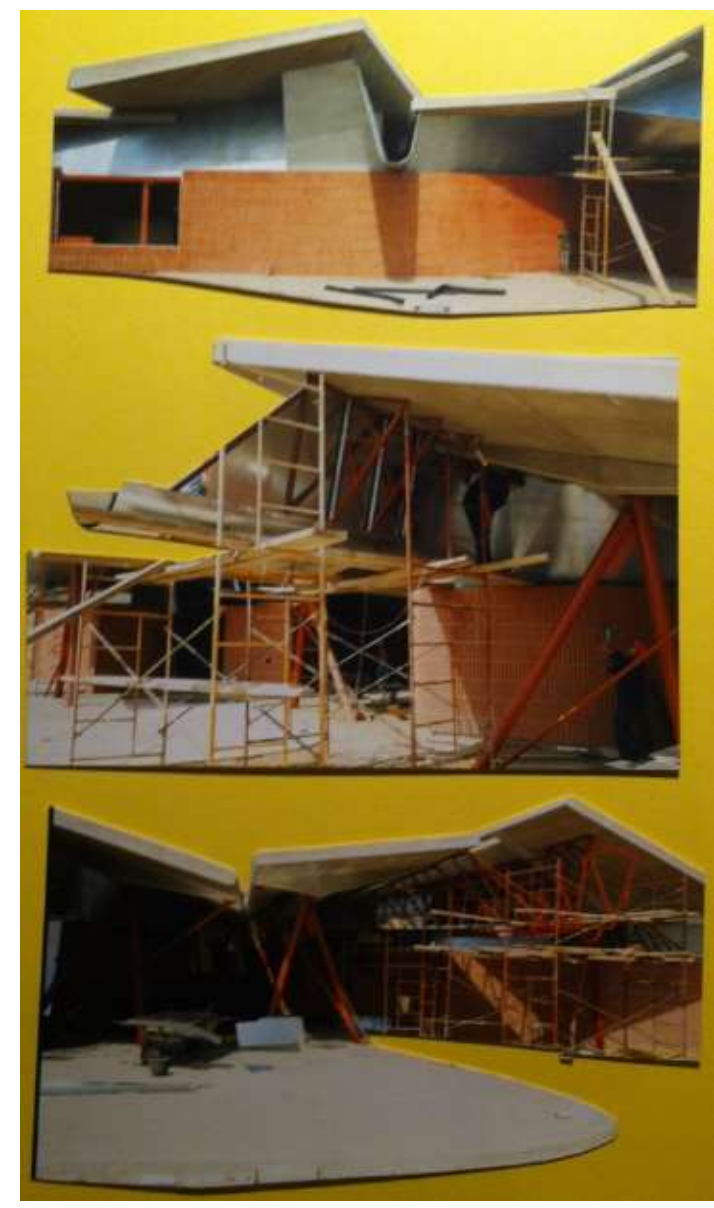

Ilustración 4-18

\footnotetext{
${ }^{367}$ Enric Mlralles. "4 studios in Barcelona", Architectural Association, London, 1992, pag. 32

${ }^{368}$ GA Document no 32. 1992. pag. 50

${ }^{369}$ Edificio de Entrenamiento en construccion. Recortables de fotos que lo muestran. @Fundació Enric Miralles.
} 

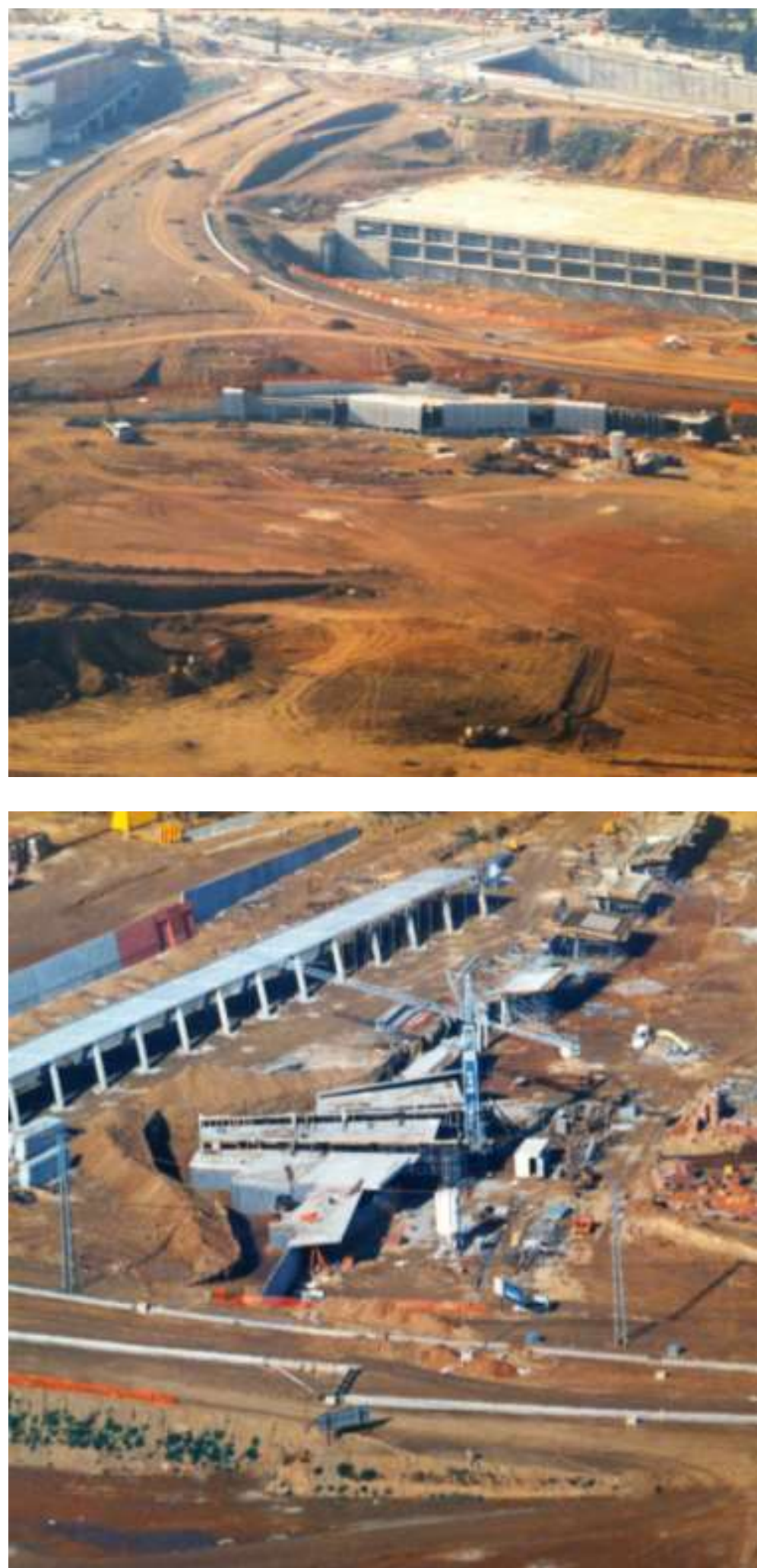

4-19 $9^{370}$

${ }^{370}$ El Complejo de Tiro con Arco en construcción. @Fundació Enric Miralles. 

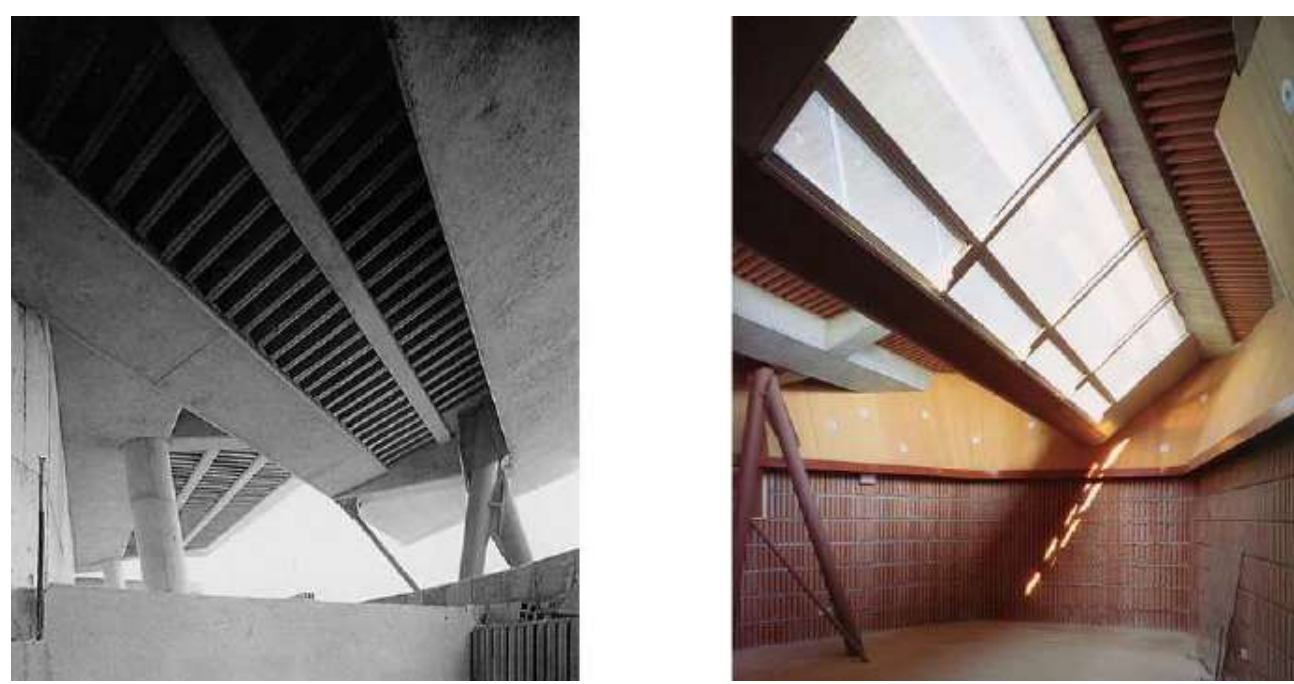

Ilustración 4-20 371

La intervencion es sobretodo topografica, es el movimiento de tierras al que se encomienda la mision de acomodar el programa funcional, de ahi que unos planos tecnicos como los topograficos, que suelen ocupar en otros arquitectos algo accesorio, en este proyecto ocupan una posicion principal. Miralles descubre la belleza que trasmiten las secciones de desmontes y terraplenes y asi les asigna una posicion principal en la definicion de su arquitectura. Unas paredes aparentemente ciegas se pliegan como movimiento de las tierras que soportan. Se accede al espacio interior que encierran a traves de las grietas que surgen en los quiebros. No hay edificios, no hay puertas ni ventanas, tan solo muros y grietas.

El edificio de Competición se tuvo que demoler para permitir la construcción de un tramo del ferrocarril subterráneo que requería pasar por donde se encontraba el edifico. El edificio de Entrenamiento, actualmente ocupa las dependencias de un club de futbol local, sin variar demasiado su programa funcional inicial. En el edificio de Entrenamiento (actualmente en uso como edificio de servicios para un equipo de futbol local), destaca actualmente la agresión arquitectónica cometida por la incorporación de una valla metálica que cierra el campo de juego y que llega los bordes de las losas de hormigón voladas que conforman la cubierta. Otra agresión es la colocación de unas casetas de obra prefabricadas para habilitar más plazas de vestuario, afectando considerablemente a la imagen. Las personas con las que pudo hablar el autor de la tesis, se quejaban del escaso presupuesto que las autoridades asignaban para el mantenimiento del edificio y ello se aprecia considerablemente en el edificio.

Para Kenneth Frampton esta obra constituye un "tour de force" en el que se fusionan estrechamente la tectónica y la topografia, atributos arraigados en la tradición de la arquitectura catalana desde la Edad Media

371 Imágenes del estado de las obras en construcción del Edificio de Entrenamiento en Diciembre de 1990. En color el edificio ya terminado. 

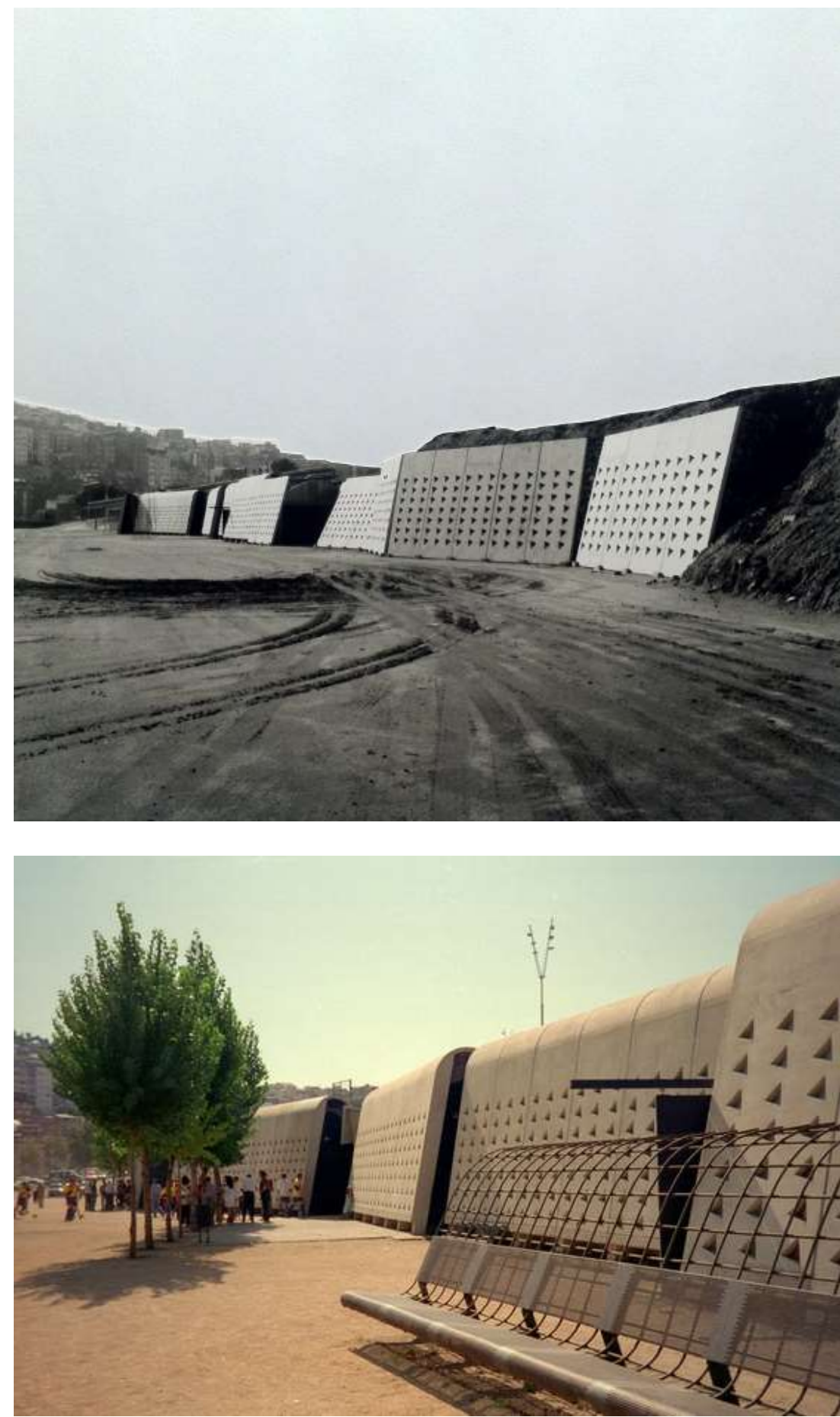

Ilustración 4-21

${ }^{372}$ En la imagen superior el Edificio de Competicion en obras. @Fundació Enric Miralles. En la inferior, el edificio en uso al termino de las Olimpiadas de Barcelona 1992. 

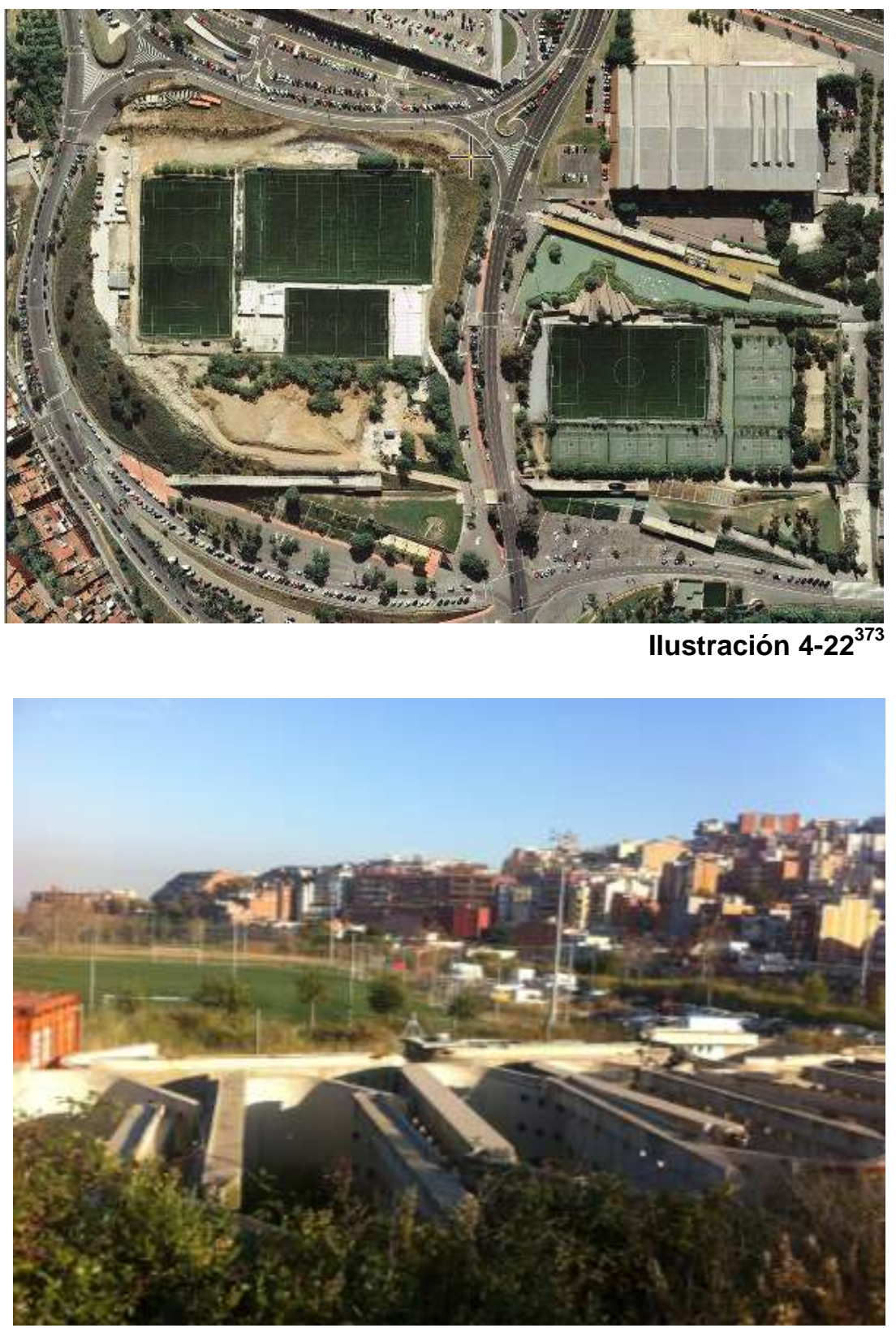

$4-23^{374}$

\footnotetext{
${ }^{373}$ Imágenes en la actualidad de los edificios de Competición (hoy desaparecido para la construcción de un ramal del ferrocarril suburbano) y Entrenamiento.

${ }^{374}$ Estado actual (fotografía tomada por el autor de la Tesis en Noviembre de 2015) de los elementos prefabricados de hormigón armado que conformaban el Edificio de Competición. Dicho Pabellón tuvo que ser desmontado en 2008 para ejecutar un túnel subterráneo ferroviario que debía pasar justo por ese lugar. Existe un proyecto de Carmen Pinos para rehabilitarlo, pero a juicio del autor de la Tesis, será difícil reutilizar todas las piezas pues algunas presentaban desperfectos irreparables.
} 

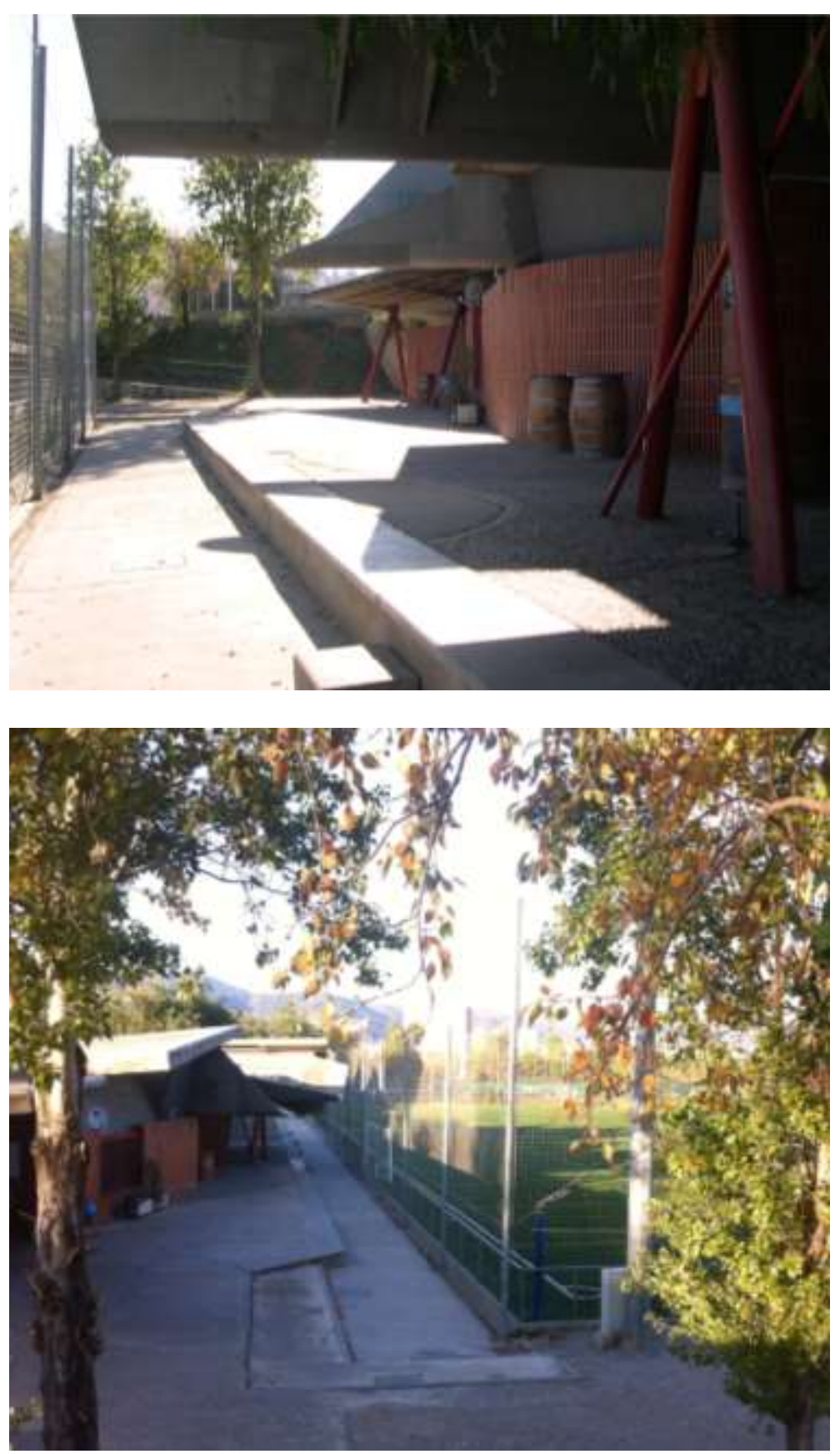

$4-24^{375}$

${ }^{375}$ Estado actual del Edificio de Entrenamiento. (fotografía tomada en Noviembre de 2015). El edificio sigue en uso sirviendo de vestuarios y bar para un Club de futbol local. 


\subsection{ACCIONES CONCRETAS}

\subsubsection{TOPOGRAFIA ${ }^{376}$}

En la intervención de los arquitectos en el Complejo de Tiro con Arco, la topografía, además de resolver aspectos relativos al emplazamiento, se manipula para disponer los usos demandados por el programa funcional. Además de atender al uso, cumple las funciones de zócalo, un zócalo desparramado. En esta obra, mover las tierras es dar acomodo a lo que pasara luego. Es dar prioridad a lo constructivo en relación al lugar. Entender la arquitectura como aquello que prepara un lugar. Lo constructivo se convierte en origen del proyecto, asegura su relación con el lugar y con ello quedan disueltos los límites entre discurso poético e instrucción técnica. ${ }^{377} \mathrm{La}$ intervención es sobretodo topográfica, pues es al movimiento de tierras al que se encomienda la misión de acomodar el programa funcional. Para Kenneth Frampton en esta obra se fusionan estrechamente la tectónica y la topografía, atributos arraigados en la tradición de la arquitectura catalana desde la Edad Media. ${ }^{378}$

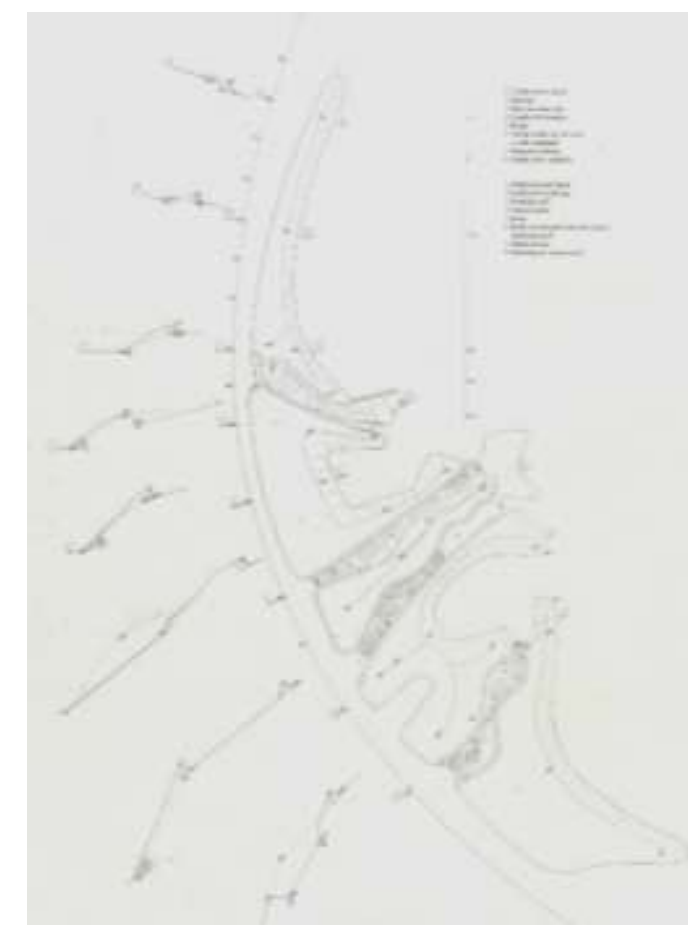

Ilustración 4-25

\footnotetext{
376 Topografía es la combinación de la palabra griega topos (lugar) y graphia (escritura). Etimológicamente significa "la escritura en el lugar".

377

FAURA, Ramón . "Palacio de deportes, Huesca (1988-1994) y Club de tiro con arco, Barcelona (1989-1991)" en Enric Mlralles: 1972-2000 Editorial Fundación Caja de Arquitectos 2011.

${ }^{378}$ Kenneth Frampton. "Sobre la tradición tectónica en la forma catalana contemporánea" Quaderns 206.

${ }^{379}$ Plano topografico en detalle del Proyecto. Estos planos normalmente relegados en los proyectos de construccion junto con los de Estructuras, Miralles y Pinos, los solian colocar despues del plano de emplazamiento.
} 
Con la tierra que resulta de la excavación (sustracción), se generan unas colinas artificiales (por adición) que configuran un umbral de transición entre calle y edificio de Competición. Dichos montículos de tierra en el nivel superior, superan la altura de una persona y guían un recorrido orquestado por los arquitectos, generando zonas estanciales aisladas de las vistas y ruidos del entorno para concentrarse mejor en las vistas hacia las pistas de competición de los atletas. Estos montículos toman contacto con el suelo mediante muretes de contención de reducida altura construidos con el sistema de gaviones de piedra ya empleado en el Parque Cementerio de Igualada.

En el proyecto se detecta una fragmentación sin jerarquías. El discurso arquitectónico no se ajusta a la narración de un proyecto convencional: de lo general a lo concreto; de lo ideal a lo prosaico. Se detectan dos estrategias compositivas: yuxtaposición y superposición. En ambos edificios se fragmenta el programa en piezas diferentes y las plantas son el resultado de una estrategia de yuxtaposición de esas piezas. En el edificio de Entrenamiento además de yuxtaposición, también se da una estrategia de superposición entre la planta y la cubierta, con formas diferentes en ambas y por tanto no coincidentes sus contornos. ${ }^{380}$

Una vez contenidas las tierras, el movimiento del muro de cerramiento exterior viene dictado por los requerimientos necesarios para albergar el programa funcional demandado. En el edificio de Competición, el programa funcional se organiza siguiendo un desarrollo lineal. los vestuarios de los equipos de atletas ocupan la mayoría del perímetro exterior adosándose a este y dejando los extremos del edificio para albergar zonas de uso público: un bar en el extremo sur y unos aseos públicos en el extremo norte. En el interior del edificio, unos vestuarios para los árbitros, una sala de reuniones y una estancia de control de accesos completan el programa funcional. El acceso privado de los atletas al edificio se realiza en la parte central del edificio, aprovechando uno de los quiebros entre dos de los módulos que conforman el cerramiento - cubierta, según una disposición retranqueada y en sombra que persigue que no se reconozca como tal dicha entrada .

En el edificio de Entrenamiento, el programa funcional habitable se localiza en una zona determinada del muro de contención, próximo a su extremo Sur. El programa consta de unos vestuarios para los equipos y los árbitros, un gimnasio, una sala de reuniones, un bar y unos aseos públicos. También aquí las entradas se encuentran ocultas, realizándose el acceso tangencialmente.

380 FERNANDEZ CONTRERAS Javier. Tesis Doctoral "La planta Miralles: Representación y Pensamiento en la Arquitectura de Enric Miralles", DPA ETSAM. UPM 2013. 


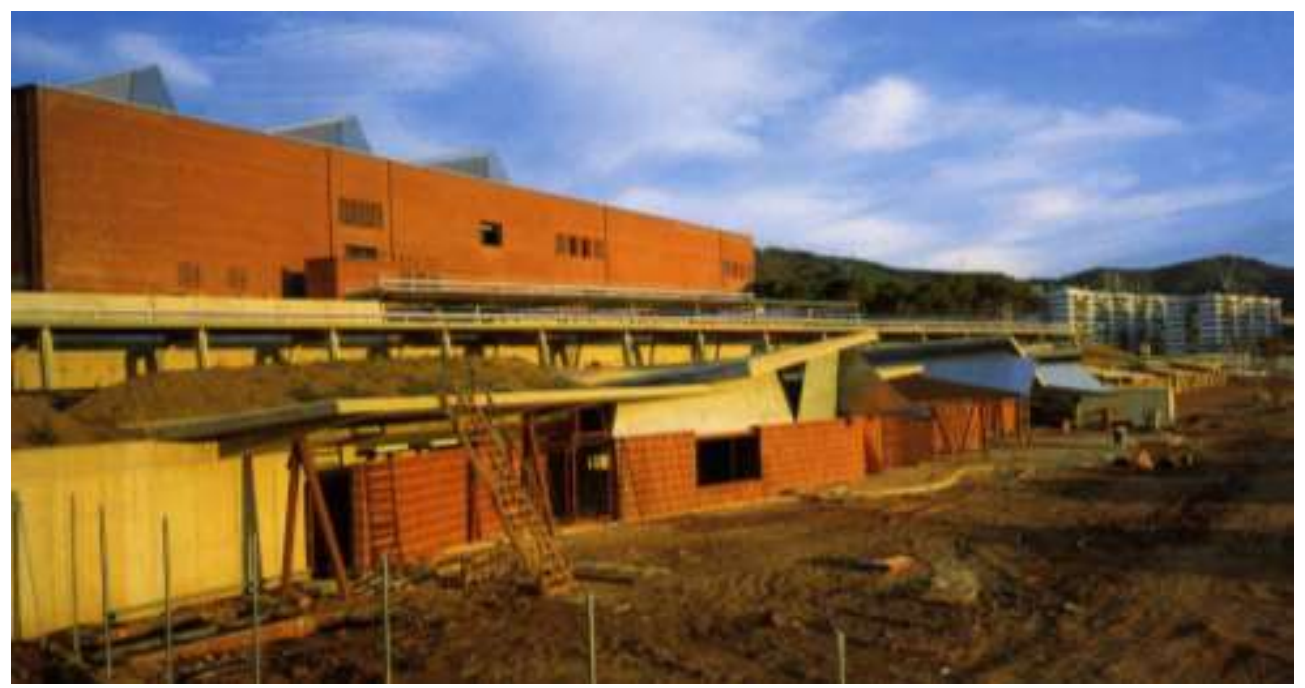

Ilustración 4-26 $6^{381}$

Ambos edificios se asemejan a un zócalo desparramado, un zócalo roto por el salto topográfico.

Cuando se percibe en escorzo el edificio de Entrenamiento se observa muy bien la diferencia entre ser zócalo ${ }^{382}$ y ser podio. ${ }^{383}$ Aunque la luz rasante del amanecer, el empleo del mismo material (ladrillo) y el ángulo desde el que se ha tomado la fotografía ayuden a unificar la intervención y a suponer que se trata de un mismo edificio apoyado sobre un zócalo, ambos edificios son diferentes y se encuentran más separados de lo que la fotografía muestra. El edificio que ocupa la parte superior de la imagen es el Pabellón de Pelota de los arquitectos Garcés y Soria, un podio, mientras que el inferior es el edificio de entrenamiento de Miralles y Pinós, un zócalo. Mientras que el Pabellón de Pelota se afirma con rotundidad; el de Tiro con Arco se funde con su entorno; allí donde uno se exhibe como objeto contra el fondo, el otro parece el resultado de un movimiento sísmico. Si el Pabellón de Pelota exige un podio, el de Tiro con Arco ofrece un zócalo. ${ }^{384}$

En este edificio, al igual que ocurrira en los pabellones de Huesca y Alicante, la fachada es tan solo el resultado de lo que ocurre entre el suelo y la cubierta, y eso se percibe en como al interior, los muros divisorios del programa funcional no llegan a tocar la cubierta

\footnotetext{
${ }^{381}$ Imagen en escorzo al amanecer del edificio de Entrenamiento de Miralles y Pinós, con el Pabellón de Pelota de Garcés y Soria en la parte superior. En esta imagen, ambos edificios parecen fundirse, y ser uno el zócalo del otro.

${ }^{382}$ Zócalo, del latín soccus (zueco) es una parte del edificio que se encarga de poner el edificio en relación con su entorno. No es un elemento clásico como lo es el podio, sino aquella marca etimológica en la que convive el origen rural del palacio con su nueva condición urbana.

${ }^{383}$ Podio tiene su origen en el griego, vinculado a la preeminencia y lo sagrado. Es un elemento clásico que se utiliza para que el edificio se desmarque con rotundidad de su entorno.

${ }^{384}$ Ramón Faura. Palacio de deportes Huesca y Club de tiro con arco. Enric Mlralles: 1972-2000, Editorial Fundación Caja de Arquitectos, Barcelona 2011, pág. 179
} 


\subsubsection{CUBIERTA}

La generación del lugar se consigue mediante la manipulación del suelo y la definición de una cubierta. Es una manera de hacer que no se centra en el cuerpo, sino en el suelo y la cubierta. El organismo construido es un zócalo y una cubierta con enormes voladizos, separados por una zona de incertidumbre. La operación de los arquitectos es clara al respecto, la generación del lugar se consigue mediante la manipulación del suelo y la definición de una cubierta.

La cubierta se configura doblando el mismo cerramiento en el caso del edificio de Competición y mediante unas losas facetadas dispuestas en abanico, de grandes voladizos como prolongación de la cota superior del desnivel en el edificio de Entrenamiento. Solo en el edificio de Entrenamiento, se da esa dialéctica cubierta - topografía, en el sentido de una topografía domesticada que alberga el programa funcional y una cubierta que flota por encima siendo la fachada el resultado de lo que queda entre medias. Aquí la tabiquería y las puertas no llegan al techo, y con ello se permite que la cubierta evolucione al margen de lo que ocurre en el suelo.

En ambos edificios, la cubierta relaciona la intervención con la escala del paisaje. En el edificio de Competición con ese elemento prefabricado de hormigón que es cerramiento vertical y cubierta a la vez; y en el de Entrenamiento con unas losas de hormigón dispuestas libremente en abanico.
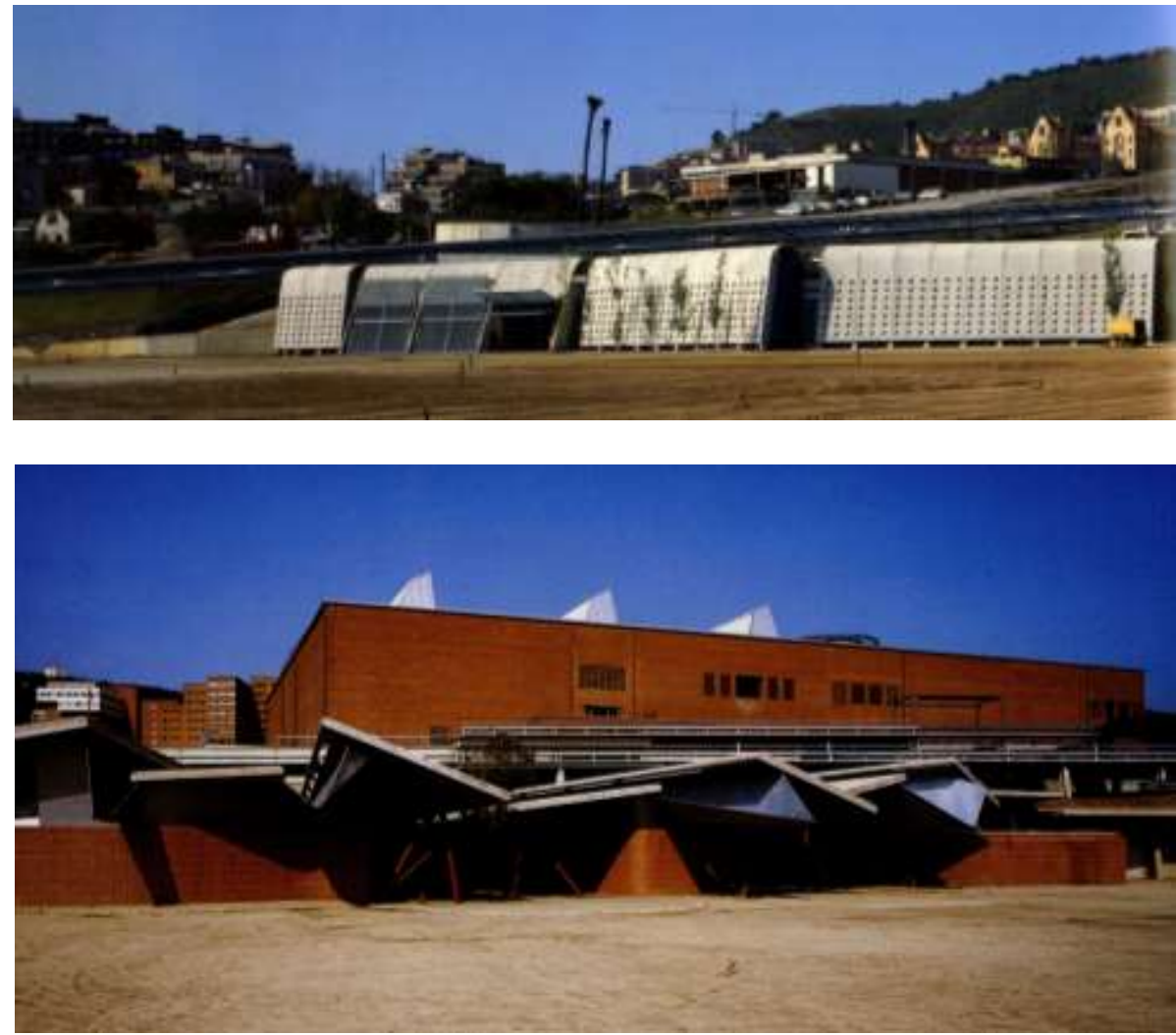

Ilustración 4-27

${ }^{385}$ Imágenes frontales en detalle de las "fachadas" de los edificios de Competición (imagen superior) y de Entrenamiento de Tiro con Arco. 
El enorme voladizo de la cubierta del edificio de Entrenamiento genera unas sombras que contribuyen a hacer desaparecer la fachada. Perceptivamente hablando, la fachada desaparece con las sombras arrojadas por la sobredimensionada cubierta y por lo próximo que suelo y cubierta se encuentran. Es la consecuencia de una manera de hacer que no se centra en el cuerpo, sino en el suelo y en la cubierta.

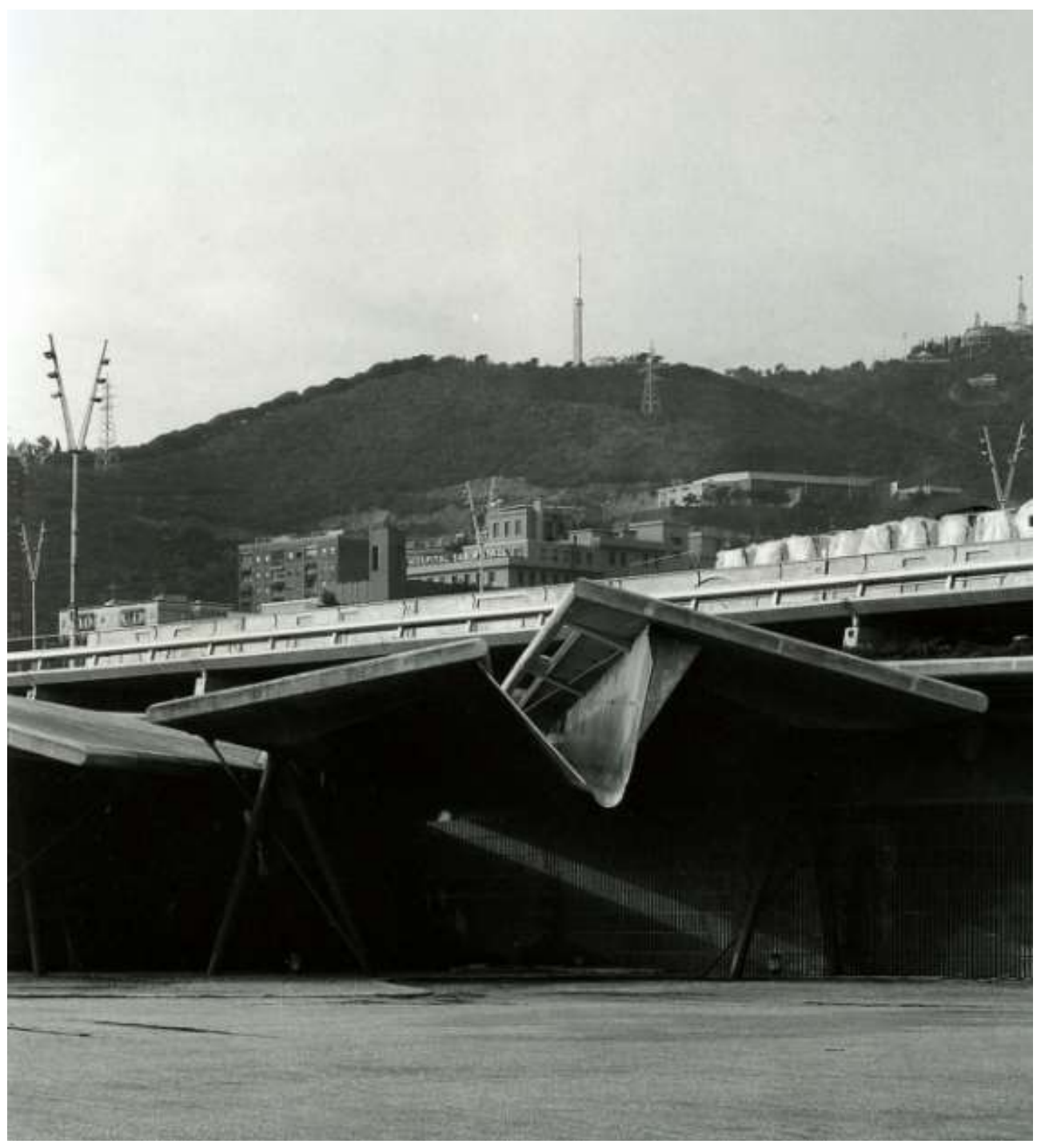

llustración 4-28 $8^{386}$

386 Imagen en detalle de un tramo de fachada del edificio de Entrenamiento. Se observa como las sombras arrojadas por las losas en voladizo que conforman la cubierta anulan la fachada. 


\subsubsection{RELACIONES INTERIOR - EXTERIOR}

En este proyecto, Miralles y Pinós buscan las relaciones entre interior y exterior a través de la estructura, haciendo que las cubiertas pasen a ser un espacio interior al no llegar a tocarlas ni tabiques, ni puertas. En el edificio de Entrenamiento, una cubierta conformada por una serie de losas de hormigón en voladizo dispuestas en abanico parecen flotar ingrávidas; mientras que un cerramiento exterior no portante de ladrillo en despiece vertical (para que se asemejen a cortinas y que hace alusión a los aparejos de ladrillo que utilizaba Coderch) que surge del suelo no llega a tocar la cubierta.

Las conexiones entre el espacio interior y el exterior son más fluidas en fase de obra, cuando todavía no se ha producido el cierre a que obliga el acondicionamiento climático entre el muro y la cubierta. ${ }^{387}$ En las fotografías tomadas durante la ejecución de este proyecto, se observa como todavía no se ha ejecutado la membrana que enlazara cubierta y cerramiento. Sin duda que esta membrana, cuya resolución se deja por los arquitectos para el final del proceso constructivo en obra, ${ }^{388}$ al construirse con un material opaco, se rompe con la fluidez visual entre el interior y el exterior que el edificio tenia mientras se construía. 389 Miralles llega a afirmar en una conferencia celebrada en la Universidad Internacional Menéndez Pelayo en 1993 que se debe a cierta tozudez de su pensamiento ${ }^{390}$ Los edificios de Tiro con Arco no se proyectan desde el interior, sino desde el exterior. No es que se renuncie a la espacialidad interna, sino que los arquitectos entienden que el organismo construido no es ya un objeto cerrado sobre sí mismo que pueda entenderse sino es dentro del campo exterior que lo incluye. La arquitectura no la conciben como un ente autónomo, y por tanto, ya no cabe mirar el mundo desde el interior. El interior no se piensa en términos de generar el proyecto, sino como el resultado de una estrategia constructiva. Se apuesta por un mecanismo de proyecto y se lleva al límite. Ramón Faura con gran agudeza detecta como la arquitectura de Miralles y Pinos en estos momentos es como una reacción en cadena para preservar la integridad de su obra: "...A partir de los noventa, los arquitectos, sin ningún operario dócil que les sonría a pie de obra, sin el prestigio social del arquitecto artesano, ya no pueden confiar en su autoridad para preservar la integridad de su obra de la volubilidad del mercado o de la ineptitud del gestor administrativo de turno. Solo la arquitectura pensada,...como reacción en cadena...es capaz de garantizar su integridad..." 391

\footnotetext{
387 Para mas información puede consultarse la Tesis de Javier Fernandez Contreras "La planta Mlralles: Representación y Pensamiento en la Arquitectura de Enric Miralles", leída en la ETSAM. UPM en el año 2013.

${ }^{388}$ Conviene destacar como el alzado que documenta el proyecto no es un plano que sirva para ejecutarse en obra con la información que contiene, puesto que nada esta dibujado en verdadera magnitud, siendo solo un dibujo representativo de lo que se quiere hacer, pero como los encuentros son tan complejos no se pueden dibujar y se deja para la fase de ejecución de obra su resolución.

389 Porque frente a materializar con vidrio dicha membrana, se hace con zinc en el exterior y con madera en el interior. A Miralles no le gustaba el vidrio, como otros habrían empleado para materializar esta membrana y no perder la continuidad visual entre interior - exterior; porque según Mlralles el vidrio generaba reflejos y ello traía consigo que se percibiese el volumen construido.

390 Enric Miralles. Conferencia dictada en la Universidad Internacional Menéndez y Pelayo de Santander. Julio 1993

${ }^{391}$ Ramón Faura. Enric Mlralles: 1972-2000, Editorial Fundación Caja de Arquitectos, Barcelona 2011 pag. 193
} 

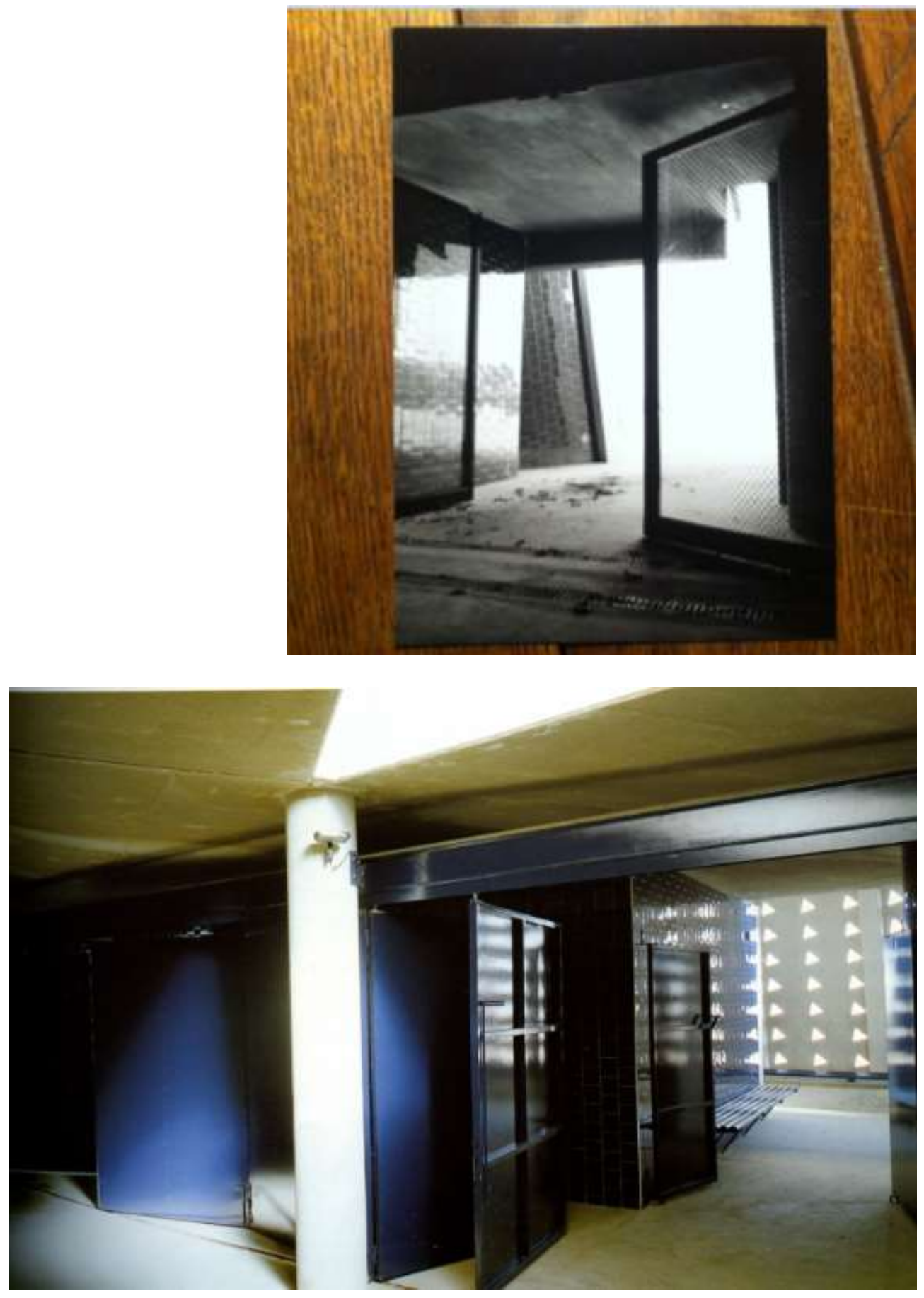

$4-29^{392}$

392 Interior del edificio de Competición antes de ser demolido, y fotografía tomada sobre la mesa Inestable en el estudio de EMBT en Pasaje de la Pau, Barcelona; en la que se muestran las relaciones interior - exterior del edificio. CFundació Enric Miralles. 

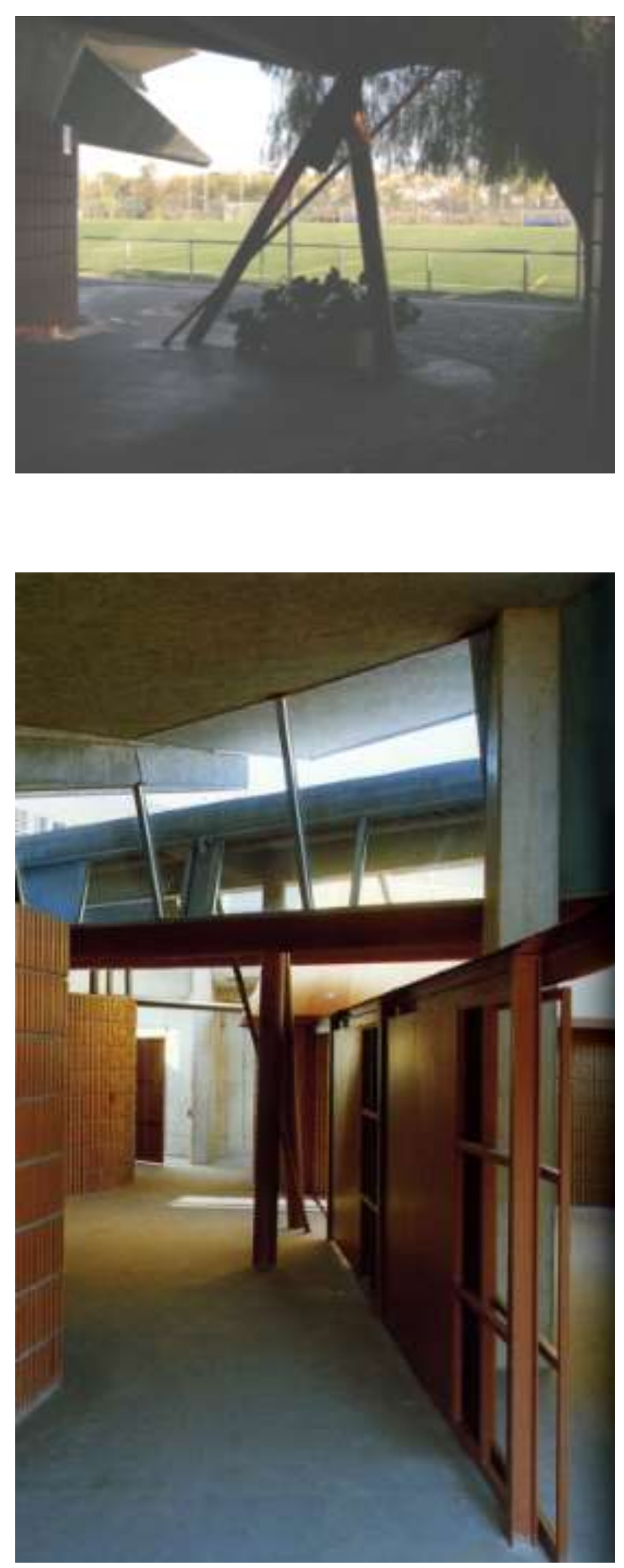

llustración 4-30 393

${ }^{393}$ Interior del edificio de Entrenamiento en la que se muestran las relaciones interior - exterior del edificio. Destaca el fluir de las cubiertas al no llegar los muros a tocarlas y lluminación cenital que se produce entre la separación de las distintas losas que conforman la cubierta. Fotografias tomadas por el autor de la Tesis. 
En los edificios de Tiro con Arco el cliente no podrá modificar aspectos concretos del interior del edificio, pues al haberse concebido la arquitectura en términos de totalidad; una vez formalizada estructuralmente no es posible desvincular la concreción del interior de la forma exterior. Es una manera de hacer de Miralles y Pinós que está pensada no como un diseño surgido de una yuxtaposición de decisiones, sino como una reacción en cadena generada por decisiones estratégicas que hacen que se garantice su integridad. ${ }^{394}$

No hay un contorno identificable que destaque lo construido del resto. En ambos edificios, tan solo se percibe el salto de nivel materializado por un muro de contención de tierras, de hormigón prefabricado en un caso y de ladrillo con despiece vertical en el otro. La cubierta del edificio de Competición al encontrarse facetada en múltiples tramos y quedar enrasada con el nivel superior tampoco genera un contorno claro y reconocible.

En el complejo de Tiro con Arco, las peculiares condiciones del encargo, en las que el contexto estaba en el aire, llevaron a los arquitectos a no trabajar las fachadas como tales, en el sentido de replicar un entorno, siendo conscientes de que este entorno próximo no aparecería hasta muy tarde, cuando el proyecto ya habría cobrado forma. El complejo de Tiro con Arco, se construye omitiendo el cuerpo, no quiere ser edificio sino un organismo donde pies y cabeza se confunden. En esta obra, los alzados exteriores son una consecuencia. Tan es así que en el caso del edificio de Entrenamiento, el alzado exterior que documenta el proyecto no es un plano técnico sino solo representativo, dado que no se ha dibujado en verdadera magnitud.

Lo que hace posible que los edificios no tengan una fachada convencional con ventanas que iluminen lo profundo del espacio interior, se debe a que dispone de iluminación cenital. En ambos edificios, se accede tangencialmente el acceso al espacio interior se realiza por los flancos de la fachada y se camufla, entre grietas o recovecos en sombra generados por los muros de cerramiento. No hay edificios, no hay puertas, tan solo muros y grietas.

Los arquitectos aprovechan el clima del lugar para generar intersticios, espacios que son interiores y exteriores a la vez sin control climático, como ocurre en la terraza del bar del edificio de Competición, un intersticio, en el que se puede disfrutar de un refrigerio sentado en la terraza al aire libre pero en sombra.

En ambos edificios se confunde la figura con el fondo, pues si en el edificio de Competición una vista lejana funde su figura con el entorno construido y la montaña que se divisa al final convirtiéndose en un zócalo de la composición; en el edificio de Entrenamiento, la figura que este determina es como el zócalo del edificio de Pabellón de pelota que se encuentra en el nivel superior. 

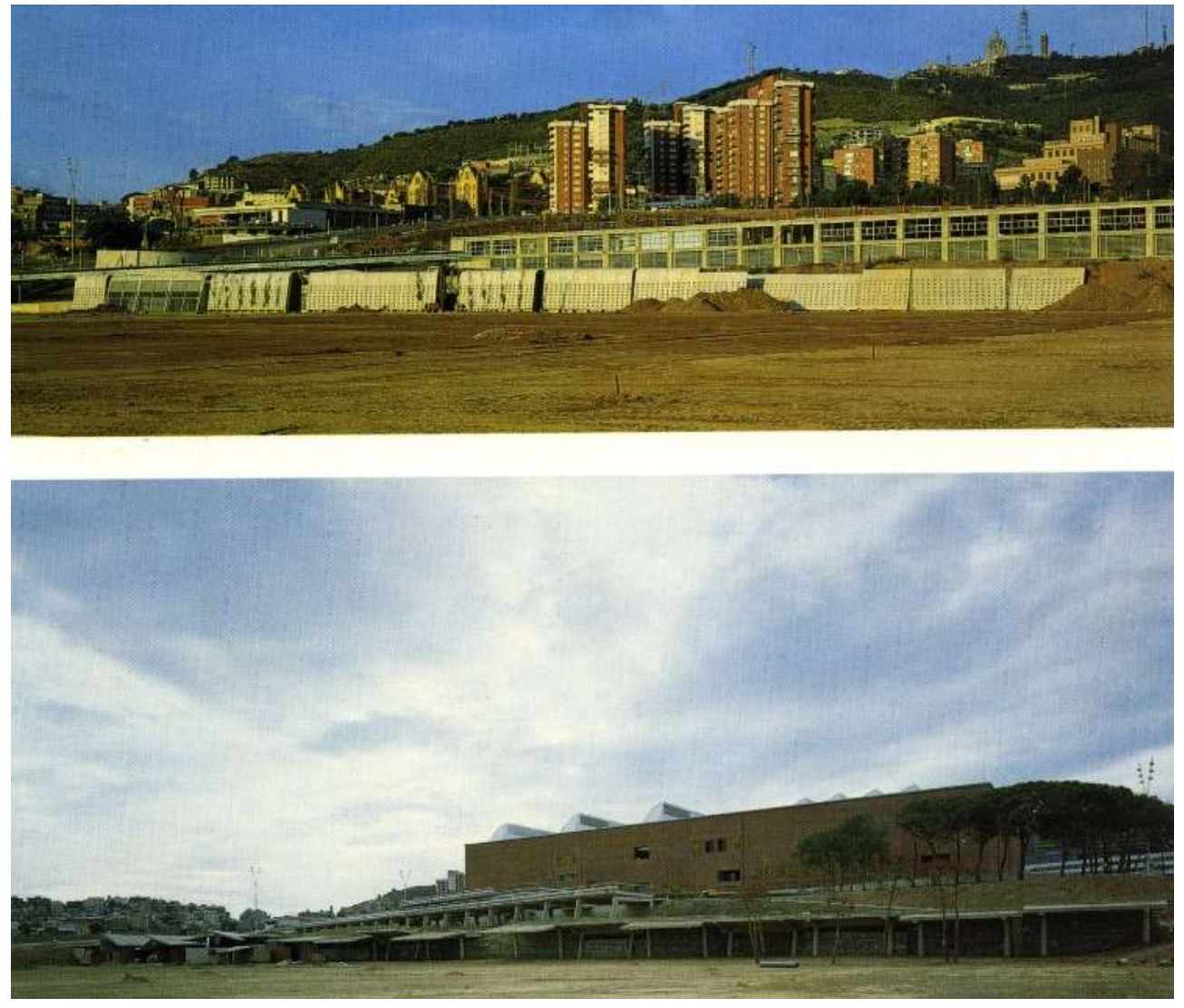

Ilustración 4-31

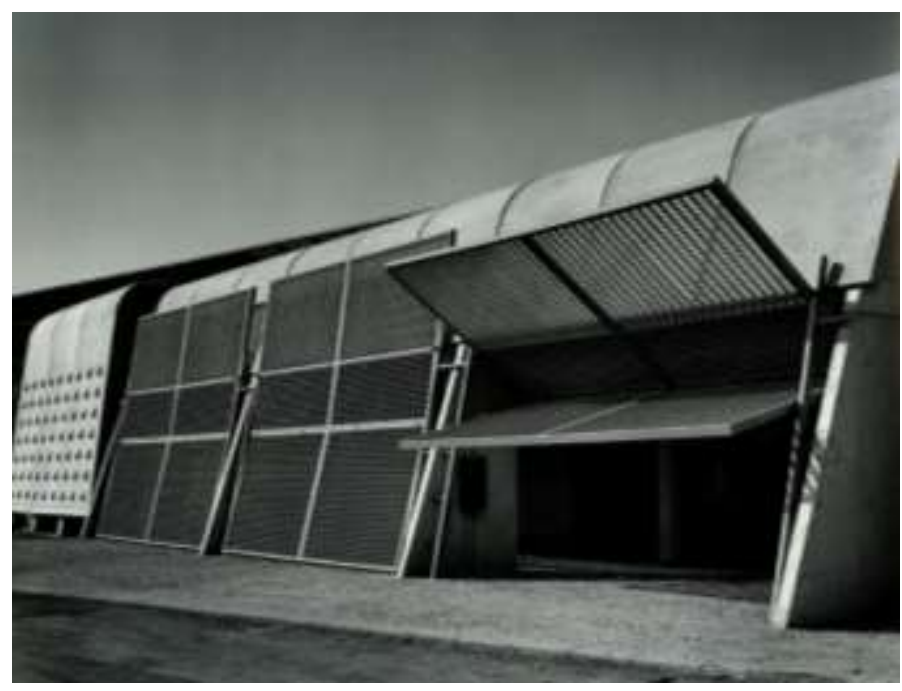

Ilustración 4-32

${ }^{395}$ Imágenes de los edificios de Competición (imagen superior) y de Entrenamiento de Tiro con Arco desde el nivel de los campos de competición.

396 Imagen del bar al aire libre en el edificio de Competición. El clima de Barcelona permite la existencia de estos espacios abiertos al aire libre sin climatizar. 


\subsubsection{RECORRIDOS}

El recorrido esta orquestado por los arquitectos para que se perciba el paisaje y la intervención desde distintos puntos de vista, teniendo como foco de atención el amplio paisaje conformado por las pistas de competición dispuestas enfrente de los edificios.

En el edificio de Competición, el recorrido en el nivel superior del desnivel aísla al espectador del entorno agresivo en el que se implanta el edificio, conduciendo al visitante desde la acera publica entre pequeñas colinas artificiales hasta llegar al lugar apropiado para contemplar la competición de tiro con arco.$^{397}$ La columna vertebral de este recorrido lo conforma una marquesina metálica dispuesta en dirección norte - sur, que además de enmarcar las vistas, genera sombras para aliviar del calor a los espectadores que presencien la competición. Dicha pérgola, además, dirige el público desde el acceso por el nivel superior en la parte trasera hasta el nivel de las pistas. El recorrido en el nivel inferior se realiza pegado a los muros de cerramiento del edificio dispuestos en zigzag. Dicho recorrido se tensa entre los extremos, donde se encuentran el bar y en el extremo opuesto, unos aseos públicos. El recorrido en el edificio de Entrenamiento, se orquesta en el nivel inferior del desnivel del terreno siguiendo la trayectoria del muro de contención acompañado de las sombras que genera el porche que acompaña dicho muro de contención. Este recorrido permite recorrer en sombra a los atletas el trayecto que tienen desde la zona de vestuarios hasta sus pistas de entrenamiento y también a los espectadores que quieran contemplar desde este nivel inferior de los entrenamientos. Ambos recorridos enmarcan el paisaje conformado por las plataformas de terreno al aire libre donde se ubican las pistas de juego.

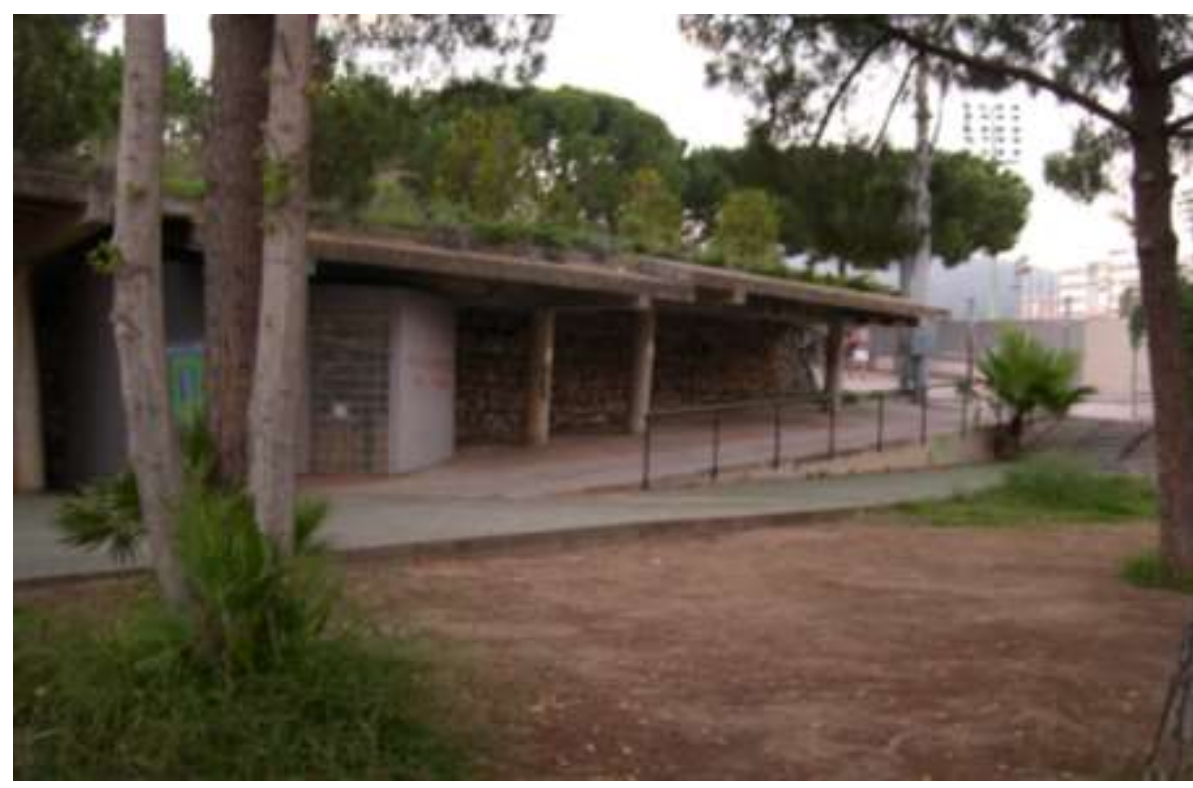

Ilustración 4-33 398

\footnotetext{
${ }^{397}$ El programa requería dar acomodo a 4000 espectadores para poder presenciar las competiciones de Tiro con Arco.

${ }^{398}$ Fotografia del autor de la Tesis en la que se observa como termina el recorrido en el edificio de entrenamiento por uno de los extremos.
} 


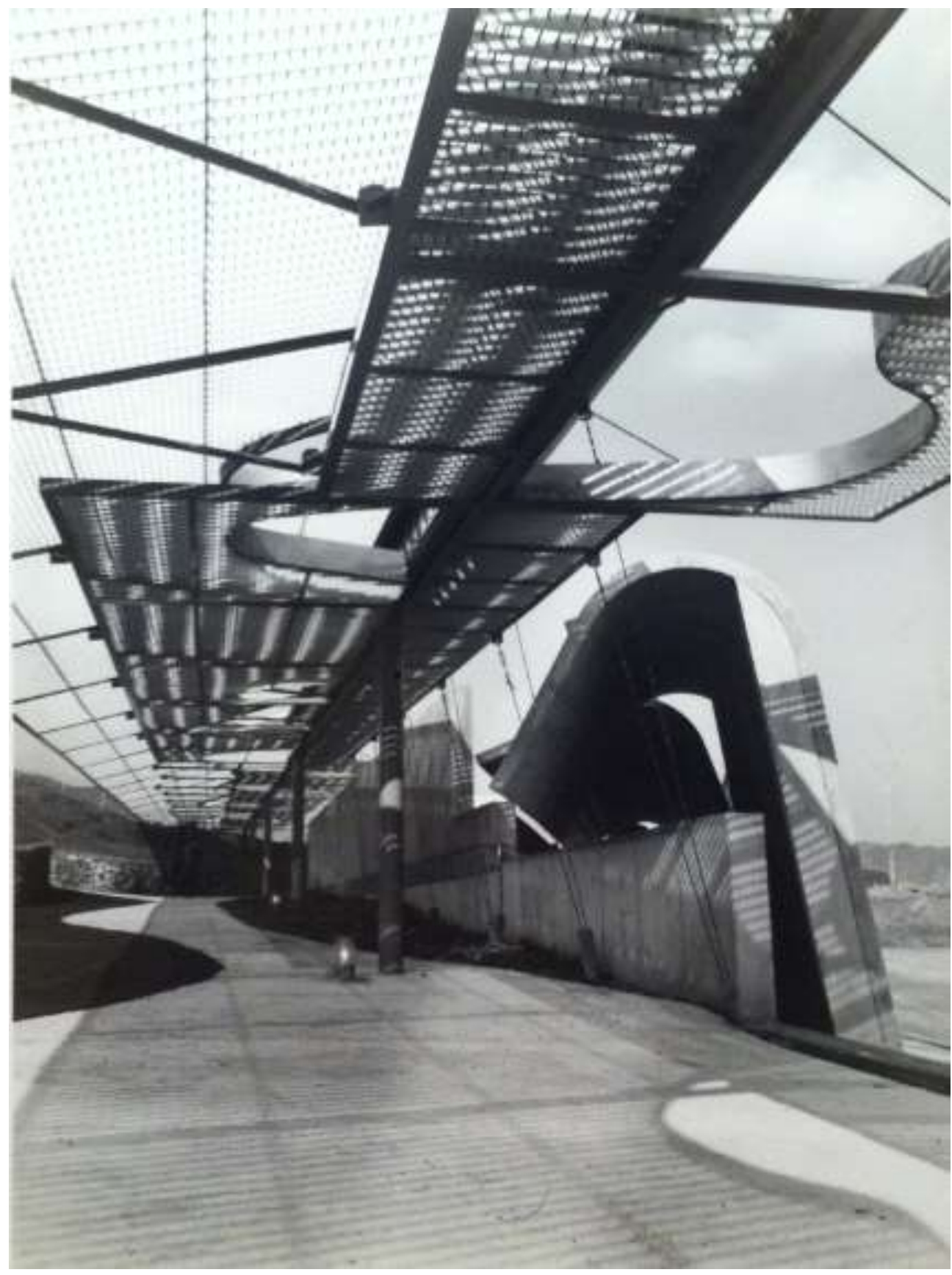

Ilustración 4-34

${ }^{399}$ Imagen en detalle de la marquesina que ordena las circulaciones y genera un umbral de sombra en el edificio de Competición. CFundació Enric Miralles. 

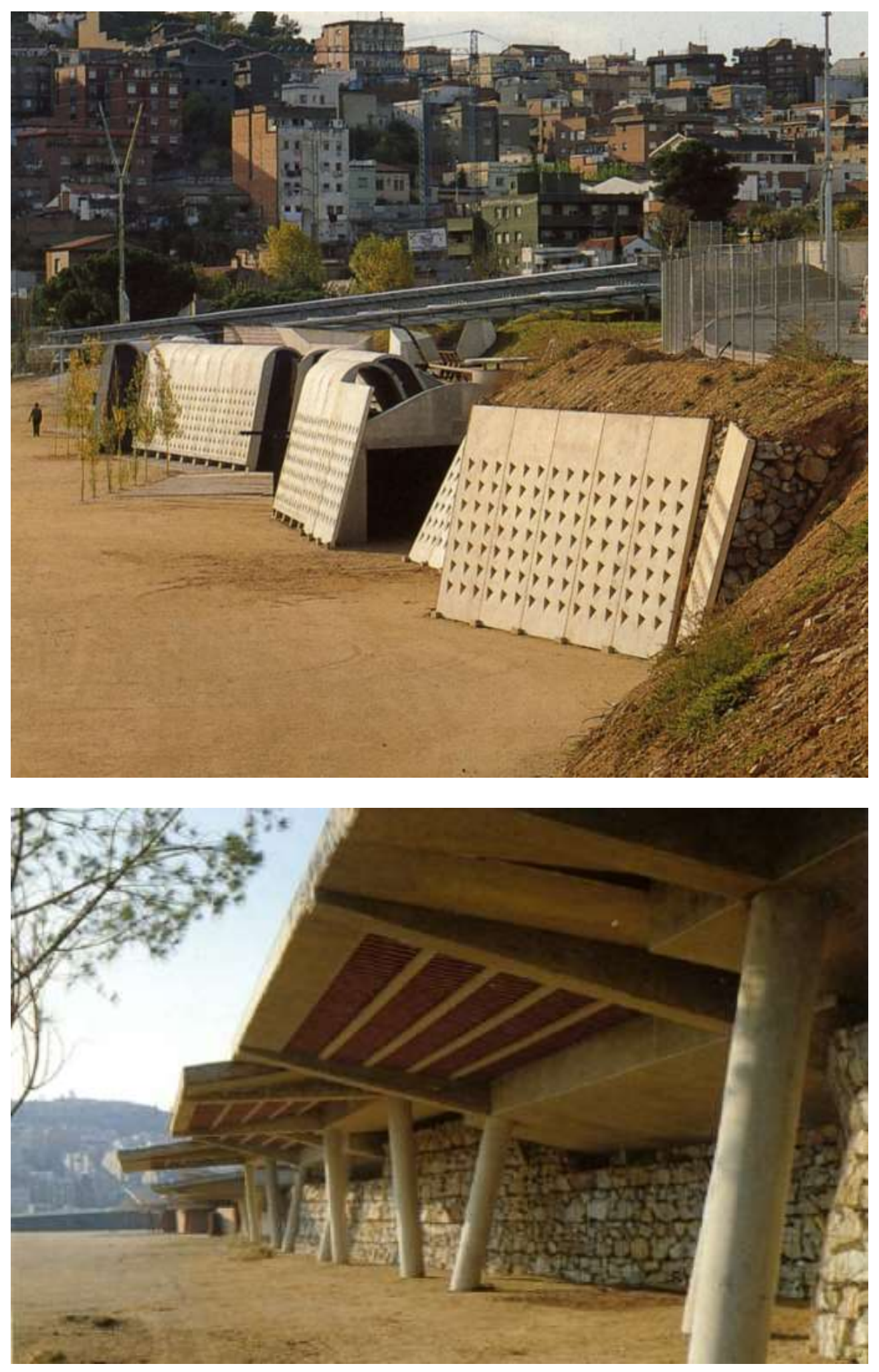

Ilustración 4-35 $5^{400}$

400 Imágenes en escorzo de las "fachadas" de los edificios de Competición (imagen superior) y de Entrenamiento de Tiro con Arco. 


\subsection{ACCIONES ABSTRACTAS}

En ambos edificios es difícil averiguar su escala, puesto que no se perciben elementos escalares (puertas, ventanas, barandillas, etc.) que permitan que el visitante se relacione con el tamaño de la obra. Las puertas se encuentran camufladas, se accede entre grietas en zonas sombreadas; las ventanas no tienen ni la forma ni el tamaño que suelen tener en un edificio convencional. En el edificio de Competición, unas perforaciones triangulares de pequeño tamaño parecen más bien una textura de acabado superficial de un elemento de construcción de alcantarillado que las ventanas que realmente son. El acceso a este edificio, escondido y en sombra, se realiza en uno de los quiebros entre dos módulos de cerramiento. En el edificio de Entrenamiento, al permanecer casi toda la fachada en sombra se impide percibir elementos escalares que ayuden a determinar su escala. Ademas se juega con distintas escalas en el mismo edificio distorsionar algunos elementos que exageran su escala habitual como es el caso del canalon en el edificio de Entrenamiento.

Es difícil asignar una forma concreta a ambos edificios. No se alcanza a entender donde comienza y donde termina el espacio habitable que encierran las piezas que los conforman. El edificio de Competición, es un amalgama de piezas repetidas de manera aparentemente desordenada con un desarrollo lineal que desde la distancia, parecen un muro de contención corrido que no alojasen espacio habitable en su interior. Del edificio de Entrenamiento, solo se percibe un porche corrido que ayudado por las sombras hace imposible determinar la forma de lo habitable.

En ambas obras, no hay un volumen nítido que permita entender donde empieza y dónde termina la intervención del arquitecto. En el edificio de Competición, la operación de retranquear el testero, genera una zona sombreada que junto al tono oscuro del material que lo cierra, hace que este se desvanezca y no ayude a configurar un volumen. En el edificio de Entrenamiento, tan solo se percibe un porche en sombra con una pequeña protuberancia conformada por un cuerpo de ladrillo próximo a su extremo Sur que tampoco hace emerger un volumen edificado propiamente dicho.

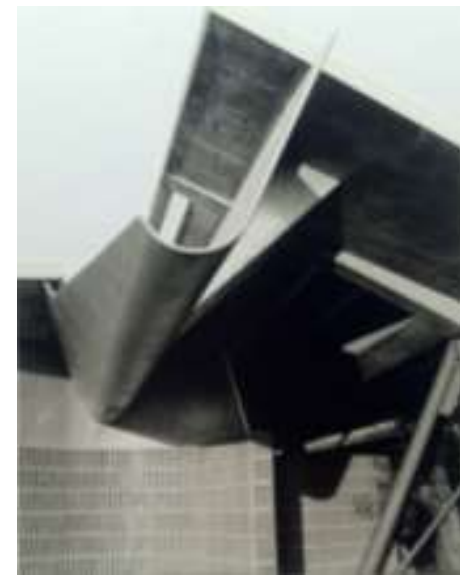

Ilustración 4-36 ${ }^{401}$

\footnotetext{
${ }^{401}$ Canalon distorsionado de escala en el edificio de Entrenamiento. @Fundació Enric Miralles.
} 


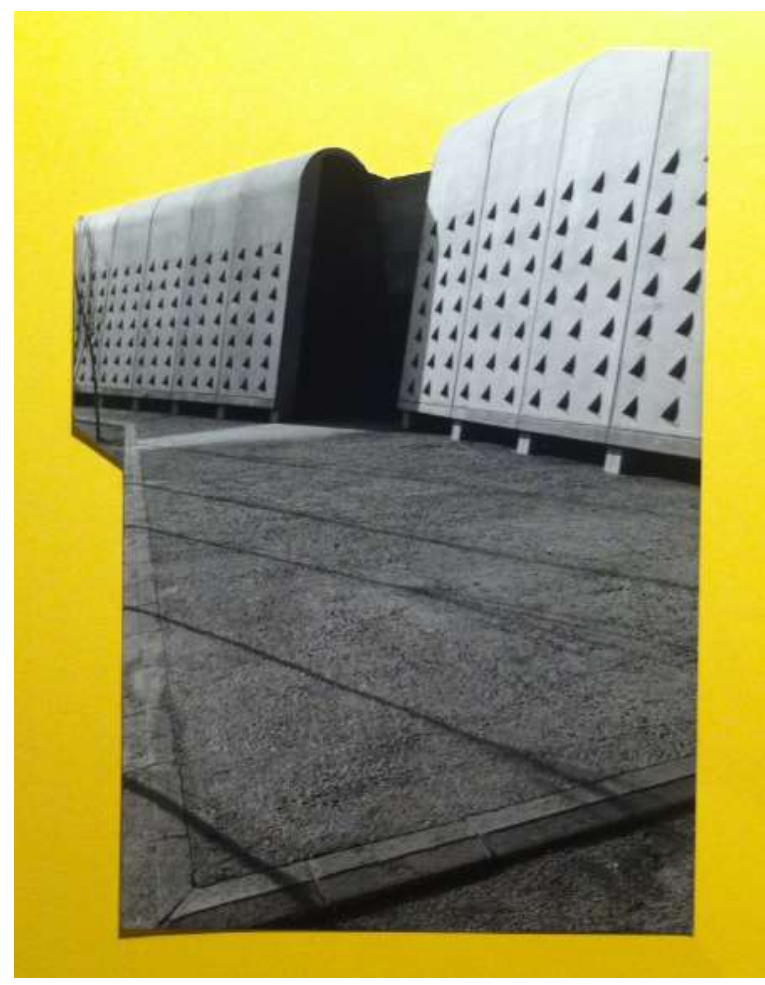

Ilustración 4-37402

El uso al que se destina la obra está oculto en esta construcción a la interpretación de cada uno, pero no solo se oculta el uso. La primera mirada solo detecta un salto en el terreno, contenido por unos muros de contención. El edificio de Competición parece una tubería de alcantarillado que todavía no estuviera conectada; y del edificio de Entrenamiento, tan solo se percibe un porche en sombra con un pequeño saliente de ladrillo que emerge próximo a su extremo Sur. Nada permite identificar desde fuera el uso al que se destinan ambos edificios, y con ello se adaptan mejor al paisaje, como si formaran parte de este. En este proyecto se puede comprobar cómo la acción del tiempo ayuda a fusionar la arquitectura con el paisaje. Antes que se demoliese el edificio de Competición, y quizás por su estado de abandono, la marquesina metálica que daba sombra a la zona del nivel superior, fue invadida por la vegetación hasta casi hacerla desaparecer y confundirla con el paisaje. Las formas de ambos edificios evocan formas naturales, como si se tratase de animales marinos. En edificio de Competición, al observar su plano de Planta, recuerda la forma de una gamba, con su cabeza, cuerpo y cola. La cabeza estaría conformada por el área que ocupa el bar; el cuerpo por la repetición del modulo de ducha-vestuario y la cola por la batería de aseos públicos. El edificio de Entrenamiento, al percibirse desde una fotografía aérea, recuerda a una manta - raya moviéndose en el fondo marino, cuyo movimiento hubiera quedado congelado. Esta especie marina, acostumbra a moverse cerca del fondo del mar generando un umbral de sombra similar al que deja el edificio cuando comienza a atardecer.

\footnotetext{
402 Imagen en detalle del testero de uno de los módulos del edificio de Competición en el que al retranquearse y recibir sombra casi desaparece. Fotografía tomada en el Archivo Enric Miralles de Barcelona. Miralles acostumbraba a recortar las fotografías que tomaba en obra para generar ideas para proyectos futuros. (F)undació Enric Miralles.
} 

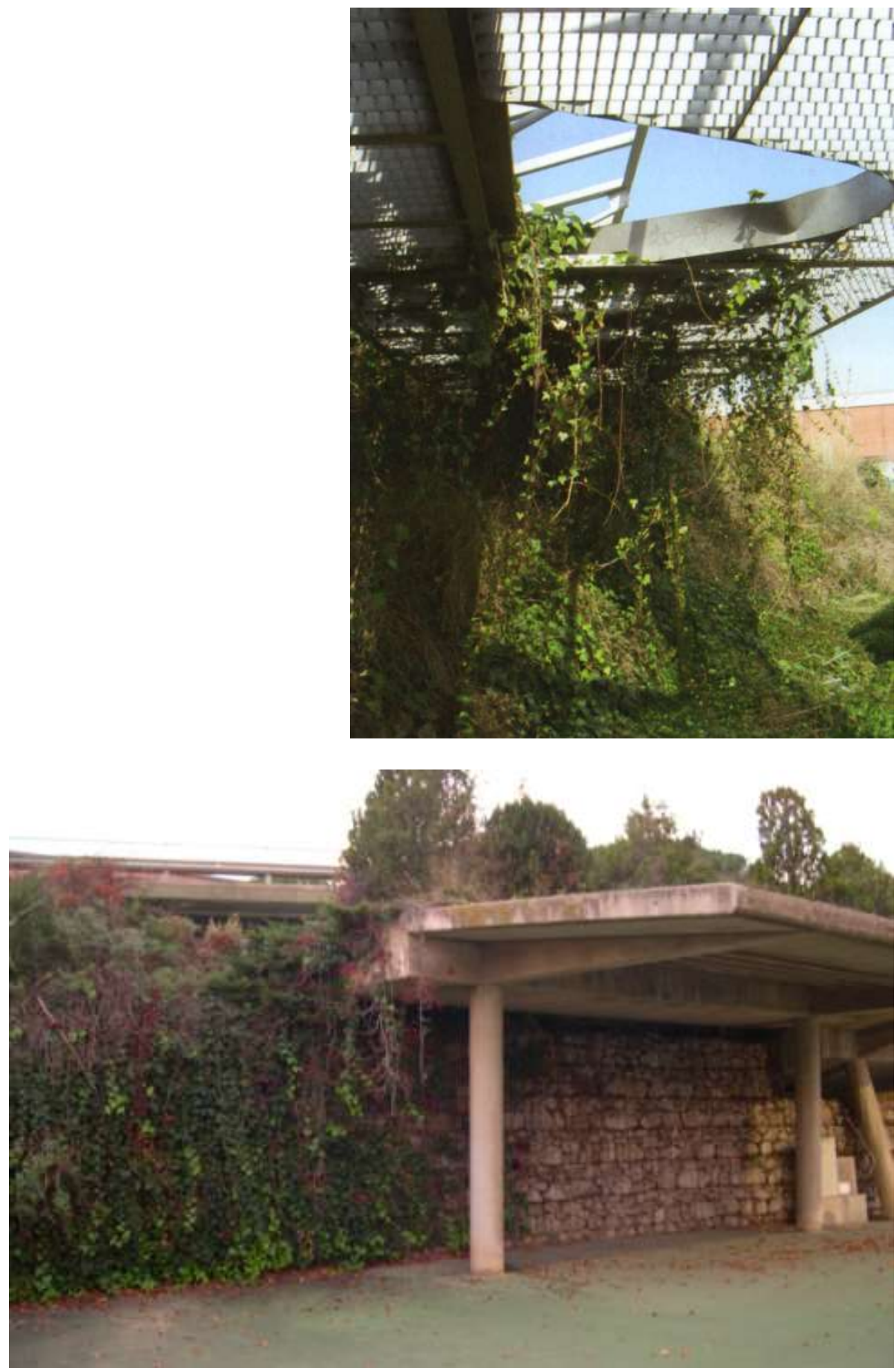

Ilustración 4-38 ${ }^{403}$

${ }^{403}$ Imágenes que constatan el crecimiento de la vegetación con el paso del tiempo y ayudan a fundir la arquitectura con el paisaje natural. 


\title{
5. EL PABELLON DE DEPORTES EN HUESCA (1988-1994).
}

\subsection{DESCRIPCION}

\begin{abstract}
“...El edificio propone una serie de correspondencias casi simétricas: una primera simetría (interior-exterior) divide una zona de juego más interior, ordenada entorno a las gradas de un anfiteatro, de una zona más exterior definida por una zanja y por perfiles artificiales de tierra dispuestos alrededor; una segunda simetría (derecha-izquierda)contrapone una hendidura en la tierra...que aproxima el edificio a la ciudad y por el otro, un paisaje llano casi agrícola. La tercera simetría está constituida por el conjunto de las dos primeras y el bosque de la colina de San Jorge, que se eleva...detrás del edificio. La cuarta simetría está constituida por el conjunto de las tres primeras y por la ciudad. Al mismo tiempo, cada una de las construcciones que forman estas parejas se entrecruza, instituyendo una relación independiente no solo con el elemento correspondiente, sino también con el lugar, con el aspecto que ofrecía antes de la edificación. Se podrían formar listas de elementos independientes entre sí: arboles, senderos, muros, pórticos, topografía, bosque...El proyecto pretende unir todos los elementos de los diversos niveles de la construcción punto por punto, como si se tratase de un tejido, partiendo del techo...para llegar hasta la base del anfiteatro."

Enric Mlralles. ${ }^{404}$
\end{abstract}

El Pabellón de Deportes de Huesca es un edificio situado entre el límite de la ciudad y un paraje natural, el Cerro de San Jorge. La amplia parcela que une la ciudad y el bosque ha sido tratada para acercar la ciudad a este. El trabajo topográfico modela el terreno existente y prepara el tránsito desde los límites de la ciudad con el edificio y el bosque de pinos del Cerro de San Jorge, cobrando gran importancia los paseos de borde que llegan a los porches laterales de acceso al edificio. La intervención de Miralles y Pinos, genera un "puente" entre la ciudad y el bosque que antes no existía. El edificio se hunde en el terreno para que su volumen construido no afecte al paraje natural. Basamento y cubierta se separan lo justo para que el público pueda acceder al edificio. Se cubre el Pabellón con una cubierta suspendida, del menor espesor posible gracias a su estructura tensada, para no superar la cota de coronación de los arboles cercanos del Cerro de San Jorge.

\footnotetext{
404 "Enric Miralles. Obra completa" Juan José Lahuerta. Electa. 1996, pag. 106.
} 
Pabellón de Deportes de Huesca. (1989 - 1994).

Dirección: San Jorge, s/n. Igualada. Barcelona.

Encargo: Concurso 1ำ premio, 1989. Ayto. de Huesca.

Arquitectos: Enric Mlralles y Carmen Pinós.

Dirección de Obra: Enric Miralles, Agustí Obiol y Luis Moya (1991 - 1994).

Colaboradores: Pedro Lafuente, Eva Prats, Rocio Peña, Josep Miás, Albert Ferré, Francesc Pla, José Bundgaard, Hugo Wilson, Fmorella José Carrasco, Joan Callis, Josep Bohigas, Rodrigo Prats, Soraya Smithson. Agusti Obiol, Luis Moya, Robert Bufrau y Josep Ustrell en Estructuras (BOMA).

Contratista: Auxini, S.A. ( 18 meses de ejecución ).

Superficie: $40.700 \mathrm{~m} 2$

Presupuesto: 10.220 .000 euros

Capacidad: 5.000 espectadores.

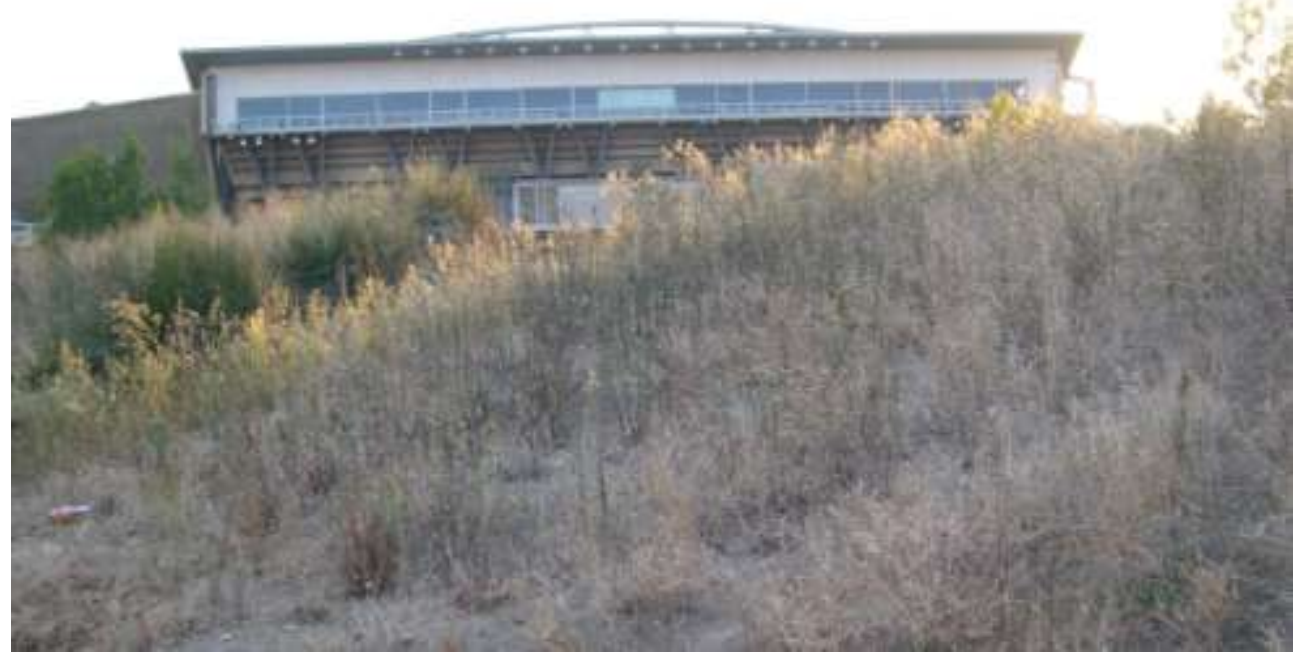

Ilustración 5-1 ${ }^{405}$

${ }^{405}$ Pabellon de Deportes de Huesca. Fotografia tomada por el autor de la tesis. 


\subsubsection{CONTEXTO}

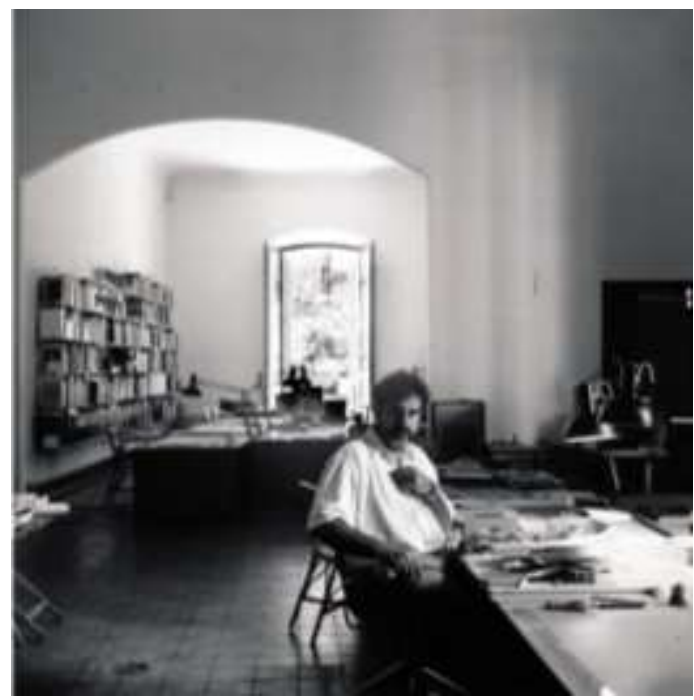

$5-2^{406}$

"Al nuevo estudio llegamos con el proyecto de Huesca y el concurso recién ganado de la sede del Círculo de Lectores en Madrid. Era un lugar magnífico, un antiguo palacio del casco antiguo con patio de entrada privado, y una enorme terraza donde jugábamos a básquet al fondo del solar. Ahí empezó otra etapa. Enric viajaba mucho, aceptó clases en Estados Unidos, en Harvard, y en Alemania. Ya nuestra colaboración requería de más aportación, desarrollábamos constructivamente sus proyectos. Ampliábamos los dibujos y guiados por él íbamos dándoles grueso constructivo. También en esa época empezaron las obras de Huesca y Alicante. Recuerdo que al cabo de unos meses de estar ahí pasé una época en ese estudio en la que estaba totalmente sola, los otros colaboradores en las obras y yo en el estudio, dibujando y contestando teléfono, que en ese momento empezaba a ser muy solicitado."

Eva Prats ${ }^{407}$

Miralles y Pinós acometen el proyecto del Pabellón de Huesca (1989-1994), proyecto que desarrollara Miralles en solitario tras la separación matrimonial y profesional de Carmen Pinos. La pareja ya ha demostrado lo bien que se manejan con su arquitectura en el paisaje natural ${ }^{408}$. Miralles en esos momentos ya es Doctor arquitecto, y profesor titular desde 1985 en la ETSAB y este curso 19881989 también es profesor visitante en la Universidad de Columbia en Nueva York.

\footnotetext{
${ }^{406}$ Enric Mlralles en su estudio del Carrer de Avinyó,donde ya separado de Carmen Pinós, desarrollo el Proyecto de Ejecución y construcción del Pabellón de Deportes de Huesca.

407 "Las tardes de dibujo en el estudio Miralles \& Pinós".

${ }^{408}$ Véase el éxito del Cementerio de Igualada que les catapulta al reconocimiento internacional.
} 
En el momento de presentarse al Concurso solo ha terminado las Pérgolas de Parets del Vallés, y El Instituto La LLauna en Badalona y tienen en marcha los siguientes proyectos: el Parque Cementerio de Igualada comenzado en 1985; el Centro Cívico de Hostalets de Balenyá ${ }^{409}$ y la Escuela Hogar en Morella, ambos comenzados en 1986. Miralles todavía no sabe que Josep Antonio Acebillo le encargara ese mismo año el complejo de Tiro con Arco en el Valle de Hebrón o que los responsables del CNAR de Alicante, harán lo mismo en un par de años.

A partir de 1990, al conseguir grandes encargos, como el Pabellón de Deportes de Huesca, Miralles se verá obligado a aumentar su equipo hasta 15 personas, lo que conllevara un cambio en las estrategias proyectuales del estudio. La separación por motivos personales del matrimonio, conllevara también la separación profesional de esta pareja de arquitectos que desde 1985 hasta 1990 habían logrado tantos éxitos profesionales. Finalmente Miralles terminara estableciendo su estudio en la calle Avinyó. ${ }^{410}$

En 1990 Miralles y Pinos se separan tras una trayectoria meteórica de éxitos cosechados desde que comenzaron a colaborar en 1984. De los proyectos que tenía el Estudio Miralles y Pinos en el momento de la separación, Carmen Pinos se quedo con la terminación de: el Centro Social en Hostalets de Balenya terminado en 1992; el Centro Social La MIna en Barcelona, terminado en 1993 y la Escuela Hogar en Morella terminada en 1994.

Enric Miralles asumió la terminación del Parque Cementerio de Igualada (1991); el Complejo de Tiro con Arco y las Pérgolas de la Avenida Icaria en Barcelona; la Casa Garau Agusti en Barcelona (1993); y el Pabellón de Deportes de Huesca terminado en 1994. Además Miralles recibió el encargo del Pabellón de Alicante en Destacar que el periodo comprendido entre que se proyecta y se construye el Pabellón de Huesca (1989-1994), fue muy intenso para Miralles, pues su reconocimiento internacional hizo que las Universidades se disputaran su presencia en las aulas. A sus labores docentes como Profesor Titular en la ETSAB se unieron los compromisos docentes desde 1990 como Director de la Máster Class en la Staedelschule de Frankfurt y desde 1992 Profesor en la Universidad de Harvard con la Kenzo Tange Chair. En el curso 1993-94 fue además profesor en la Universidad de Princeton con la Jean Labatut Chair.

Además fue un asiduo participante en Concursos de Arquitectura por todo el Mundo con proyectos destacados entre los que destacan los siguientes: el Concurso por invitación para la Bürgerhaus de Niederrad de 1991, el Concurso para la ampliación del Museo de Arte Contemporáneo de Copenhague en 1992; el Concurso para el Concert Hall on the Waterfront en Copenhage y para el Museo de Arte Contemporáneo de Zaragoza en 1993. En este periodo (1990-1994) construyo además: la Sede del Círculo de Lectores en 1992, la intervención en la Estación de Takaoka y el Pabellón de meditación de Unazuki, ambos en Japón de 1993. A pesar de sus compromisos profesionales y docentes, todavía le quedo tiempo para realizar un viaje a la India para visitar las obras de Le Corbusier y

\footnotetext{
409 El proyecto del Centro Cívico de Hostalets de Balenyá tiene relación con el Pabellón de Huesca, por la dialéctica que se establece entre suelo excavado y cubiertas.)

${ }^{410}$ Miralles, tras la ruptura matrimonial con su socia profesional Carmen Pinos, se quedo sin Estudio y tuvo que pedirle a su amigo Robert Bufrau que les dejase trabajar allí con su equipo, en la única estancia disponible del despacho de Bufrau, en la cocina. Allí desarrollo durante meses los proyectos de ejecución a los que debía dar salida, tras el reparto de proyectos entre Miralles y Carmen Pinos. Finalmente Miralles terminara estableciendo su estudio en la calle Avinyó,
} 
Louis I. Khan en febrero de 1992. Los años noventa se inician bajo los ecos de la Exposición sobre arquitectura deconstructivista celebrada en el MOMA de Nueva York ${ }^{411}$ con sus formas herederas de las vanguardias rusas y la vuelta a cierto expresionismo. El proyecto del Museo Guggenheim de Bilbao de Frank Ghery en 1992 y el Pabellón de Deportes de Huesca de Miralles (1990-1994) fueron en esos años, hitos de este tipo de arquitectura.
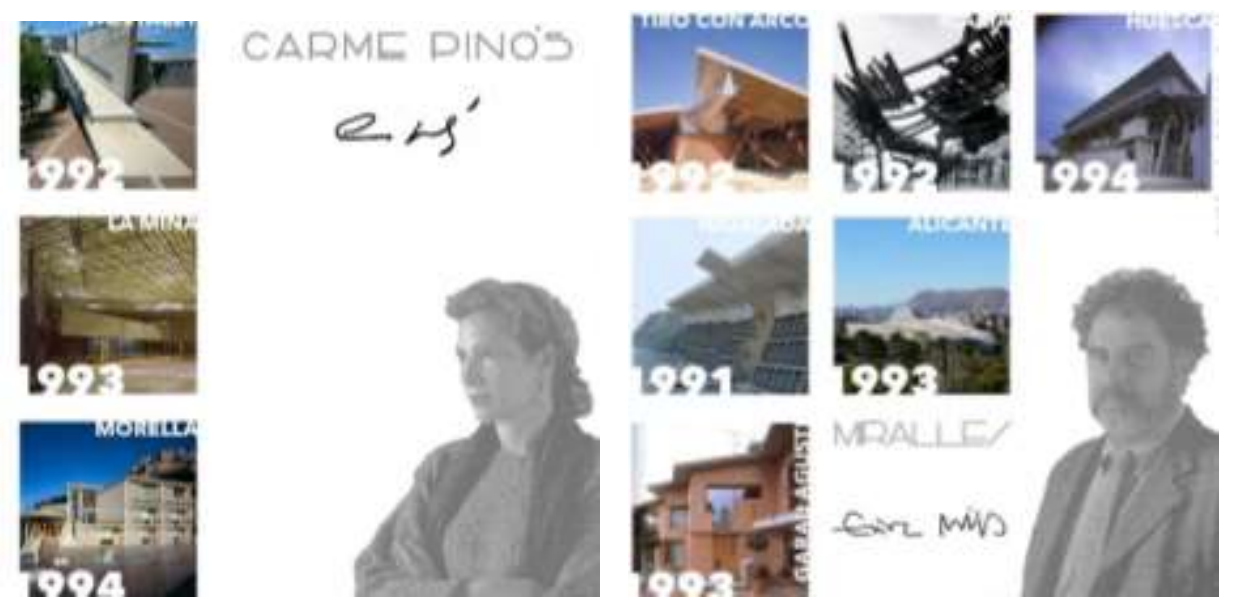

$5-3^{412}$

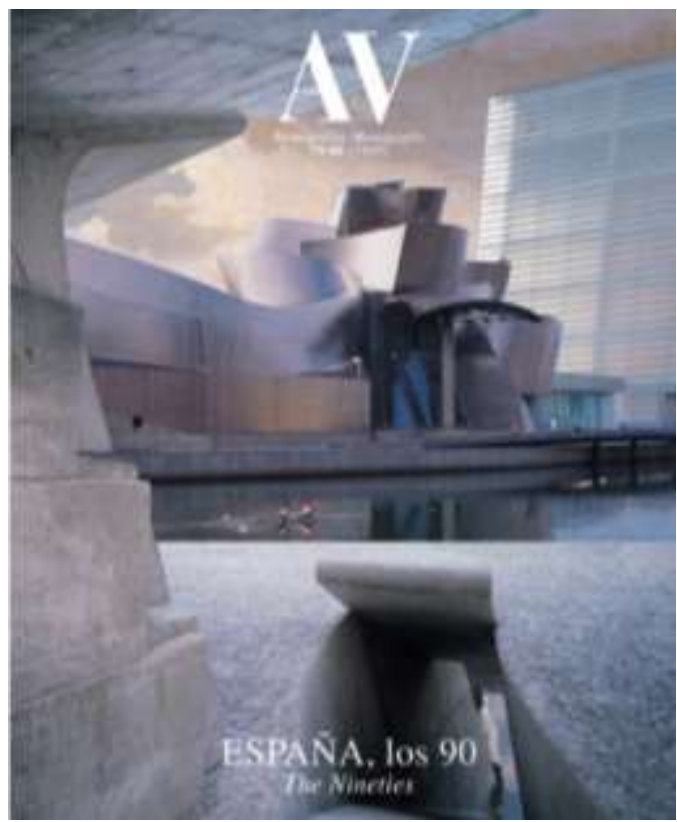

$5-4^{413}$

\section{INFLUENCIAS}

\section{RELACION CON EL LAND ART}

\footnotetext{
${ }^{411}$ Exposición sobre Arquitectura deconstructivista celebrada en el MOMA de Nueva York

${ }^{412}$ Reparto de proyectos entre Miralles Pinos y sus fechas de terminación de la construcción.

413 Portada de la revista AV Monografias editada en 1999 en la que se compara la obra de Miralles con otros edificios con repercusión internacional construidos en los años 1990s.
} 
En esta obra, Miralles al igual que los Land Artists consigue con un reducido catalogo de materiales generar una experiencia espacial rica de una intensidad notable. Respecto a la relación con la naturaleza, el posicionamiento no es de protección sino de transformación de ésta. En concreto esta obra recuerda la manera de trabajar de Michael Heizer en su obra de Land Art titulada Complex I, en el desierto de Nevada. (1972-1974)
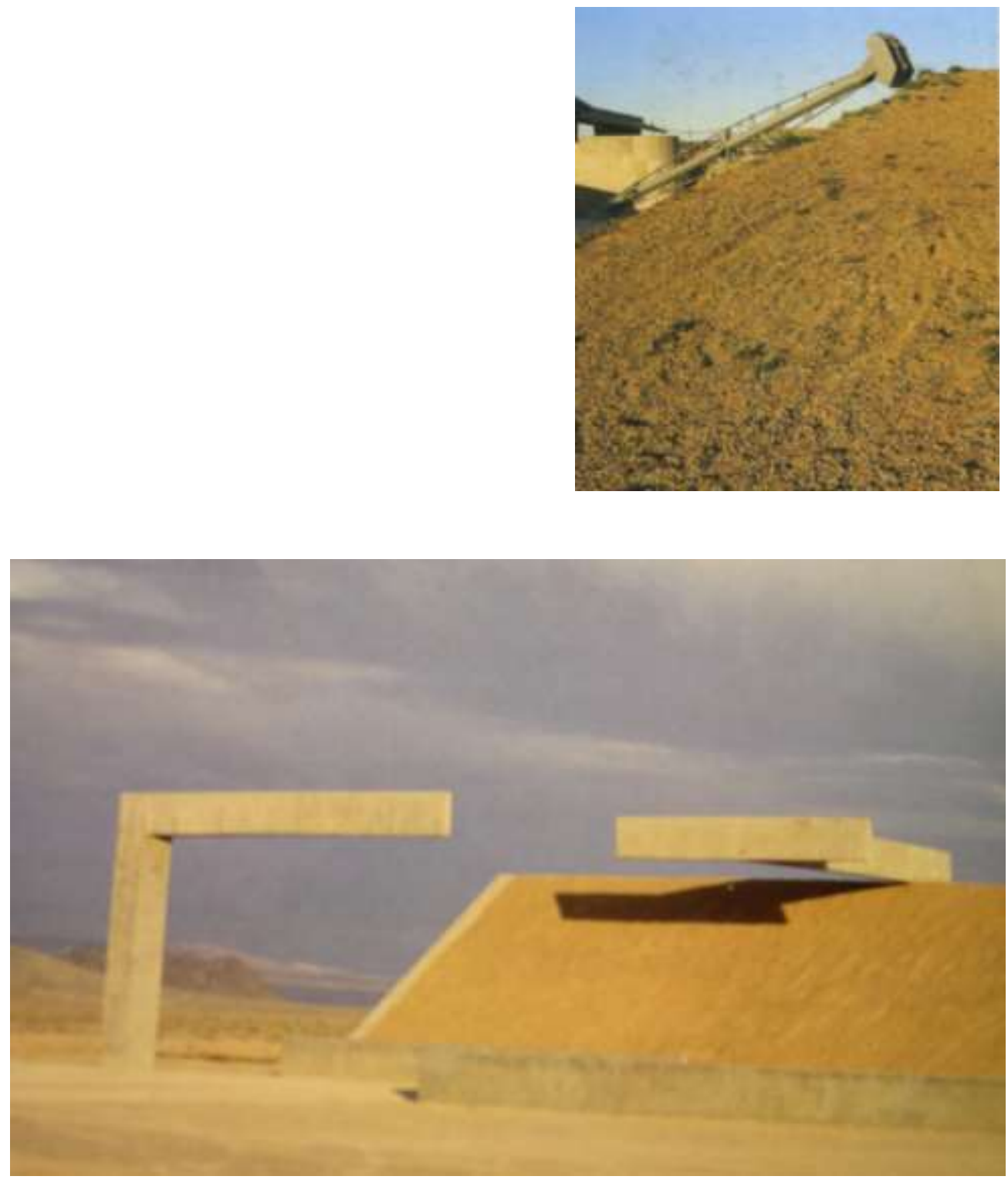

Ilustración 5-5

${ }^{414}$ Enric Miralles. Pabellón de Huesca (1988 - 1994) versus Michael Heizer. Complex I, Nevada, (19721974) 


\section{RELACION CON OTRAS ARQUITECTURAS}

Para proyectar el Pabellón de Huesca, Miralles y Pinós se inspiran entre otros en el proyecto de Alvar Aalto del Centro deportivo y musical en Viena de 1953 que podía albergar 25.000 espectadores y tenía una cubierta tensada con cables. Otra referencia la constituye el proyecto de Le Corbusier de un centro de Rejouissances populaires de 100.000 participants de 1936 en el que la cubierta tensada se ancla a un mástil. También de Le Corbusier es el estadio construido de la Maison des Jeunes et de la Culture en Firminy $(1960-1965){ }^{415}$

Le Corbusier excava en el terreno para emplazar la pista del estadio y al hacerlo, coloca las gradas de manera natural sobre los planos en pendiente generados. Es el movimiento de tierras el que genera el lugar, un lugar de recogimiento. EMCP hacen la misma operación en Huesca. Pero en Huesca, no solo se excava el terreno para emplazar su pista exterior, como hace Le Corbusier sino que continua la excavación para emplazar también la pista interior cubierta, rodeada de graderíos que partiendo del nivel de rasante, descienden para buscar la cota de la pista de juego de baloncesto.
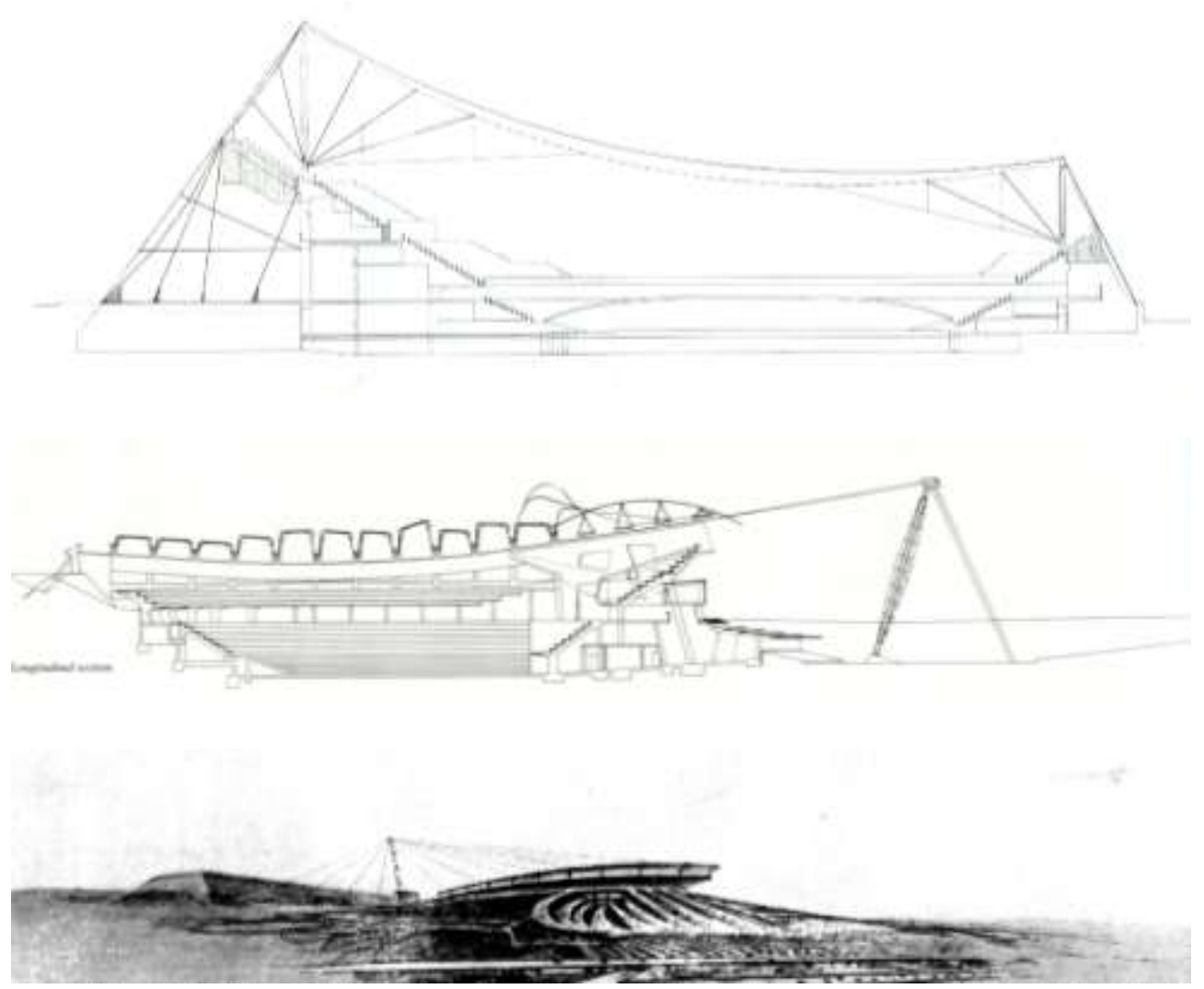

llustración 5-6 $6^{416}$

\footnotetext{
${ }^{415}$ La cubierta estaba conformada por 132 cables que salvaban una luz estructural de 18,25 metros soportando encima unas placas Celium, que configuraban un edificio lineal de 112 metros de largo con dos testeros trapezoidales que escenificaban la curvatura tensada de los cables.

${ }^{416}$ Enric Miralles. Pabellón de Huesca (1988 - 1994) versus Alvar Aalto, Centro deportivo y musical en Viena de (1953) y Le Corbusier, Centro de Rejouissances populaires de 100.000 participants (1936)
} 

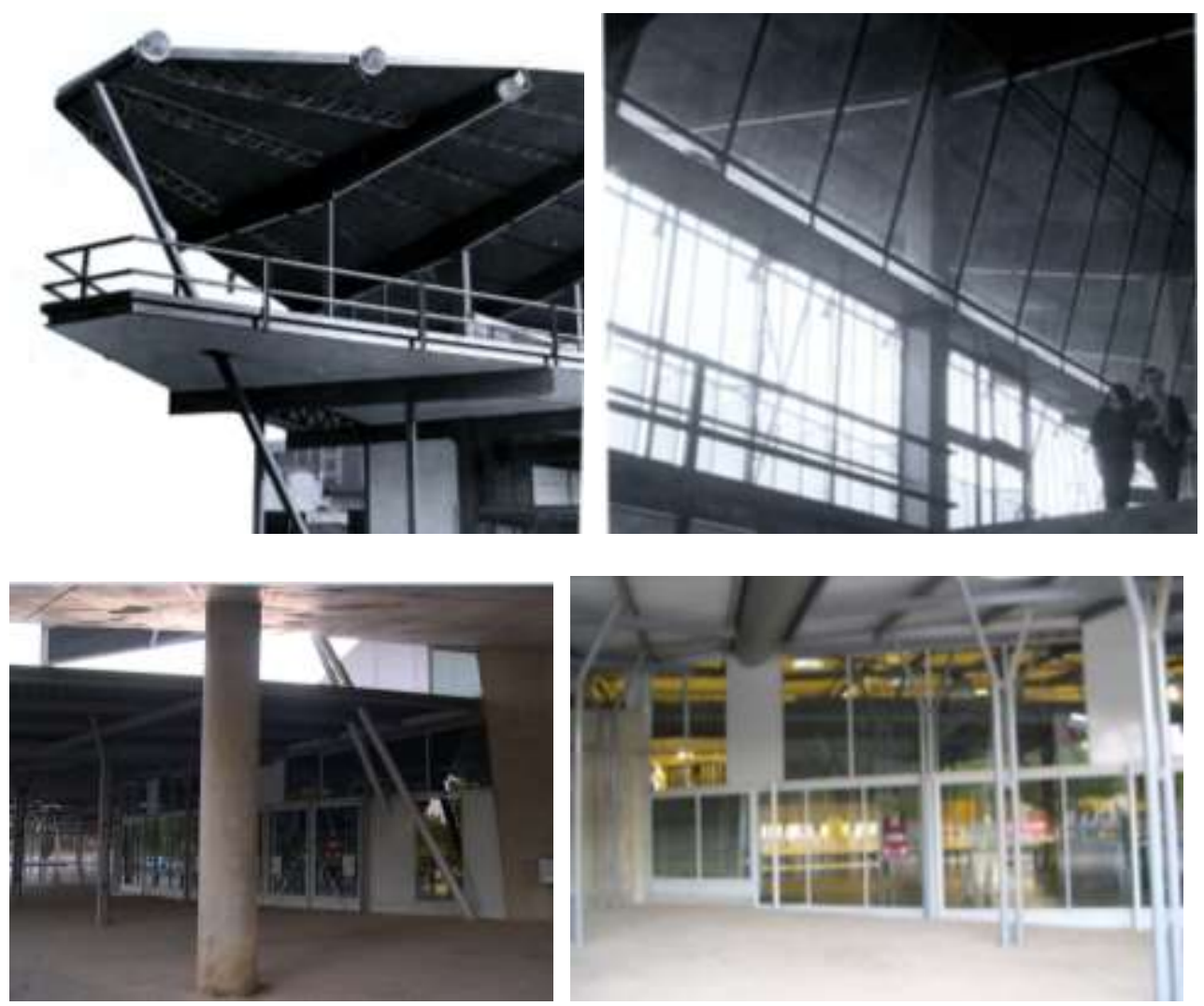

$5-7^{417}$

El Pabellon de Huesca tambien tiene relación con la obra maestra de Coderch, la Casa Ugalde en Caldes de Estrac en el trazado en curva y contracurva del muro serpenteante que conduce desde la entrada de la parcela hasta la casa sorteando el pinar en el que se inserta la vivienda unifamiliar, que recuerda al que utiliza Miralles para conducir a los espectadores desde los bloques de viviendas hasta el Pabellon. Pero tambien la Casa Ugalde y el Pabellon de Huesca, coinciden en la fragmentacion el programa en piezas diferentes, el entendimiento del clima y la importancia de los espacios exteriores, las relaciones interior exterior, la importancia de las sombras, las conexiones visuales y la morfologia Mironiana de los planos de planta y el trabajo con la topografia ${ }^{418}$ Coderch, era un admirado arquitecto de prestigio internacional cuando Miralles estudiaba en la ETSAB.. Asistente a los Congresos CIAM, relacionado con los miembros del Team Ten, era un ferviente admirador del arquitecto norteamericano Frank Lloyd Wright y un enemigo declarado de Le Corbusier. Miralles y Pinos declaran: "No. Por ejemplo, no es que no nos interese el ladrillo... sino que esperamos a utilizarlo desde el propio proyecto. Es idéntico a otro cualquier dato. Nos interesa, más que el material, el modo en que un arquitecto ha sabido interpretarlo... el ladrillo de Coderch" $^{419}$

\footnotetext{
417 Canodromo Meriadana en Barcelona. Antoni Bonet y Josep Puig. 1961 versus Pabellon de Huesca.

${ }^{418}$ Coderch, daba mucha importancia a la topografia, y para ello tenia un topografo que le realizaba levantamientos topograficos muy exactos de los terrenos en los que tenia que intervenir

${ }^{419}$ Enric Miralles y Carme Pinós. Entrevista. Ribas, Carme; Ravetllat, Pere Joan; Roig, Joan. 1 ed. Barcelona: A-30 Publicación de Arquitectura no 6, 1987. Desplegable.
} 

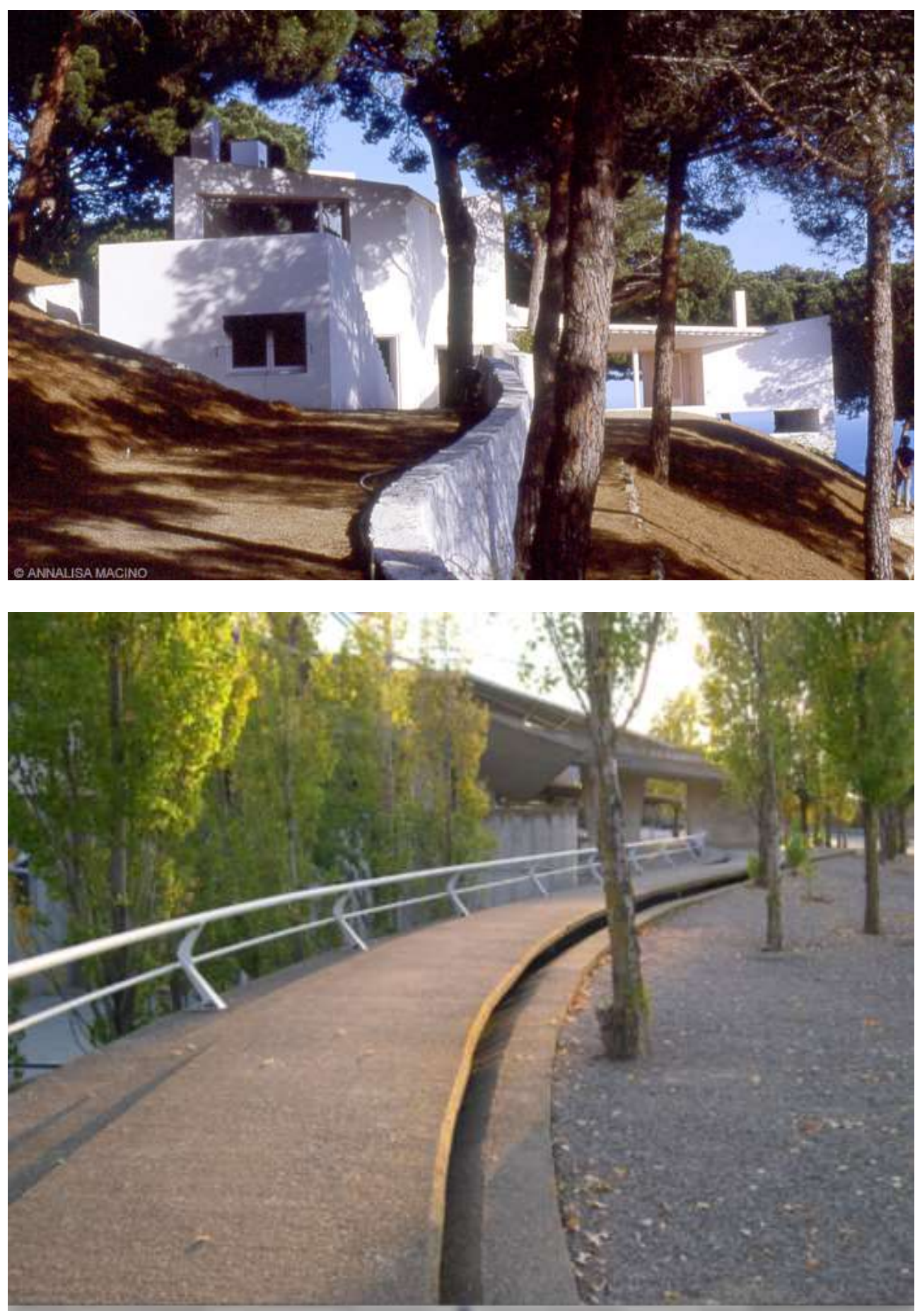

Ilustración 5-8

${ }^{420}$ Casa Ugalde en Caldes de Estrac. Jose Antonio Coderch de Sentmenat (1951) versus Enric Miralles. Pabellón Deportes de Huesca (1988 - 1994). Fotografia tomada por el autor de la Tesis. 
En Villa Mairea, Aalto logra una fusion de la Arquitectura con la Naturaleza a traves del empleo de determinados elementos como esos soportes que parecen troncos de arboles, arbustos, esas marquesinas forradas de madera, esos muros bajos de piedra, la disolucion libre en el paisaje, los recorridos, las vistas, la orientacion, etc. todo esta orquestado para fundirse con el paisaje natural en el que se ubica. Esa variedad en los nuevos tipos de soportes que Aalto emplea, doblados, geminados, inclinados...los reinterpreta Miralles y aparecen en Huesca.

Miralles declara en una entrevista que al maestro finlandes Aalto no lo tenia muy estudiado porque a diferencia de las buenas ediciones que existian en sus tiempos de la obra de Le Corbusier, las que habia de Aalto eran pocas y muy malas. Admite en esa misma entrevista que la obra de Aalto la fue conociendo poco a poco, cuando la habia consultado para solucionar problemas que se habia ido encontrando en su obra.

Elias Torres defiende que Miralles miraba la obra de Aalto aunque se negase a reconocerlo, en los siguientes terminos:"una vez estuvimos viajando juntos yo a Noruega a un Congreso a finales de los 80s y E volaba a Dinamarca... y lo le dije que de Aalto se lo tenia muy visto y el me dijo que no, que no era de su devocion...pero claro luego ves estas cosas de Aalto y te das cuenta que si que se lo tenia muy mirado...Cuando ves Huesca y los tirantes, eso esta aqui en este edif. de Aalto y muchas mas cosas..." ${ }^{421}$

Miralles admiraba de Aalto especialmente el espacio fluido del Pabellón Finlandés de la Expo de Nueva York en 1939, y como su trazo al dibujar, reflejaba la intención de su arquitectura. Así como la utilización del texto como parte integrante en las composiciones, adquiriendo el mismo valor que el resto del dibujo. Miralles absorbió esta forma de rotular, creando su propia tipografía para utilizarla en toda su vida profesional. Miralles tambien emplea en el Pabellon de Huesca y en otros proyectos las mismas geometrias dentro y fuera, ayudando a integrar su arquitectura en el paisaje como Rafael Moneo detectaba en la obra de Aalto : "Aalto se integra en el paisaje con metodos de composicion no clasicos...evita seguir convenciones...es una arquitectura natural...la continuacion de espacios interiores y exteriores la consigue empleando las mismas geometrias dentro $y$ fuera..." ${ }^{422}$

Aalto adapta su funcionalismo, contemporaneo a la participacion en los CIAM, para optimizar la relacion de la arquitectura con la Naturaleza. Al abordar un proyecto, Aalto comienza descomponiendo los programas funcionales en tipos hall, aulas, biblioteca, etc - para luego recomponerlos tras una cuidada lectura del contexto -topografia, luz, vistas, preexistencias, etc - con el fin de equilibrar la relacion entre hombre, paisaje y contexto. La gran aportacion de la obra de Aalto constituye la manipulacion de la abstraccion moderna dialogando con el paisaje empleando materiales naturales. La relacion de Aalto con el paisaje, se demuestra a todas las escalas, tanto cuando proyecta un edificio como cuando diseña un objeto de mobiliario (vease sillas, vaso en forma de ondas, etc.). En esto tiene mucha relacion tambien con Miralles.

\footnotetext{
${ }^{421}$ Elias Torres "Conversaciones con Enric Miralles". Fundacion Enric Miralles.

${ }^{422}$ Rafael Moneo. Conferencia sobre Alvar Aalto. ETSAB. Barcelona. Febrero 1981
} 

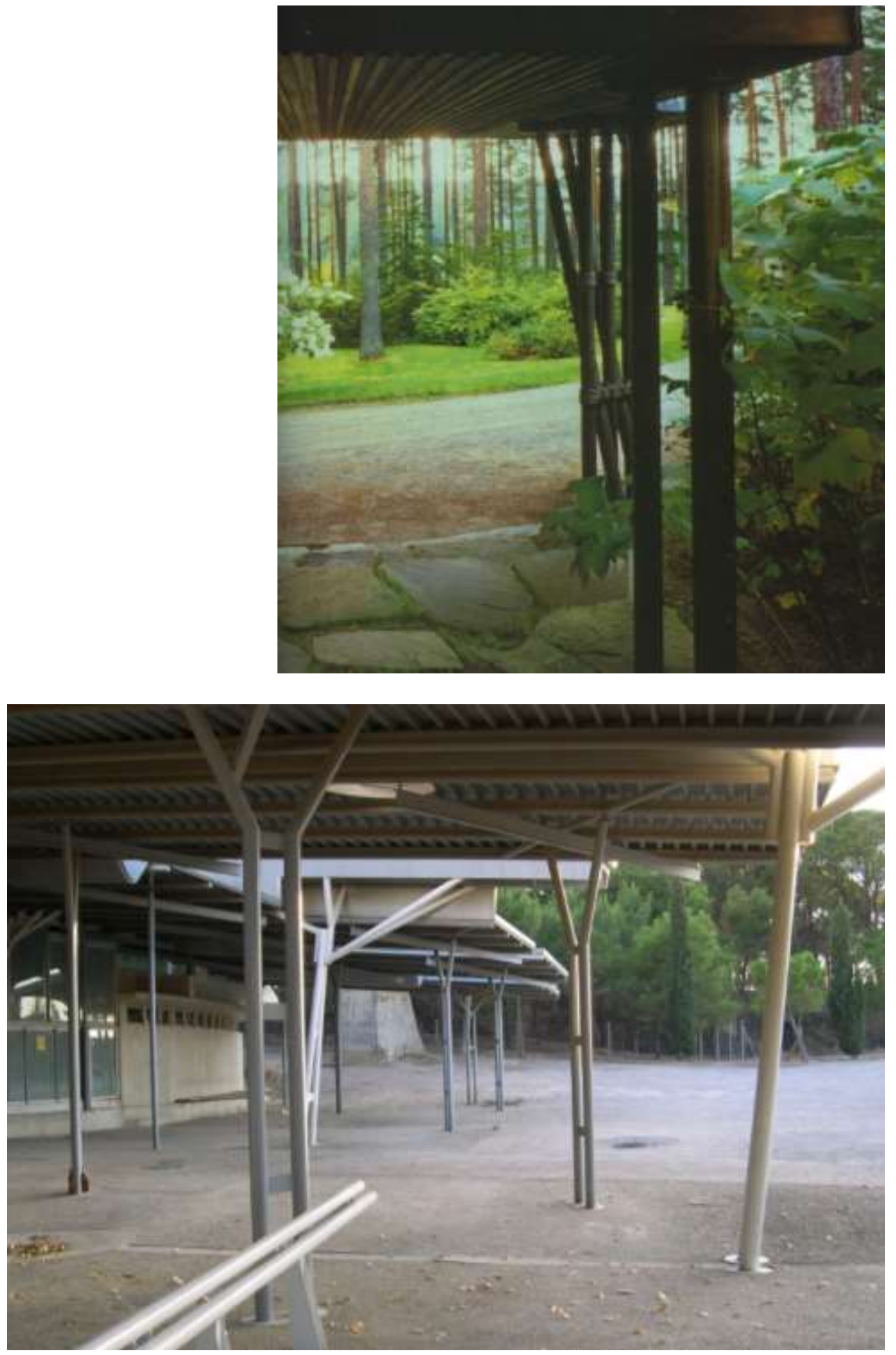

Ilustración 5-9 $9^{423}$

${ }^{423}$ Alvar Aalto. Villa Mairea (1938-39) versus Enric Miralles. Pabellón Deportes de Huesca (1988 1994). Fotografia tomada por el autor de la Tesis. 

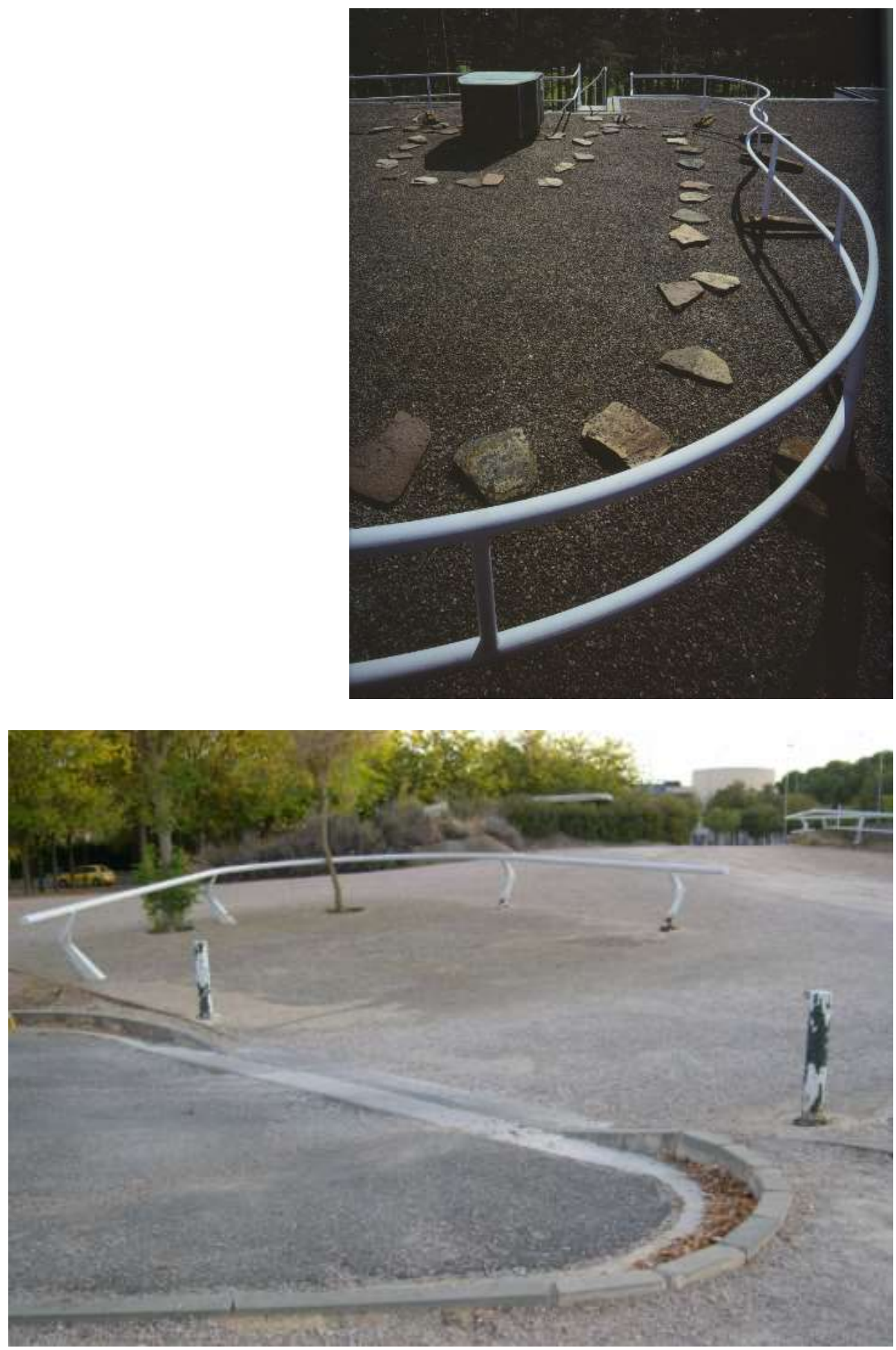

llustración 5-10 $0^{424}$

424 Alvar Aalto. Villa Mairea (1938-39) barandilla de trazo libre en la cubierta versus Enric Miralles. Pabellón Deportes de Huesca (1988 - 1994) barandilla en zona al aire libre que lleva hasta el edificio Fotografia tomada por el autor de la Tesis. 
En la obra de Utzon, Miralles aprendio la apoteosis de los sistemas estructurales se producen cuando desaparece la estructura portante y las cubiertas al no divisar donde apoyan, son como nubes que flotan. Miralles lo retomara en sus grandes cubiertas que flotan sobre el terreno y al margen de lo que ocurre debajo, algo que surge ya en su Centro Civico en Hostalets en la que sobre una base sensualmente excavada flota casi incgravida una estructura ligera en proyectos como Huesca, Alicante, Santa Caterina, etc.) Pero mientras que Utzon construye esas "nubes cubierta" con hormigon como en la Opera de Sydeny o la iglesia de Bagsvaerd, Miralles lo hara con finas laminas ligeras. Utzon, durante toda su carrera persiguio 3 arquetipos: el recinto, la cubierta ligera flotando sobre algo excavado masivo y la generacion de un organismo complejo a base de elementos sencillos repetidos que lo toma de los chinos, de Oriente y tambien de Wrigh, entendiendo la arquitectura como un organismo vivo no tiene fin, que crece, cambia, acorde con el tiempo. Utzon al igual que Miralles, tambien buscaba inspiracion en el mundo natural, el la geometria de la natrualeza, las espirales, las conchas, los fractales. Utzon dio importancia a la cubierta, en un momento en el que se llevaba la cubierta plana de los prismas de Mies o de las casas del Corbusier, haciendo cubiertas que no se habian hecho nunca sino veanse Sydney o la iglesia de perfil quebrado esa con esa cubierta que lo es todo del proyecto...
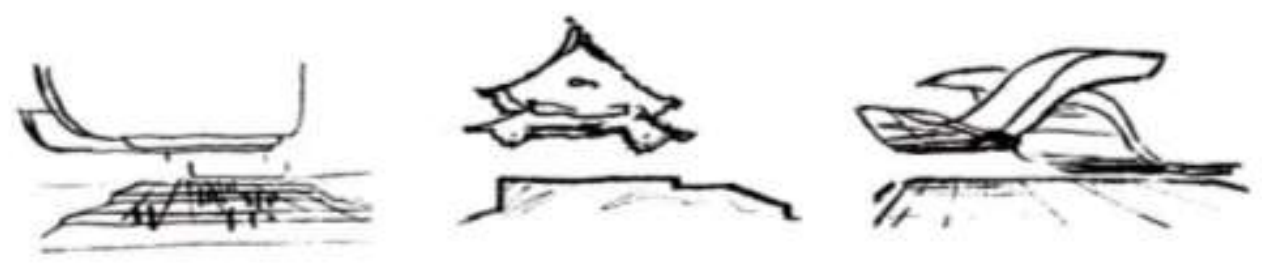

llustración 5-11 $1^{425}$

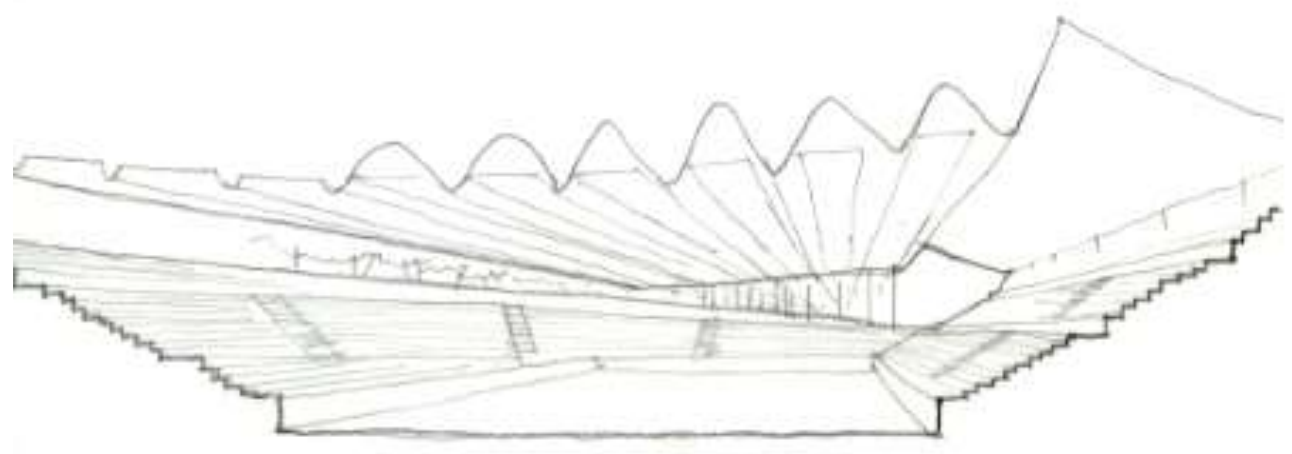

Ilustración 5-12

\footnotetext{
${ }^{425}$ Croquis de Utzon con cubiertas flotantes (1962) versus Pabellon de Huesca.

${ }^{426}$ Para minimizar el impacto, se decide excavar en la tierra como respuesta al problema planteado por el excesivo tamaño del edificio. Los asientos de los espectadores son una modificación de la topografía cercana al Cerro. La cubierta se planteara como una lamina que flota por encima de la pista de juego, que no puede tener mucho canto, para no superar la cota de coronación de los arboles mas cercanos del bosque aledaño. Dibujo realizado por el autor de la tesis.
} 


\title{
5.1.2. LA EVOLUCION DEL PROYECTO
}

El lugar que se encuentran Miralles y Pinos en su primera visita al solar para presentarse al Concurso, era un campo agrícola a los pies del Cerro de San Jorge. Antes de dar acomodo al edificio transformaran el paisaje que se encuentran.

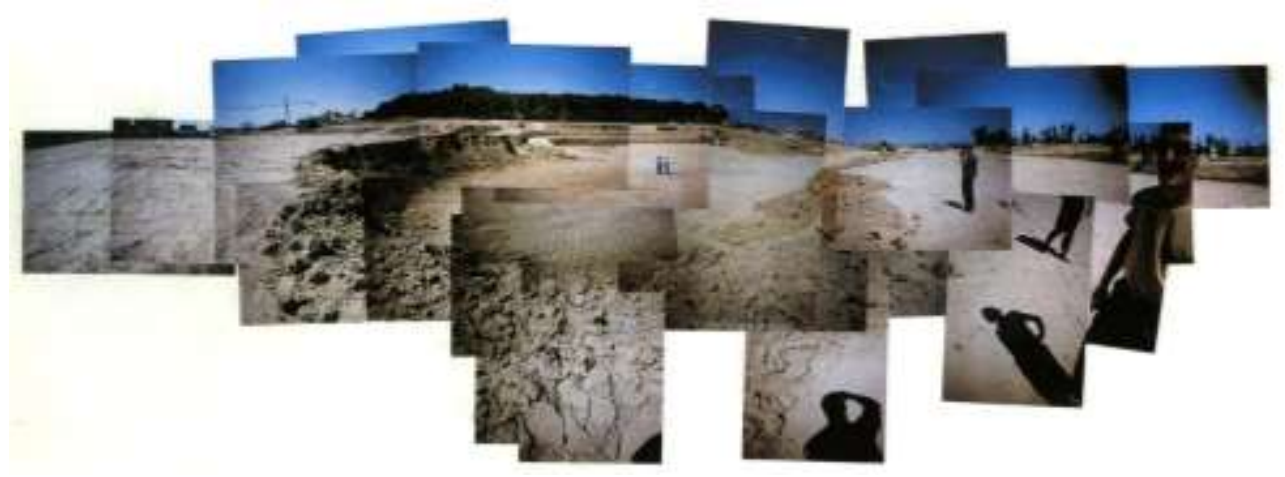

Ilustración 5-13 427

\subsubsection{LA PROPUESTA PROYECTADA}

\begin{abstract}
"Queríamos que en ese lugar... fuera un edificio enterrado, que su espacio exterior publico fuese tan grande como el interior...que los porches te reciben entre un suelo $y$ un techo...los pasos laterales...superposición de el suelo y la cubierta....no hay nada de una estructura deportiva clásica..."
\end{abstract}

Enric Miralles. ${ }^{428}$

El Concurso debió ser muy apetecible de abordar por Miralles pues en su juventud fue jugador de baloncesto en las categorías inferiores del F.C. Barcelona ${ }^{429}$, conociendo por tanto en detalle los requerimientos programáticos de la práctica del baloncesto. También se trataba de un lugar en una situación límite, entre el paisaje construido y el paisaje natural, en el que la pareja Miralles y Pinós ya habían dado muestra de manejarse bien. ${ }^{430}$

\footnotetext{
${ }^{427}$ El lugar que se encuentran Miralles y Pinos en su primera visita al solar para presentarse al Concurso, era un campo agrícola a los pies del Cerro de San Jorge.

${ }^{428}$ De la Conferencia dictada en la Escuela Técnica Superior de Arquitectura (ETSAM) el 05/05/1993.

${ }^{429}$ Deporte que se vio obligado a abandonar para dedicarse a sus estudios de Arquitectura, tal y como escribió Anachu Zabalbeascoa en el periódico El País Digital el 05/07/00.

${ }^{430}$ Véase especialmente lo realizado en el Parque Cementerio de Igualada.
} 


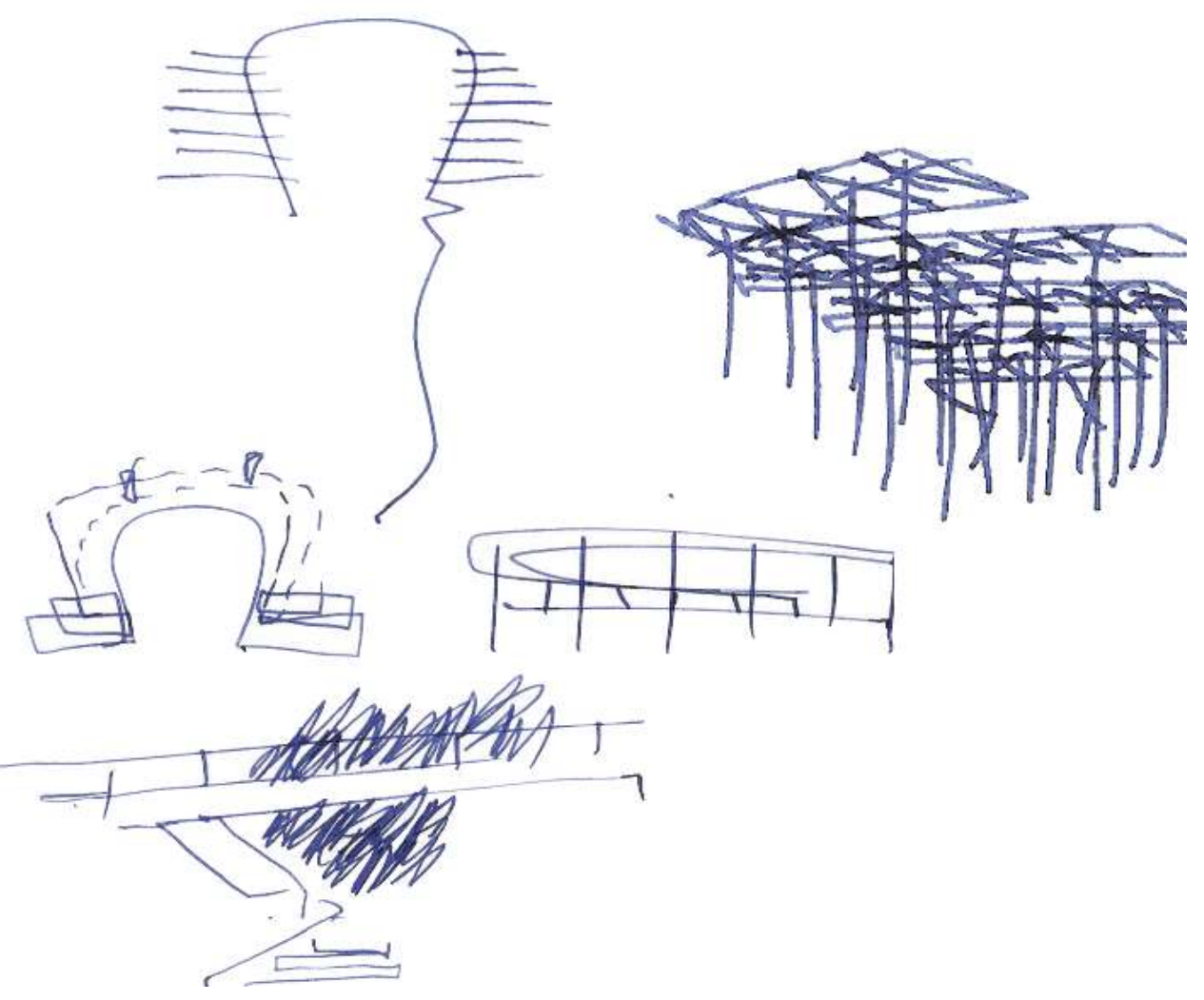

llustración 5-14

El proyecto fue el resultado de un Concurso convocado por el Excmo. Ayuntamiento de Huesca para un Palacio de los Deportes con capacidad para 5000 espectadores en la periferia de la ciudad de Huesca entre las ultimas edificaciones de la ciudad en esa zona y el Cerro de San Jorge. El Concurso fallado en 1989 lo gano el equipo formado por Miralles y Pinós teniendo como colaboradores a Agustín Obiol y Robert Brufau como expertos en Estructuras. ${ }^{432}$. El lema de concurso fue "Dentro y fuera" para enfatizar la imprecisión de los límites del edificio. ${ }^{433}$

El plano presentado a Concurso, es una transformación real del paisaje desde lo imaginado. El paisaje natural estaba caracterizado por un campo agrícola a los pies del Cerro de San Jorge, un terreno de aluvión fértil.

Para minimizar el impacto, se decide excavar en la tierra como respuesta al problema planteado por el excesivo tamaño del edificio. Los asientos de los espectadores son una modificación de la topografía cercana al Cerro. Esta excavación da la dimensión del lugar y definirá la nueva construcción. La cubierta se planteara como una lamina que flota por encima de la pista de juego para no superar la cota de coronación de los arboles más cercanos del bosque aledaño.

\footnotetext{
${ }^{431}$ Croquis de Enric Miralles estudiando los recorridos y accesos al Pabellón de Huesca. CFundació Enric Miralles.

${ }^{432}$ Entre los miembros del jurado se encontraban un amigo de Miralles, Luis Burillo.

${ }^{433}$ Cuando se visita el edificio, se comprueba como muchos de los pilares sustentantes, atraviesan el cerramiento del edificio encontrándose a la vez dentro y fuera. También se dan episodios en los que te encuentras fuera y dentro a la vez, al arroparte el edificio enrocándose.
} 

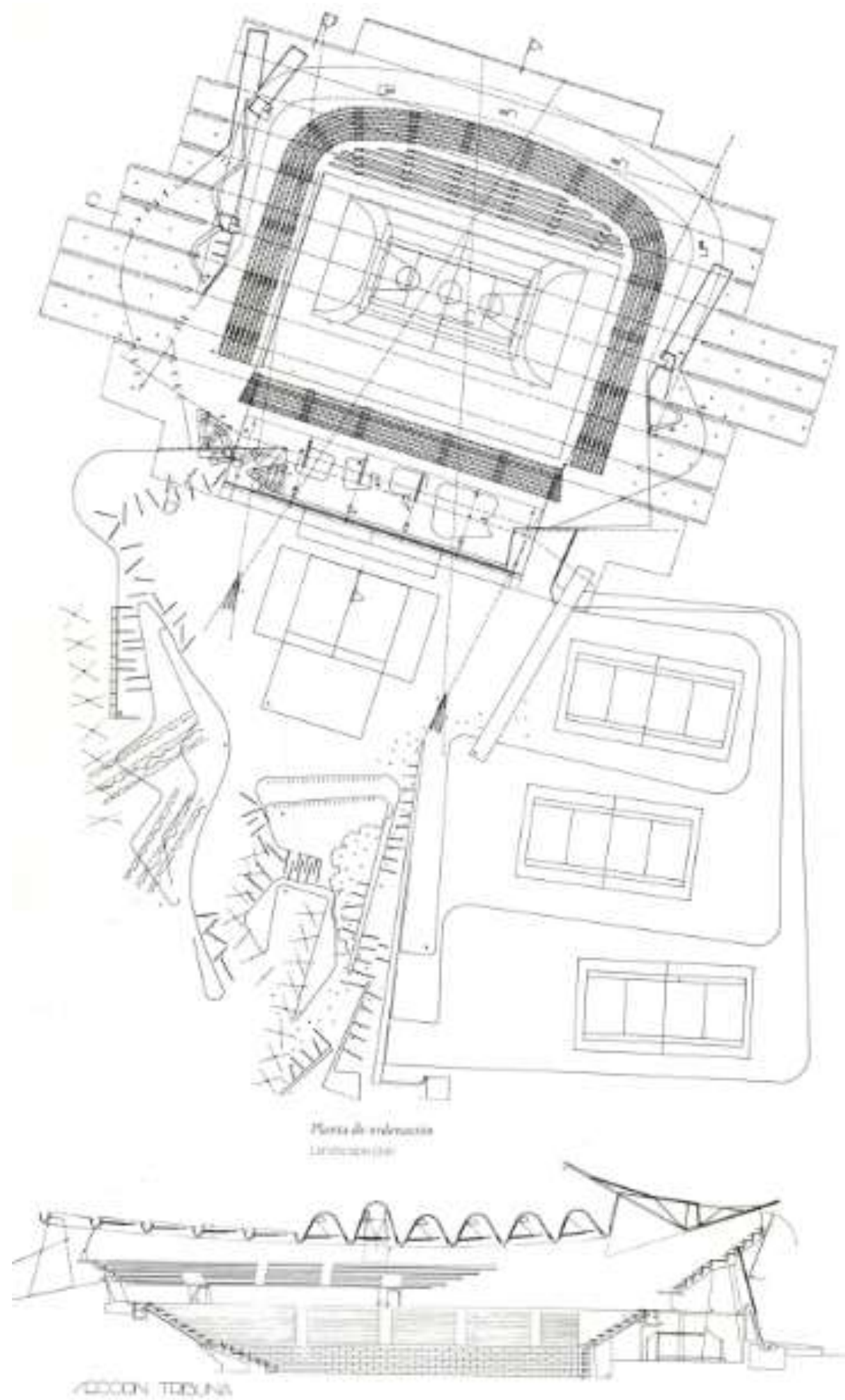

llustración 5-15

${ }^{434}$ El plano presentado a Concurso, es una transformación real del paisaje desde lo imaginado. 
En la versión del proyecto que gana el Concurso, se excava el solar modelando el terreno con un criterio tectónico para alojar las pistas de juego y el graderío, mientras que una cubierta ligera, independiente, con los soportes exteriores al edificio "flota" próxima al plano del suelo.

Dos ideas se mantuvieron desde la fase de concurso hasta el final de la Obra. En primer lugar, la excavación del graderío de la pista interior de juego por debajo del nivel inicial del terreno. En segundo lugar, la prolongación de dicha excavación al exterior del edificio para generar un lugar equivalente al del interior. La cubierta, se situó lo más cerca al plano del suelo que fue posible para que el volumen aparente del edificio no rebasase la cota de las copas de los pinos del bosque que puebla el Cerro de San Jorge y tuviese el menor impacto posible. Por ello, la estructura de la cubierta se proyecto tensada, para que su canto fuese el menor posible, trasladando los apoyos al exterior._Es una cubierta que se sostiene segun un sistema de ocho cables tensados entre las pilas de hormigon en contacto con el bosque y dos grandes mastiles en el extremo opuesto. Los haces de catenarias se cruzan y con ello se arriostran entre si. Sobre dichos haces de cables tensados, se dispone transversalmente una cubierta ondulada para alojar lucernarios, e instalaciones

La estrategia segun la cual se desarrolla el programa se realiza con la produccion de dobles. La zona de servicio y la tribuna principal separan el interior del exterior, sirviendo tanto a la pista interior de juego y a la pista exterior de juego. La tribuna, que ademas contiene el gimnasio de entrenamiento, las oficinas de administracion, etc..., hace de eje de simetria de los dos ambitos. Pero no se trata de una simetria especular sino mas parecida a una simetria de transformaciones. A uno y otro lado, las distintas piezas se doblan con sus variantes; el terreno de juego con sus especificas dimensiones se dobla al exterior, los ordenados asientos del interior se doblan al exterior en variadas topografias... Cuatro parejas de simetrias se entrecruzan en el proyecto. La primera simetria se da entre la pista interior de juego y la pista exterior; la segunda simetria relaciona un paisaje agricola llano con una excavacion en el terreno soportado por un muro de contención de forma serpenteante que relaciona la arquitectura con la ciudad. La tercera simetría se compone del conjunto de las dos primeras simetrias y el bosque de la colina de San Jorge. La cuarta simetria esta constituida por el conjunto de las tres primeras y por la ciudad.

El caracter publico de la actuacion se lo otorga el desplazamiento del interes por el propio edificio a el vacio generado entre la tribuna y las ultimas edificaciones de la ciudad, cobrando gran importancia los paseos de borde que llegan a los porches laterales de acceso al edificio.

En la versión posterior al Anteproyecto, desaparecen las tres pistas de baloncesto y se sustituyen por un muro de contención de tierras de forma curva. La cubierta se detalla mas, a medida que se trabaja en el proyecto; pues al pre dimensionar la estructura se necesitan más tirantes y una disposición que los arriostre para generar un plano de cubierta tensada que pueda acoger en sentido transversal a los tensores de primer orden que cruzan el edificio exteriormente desde los dos grandes mástiles hasta los machones de hormigón en contacto con el bosque de pinos. De los cuatro tirantes iniciales del Anteproyecto, se pasan a 8 tirantes. 


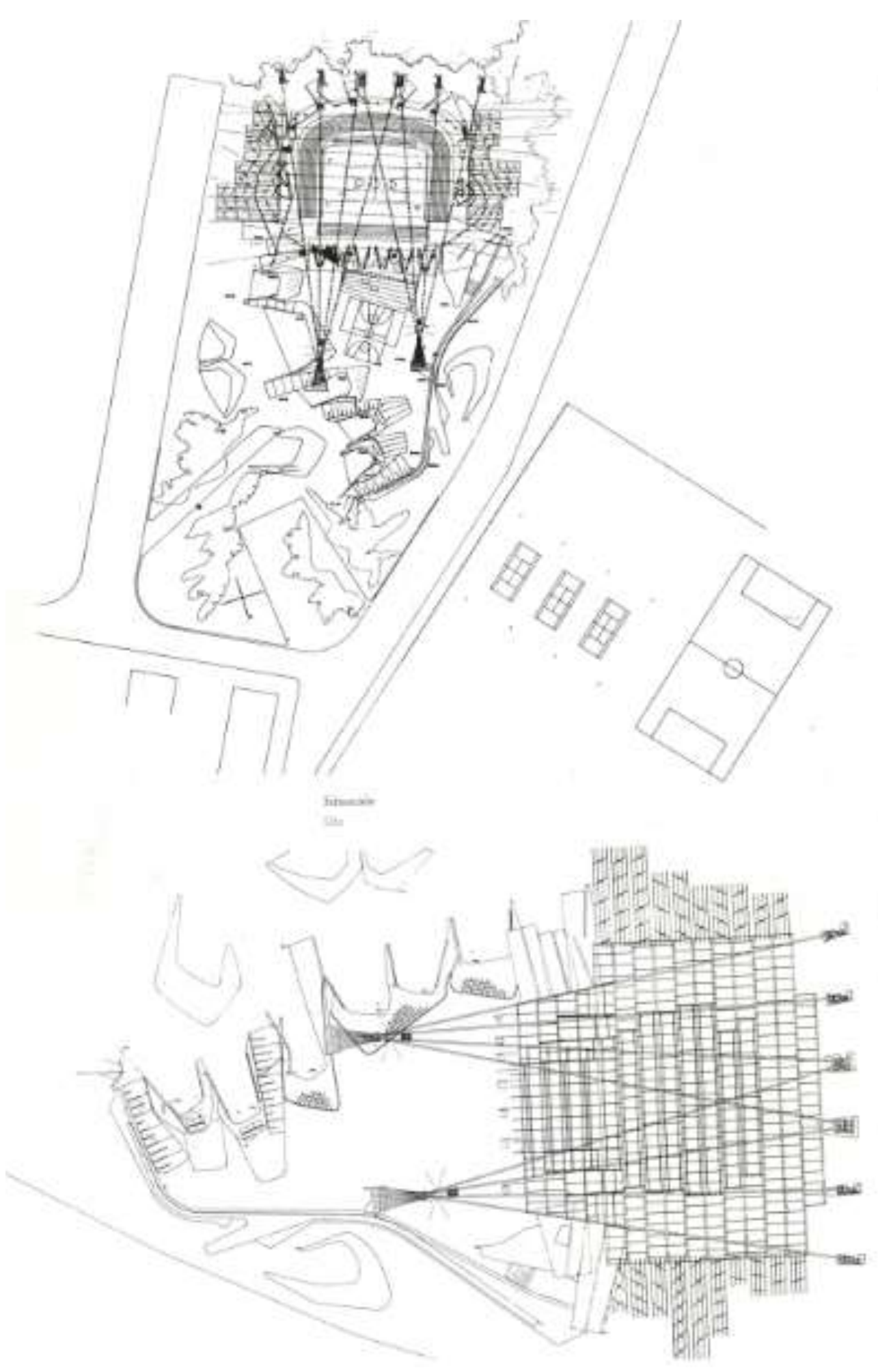

Ilustración 5-16

${ }^{435}$ Planos del proyecto de construcción con la cubierta tensada. La cubierta, dada la reducida distancia entre apoyos de aprox. 12 a 15 metros, se construirá con cables tensados entre apoyos, mediante una estructura metálica formada por dos grandes mástiles exentos situados en el ámbito de la pista exterior de juego 


\section{La construcción del edificio con la cubierta tensada}

El anteproyecto se presento en 1990 y el proyecto de construcción con la cubierta tensada entre 1990 y 1992. Tras el derrumbe de la cubierta tensada, el proyecto de construcción de la cubierta apoyada se entrego por fases entre 1992 y 1994, construyéndose el edificio entre 1991 y 1994.

La parcela ofrecida para albergar el programa edilicio, tenía una superficie de $40.700 \mathrm{~m} 2$. A pesar de la amplia extension del solar, EMCP decidieron implantar su obra pegándose al límite del Cerro generando una superficie cubierta de 9000 $\mathrm{m} 2$, pero tratando también el resto de la parcela con una intervención al aire libre de 31.700 m2. La Dirección de Obra corrió a cargo de Miralles, Agusti Obiol y Luis Moya. El contratista que ejecuto la obra fue Auxini S.A. con un presupuesto de 1.546 millones de pesetas (9.291.647 euros) y un plazo de ejecución de 18 meses, terminándose las obras en 1994

La cota del terreno manipulado donde se sitúa la pista de juegos exterior es la misma que la de la pista de juego interior. Las gradas altas tienen un sistema de sustentación que permite que entre las gradas bajas y las altas, se pueda ver el paisaje alrededor; generando conexiones entre interiores y exteriores que se persiguieron desde el Concurso. Las cotas generales de la construcción fueron: cota $-6.40 \mathrm{~m}$. para la zona de juego interior; cota $+0.00 \mathrm{~m}$. para el plano que conforma los accesos al interior; cota $+4.00 \mathrm{~m}$. como coronación de los porches; $+6.00 \mathrm{~m}$. como cota de la cubierta principal. ${ }^{436}$ El Pabellón de Huesca se compone de dos partes diferentes, una de ellas en la que pistas y gradas se configuran a partir del modelado del terreno; y la otra es la cubierta conformada por una carpa de acero colgada de cables atirantados entre una pareja de mástiles y una fila de pilas de hormigón en el lado del bosque, de tal forma que los dos haces de catenarias de los dos mástiles se cruzan y arriostran entre sí.

La cubierta, dada la reducida distancia entre apoyos de aprox. 12 a 15 metros, se construirá con cables tensados entre apoyos, mediante una estructura metálica formada por dos grandes mástiles exentos situados en el ámbito de la pista exterior de juego, mástiles de los que saldrán unos cables que enlazaran con unos contrafuertes de hormigón exentos situados en el otro extremo, en el límite del Cerro, formando unas catenarias de directrices oblicuas sobre las que se apoyaran unos elementos nervados paralelos a la directriz de la pista separados cada 5.80 $\mathrm{m}$. Los cables, guiaran la posición precisa de cada elemento en el suelo. La zona de vestíbulos de acceso al interior del edificio se cubrirá mediante placas metálicas con una altura más acorde a la escala humana, formando así una transición entre la cubierta y la topografía del terreno.

${ }^{436}$ Todos estos datos ya estaban en el proyecto presentado a concurso. 


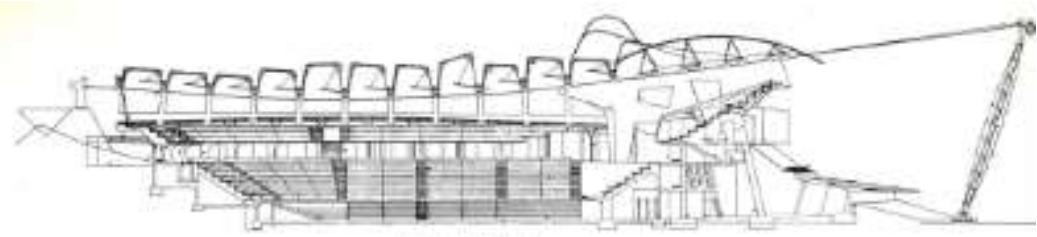

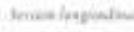

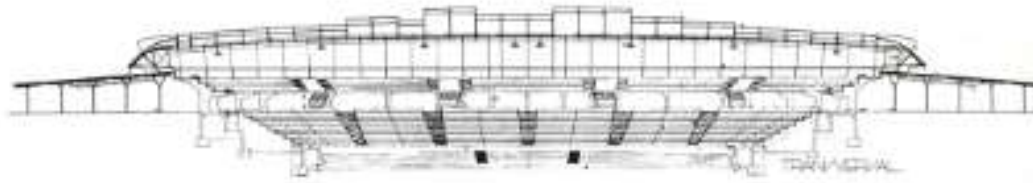

Shastomines
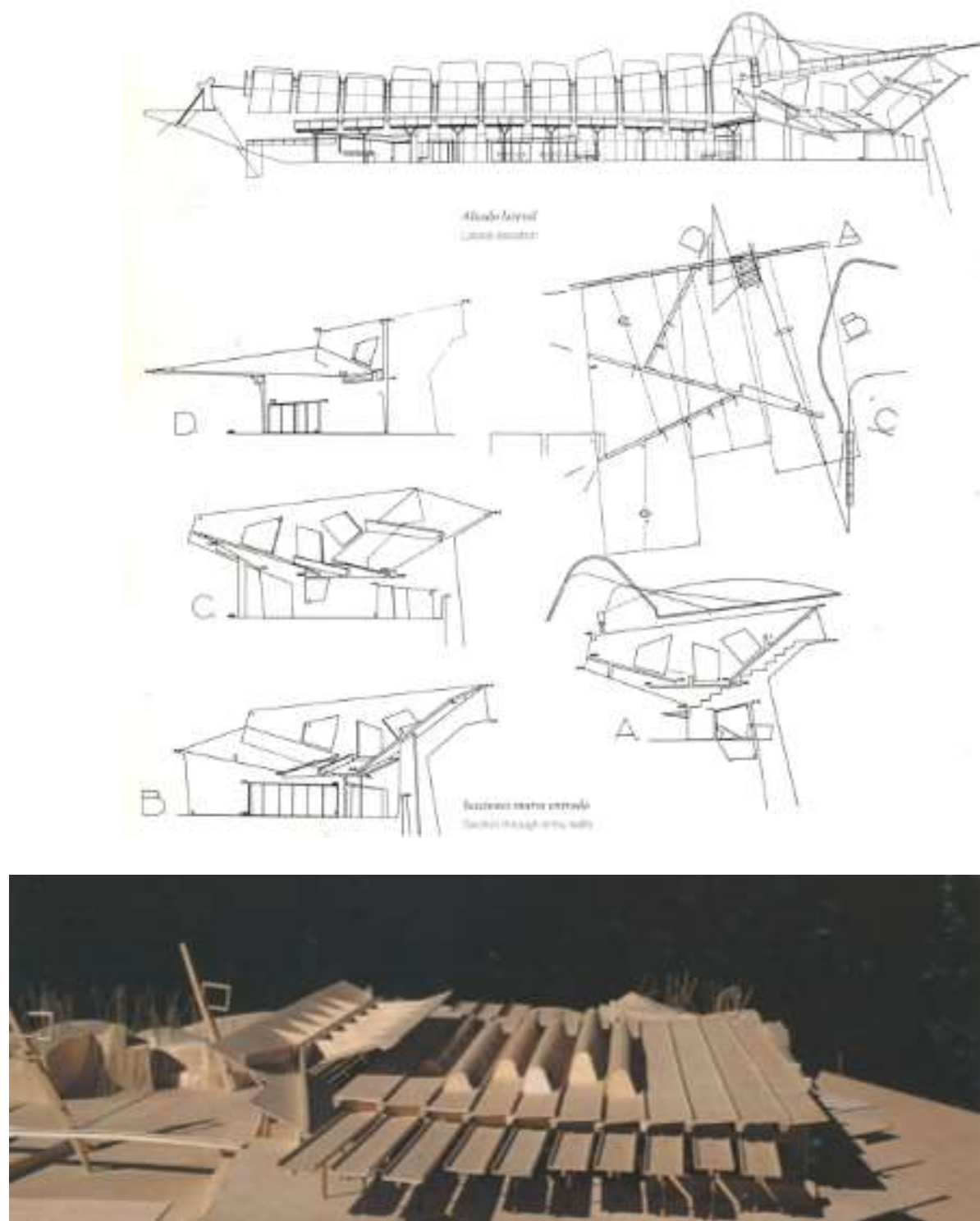

Ilustración 5-17

${ }^{437}$ Maqueta, Secciones y alzados con el proyecto con la cubierta tensada. 
La solución de montaje de la cubierta atirantada finalmente elegida, se baso en disponer elementos de fijación desde las jácenas a los cables antes de izar. Una vez izadas se iba construyendo la cubierta utilizando jácenas transversales de sección compuesta por tres elementos. El primer elemento que se dispuso fueron los tubos de sección circular y diámetro exterior de $500 \mathrm{~mm}$.

La composición de la cubierta tensada estaba conformada por un revestimiento de planchas de acero galvanizado de $1.2 \mathrm{~mm}$ que se apoyaba en las costillas de la cubierta, un aislamiento de manta de fibra de vidrio y una chapa de acero galvanizado como acabado superficial. Los lucernarios se realizaron con placas de poliéster reforzado.

Las cubiertas de menor escala que cubren los accesos de espectadores por los flancos al Pabellón, son un elemento de transición entre el exterior y el interior, se construyen con placas metálicas que se soportan por jácenas cruzadas que apoyan en pilares tubulares metálicos. Dichas cubiertas se separan dejando una separación entre ellas para colocar un canalón que además de desaguar el agua de lluvia de estas cubiertas también desagua las aguas de la cubierta atirantada. ${ }^{438}$

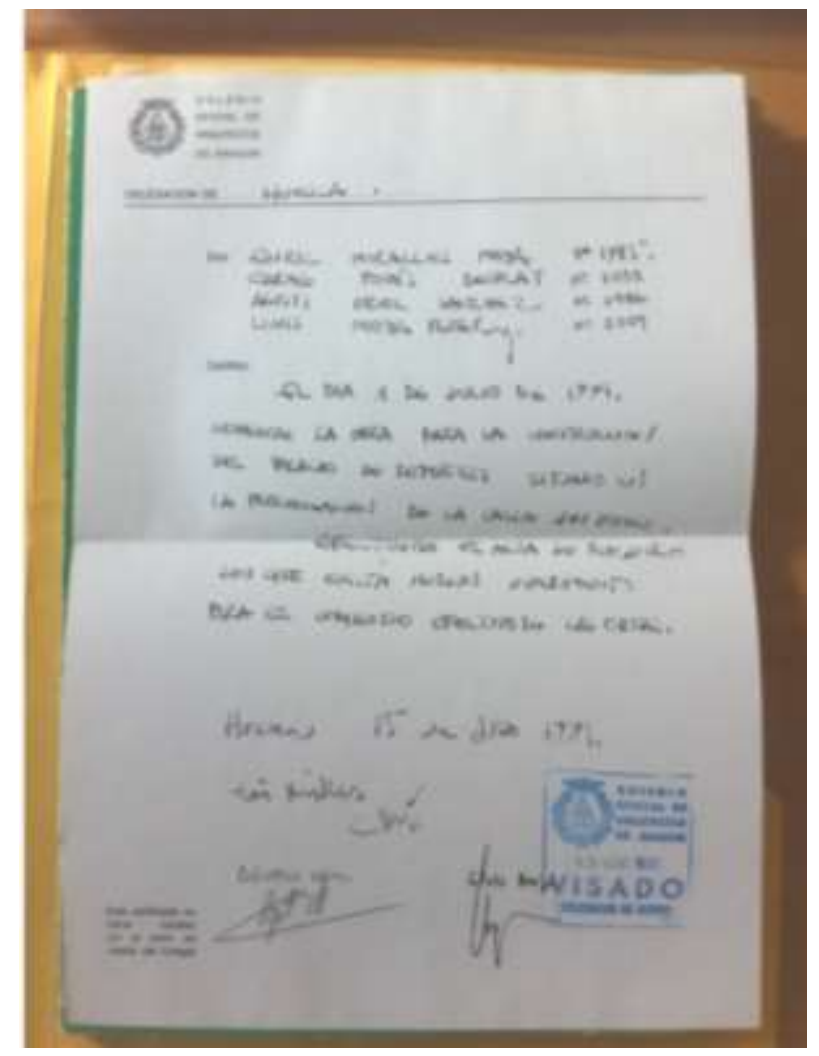

Ilustración 5-18

\footnotetext{
438 ALFAMBRA, B. "Primer paseo" en Enric Miralles: Pabellón de baloncesto en Huesca, Documentos de arquitectura 32. 1995

${ }^{439}$ Acta de Inicio de la Obra firmada el día 15 de julio de 1991. En dicho acta aparecen como firmantes Enric Miralles, Agusti Obiol y Luis Moya. @Fundació Enric Miralles.
} 


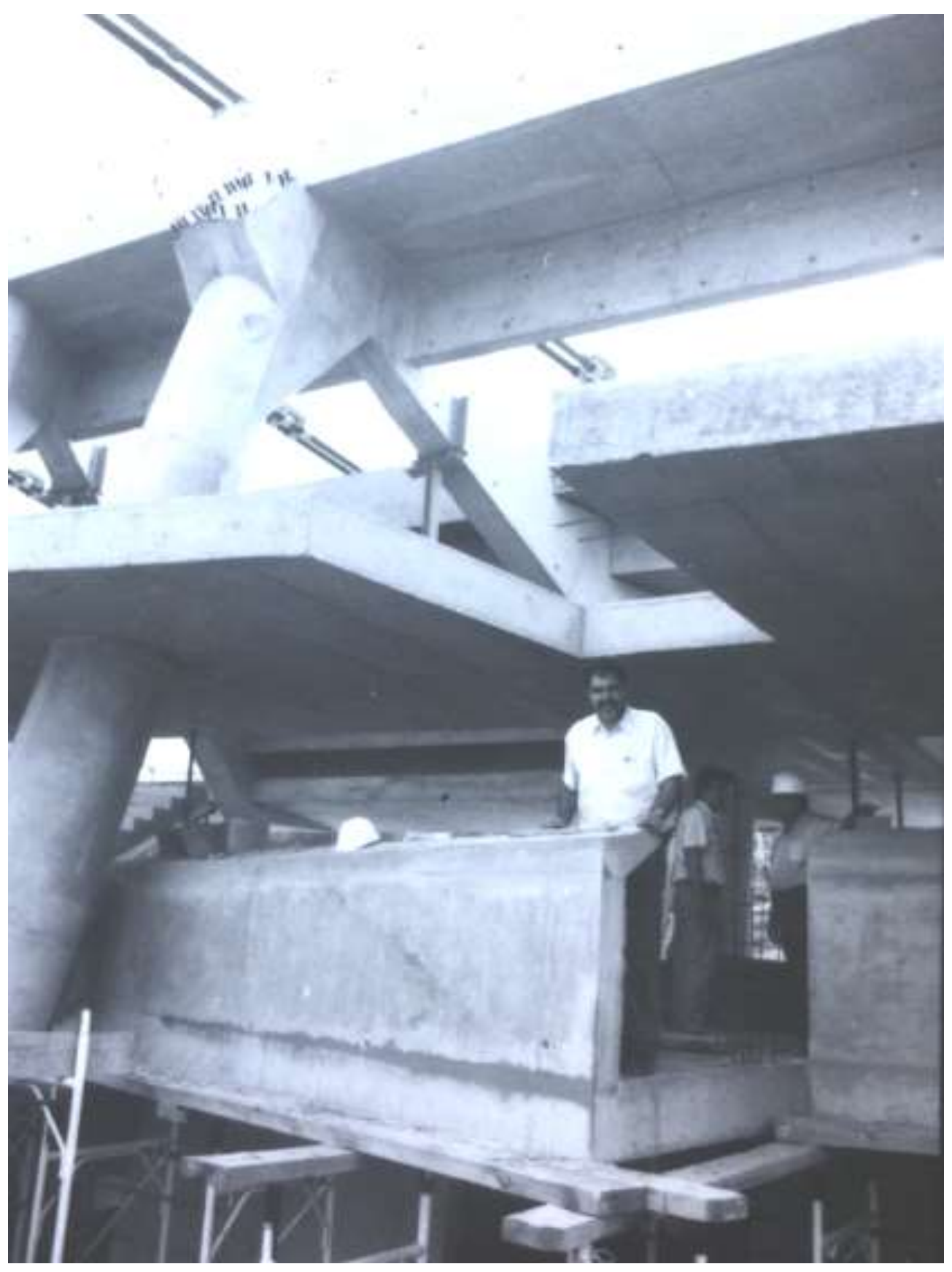

llustración 5-19 440

${ }^{440}$ Miralles fotografiado en una de las visitas de Obra a Huesca. @Fundació Enric Miralles. 

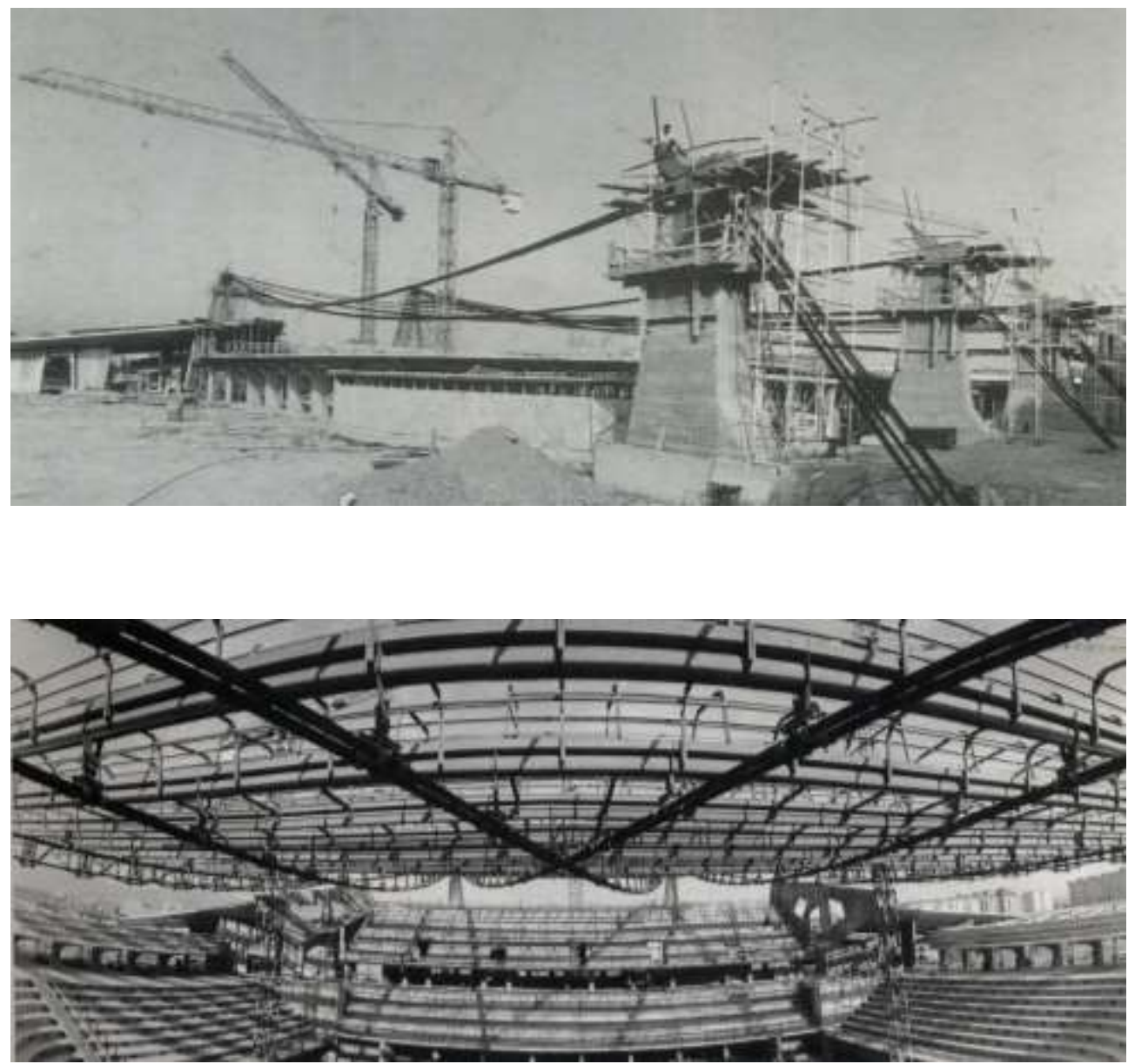

llustración 5-20 441

${ }^{441}$ Fotografías tomadas durante la construcción de la cubierta tensada. La cubierta, dada la reducida distancia entre apoyos de aprox. 12 a 15 metros, se construirá con cables tensados entre apoyos, mediante una estructura metálica formada por dos grandes mástiles exentos situados en el ámbito de la pista exterior de juego, mástiles de los que saldrán unos cables que enlazaran con unos contrafuertes de hormigón exentos situados en el otro extremo, en el límite del Cerro, formando unas catenarias de directrices oblicuas sobre las que se apoyaran unos elementos nervados paralelos a la directriz de la pista separados cada $5.80 \mathrm{~m}$. OFundació Enric Miralles. 

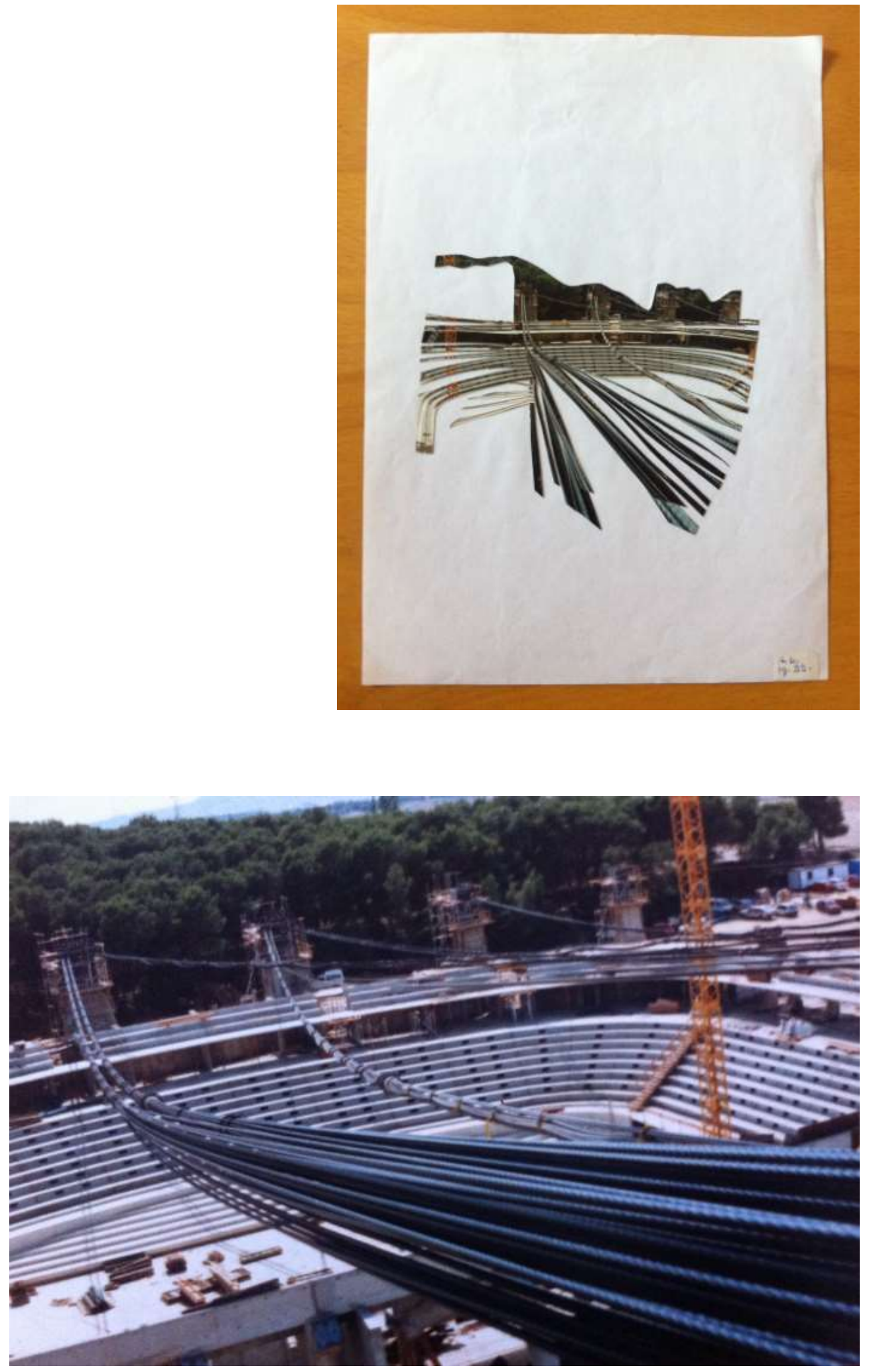

Ilustración 5-21 442

442 Los cables que conformaban los tirantes de la cubierta atirantada. Recortable de Miralles y fotografía de Obra desde la zona de la Tribuna mirando hacia el Cerro de San Jorge. OFundació Enric Miralles. 


\section{El derrumbe de la cubierta tensada}

"... la caída de la cubierta fue una experiencia en la que el tiempo se acelera, es decir, el edificio desaparece en un ciclo mucho más rápido de lo que está previsto. Eso el Ayuntamiento lo entendió muy bien y dio permiso para diríamos, usar las ruinas del edificio para levantarlo de nuevo, entendió que valía la pena dejar las huellas de lo que había sucedido...para mí fue un momento importantísimo en mi carrera..."

Enric Miralles. ${ }^{443}$
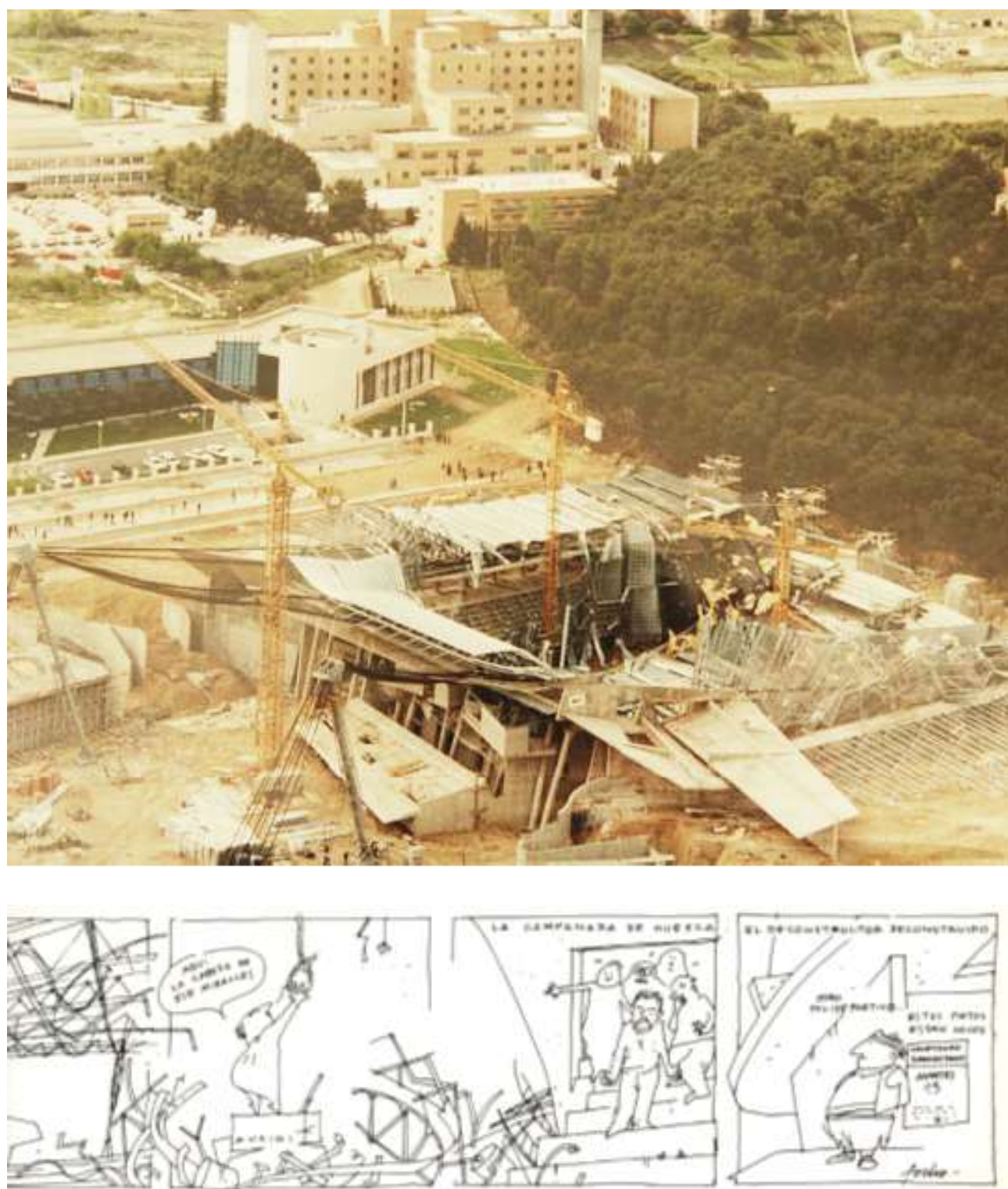

Ilustración 5-22 $2^{44}$

\footnotetext{
${ }^{443}$ Metalocus no 3. 1999. Cronotopias. Entrevistado por J.J. Barba, S. Papadopoulos y L. Stergiou.

${ }^{444}$ Fotografía de la cubierta atirantada ya desplomada sobre el suelo y tira cómica de Focho.
} 
Las obras del Pabellón estaban a punto de terminar cuando, el día 13 de Abril de 1993 a las 4 de la madrugada, la cubierta se desplomo al fallar uno de los cables tensados que soportaban la cubierta. No hubo que lamentar víctimas porque dada la hora a la que ocurrió, no se encontraba trabajando ningún operario en la obra.

Al accidente, le siguió un largo proceso judicial en el que la constructora se defendió alegando que había reiterado a la Dirección Facultativa las indefiniciones del proyecto a lo largo del proceso constructivo. Finalmente, la justicia fallo en contra de la constructora Auxini S.A. La crítica de arquitectura se hizo eco de la noticia como Luis Fernández Galiano que comento: “...entre los restos del siniestro..quedo enterrada la inocencia experimental, lirica y audaz de Enric Miralles, que ha perecido bajo los escombros fríos de una obra abrasada...el barcelonés de 37 años ha vivido su noche más triste en un omento crucial de su meteórica carrera..." ${ }^{445}$ En otros términos se refirió Gabriel Ruiz Cabrero : "... Con el polideportivo de Huesca, que se rompió contra el suelo por un fallo de ejecución, Miralles hizo una exhibición de fortaleza heroica...levanto del piso la estructura aprendiendo de la rota. Carácter fénix". ${ }^{446}$

Miralles no dio muestras externas de afectarle psicológicamente el acontecimiento del derrumbe ${ }^{447}$ y reacciono rápidamente con el merito de terminar la construcción con el mismo presupuesto inicial que tenía asignado el proyecto. Luis Burillo asistió a un acto en Huesca a los pocos días del derrumbe de la cubierta, donde se había citado a Miralles para que diese explicaciones. Miralles, según testimonio de Burillo, dispuso dos proyectores de diapositivas. Mientras en uno de ellos proyectaba las noticias diarias que habían ido saliendo en la prensa criticándole, en el otro proyectaba los croquis que había ido realizando cada día del proyecto de la nueva cubierta que se construiría con el mismo presupuesto. ${ }^{448}$ El hecho es que aunque al final la justicia exonerase de responsabilidad a Miralles y los miembros de la Dirección Facultativa (Obiol y Bufrau), este acontecimiento supuso un punto de inflexión en la carrera profesional de Miralles, al dudarse de la fiabilidad técnica de sus proyectos. Tan es así que durante mucho tiempo no recibió encargo alguno en España, hasta que le encargase Josep María Acebillo la intervención en el mercado de Santa Caterina. Según Enrique Granell, amigo de Miralles desde los tiempos de estudiante de Arquitectura, tras el derrumbe de la cubierta Miralles, en su opinión, Miralles no volvió a ser lo que era. ${ }^{449}$

El propio Miralles llego a decir que nunca más volvería a dedicarse a un edificio en exclusiva, pues es lo que hizo en su proyecto del Pabellón de Huesca y casi se queda sin trabajo para siempre.

\footnotetext{
${ }^{445}$ Luis Fernández Galiano. "La belleza convulsa. Huesca, destrucción y catástrofe". Arquitectura Viva 69. Madrid. pág. 76 .

${ }^{446}$ Gabriel Ruiz Cabrero. El moderno en España. Arquitectura 1948-2000. Hacia el fin de siglo, pág. 126.

447 Así lo pude comprobar personalmente el autor de la tesis en la conferencia que Miralles dio en la ETSAM, el día 05/05/93 tan solo unos días después del derrumbe. A tenor de los comentarios de amigos como Elias Torres, quien conto en una Conferencia en la Fundación Enric Mlralles, que se lo encontró en el duty free de un aeropuerto comprando feliz una cámara de fotos carísima.

${ }^{448}$ Trasladado al autor de la tesis, Gabriel Ruiz Cabrero en una conversación de pasillo en la ETSAM.

449 GRANELL, Enric . "Una maleta llena de arquitectura” en Enric MIralles: 1972-2000 Editorial Fundación Caja de Arquitectos 2011.
} 


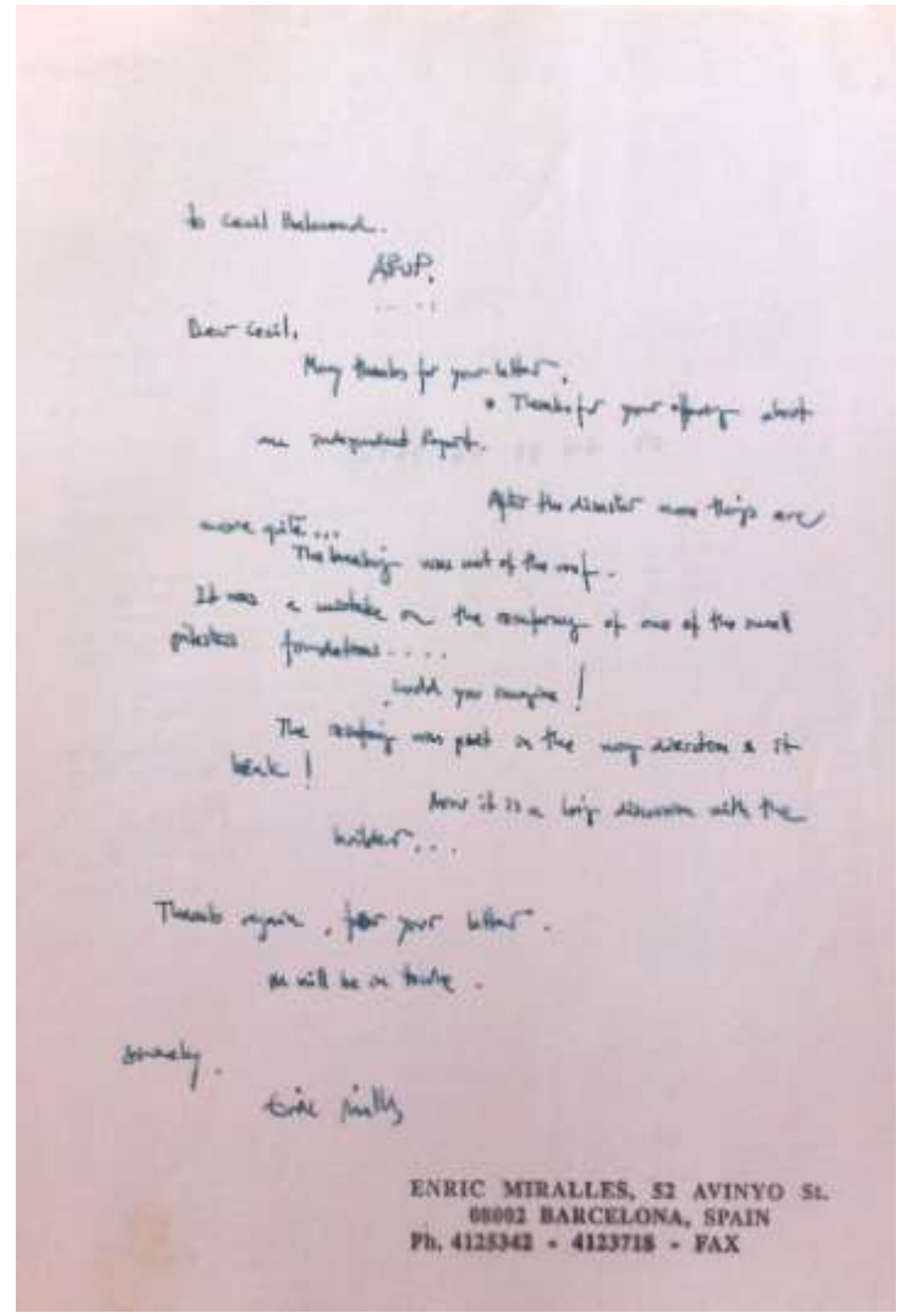

$5-23^{450}$

${ }^{450}$ Fax enviado por Mlralles a Cecil Balmond de la ingeniería ARUP en la que le agradece sus muestras de apoyo al ofrecerse en caso de necesitar un estudio independiente para dictaminar las causas del derrumbe de la cubierta. CFundació Enric Miralles. 


\title{
5.1.2.2. LA CUBIERTA APOYADA QUE SE CONSTRUYO
}

\begin{abstract}
"Al margen de otras consideraciones...la rotura de la cubierta me lanzo en manos del tiempo...haciéndolo avanzar con tal rapidez que me encontré al final de la vida de un edificio. Cuando la destrucción, el abandono...dan paso a una nueva construcción...y ocurría que en cualquiera de los estados de deformación y ruina, la construcción conservaba sus mejores cualidades...Casi sin tiempo hubo que revisar las nociones que formaron el proyecto para definir una solución alternativa. No tanto revisar las hipótesis iniciales -que creo que siguen intactas a lo largo de todo el proceso- sino revisar lo que se pide a la estructura. En la nueva solución había que conservar la libertad de movimientos de ambos brazos; conservar el sentido que tenían en el proyecto primero, así como mantener la escala propia de la construcción respecto a su sección y respecto a la dimensión del bosque. Todo está intacto en los cimientos del edificio....No interpretar la ruina que se tiene entre las manos".
\end{abstract}

Enric Miralles. ${ }^{451}$

Tras el derrumbe de la cubierta tensada, el proyecto de construcción de la cubierta apoyada se entrego por fases, hasta su terminación en el año 1994. En la nueva solución, los apoyos en los mástiles se desplazan a unos puntos que refuerzan las paredes de hormigón laterales de la tribuna principal. Sobre ellos, se apoya una viga cajón aligerada sobre la que se fijara el voladizo atirantado que cubrirá la tribuna. Estas vigas mantendrán el trazado original para permitir incluir unos contrafuertes como apoyos principales.

Miralles explica la nueva solución en los siguientes términos: "Ese suelo-techo que pasaba a ser suelo-topografía a través del trenzado de los cables-mástil, ya no sirve como referencia...desde ambos apoyos, una jácena-puente permite rehacer un abanico de elementos portantes que van a buscar sus apoyos en la zona de anclajes en el bosque...Esta conversación sobre la nueva propuesta se lleva adelante resiguiendo con distintas marcas de color las distintas trazas del edificio en ruinas.." 452

\footnotetext{
${ }^{451}$ MIRALLES, Enric. Palacio de Deportes de Huesca. El Croquis 72. El Croquis editorial, San Lorenzo de El Escorial, pág. 226-229

452 Ibidem, pág. 226-229.
} 

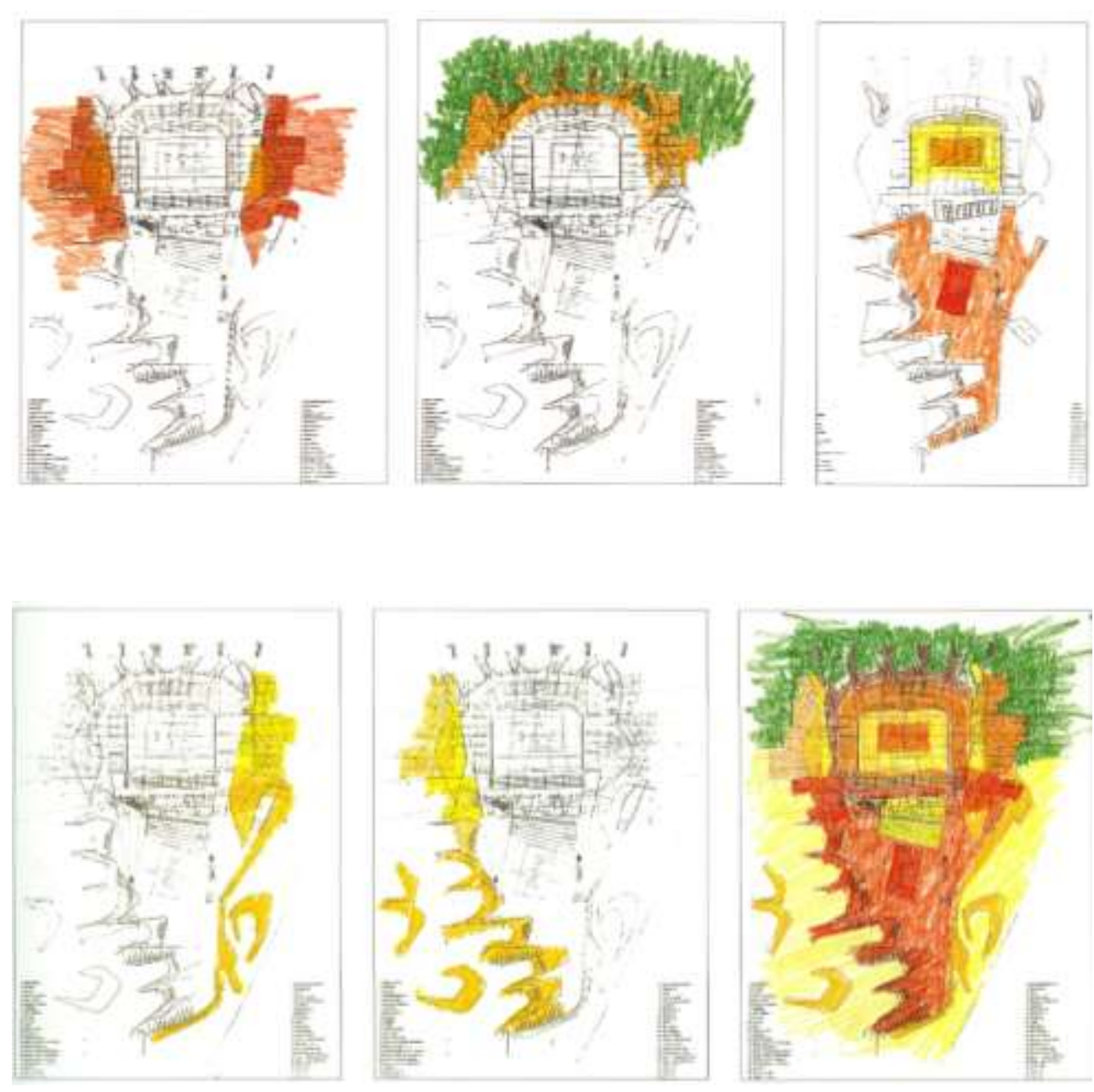

Ilustración 5-24 $4^{453}$

${ }^{453}$ Croquis realizados por Enric Miralles para explicar a las autoridades del Ayto. de Huesca el nuevo proyecto tras el derrumbe de la cubierta de Huesca. El autor de la Tesis pudo comprobar, al asistir a la conferencia que dio el dia 5 de Mayo de 1993 en la ETSAM, a los pocos días del siniestro, en la que abordo el tema del derrumbe de la cubierta, expresando su confianza en optar por una solución fiel al espíritu del proyecto, tejida desde la anterior. 

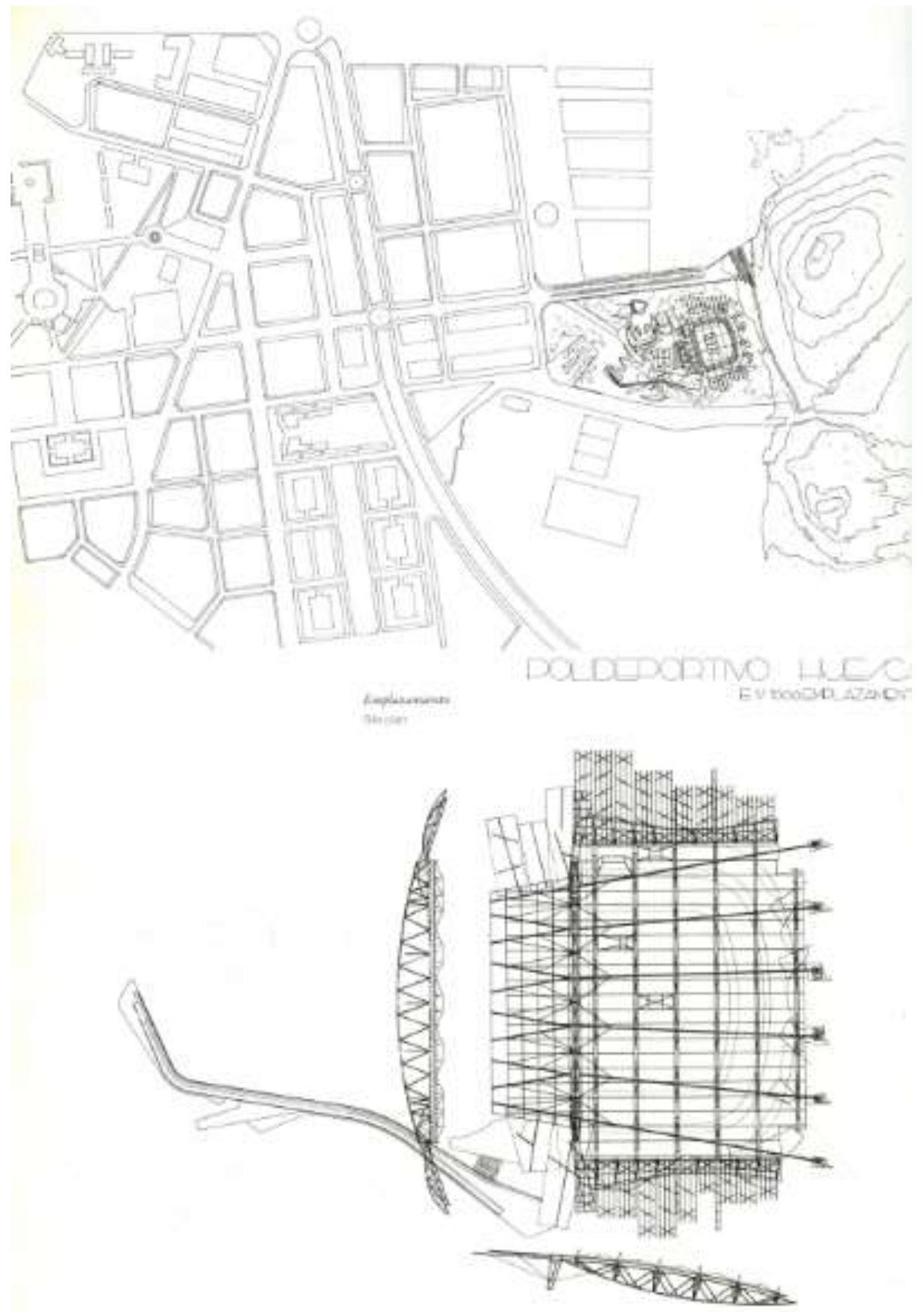

Ilustración 5-25 $5^{454}$

\footnotetext{
${ }^{454}$ Plantas del proyecto de construcción con la solución de cubierta apoyada, que siguió al derrumbe de la cubierta tensada. En la nueva solución, los apoyos en los mástiles se desplazan a unos puntos que refuerzan las paredes de hormigón laterales de la tribuna principal. Sobre ellos, se apoya una viga cajón aligerada sobre la que se fijara el voladizo atirantado que cubrirá la tribuna. Estas vigas mantendrán el trazado original para permitir incluir unos contrafuertes como apoyos principales.
} 

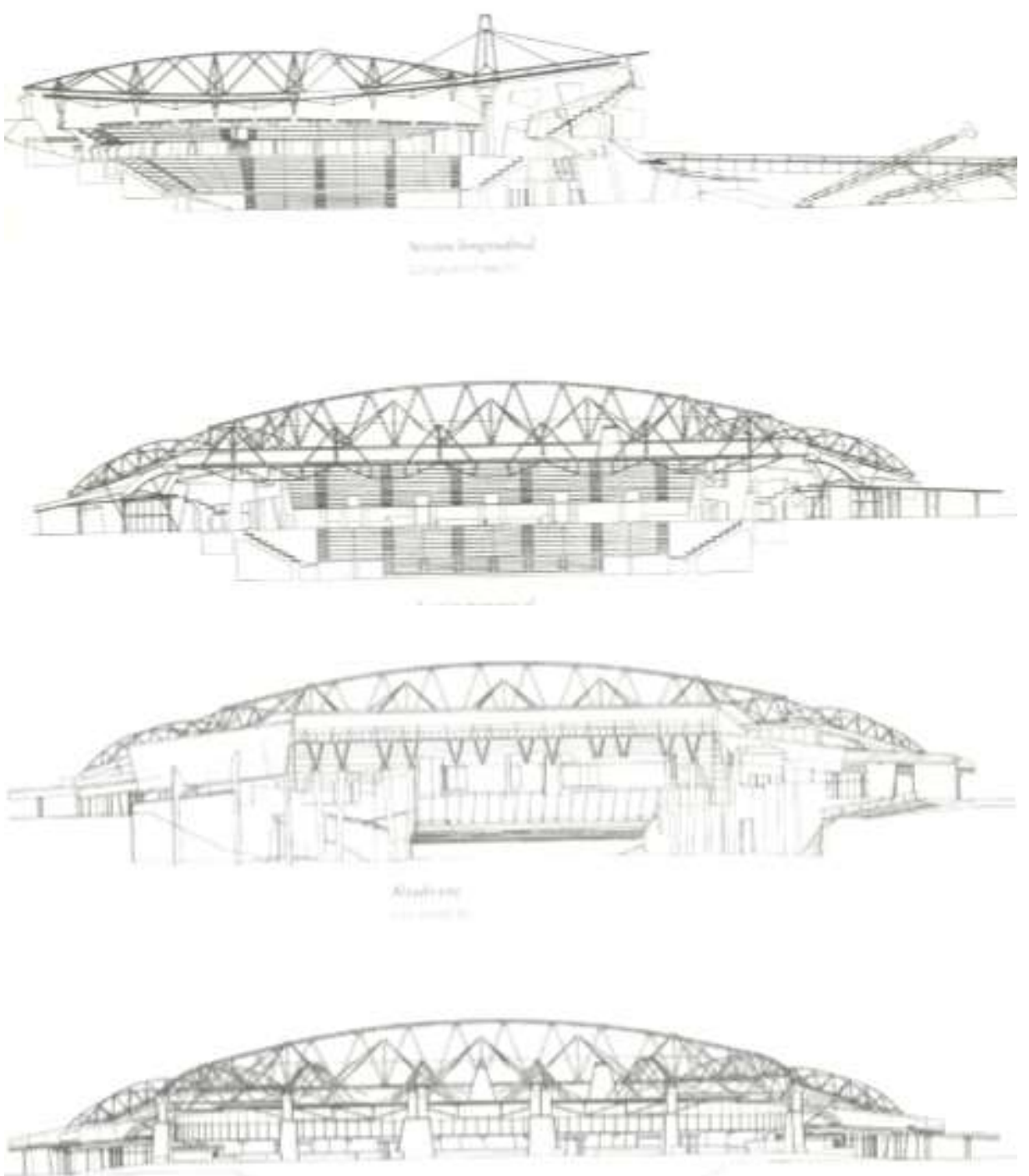

Ilustración 5-26

455 Secciones y alzados del proyecto de construcción con la solución de cubierta apoyada, que siguió al derrumbe de la cubierta tensada. 

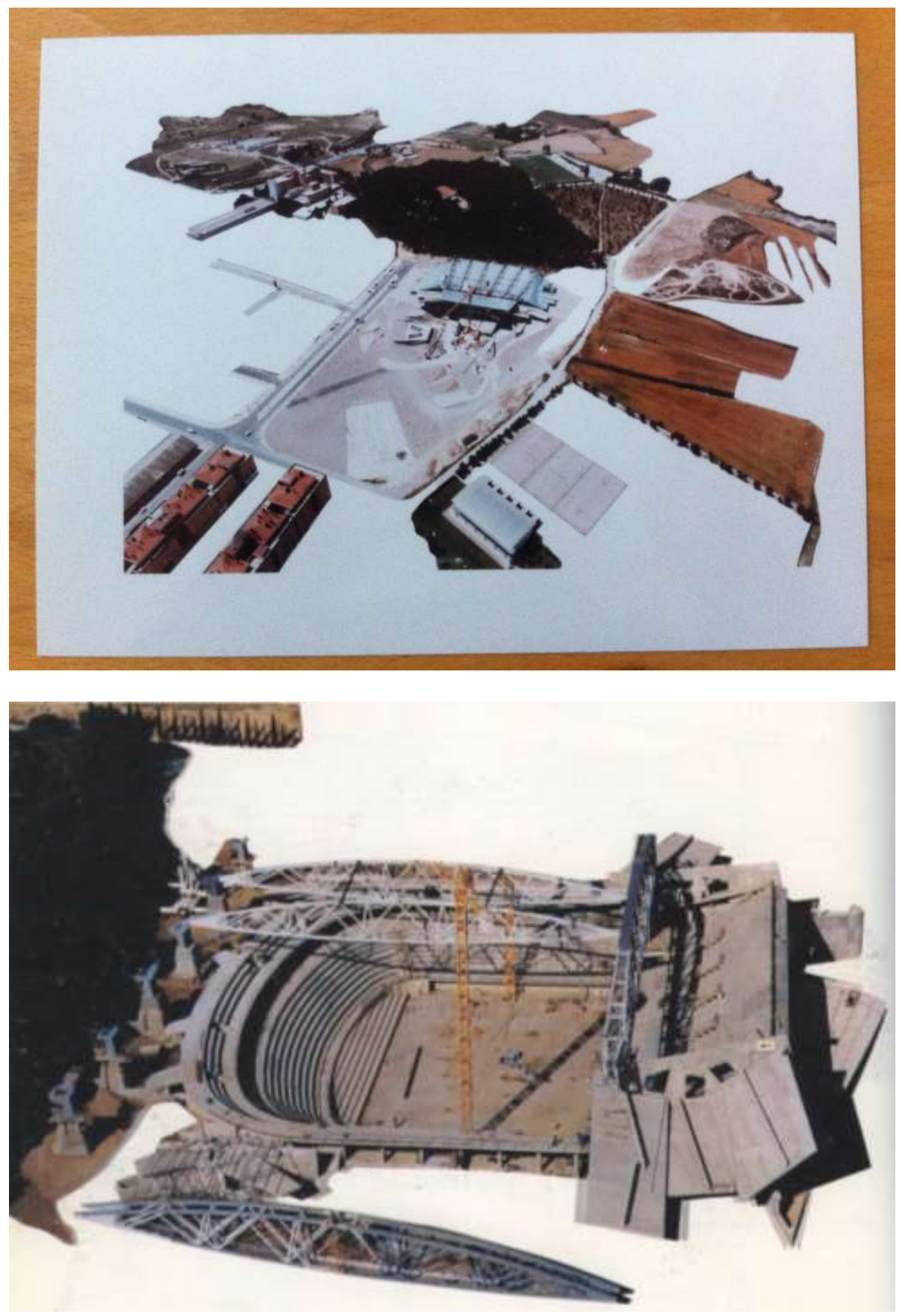

llustración 5-27 $7^{456}$

456 Fotografías aéreas que muestra la construcción de la cubierta apoyada. Como se puede comprobar, en la imagen inferior, ya se han izado y colocado dos de las cerchas que enlazan los mástiles próximos al bosque y la cercha principal ubicada encima de la tribuna principal. @Fundació Enric Miralles. 

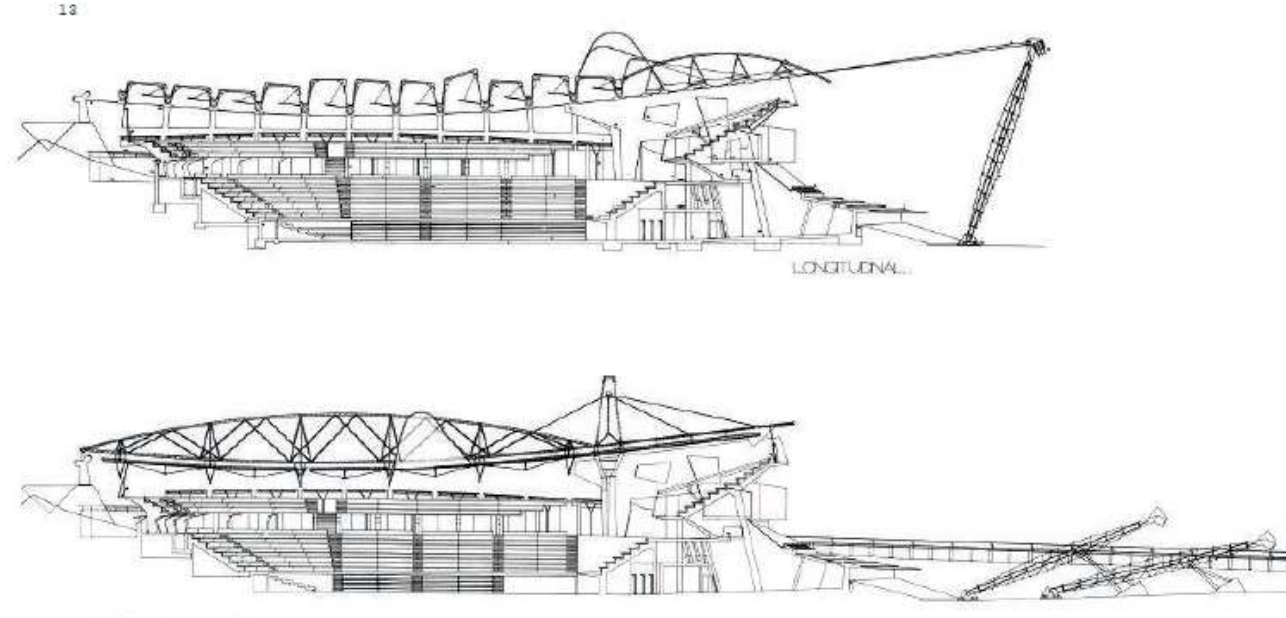

$5-28^{457}$

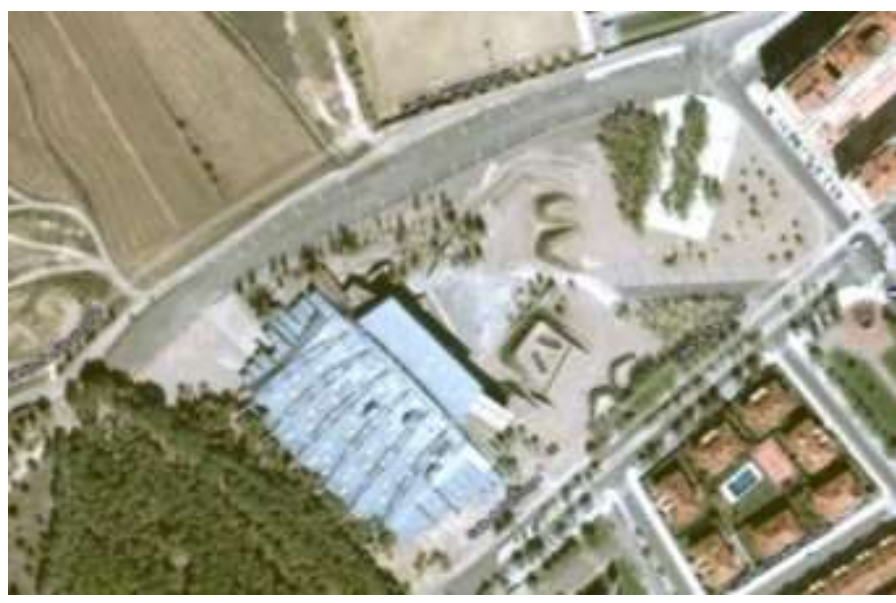

Ilustración 5-29458

Como se puede comprobar se mantuvo la catenaria que describía la cubierta atirantada, resultando el espacio el interior el mismo con la cubierta apoyada finalmente construida.

\section{La obra en la actualidad}

Mientras que por el lado Norte, sigue habiendo paisaje natural, campos de cultivo, la ciudad por el lado Sur siguió creciendo hasta llegar al solar del Pabellón de deportes, según una tipología de viviendas de baja densidad. Miralles sabia que por el lado del bosque quedaría intacta esa experiencia arquitectónica. Se observa como los pinos han seguido creciendo con rapidez como es típico en esta especie arbórea y prácticamente se introducen en la cubierta.

\footnotetext{
457 Contraste entre las secciones de la cubierta tensada que se hundió y la que finalmente se construyo apoyada en la parte inferior.

${ }^{458}$ Fotografía de satélite actual facilitada por Google Maps. Mientras que por el lado Norte, sigue habiendo paisaje natural, campos de cultivo, la ciudad por el lado oeste creció hasta llegar al solar
} 

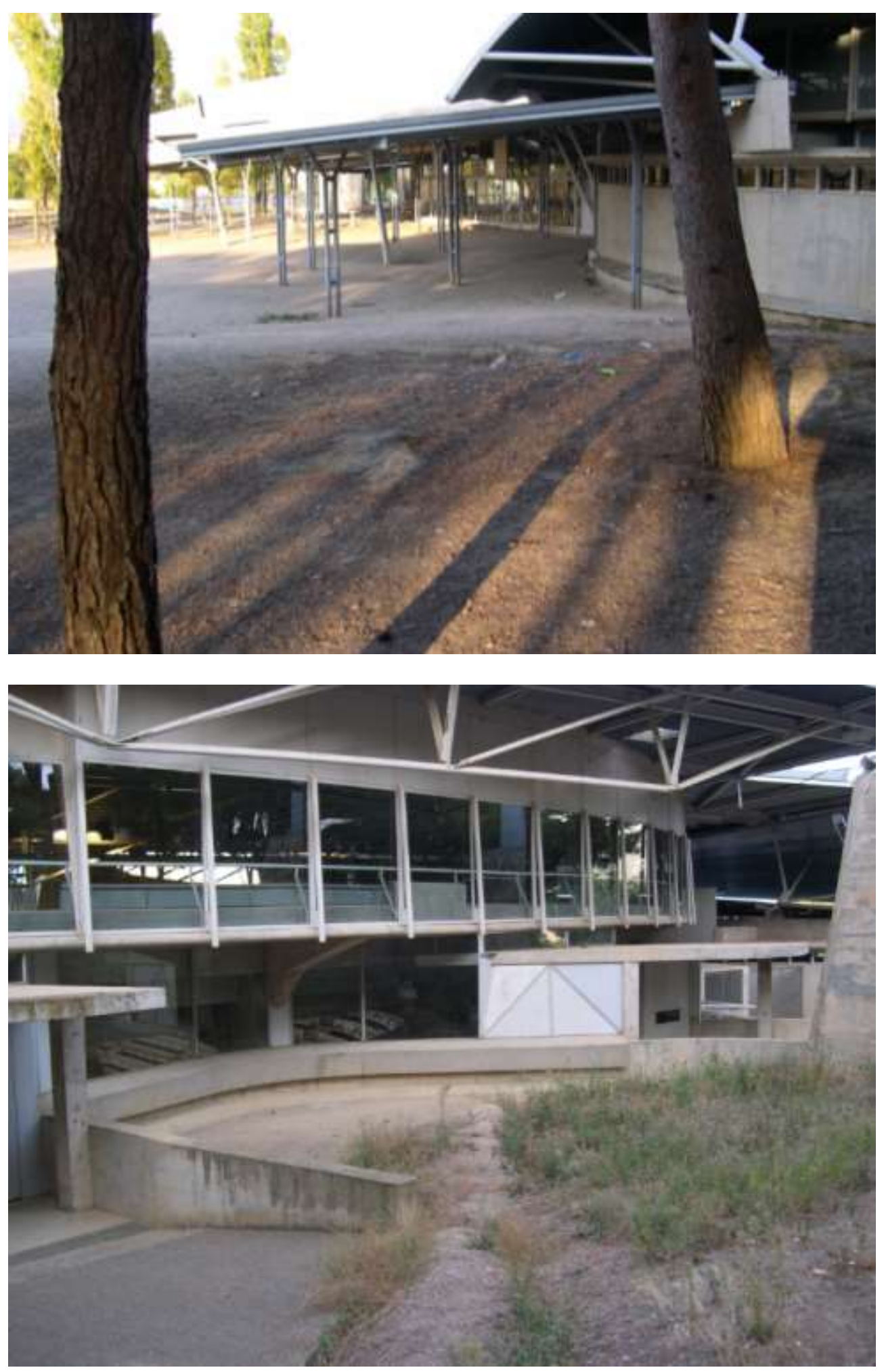

Ilustración 5-30 459

459 Pabellón Deportes de Huesca (1988 - 1994). En la actualidad. Vistas desde el bosque hacia el edificio. Fotografias del autor de la Tesis. 

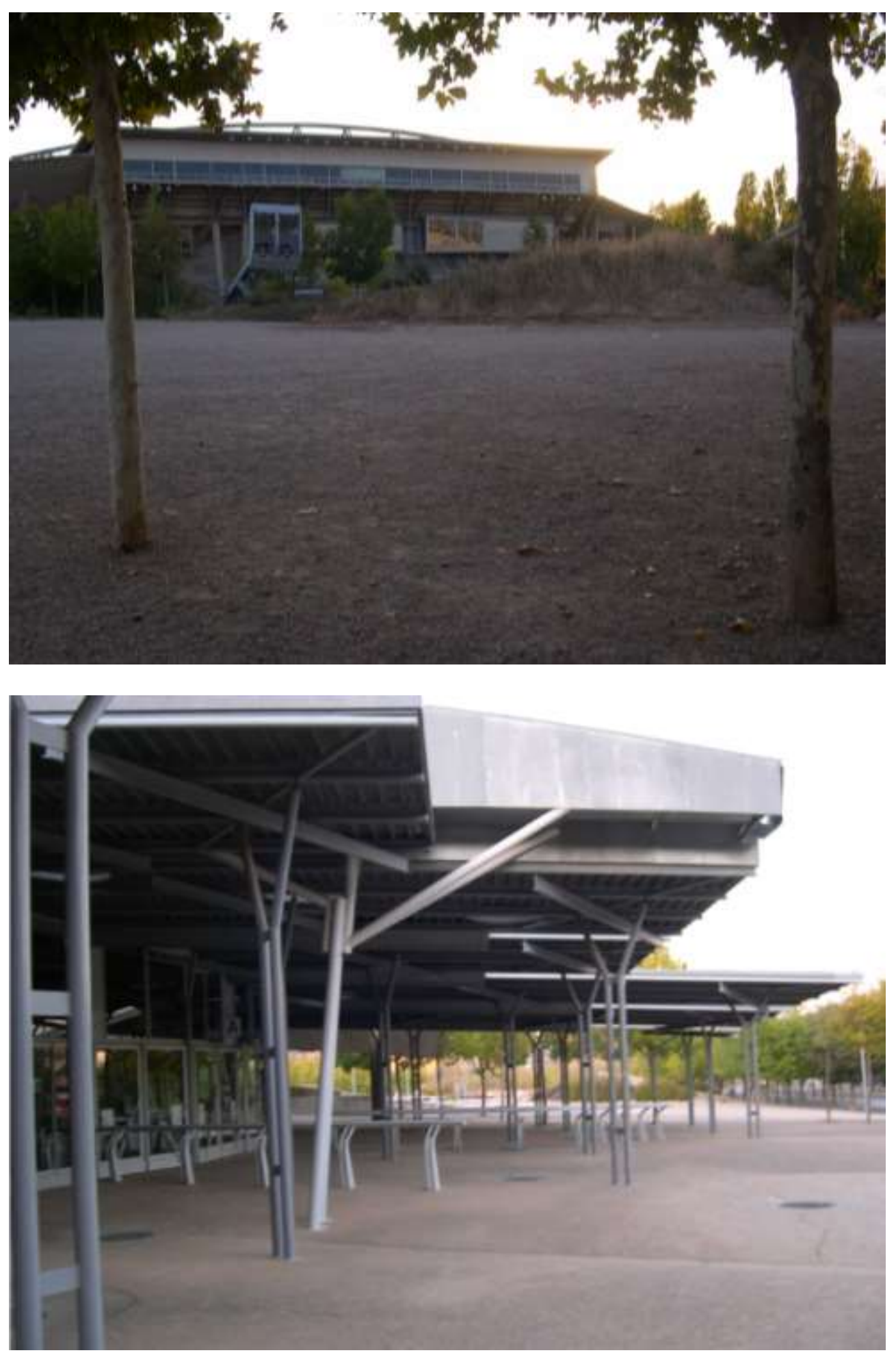

Ilustración 5-31 460

460 Pabellón Deportes de Huesca (1988 - 1994). En la actualidad. En la imagen superior como surge el edificio cuando se llega desde la ciudad de Huesca, en la inferior accesos al edificio por lateral Este. Fotografias del autor de la Tesis. 


\subsection{ACCIONES CONCRETAS}

\subsubsection{TOPOGRAFIA}

"En Huesca el suelo al acercarse al edifico le da forma...El perfil del suelo peina el agruparse de los espectadores...la construcción cubre estas formas...Huesca funciona como una plaza, como un anfiteatro al aire libre..."

Enric Mlralles. ${ }^{461}$

En este proyecto, se reúnen los experimentos topográficos ya realizados en el Cementerio de Igualada, pero aqui el salto de escala del proyecto es considerable El primer movimiento que realizan Miralles y Pinos, consiste en preparar el terreno sobre el que se levantara la obra. Para minimizar el impacto, se decide excavar en la tierra como respuesta al problema planteado por el excesivo tamaño del edificio, que desde la idea de concurso, se perseguia que fuese lo menos perceptible posible especialmente en el lado del edificio que daba al bosque. Por tanto los graderios de los espectadores se excavaran en el terreno modificando la topografia cercana al bosque.

Tambien se realiza una excavación en el extremo opuesto al bosque para generar un lugar equivalente al del interior del edificio. Esta excavacion da la dimension del lugar generando un "puente" entre la ciudad y el bosque que antes no existía mediante un amplio espacio público realizado exnovo que antecede al edificio;. Las formas de la excavación recuerdan la plasticidad de las pinturas de Arp.

El trabajo topográfico por tanto modela el terreno existente y prepara el tránsito desde los límites de la ciudad con el edificio y el bosque de pinos del Cerro de San Jorge. Construir consiste en mover material de un lugar a otro, sustrayendo la materia a la Naturaleza para reorganizarla en otro lugar. La tierra de la excavación no se transportara a vertedero, tan solo se cambiara de lugar dentro del mismo solar, para configurar los taludes y las colinas artificiales que alojan cuartos técnicos de instalaciones en su interior. Por tanto, el desplazamiento de la tierra otorga especificidad a un entorno desolado y lo transforma en un entorno apropiado para el edificio

Tres elementos de contorno generan el exterior de la intervención: una serie de topografías concatenadas que encierran salas técnicas; una rampa serpenteante y una tribuna principal que hace de telón de fondo separando interior y exterior del pabellón. El proyecto se dibuja desde el exterior, haciendo que el espacio interior sea el negativo de la suma de decisiones tomadas desde el exterior. ${ }^{462}$

\footnotetext{
461 Cejas. El Croquis 50. El Croquis editorial, San Lorenzo de El Escorial, pág. 205.

462 Para mas información puede consultarse la Tesis de Javier Fernandez Contreras "La planta Mlralles: Representación y Pensamiento en la Arquitectura de Enric Miralles", leída en la ETSAM. UPM en el año 2013, pág. 102
} 


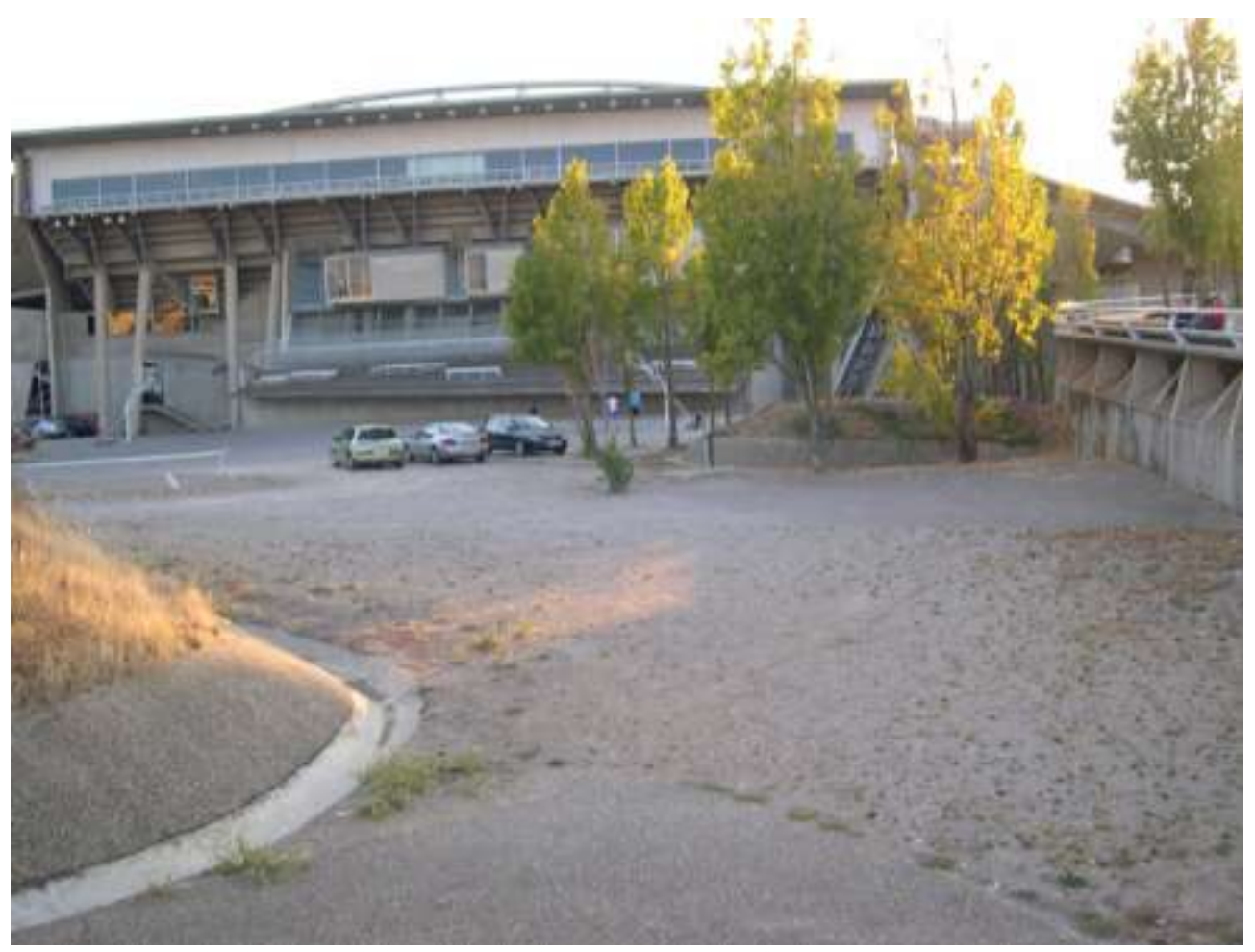

Ilustración 5-32 ${ }^{463}$

En Huesca, no solo se excava el terreno para emplazar su pista exterior, sino que continua la excavación para emplazar también la pista interior cubierta, rodeada de graderíos que partiendo del nivel de rasante, descienden para buscar la cota de la pista de juego de baloncesto. La sensación de recogimiento que se tiene cuando se desciende al plano de la pista exterior es significativa y recuerda al descenso que se produce en Igualada. Como allí, el entorno no ofrece la calidad suficiente para dialogar con este y por tanto la especificidad se crea desde el propio proyecto.

${ }^{464}$ Construir consiste en mover material de un lugar a otro, sustrayendo la materia a la Naturaleza para reorganizarla en otro lugar. La tierra de la excavación no se transportara a vertedero, tan solo se desplazara de lugar dentro del mismo solar, para configurar los taludes y las colinas artificiales que alojan los cuartos técnicos de instalaciones en su interior. Por tanto, el desplazamiento de la tierra otorga especificidad a un entorno desolado y lo transforma en un entorno apropiado para el edificio. Se excava en un lado del solar para alojar el edificio y se amontona en el otro, para conseguir recogimiento.

\subsubsection{PROGRAMA}

El proyecto tiene una vocación de experimentación basado en la composición por elementos partiendo de la fragmentación en planta. Los planos que documentan el proyecto, reflejan fragmentación, dinamismo y una heterodoxia similares a los proyectos que se expusieron en la exposición "Deconstructivist Architecture"

\footnotetext{
${ }^{463}$ El trabajo topográfico modela el terreno existente y prepara el tránsito desde los límites de la ciudad con el edificio y el bosque de pinos del Cerro de San Jorge. La intervencion de Miralles y Pinos, genera un "puente" entre la ciudad y el bosque que antes no existía. Fotografia tomada por el autor de la Tesis.

${ }^{464}$ Extracto de Ramón Faura. Enric Mlralles: 1972-2000, Editorial Fundación Caja de Arquitectos, Barcelona 2011, pág. 173-193
} 
celebrada en el MOMA ${ }^{465}$ en el verano de 1988, año en el que Miralles y Pinós proyectan el edificio. El proyecto refleja cierta dependencia de modelos tradicionales en el interior, ${ }^{466}$ pues la pista central de baloncesto y el anillo de graderío simétrico que la rodea resultan convencionales. Sin embargo, en las zonas exteriores se detecta fragmentación y dinamismo, con un repertorio de recursos formales proyectados libremente. Este proyecto se puede entender como una colección de fragmentos despiezados desde una planta matriz. ${ }^{467} \mathrm{La}$ estrategia que desarrolla el programa se realiza con la producción de dobles. La zona de servicio y la tribuna principal separan el interior del exterior, sirviendo tanto a la pista interior de juego como a la pista exterior. La tribuna, que además contiene el gimnasio de entrenamiento, las oficinas de administración, etc., hace de eje de simetría de los dos ámbitos. Pero no se trata de una simetría especular sino de transformaciones. A uno y otro lado, las distintas piezas se doblan con sus variantes; el terreno de juego con sus especificas dimensiones se dobla al exterior, los ordenados asientos del interior se doblan al exterior en variadas topografías. La organización de las distintas partes del programa ayudan a entender la organización del edificio:

1. Muros exteriores y dunas. Definen el ámbito de la pista de juego exterior Bajo las dunas se ubican las salas de maquinas, centro de transformación, grupo electrógeno, etc.

2. Porches de acceso. Son los encargados de mimetizar el edificio con los pinos del Cerro y hacen de elemento de transición de la gran cubierta con el suelo. Unas cubiertas de reducida altura, que el publico casi puede tocar, soportadas por parejas de pilares y los juegos de claros y sombras que se generan bajo estas dos cubiertas en clara alusión al bosque de pinos, así como los elementos verticales que las soportan en desorden aparente, establecen vínculos con los pinos del bosque.

3. Plataforma de acceso. Configurada en forma de anillo perimetral, funciona como un deambulatorio alrededor de la pista de juego interior, facilitando la conexión con todos los lugares públicos y las salidas de emergencia hacia el Cerro.

4. Tribuna principal. Es la pieza que enlaza la pista interior y la pista exterior de juego.

5. Sala polivalente. Funciona como eje de simetría entre interior y exterior, y la estancia donde el edificio se desdobla para pasar desde la pista de juego interior a la pista de juego exterior.

\footnotetext{
${ }^{465}$ Deconstructivist Architecture. MOMA (Museum of Modern Art de Nueva York). 23/06 -30/08/1988. La exposición incluía planos y maquetas de Coop Himmelblau, Peter Eisenman, Frank Ghery, Zaha Hadid, Rem Koolhaas, Daniel Libeskind y Bernard Tschumi.

${ }^{466}$ El tipo edificatorio de pabellón cerrado y compacto

467 Para mas información puede consultarse la Tesis de Javier Fernández Contreras "La planta Miralles: Representación y Pensamiento en la Arquitectura de Enric Miralles", leída en la ETSAM. UPM en el año 2013.
} 


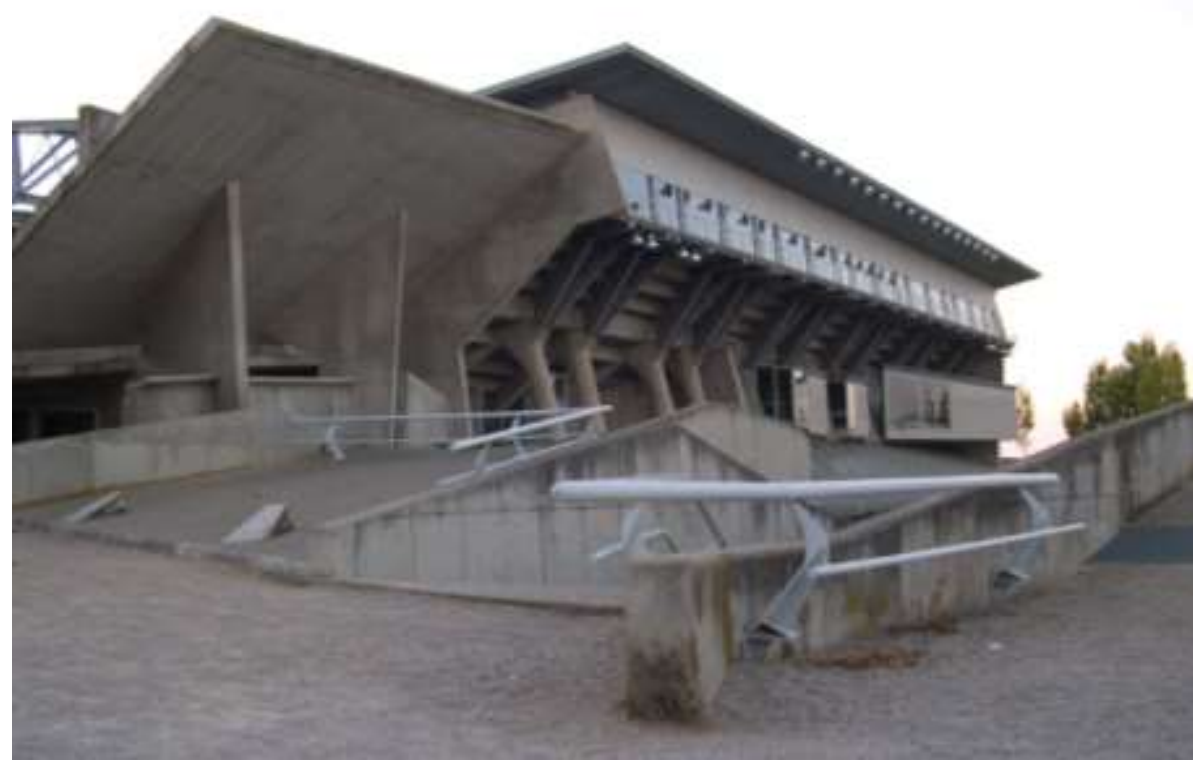

Ilustración 5-33 $3^{468}$

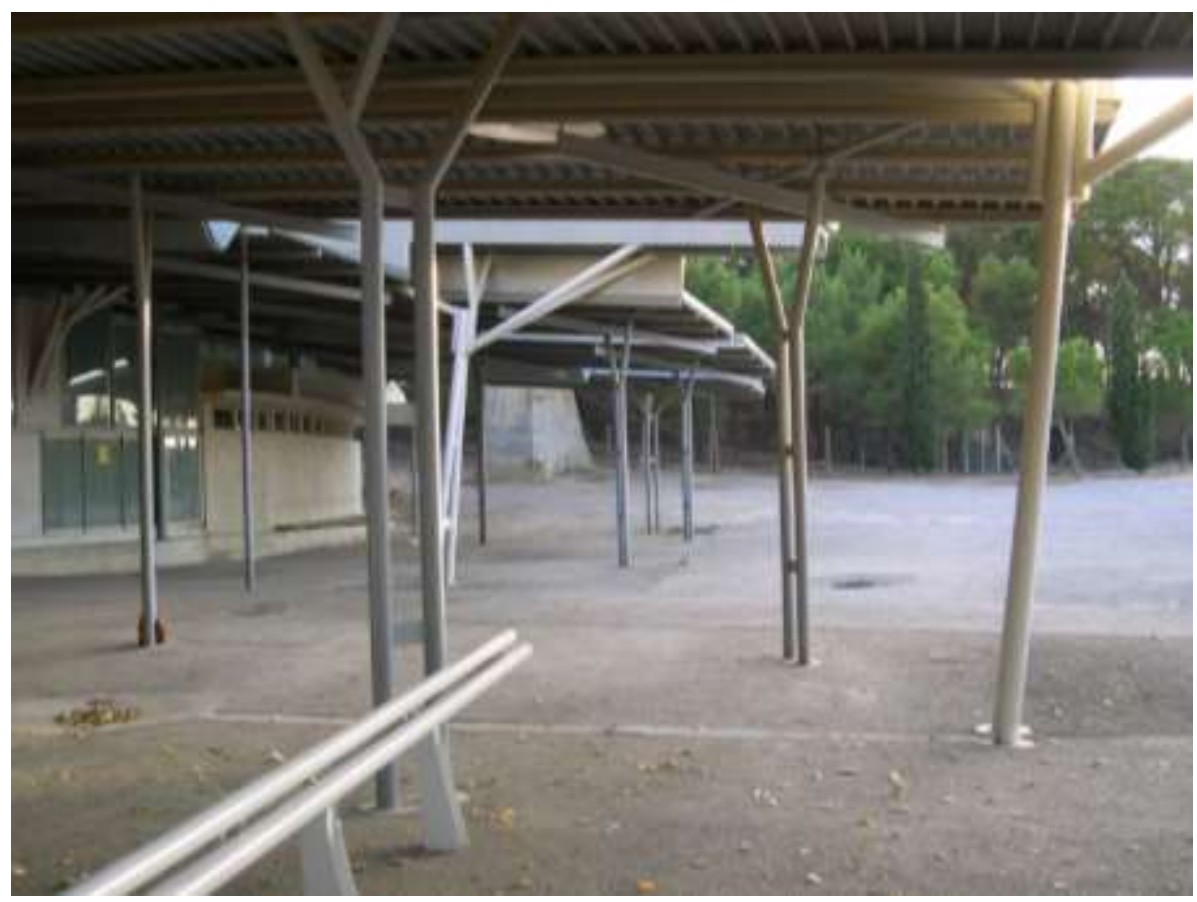

Ilustración 5-34 ${ }^{469}$

${ }^{468}$ Tribuna principal. La estrategia que desarrolla el programa se realiza con la producción de dobles. La zona de servicio y la tribuna principal separan el interior del exterior, sirviendo tanto a la pista interior de juego y a la pista exterior de juego. La tribuna, que además contiene el gimnasio de entrenamiento, las oficinas de administración, etc., hace de eje de simetría de los dos ámbitos. Fotografia tomada por el autor de la Tesis.

${ }^{469}$ Porches de acceso. Los juegos de claros y sombras que se generan bajo estas cubiertas en clara alusión al bosque de pinos, así como los elementos verticales que las soportan en desorden aparente, establecen vínculos con los pinos del bosque. Fotografia tomada por el autor de la Tesis. 


\title{
5.2.3. CUBIERTA
}

\begin{abstract}
" El techo debería casi tocar el suelo. Y levantarse ligeramente desde los mástiles lejanos..El suelo debería casi dejarnos subir al techo...Y ambas superficies deberían separarse ligeramente para permitirnos pasar al interior...la sala es el vacio excavado comprendido entre el límite del bosque y los mástiles exteriores. La estructura repite la dimensión del bosque...y se modifica hasta llegar a ser unos pequeños porches de entrada...los mástiles ocupan el vacio anterior. Son un pedazo de información. A los arboles se les pide, con el paso del tiempo, que los tejan de nuevo con la construcción...".
\end{abstract}

Enric Mlralles. ${ }^{470}$

Desde el punto de vista compositivo, se detecta una dialéctica tectónico estereotómica, en la que basamento y cubierta se separan lo justo para que el público pueda acceder a las pistas. Se cubre el Pabellón con una cubierta suspendida, del menor espesor posible gracias a su estructura tensada, para no superar la cota de coronación de los arboles cercanos del Cerro de San Jorge. Este alarde estructural es resultado de la colaboración de los arquitectos especializados en Estructuras, Obiol y Bufrau que ya venían colaborando con Miralles y Pinos desde su "Opera prima". ${ }^{471}$ La cubierta se piensa tensada como una gran lona de espesor casi despreciable para que el edificio no generase volumen, ni destacase por encima de la cota que los arboles del bosque tienen en esa zona. La cubierta se sostiene según un sistema de ocho cables tensados entre las pilas de hormigón en contacto con el bosque y dos grandes mástiles en el extremo opuesto. Los haces de catenarias se cruzan y con ello se arriostran entre sí. Sobre dichos haces de cables tensados, se dispone transversalmente una cubierta ondulada para alojar lucernarios, instalaciones, etc.

Miralles coloniza el entorno del edificio mediante la solución sustentante de la cubierta, en la que los seis caballetes de hormigón entre los pinos del bosque de la fachada oeste, y dos mástiles por el lado este, se intercambian los tensores que construirán la cubierta. Ello convierte el entorno en proyecto y el proyecto en entorno. El edificio propiamente dicho es aquello que queda entre el suelo excavado y la cubierta. La gran escala de la cubierta ayuda a relacionar el edificio con el paisaje en el que se implanta. Las cubiertas generan sombras que contribuyen a anular las fachadas, y ello ayuda a fundir la arquitectura con el paisaje.

470 "Palacio de deportes de Huesca" El Croquis 50 pág. 225-226.

${ }^{471}$ Las pérgolas en Parets del Valles, donde se hace trabajar al limite a la estructura. 


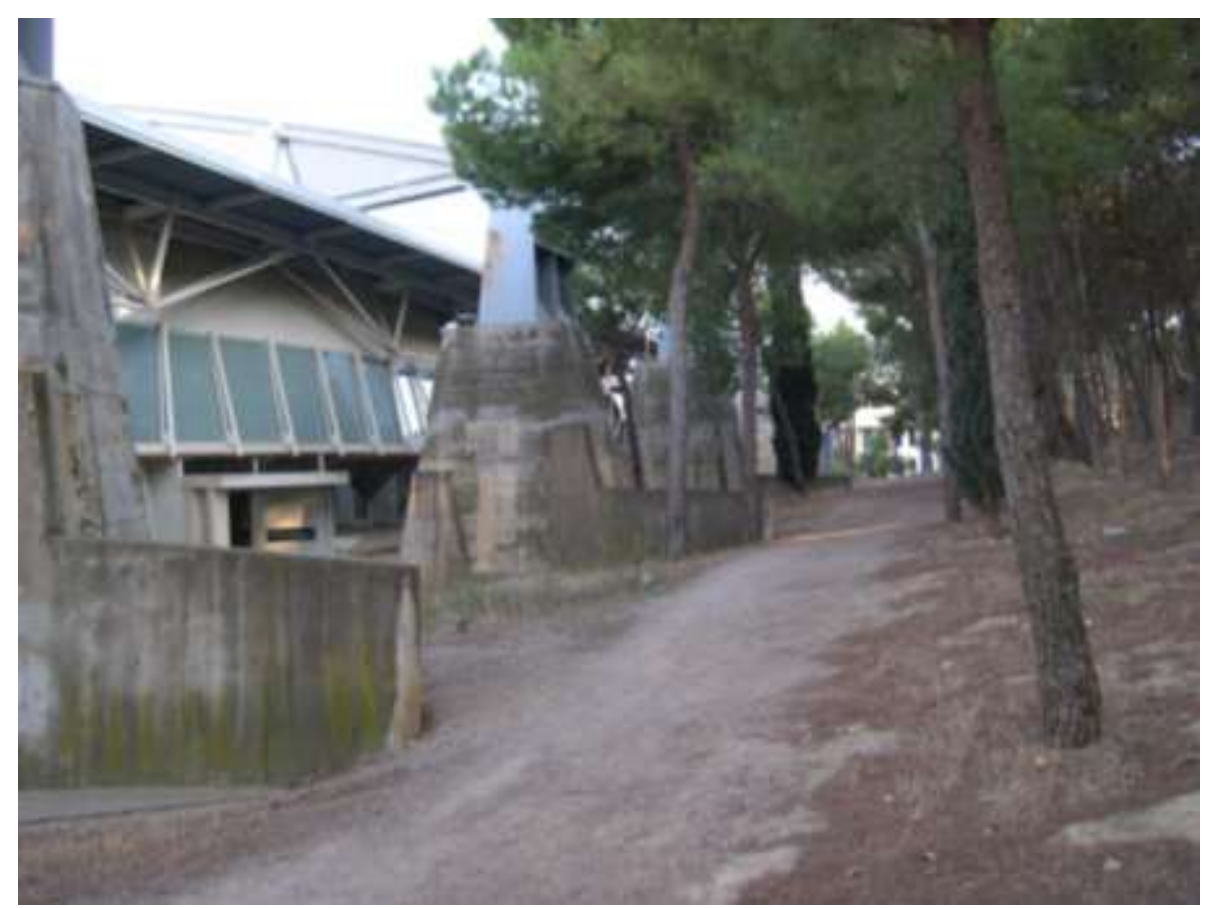

llustración 5-35

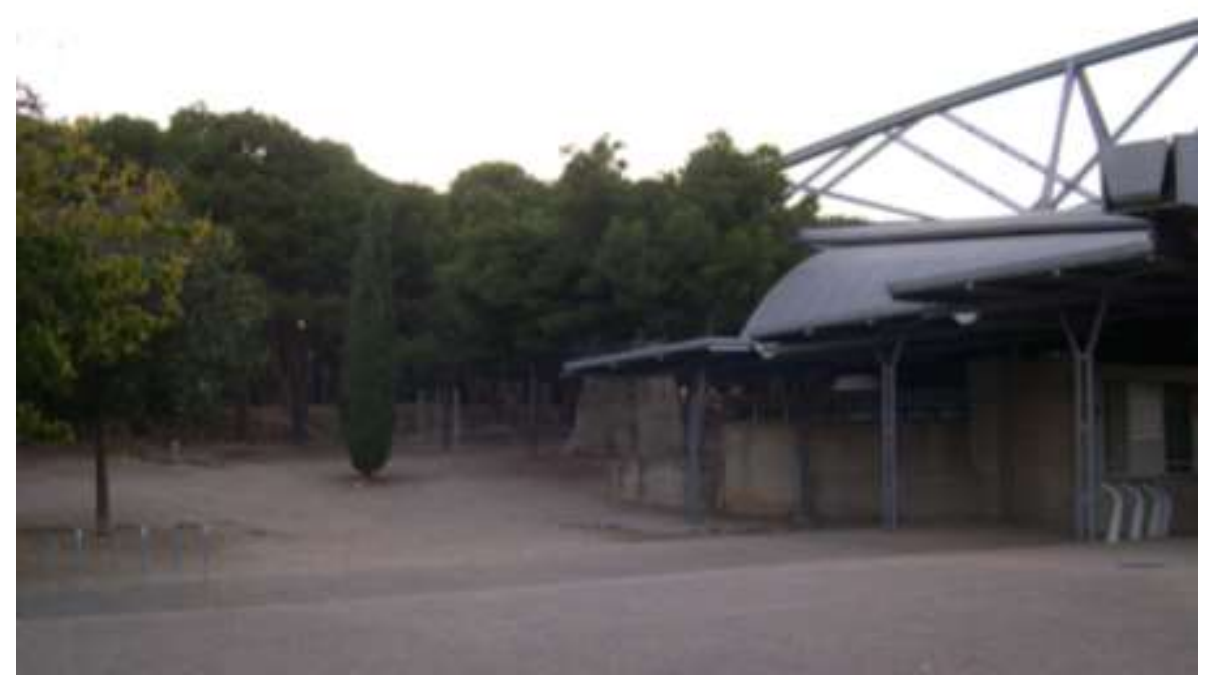

llustración 5-36

${ }^{472}$ Los mastiles que soportan la cubierta por el lado del bosque. Fotografia tomada por el autor de la Tesis.

473 Las cubiertas generan sombras que contribuyen a anular las fachadas, y ello ayuda a fundir la arquitectura con el paisaje. Fotografia tomada por el autor de la Tesis. 


\subsubsection{RELACIONES INTERIOR - EXTERIOR}

Conviene recordar que el lema con el que Miralles y Pinós se presentaron al Concurso fue "Dentro y fuera", precisamente para enfatizar la imprecisión de los límites del edificio que habían proyectado.

La cota del terreno donde se sitúa la pista de juegos exterior coincide con la de la pista de juego interior. Existen muchos episodios en la frontera entre interior exterior, en los que es difícil saber si uno se encuentra en el exterior o en el interior. El Pabellón no se proyecta desde el interior, sino desde el exterior. No es que se renuncie a la espacialidad interna, sino que los arquitectos entienden que el organismo construido no es ya un objeto cerrado sobre sí mismo que pueda entenderse sino es dentro del campo exterior que lo incluye. La arquitectura no la conciben como un ente autónomo, y por tanto, ya no cabe mirar el mundo desde el interior. El interior no se piensa en términos de generar el proyecto, sino como el resultado de una estrategia constructiva. Se apuesta por un mecanismo de proyecto y se lleva al límite. Aquí el futuro usuario no podrá modificar aspectos concretos del interior del edificio, pues al haberse concebido la arquitectura en términos de totalidad; una vez formalizada estructuralmente no es posible desvincular la concreción del interior de la forma exterior. Es una manera de hacer de Miralles y Pinós que está pensada no como un diseño surgido de una yuxtaposición de decisiones, sino como una reacción en cadena generada por decisiones estratégicas que hacen que se garantice su integridad.

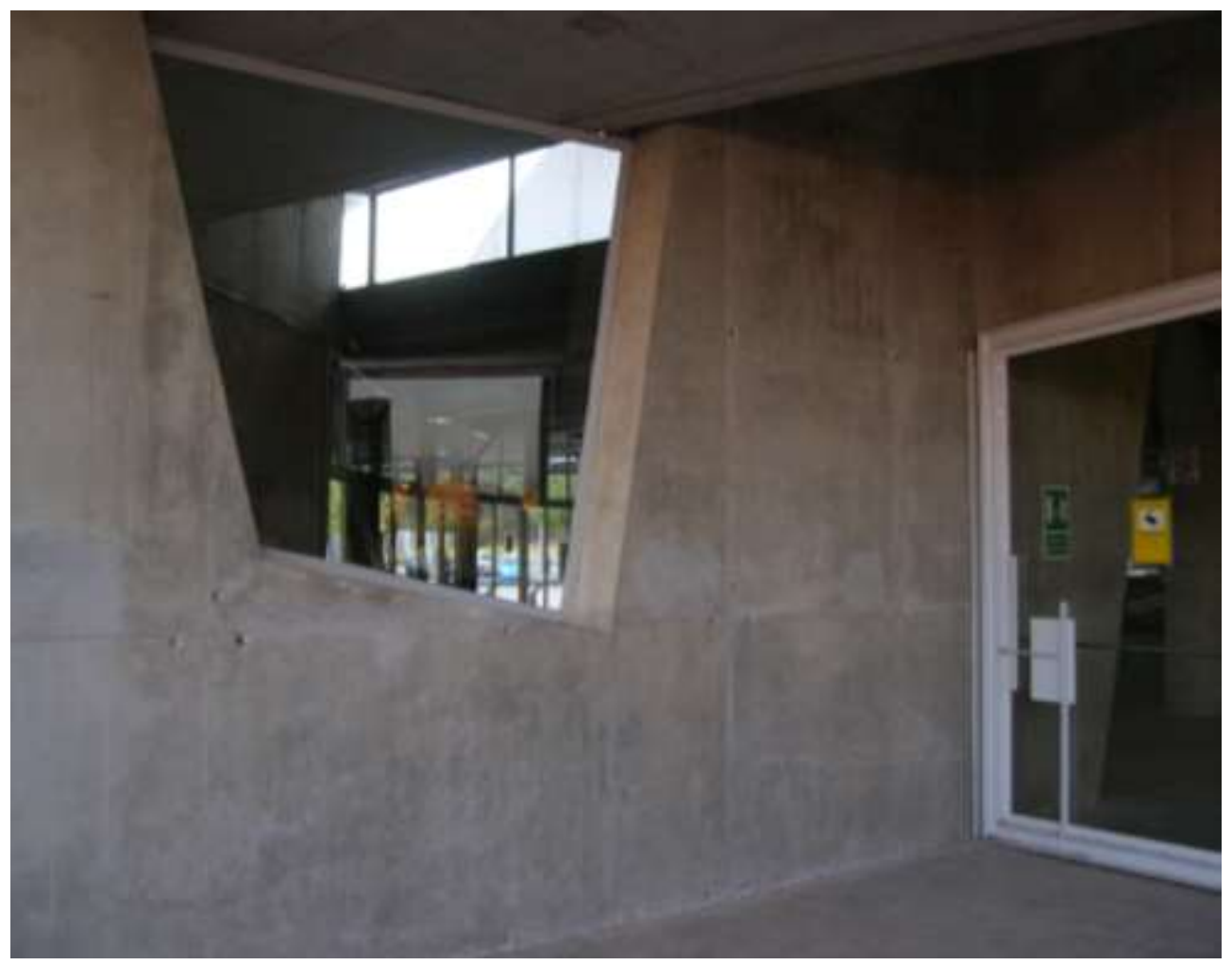

Ilustración 5-37 ${ }^{474}$

\footnotetext{
${ }^{474}$ Existen muchos episodios en la frontera entre interior - exterior, en los que es dificil saber si uno se encuentra en el exterior o en el interior. Fotografia tomada por el autor de la Tesis.
} 
En este proyecto, no se puede hablar de perímetro o contornos precisos y cerrados. No hay un contorno identificable que destaque lo construido del resto. El edificio es un continuo desparramarse que en determinados episodios incluso es atravesado por elementos constructivos, como es el caso de los pilares que atraviesan el cerramiento exterior. El edificio propiamente dicho es aquello que queda entre el suelo excavado y la cubierta, sus alzados no son el objeto de diseño de Miralles sino una consecuencia de lo proyectado en sus decisiones más generales. Lo que se entiende tradicionalmente por fachada, en Huesca no existe. Desaparece el cerramiento exterior perceptivamente hablando. Se percibe un suelo, se percibe un techo, pero entre medias casi nada, solo un fondo continuo transparente de vidrio, que al estar en sombra por los voladizos de las cubiertas, contribuye todavía más a que no se perciba la fachada. El proyecto al configurarse como dos estratos superpuestos: el que corresponde al basamento y el que corresponde a la cubierta , siendo distintos en términos de estructura; perímetro; posición y forma; traerá problemas ${ }^{475}$, pues las indefiniciones de los encuentros en términos de sección entre basamento y cubierta generaran problemas de acondicionamiento al no ser estancas las juntas entre ambos estratos superpuestos. Como señala al respecto David Bestue: "...la vulnerabilidad en los cerramientos...permiten el acceso al interior del edificio y a la cubierta. Para detener a aquellos que quieren colarse se han colocado vallas metálicas. Otra de las consecuencias de esta permeabilidad ...es la inundación sistemática del recinto cuando llueve, unas inundaciones que se han podido reparar con el tiempo, no sin antes llevarse por delante el parquet de la pista de básquet, que se pudrió a causa del agua...”. ${ }^{476}$ De ahí que en los sucesivos proyectos de Miralles, se abordara la definición detallada de los intersticios entre las piezas que componen basamento y cubierta. ${ }^{477}$

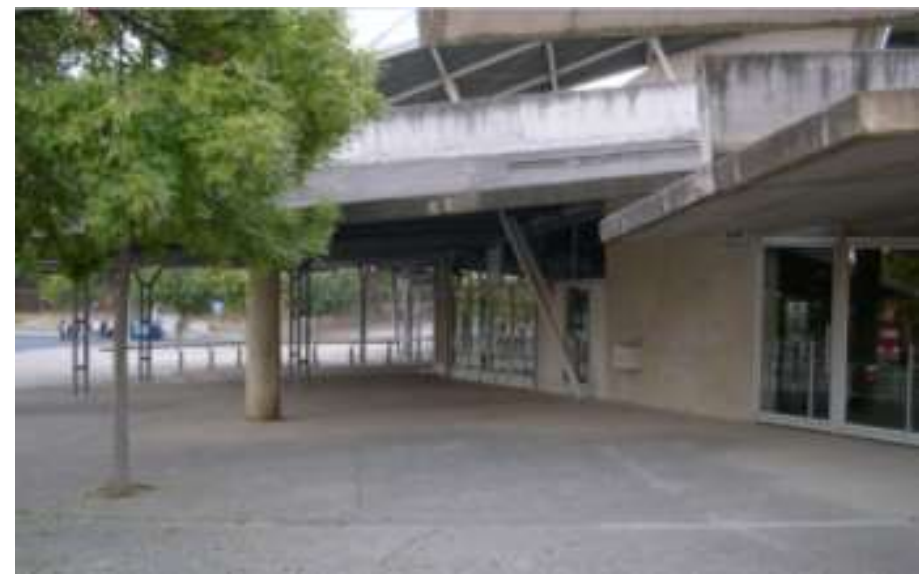

llustración $5-38^{478}$

\footnotetext{
475 Siendo muy difernte si lo comparamos con el convencional pabellón compacto en el que los perímetros de la base y de la cubierta coinciden

476 David Bestue. "Cosas vistas a izquierda y derecha también sin gafas" pág. 208.

${ }^{477}$ Este problema surge de la manera de proyectar de Miralles, que prioriza el trabajo en planta y descomponiendo la planta general en distintos fragmentos proyectados en planos diferentes. Es cuando se reúnen dichos planos en la planta matriz cuando surgen los problemas de unión, especialmente en vertical.

${ }^{478}$ Las indefiniciones de los encuentros en términos de sección entre basamento y cubierta generaran problemas de acondicionamiento al no ser estancas las juntas entre ambos estratos superpuestos. Fotografia tomada por el autor de la Tesis.
} 


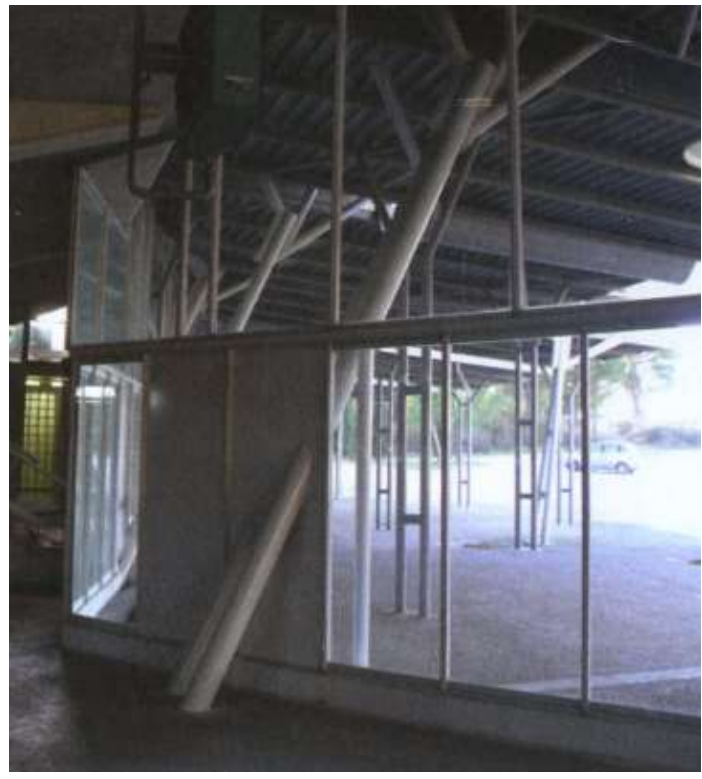

Ilustración 5-39479

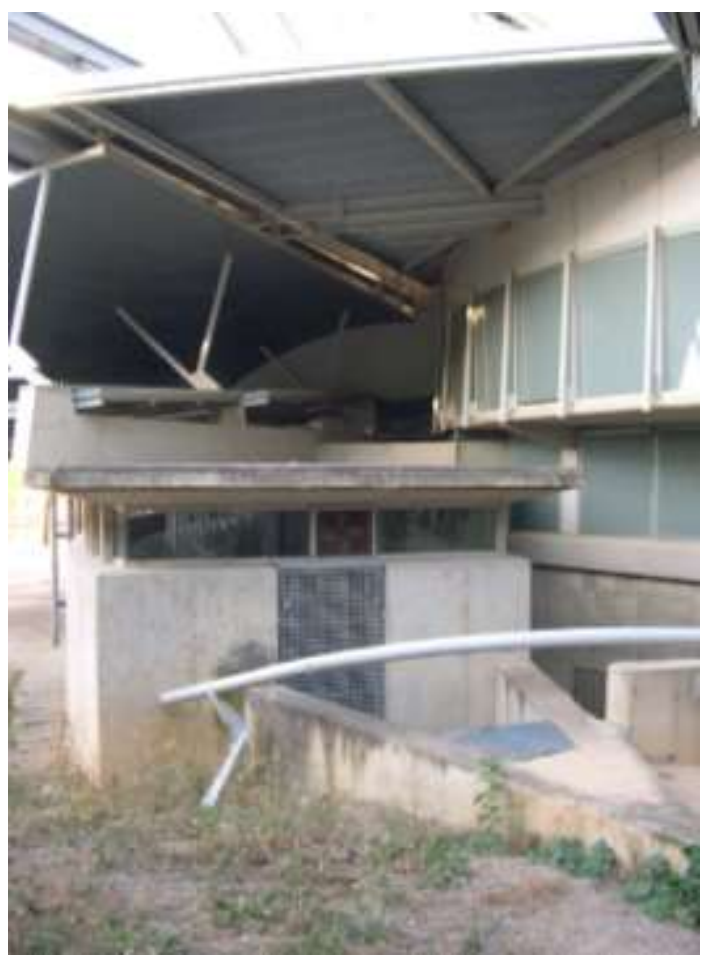

Ilustración $5-40^{480}$

\begin{abstract}
${ }^{479}$ No se puede hablar de perímetro o contornos precisos y cerrados. Aquí no hay un contorno identificable que destaque lo construido del resto. Además, es un desparramarse continuo que incluso llega a ser atravesado por elementos constructivos, como es el caso de pilares que atraviesan el cerramiento exterior

${ }^{480}$ Las indefiniciones de los encuentros en términos de sección entre basamento y cubierta generaran problemas de acondicionamiento al no ser estancas las juntas entre ambos estratos superpuestos. Fotografia tomada por el autor de la Tesis.
\end{abstract}


El acceso al Pabellón se realiza por los flancos, por sus lados menores, después del itinerario orquestado por los arquitectos que enlaza la ciudad con el edificio y el bosque, se evita una entrada simétrica que jerarquice una fachada monumental.

Existen muchos episodios en el edificio en los que estando en el interior percibes el exterior y viceversa, destacando especialmente los episodios que se generan en la fachada que da al Cerro de San Jorge. En dicha zona, merecen destacarse las salidas de emergencia y las ventanas - banco corridas que discurren por la parte de la fachada que toca el suelo.

Destacar que en especial en el lado Oeste del Pabellón en su contacto con el bosque, se dan episodios de conexión entre interior y exterior con mucha intensidad. Las gradas altas tienen un sistema de sustentación que permite que entre las gradas bajas y las altas, se pueda ver el paisaje alrededor; generando esas conexiones entre interiores y exteriores que se persiguieron desde el Concurso, haciendo el lema con el que participaron

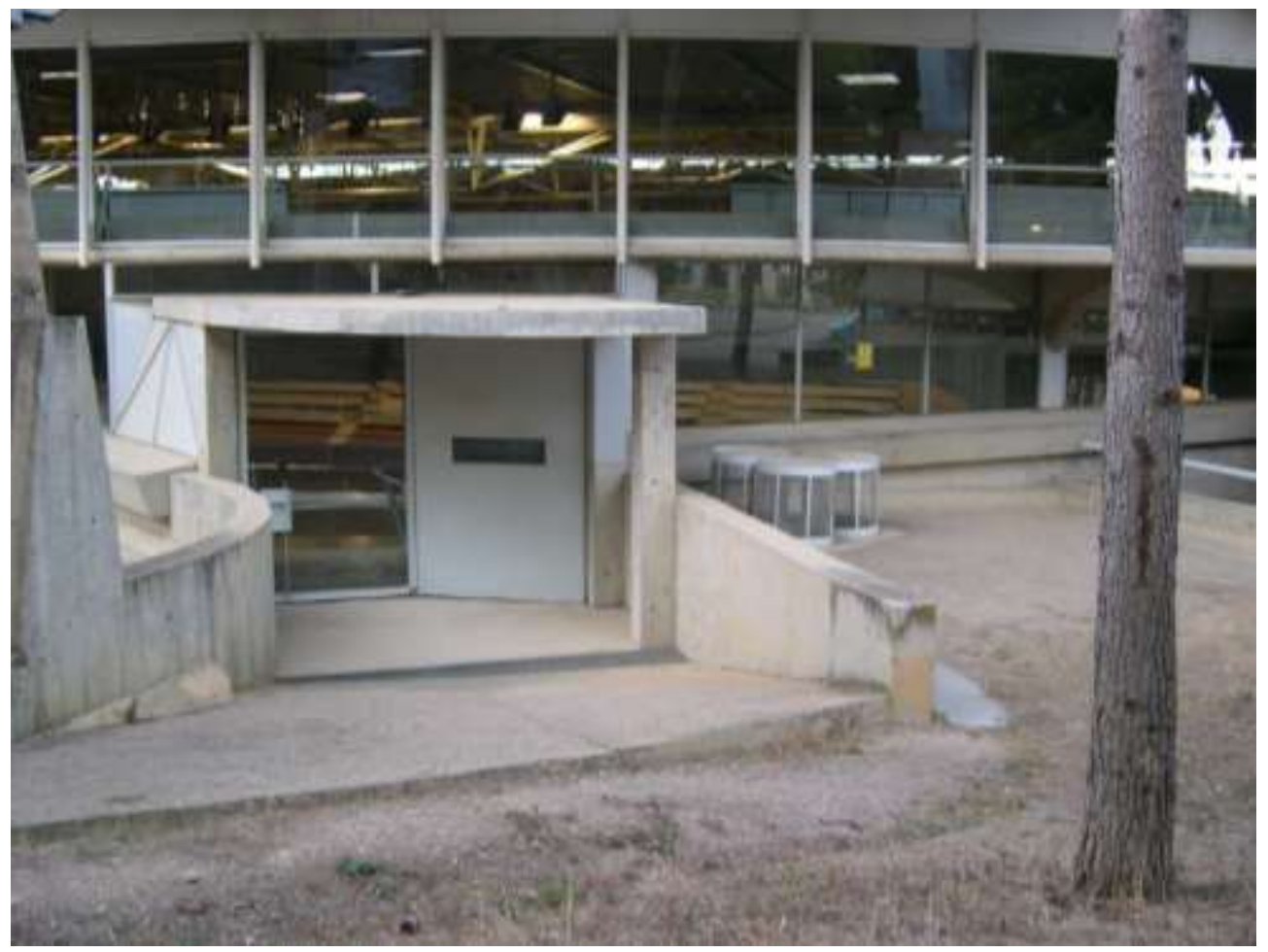

Ilustración 5-41

${ }^{481}$ imagen tomada por el autor de la Tesis, en el que se muestran las relaciones exterior interior en la fachada que da al bosque. 


\subsubsection{RECORRIDOS}

\begin{abstract}
"...In elaborating the potentialities of place and program, design also involves intuiting the forces (visual and intangible as much as functional and physical) that do, can, or can only be imagined to exert pressure on the site. These forces are then made manifest in the slashing diagonals of walls, ramps, or views, in hovering, teetering planes and elastic, sinuous curves that also guide movement through and around the projects. "
\end{abstract}

Peter Buchanan. ${ }^{482}$

El carácter público de la actuación se lo otorga el desplazamiento del interés por el propio edificio al vacio generado entre la tribuna y las ultimas edificaciones de la ciudad, cobrando gran importancia los paseos de borde que llegan a los porches laterales de acceso al edificio.

La intervención, no se puede aprehender con una sola mirada. Se necesita recorrer todo su perímetro para comprender el conjunto. Unas rampas sinuosas comunican las distintas partes del edificio. Como el mismo Miralles recomienda: "Un dato importante para la comprensión del trabajo es una visita a Huesca" ${ }^{483}$

La tensión que acompaña el paseo por el perímetro del edificio para encontrar el acceso al edificio, con una abundante profusión de elementos en forma de recodos, soportales, voladizos, etc. se transforma y contrasta al atravesar el umbral exterior - interior, donde reina una calma y una serenidad propiciadas por el estático espacio interior que sirve a la pista de juegos interior y el graderío que la rodea.

Esa tensión y dinamismo al que somete la obra al visitante cuando pasea por sus exteriores, desaparece cuando se accede al interior, debido a la centralidad que irradia la pista de juego de baloncesto interior junto con el graderío que la envuelve en forma de herradura y la cubierta que aquí en el interior se muestra ya más serena. Como relata B. Alhambra tras realizar el itinerario desde los exteriores y rebasar el umbral hacia el interior: "... hemos traspasado el enigmático laberinto y por fin nos hallamos en un ilusorio remanso de paz..." 484

Los muros de hormigón curvos "serpenteantes" generados por el motivo de la curva y contra curva que enlazan ciudad con edificio y bosque, se les encomienda la tarea de hacer de puente entre los bloques residenciales que representan en esta zona los límites de la ciudad de Huesca y el Pabellón de deportes en los límites del bosque del Cerro de San Jorge. Estos muros, de trazado dinámico, también ayudan a contener las tierras y salvar el desnivel existente entre la rasante de calle y la zona excavada para alojar la zona al aire libre que antecede al Pabellón.

\footnotetext{
482 "Dialogue and Distillation. The Architecture of Enric Miralles and Carme Pinós" The Architecture of Enric Miralles \& Carme Pinós. Edit. LUMEN, 1990.

${ }^{483}$ Enric Mlralles. "Palacio de deportes de Huesca" DA no 32, pag. 44.

${ }^{484}$ B. Alhambra. "Palacio de deportes de Huesca" DA no 32, pág. 66-67.
} 


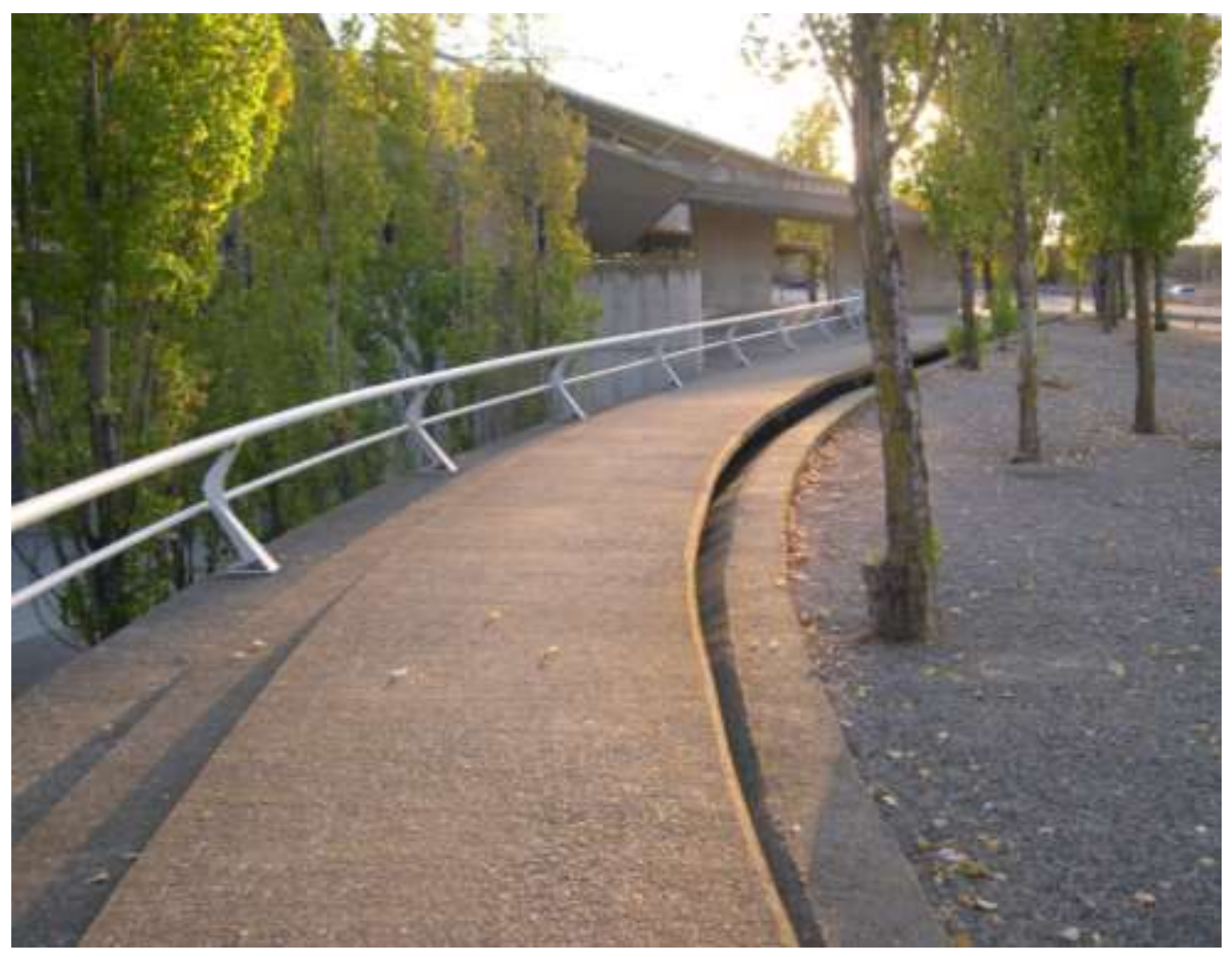

llustración $5-42^{485}$

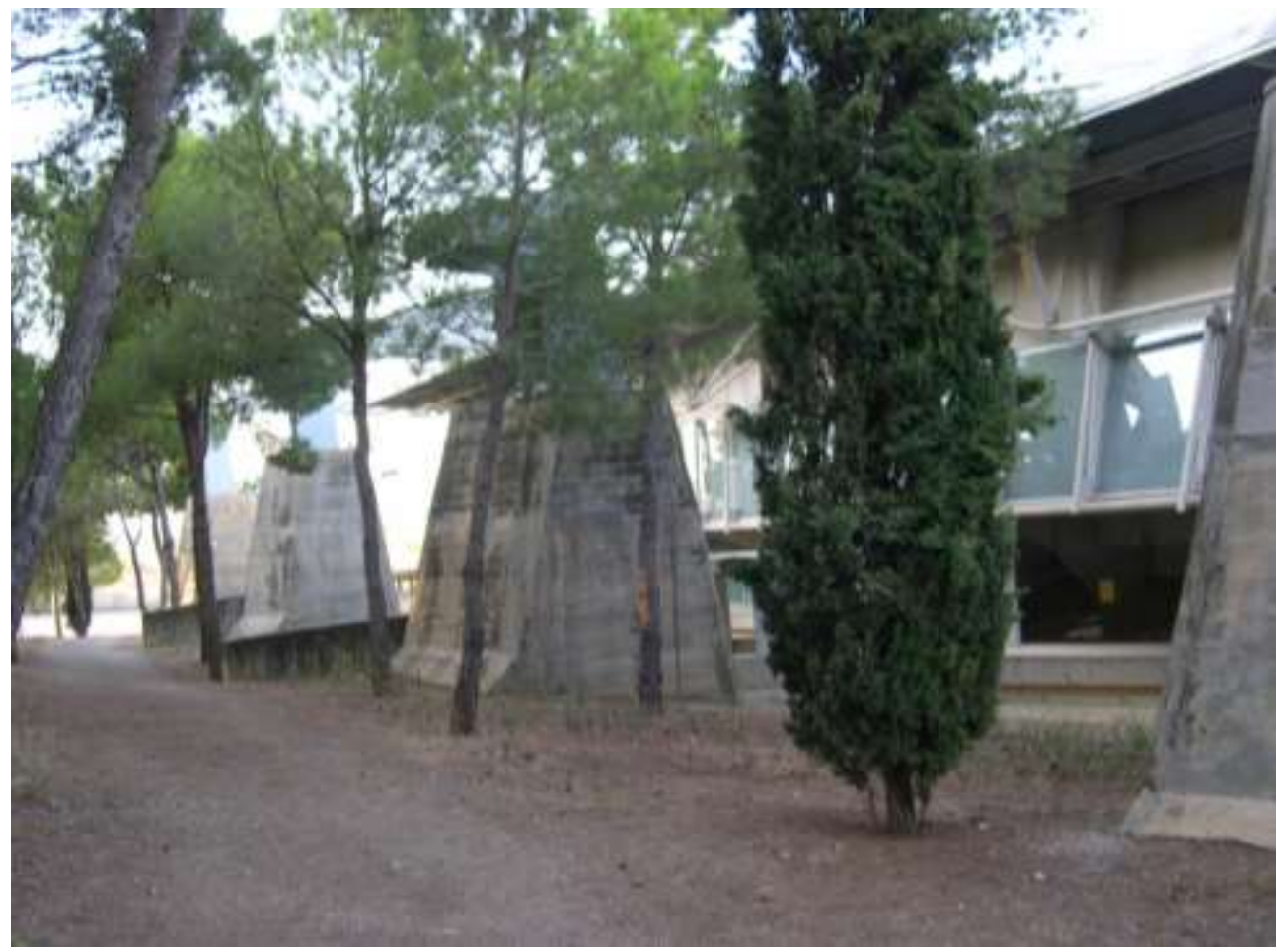

llustración 5-43

${ }^{485}$ Fotografía tomada por el autor de la Tesis en la que se aprecia la parte superior del muro de contención generándose un camino con curvas de gran radio que guía al visitante desde donde acaba la ciudad hasta las entradas al interior por los flancos. 

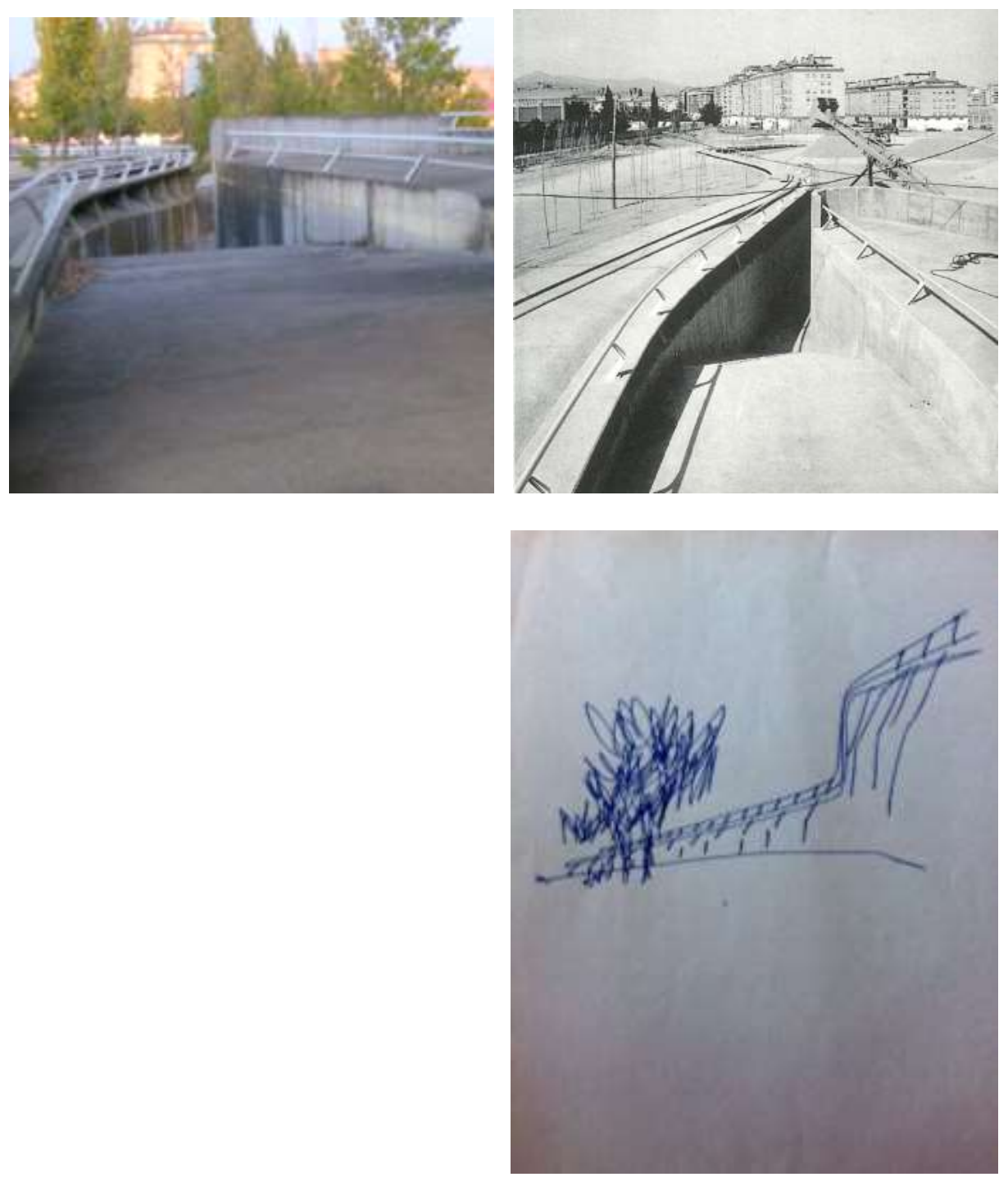

Ilustración 5-44

\footnotetext{
${ }^{486}$ Fotografía del autor de la tesis en la que se muestra el camino que discurre entre los arboles del bosque y el edificio. Destacan los contrafuertes de hormigón armado que actualmente soportan las cerchas de la cubierta apoyada.

${ }^{487}$ Los muros serpenteantes de hormigón que enlazan ciudad con edificio y bosque. A estos muros se les encomienda la tarea de hacer de puente entre el Pabellón de deportes pegado al bosque y los bloques residenciales que representan en esta zona los limites de la ciudad de Huesca. De trazado dinámico, ayudado por la estrategia de la curva y contra curva, también ayudan a contener las tierras y salvar el desnivel existente entre la rasante de calle y la zona excavada para alojar la zona al aire libre que antecede al Pabellón. Fotografia tomada por el autor de la Tesis que se compara con una en blanco y negro tomada recién terminada la Obra. En la parte inferior, croquis manuscrito de Miralles. CFundació Enric Miralles.
} 


\subsection{ACCIONES ABSTRACTAS}

Es difícil entender la escala del organismo construido al contemplarse desde la lejanía de los campos de cultivo orientados a Norte del edificio, dado que no se pueden apreciar elementos escalares (puertas, ventanas, barandillas, etc.) que relacionen su tamaño con el hombre. ${ }^{488}$

De la misma manera que Gaudí gustaba de emplear formas zoomórficas, o más recientemente Eero Saarinen en obras como la Terminal aérea de la compañía TWA en Nueva York, que parece un pájaro que fuese a echar a volar o en su Pabellón de patinaje de la Universidad de Yale, apodado "la ballena de Yale"; en esta obra de Miralles, cuando se observa desde lejos, en concreto desde las zonas de cultivo agrícola, situadas al Norte, se asemeja a una especie de insecto que acabase de salir del bosque y de repente su movimiento hubiera quedado congelado.

En la fachada opuesta orientada a Sur que da a la ciudad, al no poder alejarse al existir edificios construidos actualmente, se aprecian elementos escalares como barandillas, puertas, etc. que ayudan a entender la escala del edificio, integrándose menos con el paisaje por este lado. Y lo mismo ocurre al contemplar la fachada principal pues tiene una forma clara, y una escala monumental de edificio público y de la ciudad, por tanto rompe con la informalidad que el edificio tiene en el resto de sus lados, no cumpliendo por tanto esta cualidad que tanto ayuda a relacionar arquitectura y paisaje.

Por la fachada que da al bosque, al observar el organismo construido a través del tapiz de arboles que hacen de filtro, se velan esos elementos escalares puesto que lo que se aprecia es un zócalo desparramado al que es difícil asignar una escala arquitectónica, alcanzándose con ello una mayor hibridación entre arquitectura y paisaje.

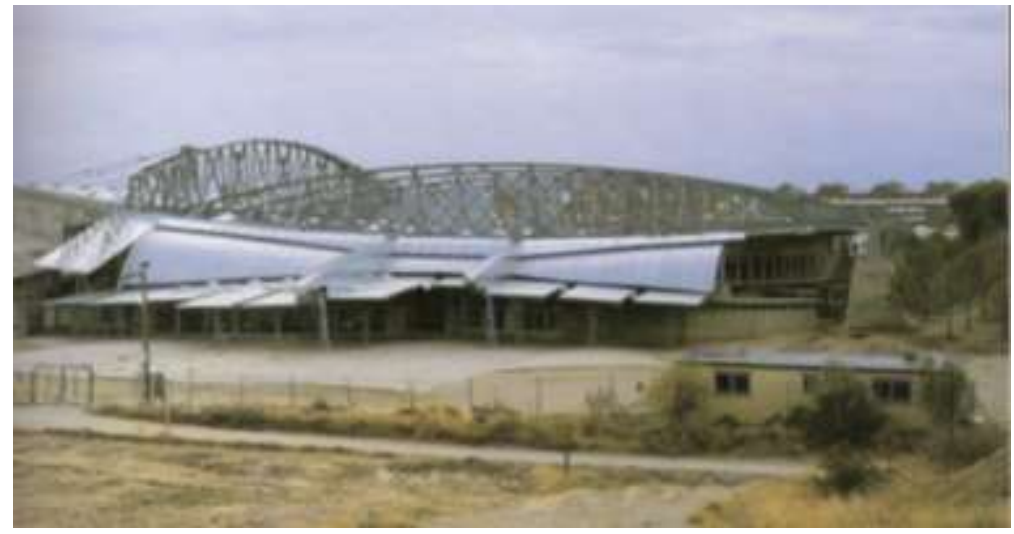

Ilustración $5-45^{489}$

\footnotetext{
${ }^{488}$ Es evidente que las cerchas que hoy soportan la cubierta de gran canto, dan pistas de estar ante una construcción industrial realizada por el hombre y además hacen ganar volumen al edificio. Por ello se añorar la solución de la cubierta tensada que habría ayudado mas a la integración de la arquitectura con el paisaje.

${ }^{489}$ El organismo construido visto desde la lejanía su lado Norte, que da a los campos de cultivo, tiene una escala paisajística y dado que no se pueden apreciar elementos escalares (puertas, ventanas, barandillas, etc.) que te relacionen con su tamaño, es difícil entender su escala. Cuando se observa
} 


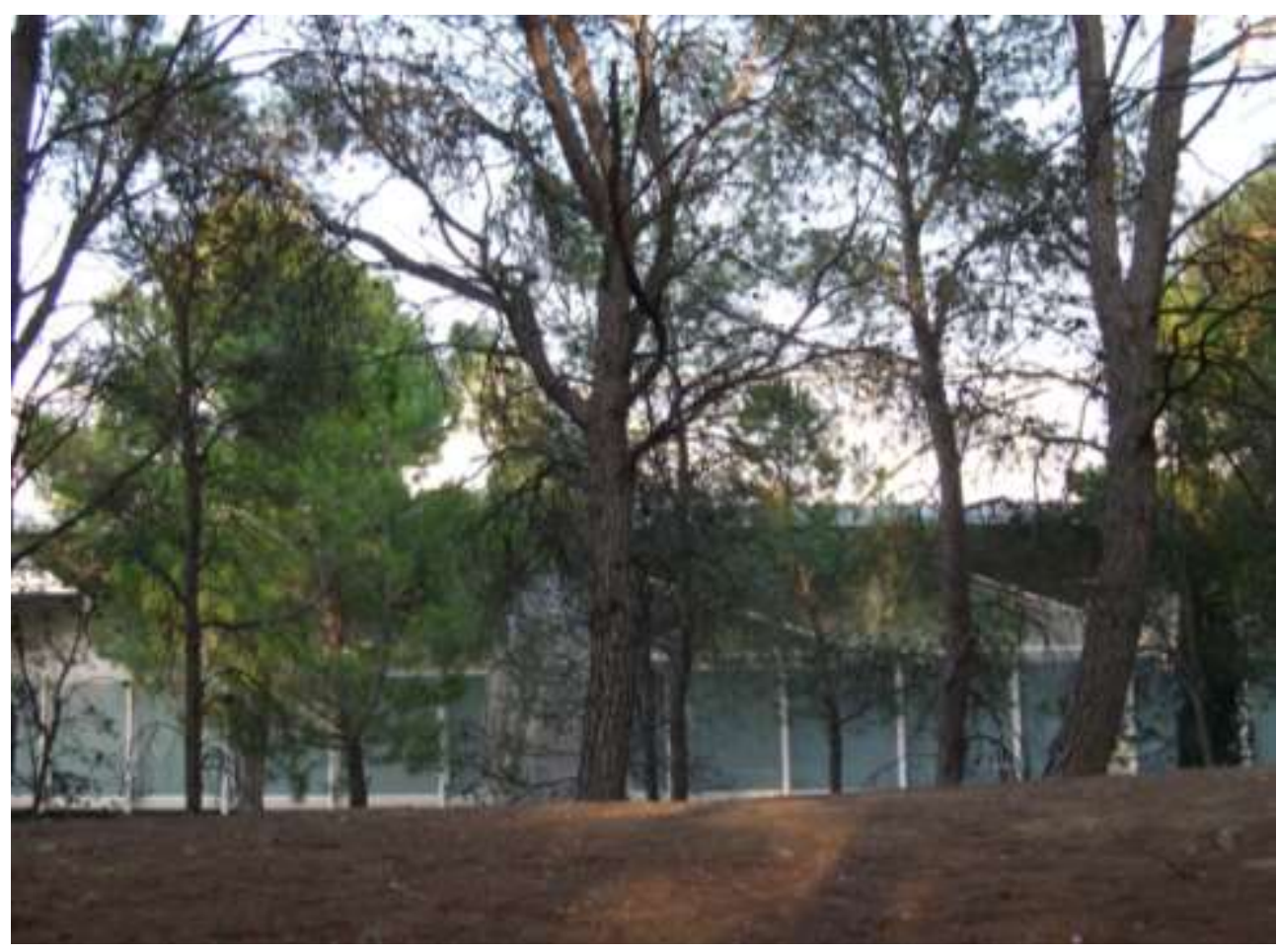

Ilustración 5-46

\subsubsection{MANIFESTAR LA ACCION DEL TIEMPO}

" La estructura repite la dimensión del bosque...y se modifica hasta llegar a ser unos pequeños porches de entrada... A los arboles se les pide, con el paso del tiempo, que los tejan de nuevo con la construcción..." 491

Al comparar las fotografías tomadas desde el Sur por Hisao Suzuki en 1994 al termino de la construcción y la imagen tomada por David Bestue en $2010^{492}$ se comprueba como la vegetación proyectada por Miralles ha crecido y su follaje ayuda a la integración del organismo construido con el paisaje natural. También en la zona donde se ubica la pista de baloncesto al aire libre, los montículos conformados con las tierras de la excavación ${ }^{493}$, hoy conforman colinas tapizadas de vegetación, que parecen haber sido creadas por la naturaleza. Lo mismo puede decirse de los chopos que con su rápido crecimiento, actualmente ocultan la esquina Suroeste del edificio.

desde lejos, en concreto desde las zonas de cultivo agrícola, situadas al Norte, se asemeja a una especie de insecto que acabase de salir del bosque y de repente su movimiento hubiera quedado congelado

\footnotetext{
${ }^{490}$ Adentrándose en el bosque, y observando el organismo construido a través del tapiz de arboles que te hacen de filtro, se velan esos elementos escalares y se aprecia una mayor hibridación de arquitectura y paisaje. Fotografia tomada por el autor de la Tesis.
}

491 Enric Miralles. "Palacio de deportes de Huesca" El Croquis 50 pág. 225-226.

492 Aparecidas en la revista El Croquis y el libro de David Bestue "Enric Miralles a izquierda y derecha, también sin gafas" respectivamente.

${ }^{493}$ Dichos montículos o pequeñas colinas artificiales, alojan cuartos técnicos del edificio. 

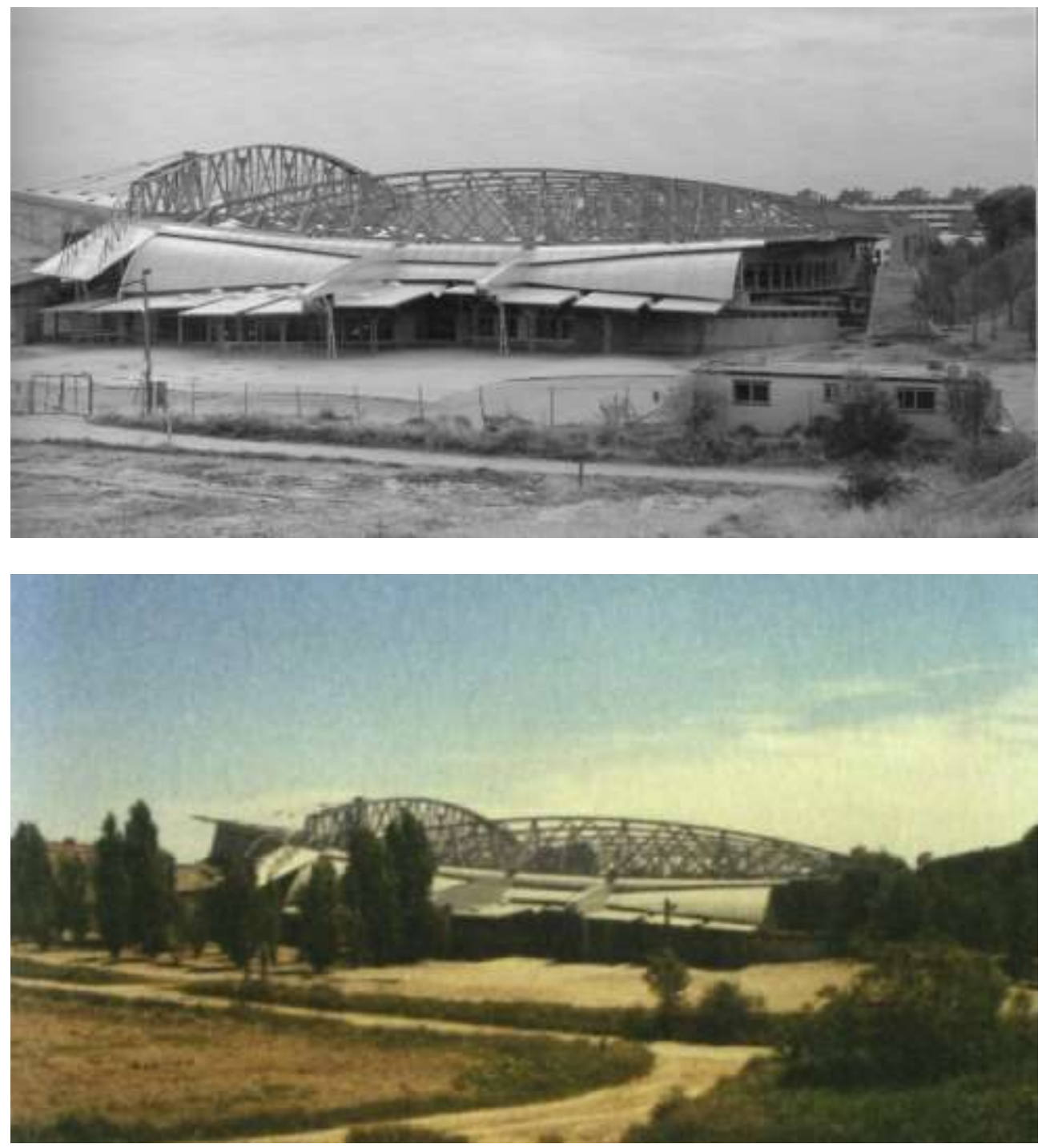

llustración 5-47 $\mathbf{7}^{494}$

${ }^{494}$ Contraste entre la fotografía tomada por Hisao Suzuki en 1994 al termino de la construcción aparecida en la revista El Croquis y en la imagen aparecida en el libro de David Bestue en 2010 


\title{
5.3.2. INACABAR
}

\begin{abstract}
"Para mí, una obra no la termina el arquitecto, sino su uso y sus avatares, el desgaste y las mismas roturas que recaerán sobre ella"
\end{abstract}

Enric Miralles. ${ }^{495}$

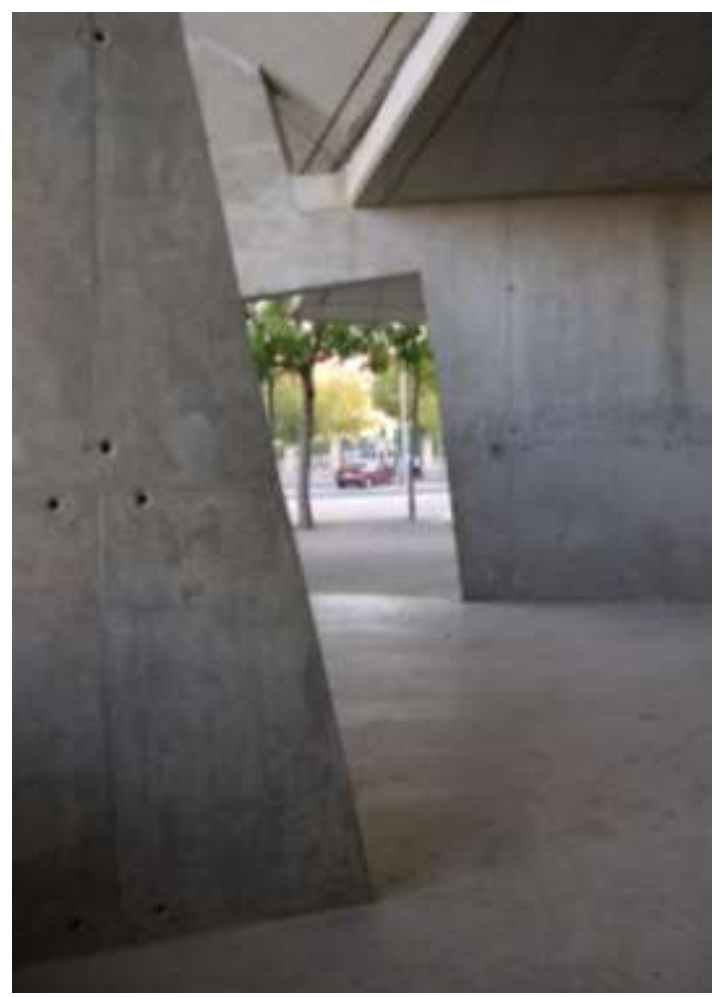

Ilustración 5-48 ${ }^{496}$

Cuando se recorre el perímetro del edificio "in situ" parece como si todavía estuviese "en construcción" o bien en "ruinas". Elementos constructivos dislocados, inclinados que no se alcanza a entender como están soportados, ponen en tensión al visitante, al pensar que en cualquier momento uno de esos elementos se pueda desprender. Si en el Complejo de Tiro con Arco, el dejar la obra a medio hacer integraba la arquitectura en su entorno y lo convertía en paisaje; en el Pabellón de Huesca, el medio deshacer (la ruina) desempeñara un papel parecido. Porque el Pabellón de Huesca es una ruina, y la ruina, se relaciona muy bien con el paisaje. La ruina esta en los dos mástiles dejados en el lugar, como resto arqueológico del pasado del edificio, cuando sujetaron hasta el día de su desplome la cubierta tensada. ${ }^{497}$. Miralles los dejo allí, para que generen la misma sensación que un día le provocaron a él los pilares de piedra encontrados a la

\footnotetext{
${ }^{495}$ Entrevista a Enric Miralles por Vicente Verdu en el Periódico El País "Me gusta innovar, pero no corro riesgos inútiles" (8 de octubre de 1993)

${ }^{496}$ Experiencia que se obtienen al recorrer el perímetro del edificio "in situ", como si todavía se estuviera construyendo o se encontrase en ruinas. Fotografia tomada por el autor de la Tesis.

497 FAURA, Ramón . "Palacio de deportes, Huesca (1988-1994) y Club de tiro con arco, Barcelona (1989-1991)" en Enric MIralles: 1972-2000 Editorial Fundación Caja de Arquitectos 2011.
} 
entrada de la Cripta de la Colonia Güell, cuando entendió lo que podía haber sido la iglesia de haberse construido con esos enormes pilares. Un símbolo que representa lo que una vez fue el edificio y de lo que podría haber sido el edificio con la cubierta tensada. Miralles lo confirma en los siguientes términos: "...El recuerdo y la autoridad de las Columnas de piedra reposando en el suelo frente a la Cripta de la Colonia Güell, que construyen la intuición de lo que sería el futuro de esa capilla, fue el recuerdo al que fui a parar para encontrar el sentido de la nueva construcción Los mástiles ocupan el vacio anterior."
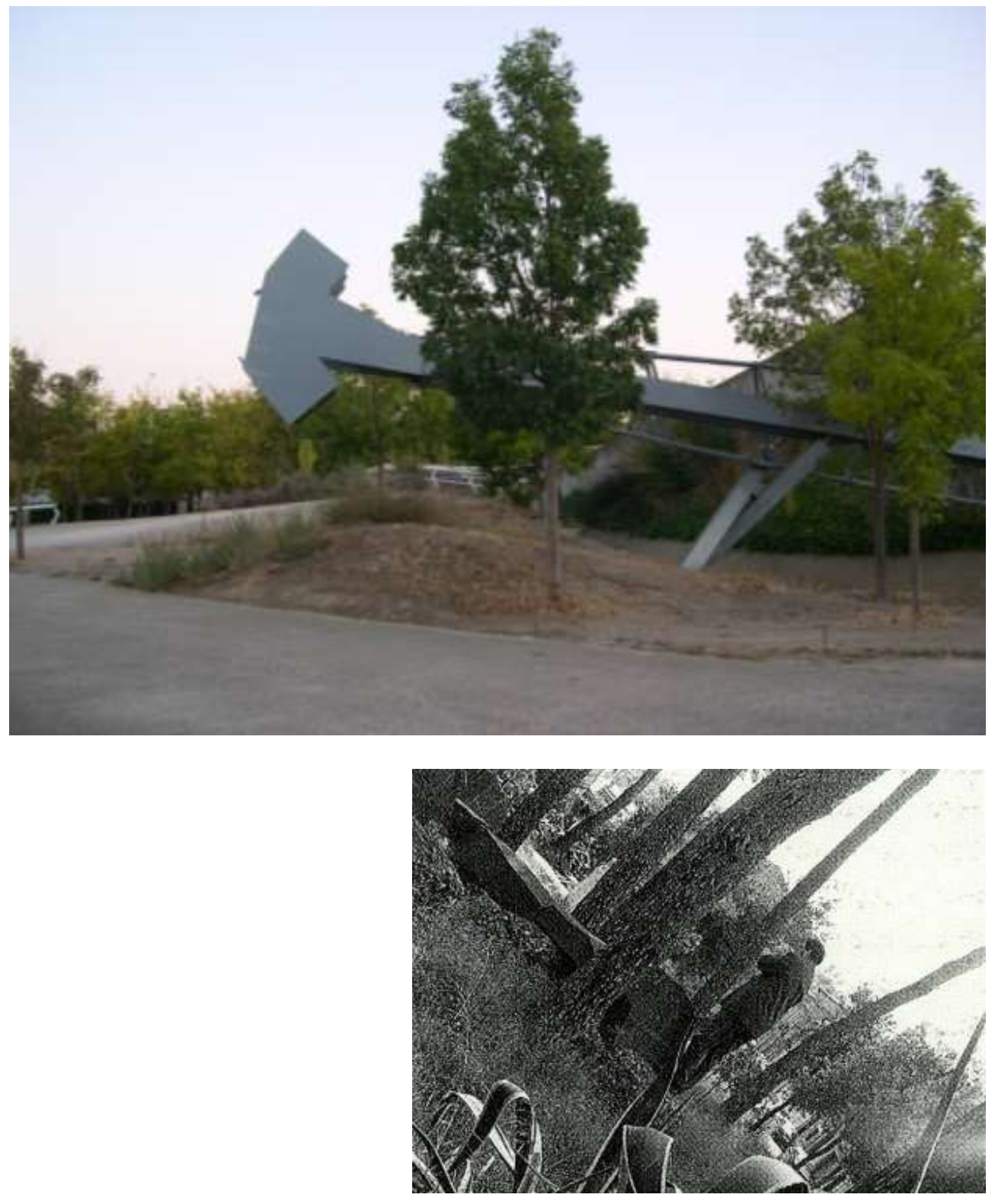

Ilustración 5-49 498

\footnotetext{
498 La ruina esta en los dos mástiles dejados en el lugar, como resto arqueológico del pasado del edificio, cuando sujetaron hasta el día de su desplome la cubierta tensada. Miralles los dejo allí, para que generen la misma sensación que un día le provocaron a él los pilares de piedra encontrados a la entrada de la Cripta de la Colonia Güell. Fotografia tomada por el autor de la Tesis.
} 
EL PABELLON DE DEPORTES EN HUESCA (1988-1994) 


\section{COMPARACION DE LAS ACCIONES ANALIZADAS}

Después del análisis de las tres obras seleccionadas, este capitulo realiza una comparacion entre las acciones analizadas en las tres obras analizadas en detalle y el resto de la obra de Miralles, ampliando el abanico de los casos de estudio para destilar un conocimiento más acertado.

Se ha seguido el mismo esquema de estudio analítico aplicado en los tres capítulos de análisis anteriores y tambien una ordenación cronológica de las obras para comprender la evolución que experimenta la obra de Miralles.

\subsection{ACCIONES CONCRETAS:}

\subsubsection{TOPOGRAFIA}

\begin{abstract}
"El trabajo continuado en algunas ideas que van de un proyecto a otro, es un ejercicio de transformación latente, desde el proyecto para el Cementerio de Igualada al palacio de Deportes de Huesca, al Tiro con Arco... la actividad del edificio reflejada en una topografía que envuelve la construcción."
\end{abstract}

Enric Miralles. ${ }^{499}$

Es la acción que utiliza Miralles para preparar el terreno, dar acomodo al organismo arquitectónico en primer lugar y relacionarse con el paisaje. Abrir un surco en la tierra es una acción con un significado especial en la cultura ancestral de los constructores que persigue definir el lugar. En la cultura japonesa, fundar se empareja con regenerar, restaurando el mundo al ponerlo en contacto con las fuerzas vivas del mas allá. Excavar, es uno de los gestos ancestrales de la cultura del constructor.

Las tres obras estudiadas en detalle en capítulos anteriores, comparten esta seña de identidad del trabajo con la topografía en la que se reinterpreta la topografía de los paisajes donde se interviene generando una nueva topografía artificial. Seña de identidad que también se detecta en obras anteriores y posteriores como se demostrara a continuación. Para William Curtis, el orden en la obra de Miralles es topográfico porque realza las direcciones principales que detecta en los paisajes.

\footnotetext{
${ }^{499}$ Diseño Interior no 40, 1996. p 53.
} 

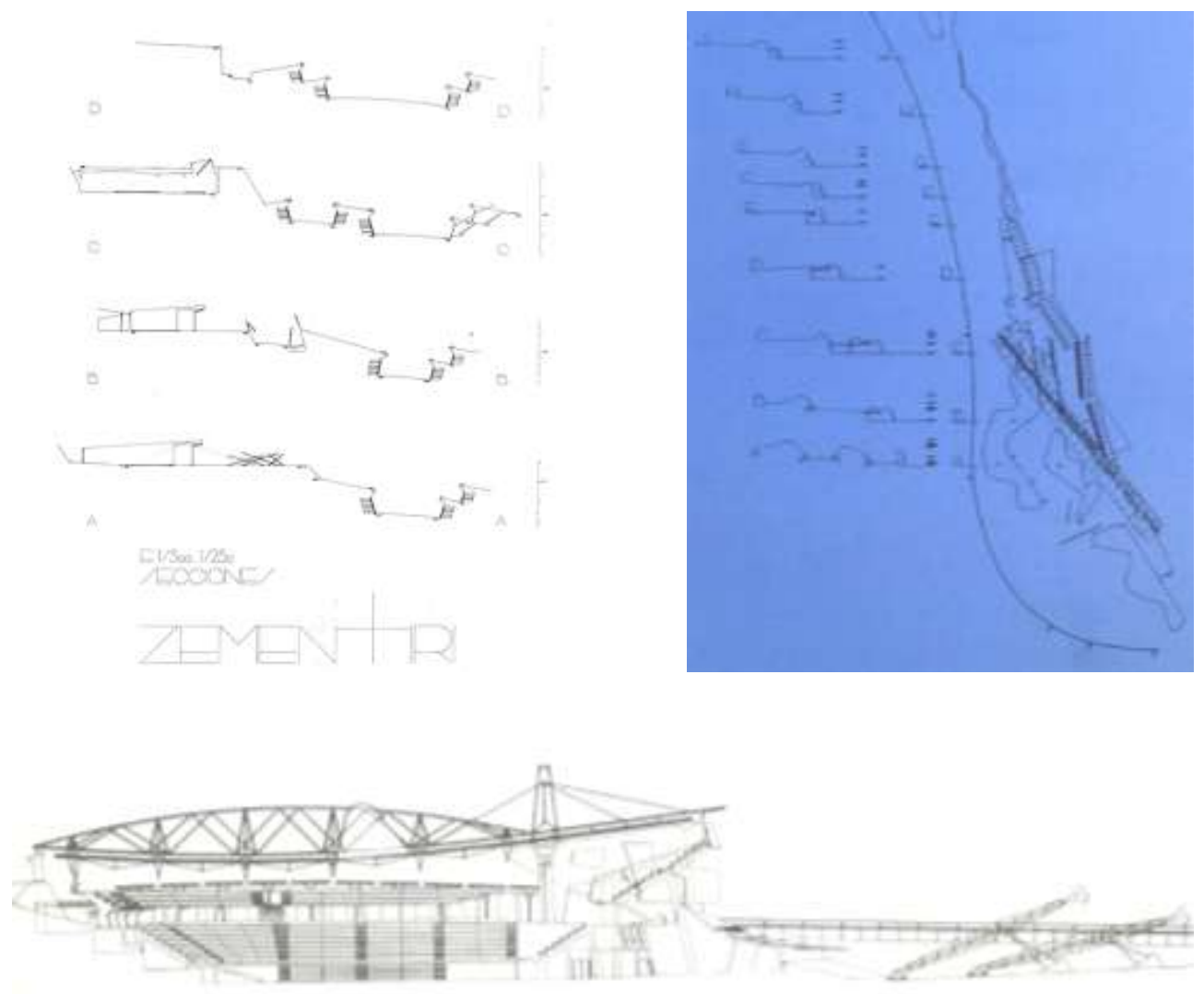

$6-1^{500}$

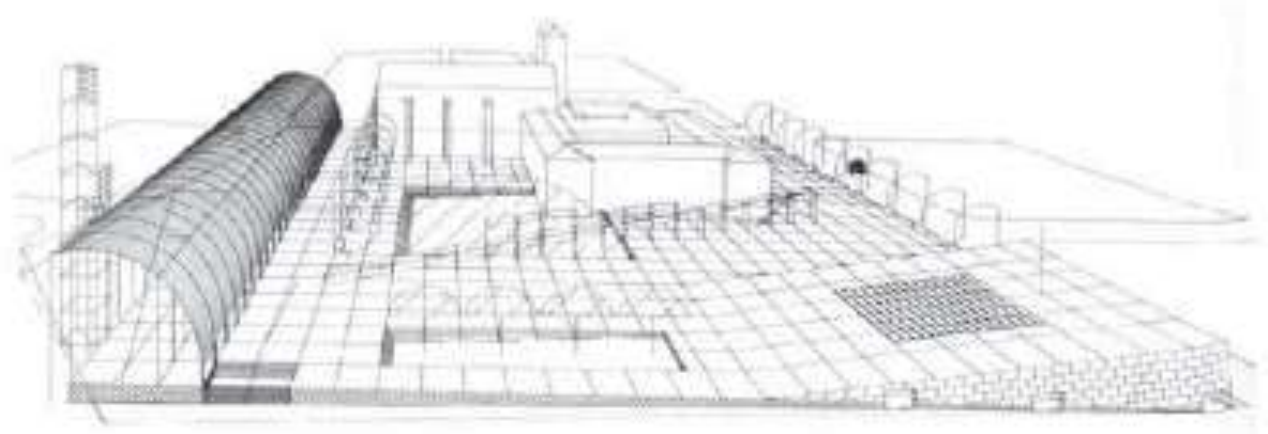

$6-2^{501}$

El trabajo de Miralles con la topografía, comienza siendo colaborador en el estudio de Viaplana y Piñon. Ya en 1978, en la propuesta elaborada para el Parque La Mediterránea en Murcia, se prepara el plano del suelo trabajándolo en varios niveles para generar un plinto en el que depositar elementos naturales y artificiales. ${ }^{502}$

\footnotetext{
500 Topografía en Igualada, Tiro con Arco y Huesca.

${ }^{501}$ Parque de la Mediterránea. Murcia. 1978. Viaplana Piñon MIralles.

502 Para mas información puede consultarse la Tesis de Javier Fernandez Contreras "La planta MIralles: Representación y Pensamiento en la Arquitectura de Enric Miralles". ETSAM. UPM.
} 
En el caso del Parque del Escorxador en Barcelona de 1981, el suelo se modela en forma de libro abierto para construir una topografía artificial sobre la que posar los elementos que conforman la propuesta arquitectónica. En la Plaza de la Constitución en Gerona, la topografía se modela en forma de zigurat invertido. ${ }^{503}$

Aunque Miralles ya había procedido a excavar levemente en una de sus primeras obras como el Centro Social de Hostalets de Balenyá, no será hasta que aborde el encargo del Parque Cementerio de Igualada cuando al enfrentarse al paisaje y su topografía le lleven a realizar grandes movimientos de tierra, a la manera de los artistas del Land Art. En el Parque Cementerio de Igualada, la topografía artificial generada por el proyecto de Miralles, busca fundirse con la topografía natural existente en el lugar. Esta acción de la topografía será fundamental en la manera singular de implantarse en el lugar. La acción topográfica conforma la intervención arquitectónica, que parece hubiera sido realizada por un agente geológico erosivo dejando al descubierto los diferentes niveles. Los taludes naturales existentes el paisaje se confunden con los taludes proyectados (los que albergan los nichos y los conformados por gaviones de piedra). En la Escuela Hogar en Morella, de 1986, el edificio solo puede entenderse como respuesta al paisaje topográfico existente, pues no se excava sino que se posa y desliza sobre la pendiente de la ladera para no romper el equilibrio del paisaje en el que se implanta, siguiendo un esquema en zig zag que Miralles y Pinos detectaron en las calles de Morella. En el Complejo de Tiro con Arco en Barcelona, además de resolver aspectos relativos al emplazamiento, se manipula para disponer los usos demandados por el programa funcional haciendo las funciones de un zócalo desparramado. En esta obra, una vez más, mover las tierras es dar acomodo a lo que pasara luego. Es dar prioridad a lo constructivo en relación al lugar. Entender la arquitectura como aquello que prepara un lugar. Lo constructivo se convierte en origen del proyecto, asegurando su relación con el lugar. Las estancias interiores se asemejan a cuevas. Para Kenneth Frampton en esta obra se fusionan tectónica y topografía, atributos arraigados en la tradición de la arquitectura catalana desde la Edad Media. ${ }^{504}$

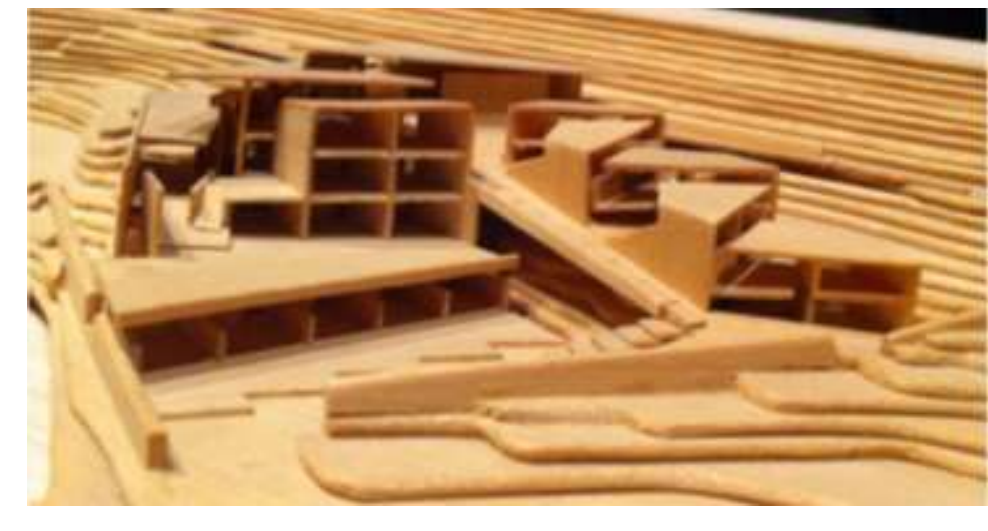

\footnotetext{
503 Para mas información puede consultarse la Tesis de Javier Fernandez Contreras "La planta Mlralles: Representación y Pensamiento en la Arquitectura de Enric Miralles". ETSAM. UPM.

${ }^{504}$ Kenneth Frampton. "Sobre la tradición tectónica en la forma catalana contemporánea" Quaderns 206.

${ }^{505}$ Maqueta de Proyecto. Escuela Hogar en Morella, 1986. Miralles Pinos. Fotografia tomada por el autor de la Tesis.
} 
En el Pabellón de Deportes de Huesca, una vez decidido acercar el organismo construido a la Naturaleza, para minimizar el volumen de un edificio público de estas características en ese lugar, se decide excavar en la tierra para que la altura de la edificación propuesta no rebase la altura de los arboles pertenecientes al bosque y para ligar más estrechamente lo natural y lo construido. Miralles en este proyecto modela el terreno existente y prepara el tránsito desde los límites de la ciudad con el edificio y el bosque de pinos del Cerro de San Jorge. La topografía artificial proyectada formada por terrazas curvas, rampas y pasarelas parece que siempre hubiera pertenecido al lugar. En este proyecto, se reúnen los experimentos topográficos ya realizados en el Cementerio de Igualada con la vocación de ligereza de las cubiertas de proyectos anteriores: Basamento frente a cubierta; hormigón frente a metal; topografía frente a lo aéreo; Igualada frente a Parets.. ${ }^{506}$ En Huesca el exterior urbano se proyecta con tres elementos de contorno. Uno de ellos corresponde a una serie de colinas artificiales concatenadas, generadas con la tierra de la excavación, que alojan cuartos de instalaciones del Pabellón. Miralles quiere que las acciones que dan forma al edificio se conviertan en "escrituras sobre el lugar", es decir topografías: Bancales de tierra, rampas exteriores, gradas y tribunas forman un conjunto de elementos dispersos sobre el terreno sin contacto físico entre ellos. ${ }^{507} \mathrm{En}$ el Pabellón de Alicante, Miralles proyecta el edificio como si fuera el resultado de la materialización de las ultimas curvas de nivel del monte aledaño anexo al edificio. Las circulaciones de acceso al interior del edificio alargan el movimiento del público mediante unas rampas que conforman una topografía artificial.

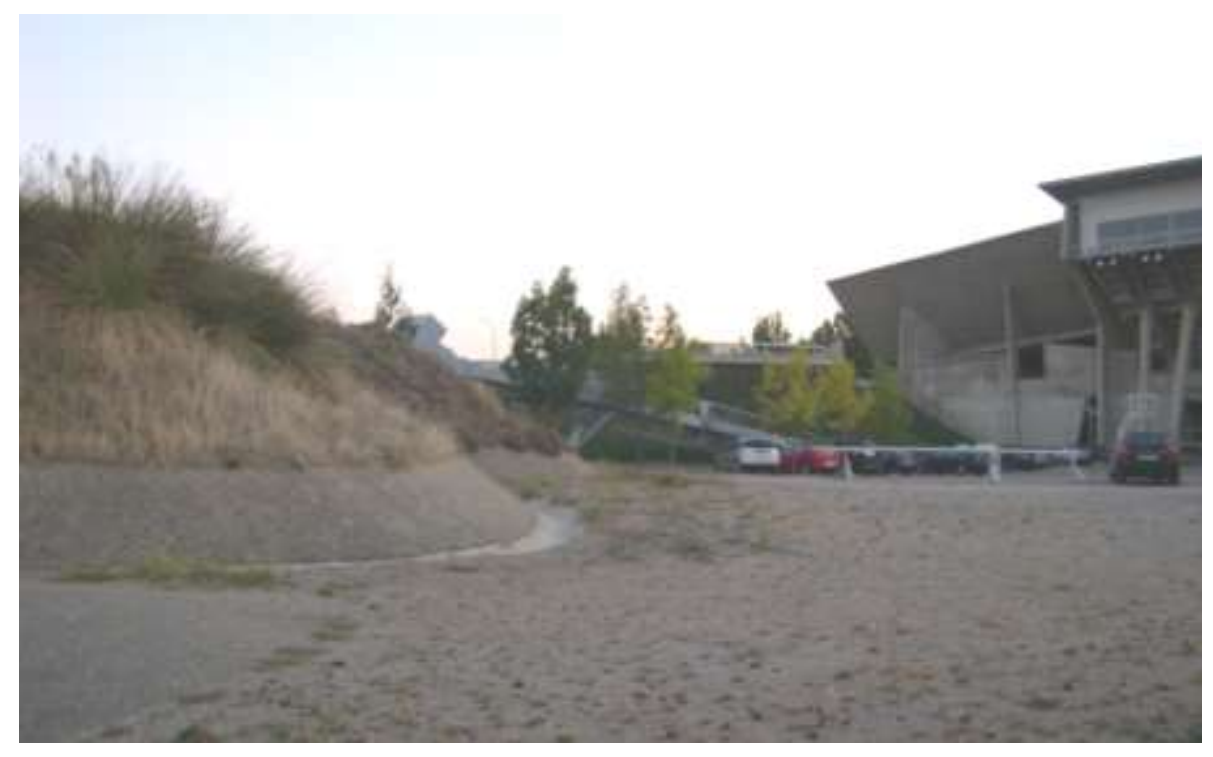

\footnotetext{
506 Para mas información puede consultarse la Tesis de Javier Fernandez Contreras "La planta MIralles: Representación y Pensamiento en la Arquitectura de Enric Miralles". ETSAM. UPM.

507 Para mas información puede consultarse la Tesis de Javier Fernandez Contreras "La planta Miralles: Representación y Pensamiento en la Arquitectura de Enric Miralles"ETSAM. UPM.

${ }^{508}$ Pabellon de Deportes de Huesca, 1988-1994. colinas artificiales concatenadas, generadas con la tierra de la excavacion, que alojan cuartos de instalaciones del Pabellon. Fotografia tomada por el autor de la Tesis.
} 


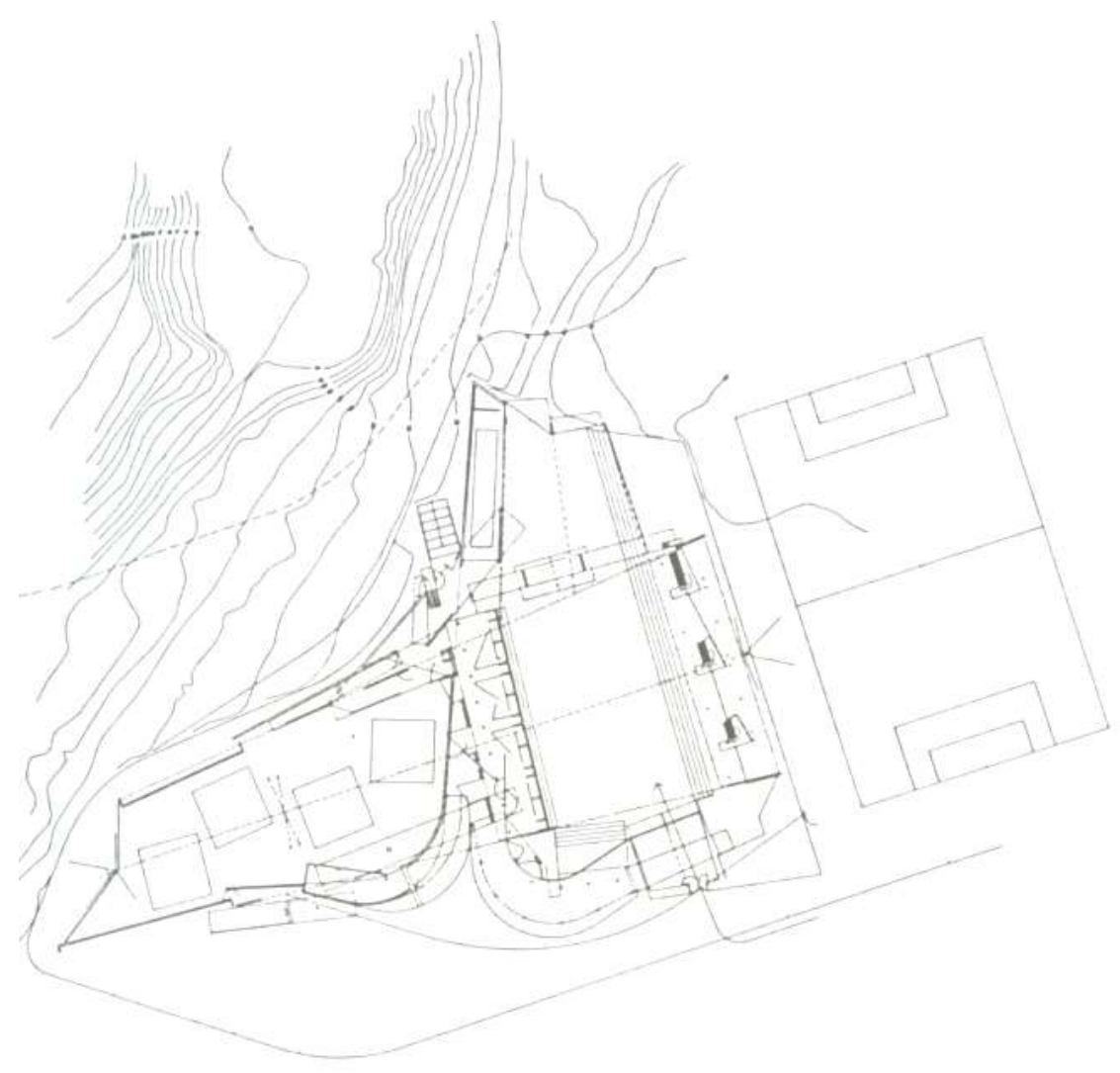

$6-5^{509}$

En la propuesta de Concurso para la Reutilización del Puerto de Bremerhaven, en Bremen de 1993, Miralles genera un laberinto formado por elevaciones artificiales en el terreno en respuesta a la gran extension llana del paisaje en que se encuentra. Cinco intervenciones se superponen para responder de manera independiente al lugar. Una de estas intervenciones, denominada Laberinto, crea una topografía para resolver los accesos rodados y el encuentro entre aparcamiento y topografía. En el concurso para la Biblioteca Nacional de Japón, de 1996, se genera una nueva topografía a imagen de las cubiertas de las viviendas tradicionales japonesas. Topografía materializada en la cubierta para evocar la imagen de las montañas y los bosques que pertenecen al imaginario colectivo de las personas que habitan aquel lugar. En un proyecto posterior como la Biblioteca de Palafolls, el trabajo con la topografía vuelve a ser lo que defina la intervención, enterrando el edificio y definiendo un lugar donde no lo había. Destaca la continuación de los muros al exterior que vinculan el edificio con el terreno conformando unos patios que prolongan los espacios interiores de lectura hacia el exterior. Esta intervención recuerda lo realizado por Alberti en la cripta de San Miniato en el Monte, dado que al nivel enterrado se accede desde un lateral en rampa, que permite el paso de la luz al interior.

${ }^{509}$ Pabellon de Alicante, 1989-1993. 


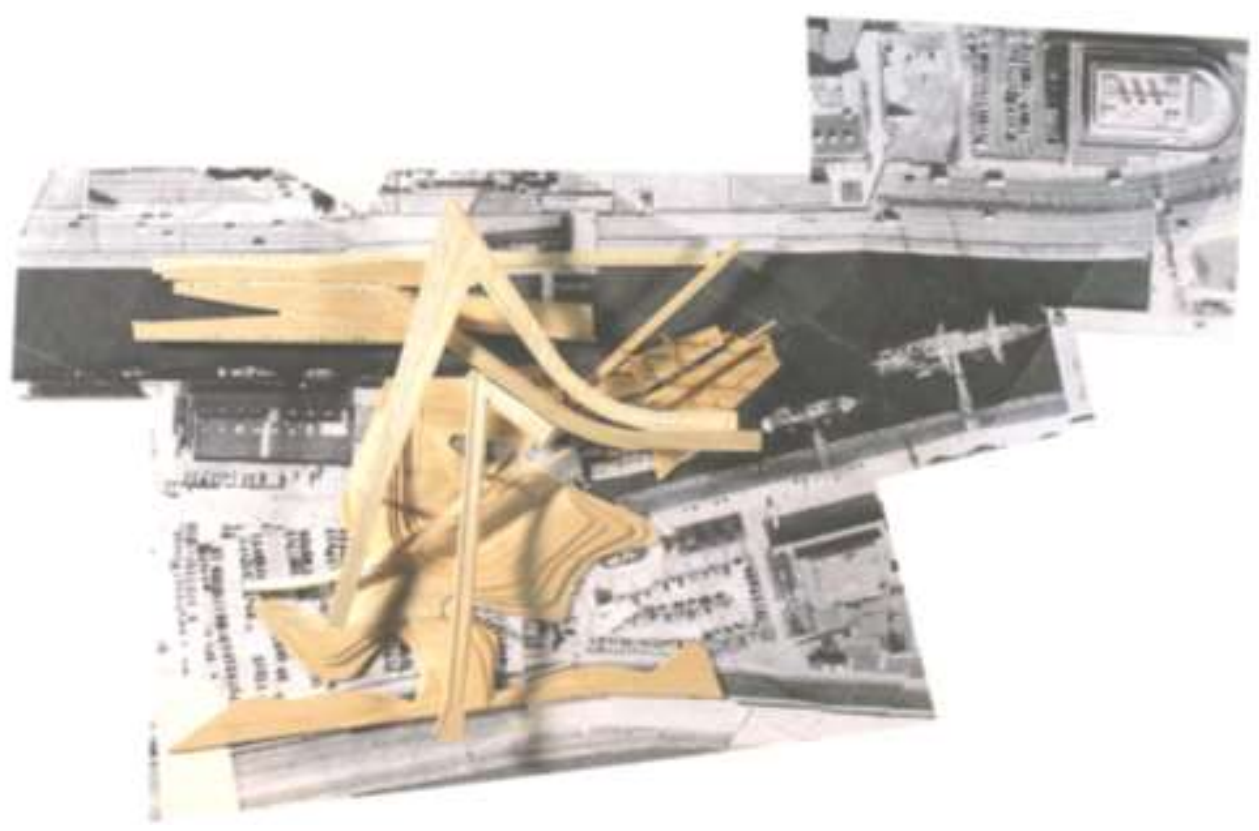

6-6 510

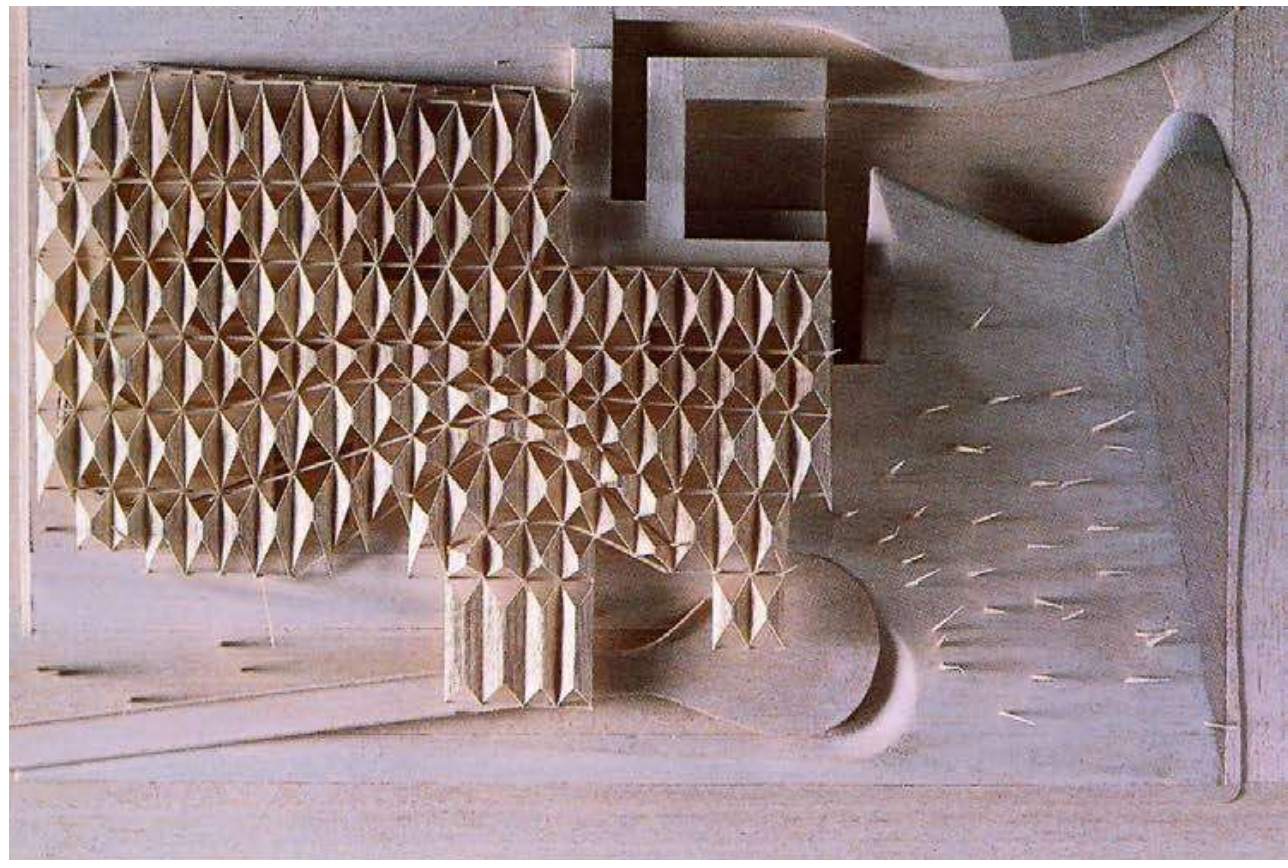

$6-7^{511}$

${ }^{510}$ Reutilizacion del Puerto de Bremerhaven. 1993.

${ }^{511}$ Biblioteca Nacional de Japón. 1996. 


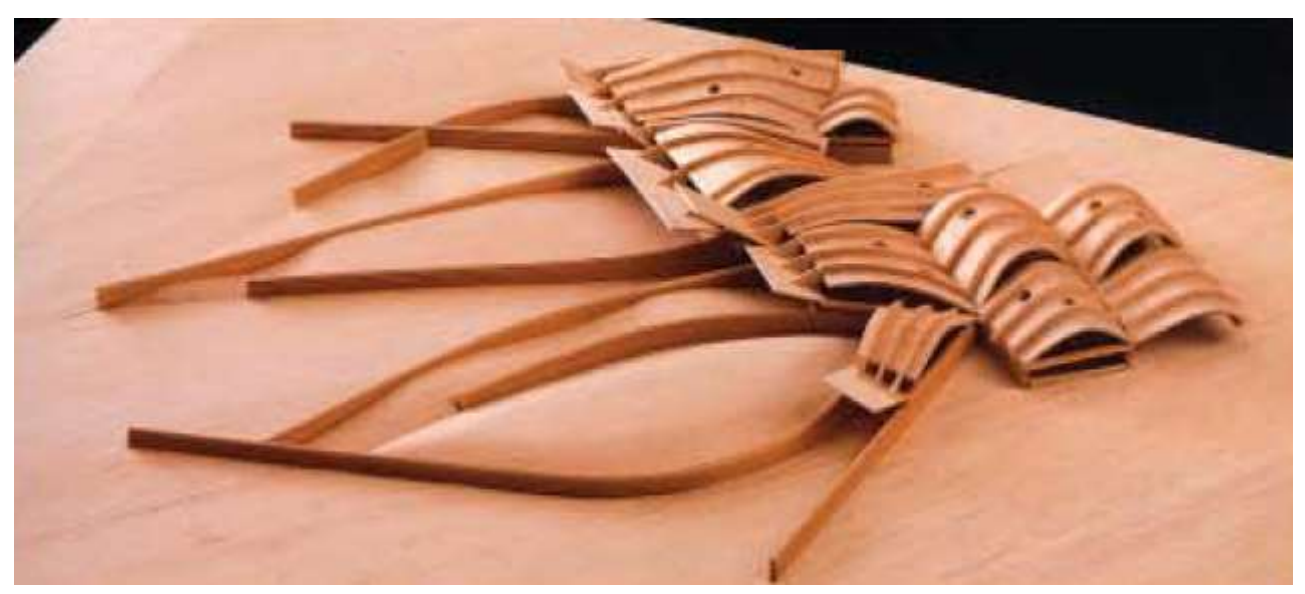

$6-8^{512}$

En la propuesta para la Ampliación del Museo Reina Sofía en Madrid, de 1999, se genera una topografía en forma de libro abierto que conforma una plaza pública, colocando las salas en un nivel semienterrado, recordando lo que Miralles ya había realizado con Viaplana y Piñon para el Parque del Escorxador en Barcelona de 1981. En el Parque de Santa Rosa en Mollet del Valles, comenzado en 1992, se crea una nueva topografía, un nuevo paisaje con la superposición de diferentes estratos: gradas, fuentes, farolas que recuerdan los mástiles de la Avenida Icaria, etc. El plano del suelo adquiere densidad, convirtiendo la topografía en una serie de curvas de nivel de amplio radio que se materializan en bordillos y bancos corridos. En la propuesta para el Palacio de Deportes de Leipzig, de 1995, al igual que ya se hizo en el pabellón de Huesca, se proyecta una zona de juegos al exterior modificando la topografía existente para dar acomodo al nuevo edificio.

En el Campus Universitario de Vigo, la primera operación que se realiza es topográfica al nivelar el terreno para redefinir la cota horizontal del campus mediante una gran excavación. En el Parlamento de Edimburgo, de 1998, el proyecto surge de la propia tierra en simbiosis con el paisaje. Miralles evoca el pasado volcánico del lugar, capta su escala geológica y proyecta el edificio para que entable una relación intima con la tierra y sus gentes, pero el trabajo con la topografía es de menor escala que en anteriores proyectos.

${ }^{512}$ Biblioteca de Palafolls, 


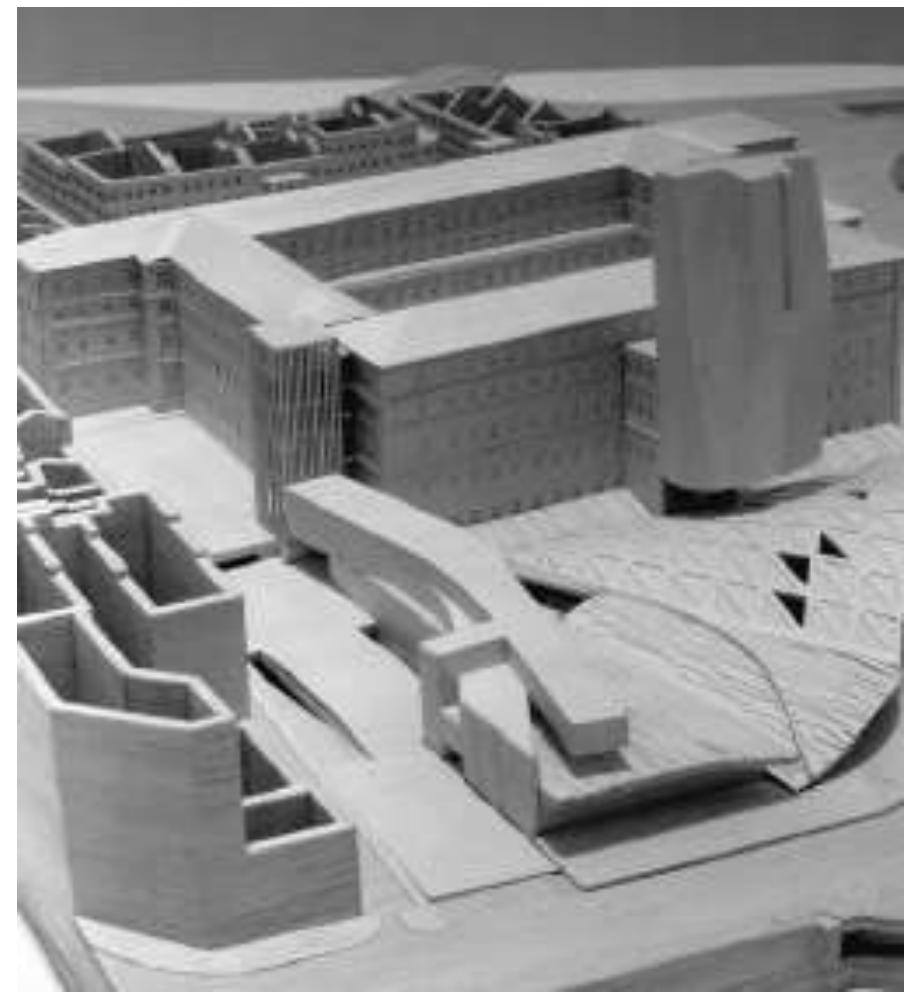

$6-9^{513}$

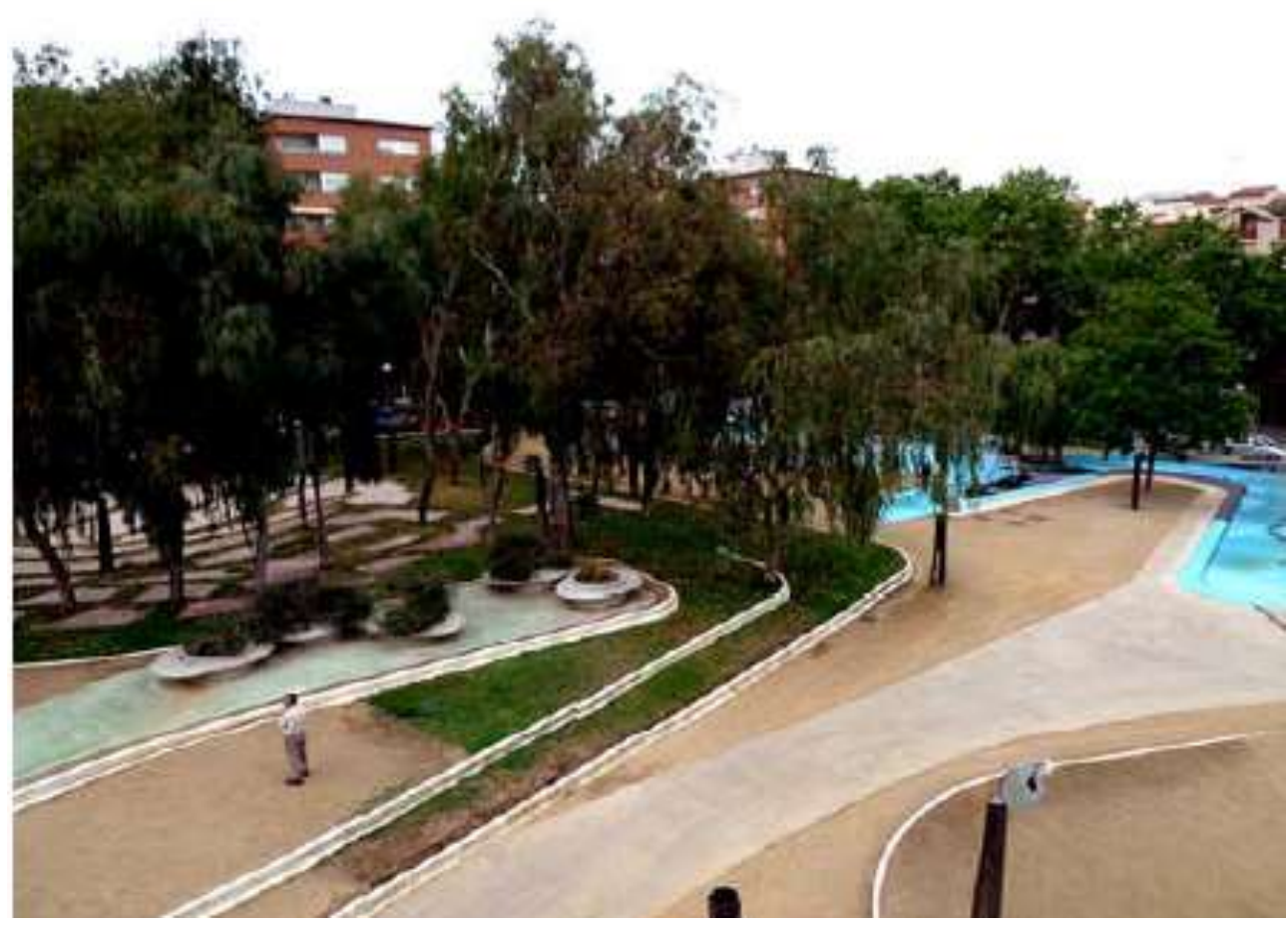

$6-10^{514}$

${ }^{513}$ Propuesta de Concurso para el Museo Reina Sofia en Madrid. 1999

514 Parque de Santa Rosa en Mollet del Valles, 


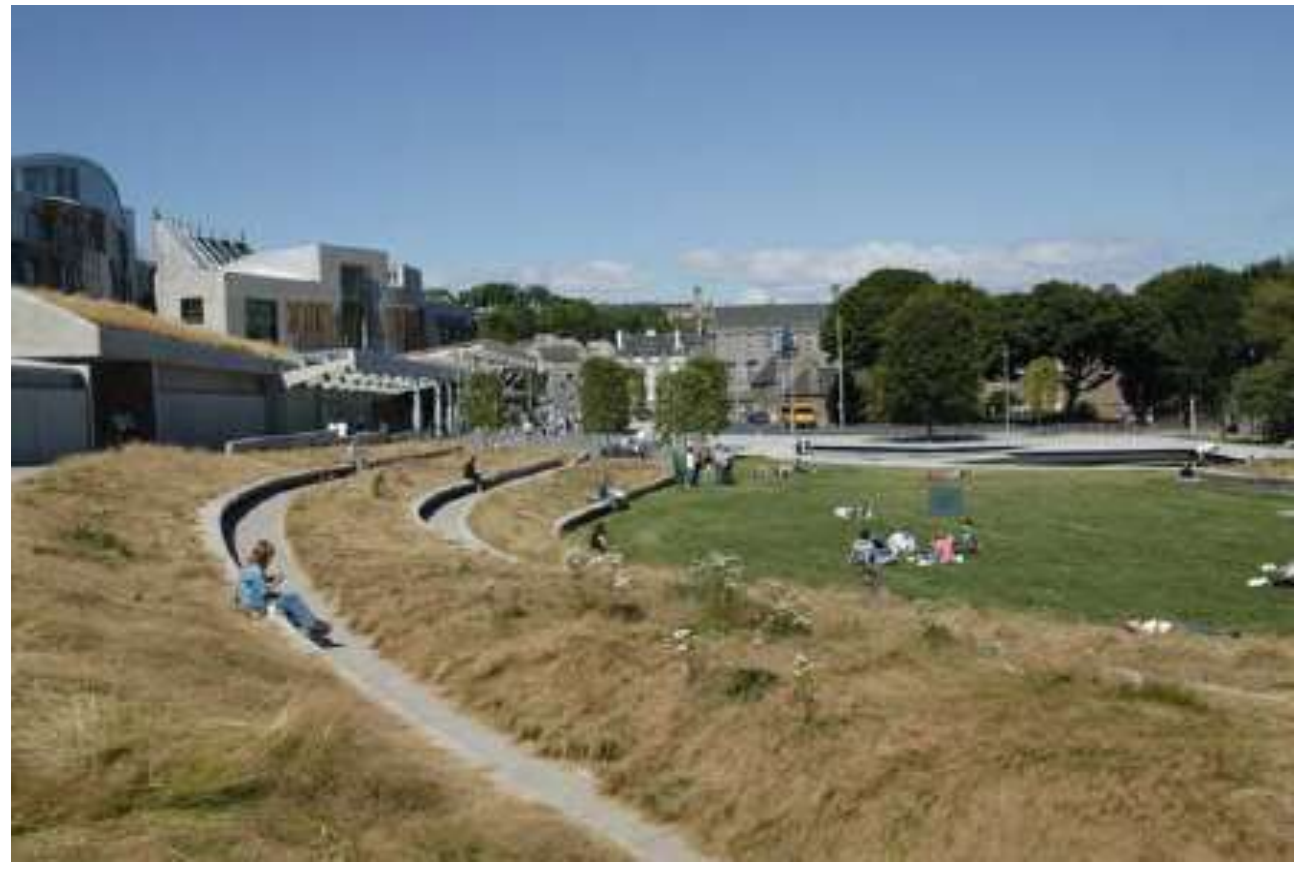

$6-11^{515}$

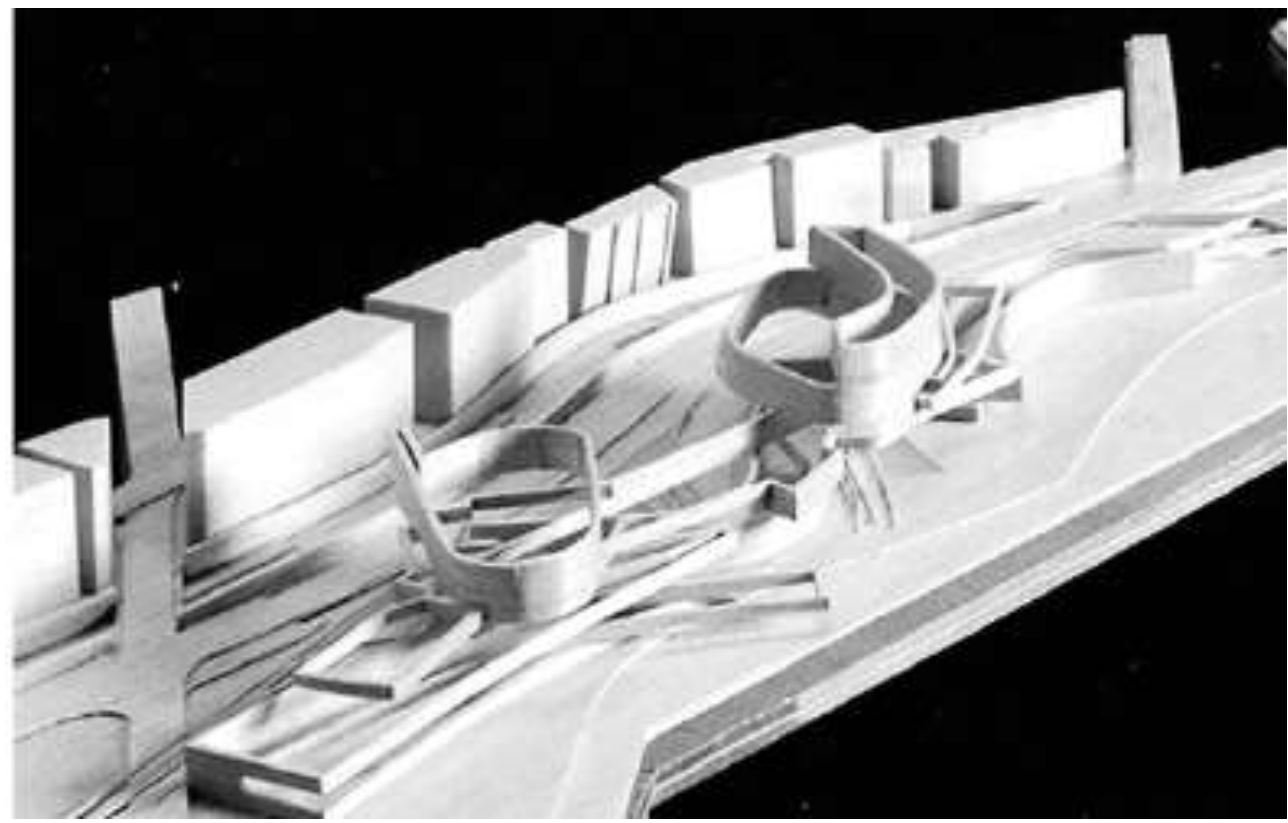

$6-12^{516}$

${ }^{515}$ Parlamento de Edimburgo

${ }^{516}$ Propuesta para el Tribunal de Justicia de Salerno 


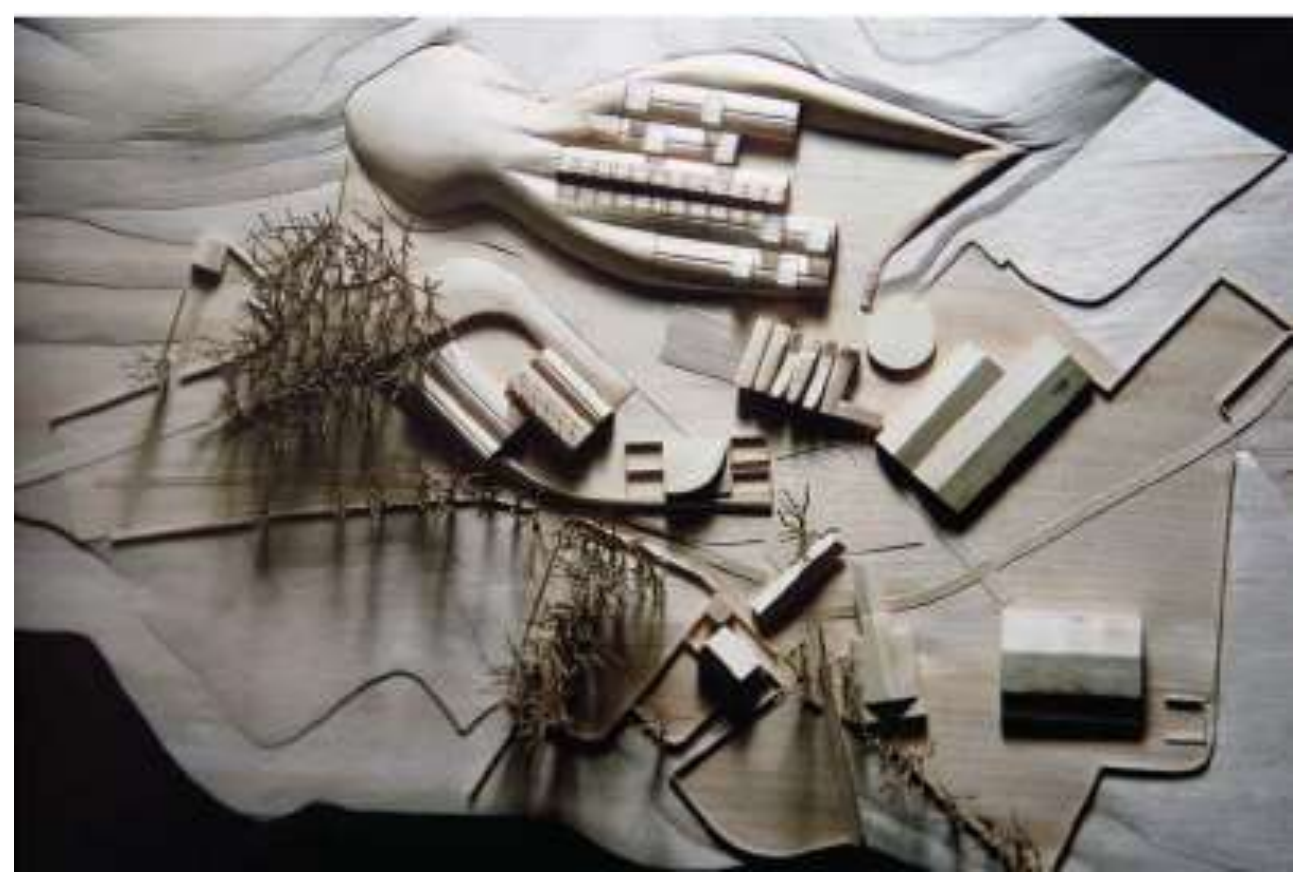

$6-13^{517}$

En la propuesta para el Tribunal de Justicia de Salerno, de 1999, Miralles genera una topografía ideal que interacciona con las vías del tren y el curso del rio existentes. Se conforma un haz de líneas que discurren en paralelo, que también se entrelazan y cruzan a distinta altura. En la propuesta para la Ampliación de la Granja Moore, de 1999, se genera una operación topográfica en primer lugar y se añaden a las construcciones existentes, unos pabellones lineales y una estructura ovoidal que hace de centro de la intervención.

La topografía, así como el conjunto de elementos naturales que configuran el paisaje donde interviene Miralles, serán datos imprescindibles que registrara meticulosamente y reinterpretara para elaborar sus propuestas. A través de la repetición de los dibujos, buscara anclar cada proyecto a la topografía natural del sitio. El trabajo con la topografía es lo que diferencia la arquitectura de Miralles no solo de la manera de hacer de los deconstructivistas, con quienes se le llego a comparar, sino del resto de la arquitectura contemporánea. Reconstruir o construir una nueva topografía es una operación fundamental en los proyectos de Miralles que antecede al construir el edificio.

El trabajo con la topografía que comienza en los proyectos realizados junto a Viaplana y Piñon, y que levemente asoma en el Centro Cívico de Hostalets de Balenya, llegara a una cota importante en el Parque Cementerio de Igualada, donde el propio paisaje natural que se encuentra le lleva a realizar artificialmente una excavación de escala casi geológica para fundirse con él. El trabajo con la topografía a gran escala que comienza en Igualada, lo volverá a practicar en el Pabellón de Huesca excavando todo el graderío sobre el terreno y además continuando la excavación hasta el extremo del solar en el que la ciudad de Huesca asoma con su edificación residencial. La intervención con la topografía a la escala de Igualada y Huesca no se volverá a repetir en toda su obra. Merece destacarse el Complejo de Tiro con Arco en el que inspirado por lo realizado en

${ }^{517}$ Propuesta para la Ampliacion de la Granja Moore, 
Igualada, pues se solaparon en el tiempo y no dispuso de mucho tiempo para realizar la propuesta, también es la topografía la que modela el terreno para alojar el programa en el salto de nivel a la manera de un zócalo desparramado. En esta misma línea se situaría la Biblioteca en Palafolls, donde como en Huesca, se excava para alojar todo el programa bajo rasante.

Existe otra variante de trapabajo con la topografía como la practicada en Morella, en la que frente a excavar a escala grande se decide posar y deslizar el organismo construido sobre la pendiente de la colina donde se implantaba.

La generación de una topografía artificial de otra índole, como respuesta a enclaves sin cualidades, comienza en el Centro cívico de Hostalets con esas rampas que enlazan las cubiertas miradores; continua en el Pabellón de Alicante con la topografía generada por las rampas que para dar entrada a los espectadores ascienden por una de las fachadas. La intervención en el Parque de Santa Rosa en Mollet del Valles sigue en esta línea de generar un paisaje nuevo ayudado por la topografía proyectada. Proyectos que quedaron sin construir como los de la reutilización del Puerto de Bremenhaven o la Biblioteca Nacional de Japón.

En definitiva, diferentes maneras de apoyarse en la topografía para generar proyectos en los que la manera de actuar viene dictada por el propio paisaje que Miralles se encuentra y en función del cual determina su respuesta.

\title{
6.1.2. FRAGMENTACION DEL PROGRAMA :
}

\author{
"Un proyecto siempre está hecho de esos \\ momentos, de diversos fragmentos a veces \\ contradictorios. Estos collages, a la manera de \\ un puzzle, forman la representación de un \\ espacio en una acción que, en cualquier caso, \\ repite el trabajo mismo de proyectar. Son como \\ una sorpresa que abre continuamente una nueva \\ definición de los límites y de los contornos." \\ Enric Miralles. ${ }^{518}$
}

Es la acción que utiliza Miralles para descomponer en distintas piezas el programa de necesidades y esparcirlas por el paisaje para relacionarse mejor con este.

El mundo que nos rodea es heterogéneo y sin unidad. Esta realidad fragmentada la captan los escritores en sus textos y los pintores en sus lienzos. La arquitectura que fragmenta la masa de los edificios se acerca a la diversidad de la naturaleza, queriendo ser paisaje. Los orígenes de la fragmentación en Arquitectura, vienen de Piranesi, que con su plano del Campo Marzio, un mar de organismos colisionan unos con otros y generan una especie de lava sin forma definida, siendo un mar de organismos. También Giulio Romano en el Renacimiento elabora una arquitectura fragmentada y por eso este autor es una de las referencias que los críticos especializados indican cuando hablan de las influencias de Miralles. En el S. XIX se intento ordenar, seriar, y normativar a la Arquitectura con los tratados y sus reglas compositivas. Solo quedo el fragmento en el pintoresquismo ingles. La fragmentación, conlleva querer aliarse con la Naturaleza, pues en sus formas

\footnotetext{
${ }^{518}$ Enric Miralles. Obras y proyectos. Lahuerta,Electa España, 1996. p. 173
} 
fragmentadas, rotas, sin bordes, sin formas definidas se funden mejor con la Naturaleza. ${ }^{519}$

Al llegar las vanguardias de principios de S. XX, los pintores comienzan a pintar con fragmentos para atrapar la cambiante realidad, fragmentada y sin unidad, una vez que se demuestra que el Positivismo no puede explicar ese hoy y por tanto ha fracasado. Constructivismo, Cubismo, Art Noveau y Modernismo se recrean en el fragmento. Hans Scharoun y Alvar Aalto, no se pueden explicar sin hablar de fragmento, que va mas allá de la Arquitectura orgánica, puesto que orgánica es la arquitectura de Frank LLoyd Wright, pero no tiene tanto que ver con el fragmento. Louis Khan, también en su Convento de Las Dominicas se atreve con el fragmento y abre el camino para que su discípulo y colaborador Robert Venturi, a la vuelta de su beca de Roma, publique "Complejidad y Contradicción en Arquitectura" libro que celebra el fragmento, lo casual, el encuentro. Al llegar los años 1970s irrumpe el Postmodernismo y aparecen los libros de Venturi "Complejidad y Contradicción en la Arquitectura" y de Rossi "La arquitectura de la ciudad". Para contrarrestar al Postmodernismo irrumpe la arquitectura fragmentada, que en su versión anglosajona se denomina deconstructivista y que se publicita desde el MOMA a finales de los 1980s. Colin Rowe y Fred Koeter, trataran en su libro "Ciudad Collage" de finales de los 1970s, como el fragmento, tan claro en el trazado de las ciudades históricas, es la clave a perseguir por la Arquitectura. Frank Ghery, desde sus comienzos practico una arquitectura fragmentada, muy influenciado por artistas con los que trabajaba, pintaba y tertuliaba.

Aunque a Miralles le gustaba estar informado de la escena internacional y formar parte de esta, a través de debates, congresos y docencia; no se le puede encasillar como arquitecto deconstructivista. En realidad, la fragmentación, las curvas, las diagonales y la angulosidad de su arquitectura, tienen que ver más con otras referencias mucho anteriores al movimiento de la Deconstrucción. Habría que irse a la obra de Picasso y la representación de la realidad a través de la fragmentación haciendo desaparecer el punto de vista único y la tridimensionalidad perspectiva. Las obras de Miguel Angel, de Gaudi, de Aalto, de Scharoun, de Hugo Haring explican mejor la fragmentación en Miralles. Conviene recordar que fueron los maestros de la arquitectura moderna, quienes experimentaron ya en los años 1920s con geometrías curvas y ángulos distintos de 90 grados, articulando las partes que componían sus edificios de manera poco convencional.

Miralles emplea la acción de la fragmentación del programa desde su etapa como colaborador con Viaplana y Piñon, en sus proyectos de paisajismo y espacio público, que ordenaban el espacio produciendo una base abstracta sobre la que depositar las distintas piezas que componían el programa. ${ }^{520} \mathrm{En}$ el Instituto La LLauna en Badalona, Miralles y Pinos, llevan al espacio interior lo que hacían Viaplana y Piñon en el espacio exterior público, se coloniza el espacio interior del edificio dispersando los distintos elementos: escaleras, radiadores, bancos, mobiliario, etc. para con la fragmentación de elementos conseguir que las relaciones entre las piezas y el edificio existente, generen un nuevo espacio que una lo existente y lo proyectado. También este proyecto recuerda las teorías del "Team Ten" del edificio como calle.

\footnotetext{
${ }^{519}$ MONEO, Rafael. "Paradigmas fin de siglo". El Croquis № 98. 2000. pag. 198

520 Para mas información puede consultarse la Tesis de Javier Fernandez Contreras "La planta Mlralles: Representación y Pensamiento en la Arquitectura de Enric Miralles"ETSAM. UPM.
} 


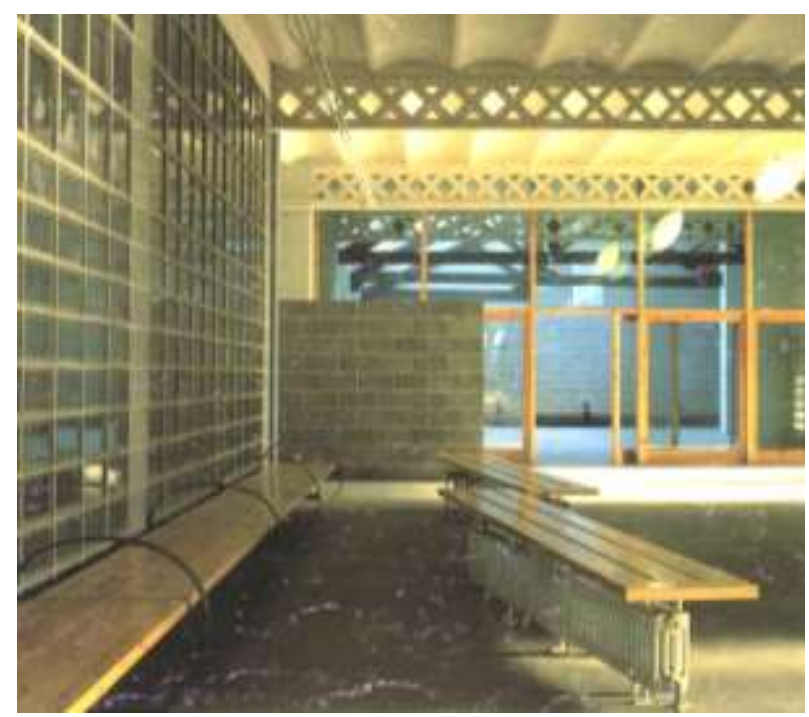

$6-14^{521}$

En el Parque Cementerio de Igualada, la formalización de la intervención se lleva a cabo con formas indeterminadas e imprecisas; destacando la componente horizontal para vincularse con la extensión del paisaje. Esta obra constituye el primer proyecto de Miralles y Pinos en el que se compone con piezas morfológicamente diferenciadas, fragmentándose el programa. La capilla, una sala semienterrada de forma triangular; y la zona de panteones, una plaza al aire libre de forma elíptica resultado de una operación topográfica, son piezas dotadas de rasgos diferenciales y con lógica propia dentro del conjunto En los Pabellones de Tiro con Arco, se fragmenta el programa en piezas diferentes y las plantas son el resultado de una estrategia de yuxtaposición de esas piezas. En el edificio de Entrenamiento además de yuxtaposición, también se da una estrategia de superposición entre la planta y la cubierta, con formas diferentes en ambas y por tanto no coincidentes sus contornos. ${ }^{522}$

Desarrollados en paralelo, el Pabellón de Huesca y el CNAR de Alicante, se configuran como una colección de fragmentos dispersos que se juntan en torno a las pistas, construyendo un organismo que irradia ecos en su entorno adyacente. Han sido pensados como una serie de piezas que definen un recinto. Sus planos determinan la vocación de Miralles de llevar al límite las posibilidades de la fragmentación. Una heterodoxia deudora quizás de la exposición Deconstructivist Architecture del MOMA, cuya celebración en el verano de 1988 fue coetánea al desarrollo de ambos proyectos.

En el Pabellón de Huesca, el interior responde al convencional tipo edificatorio compacto con una disposición clásica de los espectadores, configurando los exteriores con mayor libertad y dinamismo, como es el caso en cómo se tratan los accesos y la zona de juego exteriores En el Pabellón de Alicante, la fragmentación y dinamismo que se daban solo en los exteriores del Pabellón de Huesca, se trasladan al interior del espacio mismo

\footnotetext{
${ }^{521}$ Instituto La LLauna en Badalona.

522 Para mas información puede consultarse la Tesis de Javier Fernandez Contreras "La planta Mlralles: Representación y Pensamiento en la Arquitectura de Enric Miralles"ETSAM. UPM.
} 


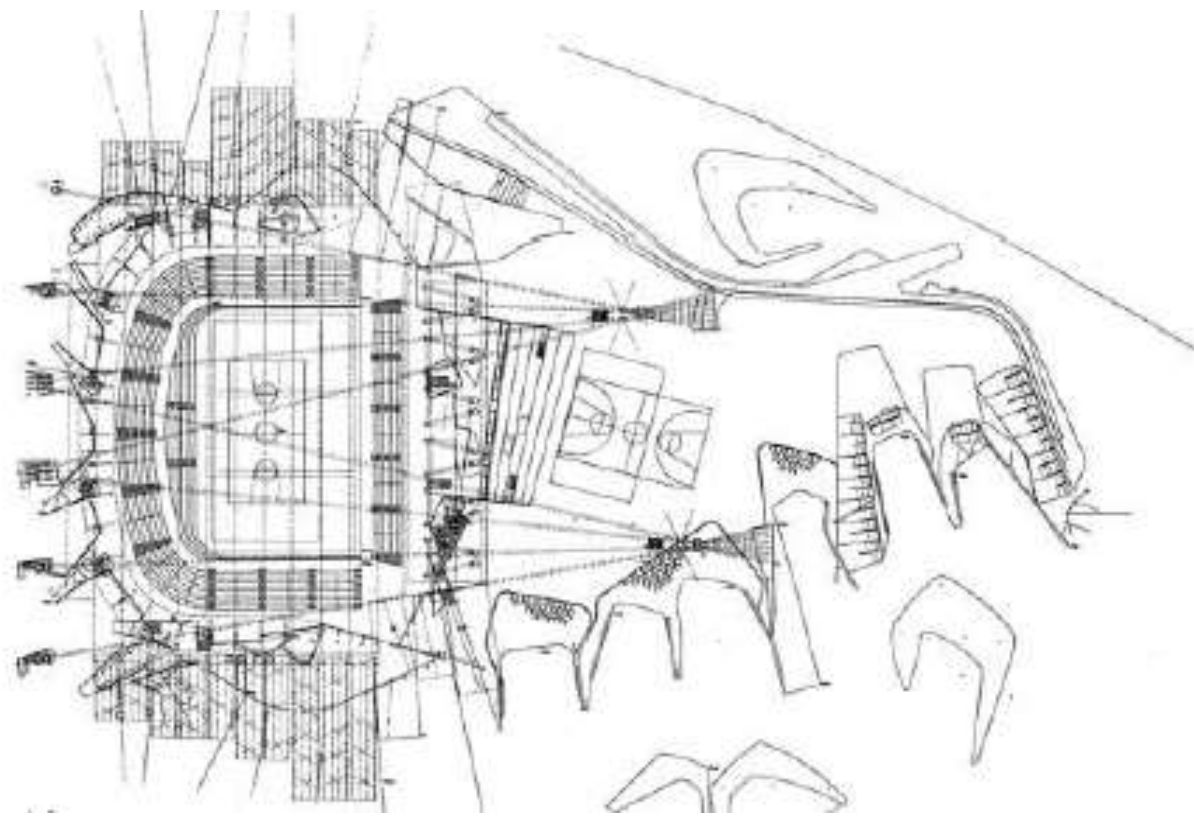

$6-15^{523}$

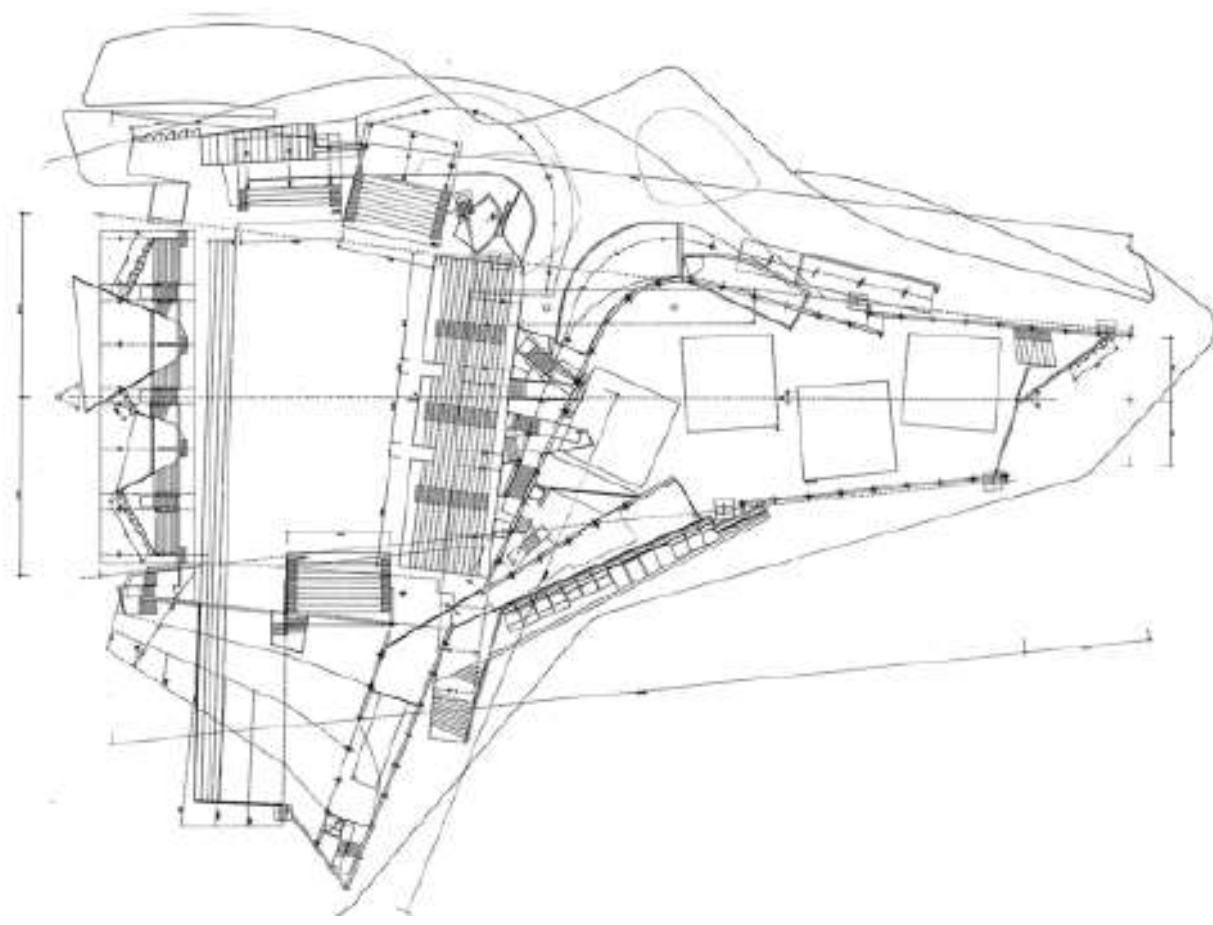

$6-16^{524}$

${ }^{523}$ Pabellon de Huesca.

${ }^{524}$ Pabellon de Alicante. 
La simetría y estatismo de la disposición de los espectadores en Huesca, en Alicante desaparece. Aquí las gradas forman una envolvente asimétrica alrededor de la pista, son objetos exentos que amueblan el entorno de la pista. La arquitectura se rompe en múltiples fragmentos. Cada una de las diferentes piezas del programa (aulas, salas, gradas, etc.) se encuentra en un equilibrio de relaciones con el resto. Se genera una exuberancia de fragmentos que responde a múltiples factores: funcionales, de relación con el lugar, de respuesta al programa, etc... manejados por el virtuosismo característico de Miralles. ${ }^{525}$ No se jerarquizan espacios, sino que como es habitual en los proyectos de Mlralles, todas las partes reciben igual protagonismo.

En la Escuela Hogar de Morella, de 1986, se fragmenta el programa para adaptarse al paisaje existente, porque de no hacerlo así, se generaría un volumen edificatorio excesivo que alteraría el equilibrio del paisaje existente. Se genera una topografía artificial que se relaciona con el paisaje y con lo aristado de las murallas del castillo que corona la montaña, del que el edificio quiere ser su zócalo. De esta manera el organismo arquitectónico se funde con el paisaje como si fuera parte de este, pero manteniendo su identidad. Como cuenta Carmen Pinos: "Fragmentación y continuidad como cualidades que se toman prestadas de la observación cuidadosa de las líneas del paisaje...una doble estrategia de ser visto y no visto en el sentido de que el edificio tiene presencia volumétrica desde la base de la ladera, se confunde con sus perfiles en alzado y sección, y es percibido como un conjunto de caminos 'cubiertas como pavimentos' desde el castillo." 526

En la propuesta para la Reutilización del Puerto de Bremerhaven, en Bremen de 1993, Miralles realiza una serie de fragmentaciones ligadas a complejas negociaciones para adecuarse al paisaje fragmentado del Puerto marítimo abandonado. La propuesta se genera como un collage de fragmentos, donde una serie de acciones conectan los fragmentos construidos existentes que se habían quedado sin relación al abandonarse la actividad en el Puerto con los fragmentos de la propuesta proyectada, para así activar el paisaje con el nuevo uso.

En la Biblioteca de Palafolls, de 1997, el desarrollo del proyecto esta guiado por la fragmentación del volumen original. Se fragmenta el volumen original en una serie de estancias abovedadas concatenadas y desplazadas entre sí. La primera maqueta se sometió a una fragmentación posibilitando la variedad espacial y de distribución En la Facultad de Arquitectura de Venecia, de 1998, se fragmentan y separan las distintas zonas del basamento y de las aulas. En el Parlamento de Edimburgo, de 1998, Miralles fragmenta el programa en pequeños volúmenes en torno a un edificio histórico existente para relacionarse con la escala que detecta en dicha zona. La agregación de las distintas piezas en forma de herradura ayuda a unificar la intervención.

\footnotetext{
525 ibidem

526 "Escuela Hogar en Morella". Arquitectos no 139, p. 72.
} 


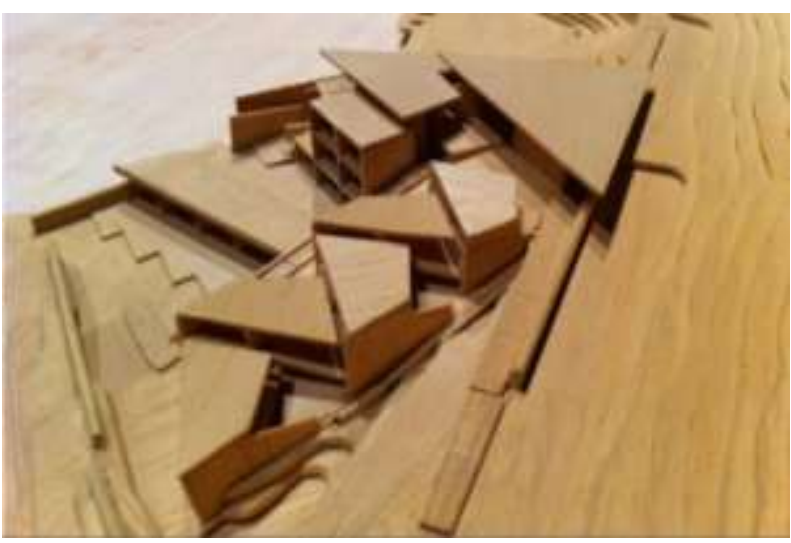

$6-17^{527}$
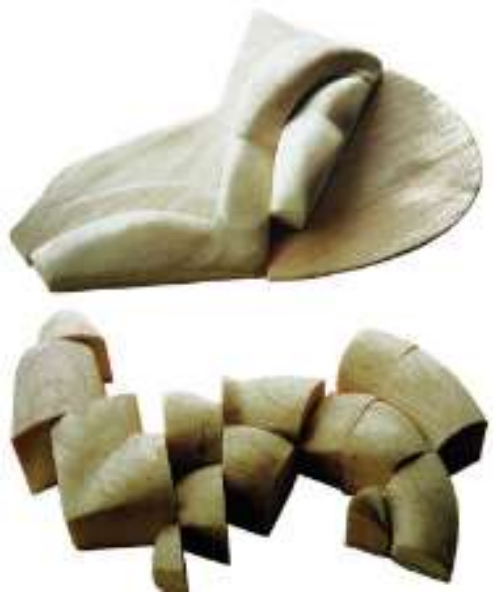

$6-18^{528}$

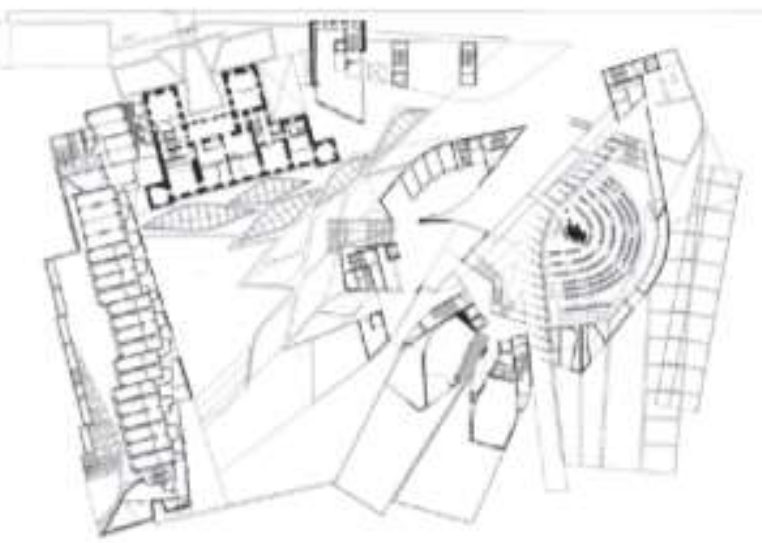

$6-19^{529}$

${ }^{527}$ Escuela Hogar en Morella. Maqueta de proyecto.

${ }^{528}$ Biblioteca de Palafolls. Maqueta de proyecto que muestra la fragmentacion en rebanadas. 
La fragmentación del programa en diversas piezas esparcidas por el lugar, es una acción que persigue Miralles para que su arquitectura se relacione mejor con el paisaje. El edificio se fragmenta y reparte por el paisaje para fundirse con todo lo circundante. Miralles se refiere a esta fragmentación del programa con términos propios: "desmembrar", "romper", "repartir", etc. La organización es orgánica, espontanea, sin ejes ni jerarquías que condicionen la solución según un "orden conglomerado" ${ }^{530}$ donde lo que importa son las relaciones entre las piezas, según posiciones relativas de tangencia, adyacencia, relación horizontal o vertical. Las relaciones topológicas que mantienen las partes entre sí reflejan dinamismo y participan de complejas relaciones geométricas que atan entre si los distintos elementos de la planta. La geometría que subyace en la arquitectura de Miralles, esta más cerca de la geometría topológica que de la euclidiana. El espacio topológico lo gobiernan relaciones de entorno o proximidad, de continuidad, envolvimiento, etc.

Miralles proyecta desde la planta, y sus formas parten en muchos casos de sintetizar las formas que se encuentra en el plano de situación. La planta baja suele ser la que ordena el conjunto, una planta matriz que se desarrolla en planos parciales para definir las distintas piezas por separado. La fragmentación en escalas intermedias es una técnica para producir el encuentro con la escala humana. También se realizan subfragmentaciones dentro de un mismo programa, como por ejemplo en las gradas del Pabellón de Alicante o los espacios concatenados de la Biblioteca de Palafolls. ${ }^{531}$

El edificio resultante es un amalgama de diferentes formas, una especie de collage en el que cada pieza responde a un propósito y una función determinadas generando un paisaje artificial, pero no basado en la abstracción simple que proponía el Movimiento Moderno, sino mas bien en la dirección indicada por Paul Klee en sus dibujos y pinturas basadas en el movimiento de la línea. En la arquitectura de Miralles, como en la del Modernismo catalán todo tiene el mismo valor. No hay en ella jerarquías, dando a sus ingredientes la misma importancia. Así es como conseguirá su condición global y unitaria. La continuidad entre arquitectura y paisaje, y las composiciones informales, sugieren afinidades con la arquitectura orgánica del noroeste europeo.

La composición en fragmentos ira evolucionando con el tiempo hacia ordenaciones más libres de formas curvas y oblongas, además dichas piezas no solo se yuxtapondrán sino que llegaran a superponerse. Sin embargo es posible entender las operaciones de fragmentación del Pabellón de Huesca y el Parlamento de Edimburgo como procesos creativos similares a pesar de separarles diez años.

La acción de fragmentar el programa para desparramarse y relacionarse con el paisaje también comenzó cuando colaboraba con Viaplana y Piñon sus intervenciones en plazas al aire libre. Desde el Parque de la Mediterránea de 1978 hasta el Parque del Escorxador en Barcelona de 1981, los elementos proyectados por los arquitectos se dispersan hasta colonizar el espacio sin límites y de la relación entre estos generar una identidad en lugares donde no existía. Ante un encargo como el Instituto La LLauna ya construido en el que su intervención se

\footnotetext{
${ }^{529}$ Parlamento de Edimburgo. Planta.

${ }^{530}$ Orden que puede asumir adiciones, sustracciones y modificaciones sin afectarle.

531 FERNANDEZ CONTRERAS Javier. Tesis Doctoral "La planta Miralles: Representación y Pensamiento en la Arquitectura de Enric Miralles", DPA ETSAM. UPM 2013. pag, 222.
} 
limita solo en los interiores, Miralles opera de la misma manera que en las plazas al aire libre antes aludidas. Ahora son bancos, escaleras, báculos de iluminación, radiadores, etc. los que se dispersan por el interior para colonizarlo y fruto de las relaciones entre las piezas existentes y las propuestas, fundir lo proyectado con el edificio existente. Esta manera de proceder se verá en un proyecto de interiorismo posterior como la Sede del Círculo de Lectores en Madrid.

Pero será de nuevo el Parque Cementerio de Igualada, de 1985, en el que ya en un espacio al aire libre y dadas las condiciones que paisaje y programa ofrecían, cuando Mlralles y Pinos, fragmenten el programa en tres piezas morfológicamente diferentes dispersas por el paisaje y relacionadas por el recorrido. El Complejo de Tiro con Arco proyectado en 1989, mientras se construía Igualada, y debido al reducido espacio de tiempo para proyectarlo será deudor de soluciones ya aplicadas en Igualada. Aquí, el programa se fragmenta siguiendo un esquema lineal esparciéndose en todo el frente del cambio de nivel al que el proyecto sirve. Destaca la fragmentación en el edificio de Competición, que encaja el programa en una pieza repetida siguiendo una directriz quebrada que sigue el curso del desnivel configurando un paisaje habitado más que un edificio propiamente dicho. ${ }^{532}$

Similar fragmentación a los casos anteriores pero más concentrada en el paisaje por lo reducido del solar, es la que proyectan en la Escuela Hogar en Morella, al fragmentar el programa de la escuela y la residencia en diferentes formas, pero unidas por una sala multifuncional de forma triangular que hace de rotula de todo el conjunto. De nuevo es la forma triangular a la que se encomienda una posición privilegiada en el conjunto, ya que en Igualada dio forma a la capilla.

En el Pabellón de Huesca, aunque proyectado después de Igualada y Morella, la fragmentación será mas tímida y solo se dará en los exteriores. Y será un año después con el encargo del Pabellón de Alicante, en 1989, cuando Miralles lleve al limite la acción de fragmentación del programa, pues aquí la arquitectura resultante es una acumulación de fragmentos sin jerarquía relacionados según diferentes criterios, orquestados por el virtuosismo de Miralles. Sera la gran cubierta que flota por encima de ese mar de fragmentos, la que dará unidad al conjunto. Alicante, será un punto y aparte en lo que respecta al incremento de fragmentación, debido a los problemas que trajo consigo la ejecución material de la obra en la que casi nada encajaba al no ser coplanarias las superficies de los volúmenes construidos debido a su rápida construcción. ${ }^{533}$ Valga como ejemplo la lección aprendida por Miralles en Alicante, que cuando se enfrente a la Biblioteca de Palafolls, proyectada en 1997, fragmentara su programa en una especie de gajos ${ }^{534}$ unidos por medianeras, lo que facilitara que en la ejecución de la obra las cosas acoplen.

En la propuesta para la Reutilización del Puerto de Bremerhaven, en Bremen de 1993, Miralles retomara la estrategia de fragmentación que empleo en el Instituto La LLauna de Badalona, salvo que aquí será al aire libre y a escala de un Puerto marítimo. Ante los fragmentos sin cohesión que se encuentra en la visita al Puerto

\footnotetext{
532 Para mas información puede consultarse la Tesis de Javier Fernandez Contreras "La planta Mlralles: Representación y Pensamiento en la Arquitectura de Enric Miralles"ETSAM. UPM.

${ }^{533}$ En la visita realizada por el autor de esta Tesis, el funcionario que le acompaño, le traslado que el dia de la inauguracion llovia dentro del edificio y que muchas veces habian sentido el intrusismo de personas en el interior del edificio por los intersticios al no acoplar las superficies.

${ }^{534}$ Como si se cortase una barra de pan y se desplazasen las rebanadas pero manteniendo su unions por los laterales.
} 
al haber cesado su actividad. Miralles propone un collage de fragmentos guiados por la relación con los fragmentos existentes para fundir lo existente y lo proyectado. Deudora de esta manera de proceder será el Parlamento de Edimburgo, de 1998, en el que la fragmentación del programa se lleva a cabo para relacionarse con el paisaje y los edificios históricos existentes en el área de intervención, pero aquí cada fragmento tiene su cubierta, no como ocurría en Alicante donde una sola cubierta flotante cubría todos los fragmentos.

Queda claro como la fragmentación que utiliza Miralles no entiende de interiores, exteriores, edificios pequeños o grandes intervenciones, es una estrategia que emplea como si fuera una red que esparce para coser y unificar lo existente y lo proyectado, dando igual el tamaño de la intervención.

\subsubsection{CUBIERTA}

La cubierta es un elemento que emplea Miralles para relacionarse con la escala del paisaje y dar unidad al organismo construido.

La generación del lugar se consigue en muchos proyectos de Miralles, mediante la manipulación del suelo y la definición de una cubierta con vocación de ingravidez. Es una manera de hacer que no se centra en el cuerpo, sino en el suelo y la cubierta. El organismo construido es, en muchos casos, un zócalo y una gran cubierta, separados por una "zona de incertidumbre". Dependiendo del paisaje en el que se implante la obra, por la necesidad de dotar al edificio de una escala paisajística, a veces se recurre a grandes cubiertas que cobijan y dan unidad a la constelación de diferentes volúmenes que conforman el edificio.

En los primeros proyectos abordados con Carme Pinós, la cubierta es, en la mayoría de los casos, un plano horizontal. separado por intersticios de aire, que desmaterializan la caja arquitectónica. Valga como ejemplo de estos primeros proyectos la Ampliación del Ayuntamiento de Algemesi de 1984.
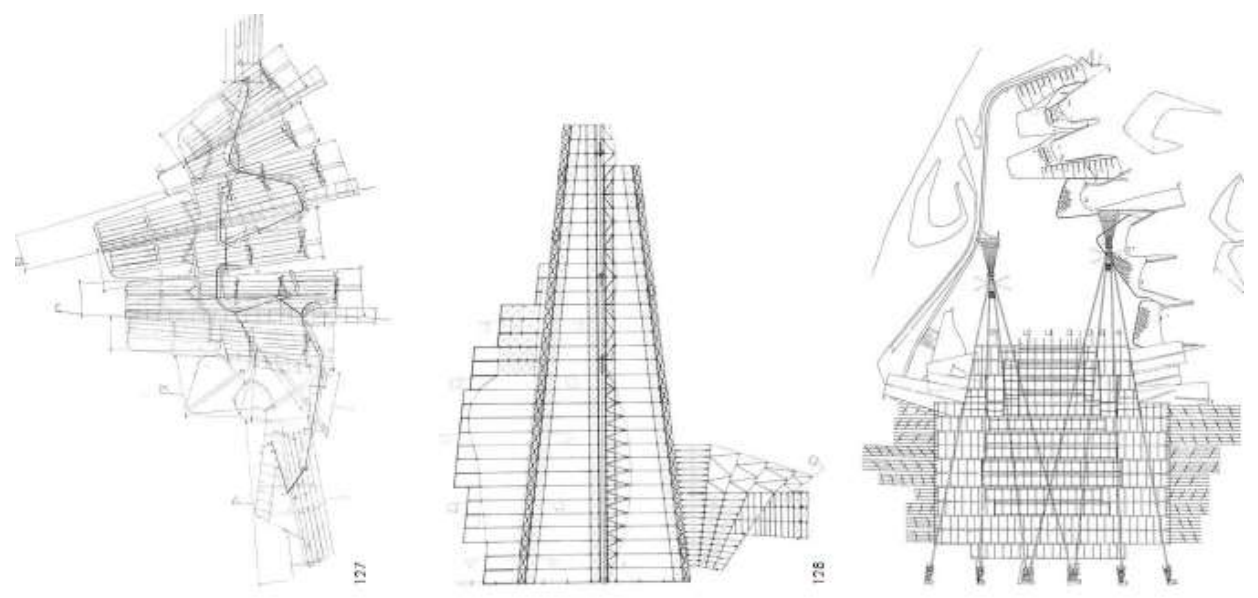

$6-20^{535}$

${ }^{535}$ Cubiertas desde izquierda a derecha: Pabellones de Entrenamiento Tiro con Arco, Pabellones de Alicante y Huesca. 


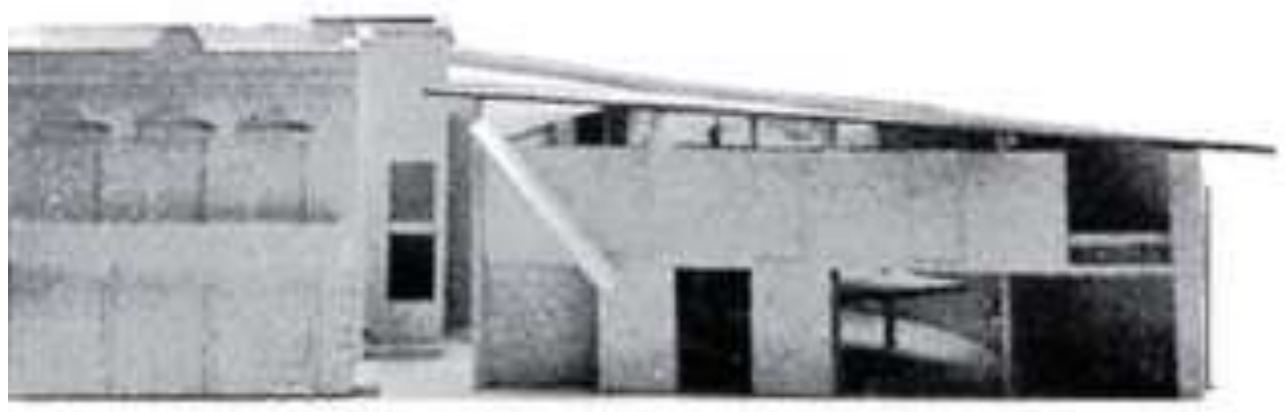

$6-21^{536}$

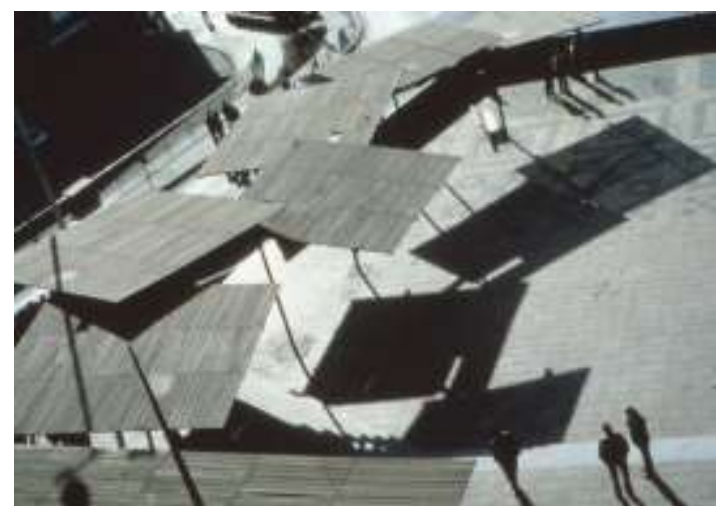

$6-22^{537}$

“...Estas pérgolas son el primer paso para repensar la plaza, desplazando el centro hacia el lugar definido por las sombras..."

Enric Miralles. ${ }^{538}$

En las Pérgolas en Parets del Valles, de 1986, el movimiento cambiante de las sombras arrojadas por estas pequeñas cubiertas según las distintas estaciones y horas del día, son las que generan el lugar. Este modesto proyecto construido en 1985, cuando la pareja Mlralles y Pinos contaban con 25 años de edad, constituye su "Opera Prima". Plantean como dar forma a las fuerzas existentes en el lugar sirviéndose de unas celosías de madera que descansan sobre soportes tubulares metálicos cuya misión es proporcionar un lugar para sentarse a la sombra. La directriz que determinara su trazado viene marcada por los limites irregulares del solar y por el movimiento del sol, también por el garabato en diagonal que traza el movimiento del caballo en ajedrez. El diagrama esencial de este proyecto de cubierta fragmentada, recorrido en angulo, tensa relación entre direcciones principales, articulado plano del suelo, etc. se volverán a encontrar en proyectos posteriores. Lo que aquí empieza como ejercicio de manipulación espacial se

\footnotetext{
${ }^{536}$ Ampliacion del Ayuntamiento de Algemesi. Maqueta de proyecto.

${ }^{537}$ Pergolas en Parets del Valles.

${ }^{538}$ Enric Miralles. Obra completa. Juan José Lahuerta. Electa. 1996
} 
legarra hasta la orquestación a gran escala de las cubiertas de los proyectos de los Pabellones de Huesca y Alicante

En el Centro Cívico de Hostalets de Balenya, de 1986, se produce un escalonamiento conformado por distintas cubiertas planas accesibles al publico incluso cuando el edificio se encuentra cerrado. Las cubiertas son una continuación de la calle y en el recorrido por estas, se pueden contemplar las montañas en la lejania, que desde el nivel de suelo no se perciben. El dialogo entre basamento excavado generado con la topografía y la cubierta elevada, comienza en este proyecto y llegara a su culminación en la construcción del Pabellón de Huesca.

En la Escuela Hogar de Morella, de 1986, los pliegues que realizan las cubiertas del fragmentado programa, se relacionan con lo facetado de los muros del castillo situado en la cúspide de la montaña cercana, de tal manera que al percibirse ambas cubiertas se observa la analogía, que John Ruskin estableciera en su libro Modern Painters entre el perfil de una casa de campo francesa y el perfil lejano de los montes que se divisan desde la casa.

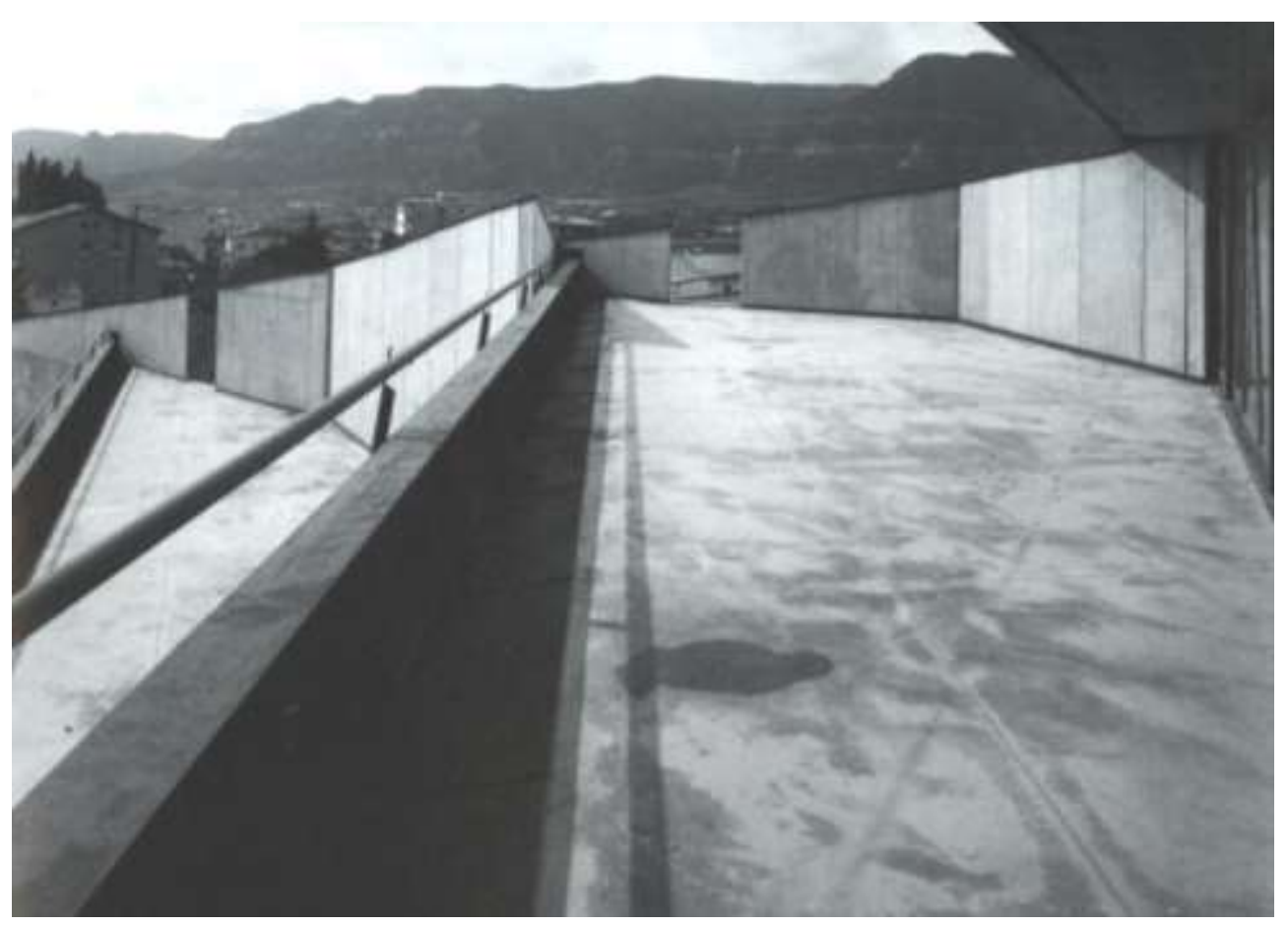

$6-23^{539}$

${ }^{539}$ Centro civico de Hostalets de Balenyá. Vista desde una de las cubiertas. 


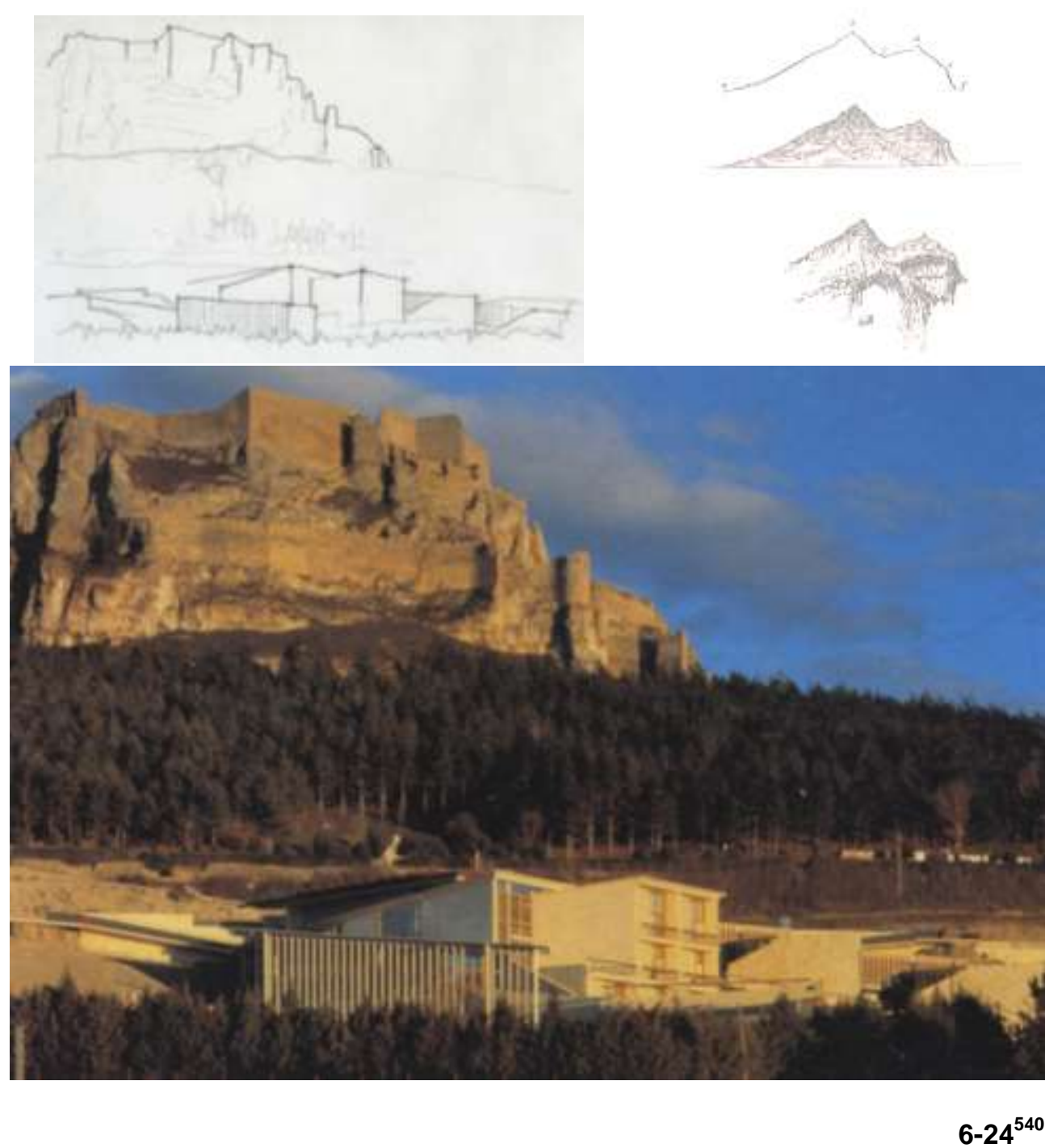

En el Complejo de Tiro con Arco, de 1989, la cubierta se configura en el edificio de Competición con un elemento prefabricado de hormigón repetido, que es cerramiento vertical y cubierta a la vez; y en el de Entrenamiento con unas losas de hormigón en voladizo dispuestas libremente en forma de abanico. Solo en el edificio de Entrenamiento, se da esa dialéctica cubierta - topografía, en el sentido de una topografía domesticada que alberga el programa funcional y una cubierta que flota por encima siendo la fachada el resultado de lo que queda entre medias. Aquí la tabiquería y las puertas no llegan al techo, y con ello se permite que la cubierta evolucione al margen de lo que ocurre en el suelo.

Los Pabellones de Huesca y Alicante, son los primeros edificios de Miralles que reúnen los experimentos topográficos del Parque Cementerio de Igualada con la vocación de ligereza de sus primeras pérgolas y cubiertas. ${ }^{541}$ Sera la cubierta el elemento que dote de unidad a ambos proyectos. Basamento y cubierta se separan lo justo para que entre el público al interior.

\footnotetext{
${ }^{540}$ Analogia existente entre el perfil de los muros facetados del castillo en la parte superior y el perfil de la cubierta de la Escuela Hogar en Morella. Dibujo realizado por el autor de la Tesis.

541 Para mas información puede consultarse la Tesis de Javier Fernandez Contreras "La planta Mlralles: Representación y Pensamiento en la Arquitectura de Enric Miralles"ETSAM. UPM.
} 


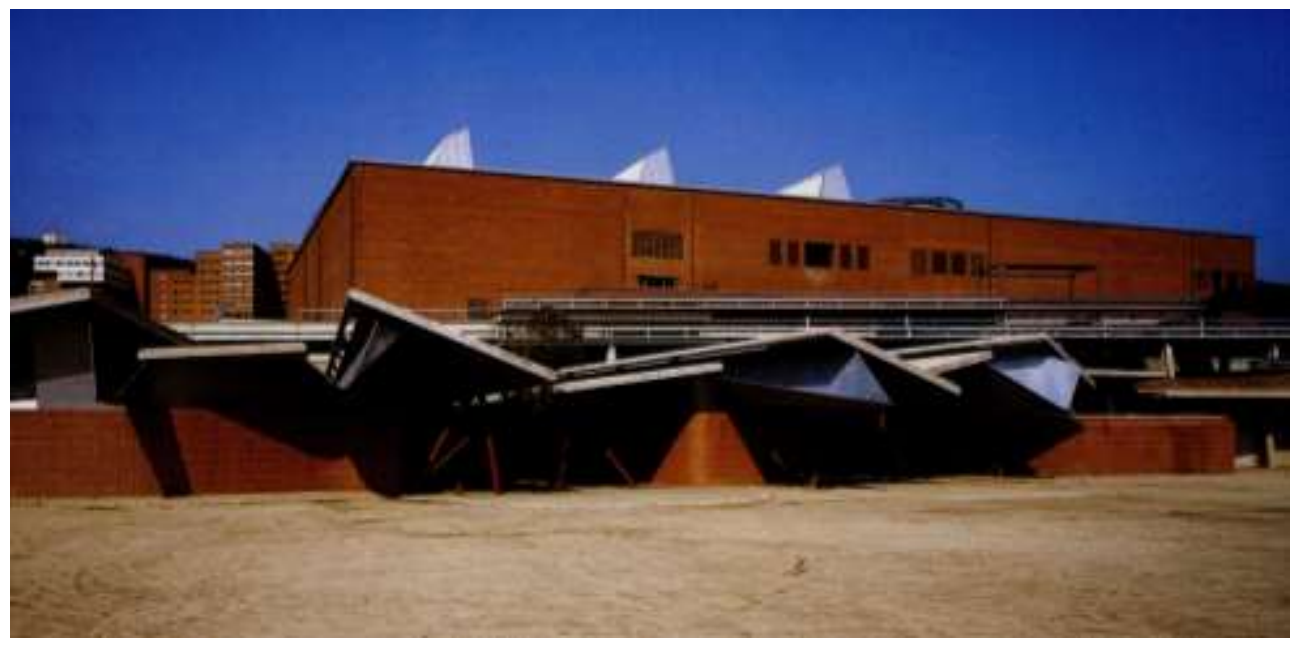

$6-25^{542}$

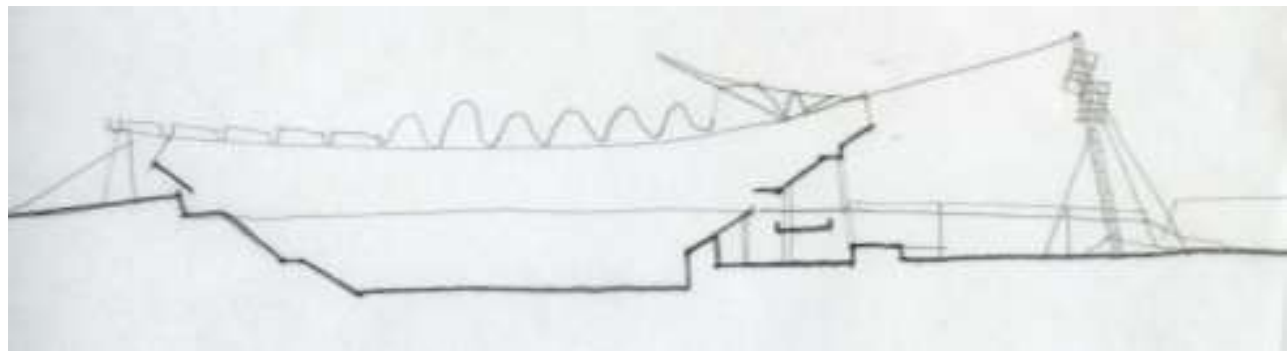

$6-26^{543}$

En Huesca, la cubierta del proyecto inicial atirantada, se plantea como una estructura tensada, que sobrevuela el organismo construido para significar su presencia mas allá de los limites. Miralles coloniza el entorno del edificio mediante la solución sustentante de la cubierta, en la que los seis caballetes de hormigón entre los pinos del bosque de la fachada oeste, y los dos mástiles del lado este, se intercambian los tensores que construirán la cubierta. Ello convierte el entorno en proyecto y el proyecto en entorno. El edificio propiamente dicho es aquello que queda entre el suelo excavado y la cubierta. La gran escala de la cubierta ayuda a relacionar el edificio con el paisaje en el que se implanta. La cubiertas generan sombras que contribuyen a anular la fachada ayudando a fundir la arquitectura con el paisaje. En palabras del propio Miralles: "la cubierta debe de trasladar el mundo del bosque hasta el espacio publico pasando por encima del edificio." ${ }^{544}$

En el Pabellón de Alicante, la cubierta también sobrevuela el organismo construido y se soporta por una exoestructura de tres cerchas desde la que se suspende la cubierta. Como en tantos otros proyectos de Miralles, casi todo surge desde la cubierta, cuya forma tiene resonancias con la silueta de la Sierra que se divisa en la lejanía. Esta gran cubierta unifica la cubrición de las dos pistas, para ganar mayor tamaño y convertirse en un hito en un entorno en el que el contexto se caracteriza en la zona Oeste del solar por anodinos bloques de vivienda colectiva.

\footnotetext{
542 Pabellón de Entrenamiento de Tiro con Arco.

${ }^{543}$ Pabellón de Huesca. Dibujo realizado por el autor de la Tesis.

${ }^{544}$ Enric Miralles. Conferencia en ETSAM. 05/05/1993.
} 


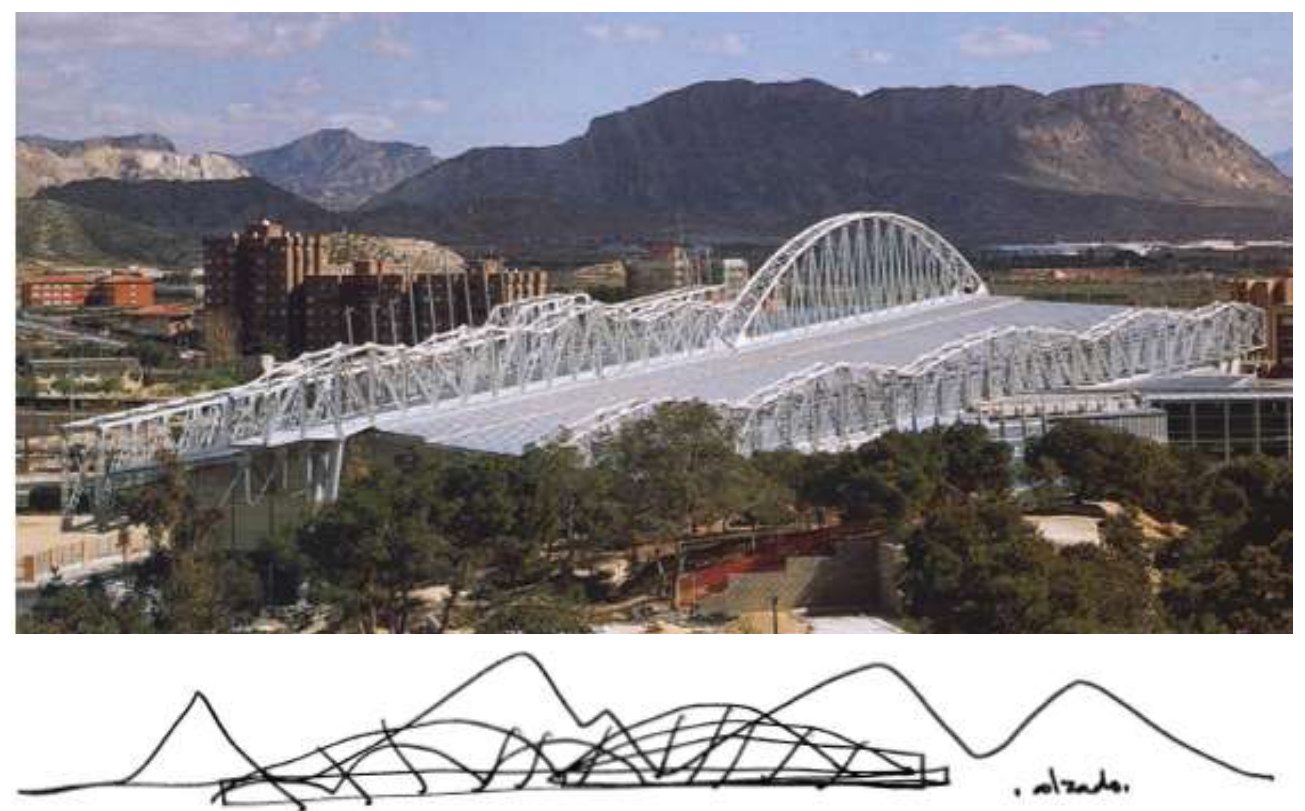

"Not in a hill, but of a hill... During our flight to Alicante, Miralles had already explained the dependence of the building on the site with hasty sketches on scrap paper...

Peter Blundell Jones. ${ }^{546}$

Además, la cubierta se extiende por mayor parte del solar, generando sombras en los espacios intermedios entre el interior y el exterior, necesarios en un clima tan cálido como el de Alicante. Aquí Miralles, vuelve a hacer una alusión metafórica al paisaje, al establecer una analogía entre el perfil de las montañas que se divisan a lo lejos y el perfil de las cerchas que sustentan la cubierta, como ya había hecho con la cubierta de la Escuela Hogar en Morella.

En la Biblioteca de Palafolls, de 1997, las cubiertas están formadas por una serie de cuerpos abovedados que se desplazan entre si haciendo alusión tanto al Pabellón de Deportes de la localidad como a las montañas que se divisan en la lejanía desde el solar. La experiencia de las secciones abovedadas se llevaran a la propuesta de concurso para el Centro Cívico de Niederrad de 1991, donde una cubierta formada por una serie de bóvedas de generatriz variable y directrices no paralelas, cubren un espacio diáfano que alberga un salón de actos y diversas estancias. Estos complejos abovedamientos controlados desde la maqueta, aparecerán en proyectos posteriores como las propuestas para la Iglesia en Roma, el Centro Laban y los laboratorios en Dresde.

\footnotetext{
${ }^{545}$ Pabellón de Alicante. Analogía entre el perfil de la montaña y el perfil de las cerchas que sustentan la cubierta

546 "Not on a hill but of a hill: Enric Miralles National Gymnastic Training Centre in Alicante", pag. 6
} 


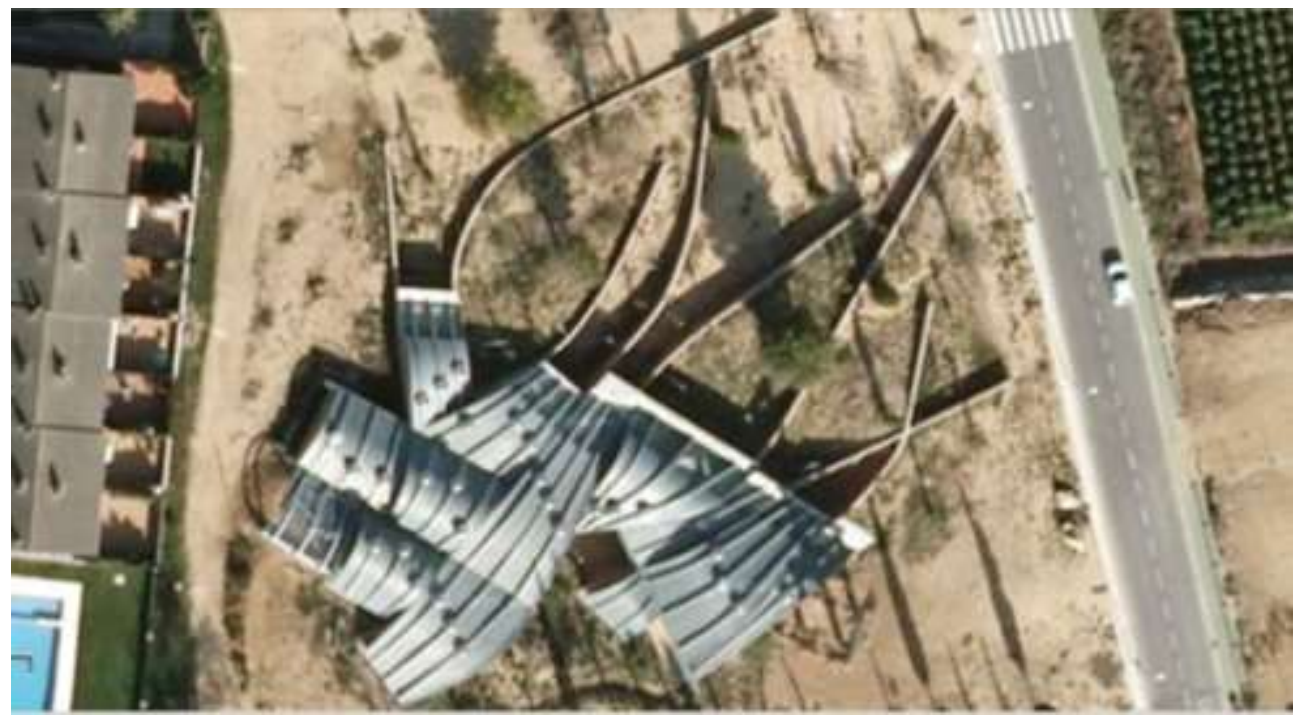

$6-28^{547}$
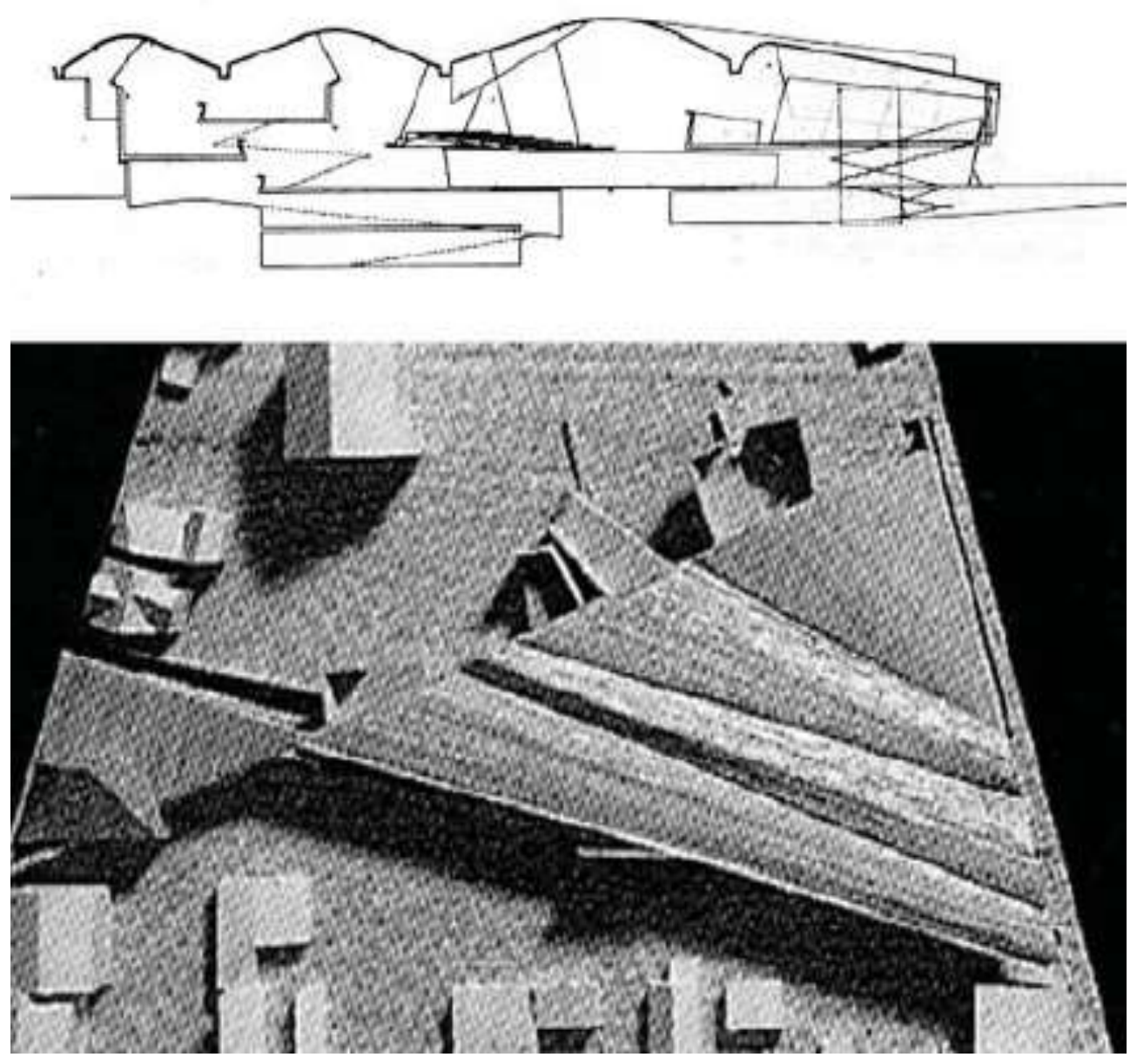

$6-29^{548}$

${ }^{547}$ Biblioteca de Palafolls. Cubiertas concatenadas.

${ }^{548}$ Propuesta de concurso para el Centro Cívico de Niederrad. 


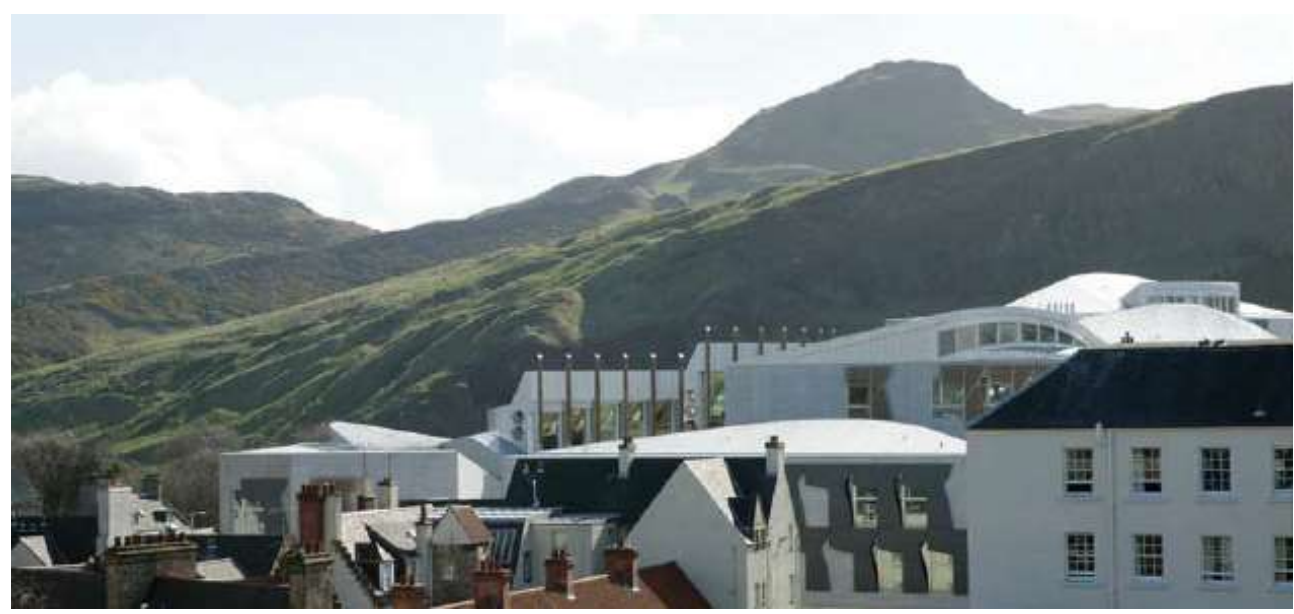

En el Parlamento de Edimburgo, de 1998, destacan las cubiertas en forma de barcas invertidas que rematan las torres dedicadas a estancias del comité, cuyo contorno tiene analogías con el perfil de las montañas cercanas.

Desde los primeros proyectos con Carmen Pinos como por ejemplo en la Ampliación del Ayuntamiento de Algemesi la cubierta se separa del cerramiento para desmaterializar el volumen arquitectónico y sobrepasar los límites del organismo construido. ${ }^{550}$

En las Pérgolas de Parets y la Avenida Icaria, las cubiertas colonizan un paisaje sin identidad configurando un lugar a través de sus sombras. En el Centro Cívico de Hostalets, las cubiertas a medida que ascienden, van girando y superponiéndose en forma de abanico para permitir vistas panorámicas hacia las montañas cercanas que no se ven desde el nivel de calle. Las cubiertas de perfiles fracturados que se dan en los proyectos de la Escuela Hogar en Morella; en la exoestructura de la que cuelga la cubierta del Pabellón de Alicante y en el Parlamento de Edimburgo, hacen referencia a las montañas y construcciones existentes en el entorno, tal y como Ruskin expresaba en su libro "Modern Painters", en el que demostraba con un dibujo la analogía entre la cubierta fracturada de una casa de campo francesa y el perfil de las montañas cercanas.

La acción de superar los limites de lo construido con la cubierta que se da en Hostalets y Tiro con Arco, continuara en Huesca y Alicante, e incluso algo mas tarde en el Mercado de Santa Caterina en Barcelona, pero no se dará en proyectos como Palafolls y Edimburgo, precisamente por los problemas generados por los encuentros no coplanarios en el proceso de ejecución de la obra al tener que sellar y compartimentar climáticamente. Lo que si evolucionara en las cubiertas de Miralles, será su forma, pues habiendo empezado con cubiertas de formas planas y ligera inclinación, se pasara a perfiles fracturados en Morella y Tiro con Arco; y se llegara hasta perfiles combados abovedados como en Palafolls, Niederrad y Edimburgo.

\footnotetext{
${ }^{549}$ Parlamento de Edimburgo.

550 Para mas información puede consultarse la Tesis de Javier Fernandez Contreras "La planta Mlralles: Representación y Pensamiento en la Arquitectura de Enric Miralles"ETSAM. UPM.
} 


\title{
6.1.4. RE C O R R I D O S:
}

\author{
"Sverre Fehn, un arquitecto noruego, lo describe \\ así: un camino comienza a ser cuando resuelve \\ el proceso de un lugar a otro, y este acto \\ determina su forma. Una definición abstracta, \\ seguida de una serie de esbozos sobre el papel \\ que al dibujarse asume formas cada vez más \\ concretas $y$ se llenan gradualmente de \\ memorias, de referencias externas, de \\ asociaciones". \\ Enric Miralles. ${ }^{551}$
}

Es la acción que utiliza Miralles orquestando los movimientos de la gente para hacerles visible el paisaje en el que se encuentran y relacionar el interior del organismo construido con el exterior del paisaje. En muchos casos es el propio recorrido el que genera la forma del edificio.

A finales del siglo XX, pierde importancia lo visual, el alzado, y lo cobra la planta, lo experiencial. El laberinto es la organización arquitectónica propia de la arquitectura contemporánea. Cada vez menos arquitectos utilizan la perspectiva tradicional en sus proyectos, los edificios se piensan para ser vistos desde múltiples puntos de vista. Miralles aplica en sus proyectos la promenade architecturale de Le Corbusier, negando la perspectiva renacentista de un único punto de vista, reforzando la geometría para introducir el movimiento en la obra y obligar al espectador a moverse para comprenderla. ${ }^{552}$

En la Plaza de la Estación Sants en Barcelona, de 1981, proyectada por Viaplana, Piñon y Miralles es el recorrido el que cohesiona el paisaje generado por los distintos elementos proyectados a los que se encomienda generar una nueva identidad en el lugar. En los primeros Concursos, realizados con Carmen Pinos, los planos denotan la preocupación por generar recorridos con la voluntad de ser espacio publico y de relacionarse con el paisaje. Valga como ejemplo su propuesta para la Plaza de España en Alcañiz de 1984.

En el Centro Cívico en Hostalets de Balenyá, de 1990, se genera una topografía artificial generada por el recorrido que lleva desde el nivel de calle hasta la última de las cubiertas, siendo dicho recorrido el que genera la geometría del edificio. Como cuenta Miralles: "...la calle de acceso se prolonga en el interior del edificio, transformándose en un pequeño teatro, mientras que las rampas hacen accesible el edificio incluso cuando está cerrado...Cada uno de los niveles alberga una función especializada: en la planta baja se encuentra la sala de convenciones exposiciones, en la primera planta el bar y una sala de lectura, en la segunda la sala de reuniones y en la ultima planta los talleres." ${ }^{553}$

\footnotetext{
551 "For what time is this place". TOPOS 8. European Landscape Magazine, 1994, p 102-108.

552 En el Barroco también nació el dinamismo de curvas y contracurvas, en arquitecturas como la de Borromini que tanto empleara Miralles en su discurso arquitectónico.

${ }^{553}$ Enric Miralles. Obra completa. Juan José Lahuerta. Electa. 1996
} 


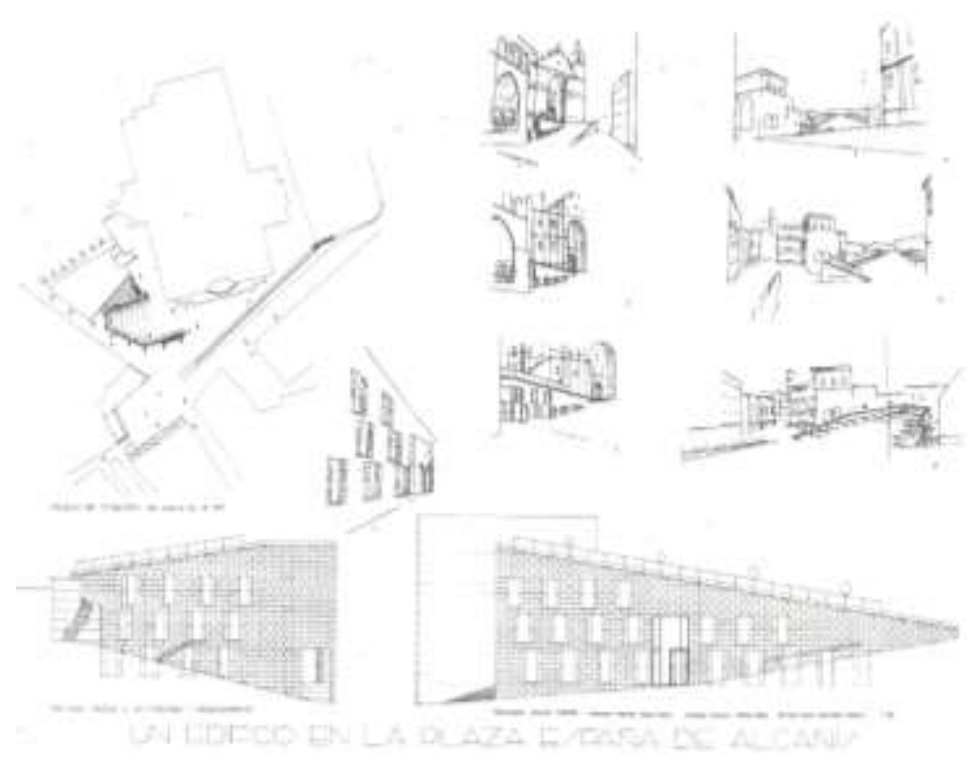

$6-31^{554}$

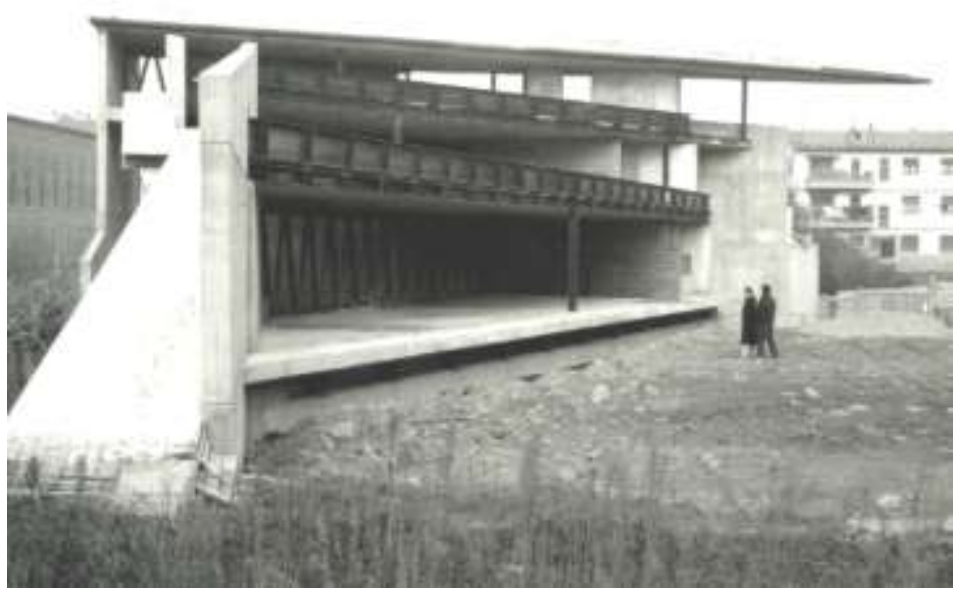

$6-32^{555}$

En el Parque Cementerio de Igualada, de 1985, la propuesta tiene una condición lineal, es un camino que conecta la parte alta del solar con la inferior a nivel del rio que discurre por allí, donde lo importante no son los extremos, sino el recorrido mismo. Todas las decisiones de proyecto se toman en relación a la manera de recorrer ese camino y las sensaciones que va provocando en el paseante. Conviene destacar la importancia del recorrido para estructurar la propuesta pues de los tres paneles entregados al Concurso, uno de ellos estaba dedicado a perspectivas que relataban secuencialmente el recorrido de la propuesta. En los Pabellones de Tiro con Arco, el recorrido esta orquestado para que se perciba la intervención desde distintos puntos de vista, teniendo como foco de atención el amplio paisaje conformado por las pistas de competición dispuestas enfrente de los edificios.

\footnotetext{
${ }^{554}$ Propuesta para la Plaza de España en Alcañiz de 1984.

${ }^{555}$ Centro Civico en Hostalets de Balenyá.
} 

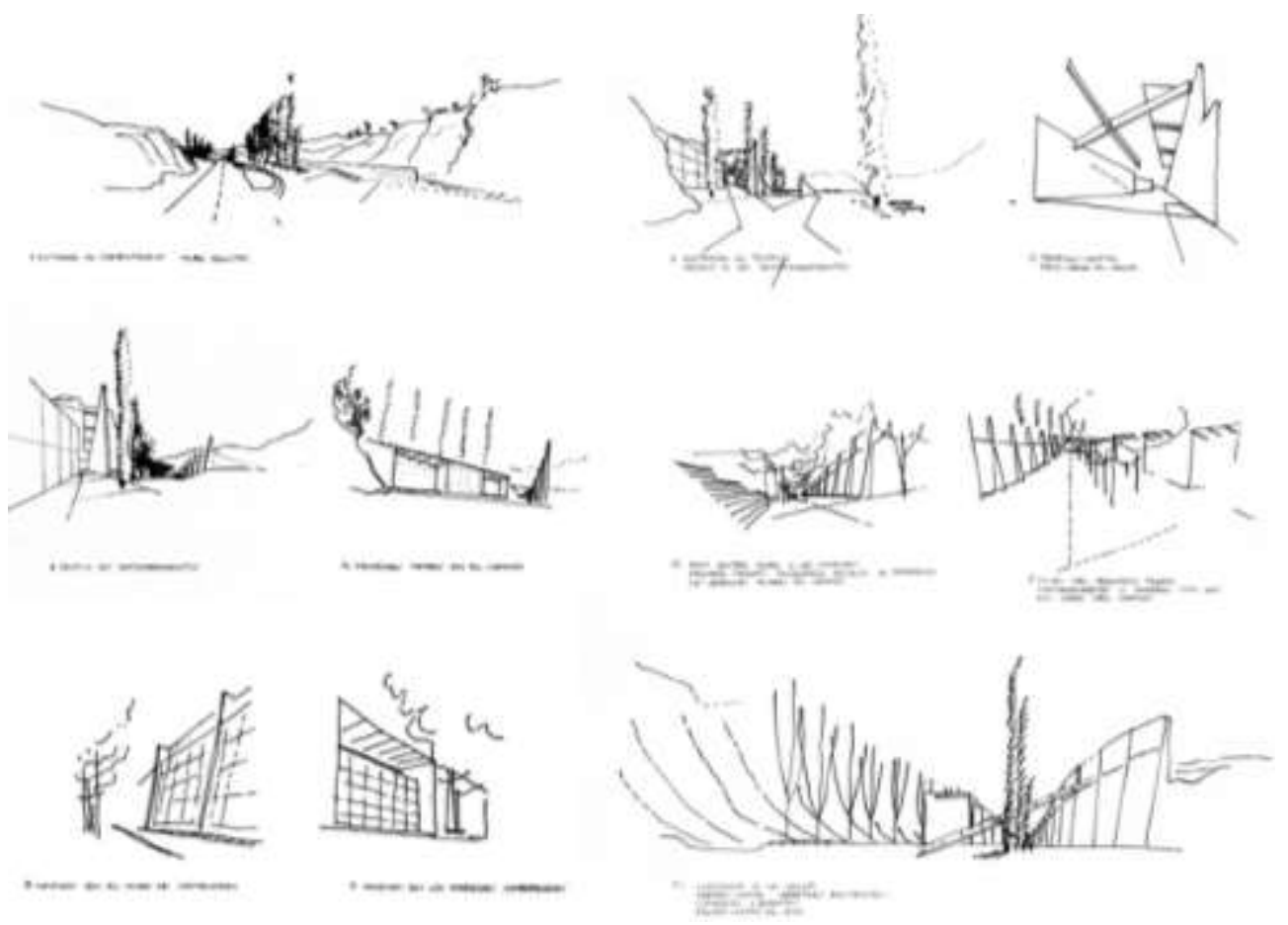

$6-33^{556}$

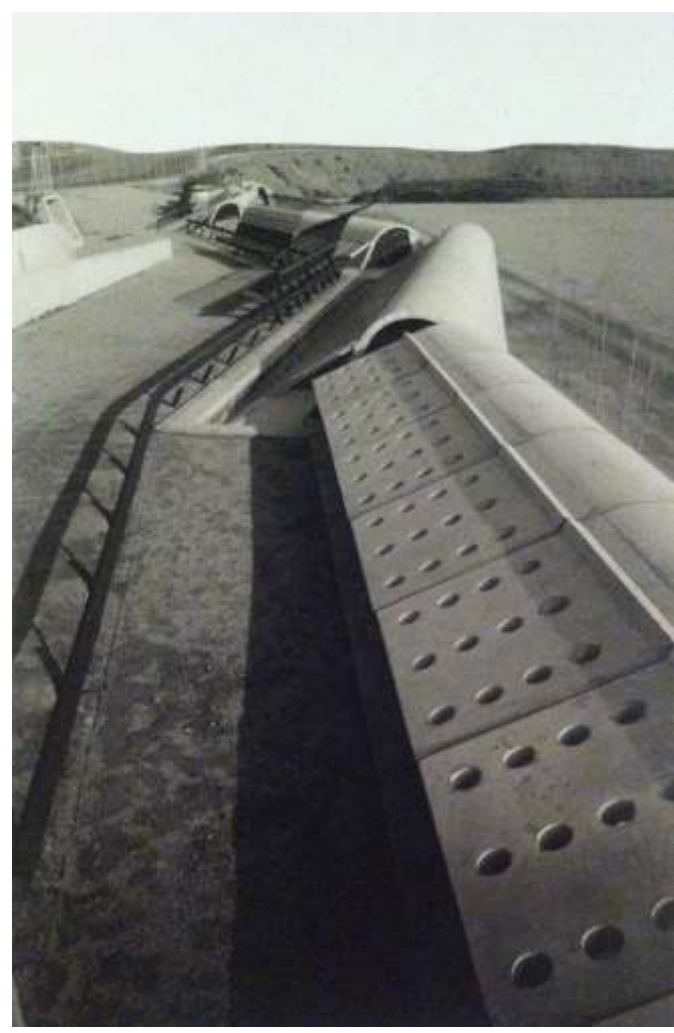

$6-34^{557}$

556 Parque Cementerio de lgualada, de 1985. Perspectivas que guian el recorrido dibujadas por Mlralles para la propuesta de Concurso.

${ }^{557}$ Pabellón de Competición de Tiro con Arco. Recorrido plataforma superior. OFundació Enric Miralles 


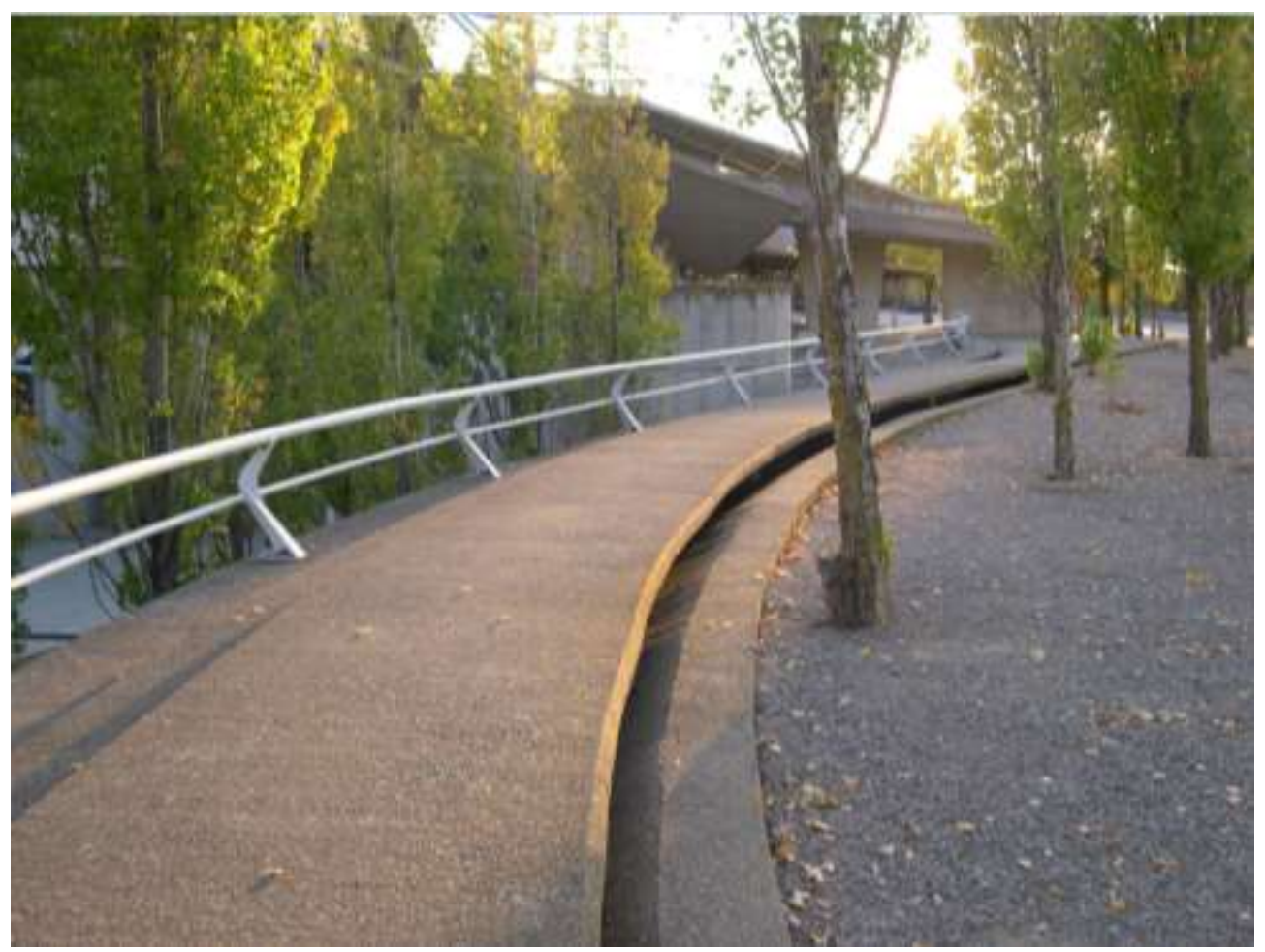

La Escuela Hogar en Morella, es un espacio laberinto al interior, mientras que los paseos exteriores focalizan las vistas sobre el paisaje natural. En los Pabellones de Huesca y Alicante, de 1990, los recorridos hacen disfrutar de la experiencia de visitarlos por las variaciones orquestadas por Miralles. En Huesca, el carácter público de la actuación se lo otorga el desplazamiento del interés por el propio edificio a el vacio generado entre la tribuna y las ultimas edificaciones de la ciudad, cobrando gran importancia los paseos de borde que llegan a los porches laterales de acceso al edificio. La intervención, no se puede aprehender con una sola mirada. Se necesita recorrer todo su perímetro para comprender el conjunto.

En Alicante, se retoma la idea de edificio como calle a través de la orquestación de un recorrido sinuoso mediante rampas y pasarelas alrededor de la actividad deportiva. Como en Centro Carpenter de Artes Visuales en Harvard de Le Corbusier, el publico accede al interior del edificio por una rampa elevada. ${ }^{559}$ Las sinuosas rampas pueden entenderse también como una transformación de las ultimas curvas de nivel de la colina colindante. Como define Ricardo Sánchez Lampreave: " El edificio cobra forma cada vez que se utiliza, los recorridos del publico coinciden con el perímetro de las salas, generando una serie de variables trayectorias y aparentemente desordenadas. El énfasis puesto en esas circulaciones, que orientan y guían al visitante...y las rampas, escaleras... los elementos que indican el camino a tomar que son los que dan forma al proyecto $y$ definen sus limites." ${ }^{560}$ Si las circulaciones de acceso al Pabellón de Huesca, se

\footnotetext{
558 Pabellón de Huesca. Recorrido por uno de los flancos hasta llegar a los accesos. Fotografia realizada por el autor de la Tesis.

${ }^{559}$ David Cohn. Architectural Record. Agosto1994

560 Conferencia impartida dentro del curso "Enric Miralles. Alegorías del tiempo" UIMP 2009. Barcelona.
} 
realizaban por los laterales de manera simétrica, en Alicante, se concentran en la fachada de mayor longitud a través de unas rampas de geometría envolvente.

En la propuesta de Concurso para el Borghetto Flaminio en Roma, de 1994, Miralles une la Porta del Popolo con el Museo de Arte Etrusco atravesando el fragmentado barrio del Borghetto mediante un recorrido que conecta los distintos episodios entre si, en el que se recrea en la cinética de los movimientos, para multiplicar las vistas en perspectiva sobre el paisaje urbano de Roma. En el Campus Universitario de Vigo, de 1999, se generan unos recorridos lineales sinuosos que enlazan las diferentes partes del conjunto, generando unos edificios de configuración lineal sobre una plataforma artificial desde la que divisar el paisaje. El acceso al campus es un paseo entre arboles, mientras que los pabellones de aulas, servicios y comerciales, se organizan respondiendo a las vistas del paisaje.
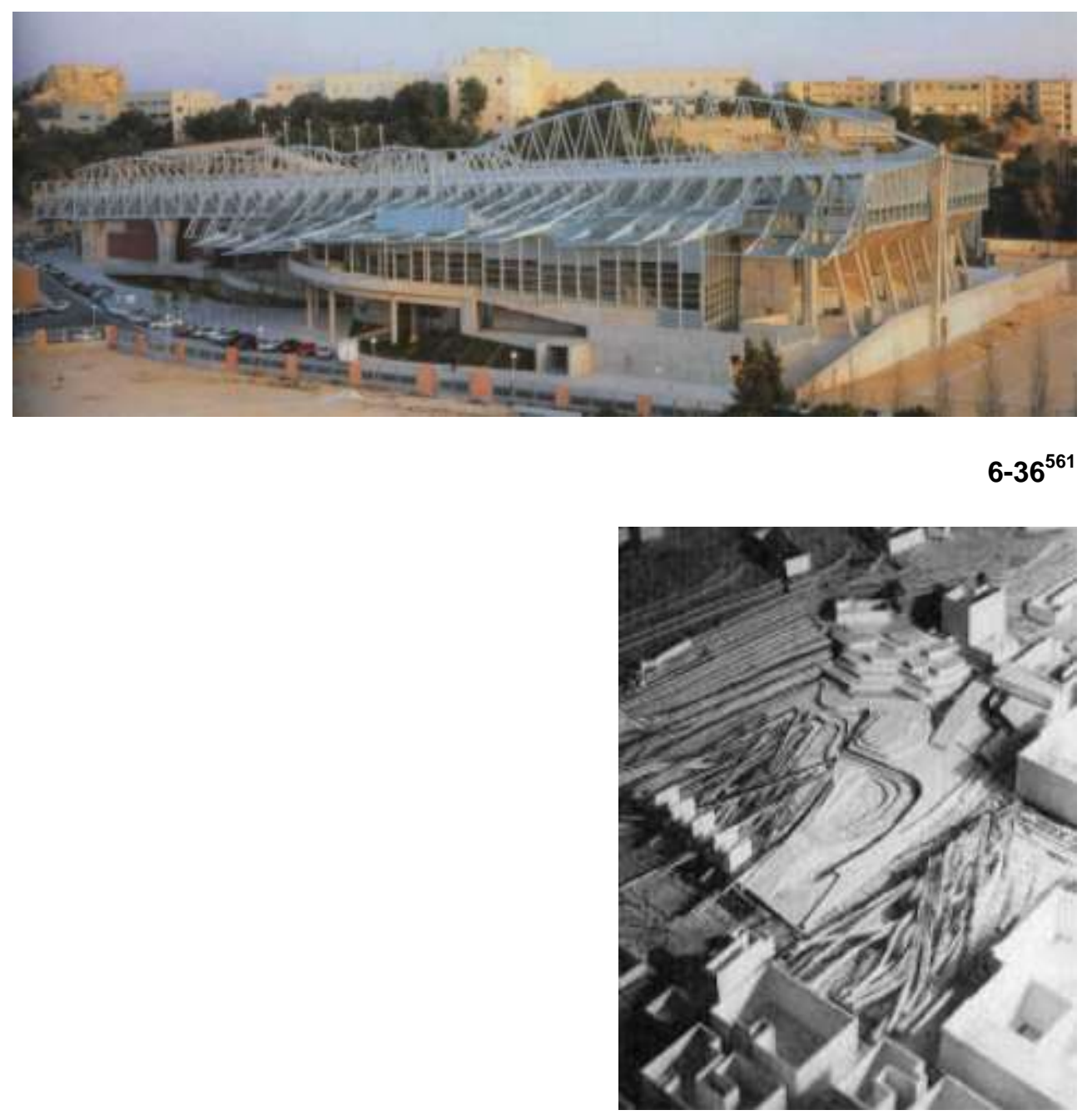

$6-37^{562}$

\footnotetext{
561 Pabellón de Alicante. Las circulaciones se concentran en la fachada de mayor longitud a través de unas rampas de geometría envolvente.

${ }^{562}$ Concurso para el Borghetto Flaminio en Roma, de 1994,
} 


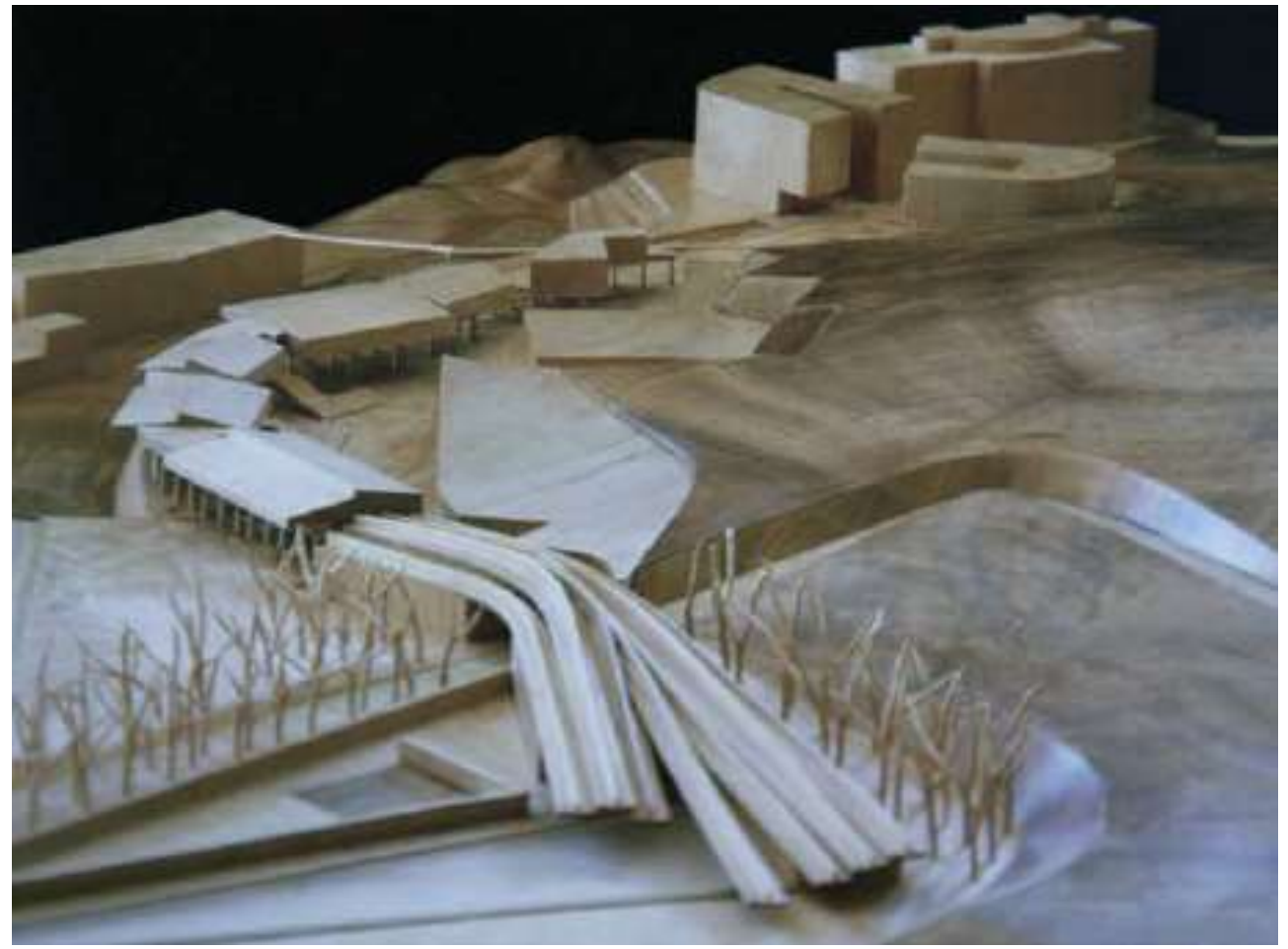

\section{$6-38^{563}$}

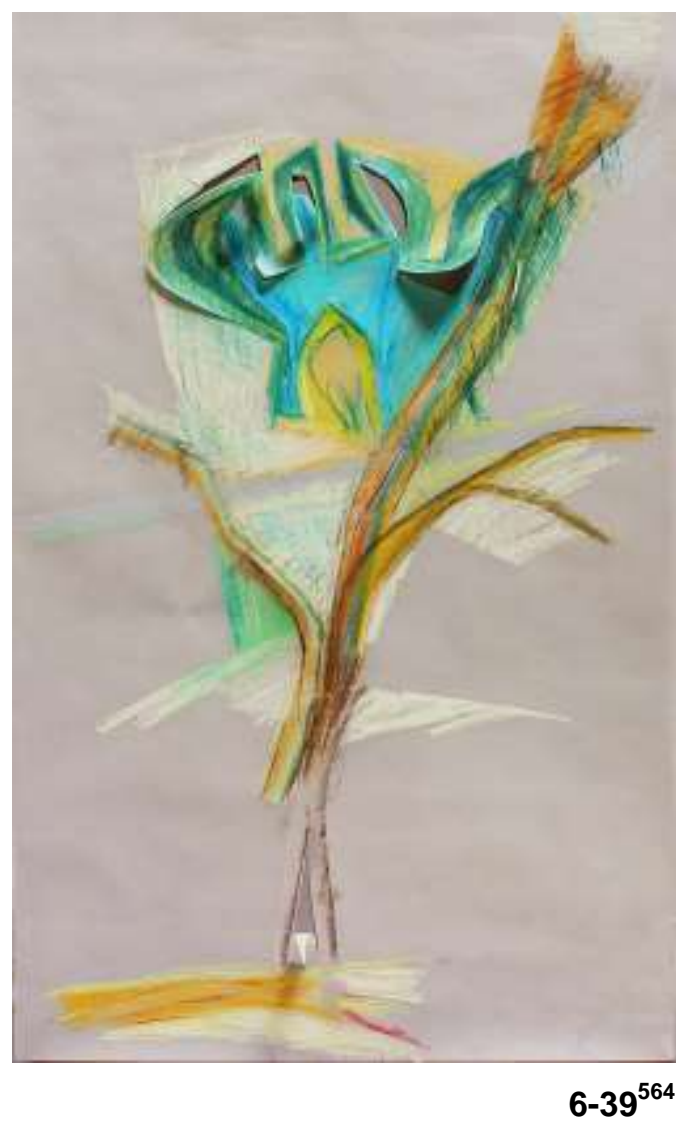

${ }^{563}$ Campus Universitario de Vigo, de 1999

${ }^{564}$ Parque Diagonal Mar, de 1997. Croquis de Miralles. 
El Parque Diagonal Mar, de 1997 se estructura siguiendo una serie de caminos en todas las direcciones como si fueran las ramas de un árbol. Dicha intención se detecta en uno de los primeros croquis de Mlralles de este proyecto. En la propuesta de Concurso para el Puerto de Bremerhaven, de 1993, cinco intervenciones se superponen para responder de manera independiente al lugar. Una de estas intervenciones, denominada Braumpromenade, constituye un paseo aterrazado que se superpone sobre la carretera; mientras que en la denominada Kristalpalast, una serie de galerías elevadas crean un recorrido equipado que sobrevuela el conjunto combinando tres directrices lineales de gran plasticidad con otras tres generatrices de sección variable.

Desde los primeros Concursos realizados junto a Carmen Pinos, Miralles da gran importancia a los recorridos y lo refleja en sus perspectivas dibujadas a mano en la que de manera secuencial expresa la mirada que el visitante tendrá al recorrer su arquitectura. Estos recorridos orquestados desde el proyecto descubren el lugar y configuran la propuesta arquitectónica. Valga como ejemplo la importancia dada al recorrido que se constata en los paneles de los Concursos de Un edificio en la Plaza de España de Alcañiz o del Parque Cementerio de Igualada, en los dibujos que relatan el recorrido conforman la tercera parte de la documentación aportada al Concurso.

Desde su propuesta para el edificio en la Plaza de España de Alcañiz, pasando por el Centro Social de Hostalets de Balenya, que surge del recorrido desde la calle hasta la última de las cubiertas accesibles como en el Pabellón de Alicante donde las rampas de acceso al edificio de la masa de visitantes generan la forma y distribución del edificio, se genera una topografía artificial que genera el edificio hilvanada por el recorrido ascendente en vertical.

Como señala Javier Fernandez Contreras, cuando el recorrido sigue un desarrollo horizontal la directriz suele ser quebrada y en un mismo plano horizontal como en el Complejo de Tiro con Arco y el Campus de Vigo, o con recorridos con amplias curvas como en la zona al aire libre del Pabellón de Huesca, el Parque Diagonal Mar, y las propuestas del Borghetto Flaminio en Roma y del Puerto de Bremerhaven. ${ }^{565}$ En el caso del Campus de Vigo, el propio recorrido genera los edificios de configuración lineal organizados en funcion de las vistas al paisaje que se divisan desde estos.

Recorridos exteriores orquestados por Miralles para encuadrar vistas y aspectos del paisaje importantes que además organizan la arquitectura funcionando sin problemas de circulaciones, dado que Miralles es consciente de los grandes problemas de logística que se dan cuando hay que conducir a grandes masas de gente.

Miralles estaba fascinado por la rampa del Carpenter Center del MIT en Cambridge, o los accesos hasta la Capilla de Ronchamp de Le Corbusier, siendo consciente de cuanto el movimiento de la gente condiciona la forma de la arquitectura y proporciona una experiencia perceptiva mas rica.

Tanto en el Pabellón de Alicante, en la propuesta de Concurso para el Museo de Arte Contemporáneo de Helsinki de 1993, la rampa de acceso también establece relación con el espacio público.

565 Para mas información puede consultarse la Tesis de Javier Fernandez Contreras "La planta Mlralles: Representación y Pensamiento en la Arquitectura de Enric Miralles"ETSAM. UPM. 


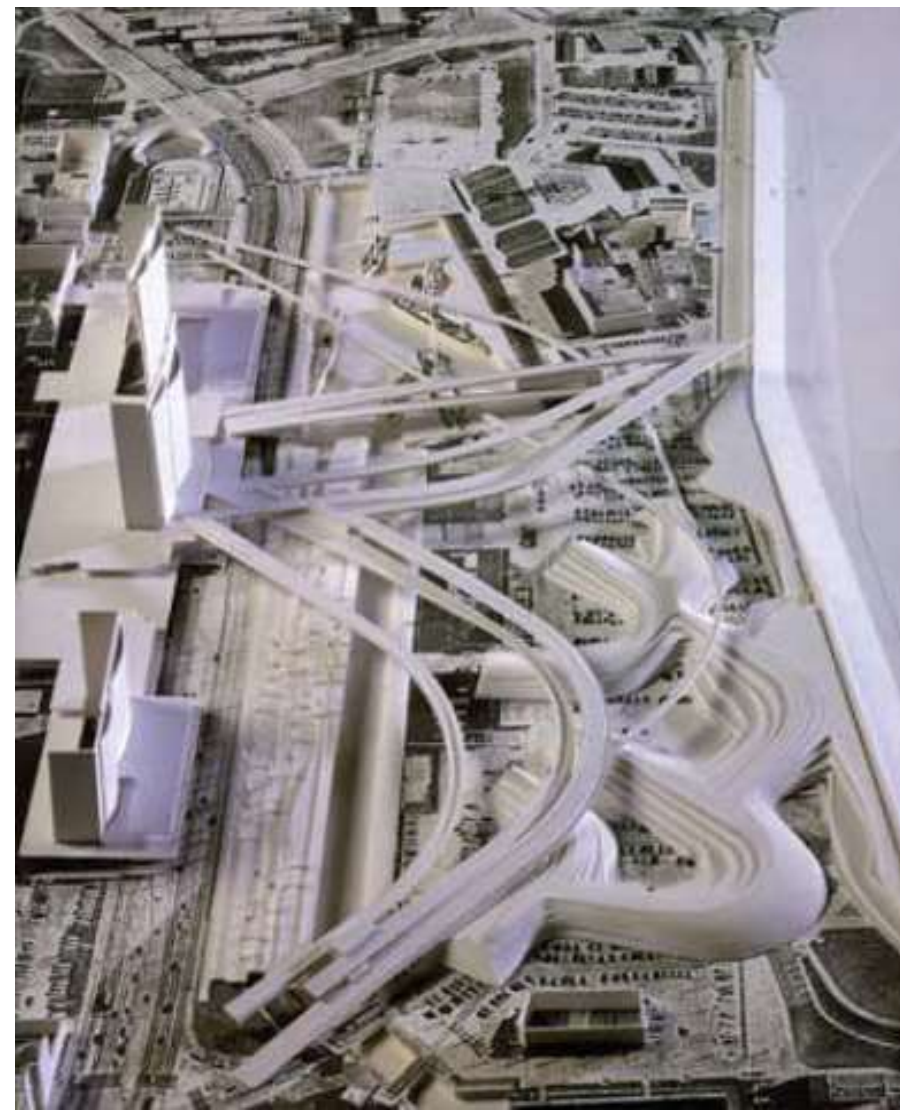

$6-40^{566}$

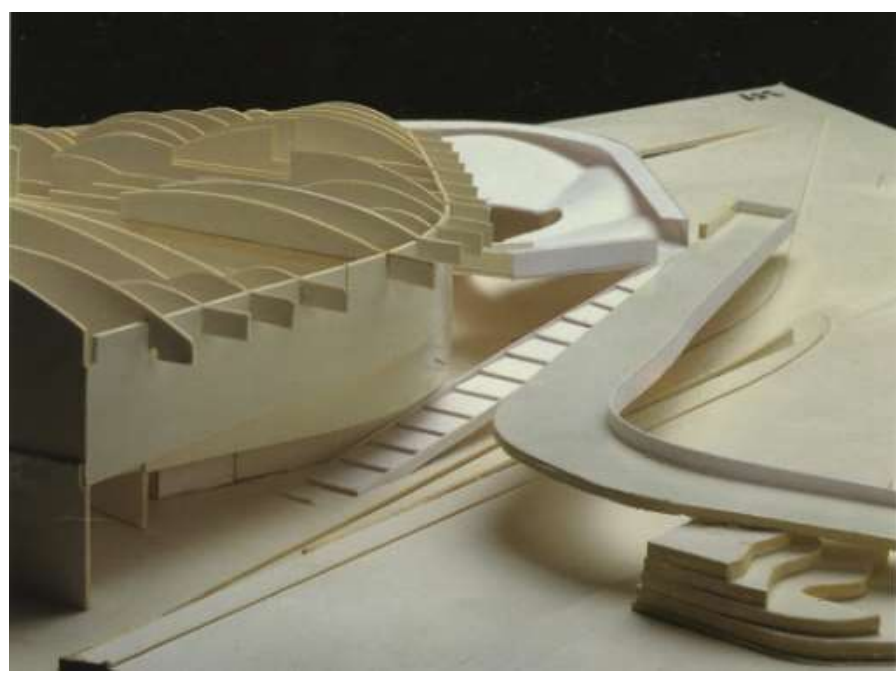

$6-41^{567}$

Respecto a los recorridos interiores, como señala Iñaki Abalos, son muy importantes en la arquitectura de Miralles, pues responden a una explosion interior

\footnotetext{
${ }^{566}$ Puerto de Bremerhaven, de 1993. Maqueta de Concurso.

${ }^{567}$ Concurso para el Museo de Arte Contemporáneo de Helsinki de 1993. El recorrido por la rampa de acceso establece relación con el parque.
} 
que se expande y colisiona hacia el exterior sin limites. ${ }^{568}$ Ello genera unos interiores, gozan de la misma riqueza perceptiva y dinamismo que en los exteriores generando espacios laberinticos parecidos a los grabados de las cárceles de Piranesi, de entre los que destaca la experiencia que se tiene al recorrer el interior en el Pabellón de Alicante. Este espacio laberinto también se da en la Escuela Hogar en Morella, y en menor medida en el Ayuntamiento de Utrecht, la Escuela de Música de Hamburgo o el Parlamento de Edimburgo.

Por tanto queda patente como los organismos construidos por Miralles, no se pueden entender desde un solo punto de vista obligando al visitante a moverse si quiere comprenderlos. Los recorridos no son nunca axiales, sino tangenciales. Se evita la aproximación inmediata, por medio de recorridos sucesivos variados, quebrados y curvos, hasta la llegada y entrada al interior del edificio. Son recorridos de una gran intensidad narrativa que unen las distintas zonas del programa edilicio, dialogando con el paisaje y haciendo interaccionar el interior y el exterior, en las que lo construido y lo natural se funden. Dichos recorridos mantienen alerta al visitante y le hacen ser mas consciente del lugar y el momento en que se encuentra.

Miralles configura un espacio continuo, laberintico, topológico, en el que lo importante no es el origen ni el final del recorrido sino el propio movimiento que toma el visitante de sus edificios. La percepción de este espacio se tiene a través de planos, no de volúmenes y se complejiza al intercalar planos que cambian de nivel proporcionando una componente topográfica semejante a la del terreno natural. ${ }^{569}$

Conviene destacar que el automóvil queda relegado, a recorridos perimetrales exteriores, alejados en la medida de lo posible del organismo construido, dado que su presencia, rompería la integración del organismo construido con el paisaje. En Igualada, el automóvil se queda en la parte superior tras llegar a la capilla, en Huesca se reserva un aparcamiento en la zona más alejada próxima a los bloques residenciales de vivienda colectiva, en Morella, se aparcan en el lado opuesto de la calle por donde se accede peatonalmente al edificio, etc.

\subsubsection{RELACIONES INTERIOR - EXTERIOR}

Es la acción que utiliza Miralles estableciendo un dialogo entre el interior y el exterior para relacionar su organismo construido con el paisaje, sumiendo al espectador en una experiencia perceptiva que le haga sentir estar dentro del edificio y al mismo tiempo fuera en el paisaje. Miralles crea en su Arquitectura mecanismos para generar una tension entre interior y exterior.

La penumbra es un lugar frontera entre la luz y la sombra, que pertenece a dos ámbitos a la vez (el de la luz y el de la sombra). No es una disociación entre pares enfrentados, sino una tensión transformadora, donde no se puede decir cuando es uno o lo otro. Con los espacios intermedios, entre organismo construido y paisaje, entre lo privado y lo publico ocurre lo mismo.

Para Miralles, "entrar significa salir" porque dichos espacios interiores se tratan como exteriores. Determinados reflejos en los materiales, espacios concatenados,

\footnotetext{
${ }^{568}$ Iñaki Abalos. "Conversaciones con Enric Miralles". Fundacio Enric Miralles. 28/11/14

${ }^{569}$ La sensación al recorrer estos espacios se asemeja a la que se tiene al vagar sin rumbo por la naturaleza de un bosque.
} 
escapes visuales, etc. ayudan a transmitir esta idea de estar en un interior sintiendo que se esta al exterior. Para Miralles, un edificio se entiende cuando estas dentro de este y ves lo que le rodea, cuando el exterior se hace presente en los espacios interiores con la entrada de luz natural y las vistas al paisaje exterior. ${ }^{570}$

En la propuesta de Concurso para un Consultorio médico en La Llagosta, Miralles y Pinos convierten su propuesta en un lugar panorámico con vistas al Parque en el que se inserta, al que los pacientes pudiesen asomarse mientras esperan su turno de consulta medica. En la Casa Garau Agusti, de 1988, la construcción se repliega sobre si misma y hace que sus relaciones se multipliquen. La casa podría estar fuera o dentro, a un lado u otro de ese muro replegado.

En el Centro Cívico de Hostalets de Balenya, el recorrido se orquesta para que dentro del edificio el visitante se sienta como si estuviera fuera. En el Parque Cementerio de Igualada, se rompe con la dualidad interior - exterior. Se relaciona el mundo exterior del paisaje con el mundo interior del mas allá. Las puertas entreabiertas de los panteones crean un espacio transitorio entre interior y exterior, un lugar de aislamiento, que deja de estar fuera sin estar dentro. Se incita al visitante a que se asome al otro lado; anunciando el misterio. El Parque Cementerio es un interior, aunque el visitante crea que al recorrerlo esta en el exterior, en realidad esta habitando un interior conformado por las paredes de los nichos y la techumbre conformada por las copas de los arboles.

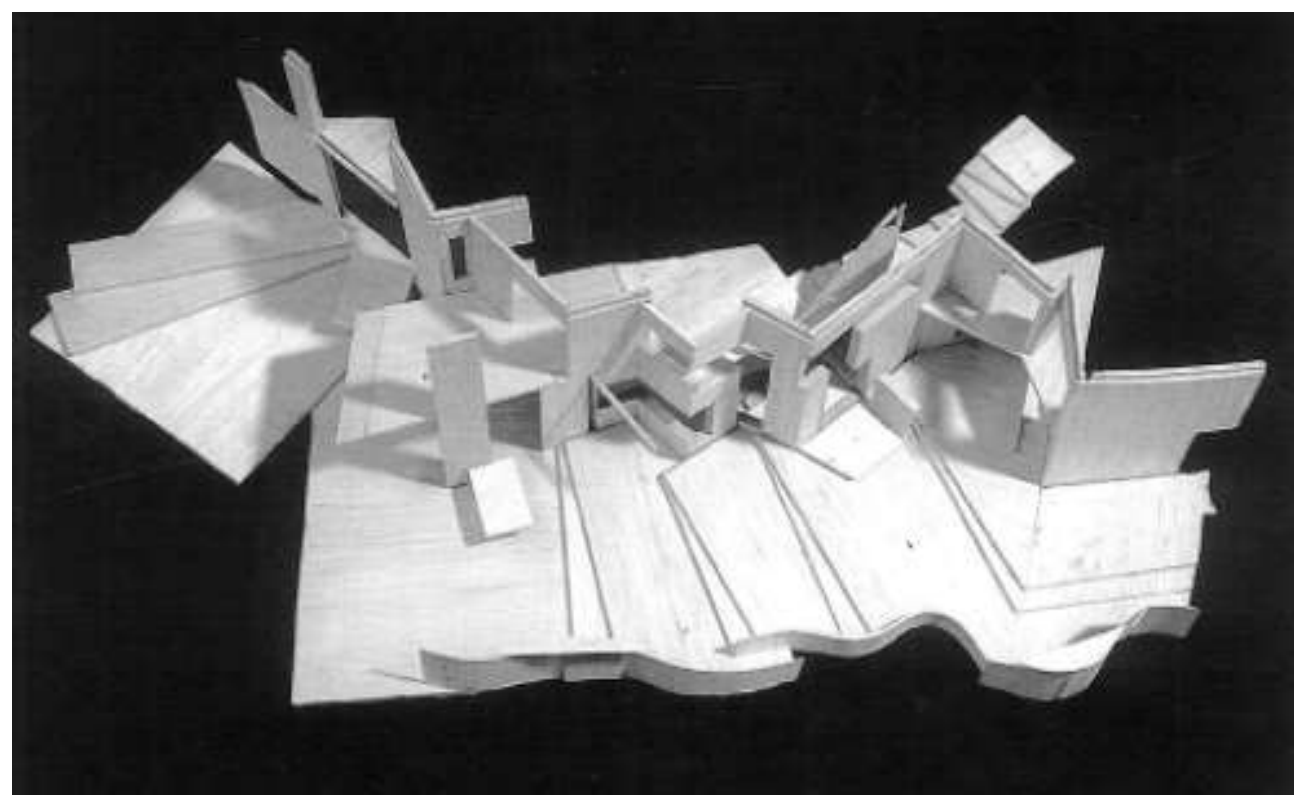

$6-42^{571}$

\footnotetext{
${ }^{570}$ En muchas ocasiones Miralles se refirió a que cuando entrabas en sus edificios ya te encontrabas fuera.

${ }^{571}$ Casa Garau Agusti, de 1988.
} 


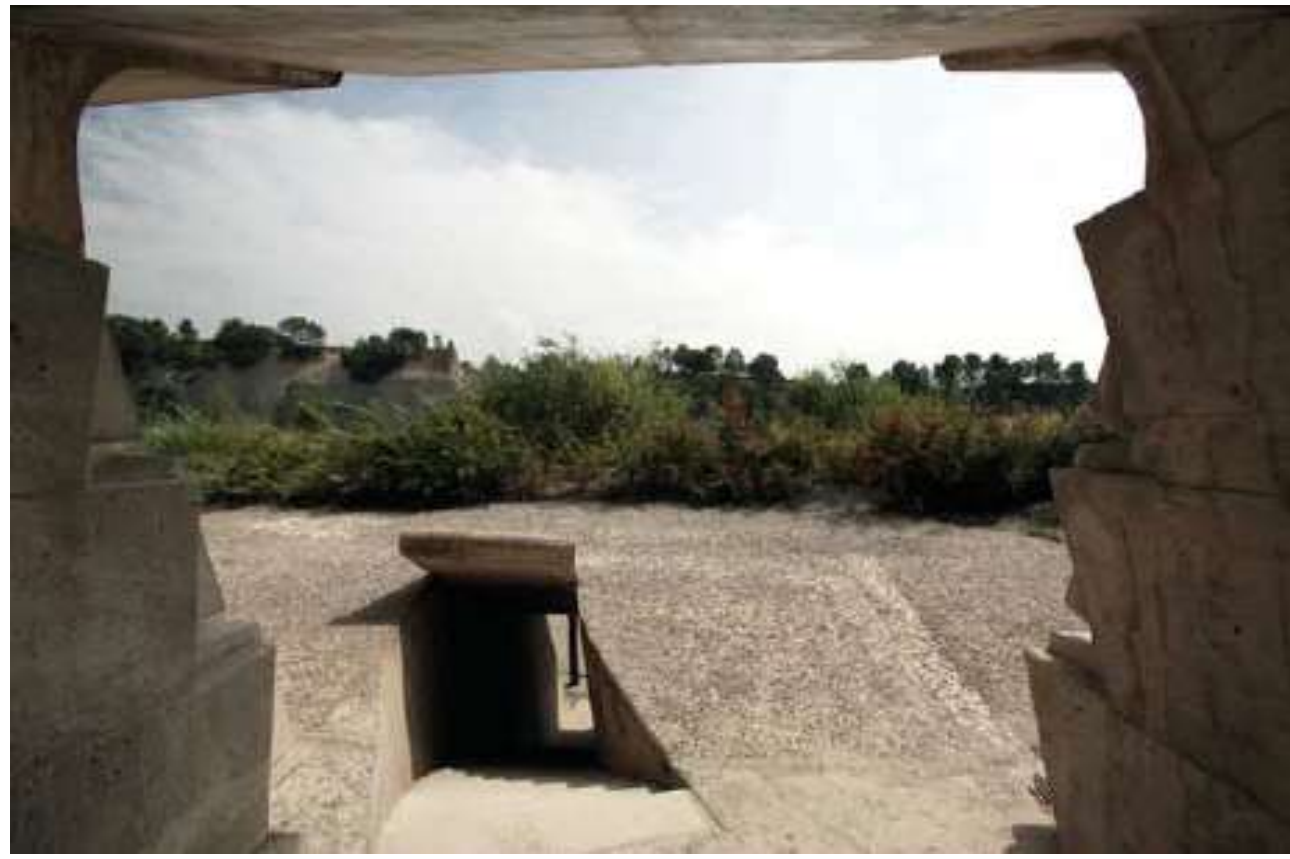

En el Pabellón de Entrenamiento de Tiro con Arco las conexiones entre el espacio interior y el exterior son más fluidas en fase de obra, cuando todavía no se ha producido el cierre a que obliga el acondicionamiento climático entre el muro y la cubierta. ${ }^{573}$ Dicha membrana, cuya resolución se deja por los arquitectos para el final del proceso constructivo en obra, ${ }^{574}$ al construirse con un material opaco, rompe con la fluidez visual entre el interior y el exterior que el edificio tenia mientras se construía. ${ }^{575}$ Miralles llega a afirmar en una conferencia celebrada en la Universidad Internacional Menéndez Pelayo en 1993 que se debe a cierta tozudez de su pensamiento ${ }^{576}$. Es decir, que la consecuencia de proyectar por separado basamento y cubierta, y no pensar en fase de proyecto su contacto, genera un problema que afecta a los dos elementos que mas influyen en el cambio de carácter que se produce en el edificio mientras se construye y cuando se termina.

\footnotetext{
572 Parque Cementerio de Igualada. Vista mientras se desciende por las escaleras que en diagonal descienden hasta el nivel inferior.

${ }^{573}$ Para mas información puede consultarse la Tesis de Javier Fernandez Contreras "La planta Mlralles: Representación y Pensamiento en la Arquitectura de Enric Miralles"ETSAM. UPM.

574 Conviene destacar como el alzado que documenta el proyecto no es un plano que sirva para ejecutarse en obra con la información que contiene, puesto que nada esta dibujado en verdadera magnitud, siendo solo un dibujo representativo de lo que se quiere hacer, pero como los encuentros son tan complejos no se pueden dibujar y se deja para la fase de ejecución de obra su resolución.

575 Porque frente a materializar con vidrio dicha membrana, se hace con zinc en el exterior y con madera en el interior. A Miralles no le gustaba el vidrio, como otros habrían empleado para materializar esta membrana y no perder la continuidad visual entre interior - exterior; porque según Mlralles el vidrio generaba reflejos y ello traía consigo que se percibiese el volumen construido.
}

576 Enric Miralles. Conferencia dictada en la Universidad Internacional Menéndez y Pelayo de Santander. Julio 1993 

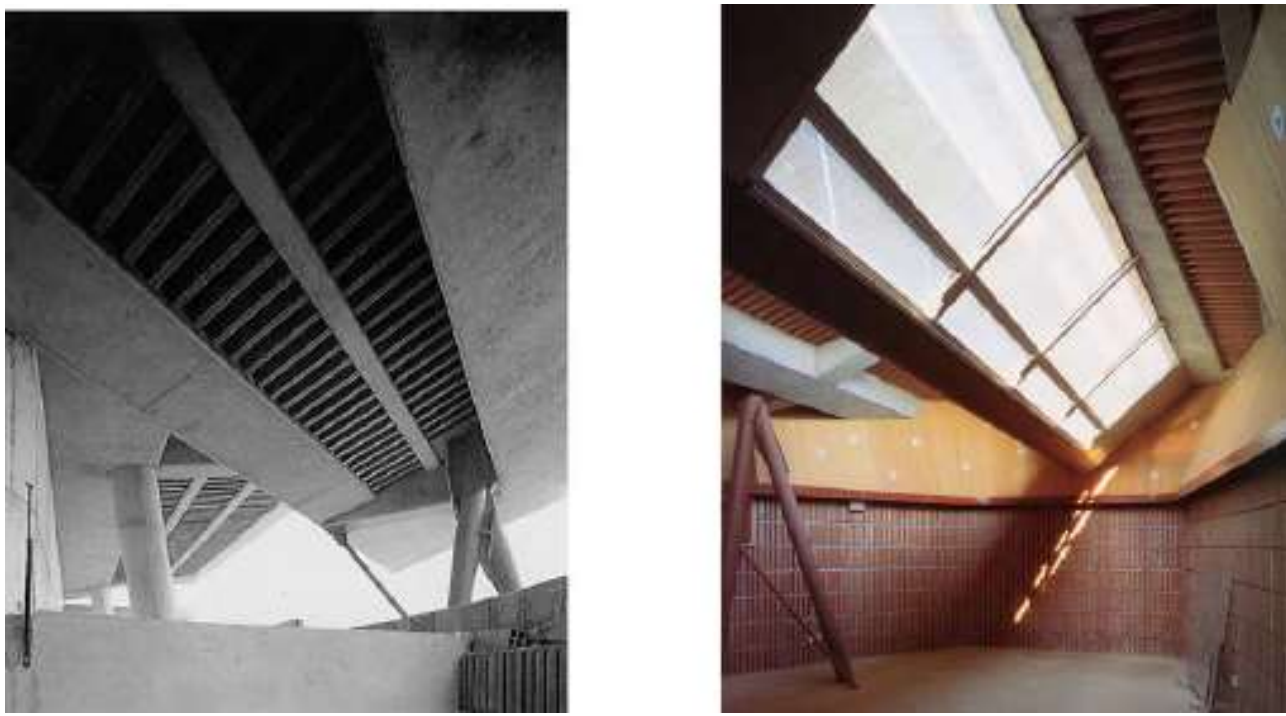

$6-44^{577}$

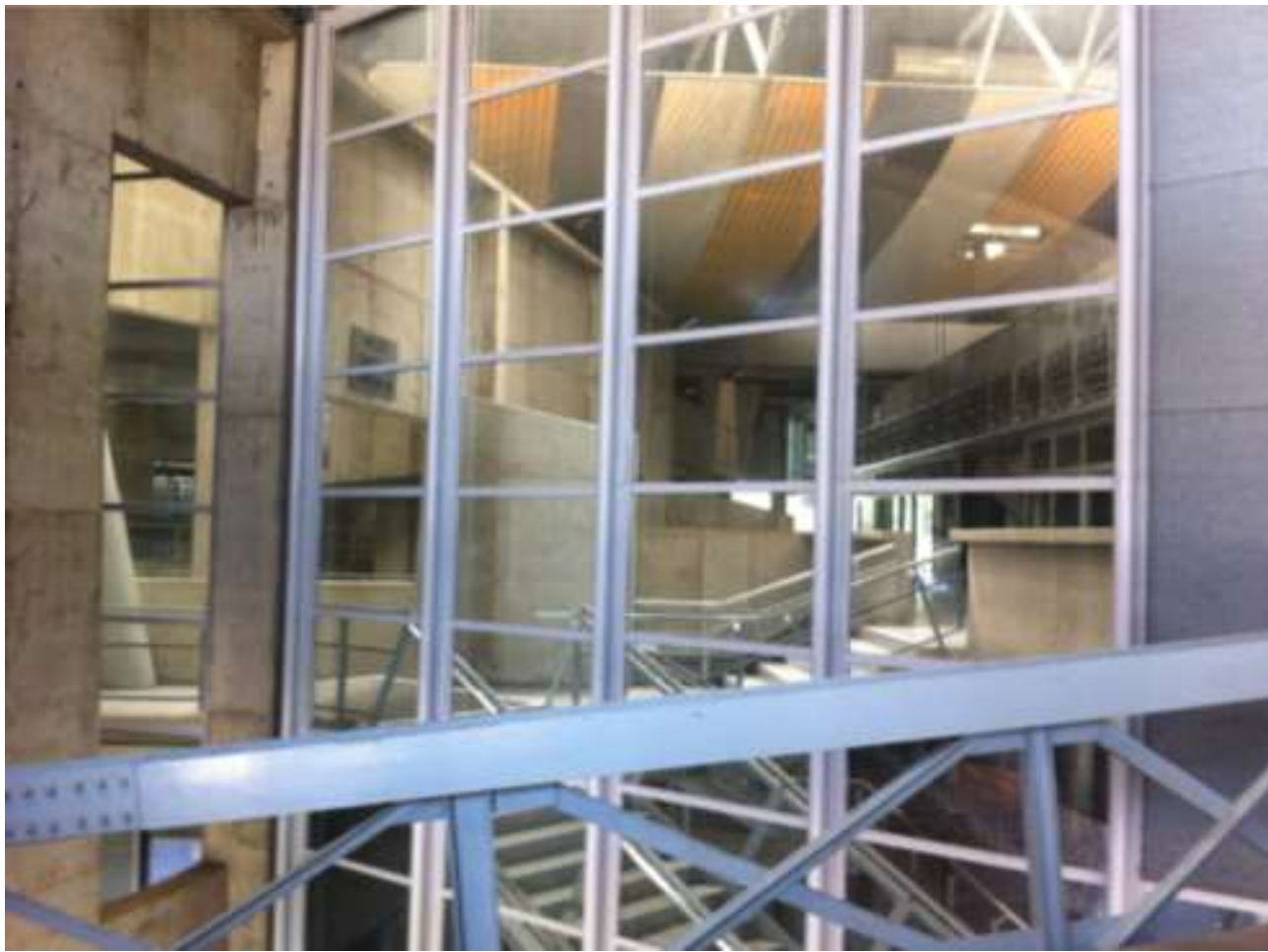

$6-45^{578}$

${ }^{577}$ Pabellón de Entrenamiento de Tiro con Arco

${ }^{578}$ Pabellón de Alicante. Relaciones exterior interior. 


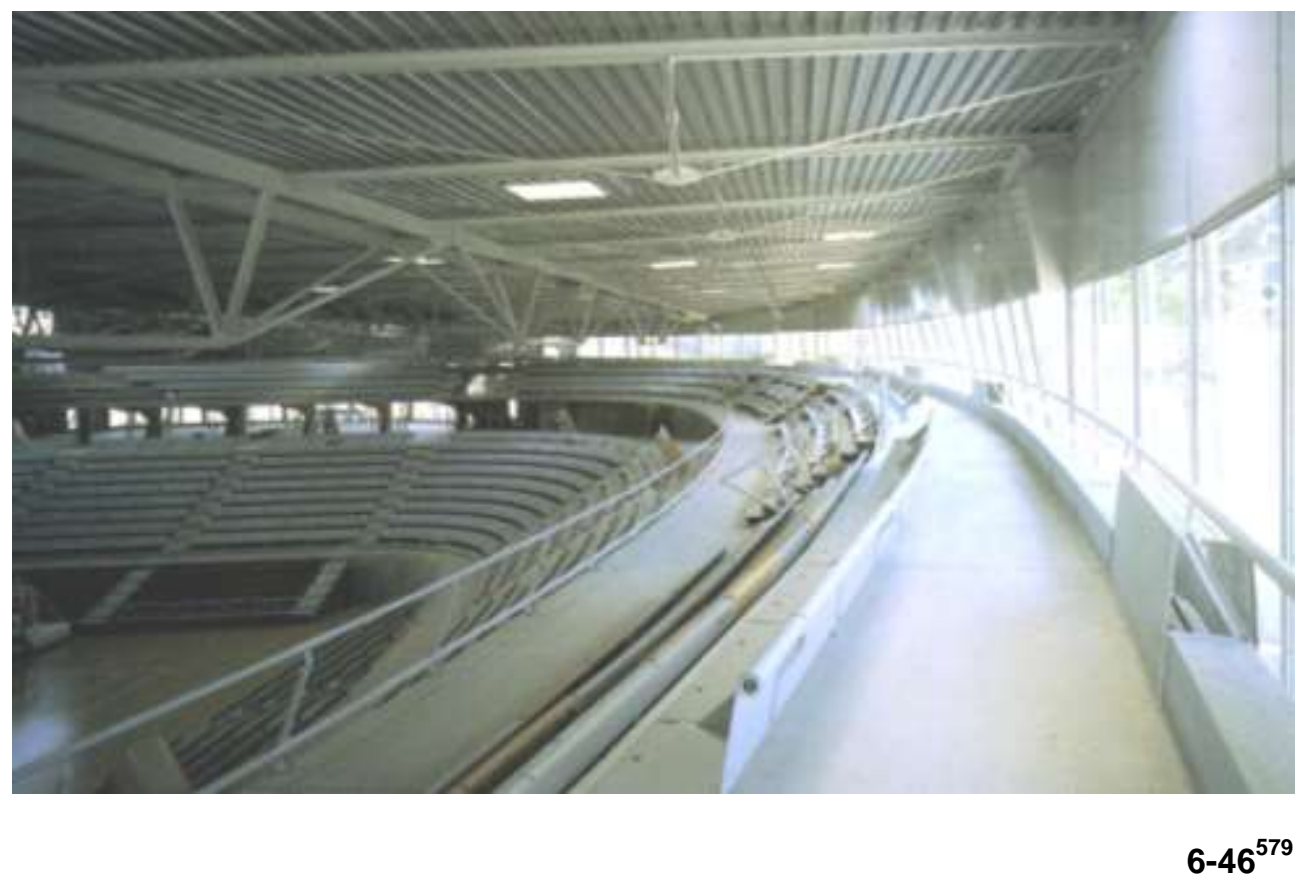

Los Pabellones de Huesca y Alicante se proyectan desde el exterior, como una serie de piezas reunidas que definen un recinto. Por lo tanto, el espacio interior resultante es el negativo de una serie de exterioridades. En el Pabellón de Alicante, se encuentran muchos episodios en los que estando en el exterior parece que se esta en el interior y viceversa. En el Pabellón de Huesca, sus exteriores, se componen de elementos que se sitúan en el terreno de manera independiente. Sin embargo, en su interior, los espacios entre las distintas piezas que sirven al programa, aparecen indefinidos. Al tratarse de una arquitectura con vocación de ser físicamente discontinua, el problema llega cuando hay que responder a las necesidades de acondicionamiento climático.

En la Escuela Hogar en Morella, de 1986, se detectan ámbitos intermedios entre interior y exterior, que aunque están a la intemperie se encuentran a cobijo del edificio, constituyendo magníficos miradores desde los que contemplar el paisaje Incluso piezas de mobiliario como los bancos exteriores, se fijan al suelo para indicar esos puntos privilegiados desde los que contemplar la mejor vista del paisaje. Como comenta Carmen Pinos: "El proyecto son estos espacios intermedios frente al paisaje y protegidos por la edificación. Esos espacios que estando fuera del edificio, están en el edificio, del mismo modo que cuando estas dentro de el, estas suspendido en el paisaje". ${ }^{580}$ En el espacio laberintico del interior de la escuela, se encuentran episodios en los que no sabe si se está fuera o dentro, pues debido a las dobles o triples alturas, y al coincidir el material de acabado exterior y el interior unido a la elevada luminosidad natural, el espectador le cueste entender si se encuentra fuera o dentro. La sala polivalente de forma triangular, que hace de rotula entre la residencia y la escuela, dispone de una puerta corredera horizontal de gran tamaño que permite abrirse en su totalidad y hacer del interior, un exterior.

\footnotetext{
${ }^{579}$ Pabellón de Huesca. Relaciones interior exterior.

${ }^{580}$ Guía de Arquitectura Española 1975-2010, pag 97.
} 


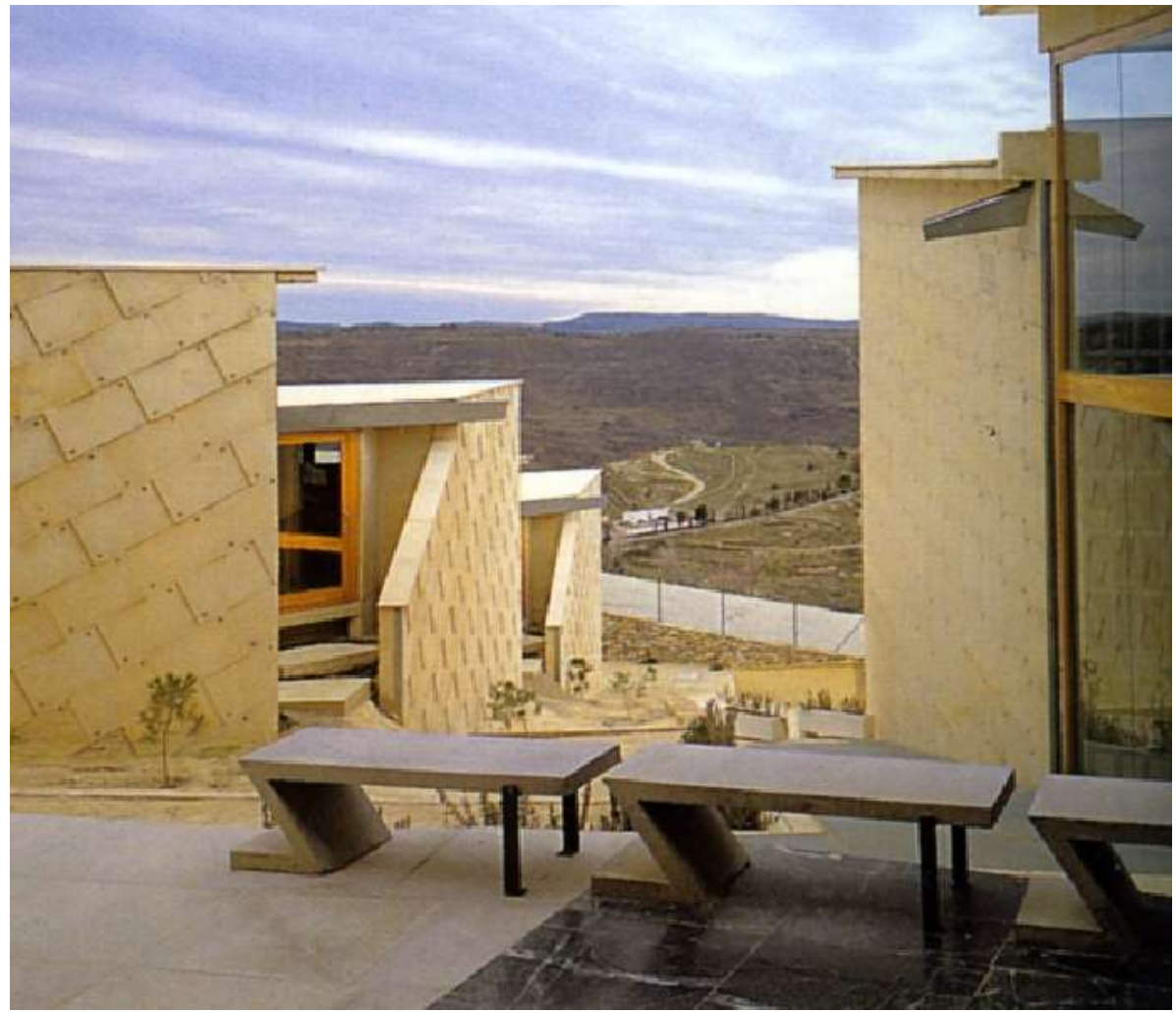

$6-47^{581}$

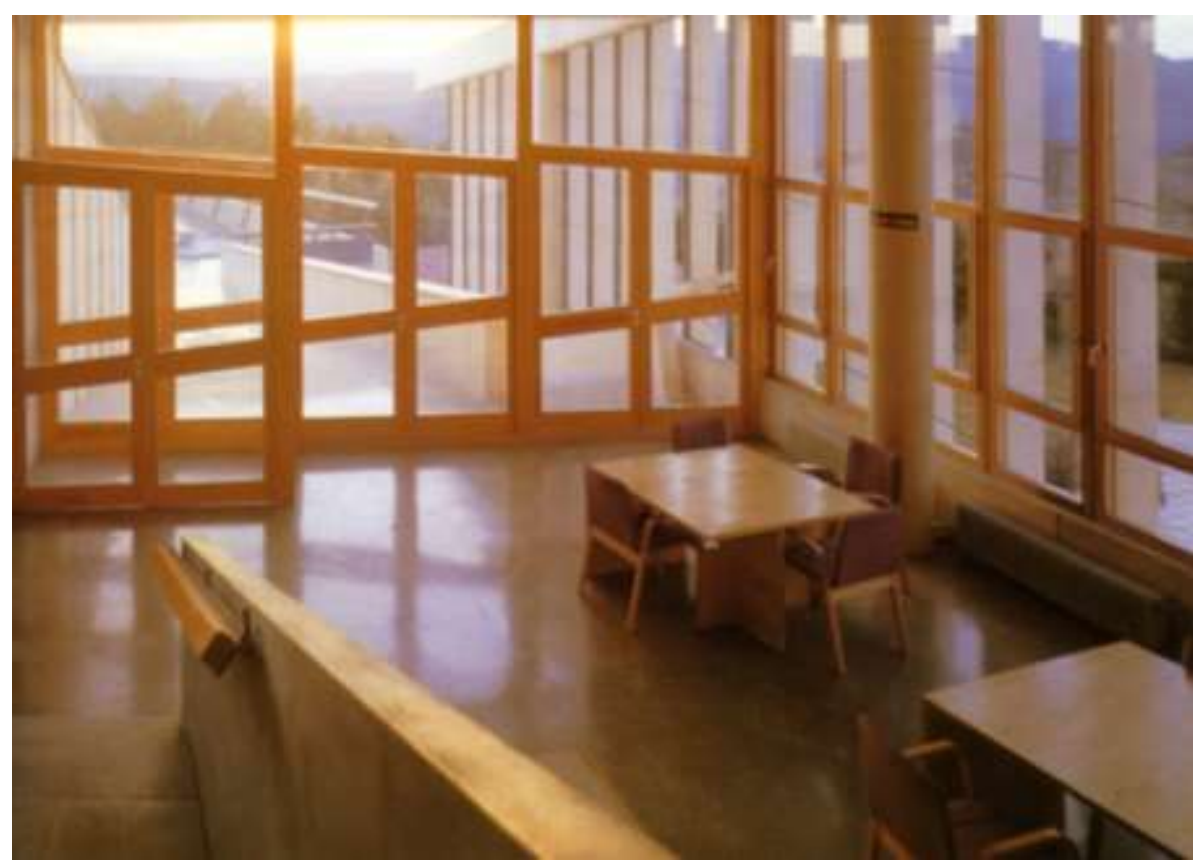

$6-48^{582}$

${ }^{581}$ Escuela Hogar en Morella. Vistas enmarcadas hacia el paisaje desde la Sala Multifuncional que enlaza la escuela y la residencia.

${ }^{582}$ Escuela Hogar en Morella. Relaciones interior exterior. 
El dinamismo de los cerramientos exteriores quebrados en las obras de Miralles, tiene su razón de ser en generar unas membranas intermedias entre interior y exterior para relacionarse mejor con el paisaje circundante. Es algo que al igual que el "edificio como calle", Miralles toma del Team Ten.

Ya en la Casa Garau Agusti en la maqueta de proyecto centrada en el muro de cerramiento, es difícil diferenciar donde está el interior y donde el exterior. Lo quebrado del muro y el continuo enrocamiento del muro exterior sobre si mismo colaboran en esa ambigüedad que construida en el Pabellón de Huesca, hará difícil determinar a que lado del cerramiento se encuentra el espectador, si en el interior 0 en el exterior. En la Escuela Hogar en Morella, estos espacios intermedios entre interior y exterior, están dirigidos a crear ámbitos desde los que contemplar el magnífico paisaje en el que se implanta el edificio. Incluso en estancias interiores de este edificio, la altura de los techos y la coincidencia de los acabados de los cerramientos en el interior y en el exterior generan la sensación de estar fuera. En Huesca, existen episodios en los que el muro de cerramiento es atravesado por elementos estructurales, negando conceptualmente la separación entre interior y exterior. Tanto en el Pabellón de Huesca como en el de Alicante, el exterior se introduce dentro y viceversa, gracias a grandes paños de vidrio retranqueados del límite de las cubierta. Incluso en proyectos de interiorismo como el Centro Social La Mina o la Sede del Círculo de Lectores, la iluminación cenital que se filtra a través de las claraboyas practicadas en lo techos, generan la sensación en el visitante de encontrarse en un exterior.
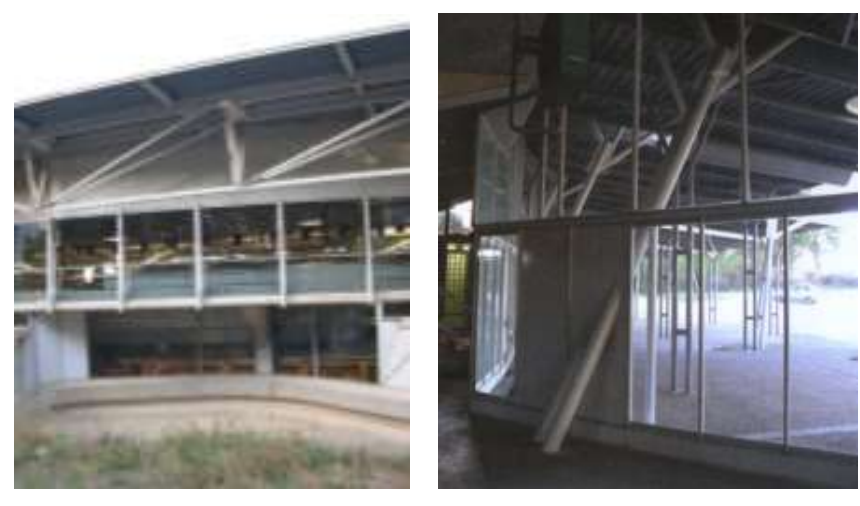

$6-49^{583}$
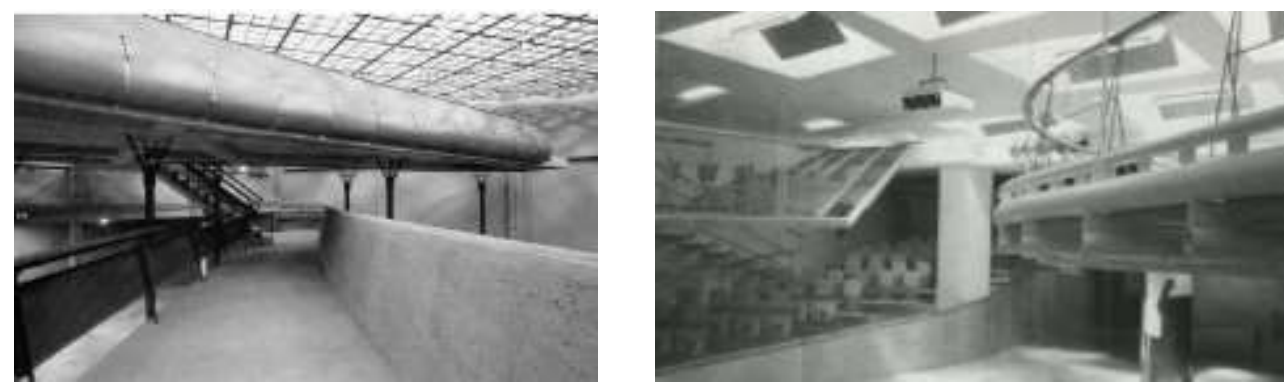

$6-50^{584}$

\footnotetext{
${ }^{583}$ Pabellon de Huesca. Relaciones interior exterior y viceversa. Fotograifa realizada por el autor de la Tesis.

${ }^{584}$ Interiores del Centro Social La Mina (a la izquierda) y de la Sede del Circulo de Lectores.
} 


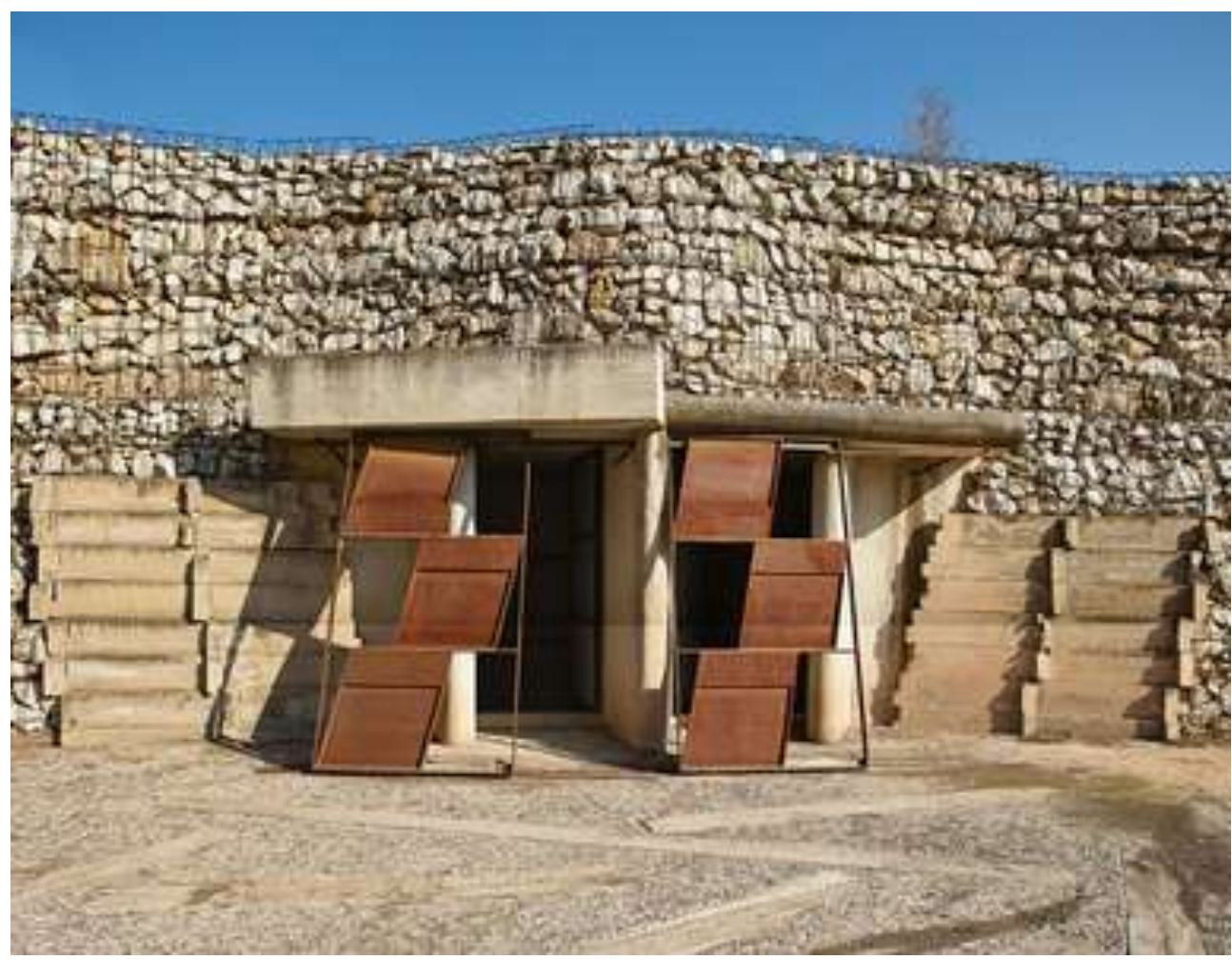

De diferente manera actúan los espacios intermedios en el Parque Cementerio de Igualada, pues la percepción que se tiene es sobre todo desde el exterior al interior $y$ ese interior es un espacio habitado por personas sin vida. Las puertas entreabiertas de los panteones crean un espacio transitorio entre interior y exterior, un lugar de aislamiento, que deja de estar fuera sin estar dentro. Se incita al visitante a que se asome al otro lado; anunciando el misterio

Las obras de Miralles, se ligan al lugar gracias, entre otras cosas, al control de las relaciones existentes entre los espacios interiores y los exteriores. Miralles potencia los mecanismos que conducen a reconciliar su arquitectura y el paisaje, con sistemas que generan una continuidad espacial entre interior y exterior generando espacios intermedios, que interactúan con los elementos que conforman el paisaje en el que se implantan sus edificios. Los limites, el perímetro construido queda disuelto por medio de espacios de transición entre arquitectura y naturaleza, espacios intermedios que envuelven el organismo construido. Los cerramientos exteriores se hacen eco del entorno establecen relaciones con este y en ocasiones establecen tránsitos fluidos entre exterior e interior gracias al clima mediterráneo en el que muchas obras se insertan.

En la obra de Miralles, los espacios exteriores quieren ser interiores y a la inversa. Se construyen en función de las relaciones que se establecen entre las distintas piezas que conforman el programa, evitando establecer cualquier tipo de

585 Parque Cementerio de Igualada. Las puertas entreabiertas de los panteones crean un espacio transitorio entre interior y exterior, un lugar de aislamiento, que deja de estar fuera sin estar dentro. 
regularidad geométrica. El espacio exterior, es una sucesión de ámbitos intersticiales, cuya cohesión se confía al recorrido.

Los espacios interiores en las obras de Mlralles, son dinámicos, se conectan fluidamente a través de sucesivas compresiones y expansiones del espacio. La atención a las vistas hacia el exterior hace que se traten espacios interiores como si fueran exteriores y viceversa.

De la misma manera que se puede pasear libremente por la naturaleza, en los interiores de Miralles, se asiste a un espacio laberinto, en el que guiado por escaleras, rampas, plataformas a distinto nivel, etc. se recrea una experiencia perceptiva similar a la sensación que se tiene cuando se recorre un bosque en la naturaleza. Los suelos que en su recorrido van cambiando de nivel, en continuo movimiento, transmiten la condición cambiante y aleatoria que tiene el terreno natural; los pilares exentos, con gran variedad de formas, se agrupan de diferentes maneras, aislados, pareados, agrupados, en muchos casos inclinados, como si fuesen arboles. Analogía con la naturaleza nuevamente, pues es bien sabido que en la naturaleza los elementos nunca son exactamente iguales, ni se agrupan de la misma manera.

\subsubsection{SIN CONTORNO}

Respecto al contorno, en el volumen segundo de la tesis doctoral de Enric Miralles titulado "fuga a tientas", se muestran los dibujos de paisaje de Alexander Cozens, que le enseñaron a captar la naturaleza a través de la esencia de sus contornos. Los contornos en la arquitectura de Miralles casi siempre son irregulares, son contornos pintorescos, rotos, que permiten a la obra vivir en buena armonia con el paisaje, con una actitud ligada a la percepción pictórica del paisaje. Destacan las analogías con el contorno de los perfiles de la naturaleza en las cubiertas de la Escuela Hogar en Morella, el Pabellón de Alicante, etc.

\subsubsection{SIN FACHADA}

En la arquitectura clásica, la transición entre lo privado y lo público, se realizaba de manera ordenada siguiendo un orden claro y regulado por las proporciones de la fachada de acceso que implicaba una jerarquía determinando un sentido de aproximación al edificio. Los edificios de las vanguardias históricas, no tenían fachada porque ninguna de las partes era jerárquica respecto al resto.

En la arquitectura contemporánea la fachada pierde su sentido y la transición entre interior y exterior, se realiza de manera más fluida.. En los primeros proyectos realizados con Carme Pinós, los planos de fachada y cubierta son entidades independientes separadas por intersticios de aire, que producen una desmaterialización de la caja arquitectónica.

En el Parque Cementerio de Igualada, la única fachada que cierra el área de servicios y se encuentra semienterrada, se ha camuflado con la apariencia de muro de contención teniendo su puerta camuflada en el despiece de dicho muro. En lo que respecta a la Capilla, la otra pieza que junto con el área de servicios puede habitarse, se construye semienterrada y por tanto sin fachadas a exterior. En el Pabellón de Entrenamiento de Tiro con Arco, el retranqueo de las fachadas y los muros, unido a las sombras arrojadas por las cubiertas en voladizo, anulan perceptivamente las fachadas. Lo mismo ocurre con las fachadas de acceso al Pabellón de Huesca. 


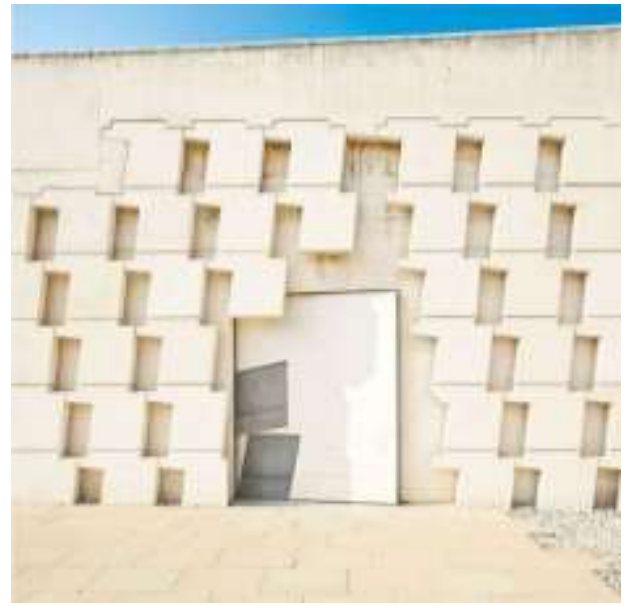

$6-52^{586}$

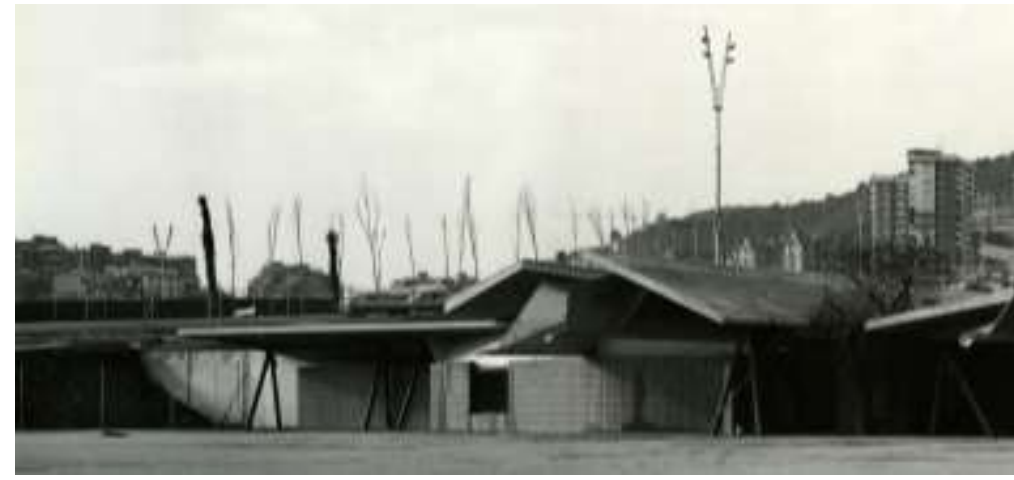

$6-53^{587}$

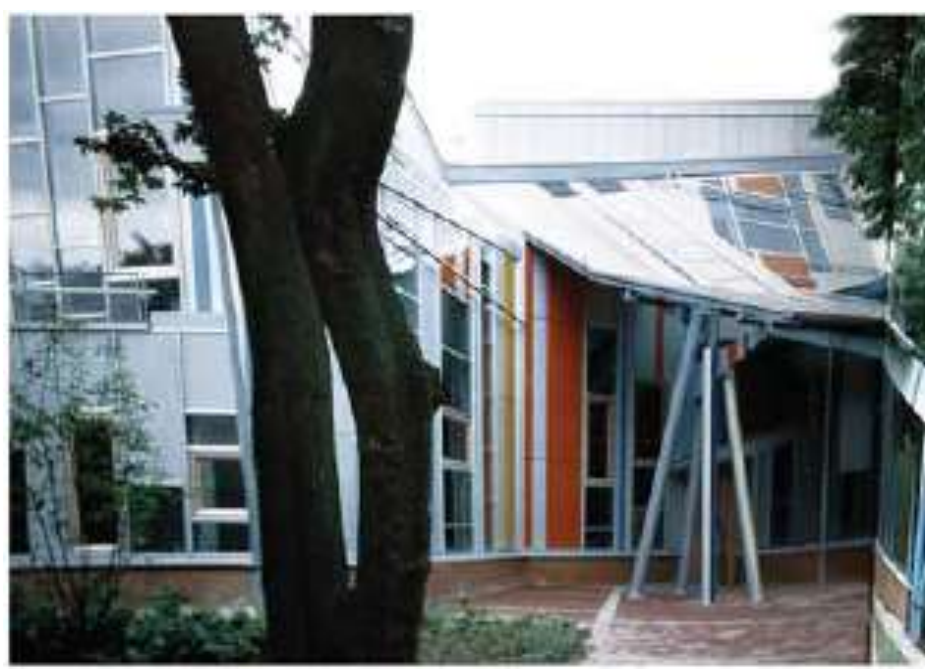

$6-54^{588}$

${ }^{586}$ Parque Cementerio de Igualada. Puerta camuflada de acceso a estancia de servicios.

587 Pabellón de Entrenamiento de Tiro con Arco. Las sombras de las cubiertas anulan la fachada.

${ }^{588}$ Escuela de Música de Hamburgo. La fachada se camufla y se hace cubierta. 
En la Escuela de Música de Hamburgo, de 1997, la fachada es una especie de fuselaje deformado en la que se desdibuja la distinción entre alzado y cubierta.

Miralles anula las fachadas para construir un paisaje nuevo que se funda con el existente. La fachada desaparece como tal, convirtiéndose en una piel continua que envuelve el interior, donde los huecos pierden importancia frente a las superficies de fachada. La acción de anular la fachada no es una acción que utilice Miralles en sus primeros concursos realizados con Carmen Pinos, quizás porque al realizarse en paisajes construidos el dialogo buscado con las construcciones existentes lo llevan a cabo a través de las fachadas que sintonizan con la escala de las existentes.

Sin embargo, cuando abordan el Parque Cementerio de Igualada, es cuando al encontrarse en un espacio natural y con la pretensión de negar toda alusión a la idea de edificio convencional, comienzan a camuflar la fachada. En primer lugar semienterrado los pocos espacios habitables como el área de servicios y la capilla. Aquí las fachadas se camuflan como si fueran muros de contención e incluso la puerta de acceso solo se descubre tras una mirada atenta. Esta estrategia se llevara al Complejo de Tiro con Arco, donde desaparece lo que se entiende como fachada, al camuflarse las puertas en los quiebros entre las piezas que conforman el edificio de Competición y al encontrase ocultas teniendo que acceder tangencialmente en el edificio de Entrenamiento. Tampoco aquí hay ventanas convencionales.

Cuando existen grandes paños de vidrio en los Pabellones de Huesca y Alicante, los alzados son el resultado de lo que queda entre el terreno y la cubierta, de manera que no se proyectan como tales; dejando de ser el reflejo de la función que se desarrolla en los interiores que delimitan. Además las fachadas en estos casos se anulan, al encontrarse en sombra debido al retranqueo de las cubiertas.

Cuando los edificios tienen una apariencia más objetual, como en el caso del Parlamento de Edimburgo, la fachada es una constelación de fragmentos de diversas formas y materiales semejante a collages pictóricos. Los huecos recortan los muros de fachada sin orden aparente, queriendo eludir el aspecto que tienen en un edificio convencional. En la Biblioteca de Palafolls, tampoco hay fachada al encontrarse el edificio semienterrado y solo aflorar en superficie las cubiertas.

La falta de compacidad en la construcción es un mecanismo que Mlralles emplea para poder pensar por separado cada uno de los cerramientos. El problema viene cuando los proyectos deben compartimentarse climáticamente, cerrarse, cuando deben definir un interior y un exterior. Proyectos como los Pabellones de Huesca y Alicante, proyectados desde la ausencia de cerramiento, cuando llega el momento de la construcción es cuando se decide la posición que deben ocupar los cerramientos para sellar el interior del exterior, y cuando se comprometen los encuentros constructivos. En proyectos de este tipo, sometidos a las vicisitudes de lo climático, se produce un cambio de carácter entre el proceso de construcción y la obra terminada, entre el edificio en proceso de construcción sin compartimentar al exterior y el edificio estanco climáticamente. ${ }^{589}$

589 Para mas información puede consultarse la Tesis de Javier Fernandez Contreras "La planta Mlralles: Representación y Pensamiento en la Arquitectura de Enric Miralles"ETSAM. UPM. 


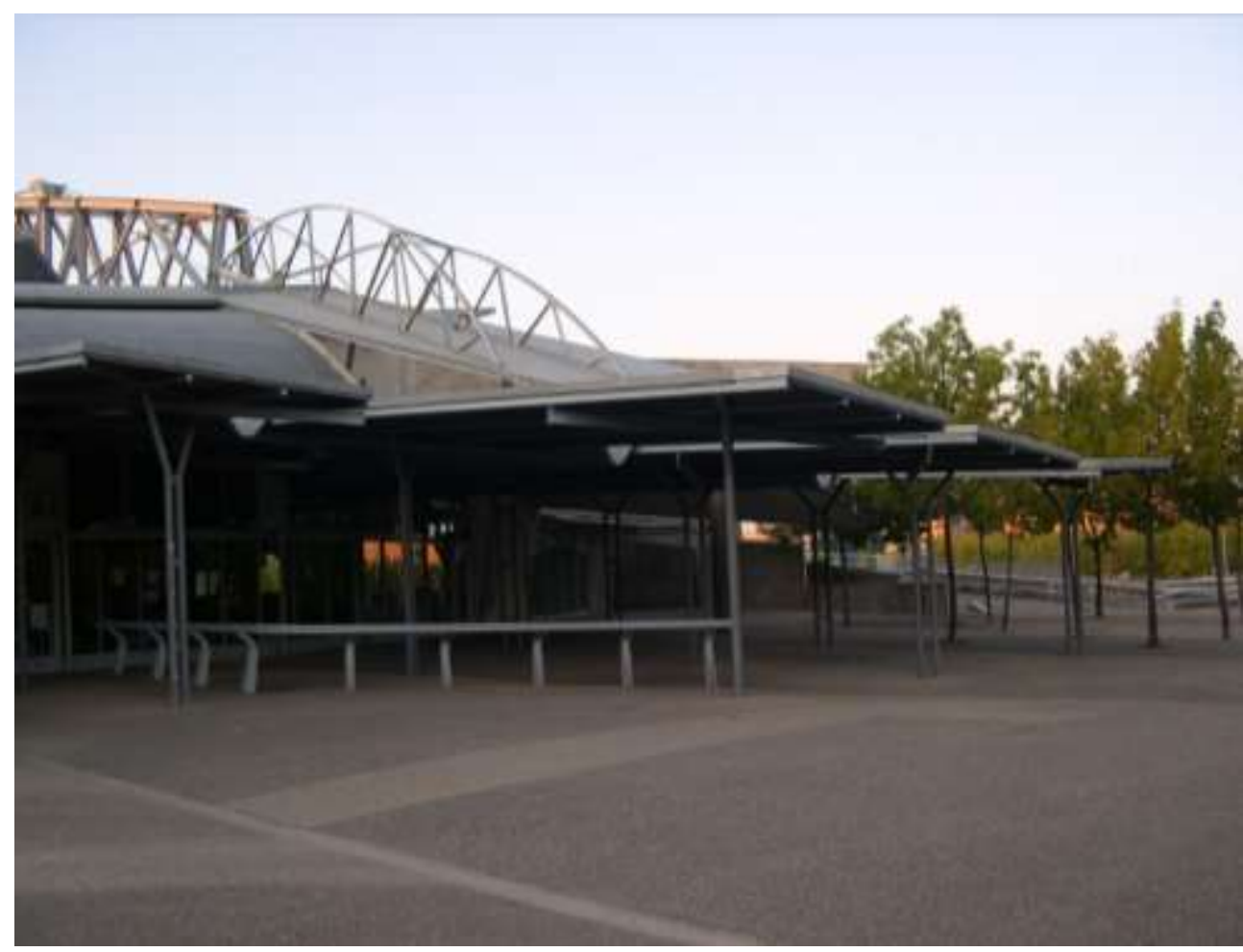

$6-55^{590}$

\subsection{ACCIONES ABSTRACTAS}

\subsubsection{FUSIONAR FIGURA FONDO :}

Es la acción que utiliza Miralles para fusionar la figura del organismo construido con el fondo del paisaje en que se implanta, y que se perciban como algo unitario; adelantadonse de nuevo en este sentido a los tiempos, como queda patente en la siguiente cita de Manuel Gausa.

"Figura y fondo han disuelto hoy sus limites en nuevos dispositivos que sugieren una fusión del proyecto contemporáneo en el medio, pero también una creciente desconfianza hacia la presencia objetual de una arquitectura entendida como volumen puro recortado contra el fondo de la acción...esa progresiva imbricación entre figura y fondo es cada vez mas evidente a medida que se produciría el traspaso de lo mas edilicio a lo mas paisajístico, de lo mas tectónico a lo cuasi-topográfico, de lo euclideo a lo fractal"

Manuel Gausa ${ }^{591}$

590 Pabellón de Huesca. Vista de uno de los accesos al interior en la que la fachada se oculta al retranquearse y recibir sombras de las cubiertas. Fotograifa realizada por el autor de la Tesis. 
La relación figura-fondo no es convencional en la arquitectura de Miralles, pues figura y fondo son equivalentes. En el Parque Cementerio de Igualada, la fusión de lo artificial, proyectado por el arquitecto (la figura) con el fondo (el paisaje natural existente) es muy intensa, tanto, que no se sabría separar la figura del fondo, lo construido del paisaje. En el Pabellón de meditación de Unazuki, la silueta de lo construido se funde con el paisaje remitiendo a los perfiles naturales de las montañas.
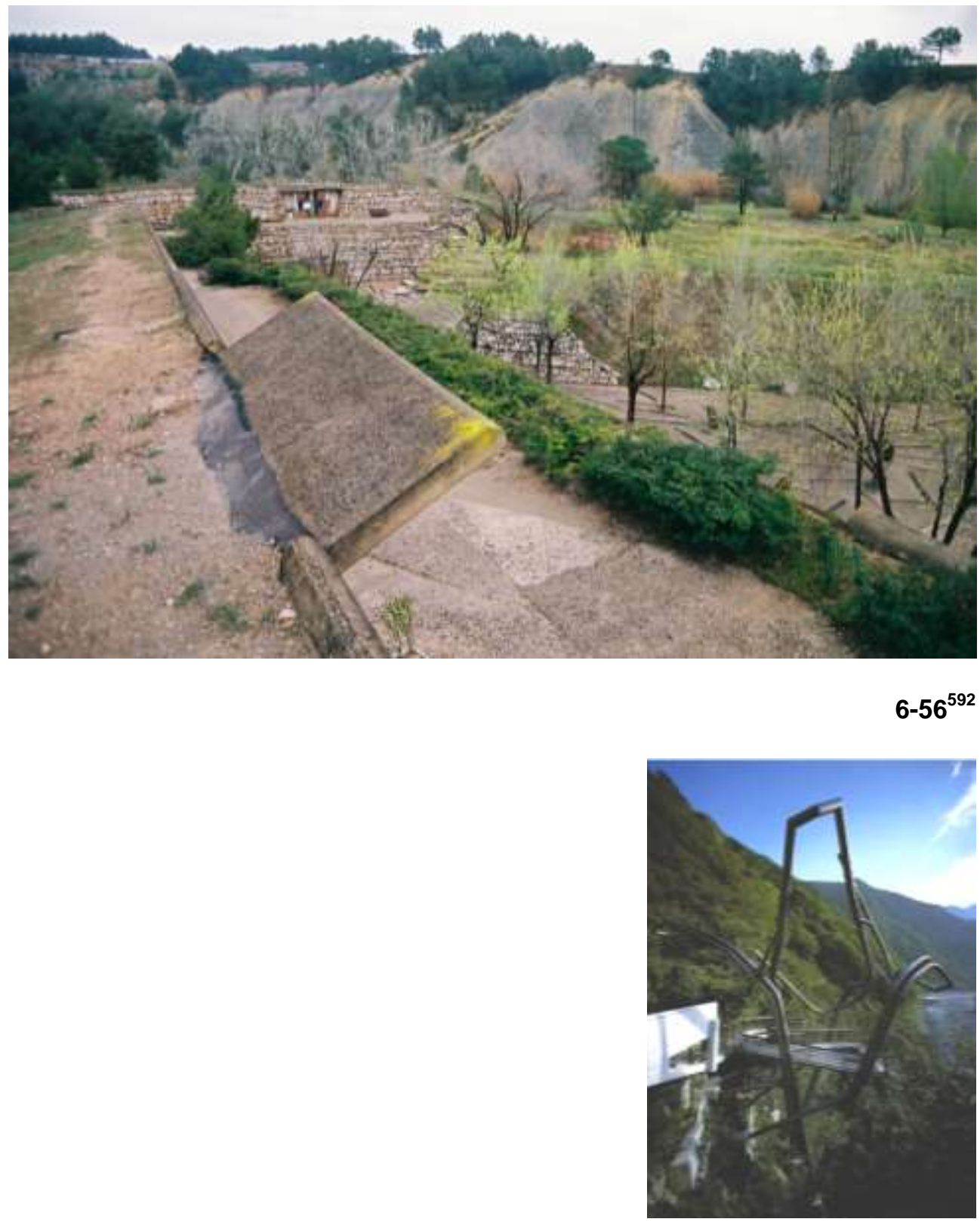

$6-57^{593}$

591 DICCIONARIO METAPOLIS DE ARQUITECTURA AVANZADA. Manuel Gausa, Vicente Guallart, Jose Morales, Willy Muller, Fernando Porras, Federico Soriano. Actar, 2001, pag. 229.

592 Parque Cementerio de Igualada. Visión desde el nivel superior hacia el paisaje. Admirable Fusión entre figura y fondo 


\title{
6.2.2. SIN ESCALA
}

\begin{abstract}
"Miralles se desprende pronto de la medida y de la escala: los ángulos agudos o los arcos de circunferencia se ajustan de una manera precisa a la geometría general del territorio, pero pueden prescindir perfectamente de la medida y de la escala"
\end{abstract}

$$
\text { M. Plá. }{ }^{594}
$$

Es la acción que utiliza Miralles para fusionar su arquitectura con el paisaje, al no tener muchos de sus edificios elementos escalares que lo relacionen con un edificio. Para ello, en primer lugar Miralles captara la escala del paisaje en el que interviene para que su arquitectura sintonize con esta.

En Miralles, la escala no determina la forma de su arquitectura. Las plantas de sus proyectos muestran estructuras similares a pesar de responder a programas 0 escalas diferentes. Algo tiene que ver con dibujar a mano. La visión conjunta de los proyectos arroja las claves, pues se muestran como gestos sin escala pero con la misma forma. Como explica Javier Fernández Contreras: "De principio a fin, Miralles siempre dibujo a mano, empezando desde pequeños croquis para luego pasar al dibujo técnico...trabaja en tamaños intermedios entre el dinA4 y el din A5, con independencia del tamaño real de la arquitectura, adaptando la escala de la representación al formato del papel, lo que justifica que ciertos gestos formales se repitan en las plantas de proyectos de distinta escala, función, lugar o carácter" 595

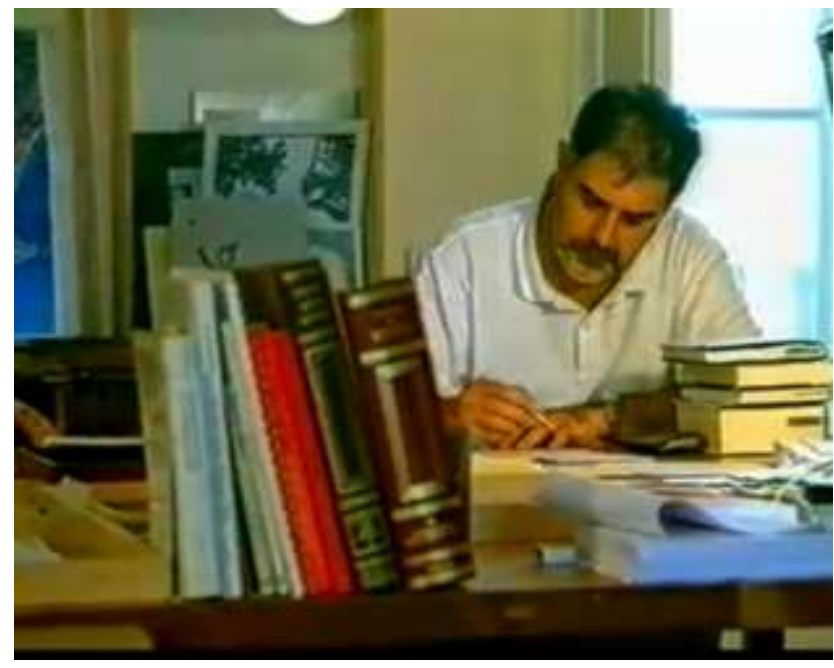

$6-58^{596}$

\footnotetext{
593 Pabellón de meditación de Unazuki. El garabato construido en el aire como analogía vegetal se confunde con el fondo del paisaje.

594 'Del punt de fuga al Lungo Mare'. INDE nำ. Colegi d'arquitectes de Catalunya. 2002. P.9.

595 FERNANDEZ CONTRERAS Javier. Tesis Doctoral "La planta Miralles: Representación y Pensamiento en la Arquitectura de Enric Miralles", DPA ETSAM. UPM 2013. pag, 40.

${ }^{596}$ Enric Miralles dibujando a mano sobre croquis tamaño DIN A5 en su estudio del Pasaje de la Pau.
} 
Miralles por medio de la repetición de los dibujos, capta la escala, las dimensiones, la estructura de las condiciones físicas del lugar demostrando en sus obras un asombroso dominio de la escala del paisaje en el que se implanta. Es interesante lo que en relación a las propiedades de dibujar a mano comenta $R$. Sennet: 'cuando el CAD empezó a utilizarse en las facultades de arquitectura en sustitución del dibujo manual, una joven profesora del Instituto Tecnológico de Massachusetts comentó lo siguiente: 'Cuando dibujas a mano el plano del lugar de la obra, añadiendo poco a poco las líneas y los árboles, el espacio se va incorporando a tu imaginación. Llegas a conocer el terreno físicamente, de un modo que no es posible cuando usas el ordenador. Has de terminar conociendo el lugar a base de dibujarlo una y otra vez, no pidiendo al ordenador que lo recree por ti'. ... es una mera descripción de lo que se pierde intelectualmente cuando el trabajo en pantalla sustituye al dibujo a mano. Como en otras prácticas visuales, a menudo los croquis arquitectónicos son una descripción de posibilidades; y estas posibilidades cristalizan a medida que vamos perfeccionando el dibujo a mano" ${ }^{597}$

En el Parque Cementerio de Igualada, se calibra la escala para relacionarse con el paisaje, con sus accidentes geográficos, el perfil del paisaje, su vegetación, etc. No existen en este proyecto elementos escalares que permitan asignar una escala arquitectónica a la intervención. Incluso en las únicas construcciones que albergan espacios habitados como la Capilla y el Pabellón de servicios, estas se disponen semienterradas pareciendo muros de contención. En los Pabellones de Tiro con Arco, es difícil averiguar su tamaño, puesto que no se perciben elementos escalares como en los edificios convencionales (puertas, ventanas, barandillas, etc.) que permitan que el hombre se relacione con el tamaño de la obra. Las puertas se encuentran camufladas, se accede entre grietas en zonas sombreadas; las ventanas no tienen ni la forma ni el tamaño que suelen tener en un edificio convencional. El propio Miralles nos los refiere en los siguientes términos: "esta pieza que conforma el cerramiento en Tiro con Arco, se podría repetir a distintas escalas, es como aescalar..." ${ }^{598}$. En los Pabellones de Huesca y Alicante, a pesar de su gran tamaño, tampoco es fácil reconocer la escala arquitectónica al no existir elementos escalares claros que la indiquen.

\footnotetext{
${ }^{597}$ Artesanía, tecnología y nuevas formas de trabajo, Katz Editores. Madrid, p.36.

${ }^{598}$ Enric Miralles. Conferencia en ETSAM.05/05/1993.
} 


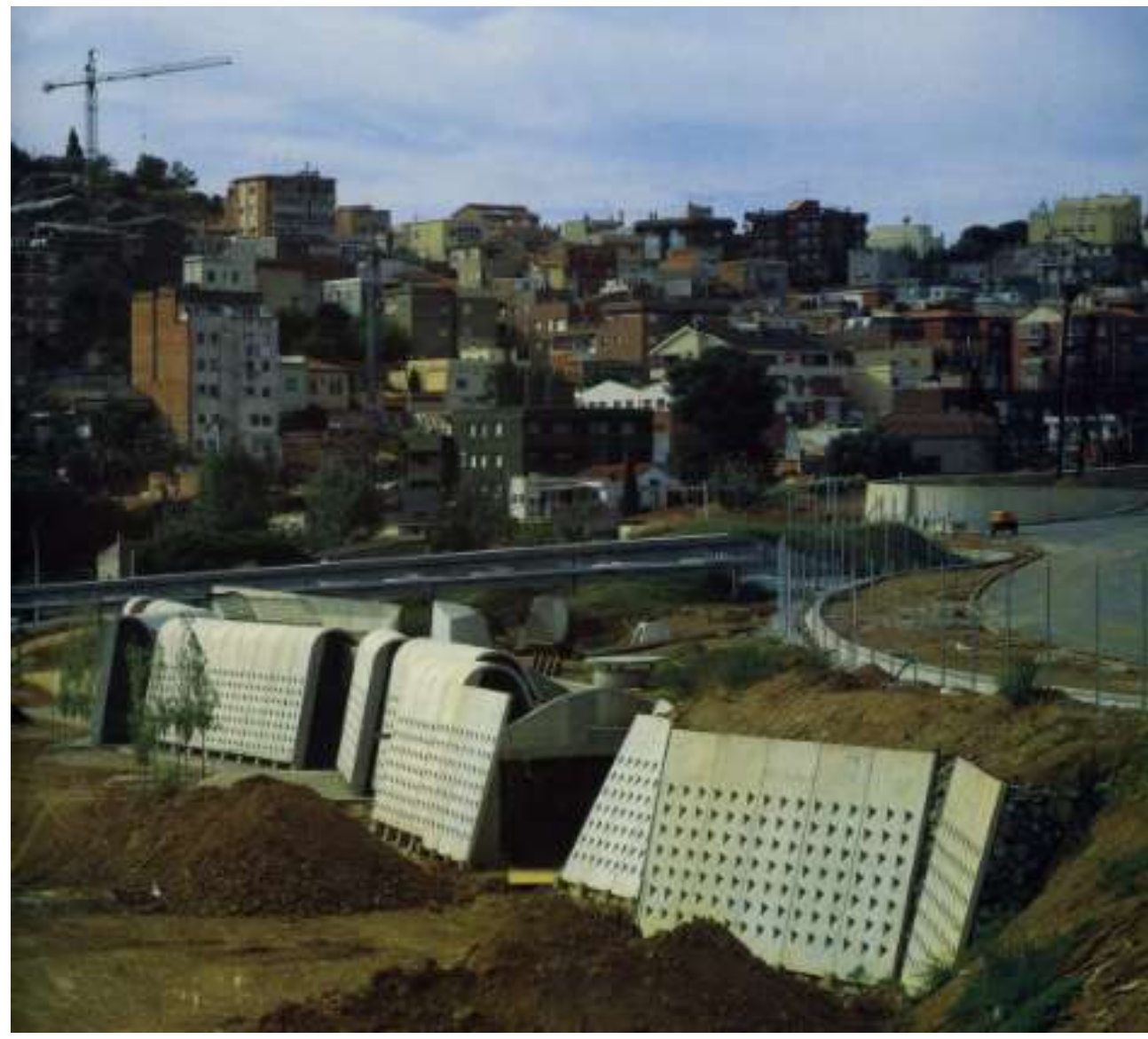

$6-59^{599}$

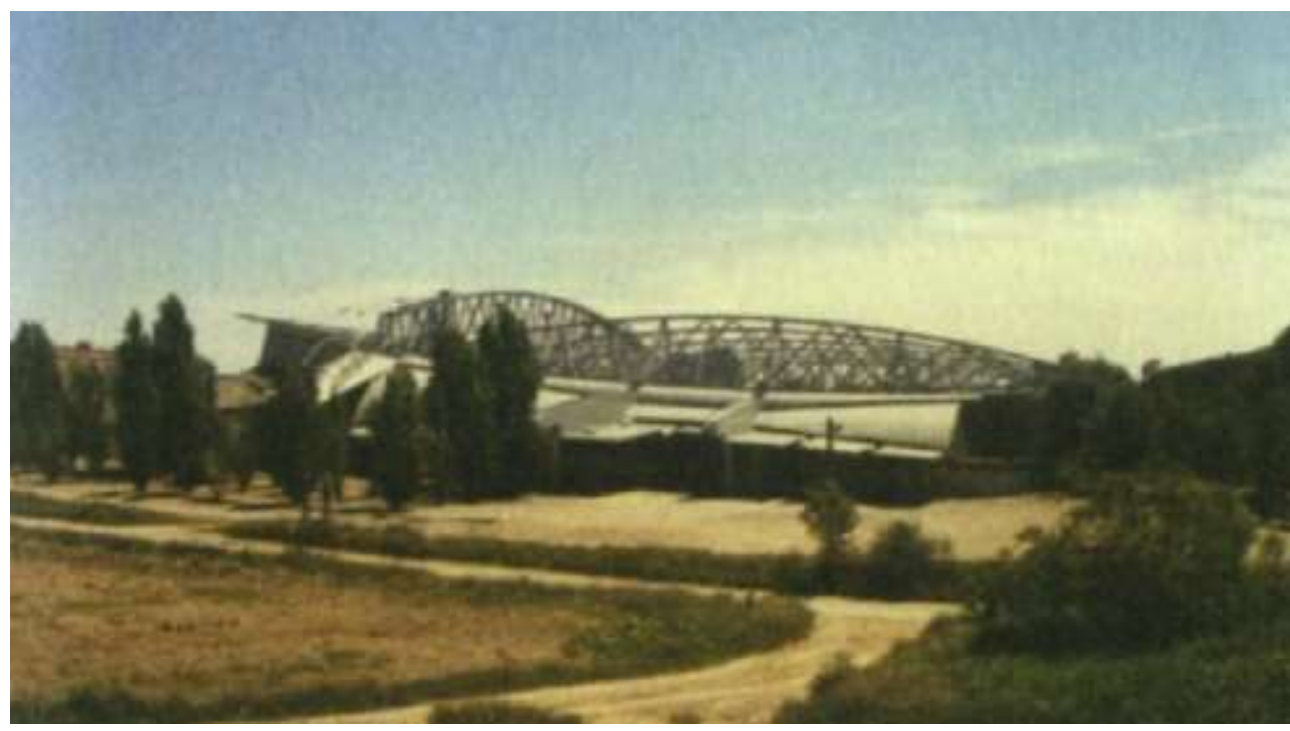

$6-60^{600}$

${ }^{599}$ Pabellón de competición de Tiro con Arco. Es difícil asignarle una escala arquitectónica.

${ }^{600}$ Pabellón de Huesca. Vista desde el paisaje agrícola. 


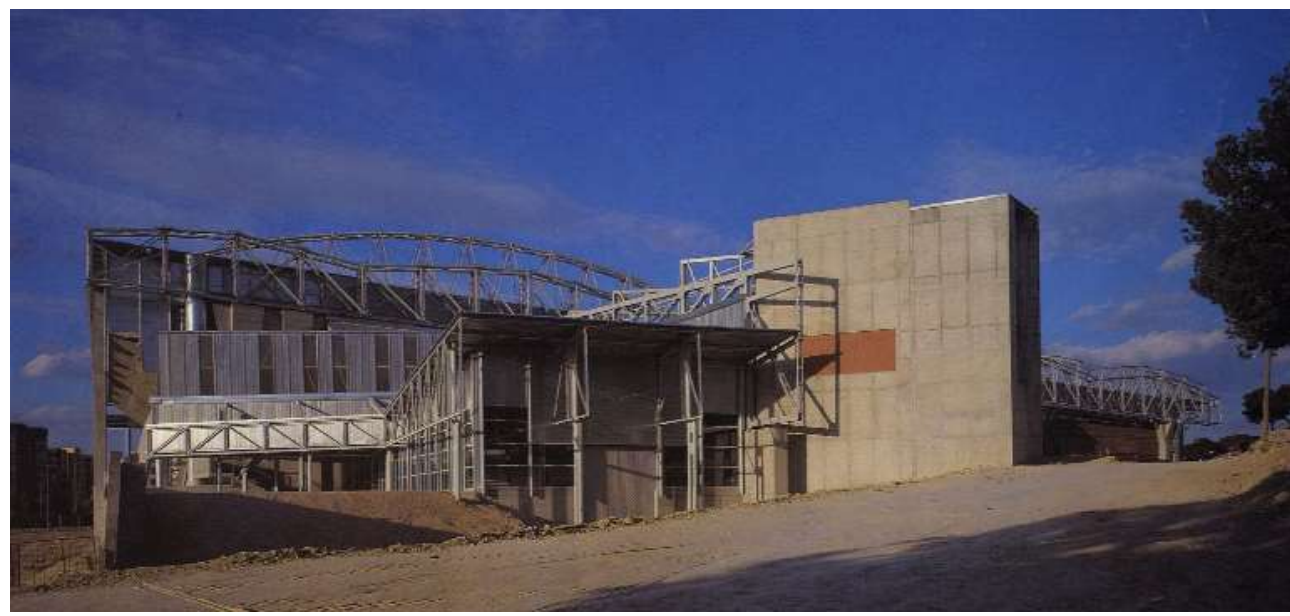

$6-61^{601}$

\title{
6.2.1. SIN FORMA, SIN VOLUMEN, SIN LIMITES :
}

Son acciones que utiliza Miralles para que sus organismos construidos de desparramen por el paisaje sin limites, y al no contar con formas ni volúmenes definidos, su obra sea un paisaje artificial que se funda con el natural.

\section{SIN FORMA}

\begin{abstract}
"Si uno se despreocupa de la forma, la arquitectura gana una enorme libertad formal, la forma solo llega al final, me gusta pensar desde términos más abstractos como la escala, la envolvente."
\end{abstract}

Enric Miralles ${ }^{602}$

La familia de formas de su arquitectura responde a la lectura del lugar y el programa. El profesor Juan Antonio Cortes, en su articulo "la geometria ha muerto. ¡viva la geometria!" 603 admite que la arquitectura de Miralles acepta la condicion dinamica de la forma y a la vez trata esa forma como algo organizado desde sus propios parametros generando una estructura geometrica interna flexible que da estabilidad formal al edificio.

Las piezas en las que se fragmenta el programa del Parque Cementerio de Igualada, difiere de la forma unitaria que tiene un cementerio convencional. Como en el Campus Universitario de Vigo, de 1999, la forma de edificio se define en relación al paisaje y el programa. En el Parlamento de Edimburgo, de 1998, el simbolismo de la tierra se representa por el empleo de diversas formas alusivas al mundo vegetal. La forma del edificio la obtendrá Miralles de la investigación de las características comunes del lugar y la tierra, persiguiendo que su organismo construido se asiente en la tierra integrándose de tal manera para que su escala conecte con la del hombre.

\footnotetext{
${ }^{601}$ Pabellón de Alicante. Vista desde la ladera de la montaña colindante.

${ }^{602}$ Miralles Tagliabue. Arquitectura del tiempo. Barcelona: Gustavo Gili; 1999.

${ }^{603}$ Juan Antonio Cortes. Lecciones de equilibrio. Fundacion Arquia, 2006, pags. $41-51$.
} 
MIralles busca que las formas de su arquitectura se extiendan y se fundan con el paisaje circundante. Sus formas responden a una concepción dinámica del espacio, negando la ortogonalidad por defecto: triángulos, zigzags, curvas de trazo libre, ondulaciones, ovoides, etc. se suceden a lo largo de su carrera profesional. ${ }^{604}$ La arquitectura de Miralles, se integra en el paisaje renovando la relación con este, y generando un nuevo paisaje construido, entre otras cosas por la redefinición de las características morfológicas del terreno, a través de la evocación de las formas de la naturaleza o de estructuras basadas en la organización natural. La forma responde a un modo de estar en el paisaje. Como cada lugar es diferente, sus edificios responden de manera diferente a cada situación y son distintos en cada caso. Aquí seria oportuno citar a Greg Lynn cuando define su propia arquitectura: "esta combinacion dinamica de indeterminacion dirigida desde el interior y las fuerzas ejercidas desde las vicisitudes externas no puede ser reducida a una forma ideal" 605

Miralles emplea formas abstractas en sus edificios junto a formas curvilíneas generando un organismo en el que lo geométrico construido se funde con lo informe natural. Formas de aspecto informal, que recuerdan a las pinturas abstractas de Arp o Miro. Formas libres, de geometría arbitraria, construidas a base de líneas rectas y curvas trazadas con compas. Como nos cuenta J. Garcia Fuentes : "Son dibujos complejos para una arquitectura compleja. Una arquitectura de formas complejas, de formas-informes, que responden a la lógica de sus propias reglas y a las que impone la realidad. Arquitectura que no puede entenderse, ni dibujarse, ni construirse con los parámetros cartesianos habituales. Arquitectura a partir de geometría no euclidiana, hecha de superposición de ideas y de conceptos." 606

En la arquitectura de Miralles, no existe correspondencia entre forma y función, pues determinada forma puede estructurar programas diferentes. Un triangulo puede estructurar la capilla en el Parque Cementerio de Igualada y a la vez la sala multiusos de la Escuela Hogar en Morella. Miralles no sigue los dictados del Movimiento Moderno en lo que respecta a que la forma debe seguir a la función, pues para el era una idea simplista que reducía la complejidad de la elaboración de un proyecto. Tampoco existe correspondencia entre forma y escala. Una forma ovoidal es utilizada por Miralles para proyectar la mesa Inestable y a la vez para la sala principal de la propuesta para el Auditorio de Copenhague. ${ }^{607}$

Para trasladar las formas complejas a los planos, Miralles junto a su colaboradora Eva Prats, ideo un método según el cual cualquier forma orgánica podía ser dibujada en dos dimensiones y abstraída gracias a la geometría. Dicho método se recogió en el articulo "Como acotar un croissant" publicado en 1991, en el no 49/50 de la revista El Croquis.

\footnotetext{
604 FERNANDEZ CONTRERAS Javier. Tesis Doctoral "La planta Miralles: Representación y Pensamiento en la Arquitectura de Enric Miralles", DPA ETSAM.

${ }^{605}$ Greg Lynn. "The renewed novelty of Symmetry". Assemblage, № 26, 1995, pags. 10 - 25.

${ }^{606}$ La estructura de un croissant, DC 17-18, UPC, 2000. p. 231

607 FERNANDEZ CONTRERAS Javier. Tesis Doctoral "La planta Miralles: Representación y Pensamiento en la Arquitectura de Enric Miralles", DPA ETSAM. UPM 2013, pag. 222
} 

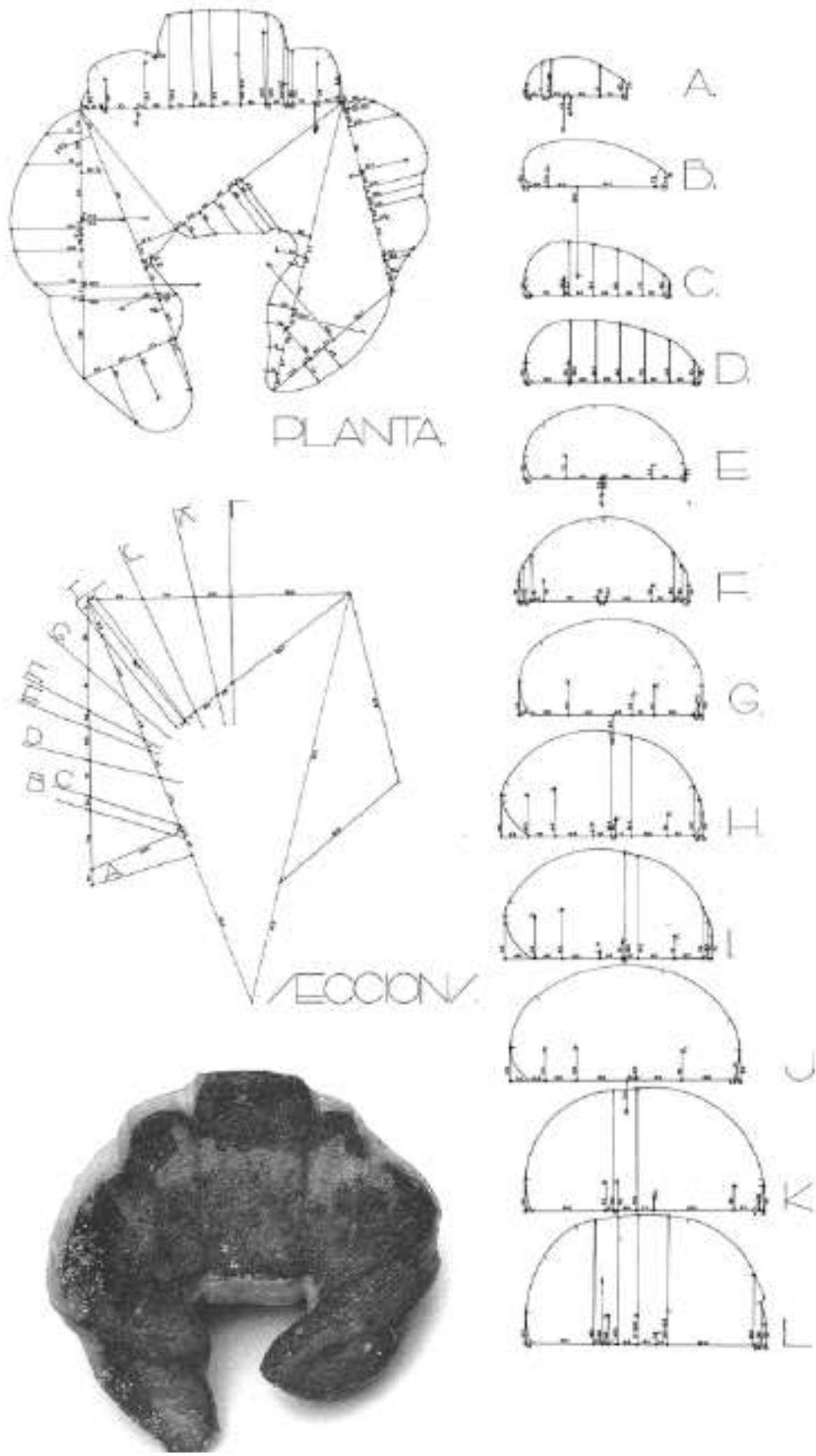

${ }^{608}$ Ejercicio de "Como acotar un croissant" publicado en 1991, en el no 49/50 de la revista El Croquis. 
En la formalización de la obra de Miralles, destaca el empleo de la curva contracurva y las curvas con elementos rectos en sus puntos de tangencia. Formas sinuosas y curvas que estarán presentes en toda su obra, repitiéndose a diferentes tamaños. Incluso estas formas serpenteantes se emplean a distintas escalas y pueden conformar desde una pieza de mobiliario hasta un edificio. Las geometrías sinuosas, se basan en leyes no euclideas, mas próximas a lo mineral y geológico que a una arquitectura basada en la geometría sistemática de las formas platónicas. También Miralles emplea formas con analogías naturales, que hacen que el organismo construido se funda con el paisaje desapareciendo la imagen de edificio convencional.

En el tratamiento de la forma, Miralles, tambien se adelanta a los tiempos, siendo en muchos casos la consecuencia del proceso y no un a priori establecido desde el comienzo, al que el proyecto se debe. Algo que detecta Federico Soriano en la arquitectura contemporánea: "Frente a la arquitectura como productora de formas significantes, en la actualidad se presenta otra concepción en la que esta será un resultado insignificante de un proceso o discurso que adquiere valor como tal...." 609

\title{
SIN VOLUMEN
}

\begin{abstract}
"Siempre más pendiente del dibujo, del trazo, que del volumen o del espacio... Son las texturas, la condición táctil de los materiales lo que cuenta."
\end{abstract}

Rafael Moneo ${ }^{610}$

Conceptualmente, un volumen tiene tres dimensiones: longitud, anchura y profundidad. Se genera cuando un plano, por ejemplo de forma cuadrada se desplaza generando un volumen cubico, un prisma. Un volumen puede ser solido o vacio (espacio contenido delimitado por planos). Según Antonio Miranda ${ }^{611} \mathrm{el}$ volumen es lo que envuelve a un edificio mientras que el contorno, seria una de las aristas de la forma. En los primeros concursos abordados por Miralles con Pinós, los edificios proyectados no se construyen como areas extruidas, no son "volúmenes". Al observar sus planos y maquetas, se aprecia su carácter a tectónico al encontrarse separados los planos de fachada y la cubierta por intersticios de aire. ${ }^{612}$

En el Parque Cementerio de Igualada, no existe un volumen rotundo que se pueda interpretar como un edificio, lo que ayuda a su fusión con el paisaje. En esta obra tienen prevalencia las superficies frente a los volúmenes, como en muchas de las obras de Miralles.

\footnotetext{
609 "Sin_tesis". Gustavo Gili. Barcelona 2004, p. 56

${ }^{610}$ Cosas vistas de izquierda a derecha (sin gafas): un comentario a la tesis doctoral de Enric Miralles Moya, 1987. "DC. Revista de crítica arquitectónica", Febrero 2009, núm. 17-18, p. 115-128.

611 “Ni robot ni bufón. Manual para la crítica de arquitectura”. Ediciones Cátedra. Madrid, 1999.

612 FERNANDEZ CONTRERAS Javier. Tesis Doctoral "La planta Miralles: Representación y Pensamiento en la Arquitectura de Enric Miralles", DPA ETSAM.
} 


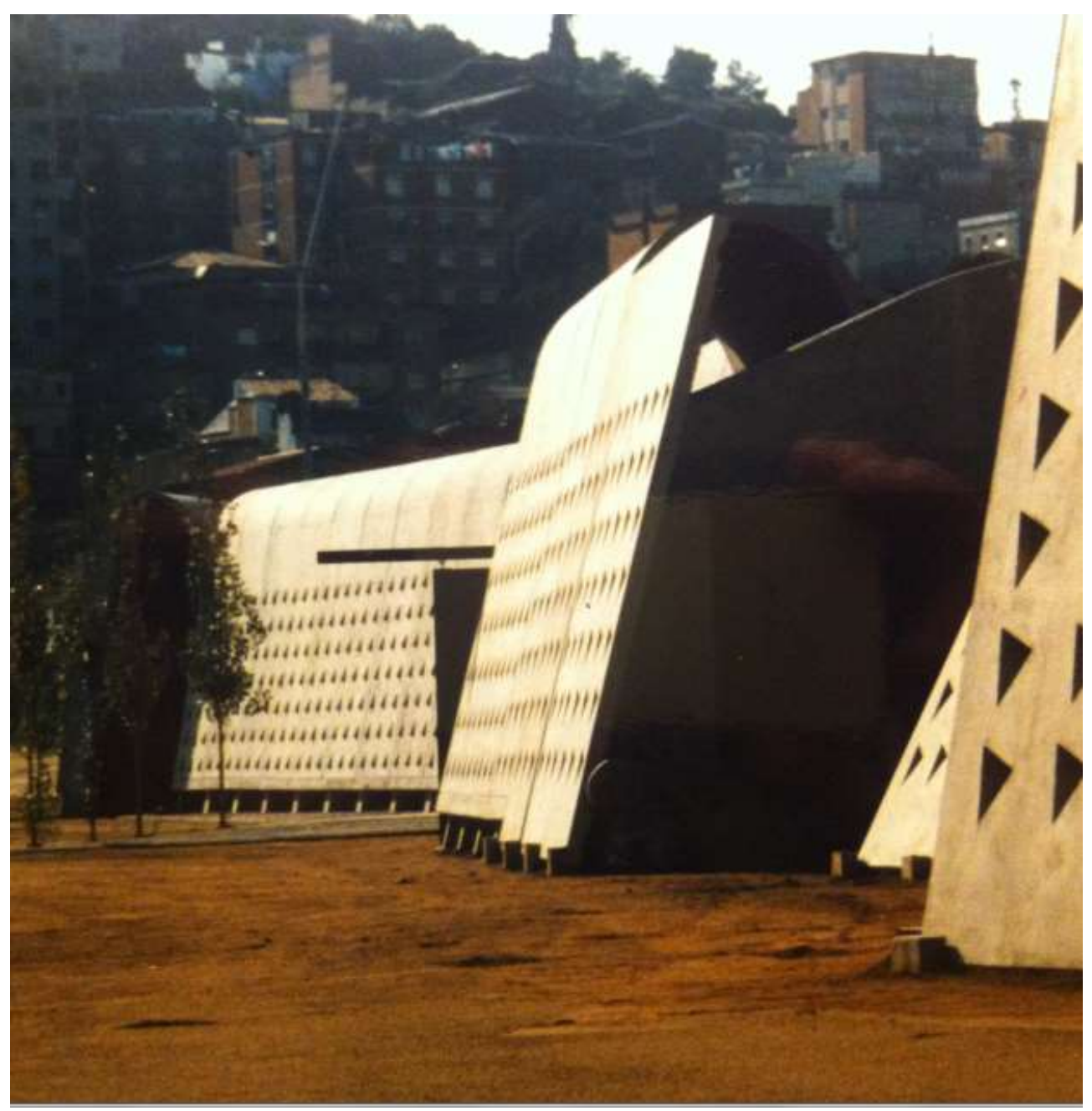

$6-63^{613}$

En el Pabellón de Competición de Tiro con Arco, los paneles de cerramiento de hormigón, perforados con una retícula de motivo triangular, que corresponden a los vestuarios, se cierran con unas teselas de vidrio enrasadas en su base y rehundidas en su vértice respecto a la cara exterior del muro. Con este retranqueo, el vidrio se queda en sombra y no se aprecia como tal. Además, el volumen de los pabellones independientes se anula en los testeros, al retranquearse estos quedando en sombra y al materializarse en tonos oscuros. ${ }^{614}$

Lejos de configurar un volumen unitario, la arquitectura de Miralles genera un conjunto fragmentado y articulado en la que cada fragmento de volumen constituye una unidad constructiva autónoma individual. Estas unidades encajan unas con otras como en un puzzle. A cada volumen le corresponde una determinada función, pero no solo es la función la que determina la forma de los volúmenes que conforman el organismo construido sino que en muchos casos, también viene determinada en respuesta al entorno. Los volúmenes tienen contornos de trazado libre, sin límite preciso que enfatizan el carácter del muro y proporcionan un ritmo

613 Pabellón de Competición de Tiro con Arco. Acción de retranquear testero para no configurar volumen. @Fundació Enric Miralles

614 Para mas información puede consultarse la Tesis de Javier Fernandez Contreras "La planta Mlralles: Representación y Pensamiento en la Arquitectura de Enric Miralles"ETSAM. UPM. 
no arquitectónico a las fachadas, un carácter más cercano al mundo geomórfico que al arquitectónico. Volúmenes que generan una intensa relación con lo natural gracias a sus formas asimétricas y su fuerza plástica.

A Miralles no le gustaba utilizar el vidrio en sus cerramientos exteriores, puesto que dependiendo del ángulo de visión reflejaba la luz produciendo reflejos y afirmando el volumen. Por eso prefería emplear otros materiales con distintas texturas y acabados. Como comenta Javier Fernández: "Se produce así una desmaterialización de la caja arquitectónica, la 'no presencia' que sus autores referirán como una de las principales cualidades de los proyectos de estos años." 615

Prevalecen las superficies respecto a los volúmenes como una constante a lo largo de su obra. La arquitectura no es compacta y la palabra volumen debe sustituirse por la palabra envolvente. Ello da como resultado una condición difusa y atmosférica de la obra de Mlralles. Los encuentros de los distintos planos que conforman los volúmenes son indefinidos, no coplanarios, no existe una continuidad entre los diferentes planos para negar la conformación volumétrica. Como en el movimiento De Stijl, es un espacio articulado mediante planos independientes, que no cierran volúmenes.

\title{
SIN LIMITES
}

\begin{abstract}
"El edificio se disuelve y se rompe en su afán de prescindir de los límites y de fundirse con todo lo circundante, bien sea el marco de lo ya construido, como en La Llauna, o el paisaje en Igualada y en Morella."
\end{abstract}

Rafael Moneo. ${ }^{616}$

Para Paul Valery, no existe el lugar en términos absolutos ya que sus limites se esparcen impregnando los alrededores. Miralles aprendió a difuminar los límites entre interior y exterior de Gaudi y de los Smithson, entre otros. Su arquitectura en muchos casos hace difícil entender a que lado se encuentra el usuario, si en el interior o en el exterior. Su obra es un continuo desparramarse de elementos desintegrados formalmente en el paisaje, sin límites, para que se fundan con el paisaje. Es una arquitectura que renuncia a toda identificación del edificio como objeto.

\subsubsection{O C U L T AR :}

Es la acción que utiliza Miralles para ocultar no solo el uso al que se destina la obra sino para velar que sea apreciado como un edificio convencional al uso. Miralles oculta la apariencia de edificio convencional, construyendo organismos arquitectónicos ligados al paisaje natural, mediante una abstracción naturalista, como si fueran afloramientos de la naturaleza que siempre hubieran estado ahí. Son decisiones encaminadas a no conferir apariencia arquitectónica al volumen que acoge la arquitectura. En el Parque Cementerio de lgualada, existe

\footnotetext{
615 FERNANDEZ CONTRERAS Javier. Tesis Doctoral "La planta Miralles: Representación y Pensamiento en la Arquitectura de Enric Miralles", DPA ETSAM. UPM 2013. pag, 30.

616 "Una vida intensa, una obra plena" El Croquis nำ100-101, Julio 2000. pag. 306-312
} 
ambigüedad respecto al uso al que se destina lo construido. Nada indica al visitante que se encuentre en uno de los muchos cementerios que pueblan la geografía española. La simbología, si existe se encuentra abstraída. En el Pabellón de Competición de Tiro con Arco, de 1989 - 1991, varios pabellones y muros de contención se disponen contra un corte en el terreno desplazándose entre si siguiendo una secuencia quebrada. Dichos pabellones y muros de contención, se construyen con unos paneles de cerramiento perforados con una retícula de motivo triangular. En una visión frontal, es imposible diferenciar que es muro de contención y que es estancia habitada para vestuarios. ${ }^{617}$

\title{
6.2.3. MANIFESTAR LA ACCION DEL TIEMPO :
}

\author{
"El tiempo como algo que es capaz de dar forma \\ a las cosas." \\ Enric Miralles. ${ }^{618}$
}

Es la acción que utiliza Miralles para fundir su arquitectura con el paisaje, al proyectar teniendo en cuenta al tiempo como un ingrediente mas de su arquitectura.

Miralles fue consciente de lo positivo que resultaba la acción del tiempo en la obra, durante la ejecución del Parque Cementerio de Igualada, en el que debido al escaso presupuesto del Ayto. de la localidad, la obra se demoro a lo largo del tiempo en distintas fases. En el Pabellón de Huesca, el factor tiempo también fue importante pero en otro sentido, pues el derrumbe de la cubierta durante el proceso de construcción genero una repentina aceleración del tiempo.

En la arquitectura de Miralles, se supera la dualidad entre naturaleza y artificio, gracias a una actitud tomada desde el proyecto de interactuar con el entorno, lo que permite a la propuesta construida evolucionar conjuntamente con el paisaje a medida que pasa el tiempo. Miralles pone énfasis en el proceso, en la transformación continuada del proyecto, sin importarle el resultado final. El tiempo se encargara de terminar la obra. Sus obras, mutan con el transcurso del tiempo, como lo hace la naturaleza. Es el indetenido cambio lo que se manifiesta en las obras de Miralles que envejecen con el paisaje. Miralles se adelanto en este aspecto a los tiempos, puesto que como detecta Vicente Guallart en la arquitectura contemporánea, el tiempo se ha convertido en un nuevo material de proyecto: "el tiempo es un nuevo material del proyecto. la arquitectura como proceso abierto, como acto no finito, necesita saber incorporar el tiempo a la partitura de su organización." 619

\subsubsection{CON LOS MATERIALES}

La materia en la obra de Miralles potencia la expresividad de las formas y es una parte indisoluble de la obra. Los materiales empleados por Miralles destacan porque en sus texturas queda manifestada la acción del tiempo. Así, los

\footnotetext{
617 FERNANDEZ CONTRERAS Javier. Tesis Doctoral "La planta Miralles: Representación y Pensamiento en la Arquitectura de Enric Miralles", DPA ETSAM. UPM 2013.

${ }^{618}$ Juan INSUA. Entrevista: Enric Miralles, La Vanguardia, Cultura-Ideas, 26 abril 1994 p. 38

${ }^{619}$ Vicente Guallart. DICCIONARIO METAPOLIS DE ARQUITECTURA AVANZADA. Manuel Gausa, Vicente Guallart, Jose Morales, Willy Muller, Fernando Porras, Federico Soriano. Actar, 2001, p. 582
} 
hormigones tienen una terminación no pulida para que la patina del tiempo se deposite en sus poros. El acero corten, empleado para que en su continuo cambio debido a la oxidación le haga cambiar de aspecto a lo largo del tiempo. El cromatismo y las texturas remiten a las percibidas en el entorno, y denotan la tosquedad con la que construyen los contratistas locales. En el Parque Cementerio de Igualada, el paso del tiempo ha oxidado los elementos metálicos, ha desbastado el solado dejando al descubierto el árido y ha hecho surgir patinas en el hormigón cuyo aspecto se funde con el del terreno en el que se implanta.

Los materiales empleados por Miralles en sus obras, hacen alusión a lo local y lo universal, puesto que en muchos casos se emplean materiales del lugar para que sintonizen en textura y coloración con el paisaje. Tambien destaca la aplicación de sistemas de construcción vernáculos (como los muros de gaviones en Igualada). El acero se emplea con tecnologías que ponen al limite las estructuras, pero su ejecución se parece mas a las construcciónes de acero del S. XIX que al "high tech" contemporáneoMiralles, destaca por el empleo de pocos materiales.

En líneas generales, utiliza el hormigón bajo rasante y el acero en estructura, cerramientos y cubiertas ligeras. Destaca también el empleo de materiales tradicionales como la piedra, el ladrillo y la madera, pero empleadas de manera no convencional.

La concepción natural y telúrica de su obra se refuerza mediante la utilización del mismo material tanto en exteriores como en interiores. En muchos proyectos, el hormigón construye suelos, escaleras y paredes. Destaca la atención prestada a los pavimentos, pues en muchos casos es lo único que determina la separación de los distintos espacios.

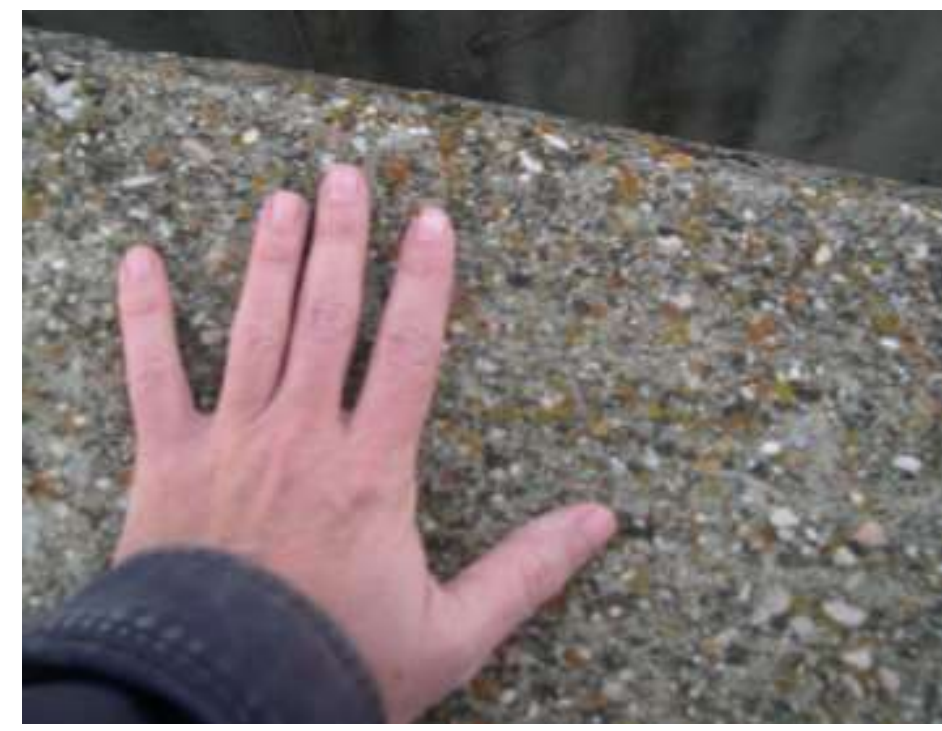

Ilustración 6-64

\footnotetext{
${ }^{620}$ Los hormigones de Miralles no son como los de Tadao Ando, sino como los de la etapa brutalista de Le Corbusier. Sus texturas permiten recoger la patina del tiempo en su superficie y ello ayuda a relacionarse con el paisaje.
} 


\subsubsection{CON LA VEGETACION}

Miralles, da mucha importancia a la vegetación natural en los paisajes en los que interviene, potenciándola e incluso reforestando si hace falta. Quiere que sus edificios manifiesten la acción del tiempo como lo hace la naturaleza. El cambio que experimenta la vegetación con el discurrir del tiempo se manifiesta en sus obras. Se emplearan especies caducas que muestren el paso de la estaciones climáticas. Especies pensadas desde proyecto en planos de jardinería que conviven con la vegetación existente.

En el Parque Cementerio de lgualada, la vegetación se proyecta para que con el paso del tiempo se funda con la existente y llegue a sellar la falla abierta artificialmente haciendo del cementerio una gran fosa común subterránea. El empleo de especies caducas como los almendros plantados en la zona de entrada y los chopos plantados en la hoz artificial, se emplean para que al cambiar su aspecto con las estaciones climáticas, también lo haga el organismo construido. En los Pabellones de Tiro con Arco, antes que se demoliese el edificio de Competición, y quizás por su estado de abandono, la marquesina metálica que daba sombra a la zona del nivel superior, fue invadida por la vegetación hasta casi hacerla desaparecer y confundirla con el paisaje En el Pabellón de Huesca, el follaje ya crecido de la vegetación proyectada por Miralles ayuda a la integración del organismo construido con el paisaje natural. Para constarlo solo hay que comprobar el aspecto de organismo retratado en las fotografías tras su inauguración en 1994 contrasta con el aspecto actual que la obra tiene terminada. En la Escuela de Música en Hamburgo, de 1997, se busca el equilibrio con el paisaje natural, al proyectar su edificio entrelazándose con los arboles existentes y su evolución en el tiempo, para que de la interacción resultante, se genere un remanso de tranquilidad entre los árboles.

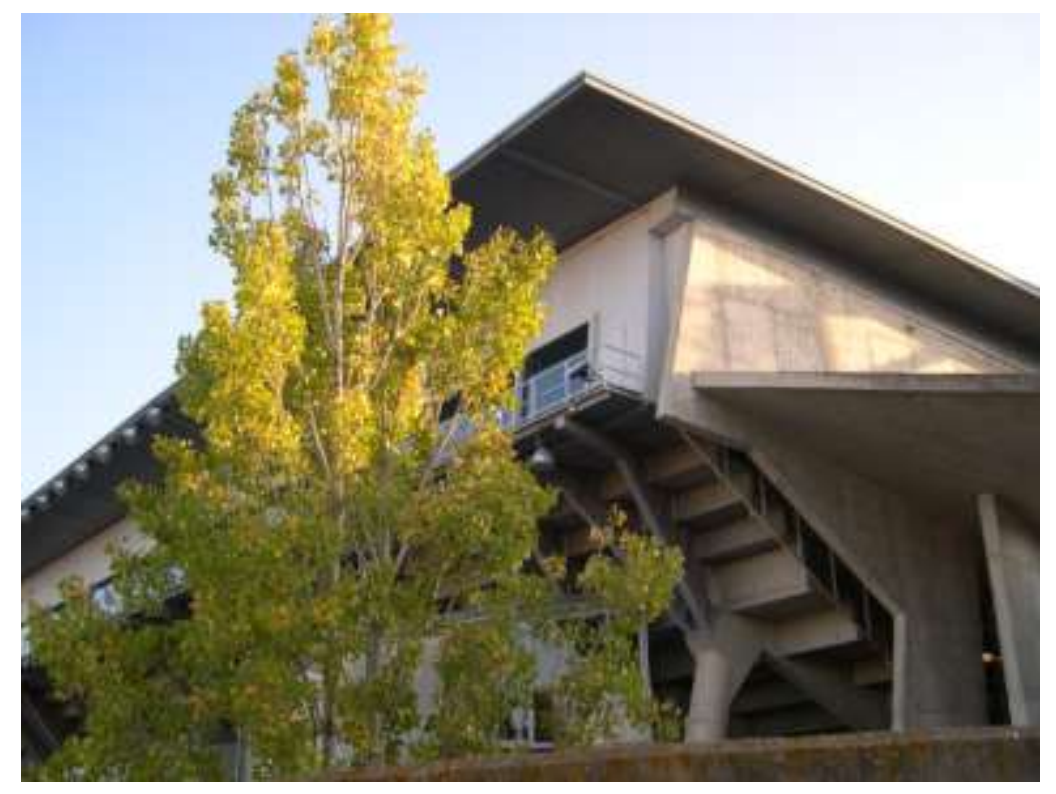

Ilustración 6-65

\footnotetext{
${ }^{621}$ La vegetacion plantada por Miralles desde el proyecto, permite con el tiempo generar episodios de ligazon a la naturaleza y en evolucionar en sintonia con la vegetacion del paisaje existente.
} 


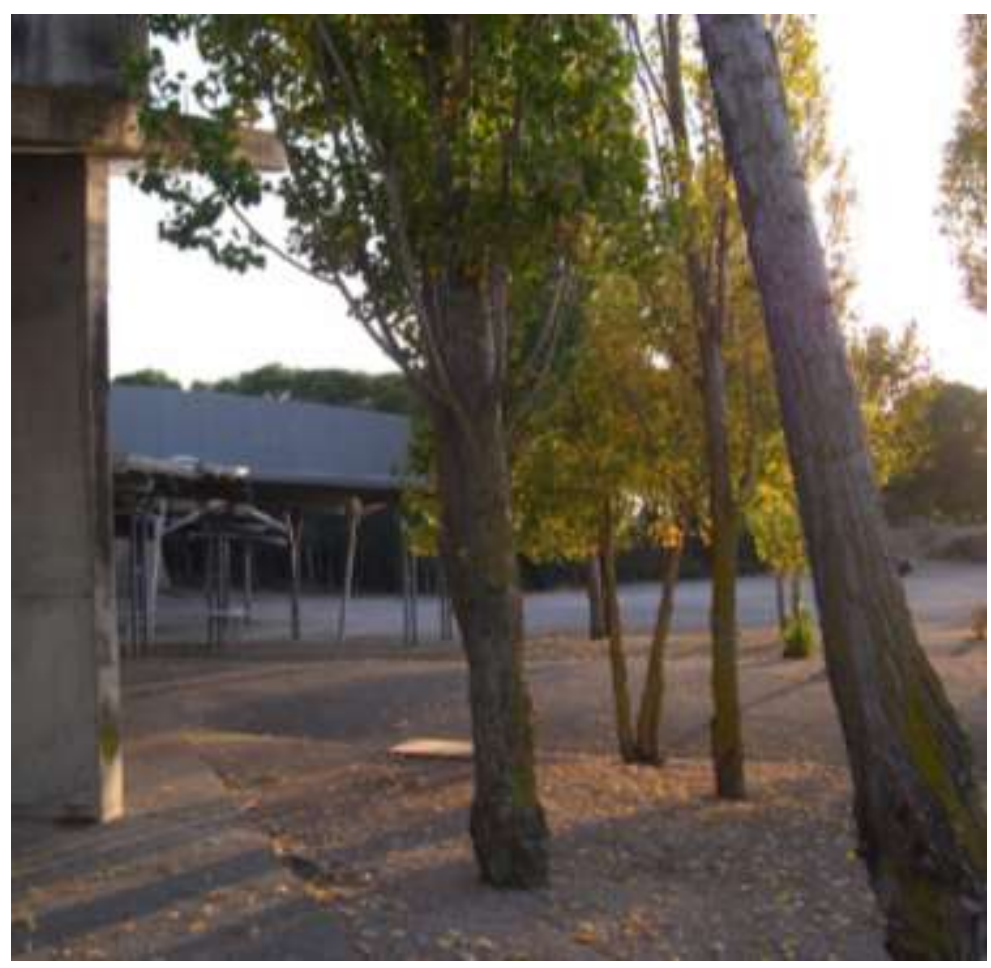

$6-66^{622}$

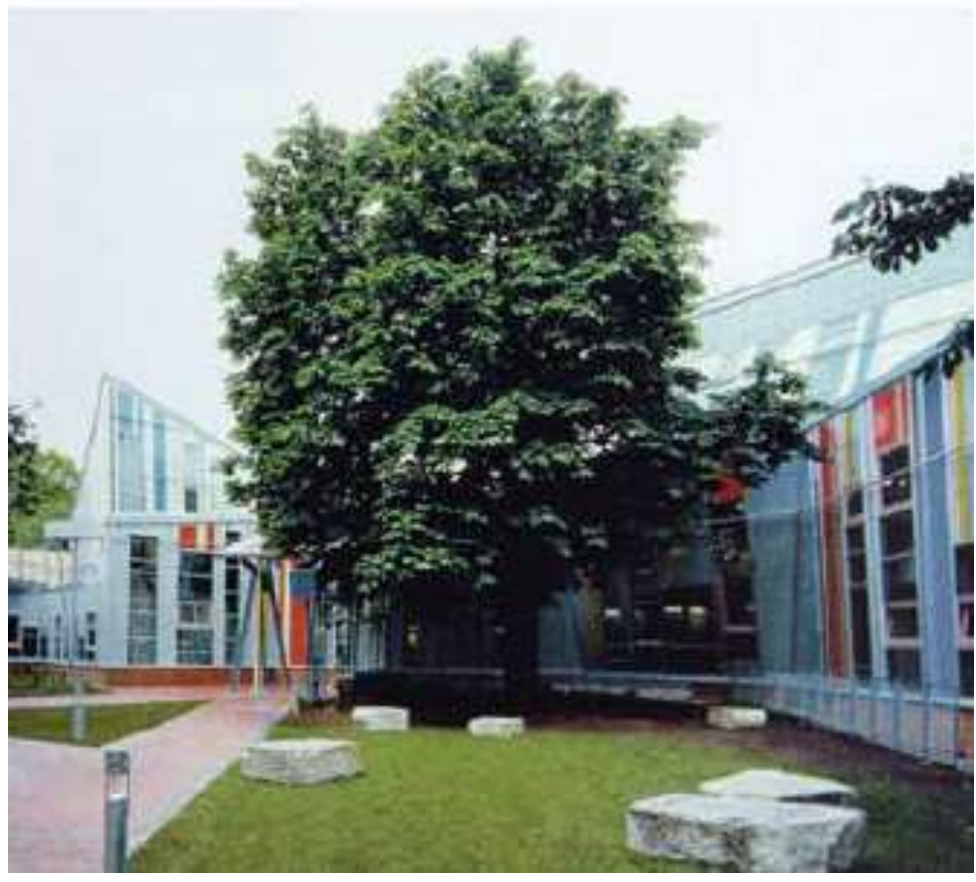

$6-67^{623}$

${ }^{622}$ Pabellón de Huesca. Relación de arboles plantados por Miralles con los soportes de la marquesina de acceso por uno de los laterales al Pabellón. Fotograifa realizada por el autor de la Tesis.

${ }^{623}$ Escuela de Música en Hamburgo, de 1997. El edificio se adapta al árbol que existía en el lugar. 


\title{
6.2.4. EVOCAR MODELOS NATURALES :
}

\begin{abstract}
"Algo de esta actitud panteísta se haría patente, por otra parte, en su obsesivo interés por crear una naturaleza artificial...presente en tantos proyectos donde lo construido y lo natural se confunden. Enric Miralles no quería esperar a que los arboles crecieran. $Y$ así, desde el comienzo de su carrera, llena (sus proyectos) ... con fantasmales plantas de acero y madera"
\end{abstract}

Rafael Moneo. ${ }^{624}$

Es la acción que utiliza Miralles para naturalizar su arquitectura por medio de la evocación de analogías con la naturaleza. Miralles como los arquitectos modernistas, se inspira en el mundo natural. El Modernismo fue una corriente estilística plural compuesta de tendencias diferentes que tenían en común la inspiración en el mundo orgánico. Una parte significativa de las corrientes modernistas del Norte de Europa utilizaron formas vegetales como fuente de inspiración ornamental arquitectónica, especialmente evidentes en el caso de las corrientes Art Nouveau de Victor Horta en Bruselas o de Hector Guimard en París, frente al carácter geométrico de las corrientes Sezessión vienesa de Otto Wagner y Joseph Maria Olbrich, o el Modern Style escocés de Charles Rennie Mackintosh. En el caso del Modernismo español, esta tendencia de carácter orgánico fue especialmente relevante, derivando en ocasiones en una operación de diseño que importaba a la arquitectura no tan solo formas propias de la Naturaleza, sino que llegó a constituirse en una operación de traslación cromática completa asentada sobre el uso de la cerámica coloreada.

Desde las Pérgolas en Parets del Valles, a las de la Avenida Icaria y en posteriores proyectos, Miralles construye arboles "artificiales". El referente natural es una constante en la arquitectura de Miralles, y la evocación de modelos naturales se da a distintas escalas, pudiendo ir desde la evocación de un proceso geológico que hubiera ocurrido en un pasado muy lejano, como es el caso de la hoz artificial construida en el Parque Cementerio de Igualada. En el Pabellón de Competición de Tiro con Arco, la planta se asemeja a la forma de una gamba, mientras que al percibir su volumen exterior tiene la apariencia de un insecto ciempiés que se hubiera quedado parado. El Pabellón de Entrenamiento visto en una fotografía aérea, se asemeja a una manta raya moviéndose a un palmo del fondo.

En el Pabellón de Huesca, cuando se observa desde lejos, en concreto desde las zonas de cultivo agrícola, situadas al Norte, se asemeja a una especie de insecto que acabase de salir del bosque y de repente su movimiento hubiera quedado congelado.

\footnotetext{
624 "Una vida intensa, una obra plena" El Croquis nำ100-101, Julio 2000. p. 307-308
} 


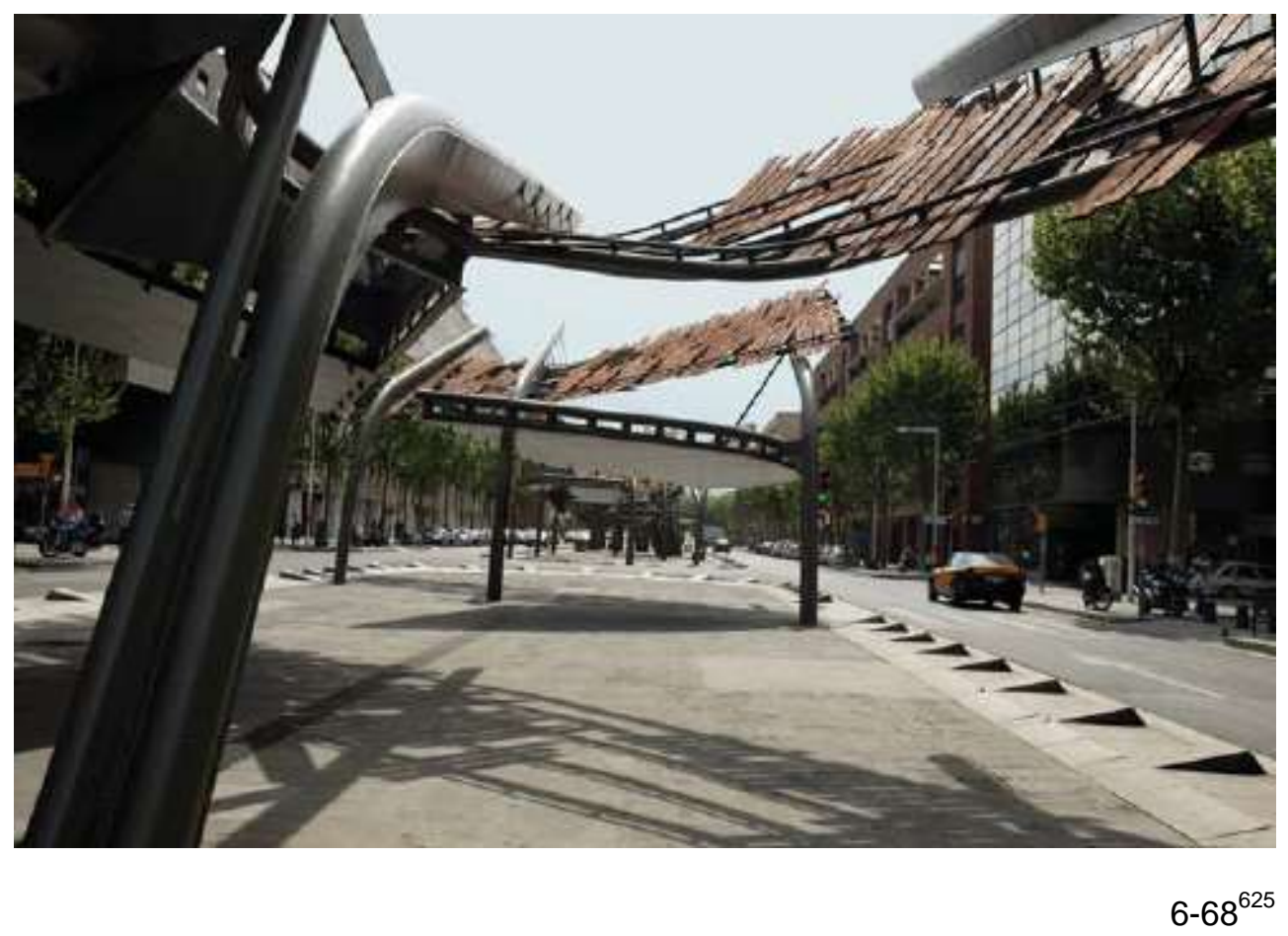

En la propuesta de Miralles para una Estación de Tranvia en Frankfurt, de 1995, al tratarse de un entorno sin identidad, Miralles incorpora la figura de una cebra en planta. Una geometría ajena al lugar, cuyo motivo da forma a las estructuras que integran la iluminación artificial. En el Parque de Santa Rosa en Mollet del Valles, de 1992-2000, Miralles al abordar el proyecto en un lugar que no tiene identidad, se inspirara en los campos de cultivo de Andalucía y Extremadura, lugar de procedencia de los ancianos que viven en ese barrio. Miralles destaca los colores de esos campos de cultivo como cualidad esencial y recurre a las pinturas de David Hockney "Plants, trees, fields and mountains" y "Terrace Hollywood Hill House with banana tree" para inspirarse en los objetos, plantaciones y pavimentos que organizan el parque.

En la propuesta de Concurso para La Feria de Jardines de Dresde, de 1995, la geometría de la propuesta se basa en los distintos tamaños de los pétalos de un ramo de flores que recibió Benedetta Tagliabue con motivo del nacimiento de su primera hija. ${ }^{626}$ En la propuesta para el Embarcadero del Puerto de Tesalónica, de 1997, al no tener trazas el agua del mar a las que agarrarse para iniciar el proyecto, Miralles decide incorporar el reflejo que sobre el agua producen las constelaciones del cielo en ese lugar.

\footnotetext{
${ }^{625}$ Pérgolas en la Avenida Icaria. Barcelona.

${ }^{626}$ Tal y como le traslado Benedetta a Javier Fernández Contreras. Citado en FERNANDEZ CONTRERAS Javier. Tesis Doctoral "La planta Miralles: Representación y Pensamiento en la Arquitectura de Enric Miralles", DPA ETSAM. UPM 2013. pag, 56.
} 

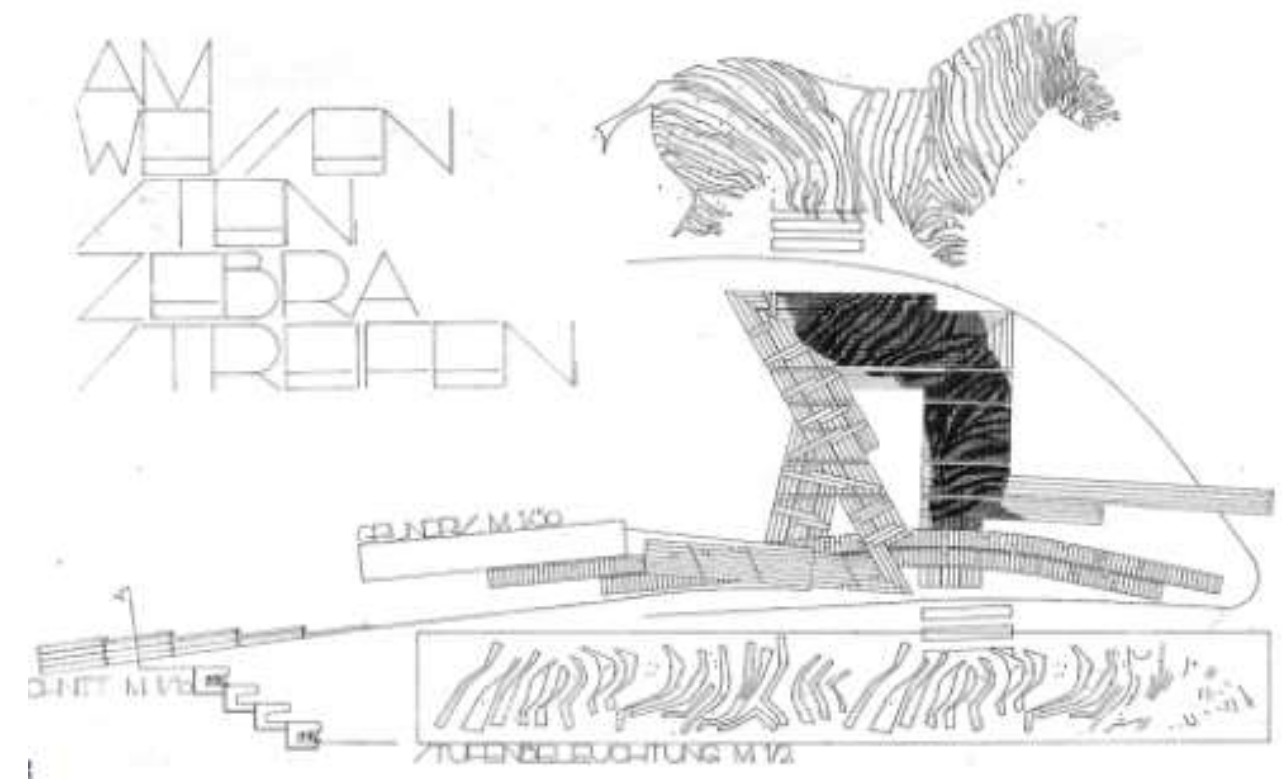

$6-69^{627}$

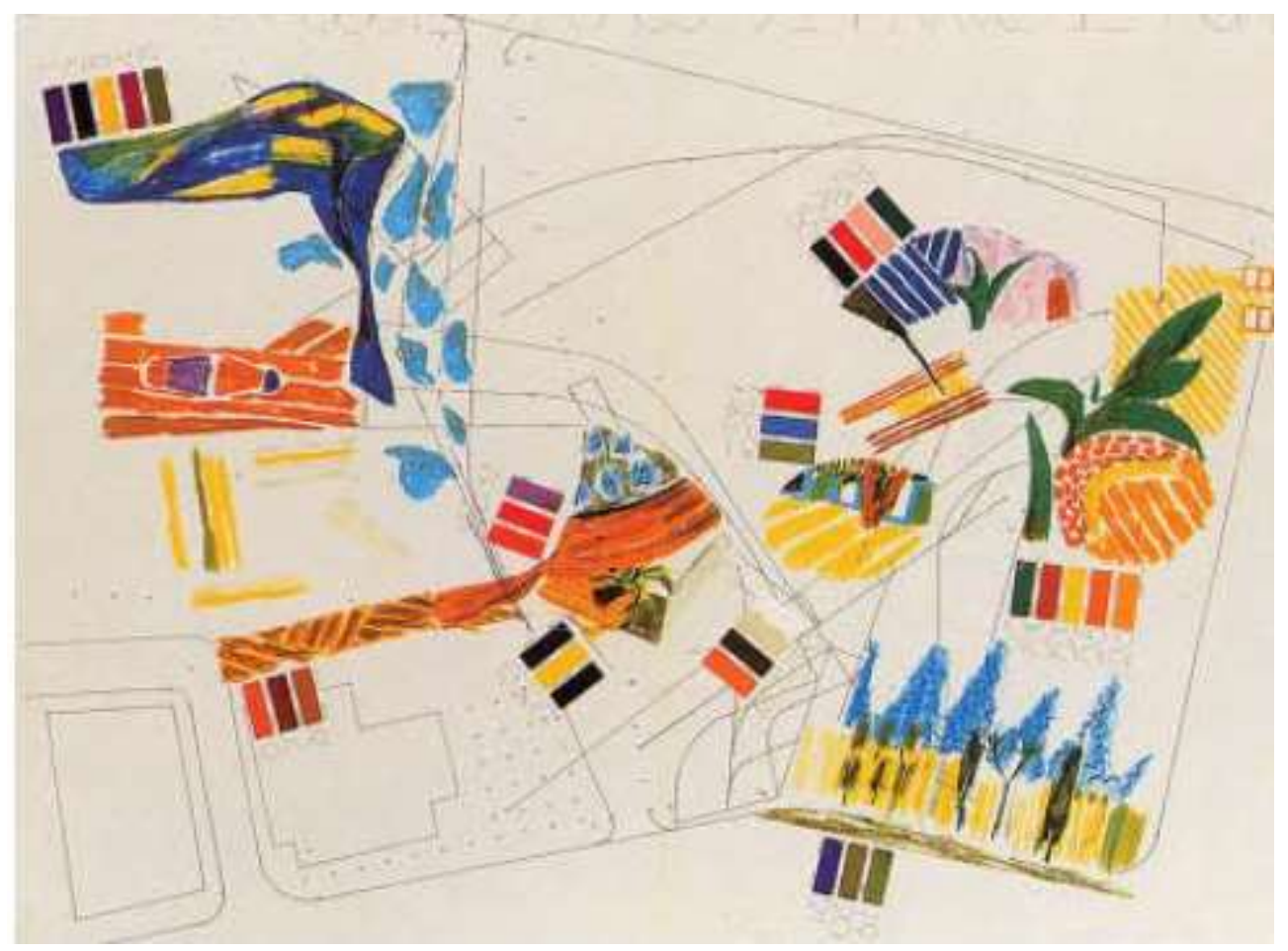

$6-70^{628}$

${ }^{627}$ Estación de Tranvía en Frankfurt, de 1995

${ }^{628}$ Parque de Santa Rosa en Mollet del Valles, de 1992-2000 


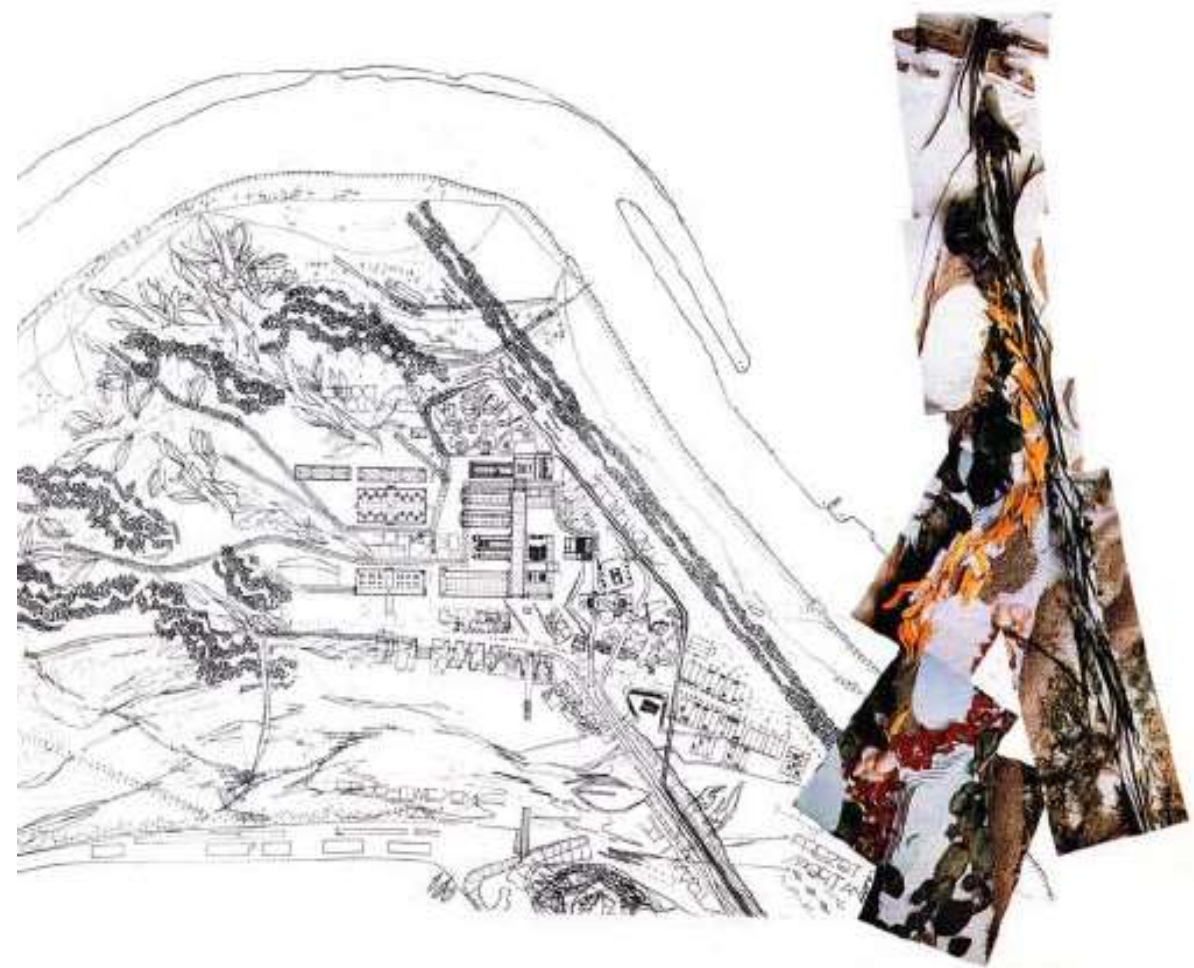

$6-71^{629}$

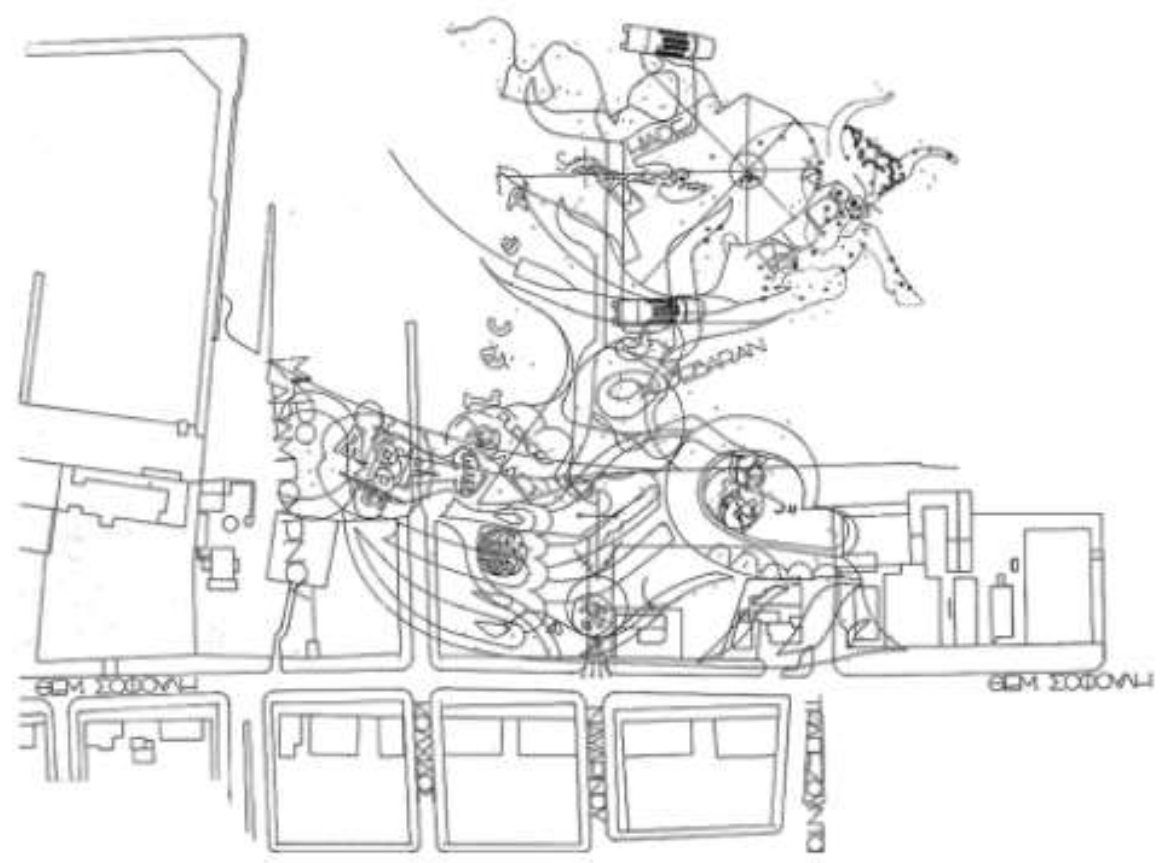

$6-72^{630}$

${ }^{629}$ Concurso para La Feria de Jardines de Dresde, de 1995

${ }^{630}$ Concurso para el Embarcadero del Puerto de Tesalónica, de 1997 
En la Escuela de Música de Hamburgo de 1997-2000 los edificios se pliegan para "dejar tiempo a que los arboles crezcan..." uniéndose a las masas de arboles para lograr un equilibrio entre arquitectura y paisaje. La pintura de la fachada con franjas de colores en vertical, simulan la verticalidad de los arboles cercanos, y la estructura que construye dicha fachada esta compuesta de soportes de sección circular y vigas que buscan asemejarse a dichos arboles. En el Pabellón de meditación de Unazuki, un garabato metálico construido en el aire soporta el mirador sobre el paisaje, pareciendo una especie vegetal surgida de la pendiente del monte en el que se implanta.

En la primera propuesta de Junio de 1998, para el Parlamento de Edimburgo, Miralles realiza un croquis - collage, con ramas y hojas para estructurar la relación de las salas principales con la topografía. Un modelo vegetal como estrategia de crecimiento que organiza los flujos de circulación, en el que no importan los objetos ni las posiciones concretas sino las relaciones entre ellos. Como relata Miralles: "El Parlamento de Escocia debería asentarse en el sitio con la misma lógica y delicadeza en que se organizan las formas vegetales; las hojas y los arboles siempre han sido un ejemplo." 631 En la propuesta de Ampliación de la Granja Moore, de 1999, se reconoce cierta analogía con la geometría del calamar o la medusa, al desplegarse desde la gran cabeza de forma ovoidal unos pabellones lineales como si fueran tentáculos.

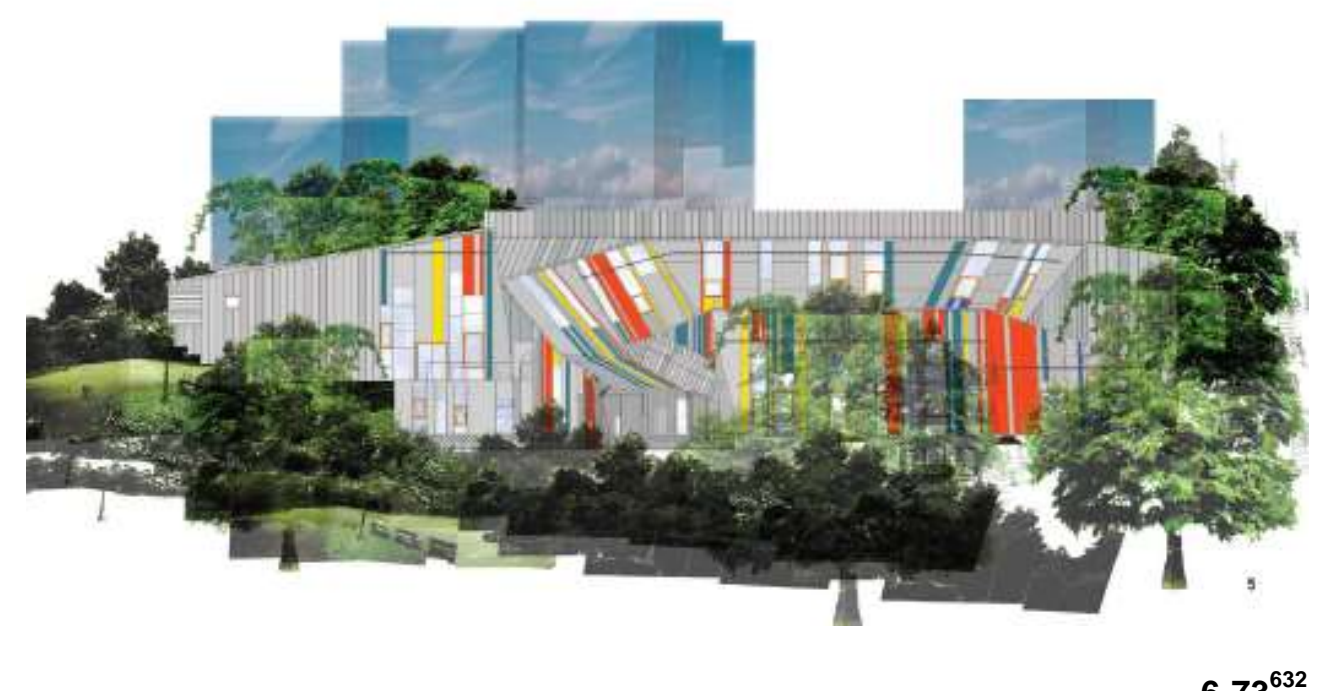

$6-73^{632}$

${ }^{631}$ Creating a Scottish Parliament, p. 62

${ }^{632}$ Escuela de Música de Hamburgo de 1997-2000 

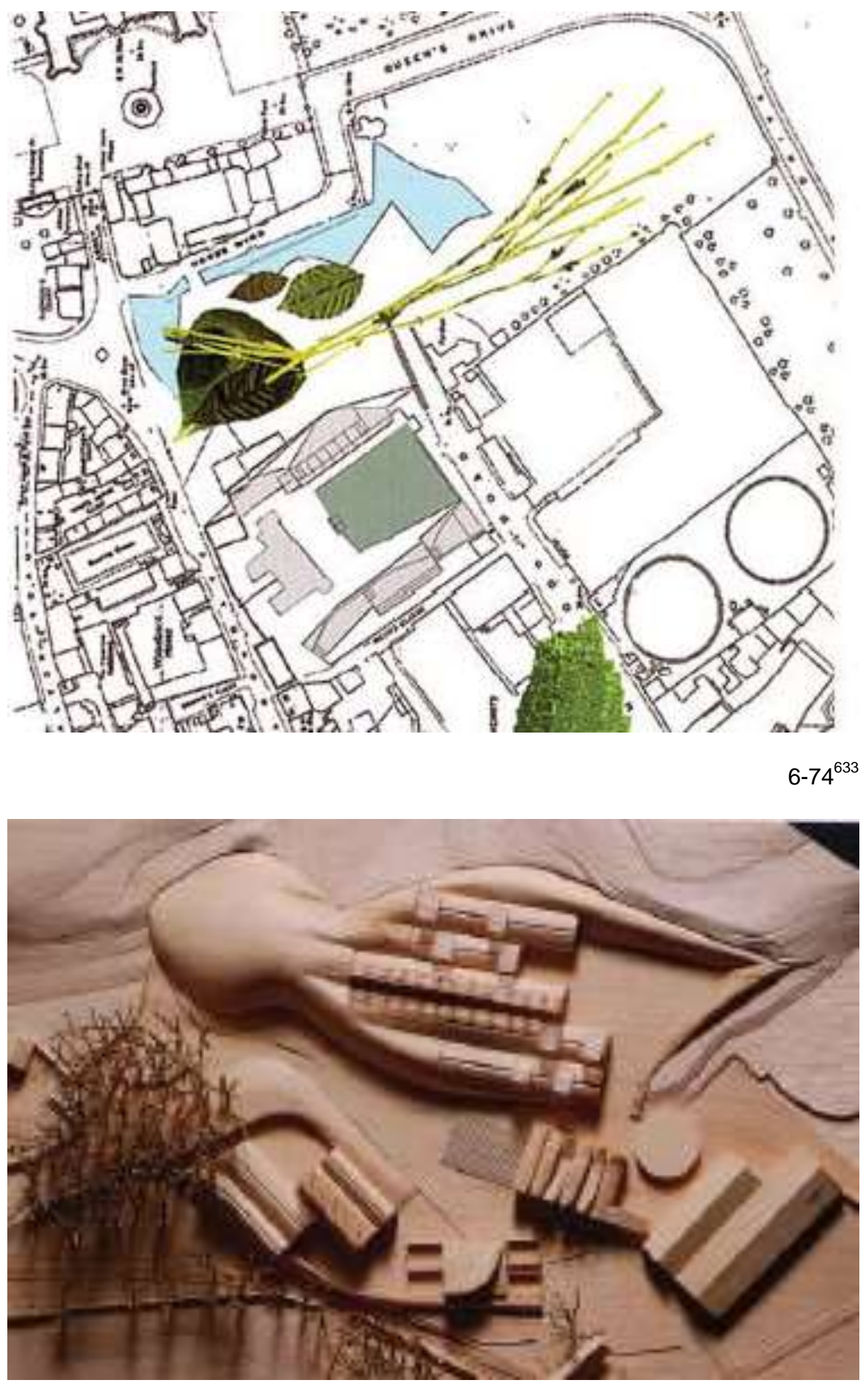

$6-75^{634}$

${ }^{633}$ Croquis - collage de la primera propuesta de Junio de 1998, para el Parlamento de Edimburgo.

${ }^{634}$ Propuesta de Ampliación de la Granja Moore, de 1999. 


\subsubsection{N A C A B A R :}

"But architecture has a different approach to time. It lives in a kind of continuous present...Igualada, Huesca, and Archery Ranges have been transformed into Bremerhaven, Mollet, etc., and ultimately into the Edinburgh Parliament...Let us take the previous list of projects, connected with a specific treatment of geometry in relation to the earth construction of buildings, and make a new list. Unfinished (Igualada), Double (Huesca), Dichotomy (Archery Ranges)"

Enric MIralles. ${ }^{635}$

Es la acción que utiliza Miralles para dejar la obra inacabada, "abierta" y que asi se complemente con el paisaje en el que se implanta. Alvaro Siza coincide con Miralles al defender lo inacabado como algo que hibrida las escalas, lo construido y el paisaje, en los siguientes términos: "Un aspecto que me impresiona mucho en la arquitectura y en la ciudad de nuestro tiempo es el empeño en llevarlo todo a su acabamiento, a su final, a su finalización. Esta tensión hacia una solución definitiva impide la complementariedad entre las varias escalas, entre el tejido humano y el monumento, entre el espacio abierto y el construido."

Los organismos construidos de Miralles no se encuentran determinados desde el principio, sino que se encuentran continuamente en proceso, de ahí que sea tan importante en su manera de proyectar el proceso y no el final. Este proceso es visible en sus edificios cuando son inaugurados, pues destilan un aire inacabado. La acción de inacabar, forma parte de acciones de Miralles, como algo consustancial a su manera de trabajar y como una manera personal de estar en el mundo. Pero lo inacabado no solo se percibe en la obra ejecutada, sino que aparece ya en la fase de proyecto y de ejecución en la obra. ${ }^{636}$ El Parque Cementerio de Igualada, es una obra inacabada, que se deja intencionadamente sin terminar por Miralles y Pinos, para que siga evolucionando con el paisaje en el que se implanta. A día de hoy, todavía no se ha construido el otro ramal de la $V$ de nichos recogida en proyecto, que parte desde la plaza elíptica de los panteones. La capilla, todavía hoy en construcción, es otro acento mas dentro de la intervención general, para transmitir que la Obra todavía se encuentra inacabada. En el Pabellón de Huesca, cuando se recorre el perímetro del edificio "in situ" parece como si todavía se estuviera construyendo o se encontrase en ruinas, el medio deshacer (la ruina) desempeñara un papel parecido. Porque el Pabellón de Huesca es una ruina, y la ruina, se relaciona muy bien con el paisaje. La ruina esta en los dos mástiles dejados en el lugar, como resto arqueológico del pasado del edificio, cuando sujetaron hasta el día de su desplome la cubierta tensada. Sin embargo, esta acción de inacabar, no se vera en proyectos posteriores como Palafolls o Edimburgo, Mercado de Santa Caterina o Torre de Gas Natural.

Según Rafael Moneo, lo inacabado para Miralles es su modo de entender el mundo y el tiempo, y lo relata en los siguientes términos: "Para Miralles lo

\footnotetext{
635 "Anymore" Cynthia Davidson. The MIT Press. 2000.

${ }^{636}$ En la visita al Archivo Enric Miralles se pudo comprobar cómo lo inacabado, era un invariante en los tres proyectos estudiados, la existencia de fotografías, del proceso de ejecución en obra, recortadas por Miralles en singulares composiciones para experimentar como podrían continuar las obras.
} 
inacabado no es una cuestión estética, es simplemente, el único camino; su modo de entender el mundo y la vida le lleva a el: lo que es tanto como su modo de entender el tiempo" ${ }^{637}$ Incluso en los textos de Miralles se repite obsesivamente la idea de que un proyecto nunca se termina. Tambien recurría a menudo a los puntos suspensivos, dejando las frases inacabadas, abiertas, reflejo de su aversión a terminar las cosas. Miguel Angel con su "non finito" era uno de sus arquitectos favoritos.
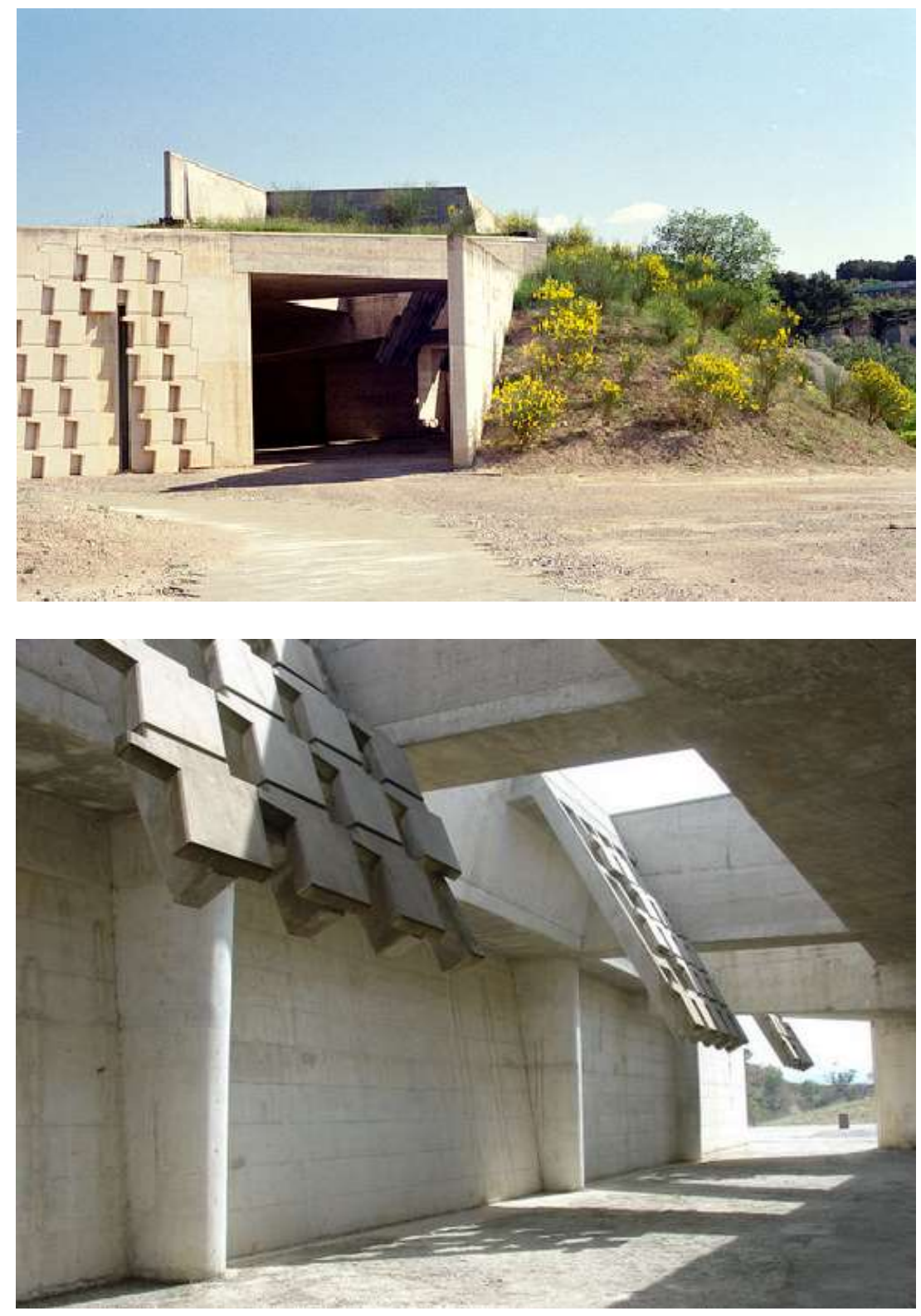

$6-76^{638}$

\footnotetext{
${ }^{637}$ Rafael Moneo. "Enric Miralles, una vida intensa una obra plena" en El Croquis. Enric Miralles 19832000. Mapas Mentales y paisajes sociales. 2002. p. 308

638 Parque Cementerio de Igualada. Acceso a la Capilla, que a día de hoy, todavía permanece inacabada.
} 


\section{CONCLUSIONES.}

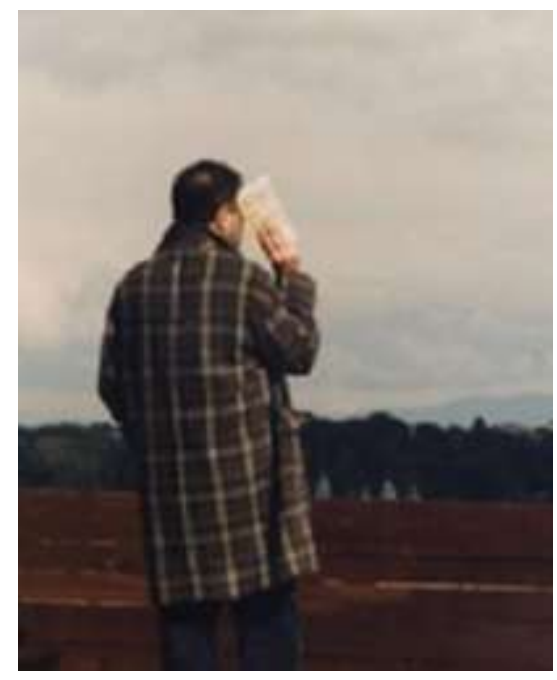

$7-1^{639}$

"Que tenga la misma logica lo que propones con lo que alli ya existia...disolver lo que estas pensando en lo que te encuentras..."

Enric MIralles. ${ }^{640}$

La Tesis demuestra como conclusión la existencia de esas acciones creadas por Mlralles desde el proyecto, unas mas concretas y otras mas abstractas, que desarrollan las estrategias proyectuales para implantar la obra en el paisaje natural materializando el objetivo perseguido por Miralles de disolver su Arquitectura en el medio. Acciones que comienzan en el Parque Cementerio de Igualada, pero que se emplearan en obras posteriores como en la Biblioteca de Palafolls, la propuesta de Concurso para la Remodelación del Puerto de Bremenhaven y el Parlamento de Edimburgo entre otros, y que consiguen que en el nuevo paisaje, transformado por las acciones de Miralles, lo construido sea un elemento mas, que al fragmentarse y desparramarse sin limites, se funde con todo lo circundante hasta llegar a confundirse siguiendo una especie de integracion infinita. Acciones que la Tesis expone y desarrolla para que puedan ser utilizadas en el futuro por la comunidad cientifica y aquellos arquitectos contemporaneos que como Miralles tengan vocacion de fundirse con el medio en el que intervienen.

Tras la investigación realizada en esta Tesis Doctoral se concluye que de las acciones que Miralles utilizaba para implantar su Arquitectura en el paisaje tales como: fusionar figura-fondo; velar la escala arquitectónica; ocultar; manifestar la acción del tiempo a través de la vegetación y los materiales; evocar modelos naturales; sin limites, inacabar, etc... destacan tres acciones por encima de las demás: la topografía, la fragmentación y el recorrido.

\footnotetext{
${ }^{639}$ Enric Miralles encuadrando la vista del Paisaje.

${ }^{640}$ Enric Miralles. Conferencia en ETSAM. 05/05/1993.
} 
Conviene a modo de introducción de las Conclusiones, destacar algunos aspectos importantes de Miralles en relación a su intervención en el paisaje natural, que tendrán mucho que ver con las estrategias de implantación que se han estudiado en esta tesis doctoral:

-Miralles, desde una actitud de dialogo con lo existente, acostumbraba a documentarse en profundidad sobre los lugares en los que tenia que intervenir para obtener las pistas por las que comenzar el proyecto. Para ello realizaba un registro exhaustivo de las curvas de nivel; la vegetación; construcciones existentes, senderos y caminos; líneas de sombra, etc. estudiando tambien la geología, los cursos de aguas subterráneas, la transformación a lo largo de la Historia, sus capas arqueológicas ocultas, etc. Al realizar una lectura hipersensibilizada, no solo física y óptica del paisaje, detectara significados, en las "marcas" encontradas en el paisaje que para la mayoría pasan desapercibidos. Miralles entendia los paisajes como "palimpsestos" y las inserciones que realizaba en ellos, como fragmentos interrelacionados que contribuian a generar una compleja unidad. El proyecto para Miralles esta en identificarse con el lugar detectando las trazas del paisaje a las que hay que dar importancia para comenzar el proyecto, siendo el plano de emplazamiento el instrumento que le ayudaba a sintetizar la compleja realidad multidimensional en las dos dimensiones del plano, ayudandole a comprender el lugar y la escala con la que conversar con su Arquitectura.

Miralles abstraía el paisaje en el que intervenía mediante el empleo de la geometría, en especial, la no euclidea. De las misma manera que Giacometti sometia a sus retratados a repetidas sesiones para ir ganando confianza y al final captar la personalidad del retratado y plasmarla en el lienzo, Miralles, que defendia que para que para aprender Arquitectura, había que calcar los planos y fotografías de las obras maestras dibujara repetidamente los mismos dibujos para con el lo, captar la esencia del lugar, defendiendo que en la reiterada repeticion, la mente genera una operacion de olvido en la que solo queda lo esencial.

Darcy Thompson, ya defendio la influencia que tenían las fuerzas exteriores en la morfología de los organismos naturales, a lo largo de su evolución. La mirada de Miralles, sabia captar las lineas de fuerzas principales existentes de los lugares en los que intervenía. Su proyecto las ordenaba y llevaba hasta un punto de máxima tensión en sintonia con las fuerzas que emanaban de su discurso arquitectónico. Se podría decir que la unión del paisaje natural con la arquitectura de Mlralles, genera un tercero superior como defendía Goethe.

\subsection{LA TOPOGRAFIA}

Mediante la topografia, Miralles redefine el paisaje en el que interviene y da acomodo al programa de necesidades de su organismo arquitectónico con vocación de relacionarse con el paisaje. De ahí que los planos de movimiento de tierras sean documentación fundamental en sus proyectos.

La importancia de la topografía, Miralles la aprende del Land Art norteamericano cuyas obras estudio "in situ" en su estancia de investigación en los Estados Unidos de América durante el curso 1980 - 1981; mientras que la preparación del lugar como paso previo a la implantación de la arquitectura, la aprende de su colaboración con Viaplana y Piñón. El trabajo de Miralles con la topografía, adopta diversas estrategias en funcion de los paisajes en los que interviene. Así, se puede hablar de: 
- Excavaciones y rellenos (sustracción y adición de la tierra ).

- Posarse y/o deslizarse.

- Recreación de una topografía artificial.

En definitiva, diferentes maneras de apoyarse en la topografía para generar proyectos en los que la manera de actuar viene dictada por el propio paisaje que Miralles se encuentra y en función del cual determina su respuesta.

\subsubsection{Excavaciones y rellenos}

Este trabajo con la topografia, se llevara a cabo cuando Miralles se encuentre enclaves atractivos con los que mantener una conversacion, como ocurre en el Parque Cementerio de Igualada, el Complejo de Tiro con Arco y el Pabellón de Deportes de Huesca, en los que la topografía "envuelve a la construcción".

En el Parque Cementerio de Igualada, la topografía generada por el proyecto de Miralles, busca fundirse con la topografía existente en el lugar hasta casi confundirse ambas. Se re-utiliza el paisaje mediante un trabajo topográfico que "cose las heridas" del lugar y también generando nuevas excavaciones. En esta obra, se aprovechan las curvas de nivel y los taludes naturales existentes para albergar los nichos de enterramiento y los panteones familiares, a la manera de muros de contención.

Inspirado por lo realizado en Igualada, pues se solaparon en el tiempo, se encuentra el proyecto del Complejo de Tiro con Arco en el que el movimiento de tierras modela el terreno para poder alojar el programa funcional, haciéndolo a la manera de un zócalo desparramado. Los experimentos topográficos realizados en Igualada y en el Complejo de Tiro con Arco, se llevan también al Pabellón de Deportes de Huesca en el que Miralles una vez decicido acercar el organismo construido al bosque natural del Cerro de San Jorge y para minimizar el impacto volumetrico de un edificio publico de dichas caracteristicas, realizara una gran excavación para alojarlo y conseguir que la altura de coronación de la cubierta no rebase la altura de las copas de los arboles del bosque, ligando así lo natural y lo construido. La tierra resultante de la gran excavación, se desplazara y amontonara conformando una zona al aire libre ubicada en el otro extremo del edificio, a la que se encomienda la misión de establecer el tránsito entre los limites de la ciudad y el edificio ligado a la naturaleza. En un proyecto posterior como la Biblioteca de Palafolls, el trabajo con la topografía vuelve a ser lo que defina la intervención, enterrando el edificio y definiendo un lugar donde no lo había, pero la intervención con la topografía a gran escala que se dio en Igualada y Huesca no se volverá a repetir en toda su obra restante.

\subsubsection{Posarse y/o deslizarse.}

Este trabajo con la topografia, se llevara a cabo cuando Miralles se encuentre enclaves atractivos con los que dialogar, pero en los que no se quiere romper la armonia existente y por tanto no procede realizar grandes excavaciones. Ejemplo paradigmatico de esta manera diferente de operar con la topografia lo constituye la Escuela Hogar en Morella, que solo puede entenderse como respuesta al paisaje topográfico donde se encuentra, posándose y deslizándose el organismo construido acompañando e la pendiente de la ladera existente, para no alterar con la intervencion el paisaje existente. Esta manera de hacer la aprendió tambien 
Miralles de su colaboración con Viaplana y Piñon en proyectos como el Parque La Mediterránea en Murcia.

\subsubsection{Recreación de una topografía artificial.}

La recreación de una topografía artificial, se da en proyectos donde el paisaje no tiene alicientes con los que establecer un dialogo tales como el Pabellón de Gimnasia Rítmica en Alicante; el Parque de Santa Rosa en Mollet del Valles y la propuesta para la Biblioteca en Japón, entre otros. Esta accion que comienza en el Centro Cívico de Hostalets mediante unas rampas que enlazan el nivel de calle con las cubiertas - miradores, desde las que se divisan las montañas que no se veian desde el nivel de calle; continuara en el Pabellón de Alicante con una topografía generada por unas rampas que asciendendo por una de sus fachadas llevan a los espectadores al interior. La intervención en el Parque de Santa Rosa en Mollet del Valles sigue en esta línea de generar un paisaje nuevo ayudado por la topografía proyectada, pues ante un paisaje existente carente de alicientes e identidad, espacio residual surgido del crecimiento desordenado de tres barrios, Miralles optara por generar una topografia artificial de curvas de nivel -bancos corridos y un anfiteatro elevado desde cuyas gradas se percibe el parque. Tambien se recreara una topografia artificial en proyectos que quedaron sin construir como en la propuesta de Concurso para la reutilización del Puerto de Bremenhaven en la que se genera un laberinto formado por elevaciones artificiales en el terreno en respuesta a la gran extension llana del paisaje en que se encuentra 0 en la Biblioteca Nacional de Japón, donde una topografía materializada en la cubierta, evoca la imagen de las montañas y los bosques pertenecientes al imaginario colectivo de los lugareños.

\subsection{LA FRAGMENTACION.}

La fragmentación es la acción que utiliza Miralles para descomponer en distintas piezas el programa edilicio, y despues al esparcir dichos fragmentos por el paisaje como si fuera una malla sin limites definidos conseguir relacionarse mejor con este. La disolución de los límites de la fragmentada arquitectura esparcida por el paisaje, recuerda la manera de operar del Método paisajista caracterizada por la desintegración formal, la inestabilidad, la eliminación de referentes espaciales, para relacionarse con la compleja realidad, etc.

Miralles comenzo a fragmentar el programa desde su etapa como colaborador con Viaplana y Piñon, en los proyectos de espacio público, que ordenaban el espacio generando una base abstracta sobre la que depositar las distintas piezas que componían el programa. En el Instituto La LLauna en Badalona, Miralles llevara al espacio interior lo que antes había hecho en sus propuestas en el espacio exterior. El primer proyecto de Miralles, en el que se compone con piezas morfológicamente diferenciadas, fragmentándose el programa es el Parque Cementerio de Igualada, un espacio al aire libre en el que dadas las condiciones que paisaje y programa ofrecían, se fragmenta el programa en tres piezas morfológicamente diferenciadas dispersas por el paisaje y relacionadas por el recorrido. En el Pabellón de Huesca, aunque proyectado después del Parque Cementerio de Igualada y la Escuela Hogar en Morella, la fragmentación será comedida y se dará sobretodo en los exteriores. Será con el encargo del Pabellón de Alicante, cuando Miralles lleve al limite la acción de fragmentación del programa tanto en los exteriores como en los interiores. Alicante, será un punto y aparte en lo que respecta al incremento de fragmentación, debido a los problemas que trajo consigo la ejecución material de la 
obra en la que casi nada encajaba al no ser coplanarias las superficies de los volúmenes construidos.

La fragmentación del programa en diversas piezas esparcidas por el lugar, es una acción que persigue Miralles para que su arquitectura se relacione mejor con el paisaje. El edificio se fragmenta y dispersa por el paisaje fundiendose con todo lo circundante. El organismo construido resultante es un amalgama de diferentes formas, una especie de "collage" en el que cada pieza responde a un propósito y una función determinadas generando un paisaje artificial. La composición en fragmentos ira evolucionando con el tiempo hacia ordenaciones mas libres de formas curvas y oblongas, además dichas piezas no solo se yuxtapondrán sino que según evoluciona su obra, tambien se superpondran. La fragmentación es una accion que emplea Miralles que se podría asemejar a extender una red sobre el paisaje, para coser y unificar lo existente con lo proyectado.

\subsubsection{LA CUBIERTA}

La cubierta la emplea Miralles, en muchos casos, para relacionarse con la escala del paisaje y otorgar unidad a su organismo construido. Miralles hablo muchas veces de comenzar sus proyectos desde la cubierta, y demostró en muchos de sus proyectos su entendimiento de una Arquitectura que es lo que queda entre el terreno excavado y la cubierta.

La generación del lugar se consigue en muchos proyectos de Miralles, mediante la manipulación del suelo y la definición de una cubierta con vocación de ingravidez. Es una manera de hacer que no se centra en el cuerpo, generando un organismo construido constituido por un zócalo y gran cubierta, separados por una zona de incertidumbre que no recibe la misma atencion desde el proyecto. Dependiendo del paisaje en el que se implante la obra, por la necesidad de dotar al edificio de una escala paisajística, a veces se recurre a grandes cubiertas que no solo cobijan sino que dan unidad a la constelación fragmentos que conforman el edificio.

Dadas las condiciones climaticas benignas de España, que permiten disfrutar de los espacios exteriores, con un Sol que genera una intensa luminosidad y calor, la generación de sombras es un asunto importante que Miralles tendra en cuenta, hasta convertirse en muchos casos la sombra la que genere el lugar como es el caso de las dinamicas Pérgolas de Parets del Valles y las de Avenida Icaria en Barcelona, en el que las cubiertas colonizan un paisaje sin identidad configurando un lugar a través de su presencia y sus sombras.

Desde los primeros proyectos con Carmen Pinos la cubierta se separa del cerramiento para desmaterializar el volumen arquitectónico y sobrepasar los límites del organismo construido. En el Centro Cívico de Hostalets, las cubiertas son transitables y a medida que se asciende por el itinerario conformado por estas, se van girando y superponiendose unas a otras, siguiendo un esquema en abanico, conformando unos palcos que se asoman hacia las montañas cercanas, cuya vista no era posible desde el nivel de calle.

Las cubiertas de perfiles fracturados que se dan en los proyectos de la Escuela Hogar en Morella; en la estructura portante exterior de la que cuelga la cubierta del Pabellón de Alicante y tambien en las cubiertas del Parlamento de Edimburgo, hacen referencia a los perfiles de las montañas y de las construcciones existentes en el entorno, tal y como Ruskin dejo ilustrado en su libro "Modern Painters", en el que demostraba con un dibujo, la analogía existente entre la cubierta fracturada de una casa de campo francesa y el perfil de las montañas cercanas. 
La acción de superar los límites de lo construido con la cubierta, comenzado en el Complejo de Tiro con Arco y seguido en Huesca y Alicante, lo aplicara también en el proyecto del Mercado de Santa Caterina en Barcelona, pero no se dará en proyectos como la biblioteca de Palafolls y el Parlamento de Edimburgo, por los problemas generados en obras anteriores por los encuentros no coplanarios que se daban entre cerramiento y cubierta, cuando era necesario compartimentar climáticamente exterior e interior. Lo que si evolucionara en las cubiertas de la arquitectura de Miralles, será su forma, pues habiendo empezado con cubiertas de formas planas y ligera inclinación, llegaran a tener formas de perfiles fracturados como en la Escuela Hogar en Morella y el Complejo de Tiro con Arco. Dicha evolución llevara hasta los perfiles combados abovedados de las cubiertas en los proyectos de Palafolls, Niederrad y Edimburgo.

\subsection{EL RECORRIDO.}

Es la acción que utiliza Miralles orquestando los movimientos de la gente para hacerles visible el paisaje en el que se encuentran y tambien para relacionar el interior del organismo construido con el exterior del paisaje. Los recorridos se llevan a cabo entre muros en pendiente, sinuosos y curvos, afianzando las tensiones entre edificio y emplazamiento, irradiando energía desde el interior hacia las vistas mas amplias.

Miralles aplica en sus proyectos la "Promenade Architecturale" de Le Corbusier, negando la perspectiva renacentista de un único punto de vista, reforzando la geometría para introducir el movimiento en la obra y obligar al espectador a moverse para comprenderla. Es el movimiento de los usuarios al recorrer los edificios en muchos casos el que genera su geometría. Los recorridos no son nunca axiales, sino tangenciales. Se evita la aproximación inmediata, por medio de recorridos sucesivos variados, quebrados y curvos, hasta la llegada y entrada al interior del edificio. Son recorridos de una gran intensidad narrativa que unen las distintas zonas del programa edilicio, dialogando con el paisaje y haciendo interaccionar el interior y el exterior, en los que lo construido y lo natural se funden. Dichos recorridos mantienen alerta al visitante y le hacen ser mas consciente del lugar y el momento en que se encuentra, donde lo importante no es el origen ni el final del recorrido sino el propio movimiento.

Desde los primeros Concursos realizados junto a Carmen Pinos, Miralles da gran importancia a los recorridos y lo refleja en sus perspectivas dibujadas a mano en las que de manera secuencial retrata la vision que el visitante tendrá al recorrer su arquitectura. Estos recorridos orquestados desde el proyecto ayudan a descubrir el lugar y al mismo tiempo, configuran la propuesta arquitectónica.

\subsubsection{RELACIONES INTERIOR - EXTERIOR.}

Es la acción que utiliza Miralles estableciendo un dialogo entre el interior y el exterior para relacionar su organismo construido con el paisaje, sumiendo al usuario de sus edificios, en una experiencia perceptiva que le haga sentir en un umbral en el que se sienta estar dentro del edificio y al mismo tiempo fuera en el paisaje. Para Miralles, un edificio se entiende cuando se esta dentro de el y se ve lo que le rodea, cuando el exterior se hace presente en los espacios interiores con las vistas al paisaje exterior. El dinamismo de los cerramientos exteriores quebrados en las obras de Miralles, tiene su razón de ser en generar unas membranas intermedias entre interior y exterior para relacionar sus edificios con el paisaje circundante, y dadas las condiciones climaticas de España, permite 
espacios semiabiertos en los que uno no sabe si se encuentra en el interior o en el exterior del edificio.

Las obras de Miralles, se ligan al lugar gracias, entre otras cosas, al control de las relaciones existentes entre los espacios interiores y los exteriores. Los limites, el perímetro construido queda disuelto por medio de espacios de transición entre arquitectura y naturaleza, espacios intermedios que envuelven el organismo construido. Los espacios exteriores quieren ser interiores y a la inversa. De la misma manera que se puede pasear libremente por la naturaleza, en los interiores de Miralles, se asiste a un espacio laberinto, en el que guiado por escaleras, rampas, plataformas a distinto nivel, etc. se recrea una experiencia perceptiva similar a la sensación que se tiene cuando se recorre un bosque en la naturaleza.

Aspecto a destacar es el empleo de las mismas geometrías dentro y fuera del edifico para conseguir continuidad entre espacios interiores y exteriores. Los contornos son irregulares y pintorescos, para relacionarse con el paisaje. Se anulan las fachadas que desaparecen como tales, convirtiéndose en una piel continua que envuelve el interior, siendo en muchos casos el resultado de lo que queda entre el terreno y la cubierta. Además se suelen retranquear del plano de las cubiertas, para desaparecer bajo la acción de las sombras.

\subsection{ACCIONES ABSTRACTAS}

FUSIONAR FIGURA - FONDO. Es la acción que utiliza Miralles para disolver su arquitectura en el paisaje en que se implanta para que lo construido y lo natural se perciban como algo unitario. Esto se consigue haciendo que su arquitectura no quede presa del perimetro rompiendo los limites, disolviendose en el medio.

VELAR LA ESCALA ARQUITECTONICA. Miralles emplea una repetición insistente de sus dibujos realizados a mano para sintonizar con la escala del paisaje en el que interviene. Captada la escala, la accion consistira en generar una arquitectura que sintonice con esta, evitando emplear elementos de escala arquitectonica (puertas, ventanas convencionales, etc. ) para que lo percibido sea parte del paisaje y no un edificio. Tambien se juega con distintas escalas en el mismo edificio, exagerando la escala de elementos (puertas, ventanas, canalones...) intencionadamente para que no sean entendidos como arquitectonicos.

VELAR LA FORMA Y EL VOLUMEN CONSTRUIDO. Son acciones que consigue Miralles utilizando formas y volúmenes de aspecto informe, próximos a los del mundo mineral y geológico pertenecientes al mundo natural, para que su obra se funda con el paisaje existente. Lejos de configurar un volumen unitario,su arquitectura es atmosferica y difusa. Miralles genera un conjunto mas cercano al mundo geomorfico que al arquitectónico. Volúmenes que generan una intensa relación con lo natural gracias a sus formas asimétricas y su fuerza plástica. Prevalecen las superficies respecto a los volúmenes como una constante a lo largo de su obra. Su arquitectura no es compacta.

OCULTAR. Miralles ocultara no solo el uso al que se destina la obra sino tambien que lo construido sea apreciado como un edificio convencional, para que como resultado de dicha accion, el edificio sea percibido como un afloramiento mas de la naturaleza, que siempre hubiera estado allí. Tambien las sombras arrojadas por las cubiertas ayudan a ocultar fachadas y accesos. 
MANIFESTAR LA ACCION DEL TIEMPO. Es la acción que utiliza Miralles para fundir la arquitectura con el paisaje, al proyectar teniendo en cuenta el tiempo para que organismo construido y naturaleza se unan a medida que transcurre el tiempo. Para Miralles el tiempo es un material de proyecto mas, el tiempo como algo que es capaz de dar forma a las cosas. Sus obras mutan con el transcurso del tiempo como lo hace la naturaleza y por ello el tiempo juega favor para fundir su arquitectura con el paisaje. El paso del tiempo lo hace patente empleando materiales "vivos" que recojen patinas en sus superficies y por medio de la vegetación proyectada.

Con los materiales con los que construye que muestran su condicion materica y su naturaleza, que parecen estar "vivos" como el hormigón poroso que deja como testigo del paso del tiempo esa patina tan característica o con el acero corten, ya sea en redondos de acero o chapones, para que su oxido cambie su aspecto a lo largo del tiempo y evolucione acorde a como lo hace el paisaje. También en soluciones constructivas proyectadas por Miralles que acumulen polvo y suciedad como en los elementos prefabricados calados, etc.

Con la vegetación, al plantar especies caducas que constaten el paso de las estaciones y al cambiar su aspecto también lo haga la percepción que se tiene de lo construido. Al plantar arbolado en zonas estratégicas entre la vegetación existente para que con el tiempo se fundan y ayuden a fundir la obra construida con el paisaje.

EVOCAR MODELOS NATURALES. Es la acción que utiliza Miralles para naturalizar su arquitectura por medio de la evocación de analogías con la naturaleza. Su obsesivo interés por crear una naturaleza artificial es patente en muchos de sus proyectos. El referente natural es una constante en la arquitectura de Miralles, y la evocación de modelos naturales se da a distintas escalas, pudiendo ir desde la creación de los arboles artificiales en la Avenida Icaria de Barcelona, hasta la evocación de un proceso geológico ocurrido en un pasado lejano, como es el caso de la hoz artificial construida en el Parque Cementerio de Igualada.

INACABAR. Es la acción que utiliza Miralles para dejar la obra "abierta" y que se evolucione a la vez que lo hace el paisaje en el que se implanta hasta fundirse en una unidad. La acción de inacabar, forma parte de acciones de Miralles, como algo consustancial a su manera de trabajar y como una manera personal de estar en el mundo. Miralles entiende la construcción como una actividad inacabada, viva, a la manera de los constructores medievales góticos, de Gaudí y Jujol, para que la obra pueda adaptarse a las circunstancias y los cambios.

La mayoría de las estrategias de implantación llevadas a cabo por Miralles para relacionarse con el paisaje natural estudiadas se dan en las tres obras analizadas en detalle en esta Tesis Doctoral. Sin embargo, en obras posteriores, muchas de estas acciones dejaron de utilizarse, echandose en falta una optima relación con el paisaje que se detecta en las tres obras estudiadas en detalle.

Miralles explicaba que cualquier trabajo del arquitecto debería mejorar la realidad a la que se enfrenta y la voluntad de que fuese la arquitectura la que dotase de sentido al paisaje. Se podría concluir diciendo que la obra de Miralles ha sido mejor cuando ha anclado los edificios profundamente en el suelo como en el Parque Cementerio de Igualada, el Complejo de Tiro con Arco y el Pabellón de Huesca. 


\section{BIBLIOGRAFIA Y DOCUMENTACION}

\subsection{PRODUCCION AUTORIA DE ENRIC MIRALLES}

\subsubsection{TEXTOS}

"Cosas vistas a izquierda y a derecha (Sin Gafas)". Tesis doctoral de Enric Miralles. 1987 ETSAB, Biblioteca. Códigos D-27316, D-27317, D-27318

"Zementiri". Texto sobre el cementerio-parque de Igualada. Obradoiro, Revista del Colegio de Arquitectos de Galicia, no 13, 1987, pp. 70-78.

"És aixó de Jujol?". Quaderns d'Arquitectura i Urbanisme, n 179-180, OctubreDiciembre 1988 / Enero-

"Llobregat: Tres memorias". Quaderns d'Arquitectura i Urbanisme, n 186, OctubreDiciembre 1990, Volumen I, pp. 20-23.

“Relieves. Manolo Hugué”. Bloc, n 9, 1990, p. 38.

"Lugar". El Croquis. Miralles / Pinós, 1983-1990, no 30, 49+50. Ed. El Croquis, 1994, p.76; "Caminar", ibidem, p.40; "En Construcción", ibídem, p. 76; "El interior de un bolsillo", ibídem, p.110; "Relieves", ibídem, p. 152; "Cómo acotar un croissant”, ibídem, p. 190; “Cejas”, ibídem, p. 204.

"Alison \& Peter Smithson”. Arquitectura, 1992.

"Marismas". Acerca de la Casa. Curso para la Universidad Antonio Machado, Baeza 1992, pp. 123-127.

"A cementery is not a Tomb". Fenster zur Architektur. 19 Approaches, Darmstadt, 1992, pp. 31-34.

"Acceder". Fragmentos de la conferencia pronunciada en Santander, Julio 1993. Arquitectos, no 132, 94/1, pp. 58-59.

"No, así no se juega". Catálogo de la Bienal de Arquitectura y Urbanismo de Zaragoza, 1993, pp. 97-117.

"Jujol y Gaudí". Tokyo, 1993.

"Al margen de otras consideraciones". Texto sobre el Polideportivo de Huesca. El Croquis, ำ 70, 1994, pp. 36-39.

“Manchas”. El Croquis ENRIC MIRALLES 1990-1994, oㅜ 72, pp. 276-381.

"Un retrato de Giacometti". El Croquis ENRIC MIRALLES 1990-1994, ㄲo 72, pp. 382-386.

"No, preferiría no hacerlo. Tres casas de R.M. Schindler" 2G, No 7, 1998, PP. 26-28 


\subsubsection{ENTREVISTAS}

AA.VV. Enric Miralles: mixed talks. Academy Editions, 1995.

BARBA, J.J. Entrevista a Enric Miralles en Metalocus nํ 3. 1999. Cronotopias.

FUTUGAWA, Yoshio. Interview with Enric Miralles. "Studio Talk. Interview with 15 architects". Ada Edita, tokyo 2002, pp. 638-670

GARCIA, Fernando. Entrevista a Enric Miralles en "Café Gourmet" Revista WAM (18 de septiembre de 1996)

GSD News nำ 9. Interview with Enric Miralles. 1995.

INSUA, Juan. Entrevista a Enric Miralles en el Periódico La Vanguardia "El discurso de la ciudad" (26 de abril de 1994)

MATEO, Josep Lluís. Entrevista a Enric Miralles en "Lugar y aprendizaje: Una entrevista con Enric Miralles", Arquitectura Viva 28, 1993, pp. 26-29.

MASSAD, Fredy y GARCIA YESTE, Alicia. Entrevista a Enric Miralles en "La forma de aquello imperfecto" Revista Transversal (julio 1996)

MASSAD, Fredy y GARCIA YESTE, Alicia. Entrevista a Enric Miralles en "La arquitectura como sentimiento" Revista Summa+ 30, (abril 1998).

OYARZUN, Armando. Entrevista a Enric Miralles en "AUToGRAFiES", 1995.

RIBAS, Carme. Entrevista con Enric Miralles y Carme Pinos. A 30. 1987

TUÑÓN, Emilio. MANSILLA, Luis Moreno. "Apuntes de una conversación informal con Enric Miralles". El Croquis ENRIC MIRALLES + BENEDETTA TAGLIABUE. 1995-2000, no 100-101, pp. 8-21.

VERDU, Vicente. Entrevista a Enric Miralles en el Periódico El País "Me gusta innovar, pero no corro riesgos inútiles" (8 de octubre de 1993)

ZAERA, Alejandro. "Una conversación con Enric Miralles". El Croquis ENRIC MIRALLES 1990-1994, № 72, pp. 260-275.

ZABALBEASCOA, Anatxu. Entrevista a Enric Miralles en "el arquitecto del nuevo siglo" Revista Ábaco (BBVA), 2000.

\subsubsection{CONFERENCIAS}

MIRALLES, Enric. Conferencia dada en el Southern California Institute of Architecture. Los Angeles. Marzo de 1989.

MIRALLES, Enric. Conferencia dada en el Seminario "Bau Kunst Bau" Triennale di Milano. Palazzo dell'Arte. Mayo de 1991. 
MIRALLES, Enric. Conferencia dada en el Seminario " técnica, método experiencias: proyecto automatico" Primera Bienal de Zaragoza de Arquitectura y Urbanismo (Bauz). Enero de 1992.

MIRALLES, Enric. Conferencia dada en la Architectural Association de Londres el día 28/02/1992. dentro del Barcelona Symposium.

MIRALLES, Enric. Conferencia dada en la Escuela Técnica Superior de Arquitectura (ETSAM) UPM el día 05/05/1993.

MIRALLES, Enric. Conferencia "Acceder" dada en la Universidad Internacional Menéndez y Pelayo de Santander. Julio 1993

MIRALLES, Enric. Conferencia "Technology, place \& architecture" dada en el Jerusalem Seminar in Architecture. Noviembre 1996.

MIRALLES, Enric. Conferencia "Palacio Municipal de Deportes de Huesca" dada en el Colegio Oficial de Arquitectos de Castilla y Leon Este. COACYLE. Mayo 1998.

MIRALLES, Enric. Conferencia dada en la Architectural Association de Londres el dia 19/05/1998.

MIRALLES, Enric. Conferencia "Anymore Architecture?" dada en el Seminario ANYmore Conference. Palais de Chaillot. Paris. Junio de 1999.

\subsection{INTERPRETACIONES DE OTROS AUTORES SOBRE MIRALLES}

\subsection{1. $\quad$ LIBROS}

A 30, no 6. Monografía "Enric Miralles y Carme Pinos, 1983-1987". Carme Ribas, Pere Joan Ravetllat, Joan Roig Barcelona mayo, 1987.

AAVV. Architectural Monographs no 40: "Enric Miralles: mixed talks". Academy Editions, London octubre, 1995.

ACTAR. EMBT Enric Miralles Benedetta Tagliabue. "Work in Progress", 2ª edición. Revisada y Ampliada. COAC y ACTAR, Barcelona. 2005.

ARCHITECTURAL ASSOCIATION. "Four studios in Barcelona: Alfredo Arribas, Pepe Cortes, Enric Miralles, Oscar Tusquets". London:, 1992. Sudjic, Deyan

BESTUE, David. "Enric Miralles a izquierda y derecha (también sin gafas"). Editorial Tenov, 2010.

CORTES, Gustavo. "Enric Miralles: aprendizajes del arquitecto" DVD dirigido por Bigas Luna. 2010

DE MICHELIS, Marco. "Miralles Tagliabue. Architetture e progetti” Skira. 2002.

DC no17-18. “Enric Miralles 1955-2000”, UPC Barcelona, 2009

DOLLENS, Denis. "The Architecture of Enric Miralles \& Carme Pinos". New York: Sites-Lumen, 1990. Buchanan, Peter. Montaner, Josep Maria. Dollens, Dennis L. Kogod, Lauren 
GARCIA, Carolina. "Enric Mlralles: 1955-2000" UPC 2009. Revista de Critica Arquitectónica. 17-18.

LAHUERTA, Juan José. "Enric Miralles: Obras y Proyectos". Electa, 1996. Al cuidado de Benedetta Tagliabue Miralles con un ensayo de Juan José Lahuerta

LOFT Publications. "EMBT Arquitectes Miralles/Tagliabue”. teNeues, 2003

MASSAD Freddy, GARCIA-YESTE Alicia. "Enric Miralles: Metamorfosi del Paesaggio". Universale di Architettura, mayo 2004.

MIRALLES/PINOS. “El Croquis 1983-1990”. El croquis editorial. 1990.

MIRALLES ENRIC. “EI Croquis 1990-1994”. El croquis editorial. 1994.

MIRALLES + TAGLIABUE. "EI Croquis 1995-2000”. El croquis editorial. 2000.

MURO, Carles. "Conversaciones con Enric Miralles”. GG. 2016.

ROVIRA, Josep M. “Enric Miralles 1972-2000." Colección Arquia/temas no 33. Caja de Arquitectos, 2011.

RIGILLO, Marina. "Architettura tra artificio e natura : progetti dal 1984 al 1990 " Cangemi 1994.

ZABALBEASCOA, Anatxu. "Igualada Cemetery: Enric Miralles and Carme Pinós". Phaidon. London, 1996.

ZABALBEASCOA, Anatxu."Miralles Tagliabue, arquitecturas del tiempo". Barcelona: Gustavo Gili/Gingko Press, 1999. Zabalbeascoa, Anatxu. Rodríguez Marcos, Javier

ZUCCHI, Cino. "Bau Kunst Bau". Clean Edizioni. 1994

\subsubsection{ARTICULOS}

AA.VV. "Enric Miralles: mixed talks". Academy Editions, 1995.

ALFAMBRA, B. "Primer paseo" en Enric Miralles: Pabellón de baloncesto en Huesca, Documentos de arquitectura 32. 1995

BLUNDELL JONES, Peter. "Not on a hill, but "of" a hill: Enric Miralles's National Gymnastic Training Centre in Alicante". ENRIC MIRALLES CNAR ALICANTE.1995

BUCHANAN, Peter. "Catalan Constructivism". The Architectural Review oํ 1088, octubre 1987, pp. 223 - 227

BUCHANAN, Peter. "Dialogues and Distillation: The Architecture of Enric Miralles and Carme Pinos" The Architecture of Enric Miralles and Carme Pinos, Sites Lumen Books, Nueva York, 1990.

BUCHANAN, Peter. "Making places in Spain" en Architectural Review 1990. $\mathrm{n}^{\circ}$ 1121 , p. $30 / 7$

COLL - BARREU, Juan. WEMBT Miralles-Tagliabue". AA . Revista 36. 2006 
CORTES, Juan Antonio. "La complejidad de lo real". El Croquis EMBT 2000 2009, № 144. 2009.

CURTIS, William. "Mapas mentales y paisajes sociales". El Croquis MIRALLES / PINÓS 1983-1990, no 30, 49+50, pp. 6-21.

DOLLENS, Dennis L. Introducción en el folleto de la Exposición: "Enric Miralles \& Carme Pinós. Projects 1985-90" Diciembre de 1989. Storefront for Art and Architecture. Nueva York. 1990.

FAURA, Ramón . "Palacio de deportes, Huesca (1988-1994) y Club de tiro con arco, Barcelona (1989-1991)" en Enric Mlralles: 1972-2000 Editorial Fundación Caja de Arquitectos 2011.

FERNANDEZ - GALIANO, Luis "La belleza convulsa. Huesca, destrucción y catástrofe". Arquitectura Viva 69. Madrid. pág. 76.

FRAMPTON, Kenneth "Sobre la tradición tectónica en la forma catalana contemporanea". Quaderns 206.

GA DOCUMENT INTERNATIONAL, Focus on an Architect: Enric Miralles, Benedetta Tagliabue. № 99, vol 60 November 1999. (A.D.A. EDITA Tokio Co., Ltd. Japan)

GAUSA, Manuel. "Delirio y razón: el diseño en Jujol." Quaderns, COAB,ํำ 172

GRANELL, Enric . "Una maleta llena de arquitectura" en Enric Mlralles: 1972-2000 Editorial Fundación Caja de Arquitectos 2011.

KOGOD, Lauren. " Enric Miralles y Carme Pinós: Three Projects" . Assemblage No. 7, 1988, pp. 92 - 107.

LAHUERTA, Juan José. "De momento..." Enric Miralles: opere e progetti. A cura di Benedetta Tagliabue Miralles. Electa. Milano, 1996. Existe una traducción en la edición castellana, Enric Miralles: obra completa. Electa España. Madrid, 1996.

LAHUERTA, Juan José. "Signos". El Croquis MIRALLES / PINÓS 1988-1991 EN Construcción, no 49+50

LAMPREAVE, Ricardo. "Centro de gimnasia rítmica, Alicante, 1991-1993". en Enric MIralles: 1972-2000 . Editorial Fundación Caja de Arquitectos 2011

MIAS, Josep. “Enric Miralles para evitar equívocos”. DPA, n 17, 2001, pp.70-75.

MIRALLES, Enric. "For what time is this place?" TOPOS 8. European Landscape Magazine, 1994.

MONEO, Rafael. "A la conquista de lo irracional". Garrido, Cánovas, Textos de arquitectura comentados 1, Madrid, etsam, 2003

MONEO, Rafael. "Paradigmas fin de siglo". El Croquis no 98. 2000. pag. 198

MONEO, Rafael Moneo. "Una vida intensa, una obra plena" El Croquis ㄲำ100-101, Julio 2000. pag. 306-312 
MONEO, Rafael "Tesis doctoral de Enric Miralles Moya, 1987" en Enric Mlralles: 1972-2000. Editorial Fundación Caja de Arquitectos 2011

MONTANER, Josep Maria. "Cuatro notas sobre la obra de Miralles y Pinós". El Croquis MIRALLES / PINÓS 1984-1987, № 30. 1987.

PIZZA, Antonio "Cementerio municipal, Igualada (Barcelona), 1985-1991" en Enric MIralles: 1972-2000. Editorial Fundación Caja de Arquitectos 2011

MUNTAÑOLA, Josep. "Las estructuras de la memoria en la arquitectura de Enric Miralles (Sobre la especificidad de la Arquitectura)". Revista 3ZU, Revista del Departamento de Composición de la ETSAB, pp. 71-77.

QUETGLAS, José. "No te hagas ilusiones". El Croquis MIRALLES / PINÓS 19831990, no 30, 49+50, pp. 24-29.

QUETGLAS, José. "Enric Miralles. Desde Vers une Architecture al primer volumen de Ouvre complete". El Croquis ENRIC MIRALLES + BENEDETTA TAGLIABUE. 1995-2000, no 100-101, pp.26-33.

ROVIRA, Josep Maria. "Etapas en la ETSAB: 1972-1985" en Enric Miralles: 19722000. Editorial Fundación Caja de Arquitectos 2011

ROVIRA, Josep Maria. "Miralles/Pinós : otros proyectos, 1983-1990" en Enric MIralles: 1972-2000. Editorial Fundación Caja de Arquitectos 2011

ROVIRA, Josep Maria. "Enric Miralles : otros proyectos, 1990-1994" en Enric MIralles: 1972-2000. Editorial Fundación Caja de Arquitectos 2011

ROVIRA, Josep Maria. "Biblioteca pública de Pallafols (Barcelona), 1997-2005" en Enric MIralles: 1972-2000. Editorial Fundación Caja de Arquitectos 2011

SALVADO, Ton. “Variaciones de Enric Miralles sobre Max Bill”. DPA, $\mathrm{n}^{\circ}$ 17, 2001, pp.66-69.

SERRA, Carles. "Parlamento de Escocia, Edimburgo, 1998-2004" en Enric MIralles: 1972-2000. Editorial Fundación Caja de Arquitectos 2011

SMITHSON, Alison + Peter. Architectural Review. Abril de 1954.

SPELLMAN, Catherine. "Projects and interpretations: Architectural Strategies of Enric Miralles". Pag. 150-163. En "Re-envisioning Landscape Architecture". SPELLMAN, Catherine, ed. Editorial ACTAR, Barcelona 2003.

SOLA MORALES, Ignasi. "Arquitectura catalana 1990" Quaderns 187.

SUSTERSIC, Paolo "Aulario de la Universidad de Vigo, 1999-2003" en Enric Miralles: 1972-2000. Editorial Fundación Caja de Arquitectos 2011

SUSTERSIC, Paolo. "Enric Miralles: arquitectura del devenir". Pasajes de Arquitectura y Critica, no 12, Diciembre 1999, pp.24-32.

TAGLIABUE, Benedetta." No es serio este cementerio". En L'Architettura Cronache e Storia núm. 409- año XXXV-no11. 1 ed. Milán. Gruppo editoriale Fabbri, Bompiani, Sonzogno, ETAS, noviembre 1989. 
TAGLIABUE, Benedetta. "Familias. Notas a la obra del estudio EMBT desde 1995". EI Croquis ENRIC MIRALLES + BENEDETTA TAGLIABUE. 1995-2000, ㄲo 100101, pp. 22-24.

TAGLIABUE, Benedetta. " ¿Y el tiempo? ¡El tiempo que se apañe! ". El Croquis EMBT 2000 - 2009, № 144. 2009.

USTRELL, Josep. "1991-1994" en Enric Miralles: Pabellón de baloncesto en Huesca, Documentos de arquitectura 32. 1995

\subsubsection{REVISTAS}

\section{GENERALISTAS}

EL CROQUIS, № 30, 49/50, 72, 100/101. Enric Miralles , 1983 - 2000. El Croquis editorial, Madrid 2002.

GREGOTTI, Vittorio. "Progetto e paesaggio" Casabella 575-576, 1991, p. 2

$\mathrm{A}+\mathrm{U}$ Architecture and Urbanism, 1988. pag. 64.

Architectural Design 12, 1962, pag. 602.

BAU 014. "Distribuciones, combinaciones, campos".. 1996.

El Croquis 41, 1989, pag. 56.

Quaderns 186, pag. 51.

ALLEN, Stan, From object to field: field conditions in architecture and urbanism, publicado en AD Vol. 67, Mayo-Junio 1997

ALLEN, Stan, "De lo biológico a lo geológico" Arquitectura Viva 166. 2014. pags. 11 a 17 ,

SMITHSON, Alison "How to recognise and read mat-building". Architectural Design, XLIV, 9, 1974 pags. 573-590.

PARQUE CEMENTERIO. IGUALADA, ESPAÑA 1985 - 1991.

RUBY, A. \& I. Groundscape - the Rediscovery of the Ground in Contemporary Architecture. Gustavo Gili - Landscape Series, 2006, Barcelona. pp. 56-59.

GROUNDSWELL - The Museum of Modern Art, 2005, New York. pp. 1 y pp. 110115.

QUADERNS D'ARQUITECTURA I URBANISME, $n^{\circ}$ 241, Marzo 2004, Barcelona. pp. 20-21.

AV MONOGRAFÍAS, oㅡ 95, Mayo-Junio 2002, Madrid. pp. 38-39.

ON DISEÑO, no 135, 1992, Barcelona. pp. 110-121. 
DOMUS, no 737, Abril 1992, Milán. pp. 40-48.

EL CROQUIS, № 49-50, Septiembre 1991, Madrid. pp. 70-109.

BAUWELT, Marzo 1990. pp. 392-395.

ARCHITETTURA CRONACHE E STORIA, Noviembre 1989. pp. 89-91.

EL CROQUIS, № 26, Octubre 1986, Madrid. pp. 62-65.

THE ARCHITECTURAL REVIEW, Mayo 1986, Inglaterra. pp. 57-60.

PALACIO DE DEPORTES. HUESCA, ESPAÑA. 1988 - 1994

EL CROQUIS, № 70 - Arquitectura Española, 1994, Madrid. pp. 14-35.

ARQUITECTURA VIVA, № 28, Febrero 1993, Madrid. pp. 58-63.

PASAJES Construcción, n 24, 2006.. "Polideportivo de Huesca: Enric Miralles".

A.V: Monografías, no 51-52, Enero-Abril 1995, pp. 34-41. "Palacio de los deportes, Huesca".

INSTALACIONES PARA TIRO CON ARCO. BARCELONA, ESPAÑA. 1990 - 1992

AA.VV. Barcelona Arquitectura Contemporánea 1979-2004. Ayuntamiento de Barcelona, Ediciones Polígrafa, 2005. pp. 116.

ARCHITECTURAL RECORD, 끙, 1992, Washington. pp. 11.

ON DISEÑO, Junio 1992, Barcelona. pp. 224-238.

DISEÑO INTERIOR, № 11, Enero 1992, Madrid. pp. 56-70.

PA - PROGRESSIVE ARCHITECTURE, № 07, 1992. pp. 58-65.

QUADERNS D'ARQUITECTURA I URBANISME, n 193, Marzo - Abril 1992, Barcelona. pp. 58-65.

EL CROQUIS, № 49-50, Septiembre 1991, Madrid. pp. 32-69.

ARQUITECTURA COAM, no 284, Octubre 1991, Madrid. pp. 99-103.

QUADERNS D'ARQUITECTURA I URBANISME, 1991, Barcelona. pp. 73.

\subsubsection{TESIS Y TRABAJOS DE INVESTIGACION}

ASENSIO, Carlos. Tesis Doctoral. "Arquitectura abierta en el paisaje. Una metodología analítica desde la fenomenología". DPA ETSAM. UPM. 2009.

BIGAS, Montserrat. "Enric Mlralles. procesos metodológicos en la construcción del proyecto arquitectónico". Tesis Doctoral. 2006. Universidad de Barcelona. Departamento Dibujo y Grabado. 
BLANCO, Arturo. Tesis Doctoral "Flujo laminar: El cementerio de Igualada y los procesos elásticos en la arquitectura de Enric Miralles y Carme Pinós" DPA ETSAM UPM. 2015.

CONTEPOMI, Gustavo. Tesis Doctoral " El país fértil. Notas para una pedagogía del proyecto ", DPA ETSAM. UPC 2009.

FERNANDEZ CONTRERAS Javier. Tesis Doctoral "La planta Miralles: Representación y Pensamiento en la Arquitectura de Enric Miralles", DPA ETSAM. UPM 2013.

GARCIA CARBONERO, Marta. Tesis Doctoral "Espacio, paisaje y rito: formas: formas de sacralización del territorio en el cementerio europeo del siglo XX". ETSAM. UPM 2011.

GARCIA HIPOLA, Mayka. Tesis Doctoral "La acción arquitectónica en el territorio a través de Peter Eisenman : transformación de las estrategias proyectuales durante la posmodernidad". DPA ETSAM UPM. 2008.

GAZAPO DE AGUILERA, Darío. Tesis Doctoral "El Land Art y la Arquitectura. Una nueva definición de Land Art". DPA ETSAM UPM. 1991.

GILABERT, Salvador. Tesis Doctoral "Enric Miralles. El dibujo de la Imaginación" Tesis Doctoral UPV, 2015.

MATEO VEGA, José Manuel. "La contribución de la arquitectura de Enric Miralles y la vigencia de su método". Comunicación en el Congreso Internacional Criticall. ETSAM UPM, Madrid, 2014

MATEO VEGA, José Manuel. "Enric Miralles Santa Rosa's Park in Mollet del Valles: Redefining public space in contemporary city". Comunicacion en el Congreso Internacional EURAU 12 (European Symposium on Research in Architecture and Urbanism Design), Faculdade Arquitectura do Universidade do Porto, Portugal. 2012.

QUESADA GARCIA, Santiago. Tesis Doctoral. "Imitatio naturae. El paisaje como referente en la arquitectura contemporánea". DPA ETSAS. 2006.

RODRIGUEZ-MORA, Oscar. Tesis Doctoral " Nuevos invariantes espacio formales en la arquitectura contemporánea. Espacio- tiempo, hiperespacio y nuevas geometrías en el siglo XX" defendida en DPA ETSAM UPM. 2004.

SORIA, Francisco Javier. "Arquitectura y naturaleza a finales del siglo XX. Una aproximación dialógica para el diseño sostenible en arquitectura. UPC

ZARAGOZA, Isabel. Tesis Doctoral " Entre la geometría y la iconografía : notas en los márgenes a documentos de Enric Miralles", UPC 2015.

\subsubsection{MATERIAL AUDIOVISUAL}

UIMP. Universidad Internacional Menéndez Pelayo. "Alegoría del tiempo: la arquitectura y el universo de otro Enric Mlralles". Ciclo de conferencias sobre Enric Miralles, con intervenciones de Carme Pinós, Benedetta Tagliabue, Robert Bufrau, Enrique Granell, Josep Maria Rovira y otros. Barcelona 6, 7 y 8 de julio de 2009. Online - http:// upcommons.upc.edu 
FUNDACIO ENRIC MIRALLES. Ciclo "Conversaciones con Enric Miralles". Fundación Enric Miralles 2014 y 2015. Conferencias dadas sobre la obra de Enric Miralles por Rafael Moneo, Iñaki Abalos, Enrique Granell, Anatzu Zabalbeascoa y otros.

BAILLO, Manuel y RULL, Rosa. http://blogs.elpais.com/del-tirador-a-laciudad/2010/07/diez-a\%C3\%B1os-sin-enric- miralles.html

CANAL PLUS. Programa televisado "La casa por el tejado". Programa: Abierto en Canal, Canal Plus. Madrid, 9 de mayo de 1998. Duración: 60'. Con la intervención de Rafael Moneo, Oscar Tusquets, Enric Miralles, Alejandro Zaera, Ábalos \& Herreros y Federico Soriano.

CANAL 33. Programa "Enric Miralles" emitido por Televisió de Catalunya, canal 33, 2001. Intervienen: Benedetta Tagliabue, Josep Lluís Mateo, Òscar Tusquets y Ricardo Bofill.

CORTES, Gustavo. "Enric Mlralles. Aprendizajes del arquitecto". Video. Arquia. Documental 15. 2000

PINOS, Carmen. "Podcast Scalae 2006". Conversaciones con Felix Arranz

PRATS, Eva . "Las tardes de dibujo en el estudio Miralles \& Pinós" . Extractado de la web: wikispaces.org

TAGLIABUE, Benedetta. "Podcast Scalae. № 127". Conversaciones con Felix Arranz

TVE. Televisión Española. Programa televisado "Tres Arquitecturas: Viaplana Piñón" Diciembre de 1990.

TVE. Televisión Española. Programa televisado "La mitad invisible: el Zementeri de Igualada". Con la intervención de Carmen Pinos, Benedetta Tagliabue y Anatxu Zabalbeascoa, proyectado en televisión el día 29 de Septiembre de 2015.

VIDOTTO, Marco. "Podcast Scalae 65". Conversación con Félix Arranz y Benedetta Tagliabue.

\subsection{BIBLIOGRAFIA GENERAL}

AKAL. Enciclopedia de Arquitectura S. XX. Akal 2004

ALGARIN, Mario. Arquitecturas enterradas. Fundación Caja de Arquitectos, Barcelona, 2006.

ALBERTI, Leon Battista. "De Re Aedificatoria", Firenze 1485. "De Re Aedificatoria", J. Fresnillo Núñez, Ediciones Akal. SA. Madrid, 1991

ALLEN, Stan. "Practice: Architecture, technique and representation". Routeledge, 2009

ASPLUND, Erik Gunnard . "Agrigento, Sicilia". Cuaderno de viaje. Febrero de 1914.

BACHELARD, G. "La poetique de l'space" Paris 1957. "La poética del espacio", FCE, Madrid 1975. 
BALLDELLOU, Miguel Angel; CAPITEL, Anton. Suma Artis. "Arquitectura Española del siglo XX", VOL. XI. Espasa Calpe, 1995.

BAUDRILLARD, JEAN. "Los objetos singulares: arquitectura y filosofía". Editorial Fondo de cultura económica de Argentina. Buenos Aires 2001.

BASSEGODA, Joan. "El gran Gaudi”, Ausa, Sabadell, 1989

BENEVOLO, Leonardo. "Storia dell'architettura moderna", Roma 1960. Trad. J. Quetglas "Historia de la Arquitectura Moderna". GG, 1974.

BLUNDELL JONES, P. "Hans Scharoun”. Phaidon Press, London 1997.

BORGES, Jorge Luis. "Labyrinths: Selected Sotires \& other writings". Irby, New York, 1962.

BURKE, Edmund "A Philosophical Enquiry into the Origin of our ideas of the Sublime and Beautiful". London 1757. "Indagación filosófica sobre el origen de nuestras ideas acerca de lo sublime y de lo bello". M. Gras Balaguer, Tecnos, Madrid 1997.

CALVINO, Italo. "Seis propuestas para el próximo milenio". Ediciones Siruela. Madrid. 1989.

CASTELLS, Manuel. "La era de la información : economía, sociedad y cultura" Alianza Editorial 1989

CHING, Francis D. K. "Architecture. Form, Space \& Order". John Wiley \& Sons, Inc. 1996. Versión castellana: "Arquitectura, Forma, Espacio y Orden". Editorial Gustavo Gili, S.A. De CV, México, 1998

COLQUHOUN, Alan. "Arquitectura moderna y cambio histórico : ensayos 1962 1976” Edit. GG. 1978

CORBUSIER LE," Un atlas de paisajes modernos" Exposición originaria del MOMA de Nueva York instalada en el Caixaforum de Madrid de Junio a Octubre de 2014. Notas tomadas por el autor de la Tesis en la visita a la exposición.

CORTES, Juan Antonio. "Lecciones de equilibrio". Editorial Fundación Caja Arquitectos. Barcelona 2006

CORTES, Juan Antonio. "Nueva consistencia. Estrategias formales y materiales en la arquitectura de la última década del siglo XX". Universidad de Valladolid. 2003.

COSTA, Xavier. " Hábitats, tectónicas, paisajes : arquitectura española contemporánea ": Ministerio de Fomento. 2001.

CURTIS, William J. R. “Modern architecture since 1900". Phaidon. London 2000.

DAVIDSON, Cynthia. "Anyymore" The MIT Press. 2000.

DE FUSCO, Renato. "Storia dell'architettura contemporánea" (1975). Traducción al castellano: "Historia de la Arquitectura Contemporánea". Editorial Hermann Blume. 1981.

DELEUZE, Gilles. "Conversaciones”. Editorial Pre-Textos. Valencia. 1995

DELEUZE, Gilles. "Difference et repetition" Paris, 1968. "Diferencia y repetición". Trad. H. Beccacece, Buenos Aires 2002. 
DESCARTES, René. "Discourse du metod" 1637. "Discurso del método" Ediciones Mestas. Madrid. 2001

DICCIONARIO DE FILOSOFIA. José Ferrater Mora. Alianza Editorial. 1983

DICCIONARIO DE LA REAL ACADEMIA ESPAÑOLA DE LA LENGUA. (DRAE). XXI Edición. Espasa Calpe. Madrid 1992.

DICCIONARIO DE USO DEL ESPAÑOL. MOLINER, María. Gredos. Madrid 1994

DICCIONARIO METAPOLIS DE ARQUITECTURA AVANZADA. Manuel Gausa, Vicente Guallart, José Morales, Willy Muller, Fernando Porras, Federico Soriano. Actar, 2001.

DOLLENS, Dennis I. “Jujol Resurfaced. Selected Prose of T.S. Eliot." Kermode, Frank, New York, 1998

ECO, Umberto. "Come si fa una tesi di laurea" 1997. Cómo se hace una tésis". Editorial Gedisa, 2004.

ELLIOT, T.S. Selected Prose of T.S. Eliot. Kermode, Frank, New York, 1975.

ECHEVERRIA, J. "Telepolis". Destino, Barcelona 1994.

EVANS, Robin. "Traducciones". Editorial PRE-textos. Girona 2005

FERNANDEZ ALBA, Antonio. "La metrópoli vacía. Aurora y crepúsculo de la arquitectura en la ciudad moderna" .Editorial Anthropos. Barcelona,1990.

FERNÁNDEZ GALIANO, Luis. "Spain builds: Arquitectura en España 1975-2005" Arquitectura Viva. 2005

FRAMPTON, Kenneth. "Estudios sobre cultura tectónica. Poéticas de la construcción en la arquitectura de los siglos XIX y XX". Ediciones Akal. Madrid,1999.

FRAMPTON, Kenneth. "Modern Architecture: A criticall history" London 1980. "Historia crítica de la arquitectura moderna". Editorial Gustavo Gili. Barcelona,1981.

GAUSA, M. "Land Arch. Paisaje y Arquitectura, nuevos esquejes". Colegio de Arquitectos de Cataluña, Barcelona, 1997.

GUELL, Xavier. "Arquitectura española contemporánea: la década de los 80" GG. 1990

GIEDION, Sigfried. "Space, Time and Architecture, the growth of a new tradition". Harvard University Press, 1941.

GIEDION, Sigfried. "The eternal present. The beginnings of Art" London 1962. "EI presente eterno: los comienzos del arte" Alianza Editorial, Madrid. 1985

GOETHE, J. W. "DieWahlverwandtschaffen" 1809. "Las afinidades selectivas" Boreal, Madrid 1999.

HAYS, K. Michael, editor. "Architecture Theory since 1968". MIT Press paperback edition. New York 2000.

HEGEL, Georg W. F. "La Arquitectura". Versión en castellano de Editorial Kairós, S.A. Madrid, 1981

HEIDEGGER, Martin. "Vortrage und Aufsatze" Pfullingen 1954. "Conferencias y artículos", Ediciones del Serbal, 2001 
HEIDEGGER, Martin. "El arte y el espacio" 1969, Versión en castellano de Editorial Herder, 2009

HERNÁNDEZ DE LEON, Juan Miguel. "Arquitectura española contemporánea : la otra modernidad" Ludwerg Editores: 2007

HOLL, Steven. "Anchoring" Princeton Architectural Press, New York 1989. "Entrelazamientos". Versión en castellano de Gustavo Gili. Barcelona 1997

HUGHES, Robert. "A toda crítica. Ensayos sobre arte y artistas". Versión en castellano de Anagrama. Barcelona 1992.

ITO, Toyo. "Escritos". Editorial Colegio Oficial de Arquitectos técnicos de Murcia. Murcia 2000

JARAUTA, Francisco. "Condiciones contemporáneas de la arquitectura". ETSAV 2003

JENCKS, Charles \& KROPF, Karl. "Theories and Manifestoes of contemporary architecture". Academy Editions. Great Britain 1997.

JOHNSON, Philip. "Deconstructivist architecture". The Museum of Modern Art, New York 1988. (exhibition, june 23 - august 30, 1988).

KANT, E. "Critik der Urtheilskraft" Berlín, 1790. "Critica del juicio". Versión en castellano de Espasa Calpe, 2004.

KOOLHAAS, R. "Delirious New York: a retroactive Manifesto for Manhattan" New York 1978. "Delirio de Nueva York: un manifiesto retroactivo para Manhattan". GG, Barcelona 2004.

KRAUS, Rosalind. "Richard Serra Sculptures”. MOMA, New York 1986.

KUBLER, George. "The shape of time. Remarks on the history of things" London 1962. "La configuración del tiempo". Nerea, Madrid. 1988.

KLEE, Paul. "Pädagogisches Skizzenbruch". Kupferger, Berlin, 1965, pags. 6 -11.

LEVI - STRAUSS, Claude. "El pensamiento salvaje". Ed. Fondo de cultura económica 1964

LYTOARD, J. "La condition postmoderne" Paris 1979. "La condición posmoderna" Altaya, Barcelona 1999.

M.A. Laugier, "Essai sur l' architecture, Paris 1755. "Ensayo sobre la arquitectura". L. Maure, Akal, Madrid 1990.

MALDEBRONT Benoit. Mandelbrot en su libro The Fractal Geometry of Nature (1977). "Los objetos fractales". Tusquets, Barcelona, 1987

MILLER, William C. "Encyclopiedia of architecture, design, engineering". AIA vol. 1, pag. 356.

MIRANDA, Antonio. "Ni robot ni bufón. Manual para la crítica de arquitectura". Ediciones Cátedra. Madrid, 1999.

MOIX, Llatzer. "La ciudad de los arquitectos" Anagrama. Barcelona, 1994. pag. 63

MONEO, Rafael. "Inquietud teórica y estrategia proyectual en 8 arquitectos contemporáneos". ACTAR. Barcelona 2004.

MONEO, Rafael. "Sobre el concepto de arbitrariedad en arquitectura". Real Academia Bellas Artes San Fernando 2005 
MONTANER, Josep Maria. "Sistemas arquitectónicos contemporáneos" Gustavo Gili 2008

MONTANER, Josep María "Arquitectura y Crítica". Editoral Gustavo Gili. Col. Básicos. Barcelona, 1999

MONTANER, Josep María "Después del Movimiento Moderno, arquitectura de la segunda mitad del siglo XX". Editoral Gustavo Gili. Col. Básicos. Barcelona, 1993

MORENO MANSILLA, Luis. "Apuntes de viaje al interior del tiempo". Tesis Doctoral de Luis Moreno Mansilla leida en la ETSAM en 1998 ante un Tribunal de Tesis en el que se encontraba Miralles.

MUÑOZ, María Teresa."La desintegración estilística de la arquitectura contemporánea" Molly 1998

MUÑOZ, María Teresa." "La otra arquitectura orgánica". Molly Editorial. Madrid 1995

NESBITT, Kate "Theorizing a new agenda for architecture : an anthology of architectural theory 1965-1995" Princeton Architectural Press 1996

ORTEGA Y GASSET, J. “Obras completas". Alianza Editorial, Madrid 1983.

PALLADIO, Andrea. "I quattro libri dell architecttura" Venezia 1570. "Los cuatro libros de la Arquitectura" Akal 2015

PUENTE, Carlos. "Idas y vueltas". Fundación Caja de Arquitectos. 2008.

PUIG, Boada. "El pensament de Gaudi" Barcelona, COAC, 1981, pag. 99.

PURINI, F. "Luogo e progetto", Kappa, Roma 1976.

PEREC, Georges. "Especies de espacios". Ed. Montesinos 2007

PEREC, Georges. "La vida instrucciones de uso". Ed. Anagrama 1988

QUETGLAS, José. "Artículos de ocasión” Gustavo Gili 2004

RAMON Y CAJAL, Santiago. "Los tónicos de la voluntad". Editorial formación alcalá. Jaén 2009.

RAMIREZ, Juan Antonio. "Cómo escribir sobre arte y arquitectura". Ediciones del Serbal. Barcelona 1996.

RAMIREZ, Juan Antonio. "Cinco Lecciones Sobre Arquitectura y Utopía".

Universidad de Málaga Departamento de historia del Arte y Delegación en Málaga del Colegio de Arquitectos de Andalucía Oriental. Málaga, 1981

RASSMUSEN, Steen Eiler . "Experiencing Architecture". The MIT Press, Cambridge (Mass.), 1959.Versión Castellana: "La Experiencia de la Arquitectura, sobre la percepción de nuestro entorno". Librería Mairea y Celeste Ediciones SA. Madrid, 2000

ROSSI, Aldo. "L'Architettura Della Città". Marsilio Editori, S.P.A., Padua, 1966 Versión castellana: "La Arquitectura de la Ciudad". Editorial Gustavo Gili, S.A. Col. Punto y Línea. Barcelona, 1976

RORTY, R. "Contingency, irony and solidarity" New York 1989. "Contingencia, ironia y solidaridad", Paidos 1991.

ROWE, Colin. "Manierismo y arquitectura moderna y otros ensayos".GG, 1978 
RASMUSSEN, Steen Eiler. "Experiencing Architecture". The MIT Press.U.S.A.,1962.

RUSKIN, John. "The Seven Lamps of Architecture". Orpington, Kent (1880). " Las siete lámparas de la arquitectura". Editorial Coyocan 2006.

RUSKIN, John. " Modern Painters". London 1843. "Pintores modernos: el paisaje". Prometeo, 1995.

ROWE, Colin "Manierismo y arquitectura moderna y otros ensayos". Editorial Gustavo Gili. Barcelona. 1999.

RUIZ BARBARIN, Antonio."Arquitectura española 1975-2000. 35+ Construyendo en democracia". Electa. 1996, pag. 52.

RUIZ CABRERO, Gabriel . "El moderno en España. Arquitectura 1948-2000." Tanais Ediciones. 2000.

RUIZ DE LA PUERTA, Felix "Principios de Arquitectura. El bosque, el desierto, la cueva". Ediciones asimétricas, 2014

SAN AGUSTIN, "Confessiones Sancti Patris nostri Augustin, 387. "Confesiones", Alianza Editorial, 1990.

SAUNDERS, William. "The New architectural pragmatism" Harvard Magazine Readers Series. 2007.

SAUNDERS, William. "Judging Architecture Value" Harvard Magazine Readers Series. 2007.

SCHILLER, F. "Über Anmut und Würde", 1793. "De la gracia y la dignidad," trad esp. J. Probst, R. Lida, Icaria, 1985.

SCHOLFIELD, P.H. "Teoría de la proporción en Arquitectura". Editorial Labor 1971

SMITHSON, Alison y Peter. "Cambiando el arte de habitar". Editorial Gustavo Gili SA. Barcelona. 2001.

SOLA-MORALES, Ignasi. "Jujol”. Ediciones Poligrafa, 1990.

SOLA-MORALES, Ignasi. "Diferencias: Topografías de la Arquitectura contemporánea”. GG. Barcelona 1995

SOLA-MORALES, Ignasi. "Los artículos de Any". Fundación Caja de Arquitectos. Barcelona 2009

SORIANO, Federico, "Sin_tesis". Gustavo Gili. Barcelona 2004

SORIANO, Federico, "100 Hiperminimos". Lampreave, 2009

TAFURI, Manfredo. "La sfere e il laberinto" Torino 1980. "La esfera y el laberinto. Vanguardias y arquitectura, de Piranesi a los años setenta". GG, 1984.

TAFURI, Manfredo. "Teorías e historia de la arquitectura". Celeste Ediciones. Madrid,1997.

THIEBAUT, Philippe. "Gaudi arquitecto visionario". Blume 2011

THOMPSON, D'Arcy. "Sobre el crecimiento y la forma". Blume. 1980

UNAMUNO, M. "Paisajes del alma”, Alianza Editorial, Madrid 1997. 
URRUTIA, Ángel "Arquitectura española contemporánea : documentos, escritos, testimonios" Colegio oficial de arquitectos. 2002.

VALERY, P. "Eupalinos ou l'architecte" Paris 1921. "Eupalinos o el arquitecto" Colegio oficial de aparejadores y arquitectos técnicos de Murcia, 1993.

VATTIMO, G. "La fine della modernitá", Milano 1991. "El fin de la modernidad" Gedisa, 2000.

VIDOTTO, M. "Alison + Peter Smithson:obras y proyectos". GG, Edición. Paperback. 1997.

VENTURI, Robert. "Complexity and Contradiction in Architecture", New York 1966. "Complejidad y contradicción en la arquitectura". Gustavo Gili. Barcelona. 1972

VIDLER , Anthony. "Histories of the immediate present. Inventing architectural modernism". The MIT press 2008.

VITRUBIO, M. "De Architectura libri decem" "Los diez libros de arquitectura". Trad. Esp. J. Ortiz y Sanz, Alta Fulla, Barcelona 1993.

VON MOOS, Stanislaus. "Le Corbusier elements of a synthesis". 010 Publishers. 2009

WATSON, James. D. Watson "La doble helice". Alianza Editorial. 2000

WAISMAN, Marina. "La estructura histórica del entorno" Ediciones Nueva Visión. 1984

WRIGHT, Frank Lloyd. "The future of architecture" New York 1953. "El futuro de la arquitectura”. Editorial Poseidón. Buenos Aires 1958.

ZEVI, Bruno. "Il linguaggio moderno dell'architettura" Torino 1974. "El lenguaje moderno de la arquitectura". Editorial Poseidón. Barcelona,1978.

ZEVI, Bruno. "Storia della architettura moderna" Torino 1954. "Historia de la arquitectura moderna". Emece. 1959.

ZEVI, Bruno. "Saper vedere l'architettura" Torino 1948. "Saber ver la arquitectura". Ediciones Apóstrofe. Barcelona, 1998.

\subsection{BIBLIOGRAFIA SOBRE EL PAISAJE}

ABALOS, Iñaki; HERREROS, Juan. "Areas de Impunidad”. Actar. 1997.

ABALOS, Iñaki. "Naturaleza y artificio: el ideal pintoresco en arquitectura y el paisajismo contemporáneos" GG 2009.

ARAVENA MORI, Alejandro. "El lugar de la arquitectura". 2002

ARGAN, Giulio Carlo. "El concepto del espacio arquitectónico: desde el Barroco a nuestros días". Nueva Visión 1980.

AUGE, Marc. "Non -lieux. Introduction a une anthropologie de la sur modernite", Paris 1992. "Los no lugares, espacios del anonimato: una antropología de la sobremodernidad" Gedisa. 2004.

AGUILO, Miguel. "El paisaje construido: una aproximación a la idea de lugar" Colegio de ICCP, 1999.

BURNS, Carol. "Site matters. Design concepts, histories and strategies" Routledge.2005 
GASTON GUIRAO, Cristina. "Mies. El proyecto como revelación del lugar". Fundación Caja de Arquitectos, 2005.

GINER DE LOS RIOS, F. "Paisaje", en boletín Institución Libre de Enseñanza, Fundación Giner de los Rios, Madrid. 1999.

LAILACH, Michael. "Land Art" Taschen. 2007

MADERUELO, Javier. "Nuevas Visiones de lo pintoresco. El paisaje como arte". Fundación Cesar Manrique, 1996, p. 16

MADERUELO, Javier. "Paisaje y territorio" Abada editores. 2008

MADERUELO, Javier. "La construcción del paisaje contemporáneo" CDAN Huesca. 2008

MADERUELO, Javier. "El Paisaje: génesis de un concepto" Abada editores. 2005

MADERUELO, Javier. "Paisaje e historia" Abada editores. 2009.

MONEO, Rafael. "Inmovilidad substancial" CIRCO M.R.T. Editado por: Luis M. Mansilla, Luis Rojo y Emilio Tuñón.

NORBEG-SCHULZE, Christian. "Genius Loci: paysage, ambiance, architecture". Pierre Mardaga. 1989.

NORBEG-SCHULZE, Christian. "Genius Loci: towards a phenomenology of architecture". Academy. 1980.

NORBEG-SCHULZE, Christian. "Intenciones en arquitectura”. GG. 1998.

SOLA - MORALES, Ignasi “Metrópolis : ciudades, redes, paisajes". GG 2004

SORIA LOPEZ, Javier. "Arquitectura y Naturaleza a finales del siglo XX 1980-2000. Una aproximación dialógica para el diseño sostenible en arquitectura". Tesis Doctoral. 2004. UPC.

PESQUERA GONZALEZ, Eduardo. "La lección de Roma: Libera, Ridolfi y Terragni" Tesis Doctoral. 2000 ETSAM

PUCH ORTA, Gonzalo. "La imagen y el lugar. Apuntes sobre la representación del paisaje en Occidente". Tesis Doctoral. 1998. Universidad de Castilla La Mancha.

RAQUEJO, Tonia. "Land Art". Editorial Nerea, 1998.

SPELLMAN, Catherine. "Re-envisioning Landscape Architecture". Actar, 2003.

SCULLY, Vincent. "The earth, the temple, and the gods" Yale University.1979.

SOSA DIAZ SAAVEDRA, José Antonio. "Contextualismo y abstracción: reflexiones sobre las interrelaciones entre suelo, paisaje y arquitectura". Tesis Doctoral. 1994. Universidad Las Palmas de Gran Canaria.

WAISMAN, Marina. "La estructura histórica del entorno".

TEDESCHI, Enrico. "Teoría de la Arquitectura”. Nueva Visión. 1976. 
AGRADECIMIENTOS 


\section{AGRADECIMIENTOS}

El doctorando desea mostrar el agradecimiento a todas las personas que me han apoyado a lo largo de esta investigación y en especial a:

- A mi familia, en especial a mis padres, Luis y Angela, porque siempre están ahí.

- Enric Miralles, el motor de esta investigación, a quien conoci por primera vez en persona, siendo yo estudiante, a la salida de la Conferencia que dio en la ETSAM, el dia 5 de Mayo de 1993, a los pocos días del derrumbe de la cubierta del Pabellón de Deportes de Huesca. Porque subido a sus "hombros de gigante" durante casi 6 años me ha seguido formando como arquitecto con su magisterio y me ha avivado con su ejemplo todavía mas la llama de mi entusiasmo por la Arquitectura.

- Mi Director Federico Soriano, quien acepto dirigir mi investigación inicial y la recondujo con sus sabias indicaciones gracias a su mirada que como la de Miralles es capaz de ver mas alla, por su apoyo incondicional en los momentos mas delicados... A Ricardo Lampreave, quien llego como CoDirector en Otoño de 2015 a la primera llamada, cuando yo mas lo necesitaba a apoyar a Federico cuya dedicación a la Direccion del DPA ETSAM le absorbia todo su tiempo. A ambos que con su generosa dedicación, talento y entusiasmo por la Arquitectura, me mostraron el camino para "separar el grano de la paja" cuando mas perdido estaba.

- A Juan Navarro Baldeweg, quien con gran generosidad se ofrecio para cuanto necesitase cuando al inicio de mi investigacion mi Tesis comparaba la manera de implantarse en el Paisaje de su Arquitectura y la de Miralles. Sin duda que estoy en deuda con esa investigacion y en cuanto disponga de tiempo la abordare.

- Benedetta Tagliabue y sus colaboradores de EMBT por su amabilidad al permitirme el acceso al Archivo Enric Miralles en Barcelona.

- A los profesores expertos designados por el DPA ETSAM, para evaluar el borrador de mi Tesis Doctoral en el acto de Prelectura: Miguel Martinez Garrido, Luis Antonio Gutierrez Cabrero y Nicolas Maruri por las generosas, entusiastas y detalladas indicaciones que me hicieron para mejorar el documento.

- A los ilustres Miembros de mi Tribunal de Tesis por aceptar formar parte de este a la primera llamada: Francisco Jarauta, Emilio Tuñon, Francisco Gonzalez de Canales, Jaime Coll, Javier Fernandez Contreras, Rodrigo Pemjean e Isabel de Cardenas Maestre.

- A Carmen Martinez Arroyo y Rodrigo Pemjean, quienes me dieron la posibilidad de realizar Labores de Apoyo a la Docencia en su Unidad Docente en la ETSAM desde 2013 hasta 2016, por todo cuanto aprendi y por sus valiosas sugerencias y las muestras de ánimo dadas en las numerosas tertulias mantenidas al término de las clases con los 
profesores de la Unidad Docente: Enrique Delgado, Raul del Valle, Miguel Kreisler, Sergio De Miguel y Jesus Ulargi . En especial a Enrique .

- Al personal de la Biblioteca de la ETSAM, en especial Pilar y Beatriz, quienes fueron un apoyo fundamental en la fase de Documentacion, por su calidad humana y apoyo mantenidas hasta el final. Tambien al personal de la Biblioteca Nacional de Madrid y la Casa de Velazquez.

- Mis compañeros de la Sala de Investigadores de la Biblioteca de la ETSAM desde 2009 en que irrumpi allí para ponerme con la Tesis, y en especial a Francisco G. Triviño y Katerina Psegiannaki, por las interesantes conversaciones mantenidas acerca del discurrir de nuestras investigaciones.

- Al personal del DPA por su infinita paciencia y generosidad con todas las gestiones y papeleos en especial a Francisco Arques, Blanca y Rosario.

- A los magnificos profesores que tuve el privilegio de tener en mis años de estudiante en la ETSAM, que con su ejemplo me hicieron amar la Arquitectura, en especial a Guillermo Cabeza, Miguel Angel Balldellou, Francisco Alonso de Santos, Emilio Tuñon, Luis Moreno Mansilla, Maria Teresa Muñoz, Pedro Moleon, Manuel de las Casas quien tanto me enseño con el Proyecto Final de Carrera y gracias a su magisterio motivo que yo siguiera estudiando el Doctorado..., Antonio Fernandez Alba, Iñaki Abalos y Juan Herreros, Anton Capitel por sus fantasticos cursos de Doctorado.

- A Carmen Espegel Alonso, por su bonita amistad, a quien siempre le agradeceré la oportunidad que me dio de colaborar en su Estudio de la "Casa de las Flores" recién licenciado y me abrió la puerta al mundo de la Academia iniciando desde alli mis cursos de Doctorado y facilitando el camino a colaborar después con Gines Garrido, Fernando Porras, Ricardo Lampreave...

- A Carlos Rubio Carvajal por su confianza depositada en mi desde que gracias a Javier nos conocemos y los animos para terminar la Tesis.

- A Matias Diaz Padron y Juan Ariño quienes me enseñaron a detectar la cantidad de matices que puede abarcar la mirada y por las interesantes tertulias mantenidas sobre Arte con ellos.

- A David y Lucho Miquel, quien fallecio este año. Del que aprendi mucho mientras trabaje con el y nunca olvidare el detalle que tuvieron por invitarme al Homenaje que le dieron sus amigos a José Antonio Corrales en un pueblo de Soria.

- A mis amigos y amigas, novias, que pacientemente soportaron mis ausencias a la que me obligaba la realización de la Tesis.

- A todas aquellas personas que en este periplo me animaron, y las que aportaron datos inéditos para mi investigación, tantos, que darían para muchas Tesis. 
AGRADECIMIENTOS 